Andrzej Piotr Wierzbicki

Teoria i praktyka

wspomagania

decyzji 


\section{Teoria i praktyka wspomagania \\ decyzji}



Andrzej Piotr Wierzbicki

Teoria i praktyka

wspomagania

decyzji
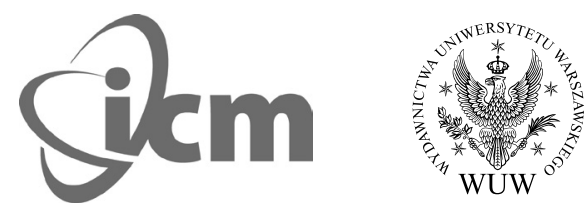
Redaktor prowadzący

Karolina Chmielewska

Indeks

Andrzej Piotr Wierzbicki

Projekt okładki i stron tytułowych

Anna Gogolewska

Publikacja finansowana przez ICM UW

(c) Copyright by Wydawnictwa Uniwersytetu Warszawskiego, Warszawa 2018

ISBN 978-83-235-3361-0 (druk)

ISBN 978-83-235-3369-6 (pdf online)

ISBN 978-83-235-3377-1 (epub)

ISBN 978-83-235-3385-6 (mobi)

Książka ta powstała we współpracy Interdyscyplinarnego Centrum Modelowania Matematycznego i Komputerowego Uniwersytetu Warszawskiego oraz Instytutu Łączności, Państwowego Instytutu Badawczego. Autor wyraża wdzięczność obu instytucjom za wspomaganie go w przygotowaniu tej książki. Książka ta ma charakter podręcznika akademickiego dla studiów drugiego i trzeciego stopnia (magisterskich i doktoranckich), jej powstanie było umotywowane utworzeniem specjalności Inżynieria Obliczeniowa na Uniwersytecie Warszawskim.

Wydawnictwa Uniwersytetu Warszawskiego

00-497 Warszawa, ul. Nowy Świat 4

e-mail:wuw@uw.edu.pl

księgarnia internetowa: www.wuw.pl

Wydanie 1, Warszawa 2018 


\section{Spis Treści}

\section{Pojęcia podstawowe}

1. Rewolucja i cywilizacja informacyjna 9

2. Proces decyzyjny i wspomaganie decyzji 31

3. Współczesny decydent: optymalizacja, sztuczna inteligencja - a kwestia prawdy i rola intuicji

II. Teoria preferencji, wartości i użyteczności

4. Relacje preferencji i funkcje wartości

5. Probabilistyczny model niepewności i funkcje użyteczności

6. Paradoksy racjonalności i alternatywne modele podejmowania decyzji oraz niepewności

\section{Optymalizacja wektorowa a wspomaganie decyzji}

7. Podstawowe pojęcia i warunki optymalizacji wektorowej

8. Różne podejścia do optymalizacji wektorowej i klasy funkcji skalaryzujących

9. Metody punktu odniesienia

10. Systemy wspomagania decyzji oparte na metodach punktu odniesienia

IV. Teoria gier a wspomaganie decyzji

11. Podstawy teorii gier

12. Zastosowania i modyfikacje teorii gier

13. Rozwiązania kooperatywne w teorii gier

V. Wspomaganie decyzji grupowych

14. Techniki podziału zasobów oraz kosztów

15. Techniki głosowania oraz techniki rankingu

16. Indeks 

I. Pojęcia Podstawowe 



\section{Rewolucja i cywilizacja informacyjna}

\subsection{Wprowadzenie}

Komputerowe wspomaganie decyzji jest dziś dziedziną bardzo szeroką, zarówno jeśli chodzi o stosowane podejścia teoretyczne i metodyczne, jak i o dziedziny i metodykę zastosowań. Ponieważ wspomaganie decyzji zawsze obejmuje automatyzację pewnych etapów czy czynności w procesie decyzyjnym, przeto nieuchronny jest spór o zakres i prawomocność takiej automatyzacji.

Badacze, którzy zwracają mniejszą uwagę na praktykę i psychologię wspomagania decyzji, preferują niejednokrotnie takie metody czy podejścia teoretyczne, które - przynajmniej potencjalnie - zapewniają duży stopień automatyzacji procesu decyzyjnego, a zwłaszcza jego decydującej fazy dotyczącej wyboru decyzji. Do tej grupy metod i podejść należą, po pierwsze, metody optymalizacyjne wspomagania decyzji oparte bezpośrednio na teorii wartości i użyteczności oraz wykorzystujące analityczne postacie modeli sytuacji decyzyjnych, jak i, po drugie, systemy eksperckie we wspomaganiu decyzji, związane ze sztuczną inteligencją i inżynierią wiedzy oraz wykorzystujące logiczne postacie modeli.

Praktyka i psychologia wspomagania decyzji akcentują jednak silniej podejście odmienne, trzecie, oparte na uwypukleniu suwerennej roli decydenta czy użytkownika systemu wspomagania decyzji - z podkreśleniem znaczenia jego intuicji i z założeniem, że może on być wprawdzie wspomagany poprzez automatyzację niektórych etapów procesu decyzyjnego, ale powinien suwerennie i w pełni świadomie dokonywać ostatecznego wyboru decyzji. 
Autor tej książki reprezentuje ten trzeci, bardziej praktyczny i psychologiczny punkt widzenia, choć jednocześnie akcentuje też możliwości wykorzystania teorii i modeli matematycznych oraz metod optymalizacji w celu wspomagania, a nie zastępowania decydenta.

Stąd też synteza, przedstawiona w tej książce, ma dość krytyczny charakter i koncentruje się na takich metodach zastosowań optymalizacji we wspomaganiu decyzji, które pozwalają decydentowi czy użytkownikowi systemu wspomagania decyzji zachować możliwie maksymalną suwerenność. Do grupy takich metod należą, m.in., interaktywne systemy wspomagania decyzji oparte na optymalizacji wielokryterialnej, dość szeroko (choć też syntetycznie) omówione w tym wykładzie.

Z drugiej strony jednak podstawowe pojęcie teorii decyzji, wartości, użyteczności, optymalizacji wielokryterialnej, teorii gier, metod wspomagania negocjacji itp. mają zasadnicze znaczenie - zarówno dla dobrego pojmowania współczesnego świata, początku epoki cywilizacji informacyjnej, jak i dla umiejętnego konstruowania systemów wspomagania decyzji. Dlatego też pojęcia te oraz niektóre ich implikacje poznawcze są dość szeroko komentowane w tym wykładzie.

Ponadto, zrozumienie współczesnego decydenta i jego roli w systemie wspomagania decyzji byłoby niepełne bez głębszego zrozumienia rewolucji informacyjnej oraz epoki cywilizacji informacyjnej. Nie ulega dziś chyba niczyjej wątpliwości, że następuje dzisiaj rewolucja informacyjna różnorodnie nazywana (cyfryzacja, rewolucją informatyczna itp.), chociaż te inne nazwy uważam za nieprecyzyjne, wprowadzające w błąd. Bowiem istotą tej rewolucji jest upowszechnienie narzędzi przetwarzania oraz dostępu do informacji.

\subsection{Epoka cywilizacji informacyjnej}

Wiele też wskazuje na to, że żyjemy dzisiaj w początkowym okresie nowej ery cywilizacyjnej - epoki cywilizacji informacyjnej - która to era nie jest zjawiskiem krótkotrwałym, ale długotrwałą strukturą dziejową (w sensie Fernanda Braudela, 1992). 
Istnieją przy tym przesłanki - które przedstawimy niżej - do stwierdzenia, że epoka cywilizacji informacyjnej zaczęła się ok. roku 1980 i potrwa jeszcze przez cały wiek XXI. Żyjemy zatem w okresie początkowym tej epoki, tak jak w końcu wieku XVIII mieszkańcy Anglii (w mniejszym stopniu mieszkańcy innych krajów świata) żyli w okresie początkowym epoki cywilizacji przemysłowej.

Dopiero takie porównanie stwarza nam właściwą perspektywę: możemy się bowiem zastanawiać nad różnicami tych dwóch okresów, ale też nad ich podobieństwami.

Nie jest to pogląd odosobniony. Nazwa spoteczeństwo informacyjne, choć funkcjonowała już wcześniej (proponowana najpierw przez Yoneji Masudę w początku lat 70-tych w Japonii) spopularyzowana była w dwóch etapach: najpierw w swej istocie, choć pod innym hasłem, przez książkę Alvina Tofflera Trzecia Fala (1980), a następnie we wczesnych latach 90-tych przez inicjatywy wiceprezydenta Stanów Zjednoczonych Al'a Gore’a dotyczące globalnej infrastruktury informacyjnej oraz raport Martina Bangemanna (1993) dla Komisji Europejskiej, który to raport dotyczył rozwoju społeczeństwa informacyjnego $\mathrm{w}$ Europie i zapoczątkował powszechną popularyzację tej nazwy.

Nie jest to przy tym społeczeństwo informatyczne, tylko informacyjne, gdyż decydujący o jego rozwoju jest fakt, że informacja $i$ wiedza staja sie podstawowym zasobem produkcyjnym (obok surowców, kapitału, pracy), a wykorzystanie przy tym technik informatycznych jest tylko kwestią narzędziową, choć istotną. Tak samo rozumieją to społeczeństwo - choć nadają mu inne, często sprzeczne nazwy - Peter F. Drucker w Post-Capitalist Society (1993) czy Lester C. Thurow w The Future of Capitalism (1996).

Obserwujemy wprawdzie dziś powszechnie fakt, że techniki informacyjne telekomunikacyjne, teleinformatyczne, medialne - stanowią czynnik napędowy rozwoju gospodarczego świata. To jednak, co obserwujemy dziś w zakresie zastosowań technik informacyjnych $i$ ich społecznych skutków, to zaledwie początki.

Pogląd taki wynika z faktu, że obserwujemy dzisiaj społeczne skutki dopiero czterech fal początkowych rozpowszechnienia narzędzi rewolucji informacyjnej: 
- Fali przygotowawczej telewizji (pierwsze wynalazki Julian Ochorowicz 1878 i George Carey 1880, udoskonalenia Vladimir Zvorikin i Kalman Tihanyi 1922-28, początek rozpowszechnienia społecznego 1950-60), z dużym opóźnieniem (40-80 lat, zależnie jak liczyć) tego rozpowszechnienia, ale potem narastającej nieuchronnie, z maksymalną prędkością ok 8\%/rok.

- Pierwszej fali rewolucji informacyjnej komputerów osobistych (pierwsze wynalazki 1931-36, Vannevar Bush i Konrad Zuse, początek rozpowszechnienia społecznego 1977, Apple 2, Steve Jobs i Steve Wozniak), ze sporym opóźnieniem (ponad 40 lat), ale też narastającej nieuchronnie.

- Drugiej fali rewolucji informacyjnej telefonii mobilnej (pierwsze wynalazki ok. 1890, podział terenu na komórki 1943, początki rozpowszechnienia społecznego firmy Radiolinia i Nokia 1990), ze sporym opóźnieniem (100 lub 40 lat), ale narastającej do dzisiaj nieuchronnie.

- Trzeciej fali rewolucji informacyjnej Internetu (pierwszy wynalazek Vannevar Bush 1945, początek rozpowszechnienia społecznego Timothy Berners-Lee 1990-92), z podobnym czasem opóźnienia, ale znów narastającej nieuchronnie.

Fale te dzisiaj integruja się ze sobq, ale na poczatek rozpowszechnienia społecznego czekaja jeszcze nastęne trzy fale:

- Czwarta fala rewolucji informacyjnej to robotyka (wynalazek - pojęcie 1921 Karel Čapek, konstrukcja 1957 Georg Devol, powszechne już dzisiaj zastosowanie w przemyśle wytwórczym, brak jak dotąd powszechnego społecznego zastosowania) - roboty nie chodza z nami po ulicach, tak jak czynią to aparaty telefonii mobilnej zintegrowane $\mathrm{z}$ komputerami osobistymi oraz Internetem.

- Piąta fala rewolucji informacyjnej to inżynieria wiedzy (zwana też mniej precyzyjnie sztuczna inteligencja - wynalazek 1958, Internetem rzeczy, yaoyorozu $^{1}$ ), obejmująca wspomaganie decyzji, w początkach rozpowszechnienia społecznego (inteligentne domy itp.), bardzo jeszcze prymitywnego.

\footnotetext{
1 Yaoyorozu to japońskie animistyczne sto milionów bogów, symbolizujące powszechność inteligencji.
} 
- Szósta fala rewolucji informacyjnej to inżynieria biomedyczna (różne wynalazki od Wilhelma Röntgena 1895), dość szeroko już ale jeszcze nie powszechnie stosowana.

Są to więc fale nadchodzące, i społeczeństwa świata powinny być na nie przygotowane. W tym celu, na wszystkich uczelniach (także na wydziałach humanistycznych, ekonomicznych i społecznych) jako przedmioty obowiązkowe powinny znaleźć się przedmioty techniczne: robotyka $i$ automatyka, informatyka $z$ inżynieria wiedzy, inżynieria biomedyczna. Politechniki już od ponad pięćdziesięciu lat wprowadziły obowiązkowe przedmioty humanistyczne i społeczne, nadal bezskutecznie oczekują wzajemności.

Rozwiązywanie problemów, właściwych dla początku nowej epoki cywilizacji informacyjnej, będzie wymagało zupełnie nowych podejść, wręcz zmiany sposobu widzenia świata - odejścia od mechanistycznej wizji świata jako wielkiej maszyny, regulowanej czy to nieubłaganymi prawami historii, czy też niewidzialną ręką rynku, i zrozumienia nowej, systemowo-chaotycznej wizji świata. Przypomnę tu, że w sensie deterministycznej teorii chaosu stanowi on nieodłączną cechę systemów nieliniowych z silnym sprzężeniem zwrotnym.

Jeszcze kilka lat temu można było traktować pojęcie społeczeństwa informacyjnego jako tylko modną nowinkę, temat dyskusji intelektualnej. Zresztą w 1790 roku też nikt sobie w pełni nie wyobrażał głębi zmian, które wywoła nadchodząca epoka cywilizacji przemysłowej, choć maszyna parowa była udoskonalona już od lat trzydziestu. Dzisiaj jednak cywilizacja informacyjna dociera do nas wieloma drogami: przez komputeryzację prac biurowych, zarządzania, księgowości; przez sieci komputerowe i Internet; przez reklamy wielkich firm międzynarodowych; przez działania rządu Stanów Zjednoczonych czy Komisji Europejskiej; przez inicjatywy strategiczne krajów - takich jak Finlandia - które zdecydowały się wykorzystać szanse początków nowej epoki.

Istotą cywilizacji informacyjnej nie jest przy tym, jak to się sądzi w uproszczeniu, powszechne wykorzystanie środków i metod informatycznych czy cyfryzacji. Znacznie bardziej istotny jest wspomniany już fakt, że informacja $i$ wiedza zaczynaja odgrywać role podstawowego, a stopniowo 
nawet decydującego, czynnika produkcji - obok kapitatu, pracy i surowców. Decydujący dla sukcesu ekonomicznego przedsiębiorstwa staje się więc dostęp do światowych zasobów informacji i umiejętność ich wykorzystania. Coraz powszechniej, podstawowym narzędziem tego dostępu staje się sieć komputerowa - Internet.

Jaki jest kres tej epoki cywilizacyjnej, kiedy można spodziewać się jej końca? To trudne pytanie, któremu poświęcimy tu nieco więcej uwagi. Jednakże z powyższej definicji istoty cywilizacji informacyjnej możemy wywnioskować wstępną, niepełną odpowiedź na to pytanie: epoka ta skończy się, gdy informacja $i$ wiedza stana się rzeczywiście decydujacym czynnikiem produkcji w skali globalnej, gdy nastąpi powszechna dematerializacja pracy ludzkiej (a może nawet, w pewnym sensie koniec pracy, o czym dalej) nawet w krajach dziś zacofanych. Ta właśnie odpowiedź jest jedną z przesłanek dla twierdzenia, że epoka ta potrwa jeszcze długo.

\subsection{Długie trwanie cywilizacji informacyjnej}

Przeciwstawienie cywilizacji informacyjnej i przemysłowej zostało zaproponowane przez Alvina Tofflera (1980). Toffler sądził, że jest to tylko trzecia fala (po cywilizacji rolniczej i przemysłowej). Znając teorie rozwoju cyklicznego należy jednak podkreślić, że cykli takich mogło być wiele. Cykle takie nie muszą być wcale regularne; najlepiej chyba analizować je w kategoriach struktur dtugiego trwania Fernanda Braudela (1992).

W historii Europy wyraźne są następujące okresy cywilizacyjne: późnego średniowiecza (od ok. 1000 do ok. 1440 roku, czyli do wynalazku druku, czy też początków jego upowszechnienia w Europie); potem łączny okres renesansu, reformacji i kontrreformacji (okres ten był właśnie analizowany przez Braudela jako okres tworzenia się kapitalizmu, a datować go można od ok. 1440 do ok. 1760 roku, czyli wynalazku maszyny parowej, czy dokładniej - jej udoskonalenia przez Jamesa Watta); potem okres cywilizacji przemysłowej. 
Fernand Braudel w swej książce Kultura materialna, gospodarka, kapitalizm w XV-XVIII wieku (1979) bardzo silnie podkreśla odrębność okresu historycznego 1440-1760, po wynalazku druku.

Nie oznacza to bynajmniej, że sam ten wynalazek, sama technika druku jest odpowiedzialna za tę specyfikę: nową cywilizację tworzą ludzie, motywowani swymi potrzebami i czynnikami gospodarczymi - przyspieszenie wymiany, wykorzystanie banków i kredytu itp. były może równie ważne, jak druk.

Ale druk przyniósł przyspieszenie obiegu informacji, ta zaś przyczyniła się do odkryć geograficznych, te przyniosły nową akumulację kapitału, ale także nowe rośliny i sposoby odżywiania się, co stopniowo stworzyło podstawy do możliwości wyżywienia większej liczby ludzi w Europie, a także przygotowało nową erę - cywilizacji przemysłowej. Wszystkie te zmiany, jak podkreśla Braudel, są niesłychanie powolne, głównie ze względu na przyzwyczajenia i umiejętności ludzkie, powoli tylko modyfikowane w strukturach dtugiego trwania.

Struktury długiego trwania Braudela można interpretować jako fale cywilizacyjne, podobne do postulowanych przez Tofflera, jednak bez ograniczania ich liczby do trzech. Interesujące jest przy tym, że mechanizm powstawania takich fal można lepiej zrozumieć, jeśli zastosuje się pewne podstawowe pojęcia $\mathrm{z}$ teorii generacji fal $\mathrm{w}$ telekomunikacji - pojęcie sprzężenia zwrotnego i jego związki z generacja sygnałów okresowych.

Mechanizm powstawania takiego cyklu można wytłumaczyć, zakładając stopniową akumulację czynników materialnych oraz kulturowych rozwoju, a także wzajemne sprzężenie zwrotne pomiędzy tymi aspektami (żaden z nich nie może się rozwinąć nadmiernie bez drugiego). Zatem to nie byt określa świadomość i nie świadomość określa byt, tylko oddziaływaja one na siebie we wzajemnym sprzężeniu zwrotnym; ale po to, aby ten fakt zrozumieć, trzeba było najpierw spopularyzować pojęcie sprzężenia zwrotnego, które wprowadzone zostało przez telekomunikację ok. 70 lat temu i dotąd nie zawsze jest dostatecznie głęboko zrozumiane.

Pod koniec poprzedniego cyklu cywilizacyjnego następuje nagromadzenie nowych odkryć, pojęć i wynalazków. Nie są one jednak natychmiast wykorzystywane gospodarczo, gdyż sprzężenie to charakteryzuje się pewnym 
cywilizacyjnym czasem opóźnienia: od powstania nowej teorii, nowego pojęcia podstawowego dla rozumienia świata, czy wreszcie nowego wynalazku o przełomowym znaczeniu, upływa zwykle (jak to widzieliśmy na przykładach kolejnych fal rewolucji informacyjnej) wiele czasu, zanim teorie te, pojęcia podstawowe i przełomowe wynalazki zostaną powszechnie zrozumiane i wykorzystane.

Stwarza się zatem wrażenie nadmiaru wiedzy, co wyraża się $\mathrm{w}$ niedofinansowaniu nauki i edukacji $\mathrm{w}$ początkach nowego cyklu. I odwrotnie, od nagromadzenia bogactwa w społeczeństwie do rozwoju nauki i nowych pojęć, odkryć i wynalazków też upływa analogiczny czas opóźnienia: jeśli się bowiem badania zaniedba, to potem trzeba najpierw inwestować w kształcenie nauczycieli, potem w uczniów, zanim się odtworzy warunki do rozwoju nauki.

Ten cywilizacyjny czas opóźnienia był bardzo długi w wiekach XV-XVIII, co wyraźnie podkreśla Braudel; wynosił wtedy zapewne co najmniej kilka pokoleń. Jednakże teoria generacji fal sugeruje, że procesy z akumulacją i czasem opóźnienia $\mathrm{w}$ sprzężeniu zwrotnym mogą łatwo wywołać powstawanie cykli o dlugości około czterech czasów opóźnienia - co można wykazać różnymi metodami, włącznie z matematyczną analizą stabilności i generacji fal, zob. np. (Wierzbicki 2011). Procesy takie i cykle są dość powszechne.

Jako przykład, można przywołać tu prostszy i opisywany w literaturze (Richard B. Freeman, 1976) cykl zapotrzebowania na absolwentów danej specjalności uniwersyteckiej w warunkach rynkowych. Przypuśćmy, że w danym momencie powstała przewaga popytu nad podażą na absolwentów tej specjalności.

Młodzież licealna dowiaduje się o tym szybko, wobec czego zaczyna studia tej specjalności w zwiększonych rocznikach. Jednakże, aby wykształcić absolwenta, potrzeba ok. 5 lat (to właśnie czas opóźnienia); więc przez pięć lat niedobór takich specjalistów będzie się pogłębiał. Po pięciu latach zacznie się zmniejszać - ale zakładając symetrię przebiegów $\mathrm{z}$ akumulacją absolwentów czy ich niedoboru na rynku pracy, potrzeba będzie następnych pięciu lat, aby niedobór ten zmalał do zera. 
Po dziesięciu latach pojawia się przewaga podaży nad popytem, zatem licealiści przestają wybierać tę specjalność. Ale na studiach jest jeszcze pięć dużych roczników studentów, więc nadmiar specjalistów w danej dziedzinie się powiększa; zacznie on maleć po piętnastu latach od chwili początkowej i trzeba będzie następnych pięciu lat, aby znów zmalał do zera. A zatem, okres cyklu to cztery czasy opóźnienia.

Ten sam wniosek można uzyskać na podstawie matematycznej analizy warunków generacji fali w systemie $\mathrm{z}$ członem całkującym i czasem opóźnienia oraz odpowiednio silnym ujemnym sprzężeniem zwrotnym, zob. (Wierzbicki 2011).

Jeśli jednak czasy opóźnienia dotyczą zjawisk cywilizacyjnych i wynoszą kilka pokoleń ludzkich, to okresy cyklu są kilkusetletnie. Przed wynalazkiem druku, ten cywilizacyjny czas opóźnienia wynosił, być może, około 110 lat, co zgadza się z cezurami cyklu 1000-1440 rok (pierwsza - to idea Treuga Dei, znacząca początek późnego średniowiecza, druga to właśnie rozpowszechnienie wynalazku druku).

Po wynalazku druku, w miarę jego upowszechnienia, czas ten skrócił się, być może, do ok. 80 lat, co zgadza się z cezurami cyklu 1440-1760 (druga data to usprawnienie przez J. Watta wynalazku maszyny parowej). W epoce cywilizacji przemysłowej, wynalazki tej epoki spowodowały dalsze skrócenie czasu opóźnienia cywilizacyjnego - do ok. 55 lat, bo końcową cezurę cywilizacji przemysłowej wypada przyjąć na lata tuż przed 1980 (rozpowszechnianie się komputerów osobistych, początki sieci Internet, protokół TCP/IP).

Można przy tym zapytać - po co komu takie cezury, czy to nie jest próżna historiozofia? A może wręcz nawrót myślenia o sztywnych prawach historii? Bynajmniej - rozważania te trzeba traktować wyłącznie jako uogólnienia w określonym czasie i miejscu, jako model pomocny w zrozumieniu możliwego rozwoju spraw.

Wróćmy do pytania - a jak dluga będzie epoka cywilizacji informacyjnej? Nie jest to pytanie nieważkie. Jeśli epoka ta będzie tylko krótką efemerydą, to nie ma o co kruszyć kopii. Jeśli jednak chodzi o epokę o czasie trwania 
przekraczającym sto lat, to żyjemy obecnie w czasie przełomu cywilizacyjnego - i pozornie drobne decyzje dziś mogą wpłynąć w sposób zasadniczy na rozwój sytuacji przyszłej.

Jeśli więc mamy prawo wyciągać wnioski $\mathrm{z}$ modelu długich fal cywilizacyjnych, to trzeba stwierdzić, że ich długość skraca się nieco wraz z przyspieszeniem obiegu informacji. Z definicji, epoka cywilizacji informacyjnej wniesie dalsze przyspieszenie - ale decydujące jest tu opóźnienie nie materialne, lecz kulturowe.

Stąd epoka cywilizacji informacyjnej będzie wprawdzie nieco krótsza może od 120 do 180 lat, skoro typowe opóźnienie obserwowane w falach rewolucji informacyjnej to ok. 40 lat - ale też dość długa, zajmie zapewne cały wiek XXI.

Zdajmy więc sobie sprawe z przetomowego znaczenia czasów, w których żyjemy: to nie przełom tysiacleci jest ważny, tylko przełom epok cywilizacyjnych, zwiazane z nim zmiany i konflikty.

\subsection{Konflikty cywilizacji informacyjnej}

Teza o stopniowej dematerializacji pracy w epoce cywilizacji informacyjnej ma jednak dalsze konsekwencje. Epoka ta będzie się charakteryzować w znacznie większym stopniu niż epoka cywilizacji przemysłowej - zmianą charakteru zawodów tradycyjnych bądź też nawet zmianą starych zawodów na nowe. Powodować to będzie wciąż nowe bezrobocie strukturalne - coraz więcej ludzi, wykonujących dawniej różne prace fizyczne, będzie szukało nowego zajęcia. Ci z nich, którzy przystosują się do wymagań nowej epoki, znajdą zajęcie łatwiej; inni mogą ulec marginalizacji.

Niebezpieczeństwo tego procesu polega na tym, że dematerializacja czy wręcz automatyzacja pracy ludzkiej może postępować zbyt szybko (już dzisiaj obserwujemy tego objawy) i duża część ludzi będzie zatrudniona na warunkach nietrwałych, dorywczo, tworząc tzw. prekariat - nową warstwę czy klasę ludzi stosunkowo dobrze wykształconych, ale mimo to nie mogących znaleźć dla siebie trwałego zatrudnienia i pespektyw na przyszłość, ulegającą właśnie marginalizacji społecznej. 
Każde nowe technologie, zwłaszcza masowo stosowane w początkach nowej epoki cywilizacyjnej, wywołują z jednej strony nową akumulację kapitału, $\mathrm{z}$ drugiej strony zaś - nowe napięcia społeczne. $\mathrm{Z}$ tego powodu, już dzisiaj możemy wymienić kilka konfliktów charakterystycznych dla tej epoki, gdyż obserwujemy ich początki. Są to:

- Konflikt o prawo do pracy;

- Konflikt o dostęp do informacji $i$ wiedzy;

- Konflikt o interpretacje demokracji.

Konflikt o prawo do pracy wynika z faktu, że dematerializacja pracy stanowi istotę epoki cywilizacji informacyjnej. Co gorsza, wynika ona z mechanizmu ekonomicznego zastępowania pracy przez kapitat (czyli maszyny za ten kapitał kupione). Mechanizm taki działa od początków rewolucji przemysłowej, ale problem w tym, że zawiera on w sobie dodatnie sprzężenie zwrotne: im więcej kapitalista zyska na wprowadzeniu u siebie nowej techniki, tym bardziej jest skłonny dalej inwestować w tę lub podobne techniki.

Zaś procesy $\mathrm{z}$ dodatnim sprzężeniem zwrotnym nieuchronnie, lawinowo przyspieszają. Dzisiaj obserwujemy takie przyspieszenie w mechanizmie zastępowania pracy przez kapitał. Jeśli w okresie luddyzmu pracownik musiał zmieniać zawód jednokrotnie $\mathrm{w}$ ciągu swego życia, to dzisiaj może być wymaganą pięciokrotna zmiana zawodów.

Co gorsza, pracodawcy wykorzystują globalizację - przenoszenie pracy do krajów rozwijających się z żądaniem elastycznego rynku pracy - który jest neoliberalnym sloganem oznaczającym $\mathrm{w}$ rzeczywistości likwidację prawa pracy, możliwość zatrudniania pracowników na dowolnych warunkach ustalonych przez pracodawcę, na ogół nietrwale. Ten sam slogan zastosowano w Polsce.

W rezultacie, poprzez podwójny wpływ globalizacji oraz automatyzacji pracy, następuje wzrost prekariatu, warstwy ludzi nietrwale zatrudnionych. Wraz ze wzrostem swego wykształcenia będą oni coraz silniej występować w obronie swego prawa do pracy na godziwych warunkach. Jeśli jednak nie doprowadzą $\mathrm{w}$ ten sposób do zasadniczej reformy kapitalizmu drogą demokratyczną, to może dojść do rewolucji globalnej organizowanej za pomocą Internetu, która 
przy obecnym nagromadzeniu broni jądrowej oraz wiedzy o jej konstrukcji może zakończyć się zagładą inteligentnej cywilizacji na Ziemi, zob. (Wierzbicki 2015).

Następnym jest konflikt o dostęp do informacji $i$ wiedzy. Twórcy sieci komputerowych i Internetu wierzyli, że umożliwią one pełną demokratyzację tego dostępu. W miarę komercjalizacji Internetu, następuje jednak stopniowo coraz większe ograniczenie tego dostępu przez wielkie korporacje. Używany jest przy tym slogan praw własności intelektualnej: skoro informacja i wiedza są środkiem produkcji, to należy je sprywatyzować, potraktować jako przedmiot własności.

Tymczasem informacja i wiedza od dawien dawna należą też do intelektualnego dziedzictwa ludzkości - zaś prywatyzacja tego dziedzictwa miałaby fatalne skutki dla rozwoju cywilizacji ludzkiej. Powoduje to konflikt pomiędzy społeczną a prywatną (głównie korporacyjną) własnościa wiedzy. Bowiem inicjatywa ustawodawcza w zakresie wzmocnienia ,praw własności intelektualnej” i zwalczania „piractwa sieciowego” pochodzi od wielkich korporacji i obsługujących je prawników, nie od bezpośrednich twórców dzieł kreatywnych.

Zaś interpretacja zasięgu tych praw przyjęta w USA (a następnie w innych krajach) nie jest korzystna dla całego społeczeństwa amerykańskiego i jego kreatywności, tylko leży $\mathrm{w}$ interesie tych wielkich korporacji i powiązanych z nimi firm prawnych. Opinia, wyrażona przez kompozytorów muzyki i piosenkarzy podkreśla, że dobrzy artyści korzystają (na reputacji itp.) z bezpłatnego upowszechniania swych utworów, mogą za to uzyskać wyższe wynagrodzenia na koncertach itp., zatem są przeciwni egzekwowaniu „praw własności intelektualnej”.

Natomiast niezależnie od inicjatyw prawnych, wielkie korporacje opłacają też rozmaite nowe rozwiązania techniczne, które mogą chronić ich „prawa własności intelektualnej”. Rozwiązania te są upowszechniane pod pełną hipokryzji nazwą ,zarządzania prawami cyfrowymi” (digital rights management, DRM) a służą do ograniczania sposobów dostępu i wykorzystania zawartości cyfrowej zasobów sieciowych. Rozwiązań takich jest wiele i służą one do ograniczania wykorzystania filmów, telewizji, dokumentów itp.; mogą mieć formę specjalnych kodów, tzw. znaków wodnych itp. 
Rozwiązania DRM spotkały się też z ostrą krytyką różnych środowisk, także informatyków. Krytykę tę najlepiej wyraża opinia Richarda Stallmana „DRM jest złośliwym dodatkiem - właściwością zaprojektowaną w celu zaszkodzenia użytkownikowi oprogramowania - a więc cechą, dla której nie może być tolerancji”.

Trzeci konflikt dotyczy interpretacji demokracji - czy ma ona być tylko przykrywką dla faktycznych rządów plutokracji, czy też powinna wyrażać interesy najuboższych a najliczniejszych warstw. Można dziś spotkać się z rozmaitymi atakami na pojęcie czy wartość demokracji, zwłaszcza ze strony prawicowej.

Rewolucja informacyjna umożliwia znaczne rozszerzenie demokracji bezpośredniej, głosowania sieciowego różnorodnych kwestii; niektórzy politycy obawiają się, że demokracja bezpośrednia ograniczy ich rolę. Rewolucja informacyjna powoduje oczywiste zjawisko, że specjaliści w zakresie technik informacyjnych poruszają się bardziej swobodnie w świecie Internetu oraz mają lepsze szanse zatrudnienia. Prawicowi socjologowie interpretują to zjawisko jako wyraz netokracji, załamania się demokracji na rzecz warstwowych struktur społecznych, zob. np. (Bard i Sőderqvist 2006). Ataki na demokrację są bardzo różnorodne, poparte argumentami merytokratycznymi (często nieprecyzyjnie zwanymi technokratycznymi), ale wszystkie wyrażają niechęć do uznania prawa głosu najuboższych i wykluczonych.

Z drugiej strony, lewicowe artykuły głoszące „koniec demokracji” (np. Bernd Hamm 2014) ograniczają się do słusznego wprawdzie, ale dość oczywistego stwierdzenia, że silny wzrost nierówności na świecie powoduje koncentrację faktycznej władzy w rękach warstwy najbogatszych.

Jaka jest więc faktyczna wartość demokracji w czasie po rewolucji informacyjnej?

Skoro przyszłe pokolenia staną przed nowymi zagrożeniami i kryzysami, także tymi wynikającymi z rewolucji informacyjnej, to - jak to już zauważył John Rawls (1971) - należy im pozostawić możliwie najbardziej sprawiedliwy system społeczny. Ale argumenty Rawlsa można wzmocnić: różnorodność opinii zapewnia największa odporność systemowa, w obliczu kryzysu lepiej mieć możliwość wysłuchania wielu opinii - i można się spodziewać, że chociaż „punkt widzenia jest określony przez punkt siedzenia”, to jednak opinie ludzi 
najuboższych oraz warstw średnich będą bardziej różnorodne i mniej zdominowane przez ,punkt siedzenia”, niż opinie ludzi najbogatszych.

Podobnie argumentował Paul Baran już w 1960 roku, proponując rozproszenie informacji w systemie sieci komputerowej jako sposób zwiększenia jej odporności - i wykazał większą odporność takiego rozwiązania za pomocą symulacji komputerowej. Zatem demokracja jest zabezpieczeniem systemowym, zapewniajacym większa odporność systemu społecznego w obliczu nieuchronnych kryzysów, które jeszcze przyniesie ze soba rewolucja informacyjna.

\subsection{Megatrendy cywilizacji informacyjnej}

Najbardziej istotnych a długotrwałych cech cywilizacji informacyjnej będziemy poszukiwać w formie megatrendów tej cywilizacji. Megatrend jest pojęciem wprowadzonym przez Johna Naisbitta (1982); tu jednak interpretujemy to pojęcie nieco odmiennie: poprzez megatrendy rozumiemy tu ważne tendencje rozwojowe, utrzymujace się przez dtuższy okres czasu (Naisbitt wymagał, aby to były trendy nowe, ale nie wymagał dlugotrwatości).

Omówiliśmy wyżej przesłanki poglądu, że okres cywilizacji informacyjnej będzie rozciągać się na wiele dziesiątków lat, być może - cały wiek XXI. Megatrendy, omawiane niżej, też mogą rozciągać się na dziesiątki lat. Dzieje się tak dlatego, że występuje zjawisko opóźnienia cywilizacyjnego, że wiele zdobyczy współczesnej nauki i techniki nie jest wdrażane tak szybko, jak by to wynikało $\mathrm{z}$ możliwości nauki czy przyczyn czysto technicznych; opóźnienia $\mathrm{w}$ ich wdrażaniu wynikają $\mathrm{z}$ różnych przyczyn społecznych i ekonomicznych.

Przykładem takiego zjawiska są opóźnienia występujące w omawianych już wcześniej falach rewolucji informacyjnej, które zresztą także mogą być traktowane jako specyficzne megatrendy. Tu jednak będziemy omawiać megatrendy bardziej ogólne. $\mathrm{Za}$ decydujące o rozwoju cywilizacji informacyjnej można uznać trzy megatrendy zasadnicze, z którymi wiąże się wiele trendów pochodnych bądź szczegółowych.

1. Pierwszy $\mathrm{z}$ nich to megatrend zbieżności (convergence) lub integracji technicznej, zwany też popularnie choć nieprecyzyjnie megatrendem cyfryzacji - 
dotyczący mediów, sposobów i systemów przekazu i przetwarzania informacji. Zawiera on $\mathrm{w}$ sobie powszechną cyfryzację tych sposobów przekazu lub przetwarzania, tendencje do wykorzystania komunikacji multimedialnej, tendencje do zapewnienia telekomunikacji mobilnej (których tylko jednym z przejawów jest popularność telefonii komórkowej), tendencje do szybkiego zwiększania przepływności czyli szybkości transmisji w sieciach telekomunikacyjnych, tendencje do integracji nowych usług telematycznych w złożone systemy usługowe itd.

Opiera się on faktycznie na łatwości masowego przetwarzania wszelkich sygnałów i danych w formie cyfrowej (stąd „cyfryzacja”) - ale to tylko jego specyficzna cecha.

2. Druga $\mathrm{z}$ tendencji zasadniczych to społeczny megatrend ksztattowania nowych zawodów, sygnalizowany już wyżej w związku z analizą konfliktów cywilizacji informacyjnej. Przypominamy, że rozwój cywilizacji informacyjnej polega na zastępowaniu starych zawodów, wymagających dużego udziału pracy fizycznej i źle wyposażonych w narzędzia technik informacyjnych, zawodami nowymi, wymagającymi dużego udziału informacji i wiedzy oraz wykorzystującymi w coraz większym stopniu narzędzia technik informacyjnych; następuje więc swoista dematerializacja pracy.

Można przy tym sformułować następujące tezy, wyjaśniające powolność zmian $\mathrm{w}$ kierunku cywilizacji informacyjnej i określające pewne trendy pochodne:

- Ponieważ adaptacyjność ludzka jest ograniczona, kształtowanie się nowych zawodów i zmiany systemów edukacyjnych niezbędne dla wprowadzania tych nowych zawodów są najważniejszym czynnikiem społecznym ograniczającym szybkość rozwoju społeczeństwa czy cywilizacji informacyjnej. Obserwować więc będziemy ważny trend pochodny oporów społecznych przeciw dematerializacji pracy.

- Nowe technologie zawsze powodują możliwości bogacenia się przez tych, którzy potrafią je wykorzystać; ale w początkach epoki cywilizacji informacyjnej jest to zjawisko szczególnie istotne. Jest ono związane z podstawowym mechanizmem systemu kapitalistycznego: zastępowaniem pracy przez kapitał (dokładniej, przez techniki i urządzenia za ten kapitał kupione). Mechanizm ten działa od początków rewolucji przemysłowej, 
ale ma cechę szczególną: zawiera w sobie dodatnie sprzężenie zwrotne (im więcej przedsiębiorca zyska na wprowadzeniu nowej techniki, tym bardziej jest skłonny do dalszego inwestowania $w$ tę technikę lub jej podobne). Zaś procesy $\mathrm{z}$ dodatnim sprzężeniem zwrotnym nieuchronnie przyspieszają.

To, co za czasów luddystów było dość powolne, dzisiaj następuje w bezprecedensowym tempie i skali. Aby ułatwić zastępowanie pracy przez kapitał, przedsiębiorcy domagają się elastycznego rynku pracy - który to slogan oznacza naprawdę prawo do zatrudniania i zwalniania pracowników na dowolnych warunkach korzystnych dla pracodawcy. W rezultacie, megatrend zmiany zawodów wywołuje megatrend pochodny rozwarstwienia społecznego, powstawania nowej warstwy społecznej ludzi zatrudnionych nietrwale lub bezrobotnych, zwanej prekariatem.

Jednak rozwinięta gospodarka rynkowa opiera się na dostatecznie dużej liczbie dość dobrze zarabiających konsumentów, którzy decydują o popycie rynkowym. Nie sposób jest więc ograniczyć społeczeństwo informacyjne tylko do tej (z natury niewielkiej) części populacji, która jest dostatecznie adaptacyjna i umie się szybko nauczyć nowych technik informacyjnych. Warunkiem powodzenia cywilizacji informacyjnej jest więc innowacyjność ludzka w wynajdywaniu nowych zawodów, które pozwolą na zatrudnienie większości, a nie tylko małej części populacji w gospodarce wiedzą.

- Inny megatrend pochodny to megatrend powszechnej poprawy wykształcenia. Ponieważ czekające nas zmiany zawodów będą bardzo głębokie, można przewidywać kilka dziesięcioleci wzrastającego popytu na edukację wszystkich szczebli, ale w szczególności edukację wyższą i podyplomową edukację ustawiczną. Razem z dyskutowanym wyżej megatrendem integracji technicznej, wyrażać się to będzie w trendzie multimedialnej edukacji zdalnej i ustawicznej.

Do tych megatrendów trzeba jeszcze dodać megatrendy demograficzne, częściowo pochodne. Np. ponieważ poziom edukacji wpływa silnie na średnią ilość dzieci w rodzinie, zaś poziom ten jest najniższy w Afryce, przeto Afryka jeszcze przez dziesięciolecia będzie regionem o najwyższym wzroście demograficznym, źródłem presji migracyjnej itp. 
3. Trzeci megatrend zasadniczy to megatrend wyzwań intelektualnych wielkie wyzwania związane ze zmianą sposobu pojmowania świata, niesione przez cywilizację informacyjną. Mechaniczny sposób pojmowania świata jako wielkiej maszyny, kręcącej się z nieuchronnością koła zamachowego zastąpiony będzie sposobem nowym, systemowo-chaotycznym, traktującym świat jako wielki a złożony system dynamiczny, w którym można zaobserwować pewne prawidłowości, ale bardzo prawdopodobne jest również zachowanie chaotyczne, w którym wszystko może się wydarzyć.

Ta zmiana sposobu widzenia świata zaczęła się od Alberta Einsteina i relatywistycznego pojmowania praw fizyki; później jednak decydowało o niej wiele pojęć podstawowych wprowadzonych przez rozwój nauki w XX wieku, między innymi pojęcie sprzężenia zwrotnego i teoria złożonych systemów dynamicznych, która doprowadziła do powstania deterministycznej teorii chaosu - zob. np. (Gleick 1987; istnieje też tłumaczenie polskie). $\mathrm{Z}$ teorią chaosu jest podobnie, jak $\mathrm{z}$ mówieniem prozą: jej zastosowania powstały znacznie wcześniej, niż wykrystalizowała się teoria. Już bowiem przy wykorzystaniu pierwszych komputerów powstał problem generacji liczb pseudolosowych. Rozwiązano go wykorzystując algorytmy, które dziś nazwalibyśmy generatorami chaotycznymi: trzeba poddać liczbę binarną przekształceniu silnie nieliniowemu (np. podnieść tę liczbę do kwadratu, a następnie przywrócić jej początkową długość przez obcięcie części najwyższych i części najniższych bitów), potem zaś powtórzyć to przekształcenie rekursywnie. Algorytm taki daje ciąg liczb okresowy, ale o niezwykle długim okresie powtarzania się; choć jest to ciąg deterministyczny, jego kolejne wyrazy zachowują się w przybliżeniu jak liczby losowe. Teoria chaosu związana jest też z teorią stabilności, katastrof, a nawet z powstawaniem porządku z chaosu, zob. (Wierzbicki 2011).

Wracając do wynikającego stąd sposobu pojmowania świata trzeba podkreślić, że to, co wydawało się naturalne przy starym sposobie pojmowania świata, może być łatwo zakwestionowane $\mathrm{w}$ cywilizacji informacyjnej. Dotyczy to zagadnień całkiem podstawowych - pojmowania rynku, demokracji, praw człowieka itp. 
Trzeba przy tym pamiętać, że podstawą cywilizacji informacyjnej jest dobrze działający, rozwinięty rynek. Na przykład, zmiany strukturalne wywołane postępem cywilizacji informacyjnej wymagają elastyczności i innowacyjności, a więc także intensywnej konkurencji rynkowej. Dlatego też rozwój cywilizacji informacyjnej odbywa się często na drodze liberalizacji rynków - np. telekomunikacyjnych. Zbyt silne działanie opiekuńcze państwa może być niesprzyjające innowacyjności. Nie oznacza to jednak, że wszystko można załatwić poprzez neoliberalny lesseferyzm; jak wykażemy niżej, zbyt słabe działanie regulacyjne państwa na rynkach nowych technologii może z kolei doprowadzić do poważnego kryzysu samych podstaw gospodarki rynkowej.

Popularna jest w Polsce - szczególnie dzisiaj - zasada wolności rynku, nieinterwencjonizmu, czyli neoliberalne przeświadczenie o tym, że rynek działa najlepiej, jeśli się go zostawi samemu sobie. Stosując metody teorii gier do teorii rynku można wykazać, że przeświadczenie to jest wprawdzie uzasadnione, ale przy dwóch bardzo poważnych założeniach, które często nie są $\mathrm{w}$ praktyce spełnione. Pierwsze $\mathrm{z}$ tych założeń dotyczy liczby producentów, która powinna być dostatecznie duża; rynek nie poradzi sobie sam z monopolistami, którzy go zdominują, potrzebna jest regulacja antymonopolistyczna. Drugie założenie dotyczy stabilności równowagi rynkowej: po niewielkich odchyleniach od równowagi, mechanizm rynkowy powinien sam do niej powracać, nie może w sobie zawierać elementów wywołujących destabilizację równowagi. Oba te założenia są dobrze znane w ekonomice klasycznej, ${ }^{2}$ choć często się o nich zapomina. Np. założenie o stabilności rynku było podważane poprzez istnienie cykli koniunkturalnych; później wydało się (niesłusznie, zaprzeczył temu kryzys 2007-8 roku), że cykle te jednak przestały być groźne dla rozwiniętej gospodarki rynkowej, więc też założenie o stabilności mechanizmów samorównoważenia się rynku przyjmowane było jako oczywiste.

\footnotetext{
2 Ważkie jest też założenie trzecie, które jest w ekonomice klasycznej często pomijane: że równowaga rynkowa jest jednoznaczna, nie ma wielu równowag czy też zjawisk katastrofy (przełączania się równowag), które mogą występować przy silnie nieliniowych cechach równoważących się rynków, zob. Rozdziały 11, 12.
} 
Źródłem poważnych zagrożeń dla gospodarki rynkowej w początkach cywilizacji informacyjnej może stać się fakt, że wymienione powyżej dwa założenia sprawnego działania rynku nie muszą być automatycznie spełnione na rynkach związanych $\mathrm{z}$ nową techniką, zwłaszcza $\mathrm{z}$ technikami informacyjnymi. Jest wiele znanych przykładów wykorzystywania nowych technik dla monopolizacji rynku, a także aktualnych przykładów samorzutnego powstawania monopolu na światowych rynkach nowej techniki. Mniej oczywisty jest fakt, że rynki z udziałem nowych technik bywają wewnętrznie niestabilne.

Przytoczymy tu więc przykład największego dziś na świecie rynku - operacji i spekulacji finansowych. Rynek ten rozwinął się znacznie w ostatnim dziesięcioleciu właśnie dzięki sieciom komputerowym i systemom wspomagania decyzji, możliwości bardzo szybkiego przekazywania i przetwarzania dużej liczby informacji finansowych. Operacje finansowe spekulacyjne (tzw. gospodarka wirtualna) przekraczają już ponad stukrotnie swym wolumenem operacje finansowe rzeczowe (gospodarkę realną), czyli związane $\mathrm{z}$ inwestycjami rzeczowymi czy handlem międzynarodowym. Jednocześnie, szybkie przekazywanie dużych zbiorów danych i szybkie ich przetwarzanie, a zwłaszcza konstrukcja dedykowanych systemów wspomagania decyzji, są kosztowne; najwięksi gracze na tym rynku inwestują duże sumy $w$ te narzędzia. Inwestycje te pozwalają największym graczom mieć szybszą informację, a więc sporo zyskać na operacjach finansowych, ale pod jednym warunkiem: jeśli na rynku wystąpią znaczne zmiany lub niestabilności. Można tu więc zadać pytanie: jeśli najwięksi gracze na rynku moga dużo zyskać na niestabilności rynku, to rynek ten będzie stabilny czy niestabilny? Pytanie to jest retoryczne, gdyż udzieliła już na nie odpowiedzi praktyka: światowy rynek spekulacji finansowych staje się coraz bardziej niestabilny, kryzys 2007-2008 był tym właśnie spowodowany, a szykują się kryzysy następne.

Powyższy przykład nie ma bynajmniej na celu uzasadnienia powrotu do interwencjonizmu państwowego w starym stylu (który zresztą nie wystarczyłby do rozwiązania tego nowego problemu). Jest to raczej przykład 
zawodności powszechnie przyjętych sądów, słusznych przy tradycyjnych założeniach, które jednak nie muszą być spełnione wobec zupełnie nowych zjawisk, związanych $\mathrm{z}$ nową techniką informacyjną; jest to przykład megatrendu wyzwań intelektualnych, konieczności ciągłej rewizji utartych poglądów.

Konkurencja rynkowa jest niezbędna dla rozwoju społeczeństwa informacyjnego, nie da się tego społeczeństwa rozwijać w warunkach totalitaryzmu czy nadmiernego interwencjonizmu państwowego. Ale trwałości mechanizmów rynkowych nie można uznawać za dogmat, trzeba tych mechanizmów bronić przed niebezpieczeństwami, które mogą wyniknąć ze spontanicznego rozwoju właśnie technik informacyjnych. Jednym z takich niebezpieczeństw jest właśnie możliwość monopolizacji czy nawet destabilizacji rynków, a czasem wręcz korupcji (oszustw rynkowych) w wyniku zastosowań nowych technik. Innym, chyba jeszcze poważniejszym, jest nadmierne bezrobocie związane ze zbyt liberalnym traktowaniem skutków pierwszego megatrendu zmiany zawodów - i to nie tylko z powodu możliwych konfliktów społecznych, które mogą sprzyjać rozwiązaniom populistyczno-totalitarnym, lecz także z powodu ograniczenia siły nabywczej znacznej części ludności, co może zagrozić nowoczesnej gospodarce rynkowej, opierającej się na masowym popycie - zagrozić deflacją i krachem giełdowym.

Przykłady powyższe tylko w niewielkim stopniu ilustrują megatrend wyzwań intelektualnych. Specjaliści mogą sami dodać tu wiele przykładów: zagrożeń dla demokracji, gdyby system totalitarny wykorzystał nowoczesne techniki informacyjne, czy zagrożeń praw osobistych człowieka, związanych np. z niedostateczną ochroną prywatności i bezpieczeństwa sieci komputerowych, kwestii etycznych, np. związanych z rozwojem biotechnologii itp. 


\section{Literatura}

Poniżej przytaczamy pozycje cytowane w tekście, ale także inne istotne dla przedmiotu tego rozdziału:

Bangemann M., ed. Europe and the Global Information Society: Recommendations to the European Council, European Commission, Brussels 1993

Baran P. (1960) Reliable Digital Communications Systems Using Unreliable Network Repeater Nodes. RAND Corporation papers, document P-995. http://www.rand.org/pubs/papers/P1995.html. Retrieved March 29, 2011

Bard A., Söderqvist J. (2006) Netokracja. Nowa elita władzy i życie po kapitalizmie. Wydawnictwa Akademickie i Profesjonalne, Warszawa

Braudel F. (1992) Kultura materialna, gospodarka i kapitalizm XV-XVIII wiek, PIW, Warszawa

Brundtland H. G., ed. (1988) Our Common Future, raport komisji ONZ

Debreu G. (1956) Theory of Value. Wiley, New York

Drucker P.E.(1993) Post-Capitalist Society, Harper Business, New York

Freeman R.B. (1976) The Over-Educated American, Academic Press, New York

Galbraith J.K. (1992) The Culture of Contentment, Penguin Books, London

Gleick J. (1987) Chaos: Making a New Science. Viking Penguin, New York

Hamm B. (2014) The End of Democracy as We Know It. Information Clearing House, http://www.informationclearinghouse.info/article38441.htm

Harvey D. (2014) Seventeen Contradictions and the End of Capitalism. Oxford University Press, Oxford

Lubacz J., ed. (1999) $W$ drodze do spoleczeństwa informacyjnego, Oficyna Wydawnicza Politechniki Warszawskiej, Warszawa

Masuda Y. (1980) The Information Society and Post-Industrial Society. World Future Society, Washington

Moor R. (2006) Towards the End of Capitalism. http://www.rafi-moor.com/english/TEOCE.htm

Naisbitt J. (1982) Megatrends: Ten New Directions Transforming Our Lives, Warner Books, New York

Rawls J. (1971) A Theory of Justice. Belknap Press, Cambridge, Mass

Stallman R. (2012) http://www.gnu.org/philosophy/right-to-read.html

The Economist (2012) A third industrial revolution. April 21, 2012

Thurow L.C. (1996) The Future of Capitalism, Penguin Books, New York

Toffler A. (1980) The Third Wave, W. Morrow, New York

Urbański J. (2014) Prekariat i nowa walka klas. Instytut Wydawniczy Książka i Prasa, Warszawa

Wallerstein I. (1999) The End of the World As We Know It: Social Science for the Twentyfirst Century. University of Minnesota Press, Minneapolis (thum. polskie Koniec świata jaki znamy, Wydawnictwo Naukowe Scholar, Warszawa 2004)

Wierzbicki A.P. (1988) Education for a New Cultural Era of Informed Reason, in J.G. Richardson, ed: Windows of Creativity and Inventions, Lomond, Mt Airy, Ma.

Wierzbicki A.P. (2011) Techne ${ }_{n}$ : Elementy Niedawnej Historii Technik Informacyjnych i Wnioski Naukoznawcze. Komitet Prognoz „Polska 2000 Plus” oraz Instytut Łączności (PIB), Warszawa

Wierzbicki A.P. (2015) Przyszłość Pracy w Społeczeństwie Informacyjnym. Komitet Prognoz „Polska 2000 Plus” oraz Instytut Łączności (PIB), Warszawa 



\section{Proces decyzyjny i wspomaganie decyzji}

W rozdziale niniejszym przedstawione są podstawowe pojęcia i definicje związane ze wspomaganiem decyzji: pojęcie decyzji, procesu decyzyjnego, wspomagania decyzji, decydenta, systemu wspomagania decyzji. Omówione są też pojęcia modelu sytuacji decyzyjnej, kwestia różnych form reprezentacji wiedzy, typy modeli sytuacji decyzyjnych: preferencyjne i rzeczowe, logiczne i analityczne, dalsze ich podziały, przykłady ogólnych formatów modeli analitycznych. Następnie omówiona jest kwestia reprezentacji niepewności w modelach sytuacji decyzyjnych oraz rola analizy wielokryterialnej modeli analitycznych, wreszcie kwestie suwerenności użytkownika systemu wspomagania decyzji.

\subsection{Definicje podstawowe}

Decyzja nazywamy zwykle wybór pomiędzy wieloma możliwościami, które będziemy nazywać opcjami lub wariantami decyzyjnymi, niezbyt poprawnie zwanymi też alternatywami. Jeśli bowiem chcemy wyrażać się precyzyjnie, to słowo ,alternatywa” oznacza wybór pomiędzy dwiema opcjami; stąd potoczne użycie słowa ,alternatywa” w sensie „opcja” nie jest poprawne.

Osobę podejmującą decyzję nazywamy zwykle decydentem; nazwa ta jednak jest do pewnego stopnia myląca, gdyż sugeruje decydenta $\mathrm{w}$ pełni niezależnego i ostatecznego. Dlatego też przy komputerowym wspomaganiu decyzji mówimy raczej o użytkowniku systemu wspomagania, gdyż w rzeczywistości użytkownik taki może być tylko projektantem a ostateczny decydent będzie zatwierdzał cały projekt - czy analitykiem, który powinien przedstawić ostatecznemu decydentowi pogłębioną analizę tzw. sytuacji decyzyjnej, czyli problemu decyzyjnego ze wszystkimi jego cechami szczegółowymi.

Problem przygotowania i podejmowania decyzji jest bowiem zazwyczaj znacznie bardziej złożony, niż - jak by to sugerowała powyższa uproszczona 
definicja decyzji - sam problem wyboru pomiędzy danymi opcjami. Początkowo zazwyczaj nie znamy opcji decyzyjnych, musimy sami je przygotować czyli generować; sam problem przygotowania opcji decyzyjnych jest często złożony i zazwyczaj bardziej czasochłonny niż problem wyboru. Zanim jednak przystąpimy do przygotowania opcji, często wręcz nie wiemy nawet, na czym dokładnie nam zależy.

Z powyższych powodów Herbert Simon (1957) wprowadził pojęcie procesu decyzyjnego; definicja Simona tego procesu obejmowała trzy etapy:

1) Rozpoznanie problemu (intelligence),

2) Modelowanie problemu (design),

3) Wybór (choice).

Później wielu autorów zwracało uwagę, że podział taki też jest zbyt ogólny, wyróżniano wiele etapów szczegółowych. Możliwe są też zupełnie inne podziały etapów procesu decyzyjnego, które przedstawimy jeszcze w dalszych wykładach. Tu trzeba tylko dodać, że Simon nie wyróżnił ${ }^{1}$ w swym podziale bardzo ważnego, często decydującego etapu końcowego:

4) Realizacja i nadzór (implementation and monitoring).

W etapie tym możemy też dokonywać modyfikacji decyzji na zasadzie sprzężenia zwrotnego, czyli obserwacji skutków decyzji, zob. np. (Lewandowski et al. 1989). Zaletą podejścia Simona jest jednak to, że zwrócił on jako pierwszy odpowiednią uwagę na rolę uczenia się, adaptacji, zmiany poglądów w procesie decyzyjnym; problematyka ta nawet do dzisiaj nie jest dostatecznie silnie doceniana w bardziej teoretycznych podejściach do podejmowania decyzji, opartych czy to na sztucznej inteligencji czy na klasycznej teorii decyzji i gier.

Można podać bardzo wiele przykładów procesów decyzyjnych, tu wymienimy tylko kilka. Dla inżyniera typowym procesem decyzyjnym jest projektowanie. Dla przedsiębiorcy można rozpatrywać różnorodne procesy zarządzania (np. alokacja wydatków inwestycyjnych). W zakresie ochrony środowiska mamy wiele przykładów procesów decyzyjnych: obok alokacji wydatków inwestycyjnych $\mathrm{z}$ celem poprawy określonych wskaźników jakości środowiska, można też rozpatrywać efekty polityki

\footnotetext{
${ }^{1}$ Chociaż dodał $\mathrm{w}$ dalszych publikacjach etap czwarty review, co może sugerować przegląd rezultatów.
} 
środowiskowej danej grupy krajów na ponadgraniczny transfer zanieczyszczeń atmosferycznych itp.

Większość z takich procesów ma charakter wielokryterialny, czyli nie ma w nich jednego wskaźnika, którego optymalizacja zapewniłaby decyzje najlepsze. Na przykład, w procesie projektowania inżynier usiłuje zwykle znaleźć kompromis pomiędzy kilkoma wskaźnikami, takimi jak niezawodność i inne cechy jakości, a z drugiej strony koszty, waga, objętość urządzenia itp. Ta kwestia poszukiwania kompromisu jest głównym aspektem podejmowania decyzji i poświęcimy jej wiele uwagi w tej książce.

Większość procesów decyzyjnych ma także charakter dynamiczny. Możemy przy tym wyróżnić kilka zasadniczych aspektów dynamiki procesu decyzyjnego:

a) Dynamika procesu decyzyjnego może dotyczyć początkowej niepewności co do preferencji decydenta czy użytkownika, które podlegają stopniowej krystalizacji w trakcie takiego procesu; mówimy wtedy o procesie decyzyjnym z dynamika ksztaltowania preferencji.

b) Zjawiska podlegające decyzjom mogą mieć dynamiczny charakter:

- Dotyczyć to może samych decyzji (wraz z ich skutkami) - możemy np. mówić o decyzjach dwuetapowych (wstępnych, a następnie uzupełniających po zaobserwowaniu skutków decyzji wstępnych), lub też wieloetapowych, czyli powtarzalnych.

- Dotyczyć to też może nie tyle decyzji, co ich skutków, które mogą rozkładać się w czasie; wieloetapowy jest wtedy model skutków decyzji, którą podejmuje się tylko na jednym etapie.

Na przykład, przy alokacji wydatków inwestycyjnych rozpatruje się ich skutki nie tylko w najbliższym roku, ale także w kilku latach następnych; jest to więc problem decyzji jednokrotnej z wieloetapowymi skutkami (który można dalej skomplikować, wprowadzając także wieloetapowość decyzji, poprzez rozpatrywanie problemu wieloletniej alokacji wydatków). Wieloetapowość decyzji lub ich skutków też w pewnym stopniu upraszcza dynamikę procesów decyzyjnych, gdyż moglibyśmy uważać, że w istocie decyzje czy ich skutki należy rozpatrywać nie w czasie dyskretnym o dużych okresach czasu (jak lata czy miesiące), ale dostatecznie gęsto w czasie, czy nawet $w$ czasie ciagtym. Takie modele $\mathrm{z}$ czasem ciągłym dotyczą jednak zazwyczaj pewnych problemów technicznych $\mathrm{w}$ teorii sterowania i automatyce (gdyż sterowanie też nie jest niczym innym, jak decyzją - zmienną i rozłożoną w czasie). 
Zauważmy, że im bardziej skomplikowany jest proces i sytuacja decyzyjna, tym bardziej dla ich analizy potrzebujemy ich modelu decyzyjnego. Model taki może oczywiście nie być dany z góry, ale - zgodnie z wynikami prac Simona - powstawać w trakcie wstępnych etapów procesu decyzyjnego, być wynikiem procesu uczenia się decydenta czy analityka. Analiza takich modeli może być sama $\mathrm{w}$ sobie zadaniem złożonym, do którego niezbędne jest wykorzystanie komputerów.

Współczesne możliwości technologii komputerowej pozwalają oczywiście wykorzystać komputerowe wspomaganie procesu decyzyjnego; ale zrozumienie, czym ma być takie wspomaganie, kształtowało się znacznie wolniej od samych możliwości współczesnych komputerów. Problem ten związany jest z paradygmatycznym charakterem rozwoju teorii decyzji, co przedyskutujemy bardziej szczegółowo w rozdziale następnym. Tu jednak trzeba podkreślić, że klasyczne rozumienie komputerowego wspomagania decyzji koncentrowało się początkowo bardziej na automatyzacji decyzji, czyli faktycznie zastępowaniu człowieka przez komputer w podejmowaniu decyzji. Jest wprawdzie wiele sytuacji, w których automatyzacja decyzji jest pożyteczna czy wręcz niezbędna (jak w przypadku decyzji powtarzalnych i monotonnych, w których chwila nieuwagi może mieć poważne skutki). Jednakże, jest równie wiele sytuacji, w których automatyzacja decyzji powoduje alienację, poczucie wyobcowania człowieka. Wszelkie systemy komputerowe, powodujące nadmierną alienację ich użytkowników poprzez nadmierną automatyzację decyzji, mają po prostu ograniczony popyt rynkowy. Dlatego też stopniowo rozwinęły się inne podejścia, polegające na interaktywnym wspomaganiu decyzji, w których decydenta czy użytkownika systemu wspomagania decyzji traktuje się jako suwerenny, nadrzędny podmiot.

Zastosowania komputerów początkowo koncentrowały się głównie nie na wspomaganiu decyzji, tylko przetwarzaniu danych. Stąd koncentracja uwagi najpierw na różnorodnych bazach danych, potem zaś - wraz ze wzrostem objętości przetwarzanych danych - na hurtowniach (sktadnicach) danych. Dopiero nadmierna objętość współczesnych zbiorów danych ${ }^{2}$ i trudność

\footnotetext{
${ }^{2}$ Ilość danych przechowywanych w pamięciach komputerów rośnie z szybkością wynikającą z szybkości wzrostu liczby komputerów na świecie mnożonej przez szybkość wzrostu pojemności pamięci przeciętnego komputera; ocenia się, że w roku 2020 ilość ta osiągnie 20 zettabajtów, czyli $2 * 10^{22}$ bajtów. Przetwarzanie tak wielkiej ilości danych wiąże się z problematyką big data (wielkich zbiorów danych), chmur obliczeniowych itp.
} 
wyszukiwania danych istotnych dla danego problemu decyzyjnego spowodowały, że wielcy producenci oprogramowania zaczęli wprowadzać choć na początku raczej hasłowo - aspekty wspomagania decyzji do swoich systemów przetwarzania danych. Z drugiej strony, komputerowe wspomaganie decyzji ma już długą historię - od końca lat 70. - choć jego zastosowania ograniczały się raczej do zagadnień specjalnych, niekomercyjnych. W szczególności, były to zastosowania wojskowe. Wielu specjalistów uważa, że szybkie zwycięstwo wojsk Stanów Zjednoczonych i NATO w wojnie w Zatoce Perskiej w początkach lat 90. wynikało głównie z szerokiego zastosowania komputerowego wspomagania decyzji. Jednak dopiero po tej wojnie pojawiły się szersze zastosowania komercyjne systemów wspomagania decyzji - SWD, po angielsku decision support systems - DSS.

Początkowo, przy wspomaganiu decyzji koncentrowano się na etapie wyboru; szybko jednak okazało się, że jeszcze bardziej istotne jest wspomaganie wcześniejszych etapów procesu decyzyjnego i uczenia się w trakcie tego procesu. Podobnie, początkowo - jak już wspominaliśmy - koncentrowano się bardziej na automatyzacji decyzji niż ich wspomaganiu. Kwestia stopnia automatyzacji decyzji jest niezwykle istotna we wspomaganiu decyzji. Sytuacje decyzyjne możemy bowiem - z punktu widzenie charakteru podejmowanych w nich decyzji - podzielić na takie, w których podejmowane są:

- Decyzje powtarzalne, operacyjne, w których decyzje mogą i często powinny być automatyzowane; cała automatyka i wiele dziedzin współczesnej elektroniki (np. techniki pomiaru) związane są w pewnym stopniu z automatyzacją decyzji operacyjnych.

- Decyzje istotnie nowe, strategiczne, niepowtarzalne, leżące niejako na drugim krańcu spektrum. W przypadku decyzji strategicznych decydenta trzeba wspomagać, ale nie zastępować; do tego typu decyzji należy większość decyzji administracji państwowych i politycznych, z przykładów bardziej technicznych należy też do nich często projektowanie inżynierskie.

Jest wiele przypadków pośrednich pomiędzy powyższymi, do pewnego stopnia skrajnymi typami sytuacji decyzyjnych (gdyż może być wiele sytuacji pośrednich pomiędzy decyzjami powtarzalnymi a niepowtarzalnymi). Jednakże, mówiąc dzisiaj o wspomaganiu decyzji, na ogół rozumie się przez to nie automatyzację, ale proces interaktywny (dialogowy), w którym decydent odgrywa rolę istotną i suwerenną. 
Podobnie ważną kwestią, jak podział typów sytuacji decyzyjnych, jest podział typów decydentów. Może być tak wiele rodzajów decydentów, jak różnorodne mogą być zawody, role społeczne i nastawienia psychiczne ludzi. Niekiedy mają oni nastawienie pasywne i wolą, aby komputer podejmował decyzje za nich; $w$ innej sytuacji nadmierna ingerencja komputera $\mathrm{w}$ ich prerogatywy decyzyjne będzie decydentów złościć lub co najmniej denerwować. Decydent polityczny wysokiego szczebla z natury rzeczy (jako ekspert w intuicyjnym podejmowaniu decyzji, wybrany na to stanowisko właśnie z powodu tych umiejętności, patrz rozdział następny o roli intuicji) będzie nieufny do systemów wspomagania decyzji. Natomiast analityk, czyli osoba przygotowująca materiał do procesu decyzyjnego wysokiego szczebla, będzie stale wykorzystywał komputerowe wspomaganie decyzji, ale raczej do generacji i wstępnej analizy różnych opcji decyzyjnych, niż do końcowego wyboru. Dlatego też mówiąc tu często o użytkowniku systemu wspomagania decyzji, rozumieć będziemy przez to raczej analityka lub projektanta, niż faktycznego decydenta wysokiego szczebla. Na niższych szczeblach decyzyjnych, funkcje te oczywiście często się łączą.

Wraz z pogłębianiem się doświadczeń komputerowego wspomagania decyzji zmieniały się też poglądy na definicję systemu wspomagania decyzji i na jego części składowe i funkcje. Stephen Andriole jeszcze w 1989 r. pisał tak: "Wspomaganie decyzji (...) dotyczy jakichkolwiek i wszystkich aspektów danych, informacji, ekspertyzy i działań, które wpływają na wybór opcji." To prawda, ale ograniczenie tej definicji tylko do fazy wyboru opcji lub wariantu decyzyjnego jest zbyt zawężające. Trzeba tu dodać, że w języku polskim używa się zwykle słowa "ekspertyza" w sensie opinii opracowanej przez eksperta; rzadziej używa się tegoż słowa w sensie wiedzy popartej doświadczeniem, czyli wiedzy eksperta. Ten drugi sens słowa "ekspertyza" będzie często wykorzystywany w tej książce.

Bernard Roy (1990) spogląda na sprawę znacznie szerzej, wprowadzając m.in. pojęcie różnych problematyk wspomagania decyzji - przez co rozumie zagadnienia, na których trzeba się koncentrować przy danym typie sytuacji decyzyjnej. Do kwestii tej powrócimy w dalszych wykładach. Opierając się na obserwacjach Roya, przyjmiemy tu jednak jeszcze nieco odmienne, ogólniejsze spojrzenie na problematykę wspomagania decyzji, uwzględniające w większym stopniu dynamikę procesów decyzyjnych, zwłaszcza w sensie dynamiki kształtowania preferencji. Dlatego też będziemy stosować jeszcze nieco szerszą definicję systemu wspomagania decyzji: 
System wspomagania decyzji SWD (DSS, Decision Support System) jest zbiorem narzędzi komputerowych wspomagających użytkownika $\mathrm{w}$ organizacji i prowadzeniu interaktywnego procesu decyzyjnego.

Interpretując tę definicję, trzeba sobie odpowiedzieć na pytanie, w czym to trzeba głównie wspomagać użytkownika? Niewątpliwie, wspomaganie dotyczy zbierania, organizacji i przetwarzania danych istotnych dla danej sytuacji decyzyjnej, ale czy wyłącznie? Czy mamy też wspomagać użytkownika w rozpoznaniu problemu decyzyjnego w sensie poznania samego siebie, czyli zrozumienia własnych preferencji, czy też w sensie organizacji, przetwarzania i wykorzystania wiedzy o otaczającym świecie $\mathrm{w}$ danej sytuacji decyzyjnej?

Rozróżnienie powyższe związane jest z typami modelu sytuacji decyzyjnej. W modelu tym okazało się celowe wyróżnienie dwóch przynajmniej części:

- modelu preferencji (preferencyjnego), który mniej lub bardziej dokładnie reprezentuje preferencje użytkownika, oraz

- modelu rzeczowego, reprezentującego wiedzę o otaczającym świecie istotną dla danej sytuacji decyzyjnej.

Klasyczna teoria decyzji nie wprowadzała takiego rozróżnienia i koncentrowała się głównie na modelach preferencji; praktyka wspomagania decyzji wskazała na znaczenie modeli rzeczowych i konieczność jasnego rozróżnienia pomiędzy tymi rodzajami modeli.

Zarówno przetwarzanie danych, jak i analiza modeli sytuacji decyzyjnych wymagają odpowiednich algorytmów - których w systemie wspomagania decyzji może być wiele, stosownie do wielu faz procesu decyzyjnego i do różnorodności stosowanych modeli. Prowadzi to do nieco bardziej specyficznej definicji systemu wspomagania decyzji:

System wspomagania decyzji to system komputerowy - bardziej w sensie środowiska oprogramowania, niż konkretnej konfiguracji sprzętowej wspomagający użytkownika $w$ racjonalnej organizacji $i$ prowadzeniu procesu decyzyjnego (lub jego wybranych faz) i zawierajacy, obok bazy danych, także reprezentacje wiedzy istotnej dla podejmowania danej klasy decyzji $w$ formie bazy modeli sytuacji decyzyjnych (rzeczowych i preferencyjnych), a także bazę algorytmów dla przetwarzania $i$ wykorzystania tych danych oraz modeli. Istotna częściq systemu jest tez odpowiedni 
interfejs użytkownika, pomocny nie tylko $w$ organizacji wymiany informacji pomiędzy użytkownikiem a komputerem, lecz także w organizacji i prowadzeniu procesu decyzyjnego.

Definicja powyższa odpowiada ogólnemu schematowi struktury systemów wspomagania decyzji, przedstawionemu na poniższym rysunku.

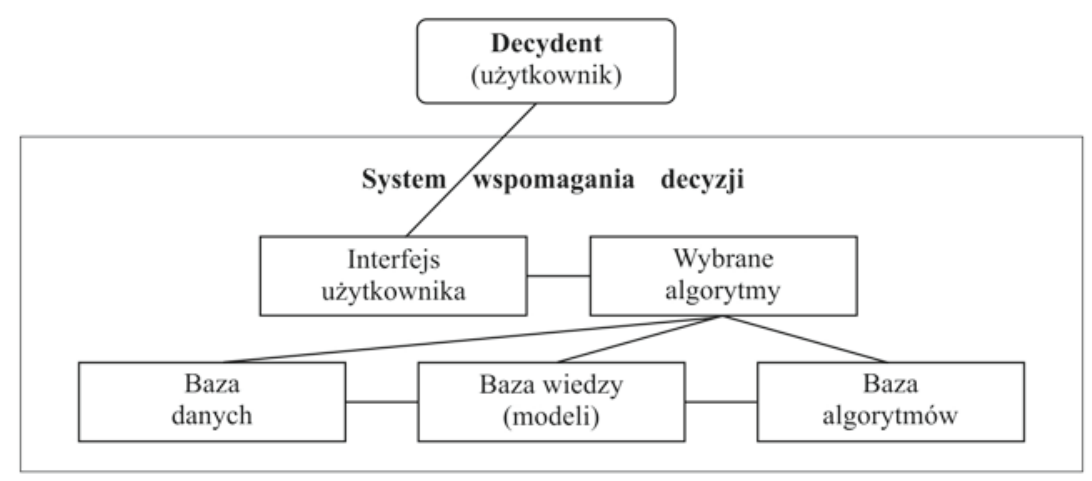

Rys. 2.1. Ogólny schemat systemu wspomagania decyzji

W schemacie tym, obok bazy danych, modeli i algorytmów, wyróżniono też wspomniany w definicji interfejs użytkownika - zwykle graficzny i dostatecznie inteligentny, aby użytkownik mógł z nim dobrze współpracować, zawierający też (niekiedy, choć nie zawsze jako wyodrębniony moduł) część odpowiedzialną za organizację procesu decyzyjnego. W bardziej typowych zastosowaniach komputerów dominują interfejsy narzucające użytkownikom pewne symbole i ergonomię uniwersalną opracowaną przez konstruktorów takich systemów (jak np. w standardach ikon MS-Windows). Praktyka systemów wspomagania decyzji wskazuje natomiast, że interfejsy takie trzeba opracowywać wspólnie $\mathrm{z}$ użytkownikiem, specjalistą $\mathrm{w}$ danej dziedzinie. Każda bowiem specjalność czy dziedzina wiedzy ma typowy dla niej język symboli graficznych (inny dla projektowania mostów, inny dla automatyki, inny dla projektowania układów scalonych, inny wreszcie dla zarządzania flotyllą statków). Dobry, specjalizowany system wspomagania decyzji musi to uwzględniać, winien być opracowany we współpracy z przyszłymi jego użytkownikami - i to nie tylko (choć szczególnie) w zakresie interfejsu użytkownika, lecz także wszystkich innych jego modułów. Dlatego też dobre, wypróbowane systemy wspomagania decyzji dla niektórych zastosowań mogą być bardzo kosztowne. Jednakże ostatecznie płaci za niego użytkownik, który w systemie wspomagania decyzji powinien mieć rolę nadrzędną - tak jak na powyższym rysunku. 
Jeśli zapytać, który element powyższej definicji i schematu decyduje o tym, że dany system czy środowisko oprogramowania można nazwać systemem wspomagania decyzji, to okazuje się, że najbardziej istotne jest - obok samego faktu wspomagania decyzji - uwzględnienie modelu lub modeli sytuacji decyzyjnej. Na przykład, prosty elektroniczny arkusz kalkulacyjny nie jest sam systemem wspomagania decyzji. Jeśli jednak przystosujemy go np. do potrzeb księgowego czy analityka finansowego - tak, by obliczał bilanse i inne wielkości ekonomiczne według kategorii i wzorów wyrażających doświadczenie tej dziedziny - to tym samym zawrzemy w nim modele sytuacji decyzyjnych, typowych dla tej dziedziny. I choć modele te mogą być bardzo proste i zwykle nie zawierają modeli preferencji, to jednak tak przystosowany arkusz kalkulacyjny jest już prostym systemem wspomagania decyzji.

\subsection{Rodzaje modeli sytuacji decyzyjnej}

Różne rodzaje modeli preferencyjnych, stanowiące przedmiot teorii decyzji, będą omawiane jeszcze szczegółowo w dalszych wykładach. Mogą one być mniej lub bardziej szczegółowe - np. w postaci funkcji wartości czy użyteczności - lub też ogólne ale mniej dokładne, wyrażające tylko ogólne aspekty preferencji użytkownika - jak np. porządek częściowy typu Pareto czy procedury rankingu. Wprawdzie modele te stanowią podstawę dobrego zrozumienia, czym jest teoria i wspomaganie decyzji, to jednak trzeba być ostrożnym $\mathrm{w}$ ich stosowaniu. Jeśli bowiem położymy zbyt duży nacisk na szczegółowe modelowanie preferencji użytkownika, to możemy naruszyć zasadę jego nadrzędnej roli $\mathrm{w}$ systemie wspomagania decyzji: system ten będzie wtedy zbytnio automatyzował decyzje, zastępował w nich użytkownika. Jeśli użytkownik tego właśnie sobie życzy, to dobrze; ale często zdarza się, że użytkownik oczekuje zupełnie innego rodzaju wspomagania od systemu.

Szczególnie istotne dla wspomagania decyzji są modele rzeczowe, reprezentujące wiedzę o otaczającym świecie: jeśli są sformułowane przez dobrych specjalistów i analityków, mogą istotnie wspomagać rozumowanie i intuicję użytkownika. Są dwie zasadnicze klasy takich modeli. W systemach eksperckich i sztucznej inteligencji stosuje się też pojęcie bazy wiedzy odpowiadające temu, co tu nazywamy ogólniej bazą modeli (wykorzystującą bazę danych i bazę wiedzy); maszyna wnioskująca należałaby wtedy do bazy algorytmów. Modele tego typu, jakie są zawarte w typowej bazie wiedzy, nazwiemy modelami logicznymi. 
Teoretycznie, każdą inną postać modelu - np. równania układu elektronicznego - można sprowadzić do postaci logicznej. Jednakże praktyka wskazuje, że eksperci danej dziedziny często myślą w kategoriach modeli analitycznych właściwych tej dziedzinie - i między innymi dlatego bardzo trudno jest od nich uzyskać reguły logiczne, mające wyrazić ich ekspertyzę w logicznej formie bazy wiedzy. Zmuszony do rozumowania w twardych logicznych kategoriach, ekspert często traci swą fachową intuicję (patrz wykład następny, gdzie przedstawiono racjonalne wyjaśnienie rozróżnienia między logiką dwuwartościową a intuicją). Jednym ze sposobów wykorzystania intuicji eksperta jest odejście od logiki twardej ("tak lub nie") i stosowanie logiki rozmytej, wielowartościowej ("do pewnego stopnia") lub przybliżonej, trójwartościowej (z trzecią wartością logiczną "być może" lub "na granicy tak lub nie") w interakcji eksperta z komputerem; zagadnienia te omówimy w dalszych wykładach.

Choć modele logiczne wiedzy mają wiele zalet, to mają też jedną podstawową wadę. Gdyby próbować wyrazić w formie logicznej pełną złożoność wiedzy, wyrażoną zwykle w formie modeli analitycznych, to pojawia się problem eksplozji złożoności - model, który w formie analitycznej ma tradycyjne, choć często tylko przybliżone metody jego rozwiązywania i wykorzystania, w formie logicznej staje się niejako zbyt precyzyjny i wymaga znacznie większego nakładu obliczeniowego. Dlatego też, choć modele logiczne i systemy eksperckie stanowią dziś ważną część zagadnień wspomagania decyzji, to jednak główną uwagę w tym wykładzie skoncentrujemy na wykorzystaniu różnorodnych modeli analitycznych dla wspomagania decyzji.

Różnorodność modeli analitycznych, opisujących wiedzę fachową w rozmaitych dziedzinach, jest tak duża, że trudno je konsekwentnie sklasyfikować. Tym niemniej, możemy je ogólnie podzielić na:

- dyskretne (systemy zdarzeń dyskretnych, teoria kolejek, sieci Petri itp.);

- ciagłe (liniowe, nieliniowe, dynamiczne itp.);

- mieszane, które najczęściej występują w praktyce, ale są trudniejsze do analizy (stąd staramy się zazwyczaj, aby wykorzystać modele ciągłe lub dyskretne).

Wspomnieliśmy także, że sytuacje decyzyjne mają często charakter dynamiczny i wymagają oceny zdarzeń przyszłych; choć możemy też dla nich stosować w uproszczeniu modele statyczne, to jednak bardziej adekwatne są 
często modele dynamiczne (opisywane równaniami różnicowymi, różniczkowymi zwyczajnymi czy cząstkowymi, różnicowo-różniczkowymi, całkowymi).

W innym przekroju klasyfikacji modeli, z punktu widzenia optymalizacji który jest szczególnie istotny dla wspomagania decyzji - możemy każdy model traktować jako:

- jednokryterialny, z jedną skalarnie optymalizowaną funkcją celu (zakładając, że dobrze wiemy, czego oczekujemy i co chcemy optymalizować); lub:

- wielokryterialny, z kilkoma wektorowo optymalizowanymi rezultatami decyzji (biorąc pod uwagę kilka wielkości, które mogą być optymalizowane w modelu).

Doświadczenia wspomagania decyzji wskazują przy tym wyraźnie, że każdy proces decyzyjny jest $\mathrm{w}$ swojej naturze wielokryterialny czy wielocelowy: w poszczególnych jego fazach kryteria i cele mogą się wprawdzie zmieniać czy agregować, ale jest ich niemal zawsze wiele. Natura ludzka dąży wprawdzie do uproszczeń, łatwiej jest analizować problemy jednokryterialne, i duża część teorii decyzji dotyczy sposobów agregacji wielu kryteriów czy celów w jeden; ale pełne zrozumienie procesów decyzyjnych wymaga ich wielokryterialnej analizy. Stąd dużą uwagę $\mathrm{w}$ tej książce poświęcimy wielokryterialnej (inaczej wektorowej) optymalizacji decyzji, a także wielokryterialnej analizie modeli rzeczowych sytuacji decyzyjnych.

Mimo takich doświadczeń praktycznych, teoria optymalizacji wektorowej jest bardziej złożona od teorii optymalizacji skalarnej, i w większości podręczników optymalizacji ${ }^{3}$ jest zazwyczaj pomijana lub wykładana w wielkim uproszczeniu. Rezultatem tego jest, że ukształtował się swoisty paradygmat optymalizacji skalarnej - a za nim nawet standardy zapisu modeli rzeczowych sytuacji decyzyjnych. W większości języków modelowania określa się standardy zapisu modeli, dobre dla zadań optymalizacji skalarnej $\mathrm{z}$ jedną, z góry ustaloną optymalizowaną funkcją celu. Tymczasem zadania praktyczne wymagają często bądź to zmiany funkcji celu, bądź optymalizacji wektorowej, bądź wreszcie wstępnej symulacji przed optymalizacją;

\footnotetext{
${ }^{3}$ Zakładamy przy tym w tej książce, że Czytelnik jest przygotowany w zakresie metod optymalizacji jednokryterialnej czy metod badań operacyjnych; jako dobry podręcznik można tu polecić książkę Ogryczak (1989), lub książkę Stachurski et al. (1999).
} 
wymagania takie narzucają wręcz odmienne standardy zapisu modeli, niezbyt jeszcze rozwinięte.

Jednym z ważniejszych aspektów bądź kryteriów, niemal zawsze występującym w procesach decyzyjnych, jest stopień niepewności co do rezultatów decyzji. Dlatego też w każdym rodzaju modeli (preferencyjnych czy rzeczowych, logicznych czy analitycznych) bardzo istotnym aspektem jest sposób reprezentacji niepewności. Gdybyśmy byli pewni, co się zdarzy W przyszłości, podejmowanie decyzji znacznie by się uprościło. W istocie, klasyczna teoria decyzji rozwinęła się początkowo jako dział probabilistyki czy statystyki, i modele probabilistyczne czy stochastyczne mają do dziś ważne miejsce we wspomaganiu decyzji. Zakładamy przeto, że czytelnik jest dość dobrze przygotowany w podstawach probabilistyki i statystyki, gdyż sformułowania probabilistyczne będą niekiedy wykorzystywane w tej książce.

Jednakże - tak jak już wspomnieliśmy w poprzednim rozdziale - w ciągu ostatnich dziesięcioleci wiele zmieniło się we współczesnym pojmowaniu świata. Pojęcie procesu chaotycznego - praktycznie nieprzewidywalnego zachowania się nawet dość prostych systemów deterministycznych, zob. rozdział poprzedni - spowodowało, że nie jesteśmy już pewni, czy wszechświat jest indeterministyczny, czy też może cała probabilistyka to tylko dogodniejszy, zagregowany i elegancki matematycznie sposób opisu zjawisk, które $\mathrm{w}$ istocie są chaotyczne? Ostatecznie, nawet w komputerze modelujemy zjawiska przypadkowe przez generatory liczb losowych, które naprawdę są tylko pseudolosowe i ich mechanizm działania to typowy proces chaotyczny. $Z$ tego i innych powodów modele probabilistyczne traktowane są dziś jako tylko jeden ze sposobów reprezentacji niepewności, zwłaszcza przy podejmowaniu decyzji.

Niektóre $\mathrm{z}$ innych modeli niepewności będą też omawiane bardziej szczegółowo w tej książce. Należą do nich np.:

zbiory rozmyte, reprezentujące logikę nieskończenie wielowartościową typu "prawdziwe do pewnego stopnia", które stały się popularne począwszy od prac Lofti Zadeha, zob. np. (1978), choć teoria logiki wielowartościowej jest starsza (Jan Łukasiewicz 1911);

zbiory przybliżone Zbigniewa Pawlaka, reprezentujące logikę trójwartościową typu "tak, nie, jeszcze nie wiem" (lub "prawda, nieprawda, na pograniczu prawdy"), zob. np. Pawlak (1991);

metody przedziałowe reprezentacji niepewności wraz z analizą wrażliwości; 
i wiele innych. Jak już wspomnieliśmy, zbiory rozmyte nadają się szczególnie dobrze do opisu niepewności decydenta co do jego preferencji.

Ponieważ w książce tej będziemy konsekwentnie wykorzystywać rozróżnienie pomiędzy modelem rzeczowym a modelem preferencji w danej sytuacji decyzyjnej, podamy tu jeszcze typowe oznaczenia, które stosować będziemy w odniesieniu do tych modeli. Typową strukturę części rzeczowej i preferencyjnej modelu sytuacji decyzyjnej przedstawia Rys. 2.2.

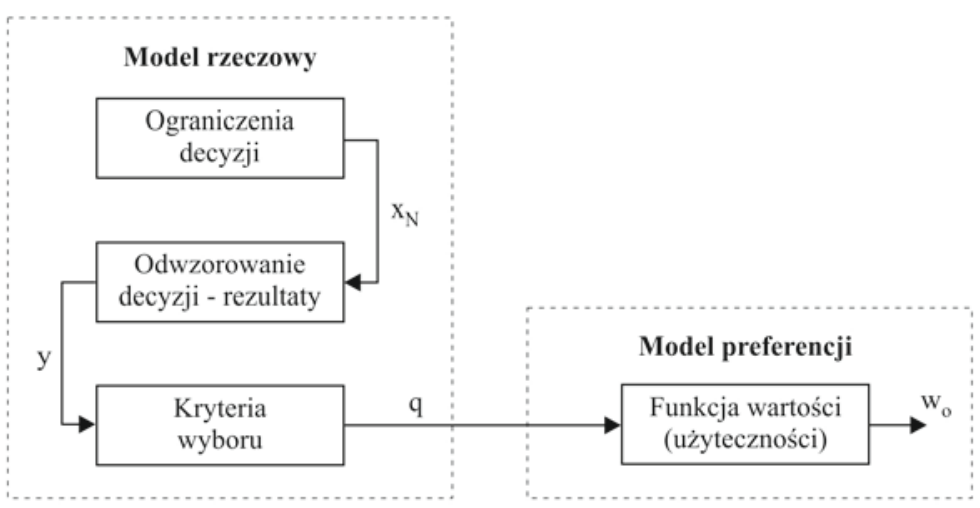

Rys. 2.2. Uproszczony schemat modelowania sytuacji decyzyjnej

Model rzeczowy, oprócz odwzorowania decyzje-skutki, obejmuje też ograniczenia dopuszczalności decyzji - w różnorodnej formie, ogólnie reprezentowanej przez zbiór decyzji dopuszczalnych $\boldsymbol{X}_{\mathbf{0}}$. Wyróżniamy przy tym:

- $\boldsymbol{X}$ - przestrzeń decyzji $\boldsymbol{x}$ (dowolnego rodzaju, choć dla uproszczenia będziemy przyjmować $\boldsymbol{x} \in \boldsymbol{X}=\boldsymbol{R}^{n}$, które w przypadku dyskretnym nazywane są też wariantami decyzyjnymi lub opcjami;

- $\boldsymbol{X}_{\mathbf{0}} \subset \boldsymbol{X}-$ zbiór decyzji (wariantów, czy opcji w przypadku dyskretnym) dopuszczalnych;

- $\boldsymbol{Y}$ - przestrzeń rezultatów $\boldsymbol{y}$, czyli skutków decyzji - znów różnorodnego rodzaju, zazwyczaj jednak przyjmuje się $\boldsymbol{y} \in \boldsymbol{Y}=\boldsymbol{R}^{m}$ (choć często znaczenie jako skutki decyzji mają też pewne charakterystyki lub trajektorie projektowanego systemu, które mogą być reprezentowane jako elementy przestrzeni nieskończeniewymiarowej), w przypadku dyskretnym zwana też przestrzenią atrybutów; 
- $\boldsymbol{Q} \subset \boldsymbol{Y}$ - przestrzeń jakości, czyli kryteriów lub wskaźników jakości $\boldsymbol{q}=S(\boldsymbol{y})$, gdzie $S$ reprezentuje selekcję pewnych rezultatów jako kryteriów, stąd często $\boldsymbol{q} \in \boldsymbol{Q}=\boldsymbol{R}^{k}, k \leq m$, a więc przestrzeń jakości stanowi podprzestrzeń przestrzeni rezultatów; będziemy ją niekiedy utożsamiać z przestrzenią rezultatów, choć to świadome uproszczenie;

- $\boldsymbol{f}: \boldsymbol{X} \rightarrow \boldsymbol{Y}$ - odwzorowanie decyzje-skutki, lub $\boldsymbol{F}: \boldsymbol{X} \quad \boldsymbol{Q}$-odwzorowanie decyzje-kryteria, które powinno zawierać też reprezentację wpływu niepewności (przypadkowości, chaosu, rozmytości) na skutki decyzji. Jeśli bowiem stosujemy model uproszczony, reprezentujący tylko wartości oczekiwane czy uśrednione skutków decyzji, to powinniśmy być świadomi możliwych paradoksów czy niedokładności, związanych $\mathrm{z}$ takimi uproszczeniami;

- $\boldsymbol{Y}_{0}=\boldsymbol{f}\left(\boldsymbol{X}_{0}\right) \subset \boldsymbol{Y}$ - zbiór rezultatów osiagalnych, lub $\boldsymbol{Q}_{0}=\boldsymbol{F}\left(\boldsymbol{X}_{0}\right) \subset \boldsymbol{Q}-$ zbiór osiagalnych wartości kryteriów (przy dopuszczalnych decyzjach), który odgrywa bardzo ważną rolę $\mathrm{w}$ teorii decyzji, gdyż problemy oceny można opisywać w kategoriach elementów tego zbioru. Trzeba być jednak świadomym, że elementy tego zbioru są zwykle określone niejawnie (dla ich obliczenia niezbędna jest symulacja odwzorowania $\boldsymbol{f}$ lub $\boldsymbol{F}$ ).

Natomiast model preferencji to przekształcenie rezultatów osiągalnych $\boldsymbol{y} \in \boldsymbol{Y}_{0}$ lub kryteriów $\boldsymbol{q} \in \boldsymbol{Q}_{0} \mathrm{w}$ ich ocenę $\boldsymbol{w}$ - która może mieć różny charakter. Przekształcenie to może być po prostu binarną relacja preferencji $\boldsymbol{P} \subset \mathbf{Y x} \mathbf{Y}$, czy też funkcja wartości $\boldsymbol{v}: \boldsymbol{Y} \rightarrow \boldsymbol{R}^{1}$, czy wreszcie funkcja użyteczności $\boldsymbol{u}: \boldsymbol{P} \times \boldsymbol{Y} \rightarrow \boldsymbol{R}^{1}$, gdzie $\boldsymbol{P}$ jest przestrzenią rozkładów prawdopodobieństwa rezultatów $\boldsymbol{y} \in \boldsymbol{Y}_{0}$. Możliwe są jeszcze inne modele preferencji; modelowaniu preferencji poświęcimy część II tej książki.

\subsection{Typy systemów wspomagania decyzji}

Jeśli chcieć klasyfikować systemy wspomagania decyzji w oparciu o klasyfikację sytuacji decyzyjnych, to można powiedzieć, że jest tak dużo możliwych sytuacji decyzyjnych, jak dużo jest ludzi na świecie, i nie sposób ich rozsądnie klasyfikować. Tym niemniej, podamy tu krótki przegląd typów systemów wspomagania decyzji, raczej celem ilustracji bogactwa problematyki niż w dążeniu do podania wyczerpującej klasyfikacji. Systemy te można klasyfikować z uwagi na:

1) Dziedzinę zastosowań, co można uważać za najważniejszy sposób klasyfikacji, gdyż dobry system wspomagania decyzji powinien być - jak już 
wspomnieliśmy - zorientowany na użytkownika: jego funkcje i szczegółowa specyfikacja muszą być ustalane wspólnie z użytkownikiem, który powinien też brać udział we wstępnym testowaniu systemu itp.

2) Typ zastosowań, według którego możemy dzielić na systemy wspomagania decyzji strategicznych, o innowacyjnym charakterze, wymagających rozwiązywania nowych problemów, bądź też na systemy wspomagania decyzji taktycznych, nieco bardziej powtarzalnych, czy wreszcie systemy wspomagania decyzji operacyjnych, ściśle powtarzalnych - które często można by nawet zautomatyzować, ale istotna w nich może być nadzorująca rola człowieka. Trzeba przy tym jeszcze raz podkreślić, że automatyzacja decyzji jest niekiedy bardzo potrzebna - z uwagi na ograniczoną szybkość reakcji człowieka, dokładność realizacji decyzji, względy bezpieczeństwa itp. - ale nie powinna być stosowana tam, gdzie istotny jest twórczy i często nawet intuicyjny wkład człowieka w decyzje.

3) Typ modelu rzeczowego, według którego można wyróżnić systemy eksperckie i inżynierii wiedzy $\mathrm{z}$ modelami logicznymi, bądź systemy wykorzystujące różnorodne modele analityczne, w różnorodny sposób analizowane. Do takich modeli należą, choć ich nie wyczerpują, tzw. modele badań operacyjnych, które, jak wspomnieliśmy wyżej, koncentrują się zazwyczaj na optymalizacji skalarnej; można uważać, że odmienne od nich podejście reprezentują systemy wielokryterialnej analizy modeli, które omówimy bardziej szczegółowo w tej książce. Typ modelu rzeczowego może być też określony przez różnorodne sposoby reprezentacji niepewności itp.

4) Typ modelu preferencyjnego, który - jak pokażemy dalej, we wstępnych rozdziałach tej książki - może wręcz zależeć od wybranej szkoły reprezentacji preferencji czy paradygmatu racjonalności decyzji, od wybranego sposobu badania czy agregacji zagadnień wielokryterialnych, a nawet od przyjętego algorytmu wspomagania wyboru.

5) Zasady interakcji z użytkownikiem mogą być także bardzo istotnym aspektem klasyfikacji systemów wspomagania decyzji: w jaki sposób użytkownik może wpływać na decyzję, sugerowaną mu przez system, jak taka decyzja jest wyjaśniana użytkownikowi? Nie każdy system wspomagania decyzji opiera się na głęboko przemyślanej odpowiedzi na te pytania. Jako przykład metodologii, która zakłada jasne odpowiedzi na takie pytania, opiszemy w tej książce dość szczegółowo metodologię punktu odniesienia w analizie wielokryterialnej modeli rzeczowych i dość elastyczne systemy 
interakcji z użytkownikiem, oparte na tej metodologii (mogą one wykorzystywać też np. zbiory rozmyte dla reprezentacji niepewności preferencji użytkownika) i zapewniające użytkownikowi pełną kontrolę nad procesem decyzyjnym.

6) Liczba użytkowników systemu i zasady ich kooperacji są też niezwykle istotnym wymiarem klasyfikacji problemów i systemów wspomagania decyzji. Może to być:

- użytkownik pojedynczy,

- zespót (team) użytkowników o tych samych celach i preferencjach (co często się zdarza w przypadku projektowania zespołowego, ale rzadziej w innych sytuacjach decyzyjnych),

- grupa użytkowników wspótpracujacych, która może mieć różne preferencje i cele, ale musi podjąć wspólną decyzję (albo ze względu na naturę tej decyzji, jak przy podziale wspólnego budżetu, albo też ze względu na umowę o współpracy),

- grupa niezależnych użytkowników growych, jeśli dotyczy to decyzyjnej sytuacji growej, gdy wielu decydentów ma różne preferencje i cele oraz każdy z nich może podejmować niezależną decyzję; w szczególnych przypadkach, analiza takiej sytuacji może kończyć się umową o współpracy i utworzeniem grupy użytkowników współpracujących. Choć mało jest jeszcze systemów wspomagania decyzji w sytuacjach growych, zagadnieniom decyzji growych poświęcimy sporo uwagi - gdyż jest to bardzo ważny element zrozumienia procesów decyzyjnych.

Przegląd powyższy przedstawiamy tu tylko celem ilustracji bogactwa tematyki systemów wspomagania decyzji. Przegląd ten nie powinien być uważany za klasyfikację, gdyż nie jest on bynajmniej ani wyczerpujący, ani też rozłączny; dobry system wspomagania decyzji może oczywiście wykorzystywać rozmaite aspekty powyższego przeglądu.

Jednakże najbardziej może istotną cechą jakości systemu wspomagania decyzji jest, aby pozwalał on użytkownikowi na wykorzystanie nie tylko wiedzy, lecz także intuicji, i tę intuicję wzbogacał. Problemowi racjonalnej, ewolucyjnej i naturalistycznej definicji intuicji, pożytecznej przy określaniu różnych funkcji systemów wspomagania decyzji, poświęcony jest rozdział następny. 


\section{Literatura}

Podajemy poniżej krótki przegląd literatury, który dotyczy nie tylko literatury cytowanej, lecz także książek zalecanych dla samodzielnych studiów. Książki te dotyczą niekiedy pozycji dość starych, ale mających charakter klasyczny lub też pozycji nowszych, mających charakter bieżących uzupełnień wiedzy.

Andriole S.J. (1989) Handbook of Decision Support Systems, TAB Professional and Reference Books, Blue Ridge Summit, Pa.

Belton S.V., Stewart T.J. (2002) Multiple Criteria Decision Analysis: An Integrated Approach. Kluwer Academic Publishers, Dordrecht, Boston

Debreu G. (1959) Theory of Value, J. Wiley, New York

Ehrgott M., Figueira J.R, Greco S. (2010) Trends in Multiple Criteria Decision Analysi. Springer, New York, Dordrecht, Heidelberg, London

Fishburn P.C. (1970) Utility Theory for Decision Making. Wiley, New York

Fisher R., Ury W. (1981) Getting to Yes. Negotiating Agreement Without Giving In, Houghton Mifflin, Boston

Hołubiec J.W., Mercik J.W. (1992) Tajniki i techniki glosowania, Omnitech Press, Warszawa

Keeney R., Raiffa H. (1976) Decisions with Multiple Objectives: Preferences and Value Trade-Offs, J. Wiley, New York

Lewandowski, A., Wierzbicki A.P., eds. (1989) Aspiration-Based Decision Support Systems, Lecture Notes in Economics and Mathematical Systems Vol. 331, Springer-Verlag, Berlin-Heidelberg

Miettinen K. (1999) Nonlinear Multiobjective Optimization, Kluwer Academic Publishers, Dordrecht, Boston

Myerson R.B. (1991) Game Theory - Analysis of Conflict, Harvard University Press, Cambridge Mass.

Ogryczak W. (1989) Programowanie matematyczne w pakiecie MPSX. Wydawnictwa Uniwersytetu Warszawskiego, Warszawa 1989.

Pawlak Z. (1991) Rough Sets. Some Aspects of Reasoning about Knowledge, Kluwer Academic Publishers, Dordrecht

Raiffa H. (1982) The Art and Science of Negotiations, Harvard University Press, Cambridge Mass.

Rapoport A. (1989) Decision Theory and Decision Behavior, Kluwer Academic Publishers, Dordrecht

Rios S. (1994) Decision Theory and Decision Analysis: Trends and Challenges. Kluwer Academic Publishers, Dordrecht

Roy B. (1990) Wielokryterialne wspomaganie decyzji, WNT, Warszawa

Roy B. (1996) Multicriteria Methodology for Decision Aiding. Kluwer Academic Publishers, Dordrecht

Saaty T. (1980) The Analytical Hierarchy Process, McGraw-Hill, New York

Sawaragi Y., Nakayama H., Tanino T. (1985) Theory of Multiobjective Optimization, Academic Press, Orlando Fl.

Seo F. and Sakawa M. (1988) Multiple Criteria Decision Analysis in Regional Planning: Concepts, Methods and Applications, D. Reidel Publishing Company, Dordrecht 
Simon H.A. (1957) Models of Man - Social and Rational, J. Wiley, New York Simon H.A. (1958) Administrative Behavior. The Macmillan Company, New York

Stachurski A., Wierzbicki A.P. (1999) Podstawy Optymalizacji. Wydawnictwa Politechniki Warszawskiej, Warszawa

Steuer R.E. (1986) Multiple Criteria Optimization: Theory, Computation and Application, J. Wiley, New York

Vincke Ph. (1992) Multicriteria Decision Aid, J. Wiley, New York

Wierzbicki A.P., Makowski M., Wessels J. (2000) Model Based Decision Support Methodology with Environmental Applications. Kluwer, Dordrecht

Yu P.L. (1985) Multiple-Criteria Decision Making - Concepts, Techniques and Extensions, Plenum Press, New York and London

Yu P.L. (1990) Forming Winning Strategies - An Integrated Theory of Habitual Domains. Springer, Heidelberg

Zadeh L.A. (1978) Fuzzy sets as a basis for a theory of possibility. Fuzzy Sets and Systems, Vol. 1, pp. 3-28

Zimmermann H-J., Gutsche L. (1991) Multi-Criteria Analyse: Einfuhrung in die Theorie der Entscheidungen bei Mehrfachzielsetzungen, Springer-Verlag, Berlin 


\section{Współczesny decydent: optymalizacja, sztuczna inteligencja - a kwestia prawdy i rola intuicji}

Na tle różnych paradygmatów podejmowania, wspomagania i racjonalności decyzji wynikających z rozdziałów poprzednich przedstawiamy tu najpierw różne filozoficzne pojęcia racjonalności teorii naukowych. Następnie omawiamy krótko pojęcie prawdy i zaleceń etycznych, co prowadzi do racjonalnej i naturalistycznej teorii intuicji oraz wynikających $\mathrm{z}$ niej wniosków i pojęć dotyczących intuicyjnych procesów decyzyjnych.

\subsection{Wprowadzenie}

Z rozdziałów poprzednich wynika, kto ma być użytkownikiem systemów wspomagania decyzji, o których traktuje ta książka: człowiek epoki cywilizacji informacyjnej, który będzie nie tylko dostatecznie wykształcony w technikach przetwarzania informacji, aby je szeroko wykorzystywać w codziennej pracy i życiu, lecz także inaczej pojmował będzie otaczający go świat, niż to dotychczas typowe. Postrzeganie świata zaś to zarówno kwestia podstawowych pojęć, kształtujących pogląd na świat, jak i paradygmatów, jak wreszcie intuicji; w rozdziale tym omówimy wpływ tych kwestii na zadania wspomagania decyzji.

Pojęcie paradygmatu traktujemy tu najpierw szeroko, jako określenie pewnej szkoły myślenia (później przytoczymy bardziej precyzyjne określenie paradygmatu przez Thomasa Kuhna, 1970). Trzeba podkreślić, że z punktu widzenia współczesnej teorii występują rozmaite paradygmaty, czy paradygmatyczne podejścia do podejmowania i wspomagania decyzji:

- Ekonomiczny paradygmat optymalizacji, który zakłada, że powinno się podejmować decyzje optymalne, maksymalizujące funkcję wartości lub użyteczności decydenta przy istniejących ograniczeniach. W dalszym ciągu książki poświęcimy temu paradygmatowi wiele uwagi; trzeba tu jednak ostrzec z góry czytelnika, że paradygmat ten, zbyt dosłownie traktowany, 
prowadzi do wielu paradoksów i nieporozumień. Na przykład, określenie „przy istniejących ograniczeniach” może być interpretowane w tym sensie, że należy najpierw przyjąć założenia o tych ograniczeniach, a potem przeprowadzić optymalizację. Ale przecież założenia te są też częścią wyboru decyzji, decydent może włączyć do swej funkcji użyteczności koszty modyfikacji ograniczeń i tym samym traktować te ograniczenia jako tzw. ograniczenia miękkie, a nie jako nierównościowe lub równościowe ograniczenia twarde. Inne nieporozumienia mogą się wiązać z identyfikacją funkcji użyteczności decydenta, który bynajmniej nie jest skory do przekazywania danych na ten temat, traktując swoje preferencje (i słusznie!) jako wartościową informację. Długa historia badań w zakresie teorii decyzji związana jest $\mathrm{z}$ różnorodnymi podejściami krytycznymi do paradygmatu optymalizacji decyzji, o czym wspomnimy jeszcze w tym rozdziale. Tu trzeba jednak dodać, że niedawno Jonathan Barzilay (2010) opublikował zasadnicze zastrzeżenia matematyczne co do użycia operacji dodawania, mnożenia i różniczkowania w stosunku do modeli wynikających tylko z relacji preferencji - a zatem $\mathrm{w}$ stosunku do całego paradygmatu optymalizacji decyzji.

- Informatyczny paradygmat sztucznej inteligencji, który zakłada, że trzeba tylko wyrazić istniejącą wiedzę w danej dziedzinie oraz preferencje decydenta $\mathrm{w}$ postaci reguł logicznych, a $\mathrm{z}$ nich już wyniknie prawidłowa decyzja lub reguła decyzyjna. Choć bardzo istotny pojęciowo, paradygmat ten ma też swoje ograniczenia i wielokrotnie w historii spotykał się z krytyką, o której też wspomnimy w tym rozdziale. Paradygmatu tego nie będziemy rozpatrywać bardziej szczegółowo w tej książce, gdyż ograniczamy się tu raczej do analitycznych niż logicznych modeli sytuacji decyzyjnych - kiedy to wykorzystujemy istniejącą wiedzę $\mathrm{w}$ danej dziedzinie $\mathrm{w}$ postaci modeli analitycznych bliskich modelom faktycznie w tej dziedzinie stosowanym, nie próbując przetwarzać ich $\mathrm{w}$ modele logiczne. Powodem takiego ograniczenia jest doświadczenie wskazujące na to, że modele logiczne wiedzy mają złożoność obliczeniową szybko rosnącą wraz ze złożonością tych modeli. $\mathrm{Ci} \mathrm{z}$ informatyków, którzy nie zajmowali się analizą modeli o dużym stopniu złożoności, często nie doceniają tego aspektu: skoro możliwości obliczeniowe komputerów rosną tak szybko, to po co przejmować się złożonością obliczeniową? Jednakże specjaliści w zakresie modelowania komputerowego bardziej złożonych sytuacji wiedzą dobrze, że potrafią łatwo napisać program powodujący nasycenie najbardziej nowoczesnego superkomputera. 
Bowiem doświadczenie analizy modeli o dużym stopniu złożoności wskazuje, że $\mathrm{w}$ tej dziedzinie zawsze pracuje się na granicy nasycenia możliwości obliczeniowych komputera. Niezależnie od tego, jak już złożony jest model i jak silnym komputerem dysponujemy, zawsze chciałoby się jeszcze rozważyć pewne aspekty dodatkowe. Jeśli jednak mamy do czynienia z dość typowym przypadkiem wykładniczego wzrostu złożoności obliczeniowej wraz z rozmiarami zadania, i jeśli model o danej liczbie zmiennych (lub reguł) wymaga, powiedzmy, 15 minut obliczeń na danym, nawet najsilniejszym komputerze, to zazwyczaj dodanie tylko jednej zmiennej (lub reguły) do modelu w celu analizy jego dodatkowego aspektu zwiększa wymagany nakład obliczeń niekiedy nie do godziny, a do miesięcy. Stąd, przy dostatecznie złożonych modelach, bardzo istotne jest wykorzystanie metod o możliwie niewielkim nakładzie obliczeniowym, które istnieją w przypadku ograniczenia się do rozwiązań przybliżonych i modeli analitycznych.

Inne ograniczenie, wspólne dla obu paradygmatów wspomnianych wyżej, związane jest z kwestią, czy decyzje należy automatyzować, czy tylko wspomagać. Rozróżnienie to, jak już wspomnieliśmy w poprzednim rozdziale, jest niezwykle istotne. Jest bowiem wiele sytuacji, w których automatyzacja decyzji jest pożądana - jeśli są to decyzje powtarzalne, uciążliwe, bardzo szybkie itp. Równie wiele jest jednak przypadków, w których automatyzacja decyzji jest niepożądana - z rozmaitych powodów, z których chyba najważniejszym jest odczuwana przez decydenta potrzeba wykorzystania swej intuicji w procesie decyzyjnym. Jeśli doświadczonemu decydentowi zarzucić, że nie chce on się posługiwać bardziej sformalizowanymi metodami wspomagania decyzji, gdyż nie chce odkrywać swoich preferencji w celu zachowania lepszej pozycji negocjacyjnej, odpowie on, że chciałby raczej zachować prawo do zmiany opinii $i$ wykorzystania swojej intuicji. Ten aspekt omówimy bardziej szczegółowo w dalszej części rozdziału.

Tu zauważmy tylko, że oba paradygmaty wspomniane wyżej prowadzą $\mathrm{w}$ istocie do automatyzacji decyzji, i nie są w pełni dostosowane dla wspomagania decyzji $\mathrm{w}$ stosunku do decydenta zmieniającego opinię i wykorzystującego intuicję. Dlatego też, stopniowo, wykształcił się paradygmat trzeci:

- Interdyscyplinarny paradygmat interaktywnego wspomagania decyzji, który zakłada, że w procesie podejmowania decyzji rola decydenta jest nadrzędna i suwerenna, a więc nie wolno go zastępować w kluczowych momentach i automatyzować decyzji, jeśli on o to wyraźnie nie poprosi. 
Komputerowy system wspomagania decyzji musi więc przede wszystkim pomagać decydentowi poprzez zakodowaną w nim wiedzę (czy to w formie modeli analitycznych, czy logicznych) o danej sytuacji decyzyjnej - gdyż to właśnie pomoże wzbogacić intuicję decydenta, mniej zaś koncentrować się na modelowaniu samego decydenta (jego preferencji czy funkcji użyteczności) - a ponadto te modele przestają być aktualne, jeśli decydent ma prawo zmieniać opinię. Nie jest przy tym istotne, czy wykorzystujemy podejście optymalizacyjne $\mathrm{w}$ oparciu o modele analityczne, czy inżynierię wiedzy w oparciu o modele logiczne - możemy je łączyć, także z jeszcze innymi podejściami - trzeba je tylko oba zasadniczo zmodyfikować. Modyfikacja ta powinna zapewnić interaktywna pracę decydenta $\mathrm{z}$ systemem wspomagania decyzji, w której łatwo i w przejrzysty sposób wpływa on na generację różnych opcji decyzyjnych przy zmieniających się założeniach i ma jasny wgląd w mechanizm wpływu tych założeń na wynikające stąd opcje.

To właśnie trzecie podejście paradygmatyczne jest podstawą dla większości rozważań w tej książce: w rozdziale tym natomiast omówimy bardziej szczegółowo przesłanki tego podejścia, a zwłaszcza racjonalną i naturalistyczną teorię i definicję intuicji, wreszcie rolę intuicji w podejmowaniu decyzji. Jeśli chcemy bowiem wspomagać kształtowanie się intuicji, to musimy ją dobrze rozumieć. Takie podejście wynika też zresztą $\mathrm{z}$ wymagań rynkowych: doświadczenie wskazuje, że użytkownik dowolnego oprogramowania komputerowego niechętnie je przyjmuje - bądź nawet w ogóle unika jego zakupu - jeśli oprogramowanie to zawiera elementy dominacji komputera nad użytkownikiem. Przed racjonalną definicją intuicji musimy jednak przedyskutować pojęcie racjonalności decyzji i racjonalności opinii.

\subsection{Pojęcie racjonalności $w$ teorii decyzji i w filozofii}

$\mathrm{W}$ paradygmacie optymalizacji, $\mathrm{w}$ klasycznej teorii decyzji, decydent jest zwany racjonalnym, jeśli wybiera decyzję najbardziej preferowaną, definiowaną zwykle jako maksymalizującą jego funkcję wartości lub użyteczności. Założenie to okazało się bardzo płodnym dla rozwoju teorii ekonomii, matematycznej teorii gier i decyzji, zaczynając od prac Johna von Neumanna i Oscara Morgensterna (1944), Gerarda Debreu (1959); założenie to umotywowało wiele innych osiągnięć teoretycznych. Samo podsumowanie literatury, związanej z tym założeniem, wymagałoby osobnej, wielotomowej książki; nic też dziwnego, że założenie to bywa traktowane - i bronione w sensie paradygmatycznym. Na przykład, niedawne (Jonathan Barzilay 2010) 
zastrzeżenia co do matematycznych podstaw modelowania ekonomicznego można ocenić następująco: Barzilay ma wprawdzie rację, ale twórcy teorii modelowania ekonomicznego po prostu przyjęli pewne niezbyt uzasadnione metazałożenie (o możliwości formułowania takich modeli z użyciem narzędzi współczesnej analizy matematycznej); dalej wyjaśnimy głębiej rolę metazałożeń w ocenie prawdziwości.

Już znacznie wcześniej, to właśnie centralne założenie klasycznej teorii decyzji było też krytykowane przez wiele szkół myślenia, próbujących wzbogacić i zbliżyć do praktyki tę teorię. Szkoły te były zazwyczaj uwarunkowane przez pewne perspektywy dyscyplinarne; będziemy je nazywać szkołami krytycznymi pojmowania racjonalności decyzji.

Najbardziej znaczącą wśród tych szkół była teoria decyzji zadowalających zapoczątkowana przez Herberta Simona (1955, 1957), reprezentująca perspektywy zarządzania, mikroekonomii, inżynierii. Według Simona, decyzje indywidualne nie są optymalizowane, gdyż jest to za trudne (szczególnie w sytuacjach z niepewnością skutków decyzji), gdyż dostęp do informacji jest ograniczony oraz gdyż indywidualna optymalizacja może prowadzić do sytuacji konfliktowych w sytuacjach pozarynkowych z ograniczoną liczbą uczestników czy graczy (jak np. w strukturach zarządzania). Zamiast optymalizować, indywidualny decydent kształtuje swoje poziomy aspiracji - stopniowo, adaptacyjnie, poprzez proces uczenia się, który odgrywa ważną rolę $\mathrm{w}$ tej teorii - i jest zadowolony $\mathrm{z}$ decyzji jeśli pozwalają one na osiągnięcie tych poziomów aspiracji. Teoria decyzji zadowalających została potwierdzona poprzez wiele badań praktycznych sposobów podejmowania decyzji i pobudziła wiele prac i podejść z nią związanych.

Wymienić tu można teorię zachowań celowo-zorientowanych - Viktora Głuszkova (1972), G.S. Pospelova i V.I. Irikova (1976); metode programowania celowego Abrahama Charnesa i Williama Coopera (1977) $\mathrm{w}$ wielokryterialnej optymalizacji i wspomaganiu decyzji, wreszcie uogólniającą te podejścia metodologię punktu odniesienia zaproponowaną przez autora tej książki (1980) i dalej intensywnie rozwijaną, patrz dalsze rozdziały. To ostatnie podejście łączy jednak $\mathrm{w}$ istocie teorię decyzji zadowalających w odniesieniu do decydenta (wykorzystując poziomy aspiracji lub ogólniej poziomy odniesienia do interakcji decydenta z komputerowym systemem wspomagania decyzji) oraz paradygmat optymalizacji decyzji w odniesieniu do komputera (ponieważ komputer nie musi zachowywać się tak, jak człowiek, więc może zachowywać się w wyidealizowany sposób, 
odpowiadający paradygmatowi optymalizacji: utworzyć specyficzne przybliżenie funkcji wartości, zwane funkcją osiagnięcia, zależne od danych mu poziomów odniesienia, a następnie optymalizować tę funkcję).

Ze względu na zarówno praktyczne, jak i teoretyczne znaczenie teorii decyzji zadowalających, została ona zasymilowana przez klasyczny paradygmat optymalizacji użyteczności pod znamienną nazwą ograniczonej racjonalności. Wybór tej nazwy ilustruje samowzmacniający się charakter paradygmatu: wierząc, że w pełni racjonalny decydent powinien optymalizować, możemy przyznać, że większość indywidualnych decydentów nie jest jednak doskonała.

Znane jest wiele innych szkół krytycznych w stosunku do założeń maksymalizacji użyteczności, jak np. szkoła psychologiczna z jej teoriq straconych korzyści, według której inaczej oceniamy straty, a inaczej zyski, zob. np. Daniel Kahneman i Amos Tversky (1982). Czysto matematyczna analiza krańcowych konsekwencji podstawowych założeń maksymalizacji użyteczności doprowadziła też do wykrycia wielu paradoksów tej teorii, zwanych paradoksami racjonalności, z których kilka omówimy w dalszych rozdziałach książki, jak paradoks Maurice Allais (1953), który umotywował rozwój niezależnej, francuskiej szkoły teorii decyzji, reprezentowanej przez Bernarda Roy'a, zob. np. (1977, 1990), czy też dotyczący nieco odmiennej dziedziny paradoks agregacji preferencji zbiorowych, wyrażony przez twierdzenie o niemożliwości Keneth’a Arrowa (1951). Później, paradoksy takie doprowadziły do hipotezy nieliniowej zależności funkcji użyteczności od prawdopodobieństw zdarzeń - zob. Mark Machina (1983) - czy łączenia teorii rynku z teorią decyzji zadowalających - zob. np. Kent Wall (1996).

Teoria decyzji w klasycznym rozumieniu, rozumiana jako teoria maksymalizacji użyteczności przy podejmowaniu decyzji w warunkach niepewności, przez długi czas była ściśle związana $\mathrm{z}$ teorią prawdopodobieństwa i statystyką, a nawet traktowana jako ich część. Później rozwinęły się inne metody matematycznego opisu niepewności, tak jak teoria zbiorów rozmytych (fuzzy sets) czyli rodzaj teorii możliwości opartej na logice nieskończenie wielowartościowej, zapoczątkowana przez Lofti Zadeha, zob. np. (1978), i rozwijana intensywnie przez wielu badaczy, czy wreszcie teoria zbiorów przybliżonych (rough sets), czyli rodzaj logiki trójwartościowej szczególnie przydatnej przy analizie wielkich zbiorów danych (gdzie zawsze jest trzecia droga), zapoczątkowana przez Zdzisława Pawlaka (1991). 
Teoria maksymalizacji użyteczności oraz silnie z nią związana teoria gier może być traktowana statycznie (w stosunku do jednorazowego aktu decyzji) bądź dynamicznie (w stosunku do ciągu decyzji powtarzalnych w czasie). Oba ujęcia prowadzą do pewnych paradoksów w sytuacjach growych, które też omówimy w dalszych rozdziałach.

Jedna ze szkół krytyki tej teorii zwróciła uwagę, że zupełnie inne konsekwencje ma założenie maksymalizacji (czy to statycznej, czy dynamicznej) użyteczności indywidualnej, a zupełnie inne - założenie o dążeniu do maksymalizacji szans rozwoju rodziny czy potomstwa. Doprowadziło to do teorii ewolucji kooperacji, zapoczątkowanej przez Roberta Axelroda (1984) z wykorzystaniem strategii opracowanych przez Anatola Rapoporta - zob. np. (1989).

Powyższa dyskusja dotyczy pojęcia racjonalności decyzji. Jednakże samo pojęcie racjonalności - opinii, czy teorii naukowej - ma jeszcze zupełny inny wymiar $\mathrm{w}$ filozofii. Ponieważ wymiar ten związany jest $\mathrm{z}$ racjonalnym rozumieniem intuicji, przeto przedstawimy tu krótko zarys dyskusji nad racjonalnością teorii naukowych w filozofii nauki. Racjonalność w filozofii nauki związana jest $\mathrm{z}$ pytaniem o charakter powstawania i sprawdzania teorii naukowych. I w tej dziedzinie mamy do czynienia $\mathrm{z}$ najrozmaitszymi interpretacjami racjonalności i rozwoju teorii naukowych. Najstarsze może rozumienie pochodzi od Platona: racjonalna jest teoria wywodząca się przez poprawne rozumowanie $\mathrm{z}$ abstrakcyjnych przesłanek, i tak nadal rozumie pojęcie racjonalności część filozofów. Współczesne rozumienie jest jednak odmienne, choć różnorodne.

Wymienić tu trzeba falsyfikacjonizm Karla Poppera, zob. np (1975), historycyzm zmiennych paradygmatów Thomasa Kuhna, zob. (1968), kilka innych - zob. np. Ian Hacking (1981) - a także epistemologię ewolucyjna zapoczątkowaną przez Konrada Lorentza (1965), zob. także Franz Wuketits (1984).

Każda z tych interpretacji ma ważkie aspekty. Wykorzystujemy tu w szerokim sensie - pojęcie paradygmatu Thomasa Kuhna, chociaż definiował on je nieco węziej - jako teorię wzorcową dla danej dyscypliny naukowej. Nie ulega jednak wątpliwości, że dla rozwoju pewnej dyscypliny naukowej racjonalne jest przyjęcie i utrzymywanie - przynajmniej przez pewien okres rozwojowy - nie tylko teorii wzorcowej, lecz także zestawu 
podstawowych założeń, analizując wszelkie ich konsekwencje. Nie tyle sprzeczna z tym pojęciem, co bardziej radykalna jest teoria racjonalności twierdzeń naukowych Poppera, zwana falsyfikacjonizmem. W myśl tej teorii, twierdzenia naukowe dotyczące rzeczywistości nigdy nie są prawdziwe absolutnie (w przeciwstawieniu do twierdzeń dotyczących poprawności logicznej czy matematycznej, dotyczących nie tyle rzeczywistości, co poprawnego języka nauki, które oczywiście mogą być prawdziwe lub nie, choć ich prawdziwość też zależy od intuicyjnych metazałożeń) i nie są indukcyjnymi lub dedukcyjnymi wnioskami z obserwacji czy innych twierdzeń, ale mają charakter hipotez, których pochodzenie może być dowolne (Popper nie wyklucza tu intuicji jako źródła tych hipotez). Istotne jest jedynie, że hipotezy te powinny być poddawane ciągłym weryfikacjom poprzez próby ich obalenia, falsyfikacji: najbardziej prawdziwe twierdzenia naukowe to te, które się oparly jak największej liczbie prób falsyfikacji.

Podobnie niesprzeczna z interpretacjami Kuhna i Poppera, choć odmienna, jest interpretacja epistemologii ewolucyjnej. Według tej interpretacji, nauka jest częścią kultury i cywilizacji ludzkiej oraz ma znaczenie ewolucyjne: rozwijane są takie teorie naukowe, które są przydatne $\mathrm{w}$ rozwoju ewolucyjnym ludzkości. Trzeba przy tym zdawać sobie sprawę zarówno z zalet, jak i ograniczeń takiego rozwoju nauki. Na przykład, rozwój taki jest obciążony przez perspektywę mezokosmiczną: ponieważ zmysły nasze są przystosowane do postrzegania świata w średniej skali, a świat skali mikro (mikroby, atomy, cząstki elementarne) oraz makro (układy planetarne, galaktyki) postrzegamy tylko poprzez instrumenty, przeto skłonni jesteśmy zarówno skali mikro jak i makro nadawać interpretacje mezokosmiczne, a także przyjmować pewne założenia wynikające z naszego doświadczenia w obserwacji mezokosmosu. W dalszym ciągu tego rozdziału wykorzystamy pewne argumenty epistemologii ewolucyjnej.

$\mathrm{Tu}$ jednak trzeba jeszcze przedstawić spojrzenie na teorię racjonalności decyzji z punktu widzenia racjonalności teorii naukowych. Z tej perspektywy, słowo „racjonalność” zostało użyte nader nieszczęśliwie w teorii decyzji. Jeśli jednak założenie o maksymalizacji użyteczności przez decydenta traktujemy jako tylko założenie badawcze, stwierdzenie pomocne w rozwoju teorii, to trzeba stwierdzić, że było to założenie bardzo płodne i skuteczne - czyli było ono samo racjonalne np. w sensie epistemologii ewolucyjnej. 
Trzeba jednak pamiętać, że w obronie klasycznego paradygmatu teorii decyzji, wielu badaczy posuwało się do deskryptywnej lub normatywnej interpretacji tej teorii: $\mathrm{w}$ tej pierwszej zakłada się, że rzeczywiste, racjonalne decyzje są zawsze podejmowane $\mathrm{w}$ najlepiej pojmowanym i wyrachowanym interesie decydenta, w tej drugiej, że racjonalne decyzje powinny być tak podejmowane. Obie te interpretacje nie sa jednak racjonalne jako teorie naukowe $\mathrm{w}$ sensie falsyfikacjonizmu Poppera, który zresztą użył właśnie tego przykładu dla ilustracji irracjonalnej teorii naukowej. Jeśli bowiem założymy, że decydent może wprawdzie powodować się różnymi czynnikami - honorem, altruizmem itp. - w swoich decyzjach, ale czynniki te przelicza, wraz z pieniędzmi, na swoją indywidualną użyteczność, to założenie o maksymalizacji indywidualnej użyteczności nie może być sfalsyfikowane w swej istocie: zawsze można bowiem znaleźć taką funkcję użyteczności, która ma akurat maksimum przy danej, arbitralnie wybranej decyzji. Takie niefalsyfikowalne twierdzenia Popper nazywał ideologią, a nie nauką.

Jednakże Kuhn uważa, że elementy ideologii zawsze występują w wyborze założeń tworzących paradygmat. Paradygmat nie jest tworzony z uwagi na testowalność empiryczną założeń; centralne założenia paradygmatu są zwykle wybierane w celu uproszczenia analizy (np. kopernikańskie założenie o zatrzymaniu Słońca i obrocie Ziemi), a ich testowalność zależy od założeń dodatkowych. To samo dotyczy założenia o maksymalizacji użyteczności. Jeśli jest ono interpretowane $\mathrm{z}$ umiarem, to staje się testowalne i racjonalne nawet w sensie Poppera. Na przykład, twierdzenie „uśrednione zachowanie konsumentów na rynku ekonomicznym możemy analizować zakładając, że maksymalizują oni swą funkcję użyteczności lub wartości” jest falsyfikowalne i było testowane w wielu pracach ekonomicznych. Nie stosuje się to jednak do interpretacji dalej idących - np. że każdy konsument na rynku maksymalizuje swą funkcję użyteczności (bo testy ekonomiczne odnoszą się, z natury rzeczy, do istniejącego tylko wirtualnie konsumenta uśrednionego) czy też do jeszcze dalej idących stwierdzeń mających charakter obrony paradygmatu, że każdy indywidualny decydent optymalizuje (lub powinien optymalizować) swoje zagregowane interesy w każdej decyzji.

Dlatego też będziemy dalej używać terminu „decyzja racjonalna” nie w sensie ekonomicznego paradygmatu teorii decyzji, a w szerszym i bardziej potocznym sensie, który może zależeć też od uwarunkowań kulturowych i dyscyplinarnych - zob. np. Manfred Grauer et al. (1985), Po-Lung Yu (1990). 
Co więcej, będziemy jednak wymagać - za Popperem - aby racjonalne wyjaśnienie sposobu podejmowania decyzji było, przynajmniej w zasadzie, testowalne empirycznie. W tym też sensie zwrócimy więcej uwagi na racjonalne wythumaczenie decyzji intuicyjnych.

W języku codziennym często używamy pojęcia „intuicyjny” z domyślnym znaczeniem „irracjonalny”. Związane to jest prawdopodobnie z interpretacją Henri Bergsona (1911), który głęboko wierzył w znaczenie intuicji, ale nadawał jej znaczenie niemal mistycznej siły, która $\mathrm{z}$ definicji nie podlega racjonalnym badaniom. Pokażemy dalej, że niemal stulecie badań w różnych dziedzinach pozwala nam dziś na odwrócenie tej interpretacji i racjonalną, realistyczną oraz naturalistyczną analizę zjawiska intuicji.

\section{3. „Myśl ponad komputerem” i granice inteligencji cyfrowej}

Jedna ze szkół krytycznych w stosunku do tradycyjnej teorii decyzji poszła dalej od innych utrzymując, że decyzje indywidualne są przedmiotem zbyt skomplikowanym do wyjaśnienia poprzez teorię analityczna, że decyzje są podejmowane raczej w sposób rozważny (ang. deliberative way). Krytyka ta pochodzi z perspektywy tzw. ogólnej teorii systemów - zob. (Ludvig Bertalanffy 1968) i zwana jest niekiedy miękkim podejściem systemowym do podejmowania decyzji. Podejście to kładzie nacisk na znaczenie synergii znanego zjawiska, że całość jest większa, niż suma jej części - oraz na znaczenie zjawiska czy momentu, zwanego różnie eureka, czy aha, czy wreszcie olśnienie poznawcze lub decyzyjne (takie, jakiego doświadczył Archimedes w wannie), a niewątpliwie występującego w złożonych procesach decyzyjnych lub poznawczych. Inną charakterystyczną cechą tego podejścia jest podkreślenie rozróżnienia pomiędzy redukcjonizmem a holizmem: podejście analityczne związane jest $\mathrm{z}$ redukcjonistyczną koncentracją na częściach problemu, podczas gdy rozważanie całości problemu może dać zupełnie odmienną perspektywę (postrzeganie całości, czyli holizm, zwane także z niemiecka percepcją „Gestalt”).

Miękkie - lub rozważne - podejmowanie decyzji polega więc na rozpatrzeniu możliwie całego obrazu, wszystkich aspektów zagadnienia, przyglądając się im z różnych punktów widzenia, i szukając prawidłowej decyzji, która powinna się pojawić na drodze postrzeżenia całości i olśnienia - czy intuicji. 
Ta droga krytyki analitycznej teorii decyzji szczególnie przekonywująco przedstawiona jest w książce Umyst ponad komputerem braci Huberta Dreyfusa i Stuarta Dreyfusa (pierwszy $\mathrm{z}$ nich jest filozofem, drugi matematykiem i specjalistą $\mathrm{w}$ zakresie teorii decyzji, współautorem metody programowania dynamicznego przypisywanej zwykle w uproszczeniu Richardowi Bellmanowi - który nadzorował prace Stuarta Dreyfusa, a potem szeroko spopularyzował metodę programowania dynamicznego). Angielski tytuł omawianej tu książki to Mind over Machine, natomiast tłumaczymy tu ten tytuł zgodnie $\mathrm{z}$ faktyczną intencją autorów, którzy przez Machine rozumieli komputer. Książka ta poświęcona jest krytyce pojęcia i założeń badawczych sztucznej inteligencji: autorzy wykazują, że sposób rozumowania ludzi jest zupełnie odmienny od sposobu „rozumowania” komputera, i że cały szereg pojęć stosowanych w teorii sztucznej inteligencji czy inżynierii wiedzy nadużywa słów, znaczących dla przeciętnego człowieka co innego, niż w tej teorii. Tak więc np. pojęcie wiedza jest $\mathrm{w}$ istocie czymś znacznie szerszym, niż zbiorem reguł logicznych; inteligencja nie sprowadza się tylko do szybkiego wnioskowania. Jednakże problem $\mathrm{w}$ tym, że maszyny matematyczne sa urzadzeniami logicznymi, zaś od Kurta Gödela (1931) wiadomo, że wiedza nasza nie jest redukowalna logicznie (metazałożenia w osądzaniu, co jest prawdą, wybiera się intuicyjnie).

Jednak dla niniejszego rozdziału bardziej istotne są pewne obserwacje autorów książki Umyst ponad komputerem, dotyczące zależności trybu podejmowania decyzji od poziomu ekspertyzy decydenta. Sposób podejmowania decyzji zmienia się ze wzrastajacym poziomem ekspertyzy decydenta. Jeśli rozróżnić sześć poziomów ekspertyzy:

1) początkujący,

2) nowicjusz,

3) praktykant,

4) specjalista,

5) ekspert,

6) mistrz (ekspert klasy mistrzowskiej),

to gdzieś pomiędzy poziomem trzecim a czwartym, przy przejściu od praktykanta do specjalisty, następuje jakościowa zmiana sposobu podejmowania decyzji. Podczas gdy początkujacy, nowicjusz, praktykant postuguja się niemal wytacznie analiza przy podejmowaniu decyzji, specjalista, ekspert $i$ mistrz $w$ coraz większym stopniu stosuja rozwage i miękkie podejmowanie decyzji. 
W przypadku decyzji operacyjnych, powtarzalnych, jest bardzo wiele obserwacji empirycznych potwierdzających tę tezę. Na przykład, nowicjusz w prowadzeniu samochodu musi rozumować i spoglądać na prędkościomierz przed zmianą biegu; ekspert zmienia biegi „całym ciałem”, intuicyjnie, podświadomie przetwarzając całość docierającej do niego informacji. W przypadku decyzji strategicznych, niepowtarzalnych, kiedy to niezbędne są elementy nowości, Dreyfusowie zaprojektowali i przeprowadzili specjalny eksperyment związany z grą w szachy. Nasycili oni analityczną część umysłu graczy prosząc ich o rozwiązywanie zadan arytmetycznych w interakcji z komputerem, a następnie zwiększając tempo tej interakcji do granic możliwości gracza. Następnie gracze ci grali w szachy, po czym w pewnym momencie wznawiano interakcję z komputerem (gracze musieli rozwiązywać zadania arytmetyczne podczas gry w szachy). Obserwowano wpływ tej interakcji na poziom gry.

Wyniki tego eksperymentu w pełni potwierdzały hipotezę o zmianie stylu podejmowania decyzji przy przejściu od poziomu praktykanta do specjalisty. Gracze o niższych umiejętnościach po prostu nie mogli grać w szachy, jeśli część analityczna ich umysłu była nasycona innymi zadaniami. Graczom o wyższych umiejętnościach nasycenie części analitycznej ich umysłu w ogóle nie przeszkadzało; zatem muszą oni podejmować decyzje w inny sposób, nie wykorzystując analizy. Dreyfusowie wyrazili opinię, że rezultaty tego eksperymentu są związane z całościowym postrzeganiem rzeczywistości i rozpoznawaniem wzorców poprzez wrażenia typu „Gestalt”, z utworzeniem się pewnych dróg neuronowych $\mathrm{w}$ mózgu $\mathrm{w}$ drodze treningu, nawet z funkcjami prawej półkuli mózgowej (które omówimy dalej) i rolą intuicji, ale nie podjęli dalszej analizy intuicji.

Wracając do pojęcia sztucznej inteligencji: idea, że praktycznie możliwe jest skonstruowanie maszyn inteligentnych, pojawiła się zresztą m.in. w związku z konstrukcją robotów (pierwsze laboratorium sztucznej inteligencji w MIT zostało utworzone przez Johna McCarthy'ego i Marvina Minsky’ego w roku 1959, w dwa lata po konstrukcji pierwszego robota w roku 1957). Od tego czasu idea sztucznej inteligencji jest silnie rozwijana na całym świecie, ale szczególnie w USA. Ogólny cel to skonstruowanie maszyny równie - czy może nawet bardziej - inteligentnej niż człowiek. Ten cel ogólny wiąże się z wieloma wątkami - rozwojem logiki, rozpoznawaniem wzorców i obrazów, uczeniem się maszyn i programów komputerowych, perceptronami 
i sztucznymi sieciami neuropodobnymi, poprawianiem pisowni w tekstach formułowanych przez człowieka, wspomaganiem decyzji i badaniami metod podejmowania decyzji przez człowieka, badaniami działania mózgu człowieka, wreszcie kognitywizmem.

Kognitywizm jest kierunkiem myślenia wiążącym część badań nad sztuczną inteligencją, nad działaniem umysłu ludzkiego oraz odłamem filozofii, ogólnie związanym początkowo z przekonaniem, że zarówno umyst ludzki, jak $i$ caly świat może być rozumiany jako ogromny komputer, zob. np. The Minds New Science: A History of the Cognitive Revolution (Howard Gardner 1985).

Taki kierunek myślenia był podtrzymywany przez obszerne badania usiłujące zredukować myślenie do języka i operacji logicznych, co zresztą umotywowało poważny rozwój szeregu przydatnych dziedzin szczegółowych, jak automatycznej klasyfikacji wzorców przez komputery, rozpoznawania wzorców (pattern recognition), rozpoznawania i syntezy mowy, automatycznego tłumaczenia itp. Redukcja myślenia do języka i operacji logicznych ma ogromne tradycje, można ją odnaleźć już wśród starożytnej filozofii greckiej, ale tendencja ta nasiliła się i sformalizowała począwszy od końca XIX wieku, poprzez prace (Gottlob Frege 1893), (Bertrand Russel i Alfred Whitehead 1910), (Ludwig Wittgenstein 1922). Od tego czasu większość filozofii XX wieku koncentrowała się na językowych aspektach poznania; podstawowe badania formalnych ugruntowań języka obejmowały pojęcia języka myśli (Jerry Fodor 1975) czy uniwersalnej gramatyki (Noam Chomsky 1986), a równolegle doprowadziły do poststrukturalistycznej teorii języka (Jacques Derrida 1974) z jej naciskiem na subiektywizm wypowiedzi.

Wszystkie te prace w pewnym sensie ignorowały rezultaty Kurta Gödela (1931) i Alfreda Tarskiego (1933) o nieredukowalności matematyki, zatem wiedzy ludzkiej do logiki oraz o pozalogicznym charakterze pojęcia prawdy. Gödel użył do swego dowodu paradoksu kłamcy ${ }^{4}$, z którego wynika, że dla określenia prawdziwości zdania musimy odwoływać się do pozalogicznej

\footnotetext{
${ }^{4}$ Kłamca twierdzi, że zawsze kłamie, ale czy w tym zdaniu też kłamie? Jeśli nie, to jego wypowiedź jest samosprzeczna. Jeśli tak, to kłamca nie zawsze kłamie, a zatem do oceny prawdziwości jego wypowiedzi potrzebne są informacje dodatkowe; logika sama nie rozwiąże paradoksu kłamcy.
} 
definicji prawdy. Tarski rozwinął to dalej i stworzył teorię prawdy, w której o prawdziwości zdania $\mathrm{w}$ danym języku orzekamy w metajęzyku. W tym metajęzyku formułujemy nasze pozalogiczne, zatem intuicyjne metazałożenia o prawdzie. $^{5}$

Wynika stąd, że komputera nie można nazwać inteligentnym, dopóki nie będzie przejawiat intuicji. Komputer można uznać za inteligentny, gdy zrobi samodzielnie istotny wynalazek techniczny. Bowiem historia badań nad sztuczną inteligencją powiązana jest $\mathrm{z}$ kolejnymi definicjami sztucznej inteligencji i ich falsyfikacjami.

Jak wiadomo, pierwsza taka definicja pochodzi od Alana Turinga. Jest to tzw. test Turinga (Turing 1950). Test ten, polegający na nieodróżnialności zachowania się maszyny od zachowania człowieka przy konwersacji, jest jednak sztuczny, bowiem zakłada sztuczny sposób komunikacji (w artykule Turinga - komunikację przez teleks). Jednakże test Turinga okazał się absolutnie zawodnym, bowiem już w końcu lat 60-tych XX wieku Joseph Weizenbaum (zob. np. Weizenbaum 1976) skonstruował program ELIZA, który potrafił prowadzić konwersację nieodróżnialną od człowieka, tyle że na poziomie niezbyt mądrego nastolatka (czy nastolatki), powtarzając elementy zapytań z wykorzystaniem kilku reguł gramatycznych przetwarzania zdań.

Zatem komputer nie będzie inteligentny, dopóki nie będzie przejawiał intuicji; ale w tym celu niezbędna jest naukowa, zatem naturalistyczna definicja intuicji; a od Platona intuicja traktowana była (i nadal jest przez tradycyjnych filozofów) jako cecha transcendentalna, nadnaturalna. Trzeba tu jednak wyjaśnić, dlaczego traktujemy podejście naturalistyczne jako niezbędne w nauce; wynika to z rozważań o etyce nauki.

Historycznie, etyka była uzasadniana w różnorodny sposób (zob. np. Roman Morawski 2011). Przyjmujemy tutaj racjonalne i realistyczne uzasadnienie etyki (traktujące ją podobnie jak kwestię prawdy) wynikające z prac Johna Rawlsa (1971): wobec niepewności co do losów przysztych pokoleń, powinniśmy wybierać rozwiazania etycznie najbardziej sprawiedliwe. Dokładniej mówiąc, etykę można racjonalnie uzasadnić jako wynikającą z następującego założenia metaetycznego (nieco tutaj rozszerzonego i sprecyzowanego w porównaniu do sformułowań Rawlsa): Przyjda po nas

\footnotetext{
${ }^{5}$ We współczesnej filozofii założenia takie często nazywane są horyzontalnymi.
} 
następne pokolenia, które wprawdzie będa dalej rozwijać wiedzę $i$ cywilizację, ale $w$ warunkach (być może nawet narastającej) niepewności co do przyszłych kryzysów i katastrof; nasze poglady etyczne powinny wynikać z troski o te przyszłe pokolenia - a także o innych wspótmieszkańców Ziemi, którzy wspólnie stworza warunki życia dla przyszłych pokoleń.

Z tego metazałożenia wynika szereg wniosków etycznych. Pierwszą ich grupę dotyczącą pojęcia sprawiedliwości, jak już wspomniano, opracował John Rawls (1971). Rozumował on następująco: jeśli nie mamy pewności, w jakich warunkach będą żyć nasze dzieci, powinniśmy im zapewnić możliwie najbardziej sprawiedliwe rozwiązania społeczne. Jednakże pojęcie trwałego rozwoju (sustainable development, Gro Harlem Brundtland, 1987) jest innym, drugim wnioskiem etycznym: powinniśmy pozostawić następnym pokoleniom podobne szanse (głównie w zakresie zasobów naturalnych i środowiska naturalnego), jakie mieliśmy my sami. Trzecia grupa wniosków etycznych dotyczy nauki, pojęcia obiektywności w nauce oraz podstaw epistemologicznych nauki. Grupę tę opisano w książkach (Wierzbicki 2011, 2015), tutaj przedstawiamy ją w skrócie.

Po pierwsze, z tego metazałożenia wynika, że nie ma prawd absolutnych. Skoro przyszłe pokolenia będą dalej rozwijać wiedzę i cywilizację, to nie można im odmawiać prawa do kwestionowania wiedzy im przekazanej; zatem jakiekolwiek stwierdzenie o prawdzie absolutnej jest wyrazem arogancji ograniczającej prawa przyszłych pokoleń.

Po drugie, $w$ trosce o przyszłe pokolenia powinniśmy im przekazać wiedze możliwie najlepsza, najwierniej opisująa rzeczywistość, najbardziej obiektywna (mimo, że nie ma prawd absolutnych, zatem ta wiedza to tylko modele). Zatem pojęcie obiektywności jest ideałem etycznym dla nauki, podobnie jak pojęcie sprawiedliwości jest ideałem etycznym dla stosunków społecznych. Jeśli tak, to powinniśmy zachować naturalizm podejścia naukowego, gdyż zgodność $\mathrm{z}$ naturą rzeczywistości jest główną cechą naturalizmu.

Trzeba tu dodać, że dwa powyższe stwierdzenia zaprzeczają paradygmatowi postmodernizmu, który też twierdzi, że nie ma prawd absolutnych, ale kładzie nacisk na indywidualny wymiar prawdy. Mimo, że nie ma prawd absolutnych, etyka nauki motywuje nas jednak zbiorowo w dążeniu do obiektywności. 


\subsection{Racjonalna, realistyczna i naturalistyczna teoria intuicji}

Najbardziej interesujące rezultaty, które mogą być pomocne przy racjonalnej definicji intuicji, pochodzą $\mathrm{z}$ badań o asymetrii funkcji półkul mózgu ludzkiego - zob. np. Sally Springer i Georg Deutsch (1981). Liczne wyniki takich badań dowodzą, że typowa ${ }^{6}$ lewa półkula mózgu jest związana z czynnościami umysłowymi o charakterze słownym, sekwencyjnym, czasowym, cyfrowym, logicznym i analitycznym, podczas gdy półkula prawa związana jest raczej z czynnościami o charakterze pozajęzykowym, wizualnoprzestrzennym, jednoczesnym, analogowym i intuicyjnym. Najlepiej udokumentowane empirycznie jest rozróżnienie pomiędzy przetwarzaniem informacji o charakterze słownym i przestrzenno-wizualnym w dwóch różnych półkulach mózgu; inne rozróżnienia mają bardziej spekulatywny charakter.

Jednocześnie, tzw. eksperymenty $\mathrm{z}$ podzielonym mózgiem ${ }^{7}$ dają liczne dowody empiryczne na to, że świadomość analityczna i funkcje werbalne zlokalizowane są w lewej półkuli mózgu, podczas gdy w półkuli prawej zlokalizowane są funkcje wizualno-przestrzenne, emocje $i$ elementy podświadomości.

Pod wpływem współpracy z naukowcami japońskimi, którzy mają skłonność do naturalizmu (przekonania, że nauka nie powinna podejmować kwestii transcendentalnych, tylko ograniczać się do kwestii naturalnych ...) autor tej książki opracował realistyczną i naturalistyczną, racjonalną, ewolucyjną teorię intuicji opartą o przesłanki techniczne (Wierzbicki 1997).

Racjonalność teorii rozumiana jest tu we współczesnym sensie, nie platońskim: teoria jest racjonalna, jeśli da się wywieść dedukcyjnie z abstrakcyjnych zasad i sensownych założeń, ale jest jednocześnie empirycznie sensowna - według Willarda Quine’a (1953) „dotyka rzeczywistości na swych brzegach” oraz według Karla Poppera (1934, 1972) daje się falsyfikować poprzez eksperyment, a przynajmniej pozwala na wyciąganie wniosków, które mogą być sprawdzane w praktyce.

Założenie o ewolucyjnym charakterze tej teorii należy już do metajęzyka, ma bardziej horyzontalny charakter; przyjmujemy tu, że cała nasza wiedza

\footnotetext{
${ }^{6}$ U ludzi praworęcznych; u ludzi leworęcznych funkcje półkul mózgu mogą być odwrócone.

7 Kliniczne eksperymenty, w których z jakichkolwiek przyczyn ograniczone jest funkcjonowanie jednej z półkul mózgowych.
} 
o historii rozwoju cywilizacji człowieka wskazuje na ewolucyjny charakter tego rozwoju, i że wyjaśnienie intuicyjnych umiejętności człowieka może wynikać z tej ewolucji.

Wreszcie techniczny charakter tej teorii polega na tym, że stosujemy elementy wiedzy nauk technicznych - telekomunikacji i informatyki - dla wyjaśnienia potęgi intuicji.

Niejako wnioskiem ubocznym jest przy tym wyjaśnienie przyczyn i oszacowanie miary nadmiarowości umystu ludzkiego wraz $\mathrm{z}$ jego sktonnościa do transcendencji.

W codziennym użyciu, słowo intuicyjny używane jest dzisiaj często z silnym zabarwieniem irracjonalności. Są po temu powody historyczne. Otóż intuicja była przedmiotem rozważań filozoficznych niemal od początków filozofii, w każdym bądź razie od Platona, ze słynnym przykładem intuicyjnego rozwiązania zadania, jak podzielić dany kwadrat na dwa mniejsze, o równych polach.

Sokrates ( $w$ obecności Platona) rozmawiał o tym zadaniu $\mathrm{z}$ młodym, niewykształconym niewolnikiem i stwierdził, że on rozumie intuicyjnie sposób rozwiązania tego zadania - a więc wywnioskował, że ludzie mają ponadnaturalną władzę intuicji. Wniosek ten można jednak zakwestionować, gdyż niewolnik ten mógł być stolarzem i wiedzieć, że wystarczy przepiłować kwadratową płytkę wzdłuż jej przekątnych, a z powstałych czterech trójkątnych płytek złożyć (skleić) dwie płytki kwadratowe. Oczywiście, matematyk nie uzna tego za rozwiązanie problemu, ale przykład ten ilustruje różnice sposobu myślenia technika i matematyka oraz wskazuje na luki rozumowania Platona (czy Sokratesa): to nie abstrakcyjna idea, a doświadczenie techniczne może sugerować intuicyjne rozwiązanie problemu.

Od Platona do Kanta, intuicja była uważana za wewnętrzne źródło wiedzy pewnej, niezawodnej, przynajmniej w matematyce. Przypomnę tu cytat z Johna Locke'a (1690): „A oto to, co, jak sądzę, możemy nazwać wiedzą intuicyjną. Umysł wtedy nie podejmuje trudu dowodu czy badania, tylko postrzega prawdę tak, jak oko postrzega światło, tylko będąc skierowane ku niemu. W ten sposób umysł postrzega, że białe nie jest czarne, że koło nie jest trójkątem, że trzy jest większe niż dwa i równa się jeden plus dwa. Tego typu prawdy umysł postrzega na pierwszy rzut oka, przez czystą intuicję, bez 
pośrednictwa innych idei; i tego typu wiedza jest najczystsza i najbardziej pewna, na jaką stać ludzką ułomność."

Jednak to sama matematyka podważyła niezawodność intuicji poprzez powstanie geometrii nieeuklidesowej, np. geometrii zjawisk na powierzchni kuli, w której stare aksjomaty geometrii euklidesowej przestały obowiązywać i być intuicyjnie oczywiste. Dzisiaj już też wiemy, że prawdy cytowane przez Locke’a (później nazwane przez Kanta sądami syntetycznymi a priori) nie sq absolutne: koło jest topologicznie równoważne trójkątowi, a jeden plus $d w a$ modulo dwa to jeden. To, że wydaje nam się intuicyjnie oczywiste, jakoby dwa plus jeden zawsze było równe trzy, wynika z naszego ukrytego, intuicyjnego metazałożenia, że obliczenia prowadzimy $w$ dziedzinie liczb naturalnych - bo taka dziedzina wynika z naszego mezokosmicznego doświadczenia o świecie nas otaczającym. Jednak w świecie mikrokosmicznym (np. w elementach pamięci komputerów) czy makrokosmicznym założenie to może nie być adekwatne.

Od powstania geometrii nieeuklidesowej filozofia borykała się z pojęciem intuicji, różnorodnie ją ujmując; ale nadal większość filozofów traktuje ja jako władze ponadnaturalna dajaca wiedze pewna, zob. np. (Alina Motycka 2010). Celem przedstawianej tu teorii było zakwestionowanie tej tradycji poprzez $\mathrm{z}$ jednej strony naturalistyczne i techniczne wyjaśnienie potęgi intuicji ( $\mathrm{w}$ porównaniu $\mathrm{z}$ językiem $\mathrm{i}$ logiką), $\mathrm{z}$ drugiej zaś strony podkreślenie zawodności intuicji.

Wyjaśnienie techniczne opiera się na porównaniu wymagań informacyjnych dwóch trybów percepcji i rozumowania ludzkiego: słownego i przedsłownego. Przez ten ostatni rozumiemy to, co fenomenolodzy nazywają percepcja immanentna, wszystkimi zmysłami, ale z wykluczeniem słów - chociaż z włączeniem percepcji słuchem (wyczucia kierunku itp.), tyle że przedsłownej, nie obejmującej mowy.

W celu porównania siły poznawczej percepcji oraz rozumowania słownego i przedsłownego używamy wiedzy nauk technicznych, dokładniej telekomunikacji oraz informatyki, a mianowicie teorii informacji Claude'a Shannona (1948). Oszacowanie - z pewnym zapasem, w sensie „co najwyżej” - złożoności informacyjnej mowy możemy oprzeć na paśmie częstotliwości niezbędnym do przekazania dźwięku, ok. $20 \mathrm{kHz}$ (w telefonii wykorzystujemy tylko 3,4 kHz). Oszacowanie - niepełne, w sensie „co najmniej” - złożoności informacyjnej obrazu, tylko jednego z elementów 
percepcji immanentnej, przedsłownej, możemy oprzeć na paśmie częstotliwości niezbędnym do przekazania obrazu, co najmniej ok. 2 MHz. Pasmo to ma niewiele wspólnego z częstotliwościami fal świetlnych, natomiast ma wiele wspólnego $\mathrm{z}$ tym, jak oko ludzkie odbiera i interpretuje obrazy, oraz z historią rozwoju telewizji ${ }^{8}$.

W filozofii techniki pojawił się też pogląd (Don Ihde 1976, 2002), że to jednak dźwięk niesie więcej informacji niż wizja - ale pogląd taki nie wytrzymuje krytyki z perspektywy teorii informacji. Ihde bowiem używa argumentu, że względny zakres fal głosowych $(20 \mathrm{kHz}$ do $20 \mathrm{~Hz}$ czyli 1000 razy), jest większy od względnego zakresu fal świetlnych (zaledwie kilka razy). Jednakże Claude Shannon znacznie wcześniej (1948) wykazał, że miarą informacji jest bezwzględna szerokość pasma roboczego.

Jeśli zatem weźmiemy pod uwagę, że percepcja immanentna, wszystkimi zmysłami, w skrócie nazywana tu przedstowna, obejmuje poza wzrokiem także inne zmysły (węch, dotyk, smak, pozasłowne aspekty słuchu), to dochodzimy do wniosku, że stosunek złożoności informacyjnej percepcji przedstownej $i$ stownej to co najmniej $100: 1$.

W celu dalszej interpretacji tego stosunku wykorzystujemy teorię złożoności obliczeniowej. Ponieważ chodzi nam o oszacowanie dolne, typu co najmniej; mamy zatem prawo przyjąć stosunkowo słabą zależność potęgową, np. kwadratową. Wynika stąd, że stosunek złożoności obliczeniowej przetwarzania informacji przedsłownej i słownej w umyśle ludzkim wynosi co najmniej 10000 : 1; obraz jest wart nie tysiąc, a co najmniej dziesięć tysięcy stów.

Miarą tej złożoności może być np. liczba neuronów potrzebna do przetwarzania obrazów czy mowy; wiadomo, że liczba neuronów w mózgu

8 Standard szerokości pasma $2 \mathrm{MHz}$ dla przesłania czarno-białego i bardzo niedoskonałego obrazu telewizyjnego przyjęto w samych początkach telewizji. Później obraz ten znacznie doskonalono, zwiększając liczbę pikseli, ale wykorzystując także kompresję kodowania (czyli informacje tylko o zmianie charakterystyki piksela w porównaniu z poprzednim stanem i pikselami sąsiednimi, bo na takich informacjach koncentruje się oko ludzkie). W rezultacie można było przesyłać obraz znacznie lepszy nie zmieniając standardu szerokości pasma na jedną barwę; dla przesyłania obrazu kolorowego używa się trzech barw i szerokości pasma $6 \mathrm{MHz}$ (lub czterech barw i szerokości pasma $8 \mathrm{MHz}$ ). 
ludzkim wynosi ok. $10^{11}-10^{12}$, nie wiadomo tylko, po co ich tyle mamy. Małpy naczelne mają mniej więcej taką samą liczbę neuronów w swych mózgach i mają różnorodne metody komunikacji, ale nie rozwinęły mowy; być może dlatego potrzebowały tylu neuronów, bo w kontaktach z otoczeniem opierały się głównie na wzroku?

Nasuwa się więc pytanie: jak percepowali rzeczywistość i rozumowali ludzie przed ewolucyjnym „wynalazkiem mowy”? Była to oczywiście rewolucja w stopniowanym rozwoju ewolucyjnym ${ }^{9}$ człowieka, a nie wynalazek, którego to słowa używamy tu w sensie metaforycznym.

Szukając racjonalnego wyjaśnienia intuicji, powinniśmy nie tylko uwzględnić zróżnicowanie funkcji półkul mózgu, ale także teorię postrzegania rzeczywistości przez ludzi. Jak już wspomnieliśmy, jest to temat o długiej tradycji w historii filozofii; trzeba tylko przypomnieć, że empiryzm logiczny zob. np. Ludwig Wittgenstein (1922) - usiłował związać postrzeganie rzeczywistości z logiką, podczas gdy wspomniany wyżej falsyfikacjonizm Karla Poppera był niejako jednym $\mathrm{z}$ następujących po empiryzmie paradygmatów opisu związków teorii, formułowanych przez ludzi, z rzeczywistością. Innym wspomnianym wyżej podejściem była epistemologia ewolucyjna - Konrad Lorentz (1965), Franz Wuketits (1984). Wykorzystamy to podejście w następującym eksperymencie myślowym. ${ }^{10}$

Rozważmy moment $w$ ewolucyjnej historii czlowieka - lub, hipotetycznie, jakiejkolwiek rasy rozumnej w jej ewolucyjnym rozwoju - w którym nastapił wynalazek mowy. ${ }^{11}$ Przed wynalazkiem mowy, ludzie niewątpliwie dawali sobie dobrze radę $\mathrm{z}$ otaczającym ich światem, postrzegając ten świat za pomocą sygnałów i zmysłów optycznych, akustycznych itp.; okres ewolucji

9 Pojęcie stopniowanego rozwoju ewolucyjnego (czyli etapów powolnej ewolucji przedzielanych etapami zmian bardziej rewolucyjnych) wprowadził Konrad Lorentz (1965).

${ }^{10}$ Technika eksperymentu myślowego została zaproponowana przez Thomasa Kuhna (1981), który jej użył celem wykazania, że podstawowe pojęcia w każdej teorii naukowej mogą zawierać głębokie, niekiedy ukryte założenia. Najlepszym sposobem analizy takich założeń jest niekoniecznie eksperyment empiryczny; bardziej klarowne wnioski często wynikają z odpowiednio skonstruowanego eksperymentu myślowego.

${ }^{11}$ Używamy tu określenie ,wynalazek” w świadomym uproszczeniu - rozwój mowy był etapem rewolucyjnym w historii cywilizacji ludzkiej, ale etap ten trwał zapewne wiele pokoleń. 
człowieka przed wynalazkiem mowy był długi, ale uwieńczony sukcesami. Na podstawie dzisiejszej teorii i praktyki przetwarzania sygnałów wiemy jednak dobrze, że przetwarzanie obrazów jest zadaniem o złożoności większej o kilka rzędów wielkości (ok. $10^{4}$ razy) niż przetwarzanie mowy. Stąd też mózg ludzki musiał być bardzo rozwinięty już przed wynalazkiem mowy - tyle tylko, że przed wynalazkiem mowy rozumowanie musiało być prowadzone na poziomie, który dziś nazwalibyśmy podświadomym. Wynalazek mowy byt więc wielkim skrótem ewolucyjnym, a sama mowa genialnym choć uproszczonym modelem rzeczywistości, który pozwolił później na znaczne uproszczenie - a więc przyspieszenie - rozumowania, przekaz międzygeneracyjny wiedzy i kultury, gromadzenie doświadczeń cywilizacyjnych, całą cywilizacyjną ewolucję rodzaju ludzkiego.

W ramach naszego eksperymentu myślowego rozważmy jednak ten moment w historii człowieka, kiedy język jest jeszcze młody i niewielka tylko liczba powiedzmy, kilkaset - słów jest w użyciu, i zapytajmy: jaki jest $w$ tym momencie dominujacy sposób myślenia - słowny czy obrazowy? Jaka była rola słów i języka w tym stadium rozwoju? Jaki typ logiki przypisalibyśmy dziś do rozumowania na tym stadium rozwoju - binarny czy wielowartościowy? Rozważmy te pytania po kolei.

Nie ulega wątpliwości, że dominujący sposób myślenia na tym etapie rozwoju był obrazowy: skoro myślenie jest wartościowe ewolucyjnie, człowiek nie może czekać z nim, aż wynajdzie język. Słowa, od początku języka, używane były w celach komunikacji; ale mniejsza liczba słów oznacza, że mają one zwielokrotnione znaczenie, są sygnałami wieloznacznymi. Jednocześnie, każde słowo może mieć rozmaite role: inne w związku z opisem pewnych kategorii rzeczywistości czy stanów świata, inne w związku z przywołaniem emocji - czyli z wywołaniem w umyśle uczuć czy związanych z nimi obrazów, tak, jak to czynią sformułowania poetyckie. ${ }^{12}$ Tak więc, od samego początku języka, słowa w nim miały charakter wieloznaczny i wielofunkcyjny; i niewiele się w tym względzie zmieniło,

${ }^{12}$ Rozróżnienie funkcji opisowych i emocjonalnych słów jest dobrze znane we współczesnej teorii języka; nie chodzi tu jednak o przedstawienie tego czy innych aspektów rozległych studiów nad rolą języka, tylko o uwypuklenie pewnych wniosków z omawianego tu eksperymentu myślowego: rola emocjonalna języka jest tak stara, jak sam język, gdyż używany był on np. dla ostrzegania przed niebezpieczeństwem. 
gdy wynaleźliśmy dziesiątki tysięcy słów, bo zawsze nam ich będzie brakować, by w pełni opisać złożoną rzeczywistość. Ten eksperyment myślowy pomaga nam tylko lepiej uświadomić sobie fakt, że język i logika są tylko modelami, nie rzeczywistością.

Ze względu na wieloznaczność i wielofunkcyjność słów, pytanie o prawdę (, to sformulowanie musi być prawdziwe, lub nie - przecież nie ma innego wyjścia!"), o zgodność słów z rzeczywistością, zawsze było trudne i wymagało odpowiedzi typu falsyfikacjonizmu Poppera, wzmocnionej wnioskami z etyki nauki: nie ma prawd absolutnych (z wyjątkiem sformułowań ideologicznych typu „taka jest prawda!”, które stają się prawdą absolutną w oczach wyznawców), każde twierdzenie jest tylko hipotezą o tym większym stopniu prawdziwości, im więcej przetrwało prób falsyfikacji. Ale wniosek ten można też uzasadnić przez opisywany tu eksperyment myślowy, poprzez pytanie o typ logiki właściwy dla opisu świata w języku zawierającym niewiele słów. Ze współczesnej nam teorii oraz studiów empirycznych - zob. np. Eleanor Rosh i Barbara Lloyd (1978) - rozpoznawania obrazów wiadomo, że kategoria obrazów w umyśle nie jest definiowana jako ostre rozróżnienie logiczne, wynika raczej z podobieństwa do pewnego prototypu. Stopień tego podobieństwa stanowi rozmytą, wielowartościową ocenę logiczną - a więc logika używana przez ludzi tuż po wynalazku mowy na pewno nie była twardą logiką binarną.

Świadoma osobowość ludzka potrzebuje jednak logiki twardej, zdecydowanej, w momencie działania (,trzeba, czy nie trzeba podjać $a k c j e ̨$ ?”) - a więc dość szybko po wynalazku mowy pojawiła się potrzeba przekonywania innych do działania i nastąpił wynalazek logiki dwuwartościowej („Nie ma trzeciej drogi - musimy zrobić to, lub tamto!”). Zauważmy jednak, że w myśl opisywanego tu eksperymentu myślowego, logika dwuwartościowa nie powstała jako narzędzie opisu rzeczywistości, tylko narzędzie argumentacji - a więc zawsze miała charakter ideologiczny.

Podsumowując ten eksperyment myślowy, trzeba powtórzyć, że wynalazek mowy był wielkim skrótem ewolucyjnym, który umożliwił cały rozwój cywilizacyjny człowieka. Jednocześnie jednak trzeba pamiętać, że język jest tylko modelem rzeczywistości, a związana z nim logika dwuwartościowa jest w większym stopniu narzędziem przekonywania niż adekwatnym modelem świata. Wykorzystanie tych narzędzi przyspieszyło rozwój człowieka, ale 
pozostawiło znaczne partie mózgu (zwykle jego prawą połowę) wykorzystywane w stary sposób, odpowiadający okresowi przed wynalazkiem mowy i często podświadomy. To, że ten sposób jest stary, nie oznacza, że jest on ułomny - wręcz przeciwnie, przetwarzanie obrazów i logika wielowartościowa wymagają znacznie większego potencjału myślowego, niż przetwarzanie mowy i logika dwuwartościowa. Ten stary, niejako głębszy sposób myślenia obrazowego, podświadomego, w prawej półkuli mózgu, jest przez nas wciąż wykorzystywany - tylko nazywamy go dziś intuicja.

Ten sposób intuicyjnego myślenia ma naturalnie związki także z myśleniem językowym, logicznym - bo w końcu wiele informacji uzyskujemy poprzez komunikację słowną, a wyniki nawet intuicyjnego przetwarzania informacji musimy potem przekazać innym też $\mathrm{w}$ formie słów. Powstaje przy tym pytanie: czy to dobrze, czy źle, że słowa mają wieloznaczne znaczenia?

Można uważać - zob. np. Wierzbicki (1984) - że ważne słowa o charakterze pojęć podstawowych sq tym bardziej wartościowe, im sq bogatsze, im są bardziej wieloznaczne, im więcej się z nimi wiąże skojarzeń i obrazów. Rozważmy takie pojęcie, jak np. czas: historyk wiąże z tym pojęciem różne sposoby datowania dokumentów czy określania cezur historycznych; fizyk cały złożony aparat względności czasu, matematyk - zagadnienia warstw brzegowych (współistnienia kilku skal czasu w złożonym modelu matematycznym), zagadnienia dyskretyzacji czasu przy komputerowej analizie modeli; specjalista w zakresie teorii systemów i automatyki - różne aspekty dynamiki systemów, zwłaszcza ze sprzężeniem zwrotnym, wpływ opóźnień czasowych na tę dynamikę; itd. Tak samo złożonych jest wiele innych pojęć podstawowych.

O ile jednoznaczność pojęć jest potrzebna dla argumentacji logicznej, o tyle bogactwo znaczeniowe pojęć niezbędne jest w procesach poznawczych i twórczych. Dynamika procesów twórczych - np. nowych pomysłów naukowych - ma zwykle charakter bardzo podobny do miękkiego czy rozważnego podejmowania decyzji, opisanego wcześniej. W pracy badawczej, często odczuwamy „twórczy niepokój” odnośnie pewnych aspektów rozważanego problemu. Staramy się wtedy spojrzeć na ten problem z różnych stron, by zmobilizować różne perspektywy czy raczej skojarzenia i obrazy związane z różnymi pojęciami podstawowymi. Po pewnym czasie, 
doświadczamy olśnienia poznawczego, pojawia się moment eureka. Często pomaga w tym odległa analogia, poczucie podobieństwa pomiędzy problemem rozważanym a innym problemem o znanym rozwiązaniu; ale nie wszystkie analogie są dobre. Większe znaczenie może mieć intuicyjne zogniskowanie uwagi na małej części ogólnego obrazu problemu i próba spojrzenia z różnych punktów widzenia na tę część. Jeśli ta część i ten punkt widzenia są dobrane właściwie, to ta pozornie mała część nagle powiększa się i rozszerza, wzbogaca się w stowarzyszone $\mathrm{z}$ nią idee i pomysły. Takie procesy twórcze często zachodza na glębokim poziomie skojarzeń pozajęzykowych, często maja charakter podświadomy i intuicyjny.

Ta ostatnia teza była wielokrotnie potwierdzana w doświadczeniu i historii wielu dyscyplin naukowych. Karl Popper (1983) też zakłada, że teorie naukowe są tworzone $\mathrm{w}$ oparciu o intuicję. Jego nacisk na stosowanie falsyfikacjonizmu, na poddawanie próbom falsyfikacji teorii w naukach empirycznych, przeświadczenie, że dana teoria jest lepsza, jeśli "przetrwała dotychczas więcej krytyki od innych”, wszystko to jest spójne z tym założeniem. Jednakże, inne ważkie decyzje - nie tylko odnoszące się do tworzenia teorii naukowych, lecz także np. o znaczeniu politycznym czy ekonomicznym - często są podejmowane w sposób intuicyjny. Nie wyklucza to wcale thumaczenia takich decyzji, w teoriach ekonomicznych, jako narzędzia maksymalizacji użyteczności: skoro intuicja może być twórcza, może być także znakomitym narzędziem bogacenia się.

\subsection{Definicja decyzji intuicyjnych}

Po wszystkim tym, co przedstawiliśmy wyżej, może się wydawać, że wystarczy zdefiniować intuicję jako pozajęzykową aktywność prawej półkuli mózgu; definicję taką podał np. Laurence Young (1983). Jednakże definicja taka jest zbyt ogólna, trzeba ją najpierw przedyskutować z różnych punktów widzenia, a następnie zawęzić, aby była przydatna w dalszych rozważaniach.

Trzeba najpierw rozróżnić świadoma, podświadoma, i quasi-świadoma pracę naszego umysłu. Praca świadoma następuje wtedy, gdy wiemy, że chcemy czegoś dokonać i jesteśmy świadomi, że nad tym pracujemy. Praca podświadoma następuje wtedy, gdy nie wiemy, że chcemy czegoś dokonać, 
i nie jesteśmy świadomi, że nad tym pracujemy. ${ }^{13}$ Wreszcie praca quasiświadoma wykonywana jest wtedy, gdy wiemy, że chcemy czegoś dokonać, ale nie uświadamiamy sobie $\mathrm{w}$ danej chwili szczegółów działania, gdy nad tym pracujemy; możemy sobie to jednak uświadomić po osiągnięciu celu, a posteriori. Jak za chwilę wykażemy, większość naszych działań ma charakter quasi-świadomy.

Decyzja jest niewątpliwie związana z przygotowaniem działania. Działanie to może być przygotowane i wykonane świadomie, ale najczęściej jest wykonywane quasi-świadomie, a niekiedy w pełni podświadomie. Jest to w dużej mierze zależne od wyszkolenia i doświadczenia: tak, jak to przedstawiają bracia Dreyfus w Mind over Machine, zwiększanie poziomu ekspertyzy powoduje zwiększanie udziału - i jakości - działań podświadomych.

Po tej dyskusji wstępnej możemy zaproponować definicję decyzji intuicyjnych: jest to quasi-świadome $i$ podświadome przetwarzanie informacji $w$ przygotowaniu działania, wykorzystujace nagromadzone wyszkolenie $i$ doświadczenie oraz dokonane przez specjalizowana część umystu człowieka (zapewne w sposób pozajęzykowy, przez prawą półkulę mózgu). Taka definicja jest jeszcze bardzo ogólna, ale jej ogólność jest uzasadniona.

Przypomnijmy bowiem jeden z podstawowych podziałów na przynajmniej dwa typy decyzji: powtarzalne czyli operacyjne, przy wykonywaniu działań, w których jesteśmy dobrze wyszkoleni, oraz twórcze czyli strategiczne, związane z rozwiązaniem problemów nowych. Oczywiście, dychotomia taka (jak każda klasyfikacja czarno-biała, dwuwartościowa) nie jest kompletna, często mamy do czynienia $\mathrm{z}$ przypadkami pośrednimi, a więc niekiedy wprowadza się kategorię pośrednią decyzji taktycznych, łączących elementy powtarzalności z elementami nowości. Ograniczając się jednak do dwóch kategorii podstawowych zauważmy, że definicja decyzji intuicyjnych, zastosowana do kategorii decyzji operacyjnych, obejmuje praktycznie większość decyzji podejmowanych codziennie przez człowieka: umyst nasz

\footnotetext{
${ }^{13}$ Używamy tu raczej potocznego pojmowania pojęcia podświadomość, nie nadając mu bynajmniej wszelkich konotacji Zygmunta Freuda - zob. powyższe uwagi o wieloznaczności pojęć. Można to też nazwać, za Carlem Gustavem Jungiem, nieświadomościa, czy wreszcie postrzeganiem pozaświadomym.
} 
dokonuje codziennie wiele decyzji operacyjnych (czy taktycznych) podświadomie, a więc intuicyjnie. Jeśli idziemy na przechadzkę, myśląc o innych sprawach, to nie tylko podejmujemy podświadome, zautomatyzowane przez doświadczenie decyzje co do każdego kroku, ale możemy też podświadomie wybierać trasę przechadzki; można podać wiele przykładów tego typu, nie tylko w odniesieniu do czynności wypoczynkowych, lecz także zawodowych. Rola treningu i kształcenia w podejmowaniu takich decyzji jest $\mathrm{w}$ pełni uświadomiona $\mathrm{i}$ zinstytucjonalizowana $\mathrm{w}$ społeczeństwie poprzez systemy edukacyjne: powtarzanie, trening czynności powtarzalnych, to $\mathrm{w}$ istocie sposób ich automatyzacji poprzez przeniesienie ich z poziomu świadomości do quasi-świadomości i podświadomości, a więc intuicji. Tę automatyzację decyzji powtarzalnych można zarówno tłumaczyć racjonalnie - przez tworzenie skróconych ścieżek, połączeń synaps, specjalizowanych „dróg mózgu” - oraz badać eksperymentalnie.

Ta możliwość jest właśnie jednym z powodów, dla których zachowujemy tu nader szeroką definicję decyzji intuicyjnych. Można bowiem sądzić, że włączanie decyzji powtarzalnych, zautomatyzowanych, do decyzji intuicyjnych nie jest niezbędne; ale zachowujemy to włączenie dla dwóch co najmniej powodów. Po pierwsze, odpowiada ono potocznemu rozumieniu intuicji; na przykład, wiele osób powie, że intuicyjnie czy instynktownie wyłączają budzik przy obudzeniu. Użycie słowa ,instynkt” w tym przypadku jest mniej uzasadnione, gdyż sugeruje ono uwarunkowanie genetyczne tej czynności podświadomej, podczas gdy budziki nie są wynalazkiem tak starym, by mogło się ukształtować takie uwarunkowanie; intuicyjny charakter tej czynności jest raczej uwarunkowany przez jej powtarzalność. Po drugie, takie rozumienie intuicji, obejmujące także czynności powtarzalne, znacznie rozszerza możliwości jej badań eksperymentalnych. Wnioski z takich badań mogą być - jeśli będą interpretowane $\mathrm{z}$ odpowiednią ostrożnością stosowane także do analizy intuicyjnych decyzji strategicznych, intuicji w pełni twórczej.

\subsection{Fazy strategicznych procesów decyzyjnych}

Jak wspominaliśmy wcześniej, Herbert Simon (1957) zdefiniował następujące trzy fazy procesu decyzyjnego o charakterze analitycznym: rozeznanie problemu (intelligence), obejmujące m.in. zbieranie danych i informacji, modelowanie problemu (design), obejmujące określenie zmiennych decyzyjnych, kryteriów, modeli związków pomiędzy nimi, wybór (choice), 
czyli właściwe określenie decyzji, przy czym później dodano jeszcze - zob. np. (Lewandowski et al. 1989) - czwartą, istotną fazę: wdrożenie, realizacja i nadzór (implementation and monitoring), a więc nie tylko faktyczna realizacja decyzji, ale także obserwacja jej skutków.

Inni autorzy zwracali uwagę, że taki podział procesu decyzyjnego jest jeszcze zbyt ogólny, proponowali bardziej szczegółowe rozbicie wyżej wymienionych etapów. Trzeba jednak zwrócić też uwagę, że procesy decyzyjne możemy dzielić na etapy w różnoraki sposób, zależnie od charakteru tych procesów. Jeśli bowiem rozważać proces przygotowania decyzji o charakterze strategicznym i z wykorzystaniem intuicji, to trzeba uwzględnić zupełnie inne fazy tego procesu - zob. (Wierzbicki 1997):

1) Rozpoznanie (recognition), czyli spostrzeżenie, że w ogóle mamy do czynienia $\mathrm{z}$ problemem decyzyjnym. Ponieważ ludzie często unikają problemów, przeto rozpoznanie zwykle zaczyna się od swoistego odczucia niepokoju (dobrze znanego decydentom wysokiego szczebla, jeśli nie są zadowoleni z materiałów przygotowanych np. przez ich współpracowników „coś jest nie tak"). Niepokój ten zwykle prowadzi do świadomego określenia ogólnych zarysów problemu decyzyjnego, ale rozpoznanie problemu może też niekiedy pozostawać w pełni podświadome.

2) Rozważanie lub analiza (deliberation or analysis). Zależnie od stopnia świadomego określenia, na czym polega problem decyzyjny - i zależnie też od poziomu ekspertyzy decydenta - po rozpoznaniu problemu może następować (przy wysokim poziomie ekspertyzy lub przy intuicyjnym tylko rozpoznaniu problemu) rozważanie, deliberacja różnych aspektów tego problemu. $\mathrm{Z}$ różnych powodów jednak - czy to $\mathrm{w}$ związku $\mathrm{z}$ niższym poziomem ekspertyzy, czy w wyniku konieczności przygotowania decyzji przez większy zespół - może być niezbędne bardziej precyzyjne określenie charakteru problemu i poddanie go analizie, z użyciem wszelkich faz i narzędzi analitycznych procesów decyzyjnych, ale z powstrzymaniem się od faktycznego wyboru decyzji.

3) Dojrzewanie $i$ olśnienie (gestation and enlightenment). Ta niezwykle ważna faza polega na celowym zapomnieniu o wszelkich aspektach rozważanego problemu po to, aby nasza podświadomość mogła nad nim pracować. Istnieje wiele obserwacji potwierdzających celowość takiego zapomnienia - zaczynając od przekazów twórców nowych twierdzeń matematycznych czy teorii, kończąc na specyficznej japońskiej kulturze 
podejmowania decyzji i jej związkach z filozofią Zen, które omówimy jeszcze poniżej. Oczekiwany moment olśnienia może być w pełni uświadomiony, ale często jest też podświadomy, może nastąpić po przysłowiowym „przespaniu się z problemem”. Stąd też np. we wskazówkach dla organizatorów „burzy mózgów" czy innych procesów decyzji grupowych zazwyczaj znajduje się zalecenie, aby procesy takie trwały przynajmniej dwa dni.

4) Racjonalizacja (rationalization). Ta faza może być pominięta, jeśli sami wdrażamy decyzję; ale po to, by przedstawić tę decyzję innym, musimy sformułować powody, które nami kierują. Stosujemy tu pojęcie „racjonalizacja” w sensie zupełnie neutralnym: jest ona niezbędna $\mathrm{w}$ intuicyjnym procesie decyzyjnym. $\mathrm{Z}$ drugiej strony, racjonalizacja może też oznaczać samousprawiedliwienie bądź przekonywanie o charakterze ideologicznym (można też powiedzieć, że logika dwuwartościowa została po to wynaleziona, byśmy mogli dobrze uzasadniać swoje decyzje, gdy przekazujemy je innym) czy wreszcie reklamę, która zawsze jest do pewnego stopnia obecna w racjonalizacji naszych decyzji. ${ }^{14}$ Zauważmy wreszcie, że faza racjonalizacji jest $\mathrm{w}$ pewnym sensie podobna do klasycznej fazy wyboru decyzji w procesach decyzyjnych o analitycznym charakterze.

5) Wdrożenie, realizacja i nadzór (implementation and monitoring), które mogą mieć charakter świadomy, po racjonalizacji, albo też - zwłaszcza dla decyzji o bardziej taktycznym niż strategicznym charakterze - być natychmiastowe, quasi-świadome lub podświadome.

$\mathrm{W}$ intuicyjnym procesie decyzyjnym mamy więc do czynienia z pięcioma, nie czterema fazami procesu decyzyjnego, ale jest to różnica raczej drugorzędna, podkreślająca tylko zupełnie odmienny charakter tych dwóch rodzajów procesów decyzyjnych.

Podobnie drugorzędne staje się - w świetle powyższej dyskusji - pytanie, czy decyzje intuicyjne są gorsze, czy lepsze od analitycznych. Wprawdzie w dotychczasowej literaturze przedmiotu, zob. np. Sixto Rios (1994), przyjmuje się zazwyczaj - bez dowodu - że decyzje intuicyjne oznaczają

14 Przekazując nasze decyzje czy myśli innym, zawsze do pewnego stopnia je reklamujemy. Np., nawet pisząc artykuł czy książkę naukową, w oczywisty sposób racjonalizujemy nasze głębsze przemyślenia, wraz z elementami reklamy. Jednakże racjonalizacja $\mathrm{w}$ terminach abstrakcyjnych okazała się ewolucyjnie bardzo korzystna dla człowieka: pomaga ona nam m.in. pokonywać ograniczenia widzenia świata w terminach mezokosmicznych. 
decyzje nieprzemyślane, z definicji gorsze niż decyzje uzasadnione w sposób analityczny. I rzeczywiście, w pewnych przypadkach tak jest - w innych przypadkach natomiast może być całkiem odwrotnie (wyobraźmy sobie, że jadąc na nartach usiłujemy uzasadnić analitycznie operację ominięcia drzewa, które się nagle przed nami pojawiło). Błędy związane z pospiesznym, intuicyjnym podejmowaniem decyzji możemy jednak popełniać tylko wtedy, jeśli pomylimy decyzje strategiczne $\mathrm{z}$ operacyjnymi. Jeśli natomiast prawidłowo rozpoznamy strategiczny charakter decyzji, to zgodnie z przedstawionym tu procesem intuicyjnego podejmowania decyzji strategicznych - nie może być mowy o pospiesznym podejmowaniu decyzji intuicyjnych, muszą one być podejmowane powoli, powinny uzupełniać wnikliwą analizę problemu.

Bardzo istotne jest natomiast pytanie, do jakiego stopnia można badać, a do jakiego stopnia wspomagać intuicyjne procesy decyzyjne. Komputerowe wspomaganie decyzji stosuje się do wspomagania - w rozmaity sposób różnych faz analitycznych procesów decyzyjnych. Czy w ogóle możliwe jest wspomaganie faz intuicyjnych procesów decyzyjnych? Zapewne nie jest możliwe bezpośrednie wspomaganie niektórych faz omawianych wyżej, zwłaszcza fazy dojrzewania i olśnienia, ale czy możliwe jest chociażby pośrednie wspomaganie, chociażby innych faz?

Aby odpowiedzieć na te pytania, potrzebne są bardziej szczegółowe badania intuicyjnych procesów decyzyjnych, zwłaszcza najważniejszej ich fazy dojrzewania i olśnienia. Mechanizm tej fazy polega prawdopodobnie na wykorzystaniu ogromnego potencjału ludzkiego umysłu na poziomie pozasłownego przetwarzania informacji. Jeśli nie jest przytłoczony logicznym, świadomym rozumowaniem, jeśli ma dostatecznie dużo informacji do przetworzenia, pozaświadoma część naszego umysłu może zająć się zadaniem uznanym przedtem za najważniejsze, ale zapomnianym na chwilę przez część świadomą.

Interesujący jest przy tym fakt, że istnieją tradycyjne mechanizmy, instytucje kulturowe wspomagające dojrzewanie i olśnienie. W japońskiej filozofii Zen czy $\mathrm{w}$ ceremonii parzenia herbaty ${ }^{15}$ znane są nakazy opróżnienia umystu, koncentracji na pustce, koncentracji na pięknie prostoty, zapomnienia uprzedzeń eksperta; nakazy te można traktować jako pożyteczne mechanizmy

\footnotetext{
${ }^{15}$ Oczywiście, nie takiej herbaty, jaką zwykle używamy w Europie, ale herbaty herbat zwanej macza (czyli sproszkowanych zielonych liści herbaty), którą przyrządza się podczas japońskiej ceremonii herbacianej.
} 
opróżnienia naszej świadomości, pozwalające na pracę podświadomości. Japońscy badacze przywiązują dużą wagę do intuicji, także w dziedzinie wspomagania decyzji; tzw. Shinayakana systems approach, zob. (Yoshikazu Sawaragi i Yoshiteru Nakamori 1992), polega na wielostronnym i obrazowym przedstawianiu informacji o złożonej sytuacji decyzyjnej i intuicyjnym podejmowaniu decyzji. Japończycy mają zresztą specyficzną, uświęconą tradycją metodę podejmowania decyzji strategicznych - nigdy nie podejmują ich szybko, zawsze odczekają przynajmniej jedną noc (przy czym pożądane jest, aby wieczorem odbyła się ceremonia herbaciana). Ten dziwny obyczaj ma oczywiście pełny sens, jeśli interpretujemy go jako czas pozostawiony na dojrzewanie decyzji i danie szansy olśnieniu, ale często był traktowany jako niezrozumiały, lub jako negocjacyjny chwyt przewlekania procesu decyzyjnego, przez obserwujących te obyczaje Amerykanów, dla których często szybkość decyzji jest świadectwem mistrzostwa decydenta. Z drugiej jednak strony, podobny obyczaj znany jest nie tylko w Japonii, lecz także $\mathrm{w}$ tradycji dyplomacji europejskiej: jest to obyczaj przeplatania złożonych negocjacji przyjęciami dyplomatycznymi, z zasadą pomijania przedmiotu negocjacji w rozmowach podczas takiego przyjęcia. Takie właśnie obyczaje czy mechanizmy mogą być wykorzystane dla wspomagania fazy dojrzewania i olśnienia.

Niezmiernie trudno jest wspomagać fazę rozpoznania problemu, wymaga ona niewątpliwie dalszych badań: bywają ludzie uzdolnieni w intuicyjnym rozpoznawaniu problemów, pytanie tylko, czy można znaleźć sposoby kształcenia w tym kierunku. Natomiast wspomaganie bardzo ważnej fazy rozważań i analizy może być oparte na różnorodnych podejściach do analitycznego wspomagania decyzji, które będą bardziej szczegółowo omówione $\mathrm{w}$ rozdziałach następnych. $\mathrm{W}$ tej fazie, sama intuicja nigdy nie zastąpi w pełni analizy: podświadoma część umysłu musi bowiem uzyskać najpierw dostatecznie bogate, a jednocześnie dostatecznie dobrze przygotowane informacje, zanim przystąpi do ich opracowania. W tym też sensie, w świecie o wciąż większej złożoności, o wciąż wzrastającym rozmiarze dostępnych zbiorów informacji, komputerowe wspomaganie decyzji - nawet intuicyjnych - staje się koniecznością.

Natomiast faza racjonalizacji jest niewątpliwie najlepiej wspomagana; narzędzia jej wspomagania obejmują wszelkie edytory tekstu, klasyczne komputerowe systemy wspomagania zarządzania, graficznej reprezentacji wyników analizy itp. Znacznie gorzej wspomagana (niezależnie od tego, czy dotyczy ona intuicyjnego, czy analitycznego procesu decyzyjnego) jest faza wdrożenia, realizacji i nadzoru, i z pewnością warto rozwijać narzędzia dla jej wspomagania. 
Pozostaje zatem pytanie: jak badać intuicyjne procesy decyzyjne, aby je lepiej wspomagać? Badanie decyzji strategicznych może być o tyle utrudnione, że zawsze dotyczą one - $\mathrm{z}$ definicji - zagadnień nowych, a więc możliwe jest raczej badanie jakościowe, niż ilościowe. Gdyby można było uogólniać wnioski z badania decyzji operacyjnych na strategiczne, byłoby to bardzo pomocne; ale oczywiście, uogólnienia takie nie zawsze są zasadne. Tym niemniej, występują podobieństwa pomiędzy operacyjnymi i strategicznymi, intuicyjnymi procesami decyzyjnymi. Jednym $\mathrm{z}$ takich podobieństw jest zasada: wykorzystanie podświadomości i intuicji opłaca się, jeśli jesteśmy dobrze przygotowani i wytrenowani. Koreańscy łucznicy, którzy wykorzystali metody medytacji Zen przed zwycięstwem na kolejnych olimpiadach, działali racjonalnie; zresztą każdy sportowiec zna wagę odpowiedniej koncentracji przed wyczynem. W odniesieniu do systemów wspomagania decyzji, zasada powyższa oznacza, że komputer może być bardzo pomocny, ale we wstępnych fazach procesu decyzyjnego, jako np. narzędzie treningu decydenta, mniej natomiast - w samym wyborze decyzji. Być może, jest więcej takich podobieństw, wymaga to jednak dalszych badań.

Trzeba na koniec jeszcze raz podkreślić, że przedstawiona tu teoria intuicji ma charakter racjonalny - w sensie falsyfikacjonizmu Karla Poppera. Można bowiem sformułować i przeprowadzić eksperymenty badawcze, które pozwolą na falsyfikację tej teorii - zob. np. (Wierzbicki 2011). Eksperymenty te mogą być związane np. z praktycznym nauczaniem sztuki i technik negocjacji. Jeśli bowiem teoria taka jest zasadna, to lepsze wyniki $\mathrm{w}$ ćwiczeniach symulacyjnych rozwiązywania złożonych zagadnień negocjacyjnych powinny uzyskiwać te grupy studenckie, którym pozwoli się nie tylko na analizę problemu, ale da także czas na dojrzewanie i olśnienie poznawcze, lub $\mathrm{w}$ których zastosuje się takie metody stymulacji podświadomości, jak np. medytacja Zen.

\subsection{Wnioski}

Po tym dość szczegółowym opisie roli intuicji we wspomaganiu decyzji powróćmy do pytania, kim jest, lub kim będzie w następnym dziesięcioleciu współczesny decydent? Zgodnie $\mathrm{z}$ tezami rozdziału wstępnego, będzie to człowiek nowej epoki cywilizacji informacyjnej - a więc nie tylko wykształcony $\mathrm{w}$ różnorodnych technikach wyszukiwania i przetwarzania informacji, lecz także widzący świat przez pryzmat nowych pojęć. Do pojęć tych powinno należeć właściwe zrozumienie tego, czym jest intuicja, dlaczego nie staramy się jej zastępować komputerem, w czym zaś komputer może być pomocny przy wspomaganiu nawet intuicyjnych procesów decyzyjnych. 


\section{Literatura}

Oprócz literatury cytowanej $\mathrm{w}$ tym rozdziale podajemy tu też pozycje, które mogą zainteresować czytelnika, zachęcając go do własnych studiów.

Allais M. (1953) Le comportement de l'homme rationel devant le risque, critique des postulates et axiomes de l'ecole Americaine, Econometrica, 21 : 503-546

Arrow K. (1951) Social Choice and Individual Values, Yale University Press, New Haven

Axelrod R. (1984) The Evolution of Cooperation, Basic Books, New York

Barzilay J. (2010) Preference Function Modelling: the Mathematical Foundations of

Decision Theory. In: M. Ehrgott, Figueira J.R., Greco S., op. cit. pp. 57-86

Bergson H. (1903) Introduction to Metaphysics, (English translation New York 1911)

Bertalanffy L. (1968) General Systems Theory: Foundations, Development, Applications, Braziller, New York

Brundtland G., ed. (1987) Our Common Future. The World Commission on Environment and Development, Oxford University Press, Oxford

Charnes A., Cooper W.W. (1977) Goal programming and multiple objective optimization. J. Oper. Res. Soc., 1: 39-54

Chomsky N. (1986) Knowledge of Language: Its Nature, Origin and Use. Praeger Special Studies, New York

Derrida J. (1974) Of Grammatology. John Hopkins University Press, Baltimore, MD

Dreyfus H., Dreyfus S. (1986): Mind over Machine: The Role of Human Intuition and Expertise in the Era of Computers. Free Press

Fodor J.A. (1994) The elm and the expert: mentalese and its semantics.MIT Press, Boston

Frege L.F.G. (1893) Grundgesetze der Arithmetik, begriffsschriftlich abgeleitet. Verlag Hermann Pohle, Jena

Gardner H. (1984) The Mind's New Science: A History of the Cognitive Revolution, Basic Books, New York

Glushkov V.M. (1972) Basic principles of automation in organizational management systems (in Russian). Upravlayushcheye Sistemy i Mashiny. 1

Gödel K. (1931) Über formal unentscheidbare Sätze der Principia Mathematica und verwandter Systeme. Monatshefte für Mathematik und Physik 38:173-98

Granat J., Wierzbicki A.P. (1996) Interactive specification of DSS user preferences in terms of fuzzy sets. Archives of Control Sciences 5: 185-201

Grauer M., Thompson M. Wierzbicki A.P. eds. (1985) Plural Rationality and Interactive Decision Processes, Lecture Notes in Economics and Mathematical Systems Vol. 248, Springer-Verlag, Berlin-Heidelberg

Hacking I. , ed. (1981) Scientific Revolutions, Oxford University Press, Oxford

Ihde D. (1976) Listening and Voice. Ohio University Press, Athens

Ihde D. (2002) Bodies in Technology. University of Minnesota Press, Minneapolis London

Kahneman D. and Tversky A. (1982) The psychology of preferences. Scientific American, Vol. 246, pp. 160-173

Kosslyn S.M. (1980) Image and Mind, Harvard University Press, Cambridge, Mass.

Kuhn T.S. (1970) The Structure of Scientific Revolutions, 2nd ed., Chicago University Press, Chicago 
Kuhn T.S. (1981) A function of thought experiments. In I. Hacking, ed.: Scientific Revolutions, Oxford University Press, Oxford

Lewandowski A., Wierzbicki A.P., eds. (1989) Aspiration Based Decision Support Systems, Lecture Notes in Economics and Mathematical Systems Vol. 331, Springer-Verlag, Berlin-Heidelberg

Locke J. (1690) An Essay Concerning Human Understanding. Przedruk w N. Stehr i R. Grundmann, eds. (2005) Knowledge: Critical Concepts. Routledge, Oxford

Lorentz K. (1965) Evolution and Modification of Behavior: A Critical Examination of the Concepts of the "Learned" and the "Innate" Elements of Behavior, The University of Chicago Press, Chicago-London

Machina M.J. (1983) The Economic Theory of Individual Behavior Toward Risk: Theory, Evidence and New Directions. Stanford University, Center for Research on Organizational Efficiency, Techn. Report No. 433

Morawski R.Z. (2011) Etyczne Aspekty Działalności Badawczej w Naukach Empirycznych. Wydawnictwa Uniwersytetu Warszawskiego, Warszawa

Motycka A. (2010) Człowiek wewnętrzny a epistéme. ENETEIA, Warszawa 2010

Nakayama H. and Sawaragi Y. (1983) Satisficing trade-off method for multiobjective programming. In M. Grauer and Wierzbicki A.P., eds. Interactive Decision Analysis, Lecture Notes in Economics and Mathematical Systems, Vol. 229, Springer-Verlag, Berlin-Heidelberg

von Neumann J. and Morgenstern O. (1944) Theory of Games and Economic Behavior, Princeton University Press, Princeton

Popper K.R. (1934) Logik der Forschung. Julius Springer Verlag, Vienna

Popper K.R. (1975) The rationality of scientific revolutions. In R. Harre, ed. Problems of Scientific Revolution, pp. 72-101, Oxford University Press, Oxford

Popper K.R. (1983) Realism and the Aim of Science, Hutchinson, London

Pospelov G.S., Irikov V.I. (1976) Program- and Goal-Oriented Planning and Management (in Russian), Sovietskoye Radio, Moscow

Pylyshyn Z.W. (1984) Computation and Cognition: Towards a Foundation of Cognitive Science, MIT Press, Cambridge, Mass.

Quine W.V. (1953) Two dogmas of empiricism. In Benacerraf P., Putnam H. (eds) Philosophy of mathematics, Prentice-Hall, Englewood Cliffs, 1964

Rapoport A. (1989) Decision Theory and Decision Behavior, Kluwer Academic Publishers, Dordrecht

Rawls J. (1971) A Theory of Justice. Belknap Press, Cambridge, Mass

Rios S. (1994) Decision Theory and Decision Analysis: Trends and Challenges, Kluwer Academic Publishers, Dordrecht

Rogowski T., Sobczyk J., Wierzbicki A.P. (1989) IAC-DIDAS-L - A dynamic interactive decision analysis and support system for multicriteria analysis of linear and dynamic linear models on professional microcomputers. In: A. Lewandowski and A.P. Wierzbicki, eds., op.cit.

Rosh E., Lloyd B.B. (1978) Cognition and Categorization, Lawrence Erlbaum, Hillsdale, N.J.

Roy B. (1977) A conceptual framework for a prescriptive theory of decision-aid. TIMS Studies in Management Sciences, No. 6, North Holland, Amsterdam

Russel B., Whitehead A.N. (1910-13) Principia Mathematica. Cambridge University Press, Cambridge 
Sawaragi Y., Nakamori Y. (1992) Shinayakana Systems Approach in Modeling and Decision Support. Proc. 10th International Conference on Multiple Criteria Decision Making, 1:77-86, Taipei, Taiwan

Shannon C. (1948) Mathematical Theory of Communication. Bell System Technical Journal 27:376-405

Simon H.A. (1955) A behavioral model of rational choice. Quarterly Journal of Economics, 69: 99-118

Simon H.A. (1957) Models of Man. Macmillan, New York

Springer S., Deutsch G. (1981) Left Brain - Right Brain, Freeman, San Francisco

Steuer R.E. (1986) Multiple Criteria Optimization: Theory, Computation, and Application, J.Wiley \& Sons, New York

Tarski A. (1933) Pojęcie prawdy w językach nauk dedukcyjnych. English translation in:

A. Tarski: Logic, semantics, metamathematics. Hackett Publishing Company, 1956

Turing A. (1950) Computing Machinery and Intelligence, Mind 59: 433-460

Vollmer G. (1984) Mesocosm and Objective Knowledge. In F. M. Wuketits, op. cit.

Wall K.D. (1992) A model of decision making under bounded rationality. The Journal of Economic Behavior and Organization

Weizenbaum J. (1976) Computer Power and Human Reason. From Judgment to Calculations. W.H. Freeman, San Francisco

Wierzbicki A.P. (1980) The use of reference objectives in multiobjective optimization. In G. Fandel, T. Gal (eds.): Multiple Criteria Decision Making, Theory and Applications, Lecture Notes in Economic and Mathematical Systems 177: 468-486, Springer-Verlag, Berlin-Heidelberg

Wierzbicki A.P. (1984) Evolving cultural paradigms. Options V. 6, No. 3, 1984

Wierzbicki A.P. (1986) On the completeness and constructiveness of parametric characterizations to vector optimization problems. OR-Spektrum, Vol. 8 pp. 73-87

Wierzbicki A.P. (1997) On the Role of Intuition in Decision Making and Some Ways of Multicriteria Aid of Intuition. Journal of Multi-Criteria Decision Analysis Vol. 6, pp. 65-76

Wierzbicki A.P., Makowski M., Wessels J. (2000) Model-Based Decision Support Methodology with Environmental Applications. IIASA - Kluwer Academic Publishers, Dordrecht

Wierzbicki A.P. (2011) Techne ${ }_{n}$ : Elementy Niedawnej Historii Technik Informacyjnych i Wnioski Naukoznawcze. Komitet Prognoz „Polska 2000 Plus” oraz Instytut Łączności (PIB), Warszawa

Wierzbicki A.P. (2015) Przyszłość Pracy w Społeczeństwie Informacyjnym. Komitet Prognoz „Polska 2000 Plus” oraz Instytut Łączności (PIB), Warszawa

Wittgenstein L. (1922) Tractatus Logico-Philosophicus. Cambridge University Press, Cambridge

Wuketits F.M. (1984) Evolutionary epistemology - a challenge to science and philosophy. In F. M. Wuketits, ed. Concepts and Approaches in Evolutionary Epistemology. D. Reidel Publishing Co. Dordrecht

Young L.F. (1983) Computer Support for Creative Decision-Making: Right-Brained DSS. In H.G. Sol, ed., Processes and Tools for Decision Support, North Holland, Amsterdam 
Yu P.L., Zeleny M. (1975) The set of all non-dominated solutions in linear cases and a multicriteria simplex method. Journal of Mathematical Analysis and Applications, 49: 430-468

Yu P.L. (1990) Forming Winning Strategies: an Integrated Theory of Habitual Domains. Springer-Verlag, Berlin, Heidelberg

Zadeh L.A. (1978) Fuzzy sets as a basis for a theory of possibility. Fuzzy Sets and Systems 1: 3-28 

II. Teoria preferencji, wartości i użyteczności 



\section{Relacje preferencji i funkcje wartości}

Rozdział niniejszy omawia typy modeli preferencyjnych, podstawowe modele preferencji, podstawowe założenia o relacjach preferencji, relacje porządków, własności porządku słabego i związanych z nim funkcji wartości, normy i otoczenia w wektorowej przestrzeni rzeczywistej oraz własności ciągłej funkcji wartości $\mathrm{w}$ tej przestrzeni, przekształcenia funkcji wartości i jej typowe postacie, skale pomiaru, problem identyfikacji funkcji wartości, wreszcie paradoksy związane ze stosowaniem liniowej funkcji wartości.

\subsection{Typy modeli preferencyjnych}

Wspomnieliśmy już $\mathrm{w}$ poprzednich rozdziałach, że w modelach sytuacji decyzyjnych można wyróżnić ich dwie zasadnicze części - modele preferencyjne i modele rzeczowe. Analiza modelu preferencji decydenta jest głównym przedmiotem klasycznej teorii decyzji - chociaż współczesny rozwój metod wspomagania decyzji wskazuje raczej na równie duże czy nawet większe znaczenie modeli rzeczowych, a zwłaszcza na niezbędne rozróżnienie i celowość separacji tych dwóch typów modeli, które w klasycznej analizie decyzji często analizowało się łącznie, z koncentracją uwagi na modelu preferencyjnym.

Najbardziej podstawową formą modeli preferencyjnych są po prostu modele preferencji, oparte na teorii relacji. Model preferencyjny może mieć jednak także inne postaci. Typowe postaci modeli preferencyjnych są następujące:

- $\boldsymbol{y}^{\prime} \boldsymbol{P} \boldsymbol{y}^{\prime \prime}$ - relacja preferencji: podzbiór iloczynu kartezjańskiego $\boldsymbol{Y} \times \boldsymbol{Y}$ przestrzeni rezultatów decyzji $\boldsymbol{Y}$ z sobą samą, obejmujący te pary $\left(\boldsymbol{y}^{\prime}, \boldsymbol{y}^{\prime \prime}\right) \in \boldsymbol{Y} \times \boldsymbol{Y}$, w których rezultat $\boldsymbol{y}^{\prime}$ jest preferowany w porównaniu z rezultatem $\boldsymbol{y}^{\prime \prime}$ oraz o rozmaitych dalszych cechach szczegółowych;

- $w=v(y)-f u n k c j a$ wartości (zwana też porządkowa funkcją użyteczności, ang. ordinal utility function), wyrażająca pewne rodzaje preferencji w zagregowanej postaci liczb skalarnych w przestrzeni ocen $W=\boldsymbol{R}^{1}$; 
- $\mathrm{w}=\mathrm{U}\left(y, P^{r}\right)-$ funkcja użyteczności (zwana też kardynalna funkcja użyteczności, ang. cardinal utility function), wyrażająca pewne rodzaje preferencji oraz stosunek do ryzyka w sytuacjach decyzyjnych $\mathrm{z}$ niepewnością opisaną poprzez rozkład prawdopodobieństwa $P^{r}$, znów sprowadzając je do postaci liczb skalarnych w przestrzeni ocen $W=\boldsymbol{R}^{1}$.

Wszystkie powyższe modele preferencyjne są podstawowe dla teorii decyzji. Omówimy je w tej książce dość skrótowo, tylko w rozdziałach 4, 5 i 6; można bowiem znaleźć wiele tomów monografii omawiających te modele bardzo szczegółowo, zob. np. (Sixto Rios 1994). Trzeba tu jednak przypomnieć podstawowe zastrzeżenia matematyczne Jonathana Barzilay'a (2010) co do wyrażania relacji preferencji w formie funkcji wartości - jednakże $\mathrm{z}$ uwagą, że także wiele innych nauk społecznych przyjmuje niezbyt uzasadnione empirycznie horyzontalne metazałożenia, takie jak przyjęte tu założenie o stosowalności całego aparatu analizy matematycznej do wartości wynikających z relacji preferencji.

\subsection{Podstawowe relacje preferencji}

Mając do porównania dwa rezultaty (dwóch różnych decyzji), czyli dwa wektory - np. $\boldsymbol{y}^{\prime}, \boldsymbol{y}^{\prime \prime}$ - uogólniamy pojęcie nierówności wektorowej poprzez wykorzystanie pojęcia relacji matematycznej (zbioru takich par wektorów, które są ze sobą $\mathrm{W}$ określonej relacji). W stosunku do rozmaitych szczegółowych relacji preferencji będziemy stosować następującą notację:

• $\boldsymbol{y}^{\prime} \boldsymbol{P} \boldsymbol{y}^{\prime \prime}$ - rezultat $\boldsymbol{y}^{\prime}$ jest lepszy niż (preferowany względem) $\boldsymbol{y}^{\prime \prime}$;

$\bullet \boldsymbol{y}^{\prime} \boldsymbol{S} \boldsymbol{y}^{\prime \prime}$ - rezultat $\boldsymbol{y}^{\prime}$ jest gorszy niż $\boldsymbol{y}^{\prime \prime}$;

- $\boldsymbol{y}^{\prime} \boldsymbol{P}^{=} \boldsymbol{y}^{\prime \prime}$ - rezultat $\boldsymbol{y}^{\prime}$ jest równoważny rezultatowi $\boldsymbol{y}^{\prime \prime}$

- $\boldsymbol{y}^{\prime} \boldsymbol{P}^{\geq} \boldsymbol{y}^{\prime \prime}$ - rezultat $\boldsymbol{y}^{\prime}$ jest lepszy niż lub równoważny $\boldsymbol{y}^{\prime \prime}$;

$\bullet \boldsymbol{y}^{\prime} \boldsymbol{S}^{\leq} \boldsymbol{y}^{\prime \prime}$ - rezultat $\boldsymbol{y}^{\prime}$ jest gorszy niż lub równoważny $\boldsymbol{y}^{\prime \prime}$;

- $\boldsymbol{y}^{\prime} \boldsymbol{P}^{\neq} \boldsymbol{y}^{\prime \prime}$ - rezultat $\boldsymbol{y}^{\prime}$ jest nieporównywalny z $\boldsymbol{y}^{\prime \prime}$.

Pamiętajmy, że relacja to odpowiedni podzbiór przestrzeni iloczynowej czyli zbiór par spełniających odpowiednią zależność. Przez relację rozumiemy więc, ściśle biorąc, na przykład zbiór:

$$
\boldsymbol{P}=\left\{\left(y^{\prime}, y^{\prime \prime}\right) \in \boldsymbol{Y} \times \boldsymbol{Y}: \boldsymbol{y}^{\prime} \boldsymbol{P} y^{\prime \prime}\right\}
$$


Wiele z relacji opisanych powyżej można traktować jako relacje pochodne od odpowiednio dobranych relacji podstawowych preferencji. Jako relacje podstawowe można np. wybrać:

- $\boldsymbol{P}$ - relacja preferencji ścisłej „lepszy”;

- $\boldsymbol{P}^{=}$- relacja braku preferencji „równoważny”.

Na przykład, pary będące ze sobą w relacji $\boldsymbol{S}$,gorszy” to wszystkie pary $\left(\boldsymbol{y}^{\prime}, \boldsymbol{y}^{\prime \prime}\right)$ z przestrzeni iloczynowej takie, że $\boldsymbol{y}^{\prime \prime} \boldsymbol{P} \boldsymbol{y}^{\prime}$, czyli:

$$
S=\left\{\left(y^{\prime}, y^{\prime \prime}\right) \in \boldsymbol{Y} \times \boldsymbol{Y}: \boldsymbol{y}^{\prime \prime} \boldsymbol{P} \boldsymbol{y}^{\prime}\right\}
$$

Natomiast pary będące ze sobą w relacji $\boldsymbol{P}^{\ddagger}$ „nieporównywalny” to wszystkie takie pary z przestrzeni iloczynowej, które nie są ze sobą w relacjach „lepszy”, „gorszy” lub „równoważny”:

$$
\boldsymbol{P}^{\neq}=\{\boldsymbol{Y} \times \boldsymbol{Y}\} \backslash\left\{\boldsymbol{P} \cup \boldsymbol{S} \cup \mathrm{P}^{=}\right\}
$$

Zamiast $\boldsymbol{P}$ oraz $\boldsymbol{P}^{=}$, za podstawową można też uważać relację:

- $\boldsymbol{P}^{\geq}$- relacja preferencji słabej „lepszy lub równoważny”.

System podstawowych relacji preferencji wraz $\mathrm{z}$ wynikającymi $\mathrm{z}$ nich relacjami pochodnymi będziemy nazywać niekiedy struktura preferencji.

Ćwiczenie 4.1: Zdefiniować relacje $\boldsymbol{P}^{=}, \boldsymbol{P}$ i wszystkie dalsze pochodne za pomocą relacji $\boldsymbol{P}^{\geq}$.

\subsection{Podstawowe zalożenia o relacjach preferencji i własności relacji binarnych}

Powyższe związki pomiędzy relacjami preferencji wydają się absolutnie logiczne, ale $\mathrm{w}$ istocie wykorzystują pewne ukryte założenia o matematycznym charakterze przestrzeni $\boldsymbol{Y}$. Istotne jest zwłaszcza założenie, że każde dwa różne elementy tej przestrzeni są rozróżnialne przez decydenta; w praktyce założenie to nie bywa spełnione (np. nie potrafimy rozróżnić stopnia słodkości dwóch szklanek herbaty, które osłodziliśmy najpierw dokładnie tak samo, a następnie do jednej dodaliśmy ziarenko cukru - zob. np. Bernard Roy (1990). Jednakże przyjęcie założenia o istnieniu klas nierozróżnialności znacznie komplikuje teorię możliwych relacji preferencji i nie będziemy tego założenia uwzględniać w tym rozdziale. 
$\mathrm{Z}$ tego powodu istotne jest jawne wyliczenie założeń podstawowych o charakterze relacji preferencji:

1) Struktura preferencji $\boldsymbol{P}, \boldsymbol{S}, \boldsymbol{P}^{=}, \boldsymbol{P}^{\neq}$jest kompletna, czyli dla wszystkich par $\left(\boldsymbol{y}^{\prime}, \boldsymbol{y}^{\prime \prime}\right) \in \boldsymbol{Y} \times \boldsymbol{Y}, \boldsymbol{y}^{\prime}$ jest albo lepsze, albo gorsze, albo równoważne, albo nieporównywalne $\mathrm{z} \boldsymbol{y}^{\prime \prime}$ (jak wykazaliśmy wyżej, założenie to nie jest bynajmniej oczywiste);

2) Relacje „lepszy” i „gorszy” są wzajemnie antysymetryczne, czyli $y^{\prime} P y^{\prime \prime} \leftrightarrow y^{\prime \prime} S y^{\prime}$

3) Relacja „równoważny” jest symetryczna, czyli $\boldsymbol{y}^{\prime} \boldsymbol{P}^{\mathbf{z}} \boldsymbol{y}^{\prime \prime} \leftrightarrow \boldsymbol{y}^{\prime \prime} \boldsymbol{P}^{\mathbf{}} \boldsymbol{y}^{\prime}$;

4) Relacja preferencji słabej „lepszy lub równoważny” jest definiowana w sposób logicznie zgodny z jej nazwą, czyli $\boldsymbol{P}^{\geq}=\boldsymbol{P} \cup \boldsymbol{P}^{=}$(podobnie relacja $\boldsymbol{S}^{\leq}$);

\section{Uwagi:}

- Mówimy tu o porównaniu czy preferencjach w stosunku do rezultatów decyzji; jeśli jednak te rezultaty opisują kompletnie charakter decyzji, możemy to oczywiście utożsamić z porównaniem czy preferencjami w stosunku do samych decyzji. W klasycznej teorii decyzji mówi się zazwyczaj o porównaniu samych decyzji (zakładając niejawnie, że traktujemy je łącznie z ich wszystkimi rezultatami); może to jednak prowadzić do niedostatecznej uwagi przykładanej do definicji rezultatów decyzji czy dyskusji atrybutów, wskaźników jakości czy kryteriów oceny decyzji.

- Przyjęliśmy tu, że jako podstawowe definiuje się albo relacje $\boldsymbol{P}$ i $\boldsymbol{P}^{=}$ osobno, albo relację $\boldsymbol{P}^{\mathbf{z}}$ - można wtedy na ich podstawie, zgodnie z założeniami podstawowymi, zdefiniować wszystkie inne relacje. W niektórych monografiach nie dyskutuje się jednak dostatecznie jasno założeń podstawowych i ich znaczenia. Na przykład, można w sposób ukryty przyjąć założenie, że nie ma $\mathrm{w}$ przestrzeni rezultatów decyzji elementów nieporównywalnych; wystarczy w tym celu jako podstawową przyjąć relację „lepszy” $\boldsymbol{P}$, na jej podstawie zdefiniować relację „gorszy” $\boldsymbol{S}$, a następnie zdefiniować relację „równoważny” poprzez zależność:

$$
\boldsymbol{P}^{=}=\{\boldsymbol{Y} \times \boldsymbol{Y}\} \backslash\{\boldsymbol{P} \cup \boldsymbol{S}\}
$$

Wydaje się to całkowicie logicznym systemem definicji, ale zawiera ukryte założenia, że struktura preferencji $\boldsymbol{P}, \boldsymbol{S}, \boldsymbol{P}^{=}$jest kompletna - czyli, że nie ma elementów nieporównywalnych, ani klas elementów nierozróżnialnych. 
Takie ukryte założenia o kompletności pewnej struktury preferencji lub jej przechodniości wynikają zazwyczaj ze zbyt pośpiesznego wyboru podstawowych własności matematycznych relacji preferencji. Przypomnimy najpierw podstawowe własności matematyczne relacji binarnych, które oczywiście można stosować także do relacji preferencji.

Definicja 4.1. Dowolną relację binarną $\boldsymbol{P}$ (pomiędzy dwoma elementami $\boldsymbol{y}^{\prime}, \boldsymbol{y}^{\prime \prime}$ danego zbioru $\mathbf{Y}$ ) nazywamy:

a) zwrotna (ang. reflexive), jeśli $\boldsymbol{y} \boldsymbol{P} \boldsymbol{y}$ (inaczej $(\boldsymbol{y}, \mathrm{y}) \in P$ ) dla wszystkich $\boldsymbol{y} \in \mathbf{Y}$;

a') przeciwzwrotna (ang. irreflexive), jeśli $(y, y) \neg € P$ (para $(y, y)$ nie należy do $\boldsymbol{P}$ ) dla wszystkich $\boldsymbol{y} \in \boldsymbol{Y}$;

b) symetryczna, jeśli $\left(\boldsymbol{y}^{\prime}, \boldsymbol{y}^{\prime \prime}\right) \in \boldsymbol{P} \leftrightarrow\left(\boldsymbol{y}^{\prime \prime}, \boldsymbol{y}^{\prime}\right) \in \boldsymbol{P}$;

b') antysymetryczna, jeśli $\left(y^{\prime}, y^{\prime \prime}\right) \in \boldsymbol{P} \rightarrow\left(y^{\prime \prime}, y^{\prime}\right) \neg \in P$;

c) przechodnia, jeśli $\left(\boldsymbol{y}^{\prime}, \boldsymbol{y}^{\prime \prime}\right) \in \boldsymbol{P},\left(\boldsymbol{y}^{\prime \prime}, \boldsymbol{y}^{\prime \prime \prime}\right) \in \boldsymbol{P} \rightarrow\left(\boldsymbol{y}^{\prime}, \boldsymbol{y}^{\prime \prime \prime}\right) \in \boldsymbol{P}$;

d) zupetna, jeśli $\left(\boldsymbol{y}^{\prime}, \boldsymbol{y}^{\prime \prime}\right) \in \boldsymbol{P}$ lub $\left(\boldsymbol{y}^{\prime \prime}, \boldsymbol{y}^{\prime}\right) \in \boldsymbol{P}$ dla wszystkich $\left(\boldsymbol{y}^{\prime}, \boldsymbol{y}^{\prime \prime}\right) \in \boldsymbol{Y} \times \mathbf{Y}$;

e) równoważnościa, jeśli jest spełnione a), b) i c).

Zauważmy, że definiowana wcześniej relacja preferencji ścisłej $\boldsymbol{P}$ jest przeciwzwrotna i antysymetryczna. Natomiast definiowana wcześniej relacja preferencji $\boldsymbol{P}^{=}$„równoważny” nie jest w pełni równoważnością (w sensie matematycznych relacji binarnych), dopóki nie jest przechodnia; jest ona natomiast zawsze zwrotna i symetryczna.

Konieczność ostrożnego podejścia do założeń o kompletności i przechodniości wynika m.in. z faktu, że typowym sposobem określania relacji preferencji jest porównanie parami (mecze pomiędzy drużynami, oceny parami przez ekspertów w konkursie itp.). Mogą przy tym zachodzić różne przypadki nieporównywalności, np.:

- niekompletne porównanie parami (np. niektóre drużyny jeszcze ze sobą nie grały);

- niemożliwość odpowiedzialnego porównania pewnych par (np. para kandydatów w konkursie różniąca się w zasadniczy sposób zarówno in plus jak i in minus w różnych atrybutach czy wskaźnikach jakości). 


\section{Przykład 4.1:}

Niech $\boldsymbol{Y}$ oznacza przestrzeń nazw drużyn piłkarskich, które dla prostoty oznaczymy $d_{1}, d_{2}, d_{3}, d_{4}, d_{5}$ - rozpatrujemy więc przykładowo pięć drużyn piłkarskich i zakładamy, że grają one między sobą mecze rozstrzygalne (dogrywką, rzutami karnymi itp.). Przypuśćmy, że relacja „lepszy” $\boldsymbol{P}$ wyznaczona jest przez mecze dotychczas rozegrane i że rozegrano ich dotąd cztery, na przykład:

$$
\boldsymbol{P}=\left\{\left(d_{1}, d_{3}\right),\left(d_{2}, d_{4}\right),\left(d_{3}, d_{5}\right),\left(d_{2}, d_{5}\right)\right\}
$$

co oznacza, że drużyna $d_{1}$ wygrała $\mathrm{z} d_{3}, d_{2}$ wygrała $\mathrm{z} d_{4}$ itd. Możemy teraz określić, w oczywisty sposób, relację „gorszy”:

$$
\boldsymbol{S}=\left\{\left(d_{3}, d_{1}\right),\left(d_{4}, d_{2}\right),\left(d_{5}, d_{3}\right),\left(d_{5}, d_{2}\right)\right\}
$$

Rozpatrzmy teraz dwie możliwe definicje relacji równoważności i nieporównywalności. Bardziej praktyczna przyjmuje, że skoro każdy mecz musi kończyć się rozstrzygnięciem, to równoważne mogą być drużyny tylko same sobie, a więc:

$$
\boldsymbol{P}^{=}=\left\{\left(d_{1}, d_{1}\right),\left(d_{2}, d_{2}\right),\left(d_{3}, d_{3}\right),\left(d_{4}, d_{4}\right),\left(d_{5}, d_{5}\right)\right\}
$$

natomiast wszystkie drużyny, które jeszcze ze sobą nie grały, są jeszcze nieporównywalne (przy czym musimy rozpatrywać dowolne kolejności par drużyn):

$$
\begin{aligned}
\boldsymbol{P}^{\neq}= & \left\{\left(d_{1}, d_{2}\right),\left(d_{1}, d_{5}\right),\left(d_{2}, d_{3}\right),\left(d_{3}, d_{4}\right),\left(d_{1}, d_{4}\right),\left(d_{4}, d_{5}\right)\right\} \cup \\
& \left\{\left(d_{2}, d_{1}\right),\left(d_{5}, d_{1}\right),\left(d_{3}, d_{2}\right),\left(d_{4}, d_{3}\right),\left(d_{4}, d_{1}\right),\left(d_{5}, d_{4}\right)\right\}
\end{aligned}
$$

Jeśli zaś przyjmiemy (w sposób jawny czy ukryty) założenie, że system relacji $\boldsymbol{P}, \boldsymbol{S}, \boldsymbol{P}^{=}$jest kompletny, to nie możemy wprowadzić relacji nieporównywalności - i musimy przyjmować, że relacja równoważności obejmuje zarówno pary identyczności, jak i wszystkie te pary, które ze sobą nie grały (w dowolnej kolejności drużyn); oczywiście, taka definicja równoważności byłaby jednak wysoce niepraktyczna.

Zauważmy wreszcie, że przyjmując dalsze założenia dodatkowe - np. o przechodniości relacji $\boldsymbol{P}$ - moglibyśmy próbować wnioskować nieco więcej $z$ uzyskanych już rezultatów. Na przykład, skoro $d_{1}$ wygrała $z d_{3}$ oraz $d_{3}$ wygrała $\mathrm{z} d_{5}$, to z przechodniości relacji $\boldsymbol{P}$ wynika, że $d_{1}$ musi wygrać z $d_{5}$; wiemy jednak dobrze, że założenie takie $w$ piłce nożnej często się nie sprawdza. 
Powyższy przykład wykorzystamy też dla ilustracji następujących definicji:

Definicja 4.2. Zbiorami porównań do danego $\boldsymbol{y}^{-} \in \mathbf{Y}$ nazywamy następujące zbiory:

- zbiór rezultatów zdominowanych przez $\boldsymbol{y}^{-}:\left\{\boldsymbol{y}^{-}, \boldsymbol{P}\right\}=\left\{\boldsymbol{y} \in \mathbf{Y}: \boldsymbol{y}^{-} \boldsymbol{P} \boldsymbol{y}\right\}$

- zbiór rezultatów dominujacych $\boldsymbol{y}^{-}\left\{\boldsymbol{y}^{-}, \boldsymbol{S}\right\}=\left\{\boldsymbol{y} \in \boldsymbol{Y}: \boldsymbol{y}^{-} \boldsymbol{S} \boldsymbol{y}\right\}$

- zbiór rezultatów równoważnych do $\boldsymbol{y}^{-}:\left\{\boldsymbol{y}^{-}, \boldsymbol{P}^{=}\right\}=\left\{\boldsymbol{y} \in \mathbf{Y}: \boldsymbol{y}^{-} \boldsymbol{P}^{\bar{x}} \boldsymbol{y}\right\}$

- zbiór rezultatów stabo zdominowanych przez $\boldsymbol{y}^{-}:\left\{\boldsymbol{y}^{-}, \boldsymbol{P}^{\geq}\right\}=\left\{\boldsymbol{y} \in \mathbf{Y}: \boldsymbol{y}^{-} \boldsymbol{P}^{z} \boldsymbol{y}\right\}$

- zbiór rezultatów stabo dominujacych $\boldsymbol{y}^{-}:\left\{\boldsymbol{y}^{-}, \boldsymbol{S}^{\leq}\right\}=\left\{\boldsymbol{y} \in \mathbf{Y}: \boldsymbol{y} \boldsymbol{P}^{\geq} \boldsymbol{y}^{-}\right\}$

Definicja 4.3. Niezdominowanymi lub zdominowanymi elementami przestrzeni $\boldsymbol{Y}$ (lub jej określonego podzbioru) nazywamy zbiory elementów:

- Zbiór elementów niezdominowanych (takich, które nie mają elementów je dominujących):

$$
N(\boldsymbol{Y})=\left\{\boldsymbol{y}^{\wedge} \in \mathbf{Y}:\left\{\boldsymbol{y}^{\wedge}, \boldsymbol{S}\right\}=\varnothing\right\}
$$

gdzie $\varnothing$ oznacza zbiór pusty.

- Zbiór elementów zdominowanych (takich, które mają elementy je dominujące):

$$
D(Y)=\left\{y^{-} \in Y:\left\{y^{-}, S\right\} \neq \varnothing\right\}
$$

Zbiór elementów niezdominowanych odgrywa podstawową rolę $\mathrm{w}$ teorii i wspomaganiu decyzji i będziemy jeszcze wielokrotnie wykorzystywać rozmaite jego odmiany. Ważną własnością tego zbioru jest fakt, że zazwyczaj zawiera on wiele elementów, nie wyznacza jednego tylko elementu jednoznacznie - $\mathrm{w}$ rozpatrywanym wyżej przykładzie drużyn piłkarskich jest to zbiór dwuelementowy, gdyż w przykładzie tym drużyny $d_{1}, d_{2}$ nie odniosły dotąd porażki. W przykładzie tym mamy $N(\boldsymbol{Y})=\left\{d_{1}, d_{2}\right\}$; $\boldsymbol{D}(\boldsymbol{Y})=\left\{d_{3}, d_{4}, d_{5}\right\} \$$.

Chociaż dodatkowe założenie o przechodniości relacji $\boldsymbol{P}$ może być nierealistyczne, to jednak $\mathrm{w}$ wielu przypadkach jest ono potrzebne. $\mathrm{Na}$ przykład, jeśli mamy dokonać rankingu, czyli uporządkować listę opcji decyzyjnych (kandydatów do zatrudnienia, ofert przetargowych itp.), to oczywiście wymagamy przechodniości odpowiedniej relacji preferencji. 
Zupełnie dowolna definicja takiej relacji może prowadzić do paradoksów nieprzechodniości, na co wskazuje poniższy przykład:

Przykład 4.2: (oparty na tzw. paradoksie Nicolasa Condorceta, zob. np. (Jerzy Hołubiec et al. 1992): Wybieramy - z wielu startujących w konkursie jednego kandydata do zatrudnienia $\mathrm{w}$ naszej firmie, na podstawie ocen poniższych atrybutów czy wskaźników jakości kandydatów:

- $y_{1}$ - ocena umiejętności zawodowych kandydata;

- $y_{2}$ - ocena jego umiejętności współpracy z ludźmi;

- $y_{3}$ - ocena jego motywacji do pracy.

Po selekcji wstępnej (którą można np. przeprowadzić na podstawie dominacji według któregokolwiek atrybutu przy niegorszych atrybutach innych, czyli tzw. dominacji Pareto - zob. dalej) załóżmy, że pozostało trzech kandydatów $\mathrm{z}$ wektorami ocen $\boldsymbol{y}^{\prime}, \boldsymbol{y}^{\prime \prime}, \boldsymbol{y}^{\prime \prime}$, a mianowicie:

\begin{tabular}{|c|c|c|}
\hline $\boldsymbol{y}^{\prime}$ & $\boldsymbol{y}^{\prime \prime}$ & $\boldsymbol{y}^{\prime \prime \prime}$ \\
\hline 7 & 8 & 9 \\
\hline 8 & 9 & 7 \\
\hline 9 & 7 & 8 \\
\hline
\end{tabular}

Przypuśćmy, że sąd konkursowy - w przekonaniu, że można dokonywać dowolnej rozsądnej agregacji ocen atrybutów - zdecydował się przyjąć następujący sposób agregacji: jeśli istnieje dla danego kandydata taki atrybut, według którego ten kandydat jest lepszy o przynajmniej dwa punkty oceny od drugiego kandydata, to dany kandydat uważany jest za lepszego od tego drugiego. Prowadzi to do następującej relacji: $\boldsymbol{y}^{i} \boldsymbol{P} y^{j} \leftrightarrow$ istnieje

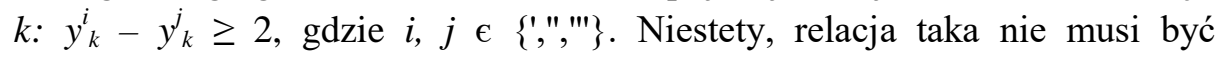
przechodnia: przy danych jak w powyższej tabeli tworzy się następujący cykl preferencji: $\boldsymbol{y}^{\prime} \boldsymbol{P} \boldsymbol{y}^{\prime \prime} ; \boldsymbol{y}^{\prime \prime} \boldsymbol{P} \boldsymbol{y}^{\prime \prime \prime} ; \boldsymbol{y}^{\prime \prime \prime} \boldsymbol{P} \boldsymbol{y}^{\prime}$.

Aby uniknąc takich cykli i wynikających z nich paradoksów, często stawia się dodatkowe wymaganie przechodniości preferencji. Zauważmy, że wymaganie to jest całkowicie naturalne przynajmniej $\mathrm{w}$ stosunku do jednej $\mathrm{z}$ relacji preferencji, a mianowicie relacji równoważności. Jeśli bowiem dwa różne elementy przestrzeni są równoważne do trzeciego, to powinny być 
równoważne względem siebie. Jednakże wymaganie przechodniości często stawia się w stosunku do całej struktury preferencji.

\subsection{Relacje porządków}

Przejdźmy teraz do ogólnych definicji struktur preferencji zwanych porzadkami; przypomnijmy, że struktura preferencji określona jest albo przez jedną relację preferencji słabej $\boldsymbol{P}^{\geq}$(i wynikające z niej inne relacje), albo przez dwie relacje podstawowe: przeciwzwrotną i antysymetryczną relację preferencji silnej $\boldsymbol{P}$ (wraz z wynikającą z niej relacją przeciwną $\boldsymbol{S}$ ) oraz zwrotną i symetryczną relację równoważności $\boldsymbol{P}^{=}$,wraz $\mathrm{z}$ wynikającymi $\mathrm{z}$ nich dalszymi relacjami pochodnymi. Dla definicji porządków przyjmiemy tę drugą możliwość.

Definicja 4.4. Porządek częściowy, słaby, zupełny.

- Strukturę preferencji $\left(\boldsymbol{P}, \boldsymbol{P}^{=}\right)$nazywamy porządkiem częściowym, jeśli obie te relacje są przechodnie.

- Strukturę preferencji (P, $\left.\boldsymbol{P}^{\overline{ }}\right)$ nazywamy porzqadkiem słabym (preporzadkiem zupetnym, porządkiem zupetnym klas równoważności), jeśli obie te relacje są przechodnie oraz:

$$
\boldsymbol{P} \cup \boldsymbol{S} \cup \boldsymbol{P}^{=}=\boldsymbol{Y} \times \boldsymbol{Y}
$$

W porządku słabym nie ma elementów nieporównywalnych, relacja $\boldsymbol{P}^{\mathbf{}}$ może być definiowana wzorem (4.4) i jest mimo to istotnie równoważnością.

- Strukturę preferencji $\left(\boldsymbol{P}, \boldsymbol{P}^{\mathbf{\Sigma}}\right)$ nazywamy porządkiem zupetnym, jeśli jest porządkiem słabym oraz

$$
\boldsymbol{P}^{=}=\left\{\left(y^{\prime}, y^{\prime \prime}\right) \in \boldsymbol{Y} \times \mathbf{Y}: \boldsymbol{y}^{\prime}=y^{\prime \prime}\right\}
$$

W porządku zupełnym relacja $\boldsymbol{P}^{=}$sprowadza się więc do relacji identyczności.

Podamy tu najpierw dwa ważne przykłady porządków:

Definicja 4.5. Porządek Pareto ${ }^{1}$. Jest to podstawowa relacja w optymalizacji wektorowej, odpowiadająca nierówności wektorowej:

\footnotetext{
${ }^{1}$ Od włoskiego ekonomisty i socjologa Vilfredo Pareto, twórcy tego pojęcia.
} 


$$
\begin{aligned}
& \boldsymbol{y} \in \boldsymbol{R}^{m}, \boldsymbol{y}=\left(y_{1}, \ldots y_{i}, \ldots y_{m}\right) \\
& \boldsymbol{y}^{\prime} \boldsymbol{P} \boldsymbol{y}^{\prime \prime} \leftrightarrow \boldsymbol{y}^{\prime} \geq \boldsymbol{y}^{\prime \prime} \text { oraz } \boldsymbol{y}^{\prime} \neq \boldsymbol{y}^{\prime \prime} \\
& \boldsymbol{y}^{\prime} \boldsymbol{P}^{=} \boldsymbol{y}^{\prime \prime} \leftrightarrow \boldsymbol{y}^{\prime}=\boldsymbol{y}^{\prime \prime} \\
& \boldsymbol{y}^{\prime} \boldsymbol{P}^{\neq} \boldsymbol{y}^{\prime \prime} \leftrightarrow\left\ulcorner( \boldsymbol { y } ^ { \prime } \geq \boldsymbol { y } ^ { \prime \prime } ) \text { oraz } \left\ulcorner\left(\boldsymbol{y}^{\prime \prime} \geq \boldsymbol{y}^{\prime}\right)\right.\right.
\end{aligned}
$$

Ćwiczenie 4.2: udowodnić, że definicja ta określa porządek, czyli wykazać przechodniość odpowiednich relacji.

Zauważmy, że relacją nieporównywalności w tym porządku objęte są wszystkie te wektory, które są ani większe lub równe, ani mniejsze lub równe po wszystkich swych współrzędnych. Jest więc wiele takich nieporównywalnych wektorów dla porządku Pareto. Ponieważ relacja nieporównywalności w porządku Pareto jest niepusta, przeto nie jest to porządek słaby ani zupełny (choć relacja równoważności jest identycznością), tylko porządek częściowy.

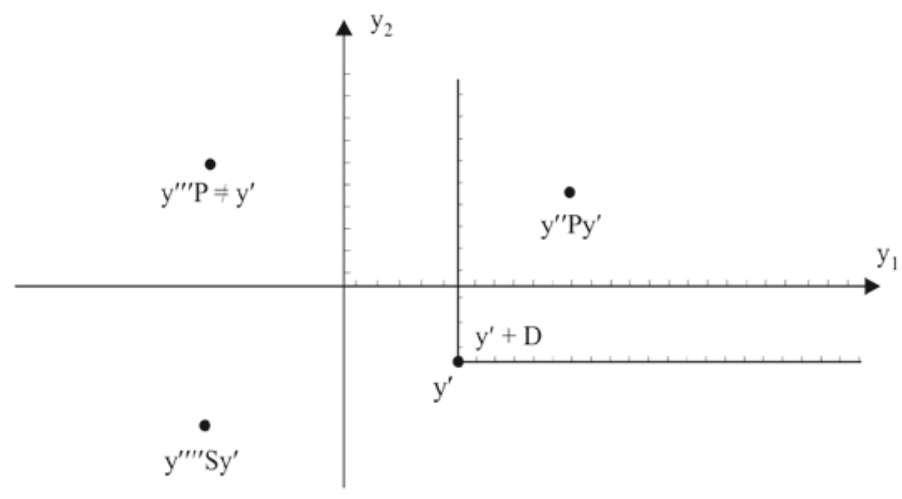

Rys. 4.1. Ilustracja graficzna porządku Pareto; $D$ - stożek dodatni tego porządku

Ćwiczenie 4.3: Udowodnić, że podana wyżej relacja nieporównywalności wynika z założenia kompletności struktury preferencji $\left\{\boldsymbol{P}, \boldsymbol{S}, \boldsymbol{P}^{=}, \boldsymbol{P}^{\ddagger}\right\}$ oraz $\mathrm{z}$ definicji relacji podstawowych $\boldsymbol{P}, \boldsymbol{P}^{=}$.

Definicja 4.6. Porządek leksykograficzny. Porządek ten odpowiada, zgodnie $\mathrm{z}$ nazwą, porządkowi słów $\mathrm{w}$ słowniku czy encyklopedii; tu zdefiniujemy go nieco odmiennie, „zaczynając od największego”. Odpowiada to przyjętej $\mathrm{w}$ tej książce konwencji, że atrybuty czy wskaźniki jakości 
decyzji wyrażamy zazwyczaj w takich skalach ocen, które maksymalizujemy; w słowniku stosujemy taki porządek oczywiście „zaczynając od najmniejszego”. Porządek taki, „zaczynając od największego”, definiujemy następująco:

$$
\begin{aligned}
& \boldsymbol{y} \in \boldsymbol{R}^{m}, \boldsymbol{y}=\left(y_{1}, \ldots y_{i}, \ldots y_{m}\right) \\
& \boldsymbol{y}^{\prime} \boldsymbol{P} \boldsymbol{y}^{\prime \prime} \leftrightarrow \exists k=1, \ldots m: y_{i}{ }_{i}=y^{\prime \prime}{ }_{i} \text { dla } i<k \text { oraz } y_{i}{ }_{i}>y^{\prime \prime}{ }_{i} \text { dla } i=k \\
& \boldsymbol{y}^{\prime} \boldsymbol{P}^{=} \boldsymbol{y}^{\prime \prime} \leftrightarrow \boldsymbol{y}^{\prime}=\boldsymbol{y}^{\prime \prime}
\end{aligned}
$$

Jest to porządek bardzo silny: można udowodnić (zob. niżej), że nie ma w nim elementów nieporównywalnych (więc jeśli jest przechodni, to jest porządkiem słabym), a ponadto relacja równoważności sprowadza się do identyczności - więc jeśli jest przechodni, to jest porządkiem zupełnym.

Ćwiczenie 4.4: udowodnić przechodniość porządku leksykograficznego.

Przykład 4.3: W celu udowodnienia, że porządek leksykograficzny jest porządkiem zupełnym, oprócz dowodu przechodniości trzeba wykazać, że jest on porządkiem słabym. Trzeba zatem udowodnić, że jeśli dwa wektory nie są sobie równe (nie są w relacji $\boldsymbol{P}^{=}$), to są one albo w relacji $\boldsymbol{P}$, albo w relacji $\boldsymbol{S}$. Jeśli dwa wektory $\boldsymbol{y}^{\prime} \in \boldsymbol{R}^{m}, \boldsymbol{y}^{\prime \prime} \in \boldsymbol{R}^{m}$ nie są sobie równe, to znajdzie się takie $k=1, \ldots$, m, że $y_{k}{ }^{\prime} \neq y^{\prime \prime}{ }_{k}$; wybierzmy najmniejsze takie $k$. Jeśli teraz $y_{k}^{\prime}>y^{\prime \prime}{ }_{k}$, to zgodnie z definicją porządku leksykograficznego zachodzi $\boldsymbol{y}^{\prime} \boldsymbol{P} \boldsymbol{y}^{\prime \prime}$; jeśli przeciwnie, $y_{k}^{\prime}<y^{\prime \prime}{ }_{k}$, to $\boldsymbol{y}^{\prime} \boldsymbol{S} \boldsymbol{y}^{\prime \prime}$. Zatem w porządku leksykograficznym nie ma wektorów nieporównywalnych, jest on porządkiem słabym - a więc też zupełnym, skoro relacja równoważności sprowadza się do identyczności.

W teorii decyzji najwięcej uwagi poświęcono własnościom porządków słabych $-\mathrm{z}$ tej prostej przyczyny, że porządek słaby daje wyrazić się za pomocą funkcji, zwanej funkcją wartości.

\subsection{Wlasności porządków słabych}

W tym i dalszych punktach przejdziemy do krótkiego zarysu teorii wartości, która dotyczy przedstawienia relacji preferencji o charakterze porządku słabego w postaci funkcji wartości. Jest to bardzo istotna część klasycznej teorii decyzji, której dobre zrozumienie warunkuje postrzeganie zarówno siły jak i słabości tej teorii. 
Przypominamy, że struktura preferencji o charakterze porządku słabego zakłada kompletność systemu preferencji o trzech rodzajach: „lepszy” $\boldsymbol{P}$, „gorszy” $\boldsymbol{S}$ oraz „równoważny” $\boldsymbol{P}^{=}$a tym samym opiera się (nie całkiem zgodnie $\mathrm{z}$ nazwą porządku słabego) na nader silnym założeniu o niewystępowaniu innych typów relacji preferencji - np. „nieporównywalny” czy „nierozróżnialny”. Tym niemniej, to właśnie silne założenie pozwala na wyciągnięcie daleko idących wniosków o charakterze matematycznym. Istnieje przy tym wiele twierdzeń określających warunki, w których dana struktura preferencji odpowiada porządkowi słabemu; przytoczymy tu kilka z nich.

Twierdzenie 4.1. Porządek częściowy określony na podstawie przechodniej relacji preferencji silnej $\boldsymbol{P}$ jest porządkiem słabym wtedy i tylko wtedy, jeśli spełnione są jednocześnie dwa poniższe warunki:

a) relacja równoważności $\boldsymbol{P}^{=}$może być określona zgodnie z założeniem o kompletności systemu preferencji $\boldsymbol{P}, \boldsymbol{S}, \boldsymbol{P}^{=}$następująco. Przypominamy, że relację $S$ definiujemy przez:

$$
\boldsymbol{y}^{\prime} \boldsymbol{S} \boldsymbol{y}^{\prime \prime} \leftrightarrow \boldsymbol{y}^{\prime \prime} \boldsymbol{P} \boldsymbol{y}^{\prime}
$$

zaś relacja $\boldsymbol{P}^{=}$wynika wtedy z założenia o kompletności:

$$
\boldsymbol{P}^{=}=\{\boldsymbol{Y} \times \boldsymbol{Y}\} \backslash\{\boldsymbol{P} \cup \boldsymbol{S}\}
$$

przy czym tak zdefiniowana relacja $\boldsymbol{P}^{=}$jest zwrotna, symetryczna i przechodnia;

b) relacje $\boldsymbol{P}$ oraz $\boldsymbol{P}^{=}$połączone przechodnio w dowolnej kolejności implikują relację $\boldsymbol{P}$, czyli:

$$
\boldsymbol{y}^{\prime} \boldsymbol{P} \boldsymbol{y}^{\prime \prime} \text { and } \boldsymbol{y}^{\prime \prime} \boldsymbol{P}^{=} \boldsymbol{y}^{\prime \prime \prime} \text { or } \boldsymbol{y}^{\prime} \boldsymbol{P}^{=} \boldsymbol{y}^{\prime \prime} \text { and } \boldsymbol{y}^{\prime \prime} \boldsymbol{P} \boldsymbol{y}^{\prime \prime \prime} \rightarrow \boldsymbol{y}^{\prime} \boldsymbol{P} \boldsymbol{y}^{\prime \prime \prime}
$$

Ćwiczenie 4.5: Posługując się materiałem poprzednich punktów, udowodnić powyższe twierdzenie oraz jego uzupełnienie - fakt, że porządek słaby jest porządkiem zupełnym klas równoważności, czyli zbiorów $\left\{\boldsymbol{y}^{-}, \boldsymbol{P}^{=}\right\}$elementów równoważnych do dowolnego $\boldsymbol{y}^{-} \in \boldsymbol{Y}$.

Rozważymy dalej konsekwencje następującej definicji preferencji quasiwypukłych i quasi-wklęsłych.

Definicja 4.7. Jeśli $\boldsymbol{Y}=\boldsymbol{R}^{m}$ (lub ogólniej, jeśli jest przestrzenią liniową lub zbiorem wypukłym w tej przestrzeni - zob. np. Tyrrell Rockafellar, 1970 lub Stanisław Kurcjusz, 1982), to relację $\boldsymbol{P}$ i wynikającą z niej 
strukturę preferencji odpowiadającą porządkowi słabemu (określoną jak w Twierdzeniu 4.1) nazywamy:

a) quasi-wypukta, jeśli $\boldsymbol{y}^{\prime} \boldsymbol{P} \boldsymbol{y}^{\prime \prime} \rightarrow \boldsymbol{y}^{\prime} \boldsymbol{P}\left((1-\lambda) \boldsymbol{y}^{\prime}+\lambda \boldsymbol{y}^{\prime \prime}\right) \quad \forall \lambda \in(0 ; 1)$

b) quasi-wklęsta, jeśli: $\boldsymbol{y}^{\prime} \boldsymbol{S} \boldsymbol{y}^{\prime \prime} \rightarrow \boldsymbol{y}^{\prime} \boldsymbol{S}\left((1-\lambda) \boldsymbol{y}^{\prime}+\lambda \boldsymbol{y}^{\prime \prime}\right) \quad \forall \lambda \in(0 ; 1)$

Twierdzenie 4.2. Jeśli $\boldsymbol{Y}$ jest zbiorem wypukłym w przestrzeni liniowej i struktura preferencji wynikająca $\mathrm{z}$ relacji $\boldsymbol{P}$ (jak w powyższej definicji i Twierdzeniu 4.1) jest porządkiem słabym, to jest ona:

a) quasi-wypukła wtedy i tylko wtedy, jeśli zbiory porównań $\{\boldsymbol{y} ; \boldsymbol{P}\}$ są wypukłe dla wszystkich $\boldsymbol{y}^{-} \in \mathbf{Y}$;

b) quasi-wklęsła wtedy i tylko wtedy, jeśli zbiory porównań $\left\{\boldsymbol{y}^{-} ; \boldsymbol{S}\right\}$ są wypukłe dla wszystkich $\boldsymbol{y}^{-} \in \boldsymbol{Y}$.

Ćwiczenie 4.6: Udowodnić powyższe twierdzenie, posługując się definicją zbiorów porównań oraz definicją zbioru wypukłego.

Twierdzenie to sugeruje analogię pomiędzy quasi-wklęsłym porządkiem słabym a znaną $\mathrm{z}$ analizy wypukłej definicją funkcji quasi-wklęsłej. ${ }^{2}$ Przypomnijmy, że funkcję $\boldsymbol{v}: \boldsymbol{Y} \rightarrow \boldsymbol{R}^{1}$ nazywamy quasi-wklęsłą, jeśli $\{\boldsymbol{y} \in \boldsymbol{Y}: \boldsymbol{v}(\boldsymbol{y}) \geq \mathrm{c}\}$ są zbiorami wypukłymi dla wszystkich c $\in \boldsymbol{R}^{1}$ (zaś quasiwypukłą, jeśli zbiory $\{\boldsymbol{y} \in \mathbf{Y}: \boldsymbol{v}(\boldsymbol{y}) \leq \mathrm{c}\}$ są wypukłe $\forall \mathrm{c} \in \boldsymbol{R}^{1}$; każde minimum funkcji quasi-wypukłej jest minimum globalnym i każde maksimum funkcji quasi-wklęsłej jest maksimum globalnym). Jeśli bowiem istnieje funkcja quasi-wklęsła charakteryzująca zbiory porównań danej relacji $\boldsymbol{S}$ w ten sposób, że:

$$
\left\{y^{-} ; S\right\}=\left\{y \in Y: v(y)>v\left(y^{-}\right)\right\}
$$

a tym samym charakteryzująca klasy równoważności przez:

$$
\left\{y^{-} ; P^{=}\right\}=\left\{y \in Y: v(y)=v\left(y^{-}\right)\right\}
$$

to quasi-wklęsły porządek słaby można wyrazić w pełni za pomocą tej funkcji. Okazuje się jednak, że dana funkcja $\boldsymbol{v}: \boldsymbol{Y} \rightarrow \boldsymbol{R}^{1}$, niezależnie od jej wypukłości czy wklęsłości, zawsze definiuje porządek słaby. Wynika to $\mathrm{z}$ następującej definicji i twierdzenia.

\footnotetext{
${ }^{2}$ Zmiana pomiędzy pojęciem wypukłości, charakterystycznej dla analizy wypukłej, a pojęciem wklęsłości wynika z faktu, że w analizie wypukłej zwykle rozpatrujemy minimalizację funkcji, natomiast w teorii wartości - maksymalizację.
} 
Definicja 4.8. Funkcja wartości. Funkcję $\boldsymbol{v}: \boldsymbol{Y} \rightarrow \boldsymbol{R}^{1}$ nazywamy funkcją wartości, jeśli określa ona strukturę preferencji w następujący sposób:

a) $\boldsymbol{y}^{\prime} \boldsymbol{P} y^{\prime \prime} \leftrightarrow v\left(y^{\prime}\right)>v\left(y^{\prime \prime}\right)$

b) $y^{\prime} P^{=} y^{\prime \prime} \leftrightarrow v\left(y^{\prime}\right)=v\left(y^{\prime \prime}\right)$

Zazwyczaj wymagamy przy tym, aby funkcja wartości była ciągła, czasami też, by była quasi-wklęsła lub wklęsła.

Twierdzenie 4.3. Struktura preferencji określona przez funkcję wartości jest porządkiem słabym.

Ćwiczenie 4.7: udowodnić powyższe twierdzenie, to jest przechodniość odpowiednich relacji oraz fakt, że relacja $\boldsymbol{P}^{=}$jest równoważnością.

Zbiory porównań odpowiadające porządkowi słabemu określonemu przez funkcję wartości $v(y)$ są zbiorami poziomicowymi tej funkcji, zob. Rys. 4.2. Jednakże nie dla każdego porządku słabego można znaleźć reprezentującą go ciągłą funkcję wartości. Na przykład, porządek leksykograficzny (który jest nie tylko słaby, ale nawet zupełny) nie może być reprezentowany za pomocą funkcji ciągłej - co wykażemy dalej.

Stąd też jednym $\mathrm{z}$ klasycznych problemów teorii wartości były warunki istnienia ciągłej funkcji wartości. Problem ten związany jest $\mathrm{z}$ pojęciem otoczeń i zbiorów otwartych, a ogólniej - przestrzeni topologicznej. W następnym podrozdziale przedstawimy ten problem w skrócie dla przypadku $\boldsymbol{Y}=\boldsymbol{R}^{m}$.

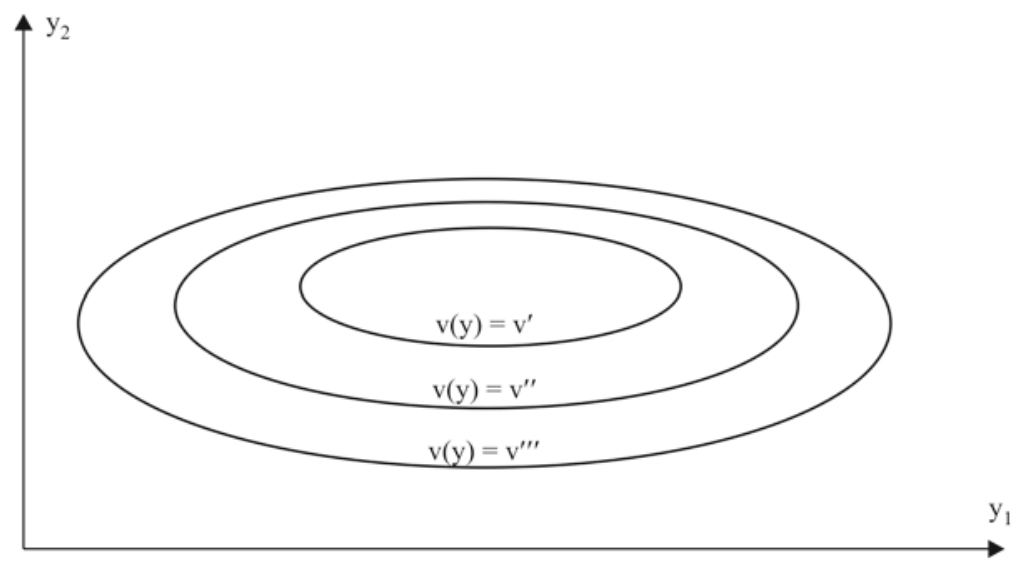

Rys. 4.2. Przykład zbiorów porównań porząaku słabego określonego przez wklęsłą funkcję wartości taką, że $y^{\prime} \boldsymbol{P} y^{\prime \prime} \boldsymbol{P} y^{\prime \prime \prime} \leftrightarrow v\left(y^{\prime}\right)=v^{\prime}, v\left(y^{\prime \prime}\right)=v^{\prime \prime}, v\left(y^{\prime \prime \prime}\right)=v^{\prime \prime}, v^{\prime}>v^{\prime \prime}>v^{\prime \prime \prime}$. 


\subsection{Normy w przestrzeni wektorów rzeczywistych oraz twierdzenie o istnieniu ciągłej funkcji wartości}

Przypomnimy, że w przestrzeni $\boldsymbol{Y}=\boldsymbol{R}^{m}$ możemy definiować rodzinę otoczeń danego punktu $y^{`}$ z parametrem $\varepsilon>0$ (czyli tzw. topologię) następująco:

$$
\boldsymbol{U}_{\varepsilon}\left(\boldsymbol{y}^{-}\right)=\left\{\boldsymbol{y} \in \boldsymbol{R}^{m}:\left\|\boldsymbol{y}-\boldsymbol{y}^{-}\right\|<\varepsilon\right\}
$$

W definicji tej ||.\| oznacza jedną z norm stosowanych w $\boldsymbol{R}^{m}$ :

- normę Euklidesowa lub $l_{2},\|\boldsymbol{y}\|_{l 2}=\left(\Sigma_{\mathrm{i}=1, \ldots \mathrm{m}}\left(y_{\mathrm{i}}\right)^{2}\right)^{0,5}$;

- normę Czebyszewa lub $l_{\infty},\|\boldsymbol{y}\|_{l}=\max _{\mathrm{i}=1, \ldots \mathrm{m}}\left|y_{\mathrm{i}}\right|$;

- normę $l_{1},\|y\|_{11}=\Sigma_{\mathrm{i}=1, \ldots \mathrm{m}}\left|y_{\mathrm{i}}\right|$

- ogólniej, normę $l_{p}, 1 \leq p<\infty,\|\boldsymbol{y}\|_{l p}=\left(\Sigma_{\mathrm{i}=1, \ldots \mathrm{m}}\left|y_{\mathrm{i}}\right|^{p}\right)^{1 / p}$.

Zbiór $\boldsymbol{Y} \subseteq \boldsymbol{R}^{m}$ nazywamy otwartym, jeśli zawiera on także otoczenia - być może, o dostatecznie małym $\varepsilon$ - dowolnego punktu w nim zawartego (otoczenie zaś jest $\mathrm{z}$ definicji także zbiorem otwartym). Interesujący jest fakt, że wybór jednej z powyższych norm w $\boldsymbol{R}^{m}$ nie wpływa na pojęcie otwartości zbioru. Zbiory w $\boldsymbol{R}^{m}$ otwarte w sensie otoczeń związanych z jedną z tych norm pozostają otwarte przy użyciu innej normy: mówimy, że normy w $\boldsymbol{R}^{m}$ są topologicznie równoważne, co nie zawsze zachodzi w innych przestrzeniach. Natomiast kształt otoczeń definiowanych przez te normy jest oczywiście rozmaity, co ilustruje Rys. 4.3.

Dokładniej mówiąc, na rysunku 4.3. (jak na większości rysunków, chyba że przyjmiemy specjalne konwencje) reprezentujemy nie otoczenia otwarte, ale ich domknięcia. Domknięcie zbioru $\boldsymbol{Y} \subseteq \boldsymbol{Y}$ określamy jako $c l \boldsymbol{Y}=\left\{\boldsymbol{y} \in \boldsymbol{Y}: \boldsymbol{U}_{\varepsilon}(\boldsymbol{y}) \cap \boldsymbol{Y} \neq \varnothing, \forall \boldsymbol{U}_{\varepsilon}(\boldsymbol{y})\right\}$. Zbiór $\boldsymbol{Y}$ jest domknięty, jeśli $c l \boldsymbol{Y}=\boldsymbol{Y}$. 

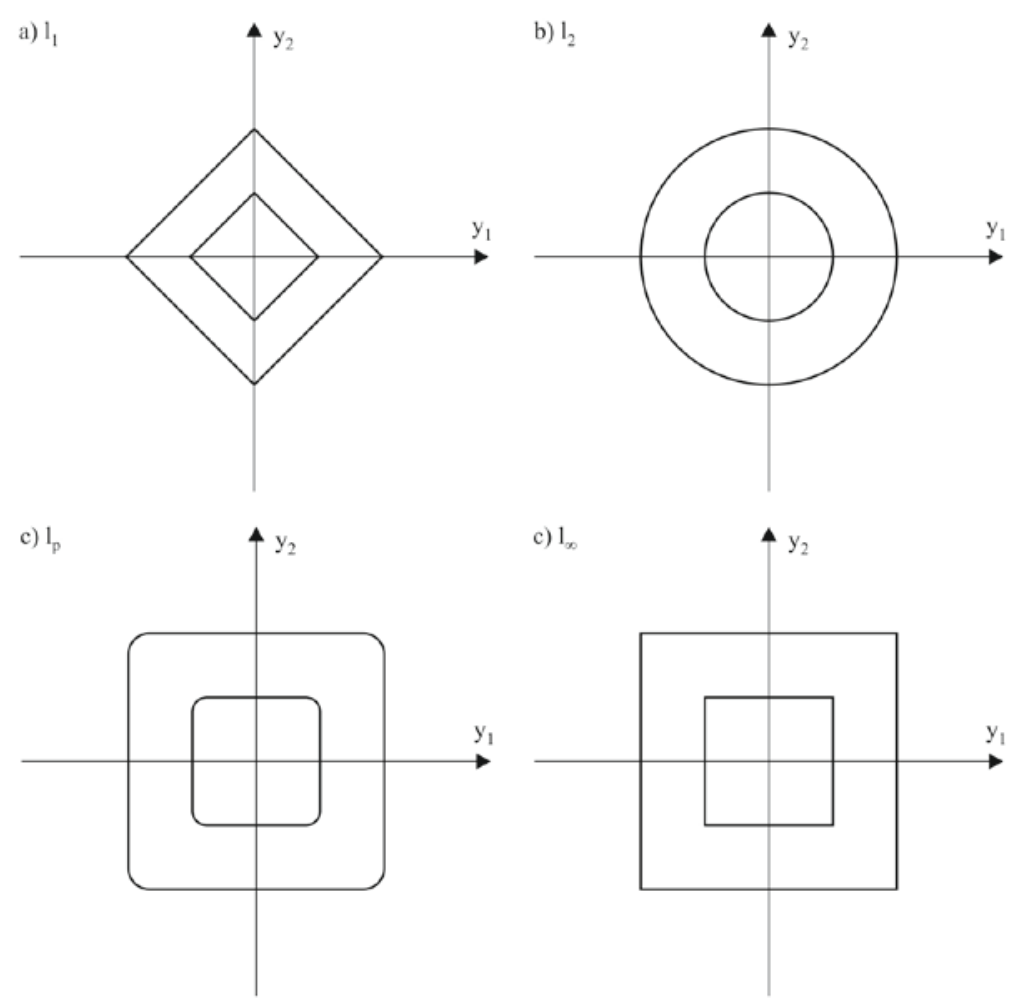

Rys. 4.3. Kształt otoczeń zera w przestrzeni $\boldsymbol{R}^{2}$ dla różnych norm: a) norma $l_{1}$;

b) norma $l_{2}$ (Euklidesowa); c) norma $l_{p}$ dla $\mathrm{p}>2$; d) norma $l_{\infty}$ (Czebyszewa).

W kategoriach zbiorów otwartych można sformułować ogólne warunki istnienia ciągłej funkcji wartości - stosujące się też do $\boldsymbol{Y}=\boldsymbol{R}^{m}$ jako przypadku szczególnego. Warunki te bywają formułowane $\mathrm{w}$ różnych formach; przytoczymy tu modyfikację twierdzenia podanego przez Gerarda Debreu $\mathrm{z}$ dostosowaniem go do $\boldsymbol{Y}=\boldsymbol{R}^{m}$ :

Twierdzenie 4.4. Jeśli $\boldsymbol{Y}=\boldsymbol{R}^{m}$ i określona jest $\mathrm{w}$ tej przestrzeni struktura preferencji $\boldsymbol{P}, \boldsymbol{P}^{=}$będąca porządkiem słabym, to strukturę tę można reprezentować za pomocą ciągłej funkcji wartości $\boldsymbol{v}: \rightarrow \boldsymbol{R}^{1}$ tak, że:

$$
\begin{aligned}
& y^{\prime} \boldsymbol{P} y^{\prime \prime} \leftrightarrow v\left(y^{\prime}\right)>v\left(y^{\prime \prime}\right) \\
& y^{\prime} \boldsymbol{P}^{=} y^{\prime \prime} \leftrightarrow v\left(y^{\prime}\right)=v\left(y^{\prime \prime}\right),
\end{aligned}
$$

wtedy i tylko wtedy, jeśli zbiory: 


$$
\begin{aligned}
& \left\{y^{-} ; \boldsymbol{P}\right\}=\left\{y \in Y: y^{-} \boldsymbol{P} y\right\} \\
& \left\{y^{-} ; S\right\}=\left\{y \in Y: y^{-} \boldsymbol{S} y\right\}
\end{aligned}
$$

są zbiorami otwartymi dla każdego $\boldsymbol{y}^{-} \in \mathbf{Y}$.

Dowód tego twierdzenia można znaleźć np. w (Gerard Debreu, 1959). $\mathrm{Z}$ twierdzenia tego wynika, dlaczego porządku leksykograficznego nie można reprezentować przez ciągłą funkcję wartości - gdyż odpowiednie zbiory porównań nie są zbiorami otwartymi (ani też domkniętymi).

Ćwiczenie 4.8: narysować zbiory porównań takie jak w Twierdzeniu 4.4. dla porządku leksykograficznego w $\boldsymbol{Y}=\boldsymbol{R}^{2}$.

Twierdzenie 4.4 traktowane bywa jako podstawowe twierdzenie ekonomii matematycznej, gdyż po to, aby badać na przykład popyt na rynku, trzeba badać preferencje konsumentów, a potem wyrażać je w postaci ciągłej funkcji wartości, z której można wyprowadzić krzywe popytu (w zależności od ceny i innych atrybutów produktu) przy założeniu, że przeciętny konsument maksymalizuje funkcję wartości przy danym ograniczeniu budżetowym. Jednakże sprawdzanie założeń tego twierdzenia w praktyce - nawet w takim zastosowaniu ekonomicznym, gdzie reprezentuje się za pomocą funkcji wartości preferencje uśrednionego konsumenta, a nie konkretnej osoby - jest niemożliwe, zatem zwykle zakłada się po prostu, że preferencje użytkownika można wyrazić za pomocą ciągłej funkcji wartości o określonej, typowej dla danego zastosowania postaci. Twierdzenie to zatem wyjaśnia nam tylko, jakie to ogólne założenia matematyczne są związane $\mathrm{z}$ założeniem o ciągłości funkcji wartości, zaś Jonathan Barzilay (2010) dowodzi, że założeń takich nie powinno się przyjmować.

\subsection{Przekształcenia funkcji wartości i jej typowe postaci}

Zanim przedstawimy typowe, często stosowane postaci funkcji wartości, trzeba najpierw podkreślić jeszcze inne podstawowe własności tej funkcji:

Twierdzenie 4.5. Jeśli $\boldsymbol{v}: \boldsymbol{Y} \rightarrow \boldsymbol{R}^{1}$ jest funkcją wartości reprezentującą porządek słaby $\boldsymbol{P}, \boldsymbol{P}^{=}$tak, że:

$$
y^{\prime} P y^{\prime \prime} \leftrightarrow v\left(y^{\prime}\right)>v\left(y^{\prime \prime}\right), y^{\prime} P^{=} y^{\prime \prime} \leftrightarrow v\left(y^{\prime}\right)=v\left(y^{\prime \prime}\right)
$$


oraz $r: \boldsymbol{R}^{1} \rightarrow \boldsymbol{R}^{1}$ jest funkcją ściśle rosnącą $\left(w^{\prime}>w^{\prime \prime} \rightarrow r\left(w^{\prime}\right)>r\left(w^{\prime \prime}\right)\right)$, to funkcja $v^{\prime}: \boldsymbol{Y} \rightarrow \boldsymbol{R}^{1}$ określona przez złożenie funkcji $r$ i $v$ :

$$
v^{\prime}(\boldsymbol{y})=r(v(\boldsymbol{y}))
$$

jest też funkcją wartości reprezentującą ten sam porządek.

Dowód tego twierdzenia jest oczywisty: funkcje $v^{\prime}$ i $v$ mają takie same zbiory poziomicowe $\left\{\boldsymbol{y} \in \boldsymbol{Y}: v(\boldsymbol{y})>v\left(\boldsymbol{y}^{-}\right)\right\}=\left\{\boldsymbol{y} \in \mathbf{Y}: r(v(\boldsymbol{y}))>r\left(v\left(\boldsymbol{y}^{-}\right)\right)\right\}$, jeśli $r$ jest funkcją ściśle rosnącą. Wynika stąd, że zbiory porównań $\left\{\boldsymbol{y}^{-} ; \boldsymbol{S}\right\}=\left\{\boldsymbol{y}^{-} ; \boldsymbol{S}^{\prime}\right\} \forall \boldsymbol{y}^{-} \in \boldsymbol{Y}$, gdzie $\boldsymbol{S}$ i $\boldsymbol{S}^{\prime}$ są relacjami preferencji ,gorszy” odpowiadającymi funkcjom $v$ i $v^{\prime}$; a więc $\boldsymbol{S}=\boldsymbol{S}^{\prime}$. Wynika stąd także, że $\boldsymbol{P}=\boldsymbol{P}^{\prime}$, gdzie $\boldsymbol{P}$ i $\boldsymbol{P}^{\prime}$ są odpowiednimi relacjami preferencji „lepszy”; w analogiczny sposób dowodzimy, że $\boldsymbol{P}^{=}=\boldsymbol{P}^{,}$, gdzie $\boldsymbol{P}^{{ }^{\prime}}$ i $\boldsymbol{P}^{,=}$są odpowiednimi relacjami preferencji „,równoważny”; a więc porządki słabe generowane przez funkcje $v$ i $v$ ' są identyczne.

Można więc mówić, że funkcje wartości $v$ i $v^{\prime}$ określona przez $v^{\prime}(y)=r(v(y))$ są równoważne, gdyż są określone $\mathrm{z}$ dokładnością do przekształcenia ściśle rosnącego. Dlatego też funkcja wartości ma tylko charakter porządkowy (ang. ordinal), i nazywana też bywa porządkowa funkcja użyteczności. Ilustruje to też następujący przykład często stosowanej w ekonomii klasy funkcji wartości typu Cobba-Douglasa: ${ }^{3}$

$$
\begin{aligned}
& v(y\})=\prod_{\mathrm{i}=1, \ldots \mathrm{m}}\left(y_{\mathrm{i}}-y_{\mathrm{i}}^{-}\right)^{\beta \mathrm{i}} ; \\
& v^{\prime}(\boldsymbol{y})=\log v(\boldsymbol{y})=\sum_{\mathrm{i}=1, \ldots \mathrm{m}} \beta_{\mathrm{i}} \log \left(y_{\mathrm{i}}-y_{\mathrm{i}}^{-}\right)
\end{aligned}
$$

gdzie zakłada się $y_{\mathrm{i}}>\overline{y_{\mathrm{i}}} \forall \mathrm{i}=1, \ldots \mathrm{m}$, a współczynniki $\beta_{\mathrm{i}}>0$ zwane są wspótczynnikami elastyczności. Funkcja $v^{\prime}$ jest dogodniejsza w zastosowaniach, gdyż ma postać addytywnie separowalną.

Nasuwa się zatem pytanie ogólne: przy jakich założeniach co do własności relacji preferencji można oczekiwać, że za pomocą odpowiedniego przekształcenia ściśle rosnącego da się sprowadzić funkcję wartości do ogólnej postaci addytywnie separowalnej:

$$
v(\boldsymbol{y})=\sum_{\mathrm{i}=1, \ldots \mathrm{m}} \alpha_{\mathrm{i}} v_{\mathrm{i}}\left(y_{\mathrm{i}}\right) ; \alpha_{\mathrm{i}}>0, \sum_{\mathrm{i}=1, \ldots \mathrm{m}} \alpha_{\mathrm{i}}=1
$$

\footnotetext{
${ }^{3}$ Od ekonomistów Paula Douglasa i Charlesa Cobba, którzy uzasadnili statystycznie tę funkcję w 1928 roku.
} 
gdzie $\alpha_{\mathrm{i}}$ nazywane są ogólnie współczynnikami wagi (które często normalizuje się tak, by sumowały się do jedności, jak zaznaczono powyżej).

Odpowiedź na to pytanie związana jest $\mathrm{z}$ następującym pojęciem niezależności preferencyjnej atrybutów (współrzędnych $y_{\mathrm{i}}$ ):

Definicja 4.9: niezależność preferencyjna atrybutów. Relacja preferencji $\boldsymbol{P}$ wykazuje niezależność preferencyjna atrybutów, jeśli dla dowolnego $\mathrm{i}=1, \ldots \mathrm{m}$, dowolnych $y_{\mathrm{i}}^{\prime} \mathrm{i} y_{\mathrm{i}}^{\prime \prime}$ oraz dowolnych $y_{1}, \ldots y_{\mathrm{i}-1}, y_{\mathrm{i}+1}, \ldots y_{\mathrm{m}}$, $y_{1}^{-}, \ldots y_{\mathrm{i}-1}^{-}, y_{\mathrm{i}+1}^{-}, \ldots y_{\mathrm{m}}^{-}$, jeśli zdefiniujemy:

$$
\begin{aligned}
& \boldsymbol{y}^{\prime}=\left(y_{1}, \ldots y_{\mathrm{i}-1}, y_{\mathrm{i}}^{\prime}, y_{\mathrm{i}+1}, \ldots y_{\mathrm{m}}\right) \in \boldsymbol{Y}, \boldsymbol{y}^{\prime \prime}=\left(y_{1}, \ldots y_{\mathrm{i}-1}, y_{\mathrm{i}}^{\prime \prime}, y_{\mathrm{i}+1}, \ldots y_{\mathrm{m}}\right) \in \boldsymbol{Y} \\
& \boldsymbol{y}^{\top}=\left(\overline{y_{1}}, \ldots \overline{y_{\mathrm{i}-1}}, y_{\mathrm{i}}^{\prime}, \overline{y_{\mathrm{i}+1}}, \ldots \overline{y_{\mathrm{m}}}\right) \in \boldsymbol{Y}, \boldsymbol{y}^{-\prime \prime}=\left(\overline{y_{1}}, \ldots \overline{y_{\mathrm{i}-1}}, y_{\mathrm{i}}^{\prime \prime}, \overline{y_{\mathrm{i}+1}}, \ldots \overline{y_{\mathrm{m}}}\right) \in \boldsymbol{Y}
\end{aligned}
$$

(zauważmy, że $\boldsymbol{y}^{\prime}$ różni się od $\boldsymbol{y}^{\prime \prime}$ oraz $\boldsymbol{y}^{-1}$ od $\boldsymbol{y}^{-\prime}$ tylko i-tymi składowymi), to z relacji $\boldsymbol{y}^{-1} \boldsymbol{P} \boldsymbol{y}^{-1 "}$ dla danych wartości $\left(y_{1}^{-}, \ldots y_{\mathrm{i}-1}^{-}, y_{\mathrm{i}+1}^{-}, \ldots y_{\mathrm{m}}^{-}\right)$wynika relacja $\boldsymbol{y}^{\prime} \boldsymbol{P} \boldsymbol{y}^{\prime \prime}$ dla dowolnych $\left(y_{1}, \ldots y_{\mathrm{i}-1}, y_{\mathrm{i}+1}, \ldots y_{\mathrm{m}}\right)$.

Twierdzenie 4.6. Jeśli relacja preferencji $\boldsymbol{P}$ ma reprezentację w postaci funkcji wartości, to można tę funkcję wartości sprowadzić do równoważnej postaci separowalnej:

$$
v(y)=V\left(v_{1}\left(y_{1}\right), \ldots v_{\mathrm{i}}\left(y_{\mathrm{i}}\right), v_{\mathrm{m}}\left(y_{\mathrm{m}}\right)\right)
$$

wtedy i tylko wtedy, gdy relacja ta wykazuje niezależność preferencyjną atrybutów. Jeśli funkcja $V$ jest ściśle monotoniczna względem swych argumentów, to można ją też sprowadzić do postaci addytywnie separowalnej.

Dowód twierdzenia 4.6 można znaleźć np. w (Sawaragi et al. 1985).

Uwaga: niezależność preferencyjna atrybutów, a nawet ściśle monotoniczna postać funkcji $\boldsymbol{V}$ nie są założeniami bardzo silnymi. Na przykład, często można założyć, że decydent uwzględnia kilka atrybutów i każdy z nich maksymalizuje - większe wartości każdego atrybutu są preferowane w stosunku do wartości mniejszych, niezależnie od poziomu innych atrybutów. W takim przypadku oba te założenia są spełnione i funkcja wartości da się (teoretycznie) sprowadzić do postaci addytywnie separowalnej.

Trzeba jednak pamiętać, że w praktyce nie wiemy z góry, jakie mamy przyjąć przekształcenie $V$ - a także jak je sprowadzić do postaci addytywnej - i jakie 
przyjąć przekształcenia $v_{\mathrm{i}}$; natomiast założenie a priori określonej postaci funkcji wartości może oznaczać (często ukryte, a trzeba z nich zdawać sobie sprawę) założenia o sile preferencji w stosunku do poszczególnych atrybutów, co związane jest $\mathrm{z}$ pojęciem skal pomiaru wartości omawianym $\mathrm{w}$ następnym punkcie.

\subsection{Skale pomiaru i problem identyfikacji funkcji wartości}

Funkcja wartości w swej postaci porządkowej z założenia nie mówi nic o sile preferencji (np. ile razy preferujemy jedną opcję w porównaniu z drugą) - właśnie dlatego, że możemy ją poddać dowolnemu przekształceniu ściśle rosnącemu. Natomiast w większości zastosowań istotne jest modelowanie siły preferencji; by ją określać, musimy zdawać sobie sprawę $\mathrm{z}$ różnorodnych skal pomiaru wartości. Rozróżnia się następujące skale pomiaru:

- Skala porządkowa - określająca tylko kolejność, a nie inne wzajemne stosunki obiektów pomiaru - niezmiennicza względem przekształceń zachowujących porządek, czyli ściśle rosnących.

- Skala różnicowa - w której różnice pomiędzy zmiennymi pomiarowymi powinny pozostawać też uporządkowane przy dopuszczalnych transformacjach skali (które powinny być wtedy ściśle monotoniczne i o ściśle monotonicznej pochodnej).

- Skala interwałowa - w której ilorazy różnic pomiędzy zmiennymi pomiarowymi powinny pozostawać uporządkowane przy dopuszczalnych transformacjach skali (transformacjami takimi są ściśle rosnące przekształcenia afiniczne typu $w=a v+b$ przy $a>0$ ). Skala interwałowa nazywana też bywa kardynalna i odgrywa podstawową rolę w probabilistycznej teorii użyteczności.

- Skala ilorazowa - w której ilorazy samych zmiennych mierzonych powinny pozostać uporządkowane (np. w przypadku masy, długości, czasu itp. gdzie sens ma zdanie „czas ten był pięć razy dłuższy niż określona jednostka”, o dopuszczalnych transformacjach skali typu $w=a v$ przy $a>0$ ).

- Skala absolutna - w której nie ma dopuszczalnych transformacji (z wyjątkiem identycznościowej, np. pomiar temperatury w skali Kelvina). 
Problem identyfikacji funkcji wartości polega właśnie na tym, że teoretycznie funkcja ta określona jest tylko w skali porządkowej, ale często przypisujemy jej (niekiedy podświadomie i bez dostatecznego uzasadnienia) co najmniej skalę interwałową lub nawet ilorazową. Na przykład, psychologiczne badania preferencji wskazują na ich silną zależność od kontekstu - właśnie w sensie siły preferencji, a nie tylko ich porządku. Zgodnie z teorią Herberta Simona o „zadowalającym” trybie podejmowania rzeczywistych decyzji, decydent kieruje się adaptacyjnie tworzonymi poziomami aspiracji dla poszczególnych atrybutów decyzji - i siła jego preferencji względem danego atrybutu istotnie zależy od faktu, czy dla innych atrybutów osiągnięto odpowiednie poziomy aspiracji, czy też nie.

Jednakże wymagając, aby założona postać funkcji wartości wyrażała też takie aspekty psychologiczne, przechodzimy w istocie do jej pomiaru w skali co najmniej interwałowej.

Dlatego też założenie o niezależności preferencyjnej atrybutów i twierdzenie 4.6 trzeba interpretować bardzo ostrożnie: choć akceptujemy w wielu przypadkach teoretyczną możliwość stosowania postaci addytywnie separowalnej, to jednak dotyczy to tylko skali porządkowej; jeśli chcemy wykorzystać skale silniejsze, postać addytywnie separowalna może nie być uzasadniona. Tym niemniej, założenie o postaci addytywnie separowalnej jest często przyjmowane $\mathrm{w}$ klasycznej teorii decyzji $\mathrm{z}$ uwagi na prostotę identyfikacji i dalszej analizy funkcji wartości.

Jeśli założymy, że funkcję wartości mierzymy w skali co najmniej interwałowej - jako swojego rodzaju poziom satysfakcji decydenta, przy którym istotne i uporządkowane są też ilorazy przyrostów tego poziomu - to wówczas zagadnienie identyfikacji funkcji wartości można sprowadzić do pytań o intensywność preferencji. Na założeniu takim, z jednoczesnym bardzo silnym założeniem o liniowości funkcji wartości, opiera się jedna z najbardziej popularnych metod identyfikacji funkcji wartości. Jest to metoda hierachii analitycznej (AHP - Analytical Hierarchy Process, zob. Thomas Saaty 1980) służąca do identyfikacji współczynników wagi przy założeniu najprostszej, wręcz liniowej postaci funkcji wartości:

$$
v(y)=\sum_{\mathrm{i}=1, \ldots \mathrm{m}} \alpha_{\mathrm{i}} y_{\mathrm{i}} ; \alpha_{\mathrm{i}}>0, \sum_{\mathrm{i}=1, \ldots \mathrm{m}} \alpha_{\mathrm{i}}=1
$$

przy czym zakłada się tu $\mathrm{w}$ istocie skalę ilorazową pomiaru znaczenia atrybutów czy kryteriów, pytając decydenta ile razy dany atrybut $y_{\mathrm{i}}$ jest 
ważniejszy od innego $y_{\mathrm{j}}$. Odpowiedzi decydenta zestawiane są w macierz, która w przypadku idealnych (bezbłędnych i wzajemnie spójnych) odpowiedzi miałaby następujące własności:

$$
\alpha_{i j}=\alpha_{i} / \alpha_{j}, \alpha_{j i}=1 / \alpha_{i j}, \alpha_{i i}=1, \boldsymbol{A}=\left[\alpha_{i j}\right]
$$

Macierz $\boldsymbol{A}$ o wymiarach $m \times m$ i powyższych własnościach nazywamy spójną z pewnym wektorem $\boldsymbol{\alpha}=\left(\alpha_{1}, \ldots \alpha_{i}, \ldots \alpha_{m}\right)$, który posłużył do ukształtowania tej macierzy. Macierz spójna ma wszystkie kolumny liniowo zależne, a więc rząd $\boldsymbol{A}=1$ i większość jej wartości własnych jest zerowa, $\lambda_{i}(\boldsymbol{A})=0$ dla $i=1, \ldots m-1$; można też wykazać, że $\lambda_{m}(\boldsymbol{A})=\lambda_{\max }(\boldsymbol{A})=m$.

Natomiast macierz utworzona $\mathrm{z}$ danych uzyskanych od decydenta oznaczymy ją przez $\boldsymbol{W}=\left[w_{i j}\right]-$ nie musi być spójna: chociaż oczywiście przyjmujemy $w_{j i}=1 / w_{i j}, w_{i i}=1$, to jednak nie musi istnieć taki wektor $\boldsymbol{w}=\left(w_{1}, \ldots w_{i}, \ldots w_{m}\right)$, że $w_{i}>0, w_{i j}=w_{i} / w_{j}$. Dlatego też problem identyfikacji wektora $\boldsymbol{\alpha}$ czy $\boldsymbol{w}$ można traktować jako zagadnienie znalezienia takiej macierzy spójnej $\boldsymbol{A}$, która jest w pewnym sensie najbliższa danej (niekoniecznie spójnej) macierzy $\boldsymbol{W}$.

W metodzie hierarchii analitycznej nie formułuje się tego problemu w kategoriach statystycznych, a stosuje się do jego rozwiązania pewne algebraiczne własności macierzy $\boldsymbol{W}$ :

- Maksymalna wartość własna macierzy $\boldsymbol{W}$ wynosi co najmniej $m$ :

$$
\lambda_{\max }(\boldsymbol{W}) \geq m=\lambda_{\max }(\boldsymbol{A})
$$

- Jeśli $\boldsymbol{w}^{\wedge}$ jest wektorem własnym odpowiadającym $\lambda_{\max }(W)$, czyli $\boldsymbol{W} \boldsymbol{w}^{\wedge}=\lambda_{\max }(\boldsymbol{W}) \boldsymbol{w}^{\wedge}$, to $\hat{w}_{i}>0$.

Taki właśnie wektor własny $\boldsymbol{w}^{\wedge}$ stosuje się w metodzie hierarchii analitycznej jako ocenę wektora współczynników wagi $\boldsymbol{\alpha}$ - po odpowiedniej normalizacji, aby suma współczynników wagi wynosiła 1 .

Przykład 4.4: Przypuśćmy, że $m=3$ i odpowiedzi decydenta układają się W następującą macierz:

$$
\boldsymbol{W}=\left[\begin{array}{ccc}
1 & 9 & 7 \\
1 / 9 & 1 & 1 / 5 \\
1 / 7 & 5 & 1
\end{array}\right]
$$


przy czym łatwo sprawdzić, że jest to macierz niespójna. Liczymy zatem maksymalną wartość własną tej macierzy jako największe rozwiązanie równania sześciennego:

$$
\operatorname{det}[\boldsymbol{W}-\lambda \boldsymbol{I}]=(1-\lambda)^{3}-3(1-\lambda)+9 / 35+35 / 9=0
$$

Rozwiązaniem maksymalnym tego równania jest $\lambda_{\max }=3,21>3$. Musimy więc tylko wykorzystać jakiekolwiek narzędzie wyznaczania wektorów własnych, z dodatkowym wymaganiem $\hat{w}_{1}+\hat{w_{2}}+\hat{w_{3}}=1$, aby uzyskać:

$$
W w^{\wedge}=3.21 w^{\wedge} \rightarrow w^{\wedge}=\left(\begin{array}{lll}
0,77 & 0,05 & 0,17
\end{array}\right)
$$

Mając zidentyfikowany wektor współczynników wagi, można zapytać decydenta czy użytkownika systemu wspomagania decyzji o oceny $y_{i}$ poszczególnych atrybutów jakości dla kolejnych opcji decyzyjnych, dla każdej z tych opcji policzyć wartość $v(\boldsymbol{y}\})=\sum_{i=1, \ldots m} \alpha_{i} y_{i}$ oraz uszeregować je - utworzyć listę rankingową - na pierwszym miejscu stawiając opcje decyzyjne o największej wartości.

Zaletami metody hierarchii analitycznej są jej względna prostota i uzasadnienie psychologiczne ocen ważności kryteriów, a także możliwość hierarchicznej agregacji większej ilości kryteriów (np. mniej ważnych). Wadą tej metody jest nadmiernie upraszające założenie o liniowości funkcji wartości - które jest upraszczające także z punktu widzenia psychologicznego, gdyż jeśli decydent kieruje się zadawalającym (według Herberta Simona) trybem podejmowania decyzji, to wzajemna waga kryteriów będzie się zmieniać zależnie od osiągnięcia poziomów aspiracji dla poszczególnych kryteriów - i odpowiednia funkcja wartości nie może być liniowa. Inną wadą jest brak interpretacji statystycznej metody określania współczynników wagi - wprawdzie wektor $\boldsymbol{w}^{\wedge}$ jest stosunkowo łatwo policzyć, ale w jakim przypadku jest on statystycznie rozsądną oceną współczynników wagi? Tym niemniej, metoda hierarchii analitycznej jest dość powszechnie stosowana.

Trzeba tu jednak ostrzec przed zbyt pochopnym stosowaniem liniowej funkcji wartości czy liniowej agregacji ocen atrybutów, która czasami nawet stosowana jest jako norma prawna (np. w ustawie o zamówieniach publicznych). Stosowanie sumy ważonej ocen doprowadziło bowiem do 
paradoksów i błędnych decyzji w wielu przypadkach praktycznych. Ułomność takiej metody ilustruje najlepiej następujący paradoks Korhonena: ${ }^{4}$

Przypuśćmy, że zagadnienie decyzyjne dotyczy wyboru partnera przeciwnej płci, przy czym rozpatrujemy tylko dwa kryteria: ocenę sexappeal $y_{1}$ i ocenę inteligencji $y_{2}$. Przypuśćmy, że do wyboru jest pięć kandydatów (czy kandydatek) z ocenami zaznaczonymi na Rys. 4.4 punktami $\boldsymbol{y}^{\prime}, \boldsymbol{y}^{\prime \prime}, \ldots \boldsymbol{y}^{\prime \prime \prime \prime}$. Zauważmy, że wszystkie te oceny leżą akurat poniżej linii prostej łączącej oceny dwóch opcji skrajnych $\boldsymbol{y}^{\prime}, \boldsymbol{y}^{\prime \prime}$, które to opcje są wprawdzie bardzo dobre $\mathrm{z}$ punktu widzenia jednego z kryteriów, ale bardzo złe z punktu widzenia kryterium pozostałego. Stosując metodę agregacji liniowej przez sumę ważoną, musimy wybrać albo opcję $\boldsymbol{y}^{\prime}$ (przy wektorach współczynników wagi takich jak $\boldsymbol{\alpha}_{1}$ ) albo opcję $\boldsymbol{y}^{\prime \prime}$ (przy wektorach współczynników wagi takich jak $\boldsymbol{\alpha}_{2}$ ). Rozsądna, zrównoważona opcja $\boldsymbol{y}^{\prime \prime \prime}$ nie będzie nigdy wybrana (bo jej oceny leżą poniżej linii prostej łączącej oceny dwóch opcji skrajnych $\left.\boldsymbol{y}^{\prime}, \boldsymbol{y}^{\prime \prime}\right)$. Paradoks ten wskazuje, jak ułomną metodą jest liniowa agregacja atrybutów czy kryteriów (i rzeczywiście, w zastosowaniu do przetargów o zamówienia publiczne doprowadziła ona wielokrotnie do trudności sugerując wybór opcji o niezrównoważonych ocenach).

Jeśli bowiem stosujemy określoną, a nie tylko porządkową skalę ocen, to preferencje decydenta pomiędzy poszczególnymi kryteriami wyrażają się zazwyczaj funkcją nieliniową. Zauważmy bowiem, że przyjmując argumenty Herberta Simona o wykorzystaniu poziomów aspiracji w ocenie opcji decyzyjnych, a jednocześnie próbując skonstruować funkcję wartości zgodną z taką obserwacją, musimy zakładać inne znaczenie dla decydenta dodatnich przyrostów ocen ponad poziomy aspiracji, a inne znaczenie ujemnych przyrostów ocen poniżej poziomów aspiracji; ${ }^{5}$ a więc realistyczna

4 Od prof. Pekka Korhonen'a, niegdyś przewodniczącego Międzynarodowego Towarzystwa Wielokryterialnej Analizy Decyzji (International Society of Multiple Criteria Decision Making), który sformułował przytoczony tu paradoks; paradoks ten przytaczamy w nieco złagodzonej interpretacji, gdyż jego oryginalne sformułowanie (zawierające kryteria sexappeal oraz umiejętność gotowania) można traktować jako męsko-szowinistyczne.

${ }^{5}$ Znacznie później od Herberta Simona, Daniel Kahneman i Amos Tversky (1979) opracowali $\mathrm{w}$ swej istocie bardzo podobną teorię perspektywy, uzasadniającą psychologicznie odmienność oceny uzyskanych korzyści ponad stan typowy oraz strat poniżej stanu typowego; za dalsze prace nad tą teorią, Daniel Kahneman otrzymał w 2003 roku nagrodę Nobla. 
funkcja wartości powinna być nieliniowa, o innym charakterze poniżej, innym powyżej poziomów aspiracji. Przykłady takich funkcji omówimy w dalszych rozdziałach.

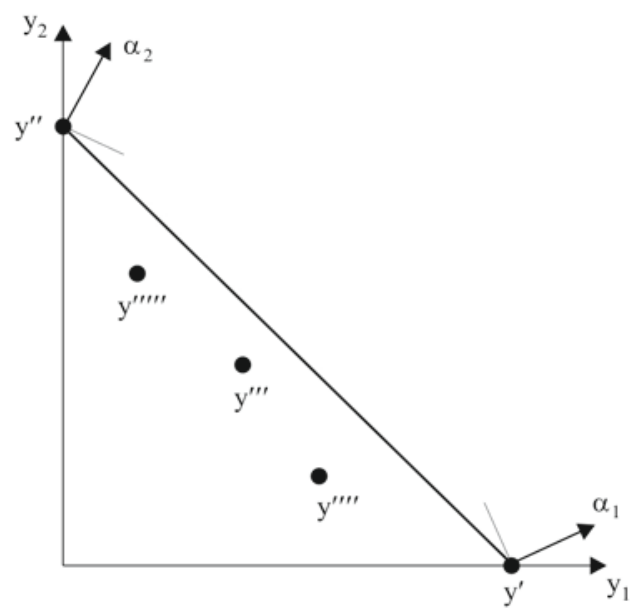

Rys. 4.4. Przykładowe opcje decyzyjne ilustrujące paradoks Korhonena.

Przyjmując założenie o interwałowej skali pomiaru (czyli prawomocności porównywania ilorazów przyrostów wartości) oraz addytywnie separowalną postać funkcji wartości - z nieliniowymi funkcjami $v_{i}\left(y_{i}\right)$ w nadziei uniknięcia paradoksów przedstawionych wyżej - można oprzeć identyfikację funkcji wartości na metodach stosowanych $\mathrm{w}$ statystyce. Można bowiem wtedy zastosować znane w statystyce metody najmniejszych kwadratów, zwane też regresją (liniową $\mathrm{W}$ przypadku liniowej zależności od parametrów podlegających identyfikacji, nieliniową w ogólniejszym przypadku).

Przypuśćmy, że dane są dwie opcje bazowe decyzji, o rezultatach $\boldsymbol{y}^{\prime}, \boldsymbol{y}^{\prime \prime} \in \boldsymbol{Y}$, oraz szereg opcji testowanych o rezultatach $\boldsymbol{y}^{j} \in \boldsymbol{Y}, j \in J$.

Zakładamy, że decydent ma pewną (ukształtowaną i niezmienną) strukturę preferencji $\boldsymbol{P}, \boldsymbol{P}^{=}$o charakterze porządku słabego, ale chcemy ją wyrazić za pomocą funkcji wartości nie tylko o skali porządkowej, lecz interwałowej, i że do reprezentacji tej funkcji stosujemy postać addytywnie separowalną ze znanymi funkcjami $v_{\mathrm{i}}\left(y_{\mathrm{i}}\right)$, a nieznanymi współczynnikami wagi $\alpha_{\mathrm{i}}$.

Załóżmy też, że $\boldsymbol{y}^{\prime \prime} \boldsymbol{P} \boldsymbol{y}^{\prime}$ i że porównanie to stanowi jednostkę miary siły preferencji. Ponadto zakładamy, że $\boldsymbol{y}^{\prime}$ odpowiada opcji zdominowanej przez wszystkie inne opcje, $\boldsymbol{y}^{j} \boldsymbol{P} \boldsymbol{y}^{\prime} \forall j \in J$. Eksperyment identyfikacji funkcji wartości 
może wtedy polegać na pytaniach w stosunku do decydenta, ile razy $k_{j}>0$ silniejsze (bądź słabsze, jeśli $k_{\mathrm{j}}<1$ ) są preferencje $\boldsymbol{y}^{j} \boldsymbol{P} \boldsymbol{y}^{\prime} \mathrm{w}$ porównaniu z $\boldsymbol{y}^{\prime \prime} \boldsymbol{P} \boldsymbol{y}^{\prime}$. Zadanie sprowadza się zatem do określenia takich $\alpha_{i}$, które zapewniają najlepsze przybliżenie oszacowań:

$$
k_{j} \approx\left(\sum_{i=1, \ldots m} \alpha_{i}\left(v_{i}\left(y_{i}^{j}\right)-v_{i}\left(y_{i}^{\prime}\right)\right) /\left(\sum_{i=1, \ldots m} \alpha_{i}\left(v_{i}\left(y_{i}^{\prime \prime}\right)-v_{i}\left(y_{i}^{\prime}\right)\right)\right.\right.
$$

Decydent może się przypadkowo mylić w oszacowaniu $k_{j}$, ale zakładamy (co ma uzasadnienie psychologiczne), że błędy te mają rozkład logarytmicznie normalny; przy tym założeniu uzasadniona jest minimalizacja sumy kwadratów błędów w skali logarytmicznej (zob. np. Norman Draper i Harry Smith, 1973). Prowadzi to do następującego zadania estymacji parametrów $\boldsymbol{\alpha}=\left(\alpha_{1}, \ldots \alpha_{i}, \ldots \alpha_{m}\right)$ :

$\min _{a} \sum_{j \in \mathcal{J}}\left(\log k_{j}-\log \left(\sum_{i=1, \ldots m} \alpha_{i}\left(v_{i}\left(y_{i}^{j}\right)-v_{i}\left(y_{i}^{\prime}\right)\right)+\log \left(\sum_{i=1, \ldots m} \alpha_{i}\left(v_{i}\left(y_{i}^{\prime \prime}\right)-v_{i}\left(y_{i}^{\prime}\right)\right)\right)^{2}\right.\right.$

Jest to zadanie regresji nieliniowej, które można rozwiązać numerycznie metodami optymalizacji nieliniowej (zob. Andrzej Stachurski et al. 1999), wyznaczając najlepszą ocenę parametrów $\boldsymbol{\alpha}$.

Podstawowymi wadami wszelkich metod identyfikacji (niekoniecznie liniowej) funkcji wartości są ponadto:

- Brak uwzględnienia preferencji decydenta w odniesieniu do opcji niepewnych; wadę tę koryguje teoria użyteczności kardynalnej, patrz rozdział następny.

- Konieczność przeprowadzania długich i skomplikowanych eksperymentów identyfikacyjnych (wielu porównań parami czy innych pytań i odpowiedzi decydenta, których doświadczeni decydenci zwykle nie lubią i unikają; patrz też rozdziały wstępne oraz uwagi o roli intuicji w podejmowaniu decyzji w rozdziale poprzednim). Ponadto, określone w ten sposób funkcje wartości mogą być nieaktualne, jeśli decydent uczy się w trakcie eksperymentu; powtarzanie eksperymentu może być zbyt pracochłonne. Ponieważ rola uczenia się przy wspomaganiu decyzji staje się coraz bardziej istotna w szybko zmiennym społeczeństwie informacyjnym, jest to wada zasadnicza klasycznej teorii decyzji.

Dlatego też inne dość powszechnie stosowane metody klasyfikacji dyskretnego zbioru opcji decyzyjnych opierają się na bardziej złożonych podejściach, niż prosta identyfikacja funkcji wartości, jak np. metoda ELECTRE (zob. Bernard Roy, 1990). 


\section{Literatura}

Barzilay J.(2010) Preference Function Modelling: the Mathematical Foundations of Decision Theory. In: M. Ehrgott, Figueira J.R., Greco S., op. cit. pp. 57-86

Debreu G. (1959) Theory of Value, Wiley, New York

Draper N.R., Smith H. (1973) Analiza regresji stosowana, PWN, Warszawa

Hołubiec J.W., Mercik J.W. (1992) Techniki i tajniki głosowania, Omnitech Press, Warszawa

Kahneman D., Tversky A. (1979) Prospect Theory: An Analysis of Decision Under Risk. Econometrica. 47(2): 263-292

Kurcjusz St. (1982) Matematyczne podstawy teorii optymalizacji, PWN Warszawa

Rapoport A. (1989) Decision Theory and Decision Behavior, Kluwer Academic Publishers, Dordrecht

Rios S. (1994) Decision Theory and Decision Analysis: Trends and Challenges, Kluwer Academic Publishers, Dordrecht

Rockafellar R.T. (1970) Convex Analysis, Princeton University Press

Roy B. (1990) Wielokryterialne wspomaganie decyzji, WNT, Warszawa

Saaty T. (1980) The Analytical Hierarchy Process, McGraw-Hill, New York

Sawaragi Y., H. Nakayama i T. Tanino (1985): Theory of Multiobjective Optimization, Academic Press, Orlando Fl.

Seo F. i M. Sakawa (1988) Multiple Criteria Decision Analysis in Regional Planning: Concepts, Methods and Applications, D. Reidel Publishing Company, Dordrecht

Simon H. (1957) Models of Man, Wiley, New York

Stachurski A. i A.P. Wierzbicki (1999) Podstawy optymalizacji, Wydawnictwa Politechniki Warszawskiej

Steuer R.E. (1986) Multiple Criteria Optimization: Theory, Computation and Application, J. Wiley, New York

Vincke Ph. (1989) Multicriteria Decision Aid, Wiley, Chichester - New York

Yu P.L. (1985) Multiple-Criteria Decision Making - Concepts, Techniques and Extensions, Plenum Press, New York - London 



\section{Probabilistyczny model niepewności i funkcje użyteczności}

\subsection{Uwagi wstępne i pojęcia podstawowe}

Zasadniczym elementem większości sytuacji decyzyjnych jest niepewność odnośnie rezultatów różnych decyzji. Jak wspomnieliśmy w rozdziałach wstępnych, wiadomo dziś, że niepewność może dotyczyć różnorodnych aspektów sytuacji decyzyjnych, mieć różnorodny charakter i być modelowana w rozmaity sposób. Jednakże historycznie pierwszym ze sposobów pojmowania i modelowania niepewności było podejście probabilistyczne. Podejście to jest dobrze umotywowane zwłaszcza w takich przypadkach, gdy możemy określić, jakie to czynniki powodują losowy charakter rozpatrywanych zjawisk, a także mamy do dyspozycji dane, pozwalające na konstrukcję i weryfikację rozkładów prawdopodobieństw.

Od dawna przy tym zwracano uwagę na fakt, że decyzje w obliczu niepewności wyrażają preferencje nie tylko w odniesieniu do możliwych rezultatów, wyników decyzji, ale i stopnia i charakteru niepewności co do uzyskania takich rezultatów. Klasycznym przykładem była tu loteria pieniężna lub inne gry losowe, w których dla opisania niepewności dobrze nadaje się aparat teorii prawdopodobieństwa. Obecnie, w teorii decyzji loteria nazywa się każdy model o określonym, dyskretnym ${ }^{1}$ zbiorze możliwych wyników:

$$
\boldsymbol{Y}=\left\{\boldsymbol{y}_{1} \ldots, \boldsymbol{y}_{i}, \ldots \boldsymbol{y}_{r}\right\} \subset \boldsymbol{R}^{m}
$$

wraz z przypisanym im zbiorem ich prawdopodobieństw

\footnotetext{
1 Pojęcie loterii można też uogólnić na przypadek zbiorów mocy kontinuum i ciągłych rozkładów prawdopodobieństwa, ale w tym rozdziale ograniczamy się do tylko elementarnego przedstawienia tej bardzo rozbudowanej, podstawowej części teorii decyzji.
} 


$$
\boldsymbol{P}^{\mathrm{r}}=\left\{p_{1}, \ldots p_{i}, \ldots p_{r}\right\}, 0 \leq p_{i} \leq 1, \Sigma_{i=1, \ldots r} p_{i}=1
$$

Ponieważ wyniki $\boldsymbol{y}_{\mathrm{i}}$ można w najprostszych przykładach interpretować jako możliwe wygrane na loterii, ograniczymy się początkowo do przypadku $m=1$, gdzie $\boldsymbol{y}_{\mathrm{i}}=y_{\mathrm{i}} \in R^{1}$.

Własności loterii analizowali już Blaise Pascal i Pierre Fermat - którzy postulowali, że wartość loterii należy oceniać na podstawie jej wartości oczekiwanej:

$$
y^{-}=E y=\Sigma_{i=1, \ldots r} p_{i} y_{i}
$$

Nie thumaczy to jednak, dlaczego ludzie grają na loteriach - które są przecież tak zorganizowane, aby przynosiły zysk, a więc wartość oczekiwana wygranej jest jednak mniejsza od ceny losu, a zatem grający na loterii wykazują skłonność do ryzyka. Z drugiej strony, skłonność do ryzyka nie jest cechą powszechną; zależy oczywiście od nastawienia decydenta, ale także od charakteru gry losowej. Np. Mikołaj Bernoulli zwrócił uwagę, że w niektórych grach ludzie są skłonni płacić za udział w grze mniej niż wynosi wartość oczekiwana wygranej. Przykładem jest tu następująca gra w orła i reszkę (tzw. paradoks petersburski):

Przykład 5.1: Za pewną cenę $c$, organizator gry zobowiązuje się do wypłaty $2^{i-1}$ rubli, gdzie $i$ - ilość kolejnych reszek w serii rzutów monetą (orzeł oznacza koniec serii, orzeł w pierwszym rzucie - wypłatę zerową). Gra ta jest zawsze (dla każdego $c$ ) nieopłacalna dla organizatora, gdyż wprawdzie $y_{0}=0, p_{0}=1 / 2$, ale $y_{i}=2^{i-1}, p_{i}=1 / 2^{i+1}$, zatem $p_{i} y_{i}=1 / 4$ dla każdego $i>0$; ponieważ jest to szereg nieskończony, wartość oczekiwana wypłaty jest też nieskończona. Tym niemniej, jeśli cena udziału $\mathrm{w}$ grze jest bardzo duża (np. $c=1000$ rubli), mało kto się zdecyduje na udział w takiej grze.

Przy dużych stawkach ludzie wykazują zatem awersję do ryzyka, przy małych stawkach - skłonność do ryzyka.

Daniel (brat Mikołaja) Bernoulli sformułował na tej podstawie hipotezę o postaci funkcji użyteczności wygranej w grach losowych, charakteryzującej wartość loterii dla jej uczestnika poprzez określenie użyteczności poszczególnych wygranych, $u\left(y_{i}\right)$, a następnie ocenę wartości loterii jako wartości oczekiwanej tych użyteczności:

$$
U\left(\boldsymbol{Y}, \boldsymbol{P}^{r}\right)=\Sigma_{i=1, \ldots r} p_{i} u\left(y_{i}\right)
$$


Wokół badania warunków istnienia i własności funkcji użyteczności o takiej właśnie postaci (lub też postaci odpowiedniej całki przy ciągłych rozkładach wyników z odpowiednimi rozkładami prawdopodobieństw) koncentrowało się bardzo wiele prac - w statystycznej teorii decyzji i abstrakcyjnej teorii użyteczności - w ciągu ostatnich stuleci. Podstawowe rezultaty tych prac przedstawimy tu w wielkim skrócie i bez stosowania zbyt ogólnego aparatu matematycznego.

Zanim przejdziemy do charakterystyki tych podstawowych rezultatów, zwróćmy najpierw uwagę na pewne stwierdzenia ogólne. Wiele sytuacji decyzyjnych $\mathrm{z}$ niepewnością probabilistyczną o charakterze bardziej złożonym niż zwykła loteria pieniężna, ale jednak o dyskretnym charakterze decyzji, ich możliwych rezultatów i prawdopodobieństw tych rezultatów, daje się sprowadzić (niekiedy poprzez przyjęcie upraszczających założeń) do ogólnego schematu loterii poprzez specyfikację drzewa decyzyjnego, czyli odpowiedniego grafu opisującego możliwe decyzje, ich skutki, ocenę (w sensie funkcji wartości) i prawdopodobieństwa tych skutków. Rozpatrzmy tu następujący przykład (patrz Hans-Jürgen Zimmermann, 1987).

Przykład 5.2: W zimową niedzielę mamy się zdecydować, czy zabrać się za przemontowanie $\mathrm{w}$ samochodzie kół $\mathrm{z}$ oponami letnimi na koła z oponami zimowymi, czy ryzykować, że nie będzie zlodowaconej jezdni i jechać w poniedziałek do pracy z oponami letnimi, czy też wreszcie wstać dostatecznie wcześnie, zostawić samochód przy domu i jechać do pracy pociągiem. Mamy zatem do wyboru trzy opcje decyzyjne:

- $a$-jechać samochodem z oponami letnimi,

- $b$-jechać samochodem z oponami zimowymi,

- $c$-jechać pociągiem,

oraz dwa stany otoczenia:

- 1 - jezdnia nieoblodzona,

- 2 - jezdnia oblodzona.

Każdej z decyzji może odpowiadać określona godzina wyjazdu oraz zależnie od stanu otoczenia - określona godzina przyjazdu do pracy; ponadto, decyzji $b$ odpowiada też czas spędzony na montażu kół, zerowy $\mathrm{w}$ przypadku innych decyzji. Jeśli ograniczymy się do tak opisanego problemu, to wydawać by się mogło, że mamy do czynienia z sześcioma przypadkami, które można opisać np. za pomocą następującej standardowej tabeli. W jej wierszach umieszczamy dane dotyczące 
poszczególnych decyzji, w jej kolumnach (lub kolejnych częściach, jak w tym przypadku) - dane dotyczące poszczególnych stanów otoczenia wraz z prawdopodobieństwami ich wystąpienia, wreszcie same dane w komórkach tabeli będą oznaczać poszczególne rezultaty - w rozpatrywanym przypadku trójkę danych „godzina wyjazdu”, „godzina przyjazdu”, „czas montażu kół”. Jednakże taki wektorowy rezultat decyzji nie przekłada się łatwo na model loteryjny decyzji z niepewnością probabilistyczną; dlatego też założymy, że decydent potrafi dokonać oceny każdego takiego rezultatu w punktach, w określonej skali, np. 0-9 punktów. Po założeniu takich ocen, przykładowo, tabela rezultatów i ich ocen może mieć postać:

\begin{tabular}{|c|c|c|c|c|}
\hline Stan otoczenia 1 & \multicolumn{4}{|c|}{ Jezdnia nieoblodzona } \\
\hline Prawdopodobieństwo & \multicolumn{4}{|c|}{0,3} \\
\hline Skutki: & Godzina & Godzina & Czas & Ocena \\
\hline Decyzja: & wyjazdu & przyjazdu & montażu (min) & (punktów) \\
\hline Opony letnie & $8: 00$ & $8: 30$ & 0 & 9 \\
\hline Opony zimowe & $7: 50$ & $8: 30$ & 75 & 6 \\
\hline Jazda pociągiem & $7: 15$ & $8: 30$ & 0 & 5 \\
\hline
\end{tabular}

\begin{tabular}{|c|c|c|c|c|}
\hline Stan otoczenia 2 & \multicolumn{4}{|c|}{ Jezdnia oblodzona } \\
\hline Prawdopodobieństwo & \multicolumn{4}{|c|}{0,7} \\
\hline Skutki: & Godzina & Godzina & Czas & Ocena \\
\hline Decyzja: & wyjazdu & przyjazdu & montażu (min) & (punktów) \\
\hline Opony letnie & $7: 00$ & $8: 30$ & 0 & 1 \\
\hline Opony zimowe & $7: 30$ & $8: 30$ & 75 & 4 \\
\hline Jazda pociągiem & $7: 15$ & $8: 30$ & 0 & 5 \\
\hline
\end{tabular}

Rezultaty przedstawione $\mathrm{w}$ powyższej tabeli możemy potraktować jako następujące loterie (o postaci $L_{j}=\left(Y_{j}, P_{j}^{\mathrm{r}}\right)$ ):

$$
L_{a}=(\{9 ; 1\},\{0,3 ; 0,7\}) ; L_{b}=(\{6 ; 4\},\{0,3 ; 0,7\}) ; L_{c}=(\{5 ; 5\},\{0,3 ; 0,7\})
$$

Możemy też, uwzględniając umowę (którą wyjaśnimy w następnych punktach), że porównywane loterie powinny mieć taki sam zbiór rezultatów a różnić się tylko rozkładami prawdopodobieństw, przepisać te loterie w równoważnej postaci:

$$
\begin{aligned}
& L_{a}=(\{9 ; 6 ; 5 ; 4 ; 1\},\{0,3 ; 0 ; 0 ; 0 ; 0,7\}) ; \\
& L_{b}=(\{9 ; 6 ; 5 ; 4 ; 1\},\{0 ; 0,3 ; 0 ; 0,7 ; 0\}) ; \\
& L_{c}=(\{9 ; 6 ; 5 ; 4 ; 1\},\{0 ; 0 ; 1 ; 0 ; 0\})
\end{aligned}
$$

Zauważmy, że wszystkie te loterie mają różne wartości oczekiwane rezultatów - przy czym największą, równą 5 punktów, ma jazda pociągiem $L_{c}$, 
a więc wybór między nimi da inne rezultaty, niż $L_{c}$, tylko przy założeniu skłonności decydenta do ryzyka.

$\mathrm{Z}$ danych zawartych $\mathrm{w}$ tej tabeli wynika jednak także, że $\mathrm{w}$ rzeczywistości modelujemy bardziej złożoną sytuację decyzyjną - nie podejmujemy bowiem decyzji $\mathrm{w}$ pełni $\mathrm{w}$ niedzielę, ale jeszcze sprawdzamy pogodę w poniedziałek rano i decydujemy się na ewentualnie wcześniejszy wyjazd zależnie od pogody. Dokładniej biorąc, moglibyśmy tu zastosować dwuetapowy proces decyzyjny: na pierwszym etapie, w niedzielę, decydujemy czy inwestować czas w przemontowanie kół i o której wstać w poniedziałek; na drugim etapie, w poniedziałek rano - po sprawdzeniu pogody, czyli z uwzględnieniem dodatkowego rozgałęzienia pod wpływem otoczenia, moglibyśmy decydować, czy jechać pociągiem czy samochodem i o której wyjechać przy jeździe samochodem. Decyzje pierwszego etapu muszą wtedy brać pod uwagę przewidywane skutki decyzji drugiego etapu. Sytuację taką można przedstawić nie tyle w postaci prostej tabeli decyzji, stanów otoczenia i ich skutków, ale w postaci drzewa decyzyjnego, przedstawionego na rys. 5.1. Zauważmy, że drzewo takie w rozpatrywanym przypadku - ze względu na dwuetapowość procesu decyzyjnego - nie przekłada się w naturalny sposób na model loterii.

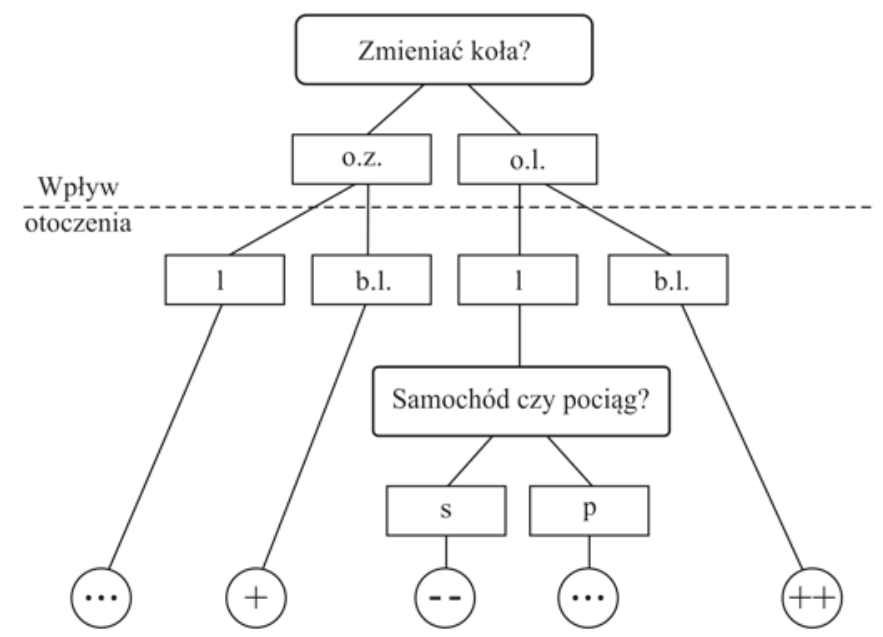

Rys. 5.1. Drzewo decyzyjne dla przykładowego (w istocie, dwuetapowego) procesu decyzyjnego: o.z. - opony zimowe; o.l. - opony letnie; l - jezdnia oblodzona; b.l. - jezdnia bez lodu; $\mathrm{p}$ - pociąg; s - samochód;

++ wynik bardzo dobry; + wynik dobry; ${ }^{\cdots}$ wynik średni; - - wynik bardzo zły. 
Aby powrócić do modelu loterii, musimy przyjąć pewne założenia upraszczające - na przykład, trzeba założyć a priori prawdopodobieństwa określonych decyzji pierwszego etapu. Na przykład, zamiast je optymalizować, moglibyśmy założyć, że decydent wybierze opcję montażu kół zimowych $\mathrm{w}$ niedzielę po południu z prawdopodobieństwem 0,2, a $\mathrm{z}$ prawdopodobieństwem 0,8 pozostawi opony letnie. $\mathrm{W}$ ten sposób powracamy do zbioru rozłącznych decyzji $a, b, c$ oraz ich rezultatów wraz $\mathrm{z}$ charakteryzującymi je prawdopodobieństwami (oczywiście nieco odmiennymi od przedstawionych w poprzednim akapicie).

Z przykładu powyższego wynika, że model loterii jest nader ograniczonym modelem sytuacji decyzyjnej, podczas gdy model drzewa decyzyjnego jest znacznie ogólniejszy (w istocie, model ten może być stosowany do opisu wszelkich dyskretnych procesów decyzyjnych). Jednakże model loterii obejmuje też inne bardzo ważne zastosowania, na co wskazuje następujący przykład.

\subsection{Przykład analizy inwestycji finansowych $z$ uwzględnieniem oczekiwanych dochodów i ryzyka}

Przykład 5.3: Inwestycje w portfel akcji. Rozważmy sytuację inwestora finansowego, który ma do wyboru zakup $n$ różnych akcji (szeroko rozumianych: zwykłych akcji spółek reprezentowanych na giełdzie, obligacji przedsiębiorstw, obligacji rządowych itp.) za określoną łączną sumę inwestowaną s. Ceny tych akcji wynoszą w chwili zakupu $c_{j}, j=1, \ldots n$. Przypuśćmy ${ }^{2}$, że znamy zbiór możliwych dochodów $w_{i, j}$ każdej akcji oraz odpowiadające tym dochodom prawdopodobieństwa ich realizacji $p_{i, j}$; w celu lepszej porównywalności decyzji zakupu poszczególnych akcji, oznaczymy rezultaty tych decyzji jako dochody względne $\boldsymbol{y}_{i, j}=w_{i, j} / c_{j}$ (czyli wartość przychodu przypadającą na jednostkę - złotego czy dolara inwestycji). Zakup danej akcji można więc interpretować jako loterię $L_{j}$ o rezultatach względnych $y_{i, j}$ oraz prawdopodobieństwach tych rezultatów $p_{i, j}$. Decyzją jednak w tym przykładzie nie jest zakup tej czy innej akcji, ale wybór portfela inwestycyjnego, czyli określenie udziału kosztów kolejnych akcji w całkowitej sumie zakupów s. Oznaczmy przez $x_{j}$ udział akcji o numerze $j$

\footnotetext{
${ }^{2}$ Jest to bardzo silne założenie upraszczające faktyczną sytuację inwestycyjną, gdyż oznacza ono m.in. stacjonarność dochodów $z$ akcji $i$ ich rozkładów prawdopodobieństwa.
} 
w sumie zakupu, a przez $\boldsymbol{x} \in \boldsymbol{R}^{n}$ wektor złożony $\mathrm{z}$ takich udziałów poszczególnych akcji w tej sumie. Mamy wtedy ograniczenia oraz momenty rozkładu rezultatów:

$$
\begin{aligned}
& \sum_{j=1, \ldots n} x_{j}=1 ; 0 \leq x_{j} \leq 1, \forall j=1, \ldots n ; \\
& y_{j}^{-}=\sum_{j=1, \ldots r} p_{i, j} y_{i, j} ; \quad y_{s r}^{-}=\sum_{j=1, \ldots n} x_{j} y_{j}^{-} ; \\
& \operatorname{Var}\left(y_{j}\right)=\sum_{j=1, \ldots r} p_{i, j}\left(y_{i, j}-y_{j}^{-}\right)^{2} ; \operatorname{Var}_{s r}(y)=\sum_{j=1, \ldots n} x_{j} \sum_{j=1, \ldots r} p_{i, j}\left(y_{i, j}-y_{j}^{-}\right)^{2}
\end{aligned}
$$

gdzie $y_{j}^{-}$oznacza dochód względny oczekiwany po zakupie $j$-tej akcji, $y_{s}^{-}{ }_{s}-$ średni oczekiwany dochód względny całego portfela akcji, Var $\left(y_{j}\right)-$ wariancję dochodu względnego po zakupie $j$-tej akcji, traktowaną w klasycznej teorii inwestycji finansowych jako miara ryzyka zakupu danej akcji, $\operatorname{Var}_{s r}(y)$ - średnią miarę ryzyka dla całego portfela akcji ${ }^{3}$.

Klasyczne podejście Harry Markowitza (1952) do tego problemu nie polega na identyfikacji funkcji użyteczności inwestora, jak to pokażemy w następnych punktach tego rozdziału, tylko na analizie problemu decyzyjnego o dwóch kryteriach: maksymalizuj względny dochód oczekiwany przy minimalizacji ryzyka, tj. wariancji. Jest to równoważne rozpatrywaniu preferencji inwestora w możliwie najsłabszej formie, nie w formie porządku słabego związanego z funkcją użyteczności, ale porządku częściowego Pareto (przy czym minimalizację wariancji możemy oczywiście wyrazić jako maksymalizację minus wariancji). Przykładową analizę dwukryterialną tego problemu ilustruje Rys. 5.2, na którym przedstawione są oczekiwane dochody względne $y_{j}^{-}$oraz miary ryzyka $\operatorname{Var}\left(y_{j}\right)$ dla pewnej liczby akcji. Zauważmy, że tylko niektóre z nich są niezdominowane w sensie porządku Pareto, czyli takie, że przez wybór innej akcji nie możemy poprawić (zwiększyć) oczekiwanego dochodu bez pogarszania (zwiększania) miary ryzyka.

Jednak nawet wśród akcji niezdominowanych są takie, które można poprawić przez wybór kombinacji liniowej dwóch innych. Rozważmy, dla przykładu, akcje 1, 2, 3 na Rys. 5.2. „Akcja” 1 to prawdopodobnie obligacja rządowa, gdyż ma ona niski względny dochód oczekiwany przy zerowym (w praktyce niemal zerowym) ryzyku $\mathrm{i}$ jest niezdominowana. Akcja 2 jest też niezdominowana przez inne akcje (sama dominuje np. akcję 7); ale może być zdominowana przez kombinację liniową akcji 1 i także niezdominowanej akcji 3, czyli portfel o względnym udziale $x_{1}$ akcji 1 oraz $x_{3}$ akcji 3, przy $x_{1}+x_{3}=1$; średnie dochody względne oraz średnie miary ryzyka dla takiego

${ }^{3}$ Ta średnia miara ryzyka jest średnią z wariancji, niekoniecznie wariancją średniej. Prowadzi to, jak zobaczymy dalej, do pewnych uproszczeń. 
portfela leżą na odcinku łączącym punkty 1, 3 na Rys. 5.2 i widoczne jest, że mogą one dominować akcję 2. W celu uwzględnienia takich przypadków, linia wypukła kreskowana na Rys. 5.2 wyznacza granicę powtoki wypuktej rezultatów zakupu jakiejkolwiek akcji - czyli zbiór osiągalnych wartości $y_{s r}^{-}$ oraz $\operatorname{Var}_{s r}(y)$. Uogólniona granica Pareto lub inaczej skuteczna granica powłoki wypuktej ${ }^{4}$ tego zbioru to jego kraniec „północno-zachodni” (przy maksymalizacji zysku jako rzędnej oraz minimalizacji wariancji jako odciętej). Można przy tym założyć, że „racjonalny” inwestor nie będzie zainteresowany innymi portfelami, niż odpowiadającymi punktom na tej granicy - bo skoro wybrałby inny portfel, to przecież przechodząc do punktu na tej granicy może albo poprawić względny dochód nie zwiększając ryzyka, albo też zmniejszyć ryzyko nie zmniejszając dochodu.

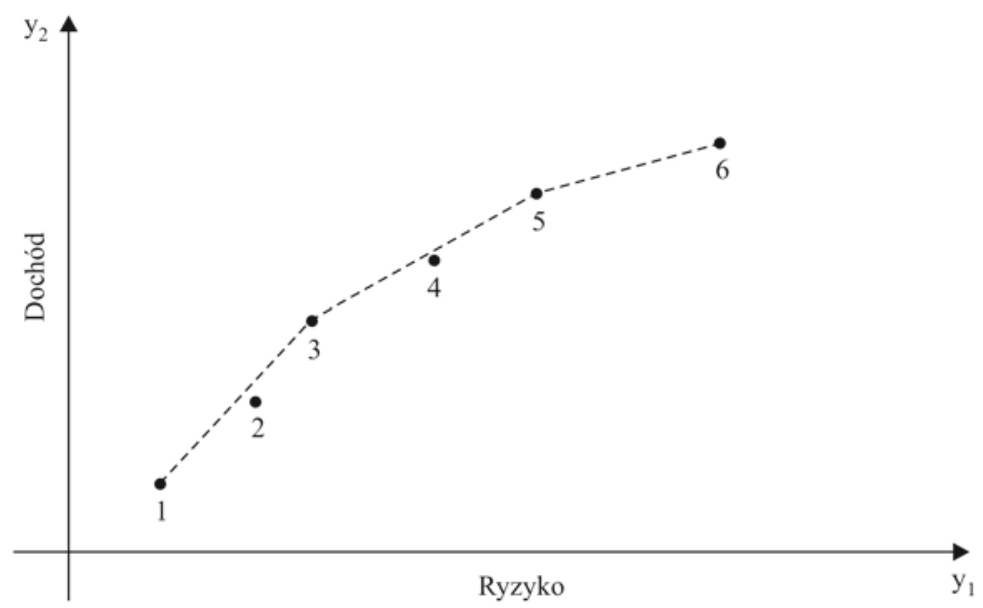

Rys. 5.2. Oczekiwane dochody względne oraz miary ryzyka dla portfela akcji (punkty numerowane to oceny oczekiwanego dochodu i ryzyka, np. wariancji, dla kolejnych akcji).

Rozumowanie powyższe wydaje się absolutnie logiczne, ale oczywiście tylko przy założeniu, że wybraliśmy adekwatne miary dochodu względnego i ryzyka. Tymczasem rezultaty powyższego rozumowania nie znajdują, niestety, potwierdzenia $\mathrm{w}$ praktyce, gdyż prowadziłyby zawsze do portfeli złożonych $\mathrm{z}$ dwóch akcji: $\mathrm{w}$ przykładzie przedstawionym na Rys. 5.2 najpierw, dla małych poziomów ryzyka, z akcji 1 i 3 (na linii kreskowanej

${ }^{4}$ Trzeba tu jednak ostrzec, że nie w każdym przypadku rezultatów dyskretnych można je uśredniać tak, jak przy zakupie portfela akcji; stąd granica Pareto dyskretnego zbioru rezultatów nie jest bynajmniej wypukła. 
łączącej te dwa punkty, bliżej punktu 1 lub punktu 3 zależnie od ich udziałów w portfelu), przy większych poziomach ryzyka z akcji 3 i 5, następnie z akcji 5 i 6 itd. W praktyce jednak lepiej sprawdzają się portfele złożone z większej liczby akcji. Można je uzyskać na wiele sposobów, z których wymienimy tylko kilka:

a) Sposób interaktywnego wspomagania decyzji. Zachowując prostotę podejścia z Rys. 5.2, wykorzystać analizę granicy sprawnej na tym rysunku do przedstawienia inwestorowi szeregu akcji leżących na tej granicy lub jej bliskich - i pozostawić mu ostateczną decyzję wyboru portfela, opartą na jego doświadczeniu i intuicji.

b) Sposób analizy statystycznej. Przeprowadzić bardziej wnikliwą analizę, niż przedstawiono wyżej, aby określić nie średnią $\mathrm{z}$ wariancji dochodów $\mathrm{z}$ akcji, ale wariancję dochodów całego portfela akcji, z uwzględnieniem możliwych współzależności i korelacji pomiędzy dochodami uzyskiwanymi z poszczególnych akcji (zauważmy, że w uproszczonej analizie przedstawionej wyżej wykorzystaliśmy ukryte założenie o niezależności rozkładów prawdopodobieństwa dochodów z poszczególnych akcji).

c) Sposób analizy użyteczności. Wykorzystując metody przedstawione w dalszych punktach tego rozdziału i traktując każdą akcję jako loterię, określić funkcję użyteczności wyrażającą preferencje inwestora w stosunku do decyzji z ryzykiem, a następnie zaproponować mu portfel akcji maksymalizujący tę funkcję.

Choć każdy z tych sposobów ma swe wady i zalety - np. sposób c) można krytykować za zbytnią automatyzację decyzji inwestora, pozbawienie go suwerennej roli - to jednak przykład ten wskazuje dobitnie na duże znaczenie modelu loterii.

\subsection{Model loterii i porównania rozkladów prawdopodobieństwa}

Model loterii jest bardzo ważnym narzędziem poznawczym klasycznej teorii decyzji i omówimy go bardziej szczegółowo w dalszych punktach tego rozdziału. Przed analizą ogólnych warunków istnienia odpowiedniej funkcji wartości dla tego modelu, zwróćmy jeszcze uwagę na dwa jego aspekty. Pierwszy aspekt ma charakter formalny: zawsze można zakładać, że różne porównywane loterie mają takie same zbiory rezultatów (czy to rezultatów wektorowych, $\boldsymbol{Y}=\left\{\boldsymbol{y}_{1}, \ldots \boldsymbol{y}_{i}, \ldots \boldsymbol{y}_{r}\right\} \subset \boldsymbol{R}^{m}$, czy rezultatów skalarnych zagregowanych np. poprzez funkcję wartości, $\boldsymbol{Y}=\left\{y_{1}, \ldots y_{i}, \ldots y_{r}\right\} \subset \boldsymbol{R}^{1}$ ). Jeśli bowiem jakaś loteria miałaby pewien rezultat odmienny, to wystarczy 
(tak jak w przykładzie 5.2) odpowiednio zwiększyć zbiór rezultatów przypisując im, $\mathrm{W}$ razie potrzeby, zerowe prawdopodobieństwa $\mathrm{w}$ innych loteriach. Wystarczy więc zakładać, że loterie $L_{j}, j=1, \ldots . n$ różnią się tylko rozkładami prawdopodobieństwa, które będziemy oznaczać przez $P_{j}$, a same prawdopodobieństwa kolejnych wyników przez $p_{i, j}, i=1, \ldots r, j=1, \ldots n$. Dla wygody analizy wpływu rezultatów na porównanie loterii będziemy też zakładać, że rezultaty te są uporządkowane, np. od najmniejszego, czyli że $y_{1} \leq y_{2} \leq \ldots \leq y_{i} \leq \ldots \leq y_{r}$, i że pożądane są jak największe rezultaty.

Drugi aspekt ma znaczenie merytoryczne, choć wynika z pierwszego: skoro loterie różnią się tylko prawdopodobieństwami wyników, to ich porównanie można oprzeć na porównywaniu rozkładów prawdopodobieństwa (teoretycznie; w praktyce zaś znajomość zbioru rezultatów, zwłaszcza o charakterze ocen wartościujących, można wykorzystywać jako dodatkową informację przy porównywaniu rozkładów). Można przy tym stosować bardzo różne podejścia. Podejście aksjomatyczne, prowadzące do określenia odpowiedniej funkcji wartości zwanej kardynalną funkcją użyteczności, omówimy w następnym podrozdziale. Ale nie jest to podejście jedyne; porównywanie różnych rozkładów prawdopodobieństwa jest starym problemem statystyki matematycznej i znanych jest szereg podejść narzędziowych do tego problemu, które wymienimy tu pokrótce. Rozpatrywać przy tym będziemy nie tylko czysty problem porównywania rozkładów, ale problem porównania loterii $L_{j}, j=1, \ldots n$ odpowiadających temu samemu zbiorowi rezultatów $Y$ z różnymi rozkładami prawdopodobieństwa $P_{j}-$ gdyż znajomość zbioru rezultatów o charakterze ocen wartościujących może wpłynąć na porównanie rozkładów.

- Podejście maksmin polega na określeniu najpierw najgorszej oceny wartościującej odpowiadającej jakiemukolwiek niezerowemu prawdopodobieństwu, a następnie wyborze takiego rozkładu czy decyzji która ma najwyższą ocenę najgorszą (oczywiście, wobec założenia jednakowych zbiorów ocen wartościujących, porównywane rozkłady muszą mieć różne przypadki zerowych prawdopodobieństw tych ocen, aby zagregowane oceny rozkładów różniły się $\mathrm{w}$ tym podejściu). Najlepsza ocena minimaksowa wyraża się więc wzorem:

$$
\operatorname{Maxmin}\left(\boldsymbol{Y}, P_{j=1, \ldots n}^{r}\right)=\max _{1, \ldots j, \ldots, n} \min _{\mathrm{i}: p i, j \neq 0} y_{i}
$$

Podejście równomierne polega na określeniu średniej arytmetycznej tych ocen, które $\mathrm{w}$ danym rozkładzie odpowiadają niezerowym prawdopodobieństwom, a następnie wyborze takiego rozkładu czy decyzji, która ma najlepszą ocenę równomiernie-średnią (oczywiście, o zróżnicowaniu ocen rozkładów znów decydują tu różne przypadki 
prawdopodobieństw zerowych). Najlepsza ocena równomierna wyraża się wzorem:

$$
\operatorname{Maxuni}\left(\boldsymbol{Y}, P_{j=1, \ldots n}^{r}\right)=\max _{1, \ldots j, \ldots n} \Sigma_{i: p i, j \neq 0} y_{i}
$$

Podejście wartości oczekiwanej odpowiada w istocie wspomnianemu już podejściu Mikołaja Bernoulliego i będzie omówione dokładniej w sensie aksjomatycznym; jeśli jednak oceny wartościujące traktujemy jako dane, nie rozpatrujemy problemu istnienia i identyfikacji funkcji wartości czy użyteczności, to podejście to można traktować też jako proste podejście narzędziowe. Polega ono na określeniu wartości oczekiwanej ocen wartościujących dla każdego rozkładu, a następnie na wyborze rozkładu czy decyzji, dla której ta wartość oczekiwana jest największa:

$$
\operatorname{Maxexp}\left(\boldsymbol{Y}, P_{j=1, \ldots n}^{r}\right)=\max _{1, \ldots j, \ldots n} \Sigma_{i=1, \ldots r} p_{i j} y_{i}
$$

Podejście wielokryterialnej analizy momentów rozkładu. Ponieważ sama wartość oczekiwana nie daje miary ryzyka, można stosować większą liczbę momentów rozkładu - np. wartość oczekiwaną i wariancję, jak w przykładzie analizy portfela akcji:

$$
E(y)_{j}=y_{j}^{-}=\sum_{i=1, \ldots . r} p_{i j} y_{i} ; \operatorname{Var}(y)_{j}=\sum_{i=1, \ldots r} p_{i j}\left(y_{i}-y_{j}^{-}\right)^{2}
$$

czy także dalsze momenty wyższego rzędu. Ponieważ jest to podejście wielokryterialne, przeto nie daje ono oceny jednoznacznej; ale w przypadku niewielkiej liczby opcji $n$ można łatwo wyliczyć wszystkie rozkłady niezdominowane w określonym sensie (np. maksymalizacji wartości oczekiwanej przy minimalizacji wariancji).

- Podejście dominacji rozkładu. Skoro przyjęliśmy założenie, że rezultaty $y_{i}$ są uporządkowane od najmniejszego do największego i chcemy maksymalizować możliwe rezultaty, to za najlepsze rozkłady można traktować takie, które przypisują możliwie najmniejsze prawdopodobieństwa rezultatom $y_{i}$ dla $i=1, \ldots, r$-1, natomiast największe prawdopodobieństwo rezultatowi $y_{r}$. Ponieważ $p_{r, j}=1-\Sigma_{i=1, \ldots r-1} p_{i j}$, przeto wystarczy minimalizować pierwszych $r-1$ prawdopodobieństw. Odpowiada to (przy zmianie znaków $\mathrm{z}$ uwagi na minimalizację) porządkowi Pareto w $(r-1)$-wymiarowej przestrzeni; rozkłady niezdominowane przez inne w tym porządku można uznać za najlepsze. Znów może być wiele takich rozkładów ze względu na wielokryterialność tego podejścia. 
- Podejście dominacji statystycznej. Zauważmy, że w celu maksymalizacji prawdopodobieństwa rezultatu najlepszego $y_{r}$ lub rezultatów bliskich jemu nie trzeba minimalizować każdego $\mathrm{z}$ osobna prawdopodobieństwa $p_{i, j}$ dla małych $i$, wystarczy minimalizować sumy $P^{r}{ }_{i, j}=\Sigma_{l=1, \ldots i} p_{l, j}$ - czyli inaczej dystrybuantę rozkładu $P_{j}^{r}-$ dla $i=1, \ldots r-1$. Jest to wymaganie słabsze, niż wymaganie dominacji rozkładu, ale ma szereg cech wspólnych.

Podejścia narzędziowe ograniczają się więc do obliczenia i użycia określonych cech rozkładu (wartości minimalnych, oczekiwanych, dalszych momentów, dominacji etc.). Ponieważ mają one dość arbitralny charakter, przeto niektóre z nich można poddać krytyce z rozmaitych punktów widzenia. Na przykład, oceny maksmin i równomierna nie są ciągłe wobec drobnych zmian rozkładu prawdopodobieństwa - zmieniają się skokowo, jeśli któreś $\mathrm{z}$ zerowych prawdopodobieństw przyjmuje małą wartość niezerową. Podejście wartości oczekiwanej zapewnia taką ciągłość - i to jest właśnie jedna $\mathrm{z}$ aksjomatycznych zalet tego podejścia. Z drugiej strony, w następnym rozdziale pokażemy, że prawdopodobieństwa zero i jedność są jednak traktowane przez ludzi w szczególny sposób, stąd wymaganie ciągłości przy zmianie prawdopodobieństwa z zera na małą wartość nie musi być spójne z rzeczywistymi preferencjami decydentów.

Trzeba też dodać, że przed rozpowszechnieniem się komputerów osobistych o olbrzymich możliwościach obliczeniowych niektóre z wymienionych wyżej podejść były preferowane w porównaniu z innymi ze względu na ich prostotę obliczeniową. Dzisiaj jednak czas pracy komputera jest zwykle tańszy niż czas pracy decydenta. Dopóki czas obliczeń nie przekracza kilkudziesięciu sekund, lepiej jest stosować podejścia zapewniające decydentowi komfort psychologiczny, poczucie suwerenności, czyli proponować mu kilka decyzji do wyboru - a nie dążyć za wszelką cenę do prostoty obliczeniowej czy do jednoznaczności decyzji „optymalnej”. Dla stosunkowo prostych modeli sytuacji decyzyjnych - jak w przykładzie 5.1 - wręcz zalecane jest więc wypróbowanie wszelkich możliwych podejść i przeanalizowanie różnych znaczeń optymalności.

Ćwiczenie 5.1: Dla omówionego wyżej przykładu wyboru sposobu dojazdu do pracy przedstawić model sytuacji decyzyjnej w postaci modelu loterii poprzez określenie odpowiednich zbiorów $\boldsymbol{Y}, P^{r}{ }_{j}$ dla $j=1, \ldots n$, zakładając $\mathrm{w}$ miarę potrzeby określone prawdopodobieństwa $p_{i, j}$. Następnie określić „najlepsze” decyzje bądź zbiory decyzji niezdominowanych kierując się kolejno omówionymi powyżej podejściami narzędziowymi. 


\subsection{Warunki istnienia kardynalnej funkcji użyteczności}

Podstawowym problemem teorii decyzji było modelowanie preferencji decydenta. $\mathrm{W}$ istocie, preferencje te dotyczą rozkładów prawdopodobieństwa w sytuacjach decyzyjnych typu loterii - przy czym w relacji preferencji porównujemy nie same prawdopodobieństwa i nie same rezultaty loterii, ale cale loterie $\boldsymbol{L}=\left\{\left\{y_{1}, \ldots y_{i}, \ldots y_{r}\right\} ;\left\{p_{1}, \ldots p_{i}, \ldots p_{r}\right\}\right\}$. Podstawowym modelem tych preferencji jest ich reprezentacja $W$ postaci funkcji użyteczności $U(\boldsymbol{L})=U^{-}$, gdzie $U$ określone jest jako wartość oczekiwana $\mathrm{z} u(y)$, tak jak w równaniu (5.4). Jak poprzednio zakładamy, że porównywane loterie mają takie same zbiory rezultatów $\left\{y_{1}, \ldots y_{i}, \ldots y_{r}\right\}$, przy czym $y_{i}$ są rosnąco uporządkowane, natomiast różnią się prawdopodobieństwami, $\mathrm{z}$ wykorzystaniem prawdopodobieństw zerowych dla reprezentacji faktycznych różnic w zbiorach rezultatów.

Tak określone loterie $\boldsymbol{L}$ można traktować jako elementy przestrzeni liniowej $\boldsymbol{L}$. W tym celu wprowadza się pojęcie loterii mieszanych pomiędzy danymi dwoma loteriami $\boldsymbol{L}_{1}=\left\{\left\{y_{1}, \ldots y_{i}, \ldots y_{r}\right\} ;\left\{p_{1,1}, \ldots p_{i, 1}, \ldots p_{r, 1}\right\}\right\}$ oraz $\left.\boldsymbol{L}_{2}=\left\{\begin{array}{llll}\left\{y_{1}, \ldots\right. & y_{i}, \ldots & y_{r}\end{array}\right\} ;\left\{p_{1,2}, \ldots p_{i, 2}, \ldots, p_{r, 2}\right\}\right\}$, które są definiowane następująco: ${ }^{5}$

$$
\begin{aligned}
& \boldsymbol{L}_{\alpha}=\alpha \boldsymbol{L}_{1}+(1-\alpha) \boldsymbol{L}_{2}=\left\{\left\{y_{1}, \ldots y_{i}, \ldots y_{r}\right\} ;\left\{p_{1, \alpha}, \ldots p_{\mathrm{i}, \alpha}, \ldots p_{r, \alpha}\right\}\right\} ; \\
& p_{i, \alpha}=\alpha p_{i, 1}+(1-\alpha) p_{i, 2}, i=1, \ldots r, 0 \leq \alpha \leq 1
\end{aligned}
$$

Współczynnik $\alpha \mathrm{w}$ loterii mieszanej można interpretować nie tylko jako współczynnik udziału w portfelu akcji, lecz także jako prawdopodobieństwo wyboru loterii $\boldsymbol{L}_{1}$, natomiast współczynnik $(1-\alpha)$ - jako prawdopodobieństwo wyboru loterii $\boldsymbol{L}_{2}$; loteria $\boldsymbol{L}_{\alpha}=\alpha \boldsymbol{L}_{1}+(1-\alpha) \boldsymbol{L}_{2}$ składa się więc najpierw z losowania $\boldsymbol{L}_{1}$ i $\boldsymbol{L}_{2} \quad \mathrm{z}$ określonymi wyżej prawdopodobieństwami wyboru, a następnie $\mathrm{z}$ losowania odpowiedniego wyniku $\mathrm{w}$ wylosowanej wstępnie loterii.

Podstawowy rezultat $\mathrm{w}$ probabilistycznej teorii użyteczności można wyrazić w stosunku do loterii mieszanych w formie następującego twierdzenia:

Twierdzenie 5.1. Istnienie kardynalnej funkcji użyteczności. Jeśli w przestrzeni loterii mieszanych $\boldsymbol{L} \in \boldsymbol{L}$ określona jest struktura preferencji $\boldsymbol{P}, \boldsymbol{P}^{=}$, to można ją reprezentować za pomocą funkcji użyteczności $U$ takiej, że:

5 Zauważmy, że loteria mieszana jest analogiczna do portfela dwóch akcji z przykładu 5.3, $\mathrm{z}$ udziałami $x_{1}=\alpha$ oraz $x_{2}=1-\alpha$, a więc opiera się na założeniu, że sumę przeznaczoną na loterie można podzielić dowolnie pomiędzy dwie loterie. 


$$
\boldsymbol{L}_{1} \boldsymbol{P} \boldsymbol{L}_{2} \leftrightarrow U\left(\boldsymbol{L}_{1}\right)>U\left(\boldsymbol{L}_{2}\right) ; \quad \boldsymbol{L}_{1} \boldsymbol{P}^{=} \boldsymbol{L}_{2} \leftrightarrow U\left(\boldsymbol{L}_{1}\right)=U\left(\boldsymbol{L}_{2}\right)
$$

oraz afinicznej względem prawdopodobieństw:

$$
U\left(\alpha \mathbf{L}_{1}+(1-\alpha) \boldsymbol{L}_{2}\right)=\alpha U\left(\boldsymbol{L}_{1}\right)+(1-\alpha) U\left(\boldsymbol{L}_{2}\right)
$$

wtedy i tylko wtedy, gdy spełnione są następujące warunki:

(A1) Struktura preferencji $\boldsymbol{P}, \boldsymbol{P}^{=}$jest porządkiem słabym;

(A2) Spełniony jest następujący aksjomat niezależności od opcji ubocznej $\boldsymbol{L}_{3}$ :

$$
\boldsymbol{L}_{1} \boldsymbol{P} \boldsymbol{L}_{2} \rightarrow\left(\alpha \boldsymbol{L}_{1}+\left(1-\alpha \boldsymbol{L}_{3}\right) \boldsymbol{P}\left(\alpha \boldsymbol{L}_{2}+(1-\alpha) \boldsymbol{L}_{3}\right) \forall \boldsymbol{L}_{3} \in \boldsymbol{L}, \alpha \in(0 ; 1)\right.
$$

(A3) Spełniony jest następujący aksjomat ciągłości:

$$
\mathbf{L}_{1} \boldsymbol{P} \mathbf{L}_{2} \boldsymbol{P} \boldsymbol{L}_{3} \rightarrow \exists \alpha, \beta \in(0 ; 1):\left(\alpha \mathbf{L}_{1}+(1-\alpha) \mathbf{L}_{3}\right) \boldsymbol{P} \boldsymbol{L}_{2} \boldsymbol{P}\left(\beta \mathbf{L}_{1}+(1-\beta) \mathbf{L}_{3}\right)
$$

Funkcja użyteczności $U$ jest wtedy określona jednoznacznie $\mathrm{z}$ dokładnością do ściśle rosnącego przekształcenia afinicznego, a więc odpowiada interwałowej skali pomiaru. Ponadto, ma ona wtedy postać (5.4).

Dowód tego twierdzenia podany był najpierw przez Johna von Neumanna i Oscara Morgensterna (zob. John v. Neumann 1947, Peter Fishburn 1982). Funkcja użyteczności o tych własnościach, wyrażana wzorem (5.4), nazywana jest krótko funkcja użyteczności, lub funkcja użyteczności kardynalnej. ${ }^{6}$ Aksjomat ciągłości ma charakter dość naturalny; aksjomat niezależności od opcji ubocznej też wydaje się naturalny, ale pokażemy w następnym rozdziale, że nie zawsze jest on spełniony przez preferencje rzeczywistych decydentów. Trzeba też pamiętać o zastrzeżeniach Jonathana Barzilaya (2010), który twierdzi, że dla zmiennych charakteryzujących preferencje po prostu nie powinno się stosować pełnego aparatu analizy matematycznej.

\subsection{Metody identyfikacji funkcji użyteczności}

Identyfikacji funkcji użyteczności konkretnego decydenta można dokonywać na różnorodne sposoby, zależnie od założeń o tej funkcji i od charakteru przeprowadzanego eksperymentu identyfikacyjnego. Może to być np. eksperyment bierny, w którym mamy do czynienia tylko z pewnym, niezależnym od konstruktora eksperymentu zespołem danych o wynikach porównań parami różnych opcji charakteryzujących rozpatrywane loterie. Trzeba wtedy jednak zakładać z góry pewną formę funkcji użyteczności

\footnotetext{
${ }^{6}$ Lub też funkcją użyteczności Johna von Neumanna i Oskara Morgensterna - choć pierwszy sformułował ją Daniel Bernoulli, to jednak ci ostatni podali matematyczne warunki jej istnienia.
} 
i identyfikować tylko jej parametry. Mimo to, eksperyment bierny prowadzi jednak do dość złożonych statystycznych problemów regresji porządkowej zob. np. Sixto Rios (1994). Może to być też eksperyment czynny, odpowiednio skonstruowany, w którym porównywane opcje są dobrane tak, aby możliwie najłatwiej zidentyfikować funkcję użyteczności. Oczywiście, jeśli nie zakładamy formy funkcji użyteczności, to eksperyment się wydłuża w eksperymencie takim potrzeba bowiem tym więcej porównań parami, im więcej mamy do zidentyfikowania parametrów, a bez założenia formy funkcji użyteczności jej parametrami są jej wartości przynajmniej dla wszystkich rozpatrywanych prawdopodobieństw $p_{i}$.

Konstrukcji eksperymentu czynnego bez zakładania formy funkcji użyteczności dokonuje się zwykle w następujący sposób. Zauważmy, że rezultat pewny $y_{i}$ można traktować jako wynik pewnej loterii $\boldsymbol{L}_{i} \in \boldsymbol{L}, \mathrm{w}$ której prawdopodobieństwo tego rezultatu zostało określone jako $p_{i, i}=1$. Mamy wtedy $U\left(\boldsymbol{L}_{i}\right)=u\left(y_{i}\right)$; dla określenia funkcji użyteczności wystarczy określić te użyteczności rezultatów pewnych dla wszystkich $i=1, \ldots r$. Przypominamy, że rezultaty $y_{1}, \ldots y_{i}, \ldots y_{r}$ są uporządkowane tak, że $y_{1} \leq y_{2} \leq \ldots \leq y_{i} \leq \ldots \leq y_{r}$ (i jednocześnie zakładamy $u\left(\mathrm{y}_{1}\right) \leq u\left(\mathrm{y}_{2}\right) \leq \ldots \leq u\left(y_{i}\right) \leq \ldots \leq u\left(y_{r}\right)$ ). Ze względu na możliwość zastosowania dowolnych ściśle rosnących transformacji afinicznych, funkcję użyteczności można zawsze znormalizować tak, aby $u\left(y_{1}\right)=0, u\left(y_{r}\right)=1$. Mamy wtedy $U\left(\alpha \boldsymbol{L}_{r}+(1-\alpha) \boldsymbol{L}_{1}\right)=\alpha$, użyteczność loterii o najlepszym wyniku $y_{r} \mathrm{z}$ prawdopodobieństwem $\alpha$ i najgorszym wyniku $y_{1}$ z prawdopodobieństwem (1- $\alpha$ ) wynosi dokładnie $\alpha$.

Żeby więc określić użyteczności $u\left(y_{i}\right)$ dla $2<i<r$-1, wystarczy dla każdego takiego $i$ przeprowadzić następujący eksperyment. Trzeba pytać decydenta, czy preferuje $\boldsymbol{L}_{i}$ (czyli $y_{i}$ jako wynik pewny, z prawdopodobieństwem 1), czy też loterię $\boldsymbol{L}_{\alpha}=\alpha \boldsymbol{L}_{r}+(1-\alpha) \boldsymbol{L}_{1}$ przy danym $\alpha$ (czyli wynik $y_{r}$ $\mathrm{z}$ prawdopodobieństwem $\alpha$ i wynik $y_{1} \mathrm{z}$ prawdopodobieństwem (1- $\alpha$ ), której użyteczność wynosi dokładnie $\alpha$. Można przy tym zacząć od takiego $\alpha=\alpha_{i}^{-}=\left(y_{r}-y_{i}\right) /\left(y_{r}-y_{1}\right)$, które odpowiada hipotezie neutralności względem ryzyka - patrz dalsze definicje. Jeśli decydent nie jest neutralny, tylko ma awersję do ryzyka, to trzeba stopniowo zwiększać $\alpha$, aby dojść do równoważności preferencji loterii mieszanej $\boldsymbol{L}_{\alpha}$ oraz wyniku pewnego - zob. Rys. 5.3.a. W przypadku skłonności decydenta do ryzyka będzie on preferował loterię mieszaną $\boldsymbol{L}_{\alpha i}$ nad wynik pewny, i trzeba będzie zmniejszać 
$\alpha$ aby dojść do równoważności. Trzeba zatem zmieniać $\alpha$ tak długo, aż dla pewnego $\alpha_{i}$ stwierdzi on, że tak określone loterie są równoważne, $\boldsymbol{L}_{i} \boldsymbol{P}^{=} \alpha_{i} \boldsymbol{L}_{r}+\left(1-\alpha_{i}\right) \boldsymbol{L}_{1}$; uzyskuje się wtedy $u\left(y_{i}\right)=\alpha_{i}$. Ciąg takich eksperymentów (każdy składa się z kilku pytań o porównanie parami) trzeba powtórzyć $r-2$ razy.

Tak przeprowadzona identyfikacja funkcji użyteczności wymaga jednak wykonania dość dużej liczby porównań parami przez decydenta - zwykle znacznie większej niż $r-2$. Ze względu na prostotę koncepcji takiego eksperymentu, oparto na nim wiele metod praktycznej identyfikacji funkcji użyteczności. W zastosowaniach okazuje się jednak, że decydenci często nie mają dość cierpliwości i czasu, by poddawać się takim eksperymentom. Zauważmy, że w eksperymencie takim wiele pytań nie przynosi znacznej dodatkowej informacji, ponieważ nie pytamy o stopień preferencji, tylko o porównanie parami; a przecież, wobec interwałowej skali pomiaru, w pełni uzasadnione byłoby pytanie następujące: „Ilokrotnie mniej preferujesz przyrost od $y_{1}$ do $y_{i} \mathrm{~W}$ porównaniu $\mathrm{z}$ przyrostem od $y_{1}$ do $y_{r}$ ? Wyraź odpowiedź jako liczbę $\alpha_{i}$ mniejszą od jedności.” Nie można przy tym zakładać, że decydent da odpowiedź bezbłędną (zresztą może on się też mylić przy porównaniach parami). W celu zmniejszenia statystycznego wpływu tych błędów, potrzebny nam jest pewien nadmiar odpowiedzi decydenta ponad liczbę estymowanych wielkości $r-2$ i trzeba zatem skonstruować dodatkowe pytania kontrolne. $^{7}$

Ponadto dla dużych $r$ uzasadniona jest wątpliwość, czy zawsze potrzeba identyfikować aż $r-2$ parametrów funkcji użyteczności. Dlatego też bardziej skuteczne w praktyce okazuje się założenie pewnej postaci funkcji $u(y, \boldsymbol{\beta})$ np. typu Cobba-Douglasa - ze z góry ograniczoną liczbą dodatkowych parametrów reprezentowanych przez wektor $\boldsymbol{\beta}$ oraz zaprojektowanie innego eksperymentu, który miałby na celu statystyczną estymację tych parametrów na podstawie możliwie najmniejszej liczby porównań parami, dokonywanych przez decydenta, z założeniem pewnego rozkładu prawdopodobieństwa błędu jego odpowiedzi, mierzonego $\mathrm{w}$ określonej skali (np. tak, jak to było zaproponowane w poprzednim wykładzie celem identyfikacji funkcji wartości w skali interwałowej).

7 Mogą być one różnej postaci, np. „Jak się zmieni twoja odpowiedź, jeśli zwiększymy (zmniejszymy) wielkość $y_{i}$ o np. 10\%?”; ale w ten sposób można zmniejszyć, a co ważniejsze - z góry ograniczyć liczbę zadawanych pytań. 
Celem określenia rozsądnych postaci możliwych do założenia funkcji użyteczności przypomnijmy, że decydenta nazywamy:

[1] Skłonnym do ryzyka, jeśli preferuje każdą loterię (niezdegenerowaną, tj. niesprowadzającą się do rezultatów pewnych) w stosunku do jej wartości oczekiwanej jako rezultatu pewnego:

$$
U(\boldsymbol{L})=\sum_{\mathrm{i}=1, \ldots r} p_{i} u\left(y_{i}\right)>u\left(y^{-}\right)=u\left(\sum_{\mathrm{i}=1, \ldots r} p_{i} y_{i}\right) ;
$$

[2] Neutralnym względem ryzyka, jeśli uważa każdą loterię niezdegenerowaną za równoważną jej wartości oczekiwanej, traktowanej jako rezultat pewny:

$$
U(\boldsymbol{L})=\sum_{\mathrm{i}=1, \ldots r} p_{i} u\left(y_{i}\right)=u\left(y^{-}\right)=u\left(\sum_{\mathrm{i}=1, \ldots r} p_{i} y_{i}\right) ;
$$

przy czym wynika stąd, że jego funkcja użyteczności jest liniowa nie tylko względem prawdopodobieństw, lecz także względem rezultatów, czyli $u(y)$ jest funkcją liniową. Przy przyjętej normalizacji $u\left(y_{1}\right)=0, u\left(y_{r}\right)=1$ mamy po prostu $u(y)=\left(y-y_{1}\right) /\left(y_{r}-y_{1}\right)$.

[3] $Z$ awersja do ryzyka, jeśli preferuje wartość oczekiwaną jako rezultat pewny w stosunku do dowolnej loterii niezdegenerowanej:

$$
U(\boldsymbol{L})=\sum_{\mathrm{i}=1, \ldots r} p_{i} u\left(y_{i}\right)<u\left(y^{-}\right)=u\left(\sum_{\mathrm{i}=1, \ldots r} p_{i} y_{i}\right) ;
$$

Można udowodnić (zob. np. Ralph Keeney i Howard Raiffa, 1975), że u(y) która jest funkcją monotoniczną w przypadku, gdy uporządkowanie $y_{i}$ według ich stopnia preferencji jest monotoniczne, tak jak dla wyników loterii pieniężnych - jest też funkcją ściśle wypukłą dla przypadku skłonności do ryzyka i ściśle wklęsłą dla przypadku awersji do ryzyka. Można przy tym wprowadzać różne miary skłonności i awersji do ryzyka; dla monotonicznych, dwukrotnie różniczkowalnych $u(y)$ stosuje się logarytmiczną miarę awersji do ryzyka:

$$
r(y)=-\partial / \partial y(\log \partial u(y) / \partial y\})=-\left(\partial^{2} u(y) / \partial y^{2}\right) /(\partial u(y) / \partial y)
$$

zwaną współczynnikiem lokalnej awersji do ryzyka. Gdyby ta miara była globalna - stała dla wszystkich $y$ - to uzyskalibyśmy w przypadku awersji do ryzyka, $r(y)=c>0$ : 


$$
u(y)=b-a \mathrm{e}^{-c y},
$$

gdzie z warunków $u\left(y_{1}\right)=0$ i $u\left(y_{r}\right)=1$ można wyznaczyć:

$$
a=1 /\left(\mathrm{e}^{-c y 1}-\mathrm{e}^{-c y r}\right) ; b=a \mathrm{e}^{-c y 1},
$$

natomiast w przypadku skłonności do ryzyka, czyli dla $r(y)=c<0$, otrzymujemy:

$$
u(y)=b+a \mathrm{e}^{-c y},
$$

gdzie:

$$
a=1 /\left(\mathrm{e}^{-c y r}-\mathrm{e}^{-c y 1}\right) ; b=-a \mathrm{e}^{-c y 1} .
$$

W obu przypadkach, parametr $c$ można by estymować statystycznie na podstawie wyników odpowiednio zaprojektowanego eksperymentu identyfikacji preferencji decydenta, z uwzględnieniem możliwości błędów przez niego popełnianych, o założonym rozkładzie prawdopodobieństwa (patrz ćwiczenia niżej).

Jednakże funkcje użyteczności dla realnych decydentów, w przypadku znacząco dużych wartości $y$, wykazują raczej skłonność do ryzyka dla małych $y$ (bliskich $y_{1}$ ) oraz awersję do ryzyka dla dużych y (bliskich $y_{r}$ ), co przedstawiono na Rys. $5.3 \mathrm{~b}$ ).

W następujących ćwiczeniach niezbędna jest dobra znajomość statystycznych metod estymacji parametrów i testowania hipotez. Zob. np. Norman Draper i Harry Smith (1973), Andrzej Pacut (1985).

Ćwiczenie 5.2: Zaproponować eksperyment identyfikacji funkcji użyteczności kardynalnej, oparty na metodzie opisanej w poprzednim rozdziale, ale ukierunkowany na identyfikację awersji bądź skłonności do ryzyka i uwzględniający model funkcji użyteczności o stałym współczynniku awersji bądź skłonności. Założyć rozkład błędów odpowiedzi decydenta w odpowiedniej skali.

Ćwiczenie 5.3: Zaproponować eksperyment identyfikacji funkcji użyteczności jak w ćwiczeniu poprzednim, ale umożliwiający testowanie statystyczne hipotezy o stałej skłonności bądź awersji do ryzyka. 
a)

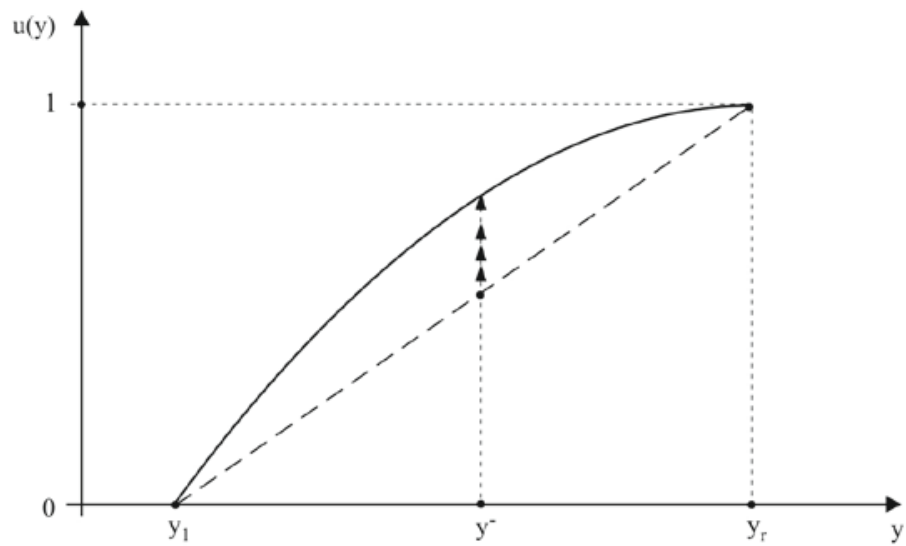

b)

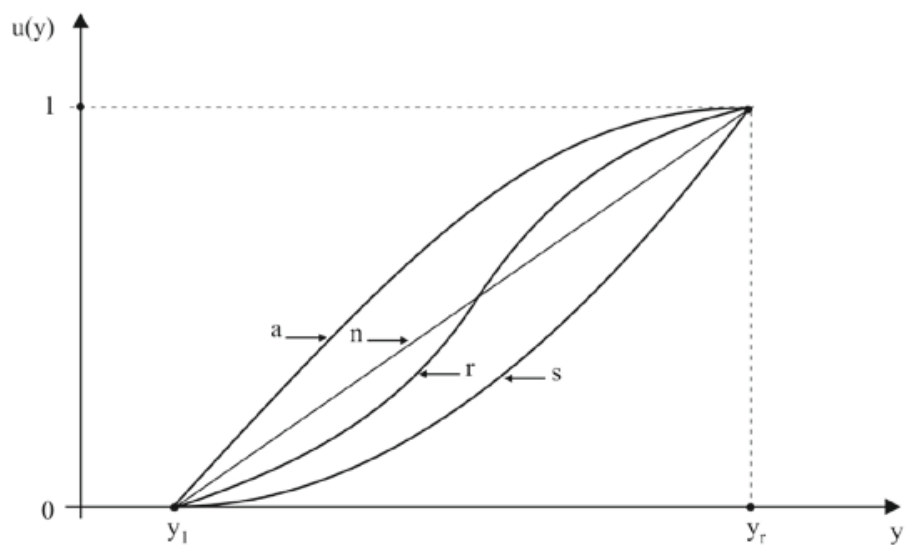

Rys. 5.3. a) Przebieg identyfikacji kardynalnej funkcji użyteczności (dla przypadku awersji do ryzyka). b) Przebieg kardynalnej funkcji użyteczności dla przypadku: s - skłonności do ryzyka; n - neutralności względem ryzyka; a - awersji do ryzyka; $\mathrm{r}$ - realnej skłonności do ryzyka dla małych stawek i awersji do ryzyka dla stawek większych.

Ćwiczenie 5.4: Zaproponować inną (co najmniej dwuparametrową) rodzinę funkcji użyteczności kardynalnej, obejmującą skłonność do ryzyka dla małych stawek oraz awersję do ryzyka dla stawek dużych, oraz odpowiedni eksperyment identyfikacji tej funkcji.

W przypadku wektorowych rezultatów decyzji, gdy $\boldsymbol{y \in} \boldsymbol{R}^{m}$, zagadnienia identyfikacji kardynalnej funkcji użyteczności nieco się komplikują - zobacz np. Ralph Keeney i Howard Raiffa (1975). Istnieją też w tym przypadku wzmocnione pojęcia niezależności preferencyjnej - tzw. niezależności 
kardynalnej atrybutów - przy której założeniu funkcja użyteczności kardynalnej zmiennej wektorowej, $u(y)$, daje się przedstawić jako suma lub iloczyn funkcji użyteczności kardynalnej poszczególnych atrybutów, czyli współrzędnych wektora $y$.

Parametry $\boldsymbol{\beta}$ funkcji użyteczności, wynikające z jej identyfikacji, zazwyczaj nie są określone w sposób jednoznaczny. Można zatem zapytać, jakie parametry reprezentują taką funkcję najlepiej. Jedną z możliwych odpowiedzi jest poszukiwanie odpornej (robust) reprezentacji funkcji użyteczności, patrz (Salvatore Greco et al. 2010).

Trzeba jednak zdawać sobie sprawę, że identyfikacja funkcji użyteczności kardynalnej ma ograniczony, choć ważki zakres zastosowań. Metoda taka nadaje się niewątpliwie w przypadku wspomagania decyzji niepewnością o wyraźnie losowym charakterze; do takich można np. zaliczyć inwestycje na rynku finansowym. W innych dziedzinach zastosowań, np. w zakresie ochrony środowiska, trudno jest wręcz stosować te same pojęcia (np. skłonność czy awersję do ryzyka) co w przypadku gier pieniężnych.

\section{Literatura}

Barzilay J. (2010) Preference Function Modelling: The Mathematical Foundations of Decision Theory. In: M. Ehrgott, J.R. Figueira, S. Greco (eds.) Trends in

Multiple Criteria Decision Analysis, Springer Verlag, New York Dordrecht Heidelberg London

Draper N.R., Smith H. (1973) Analiza regresji stosowana, PWN, Warszawa Fishburn P.C. (1982) The Foundations of Expected Utility, D. Reidel, Dordrecht

Greco S., Słowiński R., Figueira J.R., Mousseau V. (2010) Robust Ordinal Regression. In: M. Ehrgott, J.R. Figueira, S. Greco (eds.) Trends in Multiple Criteria Decision Analysis, Springer Verlag, New York Dordrecht Heidelberg London

Keeney R.L., Raiffa H. (1975) Decisions with Multiple Objectives: Preferences and Value Trade-Offs, Wiley, New York

Markowitz H. (1952) Portfolio Selection. The Journal of Finance, 7 (1): 77-91.

Pacut A. (1985) Prawdopodobieństwo: Teoria. Modele Probabilistyczne w Technice, Wyd. Naukowo-Techniczne, Warszawa

Rios S. (1994) Decision Theory and Decision Analysis: Trends and Challenges, Kluwer Academic Publishers, Dordrecht

von Neumann J., Morgenstern O. (1947) Theory of Games and Economic Behavior, Princeton University Press, Princeton

Zimmermann H.J. (1987) Methoden und Modelle des Operations Research, ViewegVerlag, Braunschweig

Zimmermann H.J., Gutsche L. (1991) Multi-Criteria Analyse, Springer-Verlag, Berlin 


\section{Paradoksy racjonalności i alternatywne modele podejmowania decyzji oraz niepewności}

Po krótkiej charakterystyce teorii wartości i użyteczności jako paradygmatu i przeglądzie różnych podejść krytycznych do tego paradygmatu, rozdział niniejszy podaje przykłady paradoksów racjonalności, opisuje teorię decyzji zadowalających i jej uzupełnienia, model programowania celowego oraz model decyzji quasi-zadowalających, wreszcie zarys teorii zbiorów rozmytych jako alternatywnego modelu niepewności i jej wykorzystanie dla specyfikacji preferencji decydenta.

\subsection{Teoria wartości i użyteczności jako paradygmat}

Jak już wspomnieliśmy wcześniej, teorii wartości i użyteczności poświęcono tak wiele książek i artykułów, że ich podstawowe założenia nabrały charakteru paradygmatu, wraz ze znanymi socjologicznymi i ideologicznymi aspektami paradygmatycznego ujęcia dziedziny nauki. Ostrożnie interpretowana, jako dobrze uzasadniony $\mathrm{i}$ wszechstronnie zbadany język matematyczny opisu pewnej klasy zachowań człowieka, ma ta teoria bardzo duże znaczenie poznawcze i przydatność praktyczną, zwłaszcza jako podstawa badań preferencji rynkowych uśrednionego konsumenta, jako podstawa teorii gier i prostych modeli rynku (o czym mówimy w dalszej części książki). Jednak pojawiało się też szereg zbyt ambitnych interpretacji tej teorii, które dziś wydają się nadmiernie uproszczone.

Te bardziej ambitne podejścia do teorii wartości i użyteczności traktują ją jako teorię normatywna lub preskryptywną: uważa się wtedy, że decydenci powinni (we własnym, najlepiej rozumianym interesie) maksymalizować swą funkcję użyteczności w każdej sytuacji decyzyjnej. Aksjomaty tej teorii interpretuje się wtedy nie jako pewne założenia matematyczne ułatwiające analizę, ale jako definicje racjonalnego zachowania się. Jeśli jakiś decydent nie zachowuje się zgodnie $\mathrm{z}$ tymi aksjomatami, to uważa się go za nieracjonalnego lub niekonsekwentnego - niejako odmawiając sensowności 
badania, dlaczego to wielu decydentów jest w tym sensie nieracjonalnych lub niekonsekwentnych.

Jednakże właśnie przeciw takiej interpretacji tej teorii podnoszono też wiele głosów krytycznych. Jak już wspomnieliśmy w poprzednich rozdziałach, taka zbyt daleko posunięta interpretacja racjonalności zachowań ludzkich nie jest sama racjonalną teorią, tylko ideologią - w myśl poglądów filozoficznych Karla Poppera o racjonalności teorii naukowych. Racjonalna teoria naukowa według Poppera powinna podlegać intensywnemu procesowi falsyfikacji, natomiast założenie, że każdy człowiek maksymalizuje bądź powinien maksymalizować swą funkcję użyteczności nie jest w ogóle falsyfikowalne, jest zatem ideologią - bowiem do każdej decyzji możemy dobrać wiele funkcji, których maksimum przypada właśnie na tę decyzję. Inny filozof nauki, Thomas Kuhn jest jednak mniej wymagający i przyjmuje, że centralne założenia pewnej teorii tworzą paradygmat i nie muszą być falsyfikowalne, często wyrażają tylko pewien dogodny model matematyczny czy nawet aspekty ideologiczne, natomiast falsyfikacji mogą podlegać tylko wnioski interpretujące daną teorię w konkretnych zastosowaniach. Stąd teorię wartości i użyteczności można jednak uznać za racjonalną, trzeba tylko uwzględniać krytykę jej założeń.

Krytyka teorii wartości i użyteczności wyrażała się w kilku formach. Należą do nich:

1) Paradoksy racjonalności, które albo pokazują, że zachowania ludzkie w rzeczywistości często nie spełniają podstawowych aksjomatów tej teorii (jeden z takich przykładów podamy poniżej), albo też ilustrują sytuacje, w których maksymalizacja funkcji wartości lub użyteczności wcale nie musi być najkorzystniejszym zaleceniem zachowania się decydenta $\mathrm{z}$ punktu widzenia jego własnych interesów (takie przykłady podamy w rozdziale poświęconym teorii gier).

2) Różnorodne odmienne wzorce racjonalności, czyli inne szkoły opisu typowych sposobów podejmowania decyzji, zwracające większą uwagę na aspekty kulturowe i psychologiczne. Poniżej podamy nieco bardziej szczegółowy opis wspomnianych już wcześniej argumentów Herberta Simona, który zapoczątkował szkołę tzw. decyzji zadowalających, wynikające z tej szkoły podejście programowania celowego, oraz uogólnienie tych podejść poprzez pojęcie decyzji quasi-zadowalających a także optymalizacji względem punktu odniesienia. 
3) Alternatywne sposoby opisu niepewności, gdyż wcale nie jest pewne, że w każdej sytuacji decyzyjnej jest sensownym modelowanie niepewności w ujęciu probabilistycznym. Wprawdzie część reprezentantów paradygmatycznej teorii użyteczności uważała, że jest to jedynie sensowne podejście, a więc rozwinięto teorię tzw. subiektywnego prawdopodobieństwa, jednak różne eksperymenty wskazują, że subiektywna aproksymacja prawdopodobieństwa przez przeciętnego człowieka wcale nie musi dawać wyników zgodnych z podstawami teorii probabilistyki. Stąd też rozwinęło się kilka innych sposobów opisu niepewności.

\subsection{Paradoksy racjonalności}

Paradoks Allais. Podany przez Maurice’a Allais w 1953 roku, paradoks ten ilustruje, że aksjomat niezależności od opcji ubocznej użyty w Twierdzeniu 5.1 wcale nie musi odpowiadać rzeczywistym zachowaniom decydentów. Rozpatrzmy następujące dwie pary loterii:

$\boldsymbol{L}_{1}$ : wygrana 1000000 \& z prawdopodobieństwem 1,00;

$\boldsymbol{L}_{2}$ : wygrana $5000000 \$$ z prawdopodobieństwem 0,10; wygrana

1000000 \& z prawdopodobieństwem 0,89 oraz wygrana 0 \$ z prawdopodobieństwem 0,01

$\boldsymbol{L}_{3}$ : wygrana $5000000 \$ \mathrm{z}$ prawdopodobieństwem 0,10 oraz wygrana $0 \$$ z prawdopodobieństwem 0,90

$\boldsymbol{L}_{4}$ : wygrana $1000000 \$$ z prawdopodobieństwem 0,11 oraz wygrana $0 \$$ z prawdopodobieństwem 0,89

Decydentowi zadaje się dwa pytania. Pierwsze: czy preferuje loterię $\boldsymbol{L}_{1}$, czy $\boldsymbol{L}_{2}$ (przy tej samej cenie losu)? Drugie: czy preferuje loterię $\boldsymbol{L}_{3}$, czy $\boldsymbol{L}_{4}$ (j.w.)? Zazwyczaj ok. $70 \%$ decydentów odpowiada $\boldsymbol{L}_{1} \boldsymbol{P} \boldsymbol{L}_{2}$ oraz ponad $90 \%$ odpowiada $\boldsymbol{L}_{3} \boldsymbol{P} \boldsymbol{L}_{4}$.

Jednakże odpowiedzi takie są sprzeczne z aksjomatem niezależności od opcji ubocznej. Żeby to wykazać, oznaczmy: $\boldsymbol{L}=\boldsymbol{L}_{1}$ oraz zdefiniujmy dwie dodatkowe loterie $\boldsymbol{L}^{\prime}, \boldsymbol{L}^{\prime \prime}$ :

$L^{\prime}$ : wygrana $5000000 \$$ z prawdopodobieństwem 10/11 oraz wygrana 0 \$ z prawdopodobieństwem $1 / 11$

L": wygrana 0 \$ z prawdopodobieństwem 1,00 
Łatwo sprawdzić, że przyjmując $\alpha=0.11$ możemy wyrazić loterie $\boldsymbol{L}_{1}, \boldsymbol{L}_{2}, \boldsymbol{L}_{3}$, $\boldsymbol{L}_{4} \mathrm{~W}$ następującej postaci:

$$
\begin{aligned}
& \boldsymbol{L}_{1}=\alpha \boldsymbol{L}+(1-\alpha) \boldsymbol{L} \\
& \boldsymbol{L}_{2}=\alpha \boldsymbol{L}^{\prime}+(1-\alpha) \boldsymbol{L} \\
& \boldsymbol{L}_{3}=\alpha \boldsymbol{L}^{\prime}+(1-\alpha) \boldsymbol{L}^{\prime \prime} \\
& \boldsymbol{L}_{4}=\alpha \boldsymbol{L}+(1-\alpha) \boldsymbol{L}^{\prime \prime}
\end{aligned}
$$

Tak więc, zgodnie z aksjomatem o niezależności od opcji ubocznej, albo zachodzi $\boldsymbol{L} \boldsymbol{P} \boldsymbol{L}^{\prime}$, z czego wynika $\boldsymbol{L}_{1} \boldsymbol{P} \boldsymbol{L}_{2}$ oraz $\boldsymbol{L}_{4} \boldsymbol{P} \boldsymbol{L}_{3}$, albo też $\boldsymbol{L}^{\prime} \boldsymbol{P} \boldsymbol{L}$, z czego wynika $\boldsymbol{L}_{2} \boldsymbol{P} \boldsymbol{L}_{1}$ oraz $\boldsymbol{L}_{3} \boldsymbol{P} \boldsymbol{L}_{4}$. Preferencje $\boldsymbol{L}_{1} \mathrm{P} \boldsymbol{L}_{2}$ oraz $\boldsymbol{L}_{3} \boldsymbol{P} \boldsymbol{L}_{4}$, wyrażane łącznie przez większość decydentów, są więc niespójne $\mathrm{z}$ tym aksjomatem.

Paradoks Allais nie jest przypadkiem odosobnionym, można podać wiele innych podobnych. $Z$ punktu widzenia psychologicznego można go tłumaczyć następująco: zazwyczaj opcja pewna ma dla nas większą wartość niż opcje niepewne. Daniel Kahneman i Amos Tversky (1982) opracowali na tej podstawie tzw. teorię żalu (theory of regret), później nazywaną teoria perspektywy. Z punktu widzenia matematycznego można na tej podstawie dojść do teorii funkcji użyteczności, które zależą nieliniowo od prawdopodobieństw (i tym samym, zgodnie z Twierdzeniem 5.1, nie spełniają aksjomatu niezależności od opcji ubocznej). Przykładowe postaci takiej funkcji są następujące:

$$
U^{\sim}=\Sigma_{\mathrm{i}=1, \ldots \mathrm{n}} P\left(p_{i}\right) V\left(y_{i}\right), \text { lub } U^{\sim}=\Sigma_{\mathrm{i}=1, \ldots \mathrm{n}} P\left(p_{i}\right) V\left(y_{i}\right) / \Sigma_{\mathrm{i}=1, \ldots \mathrm{n}} P\left(p_{i}\right)
$$

gdzie $P\left(p_{i}\right)$ jest określoną funkcją nieliniową (która też powinna podlegać identyfikacji); możliwa jest też postać analogiczna do szeregu Taylora:

$$
U^{\sim}=\sum_{\mathrm{i}=1, \ldots \mathrm{n}} p_{i} V\left(y_{i}\right)+0,5\left(\Sigma_{\mathrm{i}=1, \ldots \mathrm{n}} p_{i} T\left(y_{i}\right)\right)^{2} \ldots
$$

Więcej szczegółów o funkcjach użyteczności, które są nieliniowe względem prawdopodobieństw, można znaleźć w literaturze - patrz Mark Machina (1983), Peter Fishburn (1988).

Dalsza krytyka klasycznej teorii użyteczności wskazuje też, że samo postawienie pytania o porównanie loterii - sposób jego sformułowania może stymulować pożądaną odpowiedź (taką manipulację nazywa się po angielsku framing). Można podać następujący przykład sformułowania pytań o preferencje w warunkach niepewności, dotyczące wyboru programów 
przeciwdziałających epidemii, w której bez programu przeciwdziałania przewiduje się zgon 600 osób. Podajemy poniżej sformułowania pytań do porównań parami $\mathrm{A} \mathrm{z} \mathrm{B}$ oraz $\mathrm{C}$ z D, wraz z typowymi (wynikającymi $\mathrm{z}$ ankietyzacji przeciętnych respondentów) odsetkami preferencji.

A: 200 osób można uratować z prawdopodobieństwem 1 (75\% preferencji);

B: mamy prawdopodobieństwo $1 / 3$, że uratujemy wszystkich oraz prawdopodobieństwo $2 / 3$, że nie uratujemy nikogo (25\% preferencji)

C: 400 osób zginie z prawdopodobieństwem 1 (22\% preferencji)

D: identyczne ze sformułowaniem B \& A (78\% preferencji)

przy czym przypadki A B, C, i D to ten sam program, tylko o inaczej przedstawionych rezultatach. Oczywiście, argument taki nie podważa teorii wartości i użyteczności, wskazuje tylko, jak ostrożnie trzeba ją interpretować.

\subsection{Teoria decyzji zadowalających $i$ jej uzupełnienia}

Jak już wspomnieliśmy $\mathrm{w}$ rozdziałach wstępnych, wzorzec racjonalności zawarty w teorii wartości i użyteczności był jednak wielokrotnie krytykowany $\mathrm{z}$ różnych pozycji, przy czym szczególną rolę odegrała teoria decyzji zadowalajacych Herberta Simona (ang. satisficing decision making). ${ }^{8}$ Simon krytykował teorię wartości i użyteczności, używając następujących argumentów, które uzupełnimy o bardziej aktualne komentarze:

1) Zadanie optymalizacji jest zwykle zadaniem trudnym. O ile sensowne jest założenie, że średnie rezultaty bardziej złożonych procesów mogą być opisane poprzez optymalizację (tak jak, średnio biorąc, producenci na niemonopolistycznym rynku muszą minimalizować koszty produkcji, bo inaczej wyprzedzi ich konkurencja i zbankrutują), o tyle trudno w ten sposób opisywać zachowania indywidualne. Z perspektywy współczesnej możemy dodać, że istnieje dziś komercyjne oprogramowanie pozwalające sprawnie rozwiązywać zadania optymalizacji o dużym stopniu złożoności; ale mało decydentów umie się nim posługiwać, a ponadto budowa modeli adekwatnych do danej sytuacji decyzyjnej nadal pozostaje poważnym problemem.

2) Ocena prawdopodobieństw, zwłaszcza subiektywna, jest zadaniem jeszcze trudniejszym, ludzie mogą w tym popełnić rozmaite pomyłki;

${ }^{8} \mathrm{Nie}$ jest to błąd w pisowni angielskiej, tylko neologizm celowo stworzony przez Simona. 
zadanie optymalizacji uwzględniające niepewność probabilistyczną (dziś zwane zadaniem optymalizacji stochastycznej) jest też znacznie trudniejsze. Z perspektywy współczesnej możemy dodać, że rozwiązywane są dziś już bardzo złożone zadania optymalizacji stochastycznej, wymagają one jednak zwykle bardzo dużego nakładu obliczeń (komputerów dużej mocy, algorytmów równoległych lub rozproszonych itp.).

3) W wielu sytuacjach decyzyjnych o niewielkiej liczbie samodzielnych decydentów pojawiają się paradoksy czy pułapki racjonalności: dążenie do bezwzględnej maksymalizacji własnego rezultatu może powodować eskalację konfliktów i rezultaty gorsze niż osiągalne we współpracy z innymi (przykłady takich sytuacji growych podamy w dalszych częściach książki). Ponieważ takie sytuacje występują często - np. w pracy zawodowej wśród grupy współpracowników - sensowny model podejmowania decyzji nie może się opierać wyłącznie na maksymalizacji funkcji wartości lub użyteczności. Ten argument Simona pozostaje do dziś w pełni aktualny.

4) Preferencje decydentów na ogół ulegają zmianie w wyniku procesów uczenia się, zatem należy niezwykle ostrożnie podchodzić do wszelkich prób ich identyfikacji. Ten argument Simona nie tylko pozostaje do dzisiaj aktualny, ale ma on decydujący wpływ na praktyczną przydatność komputerowego wspomagania decyzji.

Jako alternatywny opis typowego sposobu podejmowania decyzji, Herbert Simon sformułował model decyzji zadowalających, który możemy opisać dziś następująco:

a) Decydent określa poziomy aspiracji dla poszczególnych rezultatów decyzji - atrybutów, kryteriów, wskaźników jakości - które uważa za ważne. Te poziomy aspiracji są określane adaptacyjnie, w procesie uczenia się, niekiedy podświadomie - a w wieloosobowych czy growych sytuacjach decyzyjnych nie zawsze korzystne jest odsłanianie swej struktury preferencji, w tym także poziomów aspiracji.

b) Wybór decyzji nie jest pojedynczym aktem optymalizacji, ale dynamicznym procesem poszukiwania rozwiązań, w trakcie którego decydent też się uczy i może zmienić preferencje i aspiracje.

c) Proces ten kończy się, gdy decydent znajduje taką decyzję, która pozwala na osiągnięcie rezultatów spełniających jego aspiracje (stąd nazwa decyzja zadowalająca) lub w pewnym sensie najbliższych do tych aspiracji. 
Teoria Simona wywołała wprawdzie wiele kontrowersji, potwierdzona była jednak przez badania empiryczne i psychologiczne, zwłaszcza przez dalszy rozwój teorii żalu lub teorii perspektywy Kahnemana i Tversky’ego. Badania te potwierdziły, że poziomy aspiracji odgrywają istotną rolę w podejmowaniu decyzji (zauważmy, że wpływ poziomu aspiracji może być np. użyty dla wytłumaczenia, dlaczego aksjomat niezależności od opcji ubocznej często nie jest w praktyce spełniony). Okazało się też, że ludzie w swych decyzjach mogą formować kilka poziomów aspiracji dla jednego atrybutu decyzji - najbardziej istotne jest tu rozróżnienie pomiędzy poziomem rezerwacji, który należy osiągnąć, a poziomem aspiracji, który dobrze byłoby osiągnąć. Kontrowersje dotyczyły m.in. podejmowania decyzji w warunkach niepewności; zauważmy jednak, że (tak jak w narzędziowym podejściu momentów rozkładu, omawianym w poprzednim rozdziale) miara niepewności czy ryzyka może być traktowana jako atrybut decyzji, co do którego też określa się poziom aspiracji.

Teoria Simona została w pewnym sensie zinternalizowana (czyli włączona jako element trudny do odrzucenia) przez paradygmatyczną teorię użyteczności i wartości, pod znamienną jednak nazwą racjonalności ograniczonej (bounded rationality). Z tej perspektywy uznaje się, że większość ludzi nie podejmuje decyzji w sposób idealny - postępując np. w sposób opisany przez Simona - ale to tylko dlatego, że ich racjonalność jest ograniczona.

Jest wiele innych alternatywnych podejść do wspomagania decyzji; tu wspomnimy tylko podejście Zdzisława Pawlaka (1991), oparte na logice zbiorów przybliżonych w zastosowaniu do analizy wielkich zbiorów danych, gdzie zawsze istnieje trzecia droga.

\subsection{Programowanie celowe}

Teoria Simona została też wyrażona w formie matematycznej paradoksalnie, jednak w oparciu o optymalizację, a mianowicie jako minimalizacja odległości od danego punktu złożonego z poziomów aspiracji i zwanego celem; podejście takie nazywa się programowaniem celowym (ang. goal programming), zob. Abraham Charnes i William Cooper (1977). Jest to dość popularny sposób wspomagania decyzji, który omówimy nieco 
dokładniej w następnej części książki; tu naszkicujemy tylko istotę koncepcji programowania celowego.

Jeśli dysponujemy modelem określającym zbiór decyzji dopuszczalnych $\boldsymbol{X}_{0}$ oraz przekształcenie decyzje-rezultaty $\boldsymbol{y}=\boldsymbol{f}(\boldsymbol{x})$, zwane łącznie także modelem rzeczowym sytuacji decyzyjnej; jeśli ponadto w przestrzeni rezultatów $\boldsymbol{Y}=\boldsymbol{R}^{m}$ określimy cel $\boldsymbol{y}^{-}$jako wektor złożony z celów cząstkowych czy poziomów aspiracji $y_{i}$, to poszukiwanie decyzji zadowalających możemy wyrazić jako zadanie optymalizacji:

$$
\operatorname{minimize}_{x \in \mathrm{X} 0}\left\|f(x)-y^{-}\right\|
$$

gdzie \|.\| oznacza jedną z norm w $\boldsymbol{R}^{m}$. Programowanie celowe w swej oryginalnej formie dotyczy takich modeli, w których zależność $\boldsymbol{y}=\boldsymbol{f}(\boldsymbol{x})$ jest liniowa, zaś zbiór decyzji dopuszczalnych $\boldsymbol{X}_{0}$ jest wielościenny, czyli określony przez układ nierówności lub równań liniowych. Jeśli by funkcja minimalizowana w (6.3) miała postać liniową, to można by tu stosować dobrze wypróbowany aparat programowania liniowego. Norma jest wprawdzie funkcją nieliniową, ale jej szczególne postaci - bądź to norma $l_{1}$, bądź norma Czebyszewa $l_{\infty}$, zob. Rozdz. 4 - mają zbiory poziomicowe nie tylko wypukłe, lecz także dające się wyrazić przez układ nierówności liniowych. Przy użyciu jednej z tych norm - przy czym w programowaniu celowym stosuje się zazwyczaj normę $l_{1}$ - i przy liniowym przekształceniu $\boldsymbol{y}=\boldsymbol{f}(\boldsymbol{x})$ oraz wielościennym zbiorze $\boldsymbol{X}_{0}$, zadanie (6.3) daje się sprowadzić do odpowiedniego zadania programowania liniowego. Programowanie celowe jest to więc wykorzystanie metod programowania liniowego do znajdowania decyzji, których rezultaty są możliwie najbliższe do danych celów czy punktów aspiracji $\boldsymbol{y}^{-}$. Podobnie jak w oryginalnym modelu zadowalającego podejmowania decyzji zakłada się, że decydent może się uczyć i modyfikować swe cele $\boldsymbol{y}^{-}$, a więc zadanie (6.3) rozwiązywane jest interaktywnie: decydent określa $\boldsymbol{y}^{-}$, natomiast komputer - czyli system wspomagania decyzji rozwiązuje (6.3) oraz podaje decydentowi propozycje decyzji i ich rezultatów odpowiadających rozwiązaniu tego zadania. Jeśli decydent jest zadowolony z tych propozycji, akceptuje je jako decyzje zadowalające; jeśli nie, może zmodyfikować $y$. 


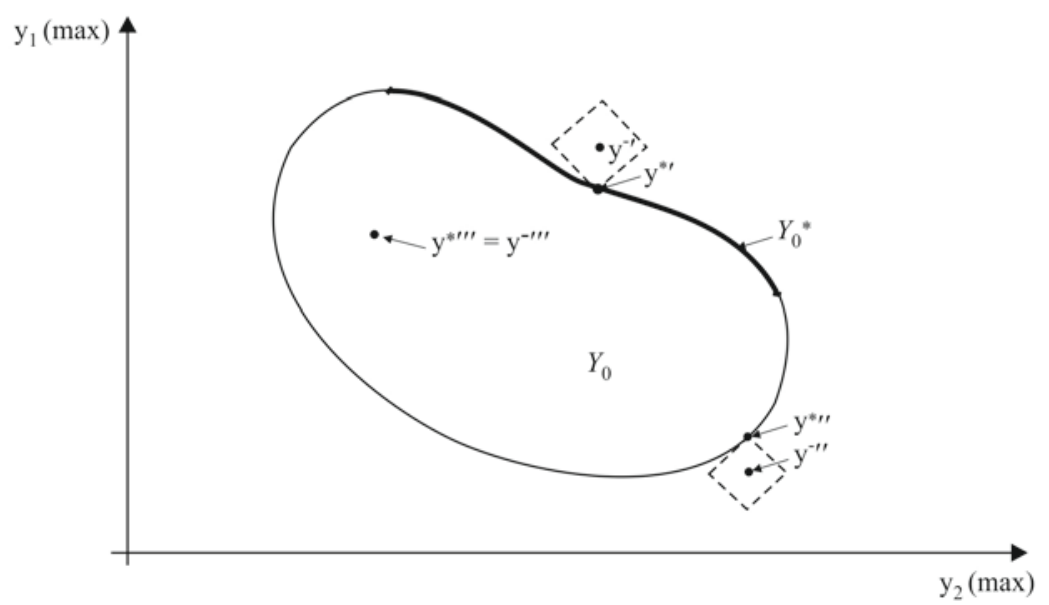

Rys. 6.1. Uzyskiwanie rezultatów $\boldsymbol{y}^{*}$ niezdominowanych $\left(\boldsymbol{y}^{*} \in \boldsymbol{Y}_{0}^{*}\right)$ bądź zdominowanych $\left(\boldsymbol{y}^{*},, \boldsymbol{y}^{*}+{ }^{*}\right)$ w wyniku zadowalającego podejmowania decyzji i programowania celowego z normą $l_{1}$, zależnie od położenia punktu odniesienia (celu) $\boldsymbol{y}^{-}$względem zbioru rezultatów osiągalnych $\boldsymbol{Y}_{0}$.

Ten interaktywny proces wspomagania decyzji jest szczególnie atrakcyjną cechą programowania celowego. Ale programowanie celowe, a także teoria decyzji zadowalających, mają jedną wspólną, istotną wadę: dopuszczają one decyzje zdominowane w sensie określonego porządku Pareto nawet w takich przypadkach, gdy z łatwością można by znaleźć decyzje od nich lepsze. Ilustruje to przykład na Rys. 6.1, gdzie przedstawiona jest sytuacja typowa dla programowania celowego (przy nieliniowym modelu rzeczowym, ale podobne efekty obserwujemy także dla modeli liniowych; przy wielościennym zbiorze $\boldsymbol{X}_{0}$ oraz liniowym przekształceniu $\boldsymbol{y}=\boldsymbol{f}(\boldsymbol{x})$, zbiór osiągalnych rezultatów $\boldsymbol{Y}_{0}=\boldsymbol{f}\left(\boldsymbol{X}_{0}\right)$ jest także wielościenny).

Załóżmy przy tym, że rozpatrywane są dwa rezultaty (kryteria) $y_{1}$ oraz $y_{2}$, przy czym oba należy maksymalizować. Jeśli cel czy punkt aspiracji, tak jak $\boldsymbol{y}^{-1}$ na rysunku, leży „na północny wschód” od zbioru rezultatów osiągalnych $\boldsymbol{Y}_{0}$, to punkt $\boldsymbol{y}^{*_{1}}$ odpowiadający minimum normy $\left\|\boldsymbol{y}-\boldsymbol{y}^{-1}\right\|_{l 1}$ jest niezdominowany w sensie porządku Pareto odpowiadającego maksymalizacji obu rezultatów, czyli leży na „północno-wschodniej” granicy zbioru $\boldsymbol{Y}_{0}{ }^{9}$ Dla celów inaczej położonych względem zbioru $\boldsymbol{Y}_{0}$, tak jak punkt $\boldsymbol{y}^{-1}$ na rysunku, minimalizujący odległość punkt $y^{*}$ jest już rezultatem zdominowanym.

${ }^{9}$ Nie jest to jednak własność ogólna, wynika tylko z wypukłości zbioru $\boldsymbol{Y}_{0}$, zob. dalsze rozdziały. 
Problemy zastosowań programowania celowego najbardziej wyraźnie na rysunku ilustruje jednak przykład punktu $\boldsymbol{y}^{\text {-"', }}$ który jest punktem wewnętrznym zbioru $\boldsymbol{Y}_{0}$. W takiej sytuacji minimum normy przypada oczywiście w tym samym punkcie, $\boldsymbol{y}^{*}{ }^{\prime \prime}=\boldsymbol{y}^{-{ }^{\prime \prime}}$. Jest to więc nie tylko rezultat zdominowany, ale $\mathrm{w}$ jego otoczeniu można $\mathrm{z}$ łatwością znaleźć wiele rezultatów od niego lepszych. Powstaje przy tym kwestia interpretacji tego wyniku. Jeśli interpretujemy go $\mathrm{w}$ sensie zadowalającego trybu podejmowania decyzji przez człowieka, to można twierdzić, że przyjęcie decyzji prowadzących do tego rezultatu ma cechy racjonalności. Człowiek może nie mieć czasu na dalszą analizę i poprawę decyzji, może też świadomie zrezygnować z dalszej poprawy, jeśli - zgodnie z trzecim argumentem Herberta Simona - rezygnuje z dalszych korzyści nie chcąc spowodować konfliktu z otoczeniem, może też wreszcie nie aprobować tych decyzji i ich rezultatu, i podwyższyć poziomy aspiracji stawiając bardziej ambitny cel. I ten ostatni argument jest przytaczany typowo jako obrona przed zarzutem uzyskiwania rezultatów zdominowanych w metodzie programowania celowego. Wystarczy bowiem, aby decydent wielokrotnie zwiększał - o skończone przyrosty - poziomy aspiracji, a w końcu (przy założeniu zwartości $\boldsymbol{Y}_{0}$ ) dojdzie do takiego celu, który leży na „północny wschód" od $\boldsymbol{Y}_{0}$.

Tu jednak pojawia się ponownie podstawowe pytanie wspomagania decyzji: czy komputer powinien naśladować zachowanie człowieka i zastępować go w podejmowaniu decyzji, czy też - przyjmując pewne założenia o zachowaniu się człowieka - możliwie najlepiej wspomagać go w podejmowaniu decyzji? Jeśli przyjmiemy, że prawidłowa jest druga część odpowiedzi, to programowanie celowe nie jest najlepszą metodą wspomagania decyzji: skoro czas pracy komputera nie jest kosztowny, to powinien on poinformować użytkownika, że proponowany rezultat jest zdominowany, i zaproponować mu nie tylko decyzje prowadzące do tego rezultatu, lecz także decyzje prowadzące do przykładowego, osiągalnego rezultatu dominującego określony cel czy punkt aspiracji. Nie można wtedy jednak stosować minimalizacji normy, a ponadto trzeba najpierw przemyśleć dokładniej rolę decydenta czy użytkownika oraz rolę komputera w systemie wspomagania decyzji. Prowadzi to do nieco odmiennego podejścia, które przedstawimy w następnym punkcie. 


\subsection{Decyzje quasi-zadowalające i optymalizacja względem punktu odniesienia}

W swym oryginalnym ujęciu Herbert Simon nie określał wyraźnie, co się dzieje w przypadku, gdy możliwe jest spełnienie wszystkich aspiracji z nadmiarem. Można jednak domyślać się, że następuje wtedy albo przejściowe przyjęcie decyzji, którą by można poprawić (jak w programowaniu celowym, gdy minimum odległości od celu jest zerowe), albo przedłużenie procesu decyzyjnego $\mathrm{z}$ adaptacyjnym podwyższeniem aspiracji. Podobnie, przypadek niemożliwości realizacji aspiracji można interpretować jako adaptacyjne ich obniżenie. W ten sposób proces podejmowania decyzji zadowalających można jednak interpretować jako swoisty proces optymalizacji adaptacyjnej którego najbardziej istotną cechą jest fakt, że funkcja wartości nie jest ukształtowana a priori, ale ulega modyfikacjom podczas procesu decyzyjnego, i zależy parametrycznie od przyjętego punktu aspiracji. ${ }^{10}$

Taka interpretacja była nazwana quasi-zadowalajacym podejmowaniem decyzji - zob. (Wierzbicki 1982). Wynika z niej, że identyfikacja funkcji wartości nie powinna być zbyt dokładna - skoro ta funkcja może ulec zmianie - i że można się zadowalać stosunkowo prostymi modelami funkcji wartości, pod warunkiem jednak, że modele te będą oparte o pojęcie poziomów aspiracji. Taki prosty model funkcji wartości nie może jednak być liniową funkcją atrybutów, gdyż preferencje pomiędzy przyrostami poszczególnych atrybutów czy też wagi przykładane do stosunków tych przyrostów (zwane niekiedy współczynnikami wymiany, trade-off coefficients) mogą ulegać zmianie po przekroczeniu poziomu aspiracji dla pojedynczego atrybutu. Musi to być więc co najmniej funkcja przedziałami liniowa, zob. Rys. 6.2.

Metoda quasi-zadowalającego podejmowania decyzji opracowana była dla zastosowań w interaktywnym komputerowym wspomaganiu decyzji. Można wtedy bowiem zakładać, że człowiek - suwerenny użytkownik systemu wspomagania decyzji - ma prawo posługiwać się jakąkolwiek metodą ostatecznego podjęcia decyzji, powinien jednak przekazywać jasne instrukcje komputerowi. Instrukcje te, w oparciu o teorię Simona i jej potwierdzenia przez dalsze badania psychologiczne, mogą mieć przejrzystą postać poziomów aspiracji lub też rezerwacji. Poziomy te zwane są też łącznie punktami

${ }^{10} \mathrm{Z}$ tym, że jest to jednak monotoniczna aproksymacja funkcji wartości, a nie norma, tak aby zapewnić niezdominowane rezultaty w wyniku jej optymalizacji; zob. następne rozdziały. 
odniesienia (nie celami, gdyż pożądane może być ich przekroczenie) $\mathrm{w}$ metodzie quasi-zadowalającego podejmowania decyzji. W związku z tym, metoda ta nazywana bywa też metoda optymalizacji względem punktu odniesienia, gdyż komputer - w odróżnieniu od człowieka - może jednak optymalizować przybliżoną funkcję wartości, rozwiązując przy tym nawet bardzo złożone zadania optymalizacji.

a)

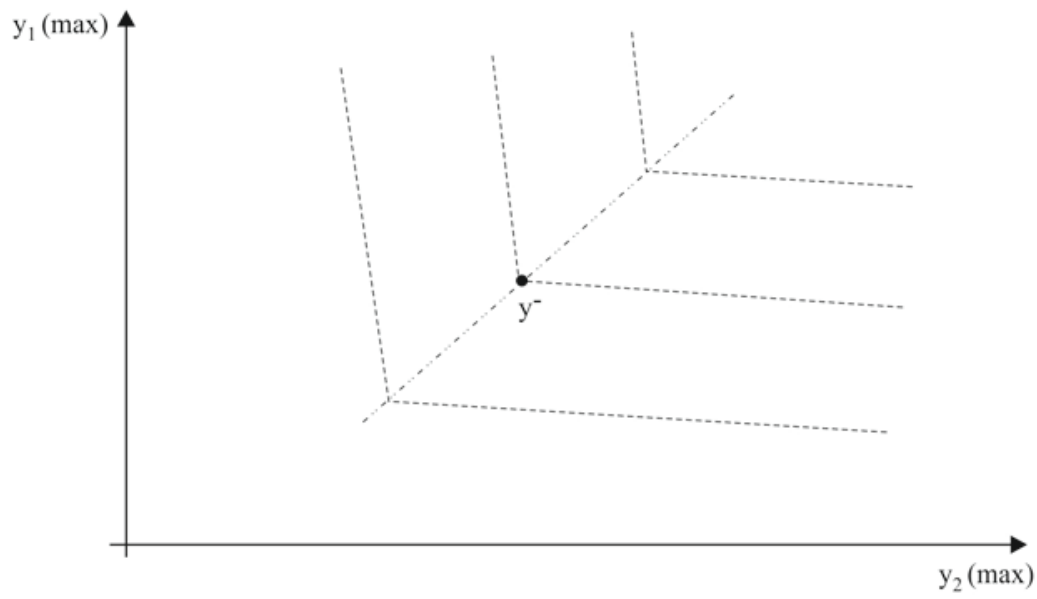

b)

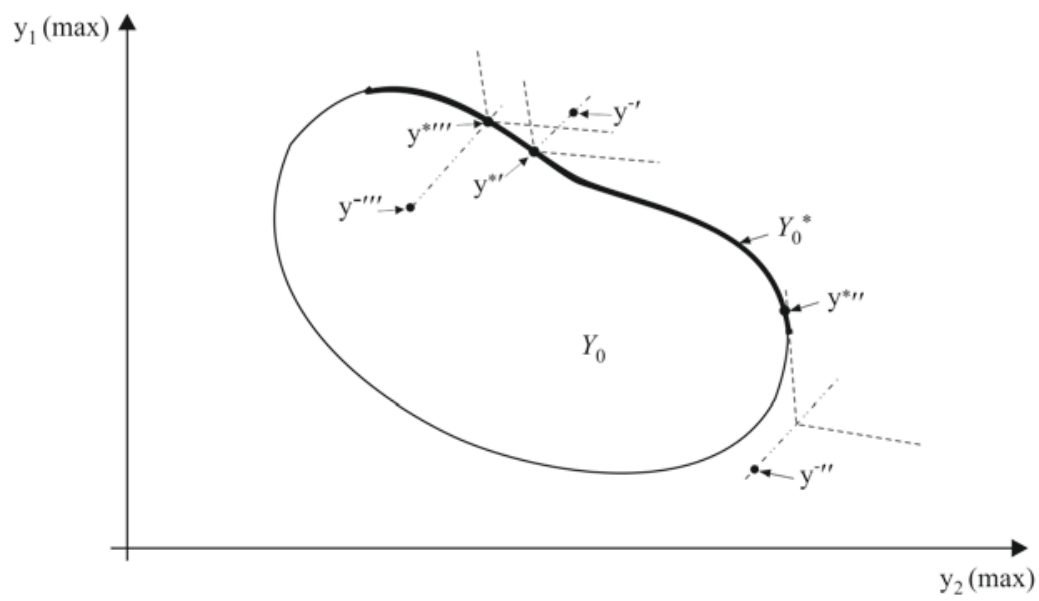

Rys. 6.2. a) Linie poziomicowe przybliżenia funkcji wartości opartego na poziomie aspiracji $\boldsymbol{y}^{-, 0} \mathrm{w}$ quasi-zadowalającym podejmowaniu decyzji; b) Niezdominowane rezultaty optymalizacji $\left(\boldsymbol{y}^{*}, \boldsymbol{y}^{*},, \boldsymbol{y}^{*}{ }^{*} \in \boldsymbol{Y}^{*}\right)$ takiego przybliżenia funkcji wartości dla przykładu analogicznego do Rys. 6.1. 
Komputerowy system wspomagania decyzji pracuje wtedy jako swoisty idealny zespół analityczny. Realny zespół analityczny złożony z ludzi jest niekoniecznie idealny. Gdyby otrzymał od szefa zadanie przygotowania decyzji, wraz z poziomami aspiracji odnośnie poszczególnych wskaźników oceny tej decyzji, mógłby się zachowywać różnie, zależnie od osiągalności tych aspiracji:

a) Jeśli możliwe jest znalezienie zarówno takich decyzji, które pozwalają na osiągnięcie wszystkich poziomów aspiracji, jak i takich, które pozwalają na wyniki lepsze niż poziomy aspiracji, to realny zespół analityczny mógłby poprzestać - zgodnie z teorią Simona - na decyzji pozwalającej osiągnąc poziomy aspiracji, po czym zająłby się dyskusją bieżących plotek przy kawie. Nie ma jednak powodu, by tak samo zachowywał się idealny, komputerowy zespół analityczny czyli system wspomagania decyzji - stąd też metoda programowania celowego niepotrzebnie imituje w takim przypadku realne zachowania ludzkie. Idealny zespół analityczny powinien poinformować szefa, że zdefiniowane przez niego poziomy aspiracji są osiągalne $\mathrm{z}$ nadmiarem, po czym zając się określeniem decyzji pozwalającej na możliwie największą, ale równomierną poprawę wszystkich poziomów aspiracji.

b) Jeśli poziomy aspiracji nie są osiągalne, to realny zespół analityczny mógłby ulec pokusie modyfikacji rzeczywiście osiągalnych rezultatów tak, by wydawało się, że jednak można te poziomy osiągnąć - albo też wdać się z szefem $\mathrm{w}$ dyskusję, że osiągnięcie niektórych poziomów aspiracji nie jest tak naprawdę potrzebne. Idealny, komputerowy zespół analityczny powinien wtedy znaleźć - podobnie jak metoda programowania celowego w tym przypadku - decyzję możliwie najlepszą, z rezultatami równomiernie najbliższymi do nieosiągalnych poziomów aspiracji.

c) Jeśli wreszcie poziomy aspiracji są osiągalne, ale nie ma decyzji pozwalających na wyniki lepsze, to realny zespół analityczny mógłby np. podjąć dyskusję, że tak naprawdę, zdaniem tego zespołu, na szczególną uwagę zasługują zupełnie inne decyzje, z rezultatami odbiegającymi od podanych przez szefa poziomów aspiracji. Idealny, komputerowy zespół analityczny powinien natomiast najpierw zameldować, że poziomy aspiracji są osiągalne bez możliwości ich poprawy, podać szczegółowe decyzje niezbędne do osiągnięcia tych poziomów, a potem dopiero zapytać, czy przeprowadzić dodatkową analizę przy zmienionych poziomach aspiracji. 
Oczywiście, tylko komputer może się zachowywać w tak idealny sposób; zachowania realnego zespołu analitycznego będą raczej podobne do tych, które przewiduje teoria decyzji zadowalających. Ale ponieważ mamy wykorzystać do wspomagania decyzji właśnie komputer a nie zespół ludzi, przeto powinniśmy wymagać takiego idealnego, quasi-zadowalającego zachowania - które różni się od zachowania zadowalającego głównie w opisanym wyżej punkcie a).

Wymagamy zatem od komputera zachowania idealnego, optymalizującego pewną funkcję wartości. Natomiast odrębną kwestią jest, czym ma być taka funkcja wartości. Ponieważ w zadowalającym procesie decyzyjnym zakładamy, że decydent ma prawo się uczyć i zmieniać zdanie - a zwłaszcza zmieniać poziomy aspiracji - przeto taka funkcja wartości może być tylko lokalną, tymczasową aproksymacją nieznanej funkcji wartości decydenta. Aproksymacja ta jednak powinna być oparta na definiowanych przez decydenta poziomach aspiracji - np. tak, jak na rys. 6.2 powyżej - a także wykorzystywać wszelkie inne informacje (takie jak kierunki optymalizacji maksymalizacji bądź minimalizacji - poszczególnych wskaźników oceny decyzji, dodatkowe punkty odniesienia w postaci np. poziomów rezerwacji itp.). Jeśli założymy, że wszystkie rezultaty czy kryteria oceny decyzji mają być maksymalizowane, to możliwie prosta postać takiej aproksymacji jest następująca:

$$
s\left(\boldsymbol{y}, \boldsymbol{y}^{-}\right)=\min _{1 \leq i \leq m}\left(y_{i}-y_{i}^{-}\right)+\varepsilon \sum_{1 \leq i \leq m}\left(y_{i}-y_{i}^{-}\right)
$$

gdzie $\varepsilon>0 \$$ jest współczynnikiem, którego odwrotność ${ }^{11}$ mówi nam, jak silnie zmienia się względna waga poszczególnych kryteriów $y_{i}$ po przekroczeniu przez nie odpowiednich poziomów odniesienia $y_{i}^{-}$, tworzących łącznie punkt odniesienia $y$. Taka aproksymacja funkcji wartości, zależna od punktu odniesienia, nazywana jest funkcja osiagnięcia - gdyż jej wartości, jeśli są dodatnie dla pewnych $\boldsymbol{y} \boldsymbol{\epsilon} \boldsymbol{Y}_{0}$, wskazują na osiągalność punktu odniesienia $\boldsymbol{y}^{-}$, a jeśli są ujemne dla wszystkich $\boldsymbol{y} \boldsymbol{\epsilon} \boldsymbol{Y}_{0}$, to wskazują na nieosiągalność punktu $\boldsymbol{y}^{-}$. Taka właśnie aproksymacja funkcji wartości oraz skutki jej maksymalizacji zostały przedstawione na Rys. 6.2.

W quasi-zadowalającym podejściu do podejmowania i wspomagania decyzji wymagamy zatem zachowania idealnego od komputera, decydentowi zaś pozostawiamy możliwie jak największą swobodę - w tym także swobodę formułowania poziomów aspiracji $\mathrm{z}$ uwzględnieniem niepewności, co omówimy bardziej szczegółowo w punkcie następnym.

${ }^{11}$ Dokładniej $1+1 / \varepsilon$; zob. rozdziały następne. 


\subsection{Alternatywne sposoby opisu niepewności; zbiory rozmyte}

Niepewność odnośnie określenia poziomu odniesienia wcale nie musi być modelowana przez rozkład prawdopodobieństwa. Zastosowanie probabilistycznego sposobu opisu niepewności jest uzasadnione, jeśli mamy dane statystyczne w odniesieniu do dużej populacji przypadków. Nawet przy takim założeniu trzeba jeszcze dokładnie sprawdzić, czy spełnione są niezbędne założenia wnioskowania statystycznego. Bardzo często pomija się przy tym sprawdzenie tzw. hipotezy ergodycznej - czyli założenia, że obliczenie wartości oczekiwanej, to jest uśrednianie po zbiorze niezależnych przypadków w jednej chwili czasu, jest równoważne uśrednianiu po kolejnych podobnych przypadkach w czasie (co faktycznie interesuje pojedynczego decydenta). Co prawda, jest wiele takich przykładów, w których powyższe założenia są uzasadnione, a opis probabilistyczny niepewności jest najlepszym sposobem jej modelowania.

Jest jednak także wiele przykładów sytuacji z niepewnością, w których opis probabilistyczny nie jest adekwatny. W szczególności, ludzie często posługują się słownym (lingwistycznym) opisem niepewności typu „w przybliżeniu”, „liczba duża” itp. Formalizacja takiego opisu niepewności może być oparta na logice wielowartościowej (zapoczątkowanej przez polskiego matematyka Jana Łukasiewicza, 1911) lub, co równoważne ale znacznie lepiej spopularyzowane, na teorii zbiorów rozmytych, którą wprowadził niezależnie, choć kilkadziesiąt lat później, Lofti Zadeh - zob. np. (Zadeh 1978). Podamy tu tylko zarys podstawowych pojęć tych teorii, odsyłając po dalsze szczegóły do rozległej dziś bardzo literatury, zob. np. (Janusz Kacprzyk 1988).

Jak wiadomo, dany zbiór może być reprezentowany poprzez jego funkcje charakterystyczna. Na przykład, zbiór $X_{a}=\left\{x \in R^{1}: x \geq a\right\}$ reprezentujemy przez funkcję charakterystyczną równą 1 , gdy $x \geq a$, zaś 0 , gdy $x<a$, przy czym funkcja ta wyraża po prostu wartość logiczną stwierdzenia, że $x \geq a$. Przypuśćmy jednak, że zamiast tak prostego stwierdzenia użyjemy określenia lingwistycznego „ $X$ jest liczbą dużą w przedziale [0;10]”. Nie będziemy wtedy mogli określić ściśle, dla jakiego $a$ prawdziwe jest stwierdzenie, że $x \geq a$ „liczbą dużą”. Stwierdzenie tego typu może mieć nie tylko dwie, a nawet nieskończenie wiele wartości logicznych, zawartych $\mathrm{w}$ przedziale $[0 ; 1]$. Zastępujemy wtedy funkcję charakterystyczną przez funkcję przynależności (do tzw. zbioru rozmytego), $\mu(x) \epsilon[0 ; 1]$. 


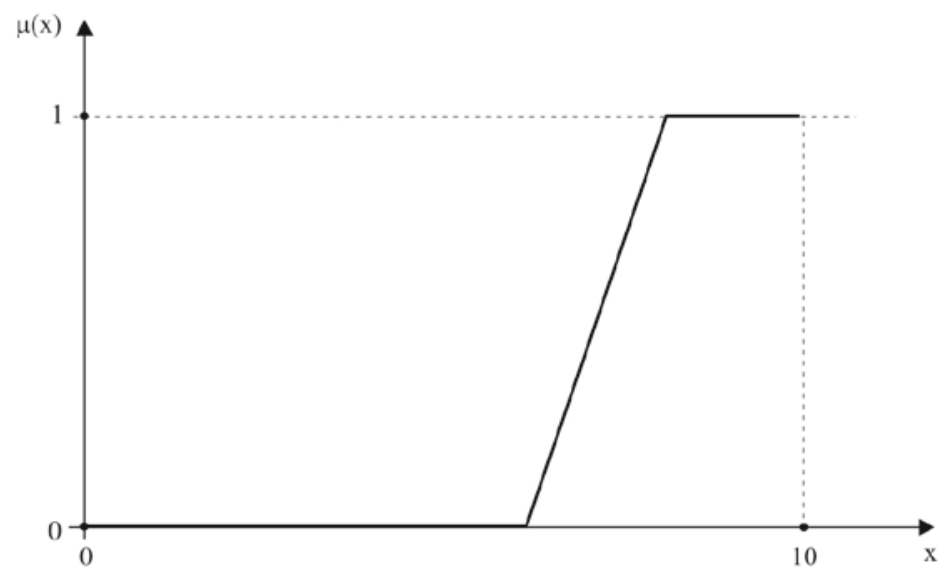

Rys. 6.3. Przykład funkcji przynależności do zbioru rozmytego, wyrażającej prawdziwość logiczną stwierdzenia,$X$ jest liczbą dużą w przedziale $[0 ; 10] ”$.

Ilustracja takiej funkcji przynależności przedstawiona jest na Rys. 6.3. Jeśli chcemy dokonywać operacji logicznych na wartościach takich funkcji, a nie na liczbach binarnych, to trzeba oczywiście odpowiednio rozszerzyć reguły dwuwartościowej logiki klasycznej (zwanej twarda lub czarno-biata w odróżnieniu od nieskończenie-wartościowej logiki rozmytej).

Istnieje cały szereg sposobów takiego rozszerzenia, przytoczymy tu tylko jeden z nich. Jeśli przez $a, b \in[0 ; 1]$ oznaczymy wartości funkcji $\mu(x)$, czyli zmienne logiczne, to możemy następująco zdefiniować podstawowe operacje logiczne - tak, aby pozostawały one zgodne z operacjami logiki twardej ale nadawały się też do logiki rozmytej:

$$
\begin{aligned}
& a \cap b=\min (a, b) \\
& a \cup b=\max (a, b) \\
& \neg a=1-a \\
& a \rightarrow b=\max (1-a, b)
\end{aligned}
$$

czemu odpowiadają następujące reguły przekształcania funkcji przynależności:

$$
\begin{aligned}
& \mu_{a}(x) \cap \mu_{b}(x)=\min \left[\mu_{a}(x), \mu_{b}(x)\right] \\
& \mu_{a}(x) \cup \mu_{b}(x)=\max \left[\mu_{a}(x), \mu_{b}(x)\right]
\end{aligned}
$$

oraz analogicznie dla zaprzeczenia i wynikania. Jeśli $\mu_{A}(x) \leq \mu_{B}(x)$, to $\mu_{B}(x)-\mu_{A}(x)$ możemy interpretować jako ocenę wartości logicznej zdarzenia $A \subseteq B$. 
Istnieje wiele zastosowań teorii zbiorów rozmytych - m.in. w eksperckich systemach wspomagania decyzji. Jednym $\mathrm{z}$ interesujących zastosowań tej teorii jest rozmyte programowanie wielokryterialne, które można też rozmaicie interpretować. Przedstawimy tu jego interpretację jako sposobu wyrażenia - za pomocą zbiorów rozmytych - niepewności decydenta o jego preferencjach, a także - jako sposobu konstrukcji interfejsu graficznego w przyjaznym dla użytkownika systemie wspomagania decyzji, opartym na wielokryterialnej analizie modeli rzeczowych $\mathrm{z}$ wykorzystaniem optymalizacji względem punktu odniesienia czy quasi-zadowalającego podejmowania decyzji. Jak uprzednio zakładamy tu ogólnie, że dany jest zbiór decyzji dopuszczalnych i model rzeczowy (niekoniecznie liniowy), wyrażone w skrócie następująco:

$$
x \in \boldsymbol{X}_{0}, \boldsymbol{f}: \boldsymbol{X}_{0} \rightarrow \boldsymbol{Y}=\boldsymbol{R}^{m}
$$

przy czym wszystkie rezultaty decyzji $y_{i}=f_{i}(x)$ mogą być optymalizowane. ${ }^{12}$ Przypuśćmy, że niepewność decydenta co do jego preferencji wyrazimy poprzez podanie dwóch poziomów odniesienia: poziomu aspiracji $y_{i}^{-}$ i poziomu rezerwacji $\tilde{y}_{i}$ dla każdego $y_{i}$. Załóżmy wreszcie, że mogą zachodzić następujące przypadki wymagań odnośnie danego rezultatu $y_{i}$ :

a) Rezultat $y_{i}$ jest maksymalizowany, co oznacza, że $\tilde{y}_{i}^{\sim}<y_{i}^{-}$oraz pożądane jest spełnienie nierówności $y_{i}=f_{i}(x)>^{\sim} y_{i}^{\sim}, y_{i}^{-}$, przy czym symbol $>^{\sim}$ oznacza tu nierówność rozmytą (oczywiście silniejszą w stosunku $y_{i}^{\sim}$, a słabszą w stosunku do $y_{i}^{-}$, na przykład wyrażoną funkcją przynależności $\mu_{i}\left(y_{i}\right)$. Funkcja ta określa stopień prawdziwości stwierdzenia, że decydent jest zadowolony ze stopnia osiągnięcia danych poziomów rezerwacji i aspiracji, oraz może mieć np. postać (zob. także Rys. 6.4a):

$$
\mu_{i}\left(y_{i}\right)=\left\{\begin{array}{l}
0, \text { jeśli } y_{i} \leq \tilde{y}_{i} ; \\
\left(y_{i}-y_{i}^{\sim}\right) /\left(y_{i}^{-}-\tilde{y_{i}}\right), \text { jeśli } \tilde{y}_{i}<y_{i}<\overline{y_{i}} \\
1, \text { jeśli } y_{i} \geq \overline{y_{i}^{-}}
\end{array}\right.
$$

b) Rezultat $y_{i}$ jest minimalizowany, co oznacza, że $y_{i}^{-}<\tilde{y}_{i}$ oraz pożądane jest spełnienie nierówności rozmytej $y_{i}=f_{i}(\boldsymbol{x})<\sim \tilde{y}_{i}^{-}, \tilde{y}_{i}^{\sim}$ (interpretowanej także jako silniejsza $\mathrm{w}$ stosunku do $\tilde{y}_{i}$, a słabsza w stosunku do $y_{i}^{-}$; zamiana miejsc poziomu rezerwacji i aspiracji nie zmienia ich roli, gdyż poziom rezerwacji powinien być oczywiście osiągnięty zanim osiągniemy poziom aspiracji). Odpowiednia funkcja przynależności,

12 Jak w większości tekstu tej książki, nie rozróżniamy tu formalnie pomiędzy rezultatami $y_{i}$ i wybranymi wśród nich wskaźnikami jakości - atrybutami, kryteriami - $q_{i}$. 
interpretowana jako stopień prawdziwości stwierdzenia, że decydent jest zadowolony $\mathrm{z}$ osiągnięcia danych poziomów odniesienia, może mieć postać (zob. także Rys. 6.4b):

$$
\mu_{i}\left(y_{i}\right)=\left\{\begin{array}{l}
1, \text { jeśli } y_{i} \leq \tilde{y_{i}^{-}} ; \\
\left(\tilde{y_{i}}-y_{i}\right) /\left(\tilde{y}_{i}^{\tilde{i}}-y_{i}^{-}\right), \text {jeśli } y_{i}^{-}<y_{i}<\tilde{y_{i}} \\
0, \text { jeśli } y_{i} \geq \tilde{y_{i}}
\end{array}\right.
$$

(a)

(b)

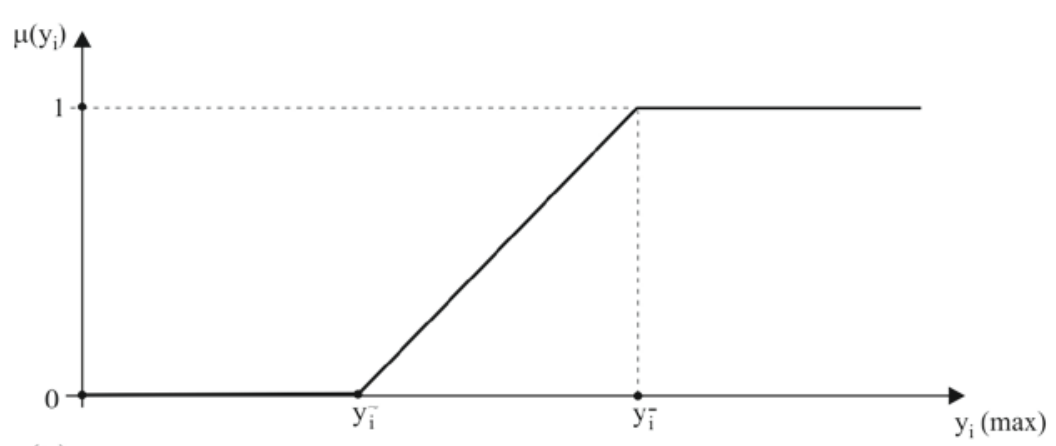

(c)
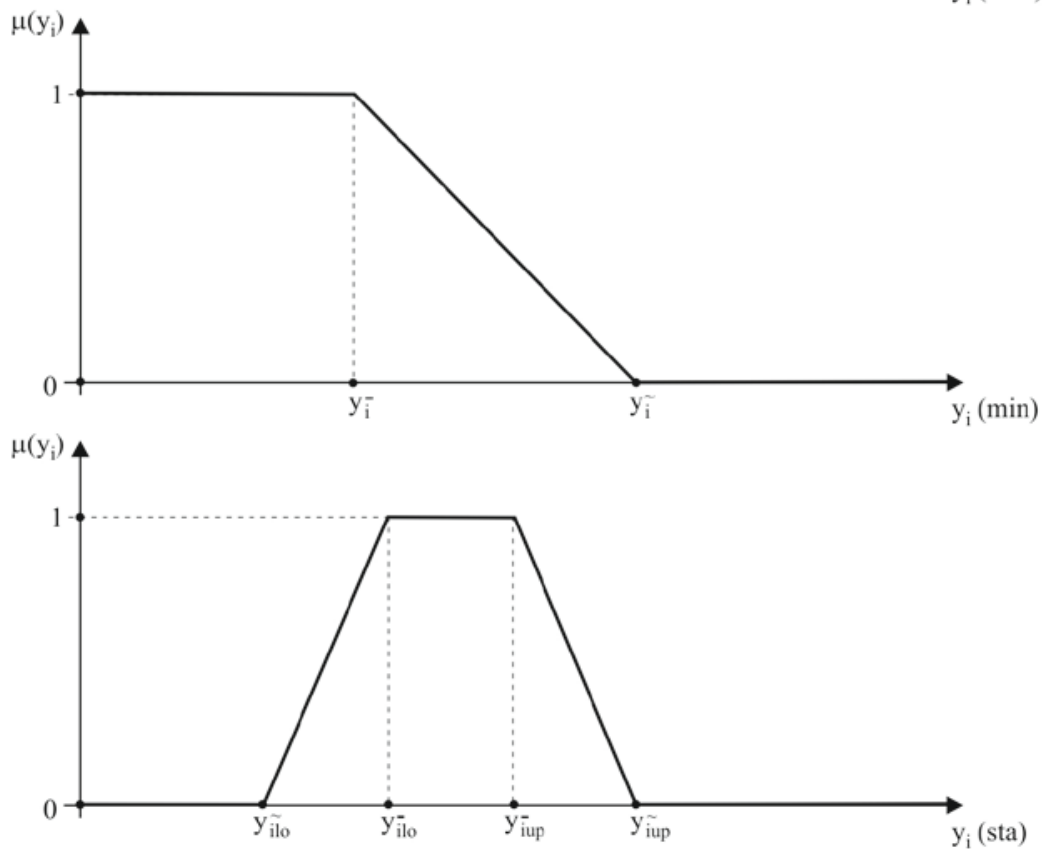

Rys. 6.4: Funkcje przynależności, określające stopień prawdziwości stwierdzenia, że decydent jest zadowolony z osiągnięcia poziomów odniesienia, w przypadkach: a) maksymalizacji, b) minimalizacji, c) stabilizacji danego wskaźnika (kryterium, atrybutu) $y_{i}$. 
c) Rezultat $y_{i}$ jest stabilizowany, czyli utrzymywany blisko danego, stałego poziomu. Trzeba wtedy jednak określić dwie pary - górną i dolną poziomów aspiracji i rezerwacji, np. przyjmując $y_{i, l o}^{\sim} \leq y_{i, l o}{ }_{i, y_{i, u p}} \leq y_{i, u p}^{\sim_{i}}-$ gdyż stabilizacja jest równoważna maksymalizacji w zakresie mniejszych wartości $y_{i}$ oraz minimalizacji dla większych wartości $y_{i}$. Za wartość graniczną można traktować albo średnią arytmetyczną dolnego i górnego poziomu aspiracji, $y_{i}^{-}=0,5\left(y_{i, l o}^{-}+y_{i, u p}^{-}\right)$, albo też - zgodnie z filozofią zbiorów rozmytych - dowolny punkt z przedziału $\left[y_{i, l o}^{-}, y_{i, u p}^{-}\right]$. Pożądane jest zatem spełnienie równości rozmytej $y_{i}=f_{i}(\boldsymbol{x}) \approx y_{i}^{-}$. Odpowiednia funkcja przynależności, określającą stopień prawdziwości stwierdzenia, że decydent jest zadowolony z przybliżonego spełnienia tej równości, może mieć postać (zob. Rys. 6.4c):

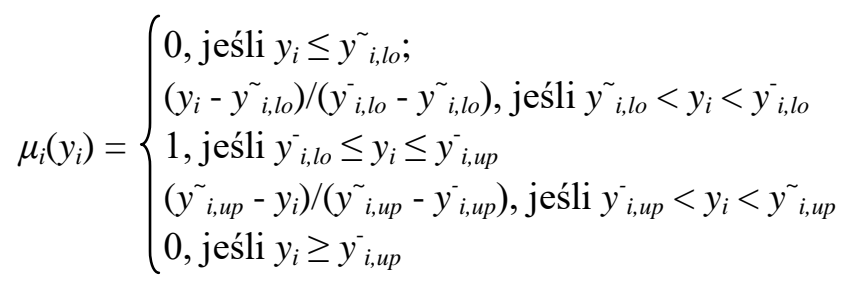

Zaletą powyższego sposobu definicji funkcji przynależności jest fakt, że takie poziomy odniesienia i funkcje przynależności mogą być określane jako część graficznego interfejsu użytkownika systemu wspomagania decyzji. W celu przedstawienia funkcji takiego interfejsu, wyobraźmy sobie po prostu Rys. 6.4 przeniesiony na ekran komputera, z możliwością "przeciągania" za pomocą myszy punktów określających poszczególne poziomy odniesienia i automatycznym dostosowaniem się kształtu funkcji przynależności.

Łączna funkcja przynależności, określająca stopień prawdziwości stwierdzenia o zadowoleniu użytkownika $z$ danej decyzji $\boldsymbol{x}$, powodującej rezultaty $y=f(x)$, powstaje przez połączenie funkcji składowych poprzez logiczną relację rozmytą $\cap$ :

$$
\mu(\boldsymbol{f}(\boldsymbol{x}))=\bigcap_{1 \leq i \leq m} \mu_{i}\left(f_{i}(\boldsymbol{x})\right)=\min _{1 \leq i \leq m} \mu_{i}\left(f_{i}(\boldsymbol{x})\right)
$$

Funkcję tę możemy maksymalizować względem $\boldsymbol{x} \in \boldsymbol{X}_{0}$, co nazwaliśmy właśnie rozmytym programowaniem wielokryterialnym. Ma to jednak pewne wady rozwiązania takiego zadania są niejednoznaczne, jeśli $\mu(\boldsymbol{f}(\boldsymbol{x}))=0$ lub $\mu(\boldsymbol{f}(\boldsymbol{x}))=1$; 
funkcja, podlegająca maksymalizacji, nie powinna mieć obszarów, na których jest stała. Sposobem uniknięcia tych wad jest zastąpienie słabo monotonicznej funkcji przynależności (6.10) przez ściśle monotoniczną funkcję osiągnięcia analogiczną do (6.4), co jest dyskutowane bardziej szczegółowo w następnej części książki.

\section{Literatura}

Allais M. (1953) Le comportement de l'homme rational devant de risque: Critique des postulates et axioms de l'ecole americaine, Econometrica 21:503-546

Charnes A., Cooper W.W. (1977) Goal programming and multiple objective optimization, Journal of Operations Research Society 1: 39-54

Fishburn P.C. (1988) Nonlinear Preference and Utility Theory, Wheatsheaf Books

Goodwin P., Wright G. (2004) Decision Analysis for Management Judgment (3rd ed.). Chichester: Wiley

Hansson S.O. (2005) Decision Theory: A Brief Introduction. Stockholm: Royal Institute of Technology (KTH)

Kacprzyk J.(1988) Teoria zbiorów rozmytych, PWN, Warszawa

Kahneman D., Tversky A. (1982) The psychology of preferences, Scientific American 246:160-173

Keeney R.L., Raiffa H. (1975) Decisions with Multiple Objectives: Preferences and Value Trade-Offs, Wiley, New York

Łukasiewicz J. (1911) O wartościach logicznych. Ruch Filozoficzny I:50-59

Machina M.J. (1991) Dynamic consistency and non-expected utility. In M. Bacharach and S. Hurley, (eds): Foundations of Decision Theory, Blackwell

Simon H. (1957) Models of Man, Wiley, New York

Pawlak Z. (1991) Rough Sets. Some Aspects of Reasoning about Knowledge, Kluwer Academic Publishers, Dordrecht

Raiffa H. (1997) Decision Analysis: Introductory Lectures on Choices Under Uncertainty. McGraw Hill

Rios S. (1994) Decision Theory and Decision Analysis: Trends and Challenges, Kluwer Academic Publishers, Dordrecht

Wierzbicki A.P. (1982) A mathematical basis for satisficing decision making, Mathematical Modeling 3: 392-405

Zadeh L. (1978) Fuzzy sets as a basis for a theory of possibility, Fuzzy Sets and Systems 1: 3-28 


\section{Optymalizacja wektorowa a wspomaganie decyzji}





\section{Podstawowe pojęcia i warunki optymalizacji wektorowej}

\subsection{Wprowadzenie i oznaczenia podstawowe}

W tej części książki omówimy wykorzystanie optymalizacji wektorowej czy inaczej analizy wielokryterialnej rzeczowych modeli sytuacji decyzyjnej dla wspomagania decyzji. Zakładamy przy tym dobre przygotowanie Czytelnika w zakresie podstaw optymalizacji skalarnej czyli jednokryterialnej, a więc nie będziemy tu powtarzać informacji o algorytmach rozwiązywania poszczególnych typów zadań optymalizacji, tylko powoływać się na możliwości takich algorytmów. Czytelników pragnących pogłębić wiedzę w zakresie optymalizacji skalarnej odsyłamy do specjalistycznych monografii czy podręczników - np. książki (Stachurski et al. 1990).

Na wstępie trzeba przypomnieć, dlaczego koncentrujemy się właśnie na optymalizacji wektorowej; skoro w teorii decyzji potrafimy scharakteryzować decydenta poprzez jego funkcję użyteczności czy wartości, to może lepiej byłoby najpierw zidentyfikować tę funkcję, a następnie przeprowadzić jej optymalizację skalarną? Rozumowanie takie, choć przyjmowane przez wielu specjalistów w zakresie metod optymalizacji, kryje jednak w sobie poważne uproszczenie.

Wspomnieliśmy już w poprzednich rozdziałach, że w początkowych etapach procesu decyzyjnego trzeba koncentrować uwagę nie tyle na modelu preferencji decydenta, co na budowie i analizie modelu rzeczowego sytuacji decyzyjnej, reprezentującego wiedzę istotną dla analizy i oceny tej sytuacji. Model preferencyjny - wyrażony np. przez funkcję użyteczności czy funkcję wartości decydenta - może się zmieniać w trakcie procesu decyzyjnego. Na początku tego procesu potrzebne nam jest wprawdzie ogólne określenie wymagań, stawianych przez decydenta - ale sensowne jest zakładanie w początkowych etapach tego procesu możliwie najogólniejszego 
i najprostszego modelu jego preferencji. Matematycznie oznacza to, że w początkowych etapach procesu decyzyjnego nie dążymy do określenia preferencji $\mathrm{w}$ formie porządku słabego, ale tylko $\mathrm{w}$ formie porządku częściowego - zwykle porządku Pareto z możliwymi jego uogólnieniami i możliwością jego pełnej modyfikacji przez decydenta.

Powyższe przesłanki metodologiczne można też uzasadnić w inny sposób, w oparciu o praktykę wykorzystania modeli matematycznych dla wspomagania pracy ekspertów. Jeśli specjalista w zakresie np. badań operacyjnych i optymalizacji uda się do eksperta w określonej dziedzinie np. organizacji przewozu przesyłek - i powie mu, że dysponuje modelem optymalizacyjnym, który pozwoli na zmniejszenie kosztów przewozu np. o $10 \%$, to najbardziej prawdopodobną reakcją eksperta będzie odmowa współpracy. Ekspert sądzi bowiem, że tak poważne możliwości zmniejszenia kosztów przewozu wynikają tylko z uproszczeń stosowanego modelu - np. niepełnego uwzględnienia wymagań terminowości przewozu; a jednocześnie obawia się podświadomie, że zastosowanie modelu optymalizacyjnego oznacza próbę automatyzacji jego osobistej wiedzy i intuicji, którą osiągnął po wielu latach pracy. Właściwym podejściem specjalisty $\mathrm{w}$ dziedzinie optymalizacji jest więc raczej propozycja współpracy nad wykorzystaniem modeli i algorytmów harmonogramowania przewozu przesyłek, które mogą pracować przy różnych założeniach - różnych poziomach wymagań co do terminowości bądź wręcz minimalizacji opóźnień przesyłek, oczywiście przy ograniczeniach na koszty, bądź też z jednoczesną - w sensie wielokryterialnym - minimalizacją tych kosztów. Taka propozycja nie przesądza postaci funkcji użyteczności eksperta-decydenta, nie budzi jego podświadomego oporu przed określeniem bądź wyjawieniem takiej funkcji, a więc ma znacznie większe szanse akceptacji.

Innymi słowy, każde praktyczne zadanie optymalizacji jest ze swej natury wielokryterialne, z wektorową funkcją celu złożoną z kilku kryteriów. W powyższym przykładzie są to kryteria takie jak koszty i wskaźniki terminowości; w innych przykładach można rozpatrywać oddzielnie koszty rozmaitego rodzaju (np. koszty bieżące i koszty inwestycji), w projektowaniu inżynierskim - wskaźniki niezawodności, sprawności, rozmiarów i kosztów projektowanego urządzenia, itd. Oczywiście, możemy zamieniać te rozmaite wskaźniki na ograniczenia, żądając np. aby wskaźniki niezawodności i sprawności były niemniejsze od pożądanych wartości. Takie jednak podejście, choć powszechnie stosowane, kryje w sobie kilka niebezpieczeństw: 
1) Ograniczenie na dany wskaźnik traktowane jest w optymalizacji jako twarde, tj. algorytm optymalizacji będzie się starał je spełnić za wszelką cenę, a jeśli się to nie uda, to będzie traktował uzyskane rozwiązania jako niedopuszczalne. Tymczasem cały sens optymalizacji wektorowej lub wielokryterialnej polega na sprawdzaniu, czy przypadkiem pogorszenie jednego z kryteriów o nieznaczną wartość mogłoby pozwolić na poważną poprawę innego kryterium. Często zdarza się, że dokładne spełnienie ograniczenia twardego na dodatkowe kryterium jest bardzo kosztowne $\mathrm{w}$ sensie kryterium podstawowego, pozostawionego do optymalizacji. Trzeba więc znaleźć sposób, aby ograniczenia na dodatkowe wskaźniki optymalizacji traktować jako miękkie, co można uzyskać albo stosując specjalnie dobrane metody funkcji kary, albo konsekwentnie wielokryterialną analizę problemu.

2) Jeśli się już wprowadza ograniczenia na dodatkowe wskaźniki, to trzeba pamiętać, że powinny być one przedmiotem parametrycznej analizy problem optymalizacji powinien być rozwiązany wielokrotnie, dla różnych wartości tych ograniczeń. W praktyce, zwłaszcza jeśli spełnienie tych dodatkowych ograniczeń jest trudne i wymaga sporego nakładu obliczeń przy optymalizacji, często się o tym zapomina.

3) W pewnych szczególnych przypadkach, omawianych dokładniej $\mathrm{w}$ następnym rozdziale i związanych $\mathrm{z}$ występowaniem rozwiązań słabo wektorowo optymalnych, wprowadzanie ograniczeń zastępczych na kryteria może prowadzić do nienajlepszych praktycznie rozwiązań.

$\mathrm{Z}$ powyższych - a także innych, omawianych w dalszych punktach powodów należy bardzo ostrożnie podchodzić do wszelkich prób zbyt szybkiego przekształcania problemu optymalizacji wektorowej, wielokryterialnej $\mathrm{w}$ problem optymalizacji skalarnej. Takie przekształcenie zawsze w końcu następuje w celach obliczeniowych - gdyż definicja optymalności wektorowej, którą przedstawimy dalej, jest wprawdzie bardzo ważna poznawczo ale niekonstruktywna obliczeniowo i może być obliczeniowo wykorzystana tylko jako sparametryzowany ciąg optymalizacji skalarnych. Chodzi tu jednak o taki wybór zastępczych zadań optymalizacji skalarnej, który jest najkorzystniejszy - i to też wielokryterialnie: nie tylko z punktu widzenia koncepcyjnej prostoty, ale także z punktu widzenia wspomnianego wyżej rozróżnienia pomiędzy ograniczeniami 
twardymi a miękkimi, z punktu widzenia wygody użytkownika systemu wielokryterialnej analizy modeli i wspomagania decyzji, i wielu innych aspektów dyskutowanych w dalszych punktach.

Będziemy więc stosować analizę wielokryterialną, opartą na optymalizacji wektorowej, do modeli rzeczowych sytuacji decyzyjnych. Przypomnijmy, że przy opisie modeli rzeczowych sytuacji decyzyjnych stosowaliśmy następujące oznaczenia podstawowe:

- $\boldsymbol{x} \in \boldsymbol{X}_{0}$ oznacza decyzję, należącą do zbioru decyzji dopuszczalnych. Decyzja taka może być rozmaitej natury. Często zakładamy, że $\boldsymbol{X}_{0} \subseteq \boldsymbol{R}^{n}$, przy czym postać zbioru decyzji dopuszczalnych $\boldsymbol{X}_{0}$ może być określona poprzez szereg ograniczeń tak jak w optymalizacji skalarnej, np. o postaci $g_{i}(x) \leq 0$ lub $h_{i}(x)=0$ (nierównościowych lub równościowych):

$$
\boldsymbol{X}_{0}=\left\{\boldsymbol{x} \in \boldsymbol{R}^{n}: g_{i}(\boldsymbol{x}) \leq 0, \forall i=1, \ldots, m_{1}, h_{i}(\boldsymbol{x})=0, \forall i=1, \ldots, m_{2}\right\}
$$

Jednak decyzje mogą należeć też do ogólniejszych przestrzeni (np. decyzja może być funkcją czasu lub rozkładem prawdopodobieństwa) lub też mieć znacznie prostszą postać (np. decyzją może być wybór jednej z kilku opcji). Dla uproszczenia wnioskowań matematycznych będziemy zakładać, że zbiór $\boldsymbol{X}_{0}$ jest zwarty (domknięty i ograniczony, jeśli $\boldsymbol{X}_{0 \subseteq} \subseteq \boldsymbol{R}^{n}$ ).

- $\boldsymbol{y} \in \boldsymbol{Y}_{0 \subseteq} \boldsymbol{Y}$ oznacza skutek czyli rezultat decyzji $\boldsymbol{x}$, należący do zbioru rezultatów osiągalnych $\boldsymbol{Y}_{0}$ (dla danego modelu); $\boldsymbol{Y}$ oznacza przestrzeń rezultatów. Zazwyczaj zakładamy skończenie-wymiarową przestrzeń rezultatów, $\boldsymbol{Y}_{0} \subseteq \boldsymbol{R}^{m}$.

- $\boldsymbol{y}=\boldsymbol{f}(\boldsymbol{x}), \boldsymbol{f}: \boldsymbol{X}_{0} \rightarrow \boldsymbol{Y}$ oznacza w skrócie model rzeczowy sytuacji decyzyjnej, przekształcający decyzje $\mathrm{w}$ ich rezultaty (przewidywane za pomocą modelu). Jeśli przy tym rezultaty są określane $z$ niepewnością, to odwzorowanie $\boldsymbol{f}$ zawiera w sobie też reprezentację tej niepewności, np. operacje wartości oczekiwanej czy agregacji funkcji przynależności itp. Nawet jeśli $\boldsymbol{X}=\boldsymbol{R}^{n}, \boldsymbol{Y}=\boldsymbol{R}^{m}$, i niepewność została już zagregowana, to odwzorowanie $\boldsymbol{f}$ Z pozoru stosunkowo prosta funkcja wektorowa zmiennej wektorowej często dane jest w postaci niejawnej, np. w formie złożonego modelu 
z wieloma zmiennymi pomocniczymi itp. Sposoby formułowania takich modeli złożonych i ich wielokryterialnej analizy omówimy później.

Tu trzeba tylko jeszcze podkreślić, że wśród składowych wektora zmiennych wyjściowych $y$ modelu użytkownik może wybrać podwektor kryteriów czy wskaźników jakości (czy atrybutów) danej decyzji:

$$
\begin{aligned}
& \boldsymbol{q}=\left(q_{1}, \ldots q_{i}, \ldots q_{k}\right)^{\mathrm{T}}, q_{i}=y_{j}, k \leq m, \\
& \boldsymbol{q}=\boldsymbol{F}(\boldsymbol{x}) ; \boldsymbol{Q}_{0}=\boldsymbol{F}\left(\boldsymbol{X}_{0}\right)
\end{aligned}
$$

gdzie oznaczenie $(\ldots)^{\mathrm{T}}$ podkreśla, że wektory będziemy zwykle traktować jako kolumnowe, zaś $\boldsymbol{Q}_{\mathbf{0}}$ jest zbiorem osiągalnych wskaźników jakości czy atrybutów. Rozróżnienie powyższe jest bardziej istotne w praktyce budowy systemów wspomagania decyzji niż w teorii - gdyż teoretycznie moglibyśmy analizować tylko te rezultaty decyzji, które są jednocześnie wskaźnikami jakości. Nie będziemy zatem na razie wykorzystywać tego rozróżnienia, prowadząc dalsze rozważania raczej $\mathrm{w}$ terminach wektorów $\boldsymbol{y}$. Należy też podkreślić, że zbiór osiągalnych rezultatów $\boldsymbol{Y}_{0}$ (czy osiągalnych wskaźników jakości $\boldsymbol{Q}_{0}$ ) dany jest zwykle w postaci niejawnej - poprzez zbiór decyzji dopuszczalnych $\boldsymbol{X}_{0}$ oraz odwzorowanie modelu $\boldsymbol{f}, \boldsymbol{Y}_{0}=\boldsymbol{f}\left(\boldsymbol{X}_{0}\right)$. Jeśli na rezultaty nałożone są dodatkowe ograniczenia jawne, np. w postaci:

$$
y_{i, l_{o}} \leq y_{i} \leq y_{i, u p}, i=1, \ldots m \leftrightarrow \boldsymbol{y}_{l o} \leq \boldsymbol{y} \leq \boldsymbol{y}_{\text {up }}
$$

to można je oczywiście traktować jako część definicji decyzji dopuszczalnych, czyli zmodyfikować zbiór $\boldsymbol{X}_{0}$ do postaci:

$$
\boldsymbol{X}_{0}=\boldsymbol{X}_{0} \cap\left\{\boldsymbol{x} \in \boldsymbol{R}^{n}: \boldsymbol{y}_{l o} \leq \boldsymbol{f}(\boldsymbol{x}) \leq \boldsymbol{y}_{\text {up }}\right\} ; \boldsymbol{Y}_{0}=\boldsymbol{f}\left(\boldsymbol{X}_{0}\right)=\boldsymbol{Y}_{0} \cap\left\{\boldsymbol{y} \in \boldsymbol{R}^{m}: \boldsymbol{y}_{l o} \leq \boldsymbol{y} \leq \boldsymbol{y}_{\text {up }}\right\}
$$

Zbiór $\boldsymbol{Y}_{0}$ czy $\boldsymbol{Y}_{0}$ odgrywa podstawową rolę $\mathrm{w}$ analizie wielokryterialnej modeli matematycznych. W rozważaniach teoretycznych często będziemy zakładać, że $\boldsymbol{Y}_{0}$ jest danym zbiorem zwartym (domkniętym i ograniczonym), co odpowiada założeniu zwartości $\boldsymbol{X}_{0}$ i ciągłości $\boldsymbol{f}$. W praktyce natomiast często chodzi właśnie o rozpoznanie kształtu i szczegółowych własności tego zbioru, danego zazwyczaj w formie niejawnej. 


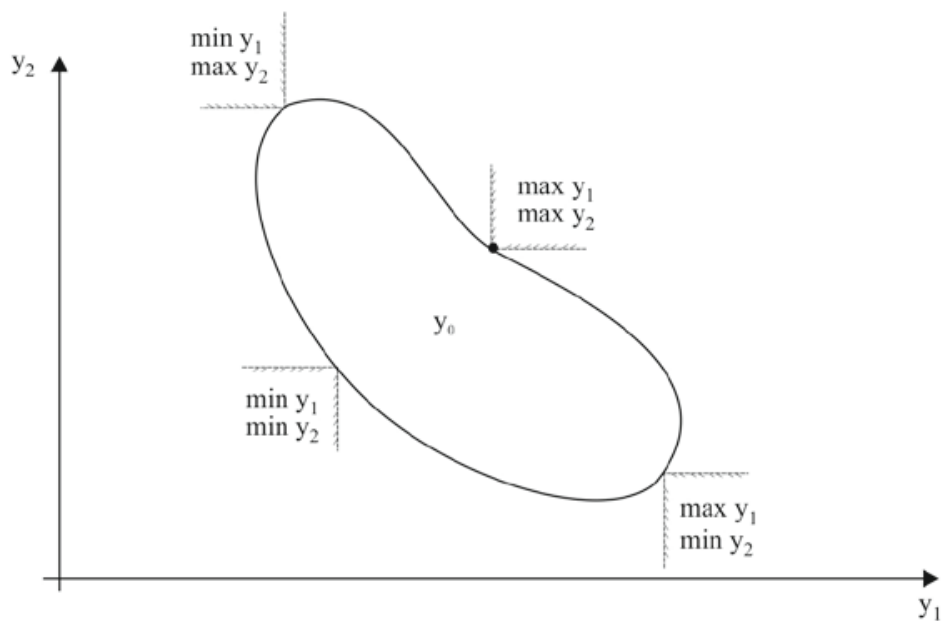

Rys. 7.1. Badanie granic zbioru $\boldsymbol{Y}_{0}$ poprzez optymalizację wektorową.

Zilustrujmy to na przykładzie jak na Rys. 7.1. Załóżmy, że zbiór $\boldsymbol{X}_{0}$ jest stosunkowo prostej postaci, ale nieliniowa funkcja $\boldsymbol{f}$ powoduje przekształcenie go w bardziej skomplikowany zbiór $\boldsymbol{Y}_{0 \subseteq \boldsymbol{R}^{2}}$ jak w przypadku ilustrowanym na rysunku. Choć na rysunku przedstawiliśmy kształt tego ostatniego zbioru, to w rzeczywistości możemy tylko najpierw założyć wartość dopuszczalnej decyzji $\boldsymbol{x} \in \boldsymbol{X}_{0}$, a następnie obliczyć odpowiadającą jej wartość $\boldsymbol{y}=\boldsymbol{f}(\boldsymbol{x}) \in \boldsymbol{Y}_{0}$. Chcąc poznać cały kształt $\boldsymbol{Y}_{0}$, musielibyśmy obliczyć bardzo wiele takich punktów. Przy obliczeniach takich ważne jest rozpoznanie granic zbioru $\boldsymbol{Y}_{0}$. Zauważmy jednak, że granice te możemy wyznaczać poprzez wspólną maksymalizację i minimalizację współrzędnych $y_{1}$ i $y_{2}$ wektorów $\boldsymbol{y} \in \boldsymbol{Y}_{0}$ : dla granicy "północno-wschodniej" tego zbioru powinniśmy maksymalizować jednocześnie $y_{1}$ i $y_{2}$; dla granicy "południowo-wschodniej" - maksymalizować $y_{1}$ i minimalizować $y_{2}$; dla granicy "południowo-zachodniej" - minimalizować zarówno $y_{1}$ jak i $y_{2}$; dla granicy "północno-zachodniej" - minimalizować $y_{1}$ ale maksymalizować $y_{2}$. Dokładniejszy sens takiej optymalizacji wektorowej, odpowiadającej badaniu części granic zbioru $\boldsymbol{Y}_{0}$ - właśnie dla przypadku, gdy zbiór ten jest określony w złożony, uwikłany sposób - omówimy w punkcie następnym.

W dalszym ciągu tej książki będziemy często rysować granice zbiorów $\boldsymbol{Y}_{0}$ tak, jak gdyby były one dane. Pamiętajmy jednak zawsze, że jest to tylko uproszczenie teoretyczne, i że wyznaczenie tych granic oznacza w praktyce złożone obliczenia typu optymalizacji wektorowej. 


\subsection{Porządek Pareto, stożki dodatnie i uogólnione nierówności}

Wstępny model preferencji użytkownika podawany jest zwykle (jak we wspomnianym uprzednio rozmytym programowaniu wielokryterialnym) przez określenie, które rezultaty należy maksymalizować, które minimalizować, które zaś np. stabilizować. Określa to $\mathrm{w}$ przestrzeni rezultatów pewien porządek częściowy, w swej istocie podobny do porządku Pareto. Pokażemy najpierw, że porządek Pareto można wyrazić za pomocą tzw. stożka dodatniego $\boldsymbol{D}^{=} \boldsymbol{R}^{m}{ }_{+}$.

Stożkiem nazywamy taki zbiór $\boldsymbol{D} \subset \boldsymbol{R}^{m}$, że jeśli $\boldsymbol{y} \in \boldsymbol{D}$, to $\alpha \boldsymbol{y} \in \boldsymbol{D}, \forall \alpha \geq 0$. Jest to tzw. stożek ostry; jeśli w definicji tego stożka zmienimy kwantyfikator na $\forall \alpha>0$, będzie to tzw. stożek tępy. Z definicji stożka wynika, że można go określać nie tylko jako podzbiór $\boldsymbol{R}^{m}$, lecz także w dowolnej przestrzeni liniowej. $Z$ definicji stożka wynika też, że stożek ma zawsze wierzchołek w zerze, początku układu współrzędnych (przy czym ten wierzchołek należy do niego, jeśli stożek jest ostry); będziemy jednak stosować także stożki przesunięte o postaci $\boldsymbol{y}^{-}+\boldsymbol{D}$, czyli składające się z wektorów $\boldsymbol{y}^{-}+\boldsymbol{y}, \boldsymbol{y} \in \boldsymbol{D}$, o wierzchołku w $\boldsymbol{y}^{-}$.

Stożkiem dodatnim nazywamy wybrany stożek wypukły i domknięty $\boldsymbol{D} \subset \boldsymbol{R}^{m}$, $\boldsymbol{D} \neq \boldsymbol{R}^{m}$, generujący porządek częściowy w $\boldsymbol{Y}=\boldsymbol{R}^{m}$ w sposób analogiczny do poniższej definicji.

Definicja 7.1. Porządek Pareto wyrażony przez stożek dodatni. Jeśli $\boldsymbol{D}=\boldsymbol{R}^{m}{ }_{+}=\left\{\boldsymbol{y} \in \boldsymbol{R}^{m}: \boldsymbol{y}_{i} \geq 0, \forall i=1, \ldots m\right\}$, to możemy za pomocą tego stożka zdefiniować następujące relacje preferencji i nierówności odpowiadające porządkowi Pareto:

(1) preferencja i nierówność słaba:

$y^{\prime} P^{\geq} y^{\prime \prime} \leftrightarrow y^{\prime} \geq y^{\prime \prime} \leftrightarrow\left(y^{\prime}-y^{\prime \prime}\right) € D \leftrightarrow y^{\prime} \in\left\{y^{\prime \prime}+D\right\}$

(2) preferencja i nierówność ścisła:

$y^{\prime} \mathbf{P} y^{\prime \prime} \leftrightarrow y^{\prime} \geq y^{\prime \prime}, y^{\prime} \neq y^{\prime \prime} \leftrightarrow\left(y^{\prime}-y^{\prime \prime}\right) \in D^{\neq}=D \backslash\{0\} \leftrightarrow y^{\prime} \in\left\{y^{\prime \prime}+D^{\neq}\right\}$

(3) preferencja wzmocniona, nierówność silna:

$$
y^{\prime} P^{+} y^{\prime \prime} \leftrightarrow y^{\prime}>y^{\prime \prime} \leftrightarrow\left(y^{\prime}-y^{\prime \prime}\right) \in I n t D \leftrightarrow y^{\prime} \in\left\{y^{\prime \prime}+\text { Int } D\right\}
$$


gdzie Int $\boldsymbol{D}$ oznacza wnętrze stożka $\boldsymbol{D}$. Definicja powyższa jest, co łatwo sprawdzić, równoważna do definicji porządku Pareto (z rozszerzeniem niektórych jego aspektów) podanej w Rozdziale 4.

Zauważmy, że z punktów (1) i (2) powyższej definicji wynika $\boldsymbol{y}^{\prime} \boldsymbol{P}^{\bar{\prime}} \boldsymbol{y}^{\prime \prime} \leftrightarrow \boldsymbol{y}^{\prime}=\boldsymbol{y}^{\prime \prime}$. Oprócz nierówności słabej i ścisłej, odpowiadających relacjom $\boldsymbol{P}^{z}$ i $\boldsymbol{P}$ w porządku Pareto, możemy określić też nierówność silną i odpowiadającą jej preferencję wzmocnioną - co ma istotne konsekwencje w optymalizacji wektorowej. Definicja 7.1 została tak sformułowana, aby można ją było łatwo uogólnić:

Definicja 7.2. Porządek częściowy wyrażony przez stożek dodatni. Jeśli dany jest dowolny stożek dodatni (wypukły, domknięty, nie będący całą przestrzenią) $\boldsymbol{D} \subset \boldsymbol{Y}=\boldsymbol{R}^{m}$, to można za jego pomocą zdefiniować porządek częściowy określony przez relacje (1), (2), a także - jeśli stożek ten ma niepuste wnętrze - dodatkową relację preferencji wzmocnionej i nierówność silną (3).

Wybierając specyficzne postaci stożka $\boldsymbol{D}$, możemy też w ten sposób definiować uogólniony porządek Pareto - nie ograniczony tylko do maksymalizacji, lecz obejmujący także minimalizację lub stabilizację składowych $y_{i}$ wektora $y$. Minimalizacja jest oczywiście równoważna maksymalizacji odpowiedniej składowej $y_{i}$ po zmianie jej znaku. Stabilizację natomiast można by traktować jako nałożenie dodatkowego ograniczenia równościowego $y_{i}=y_{\mathrm{i}}^{-}$, ale interpretacja taka nie jest w pełni precyzyjna. Jeśli bowiem któreś $\mathrm{z}$ ograniczeń w definicji zbioru decyzji dopuszczalnych nie jest spełnione, to decyzja taka traktowana jest jako niedopuszczalna - jest to typowa interpretacja ograniczeń $\mathrm{w}$ optymalizacji skalarnej, i ograniczenia tak interpretowane nazywamy twardymi. Natomiast przy stabilizacji

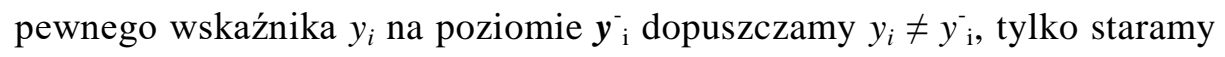
się maksymalizować ten wskaźnik, jeśli $y_{i}<y_{\mathrm{i}}^{-}$, oraz minimalizować go, jeśli $y_{i}>y_{\mathrm{i}}^{-}$; ograniczenia tak interpretowane nazywamy miękkimi. Optymalizacja wektorowa pozwala w pewnych jej ujęciach (zob. dalsze rozdziały) interpretować także ograniczenia nierównościowe jako miękkie.

Łącznie, uogólniony porządek Pareto można wyrazić jak w definicji 7.2 przy założeniu, że stosowany jest następujący stożek dodatni:

$$
\boldsymbol{D}=\left\{\boldsymbol{y} \in \boldsymbol{R}^{m}: y_{i} \geq 0, i=1, \ldots m_{1} ; y_{i} \leq 0, i=m_{1}+1, \ldots m_{2} ; y_{\mathrm{i}}=0, i=m_{2}+1, \ldots m\right\}
$$


przy czym, jak zawsze w definicji stożka, jego elementy trzeba traktować jako zmienne przyrostowe $\mathrm{w}$ stosunku do danego poziomu odniesienia $\left(y_{i}=0\right.$ należy interpretować jako $\Delta y_{i}=y_{i}-y_{i}^{-}=0$ ). Jeśli $m_{2}<m$, to powyższy stożek $\boldsymbol{D}$ ma puste wnętrze i nierówność ścisła $\boldsymbol{y}^{\prime}>\boldsymbol{y}^{\prime \prime}$ nie zachodzi dla żadnych wektorów $\boldsymbol{y}^{\prime}, \boldsymbol{y}^{\prime \prime}$.

W teorii optymalizacji ważne też jest pojęcie stożka sprzężonego $D^{*}$ lub stożka polarnego - $\boldsymbol{D}^{*}$, zdefiniowane następująco:

$$
\begin{aligned}
& \boldsymbol{D}^{*}=\left\{\tilde{\boldsymbol{y}}^{\tilde{\epsilon}} \in \boldsymbol{R}^{m}:\left\langle\boldsymbol{y}^{\tilde{y}}, \boldsymbol{y}>\geq 0 \forall \boldsymbol{y} \in \boldsymbol{D}\right\}\right. \\
& -\boldsymbol{D}^{*}=\left\{\boldsymbol{y}^{\tilde{\epsilon}} \in \boldsymbol{R}^{m}:\left\langle\boldsymbol{y}^{\sim}, \boldsymbol{y}>\leq 0 \forall \boldsymbol{y} \in \boldsymbol{D}\right\}\right.
\end{aligned}
$$

gdzie $<.$, .> oznacza iloczyn skalarny. Jeśli np. $\boldsymbol{D}$ ma postać (7.8), to:

$$
\boldsymbol{D}^{*}=\left\{\tilde{\boldsymbol{y}^{\sim}} \in \boldsymbol{R}^{m}: \tilde{y}_{i} \geq 0, i=1, \ldots m_{1} ; \tilde{y}_{i} \leq 0, i=m_{1}+1, \ldots m_{2}\right\}
$$

\subsection{Optymalność wektorowa - w sensie Pareto i względem stożka dodatniego}

Przypuśćmy dla przykładu, że użytkownik (wielokryterialnego systemu analizy modeli matematycznych czy systemu wspomagania decyzji) dla danego modelu rzeczowego $\left(\boldsymbol{X}_{0}, \boldsymbol{f}\right)$ określił dwa kryteria czy atrybuty, mające podlegać maksymalizacji, czyli $\boldsymbol{Y}=\boldsymbol{R}^{2}, \boldsymbol{D}=\boldsymbol{R}^{2}{ }^{2}$. Jaka część zbioru rezultatów osiągalnych $\boldsymbol{Y}_{0}=\boldsymbol{f}\left(\boldsymbol{X}_{0}\right)$ będzie wtedy interesująca dla użytkownika?

Można oczywiście odpowiedzieć, że interesuje go cały zbiór $\boldsymbol{Y}_{0}$; ale elementów tego zbioru może być bardzo wiele; zatem trzeba wyeliminować te, które są zdominowane w sensie określonego przez niego porządku częściowego Pareto. Interesujące więc dla niego są elementy niezdominowane w tym porządku, czyli tak zwane rezultaty Pareto-optymalne - których może być wprawdzie też dużo, ale nie można już ich dalej ograniczyć bez dodatkowej informacji o preferencjach użytkownika.

Definicja 7.3. Zbiory rezultatów i decyzji Pareto-optymalnych definiuje się zakładając $\boldsymbol{D}=\boldsymbol{R}^{m}{ }_{+}, \boldsymbol{D}^{\neq}=\boldsymbol{D} \backslash\{0\}$ w następujący sposób:

$$
\begin{aligned}
& \boldsymbol{Y}_{0}^{*}=\left\{\boldsymbol{y}^{*} \in \boldsymbol{Y}_{0}: \boldsymbol{Y}_{0} \cap\left\{\boldsymbol{y}^{*}+\boldsymbol{D}^{\neq}\right\}=\varnothing\right\} \\
& \boldsymbol{X}_{0}^{*}=\left\{\boldsymbol{x}^{*} \in \boldsymbol{X}_{0}: \boldsymbol{f}\left(\boldsymbol{X}_{0}\right) \cap\left\{\boldsymbol{f}\left(\boldsymbol{x}^{*}\right)+\boldsymbol{D}^{\neq}\right\}=\varnothing\right\}
\end{aligned}
$$


Zbiór rezultatów i decyzji Pareto-optymalnych to najprostszy przykład zbioru rezultatów i rozwiązań wektorowo optymalnych, które też definiuje się powyższym wzorem, tylko dla ogólniejszej postaci stożka $\boldsymbol{D}$ (zob. definicja 7.4). Inaczej można powiedzieć, że rezultaty i decyzje wektorowo-optymalne (Pareto-optymalne) to takie, w których nie można poprawić (zwiększyć) jednego ze wskaźników jakości bez pogarszania (zmniejszania) wskaźników pozostałych. Widzimy też, że pojęcie optymalności wektorowej dotyczy nie pojedynczego rozwiązania czy decyzji, ale całego ich zbioru. ${ }^{1}$ Stanowi to wadę tego pojęcia w sensie obliczeniowym, gdyż charakterystyka całego zbioru wymaga zwykle dużego nakładu obliczeń, ale zaletę w sensie wspomagania decyzji - gdyż nie musimy narzucać decydentowi jednego rozwiązania, może on wybierać pomiędzy różnymi rozwiązaniami Paretooptymalnymi.

W terminach przykładu z Rys. 7.1, powtórzonego dla nieco bardziej złożonej postaci niewypukłego zbioru $\boldsymbol{Y}_{0}$ wraz z ilustracją Definicji 7.3 na Rys. 7.2, zbiór $\boldsymbol{Y}_{0}^{*}$ to część „północno-wschodniej granicy” zbioru $\boldsymbol{Y}_{0}$, natomiast $\boldsymbol{X}_{0}$ to zbiór takich decyzji $\boldsymbol{x}^{*} \in \boldsymbol{X}_{0}$, które zapewniają osiągnięcie tej części (niekoniecznie należących do brzegu zbioru $\boldsymbol{X}_{0}$ ). Rysunek 7.2 podkreśla, że zbiór rezultatów Pareto-optymalnych może mieć złożoną strukturę - np. być niespójny, składać się z kilku zbiorów przedzielonych przerwami (punkt $\boldsymbol{y}^{\prime}$ na Rys. 7.2 nie jest rezultatem Pareto-optymalnym, gdyż w zbiorze $\boldsymbol{Y}_{0}$ można znaleźć rezultaty należące do $\left\{\boldsymbol{y}^{\prime}+\boldsymbol{D}^{\ddagger}\right\}$, czyli dominujące punkt $\left.\boldsymbol{y}^{\prime}\right)$.

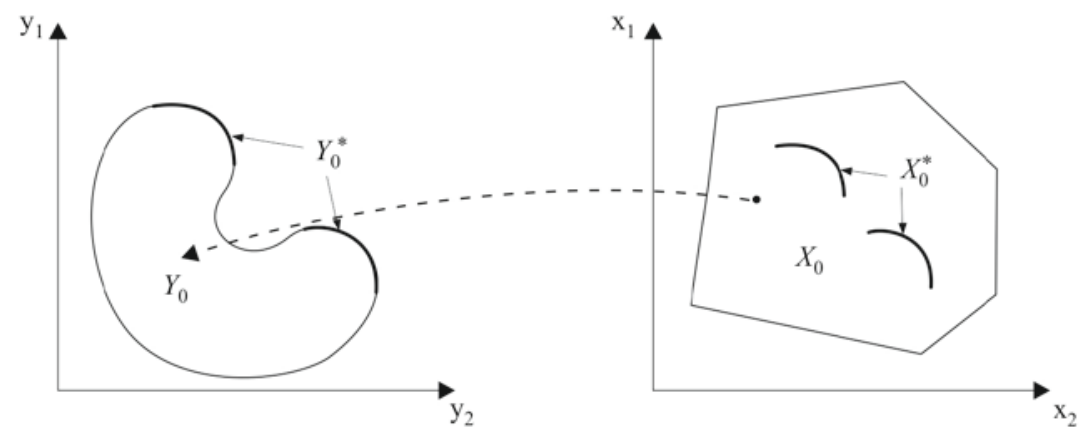

Rys. 7.2. Granica Pareto zbioru rezultatów oraz jej przeciwobraz w zbiorze decyzji.

\footnotetext{
${ }^{1}$ Tylko w bardzo szczególnych przypadkach może się zdarzyć, że zbiór rezultatów Pareto-optymalnych sprowadza się do jednego punktu, zwanego idealnym - zob. dalsze podrozdziały.
} 
Oprócz rezultatów i decyzji Pareto-optymalnych, definiuje się też zbiory rezultatów i decyzji słabo Pareto-optymalnych:

$$
\begin{aligned}
& \boldsymbol{Y}^{*{ }_{0}}=\left\{\boldsymbol{y}^{*} \in \boldsymbol{Y}_{0}: \boldsymbol{Y}_{0} \cap\left\{\boldsymbol{y}^{*}+\operatorname{Int} \boldsymbol{D}\right\}=\varnothing\right. \\
& \boldsymbol{X}^{*_{w}}{ }_{0}=\left\{\boldsymbol{x}^{*} \in \boldsymbol{X}_{0}: \boldsymbol{f}\left(\boldsymbol{X}_{0}\right) \cap\left\{\boldsymbol{f}\left(\boldsymbol{x}^{*}\right)+\operatorname{Int} \boldsymbol{D}\right\}=\varnothing\right.
\end{aligned}
$$

Indeks górny $w$ we wzorach $(7.14,7.15)$ odpowiada angielskiej nazwie weak. Zauważmy, że drugie części definicji rezultatów i decyzji Pareto-optymalnych - czy słabo Pareto-optymalnych - to po prostu powtórzenie części pierwszych $\mathrm{z}$ oczywistymi modyfikacjami; definicje te więc odnoszą się $\mathrm{w}$ istocie do przestrzeni rezultatów, choć mówią też o optymalności decyzji niezbędnych dla uzyskania takich rezultatów. Dlatego też mówimy zwykle o zbiorze $\boldsymbol{Y}_{0}^{*}$ lub $\boldsymbol{Y}^{*}{ }_{0}{ }_{0}$ jako o brzegu Pareto zbioru rezultatów osiągalnych, choć to tylko część brzegu zbioru $\boldsymbol{Y}_{0}$; łatwo sprawdzić, że do zbiorów $\boldsymbol{Y}_{0}^{*}$ i $\boldsymbol{Y}^{*}{ }_{0}$ nie mogą należeć punkty wewnętrzne $\boldsymbol{Y}_{0}$, natomiast zbiór $\boldsymbol{X}_{0}^{*}$ bynajmniej nie musi być częścią brzegu zbioru $\boldsymbol{X}_{0}$.

Inne, równoważne sformułowanie słabej wektorowej optymalności (słabej Pareto-optymalności) stwierdza, że rezultaty i decyzje słabo wektorowooptymalne (słabo Pareto-optymalne) to takie, że nie możemy poprawić (zwiększyć) jednocześnie wszystkich wskaźników jakości. Definicję rezultatów i decyzji słabo Pareto-optymalnych stosuje się dlatego, że znacznie łatwiej je analizować matematycznie (stożek Int $\boldsymbol{D}$ ma prostsze własności, niż stożek $\boldsymbol{D}^{\ddagger}$ ); niestety, rezultaty te mają znacznie mniejsze znaczenie praktyczne. Wynika to z faktu, że rezultaty słabo Pareto-optymalne obejmują też takie, w których można znacznie poprawić jeden ze wskaźników jakości utrzymując pozostałe wskaźniki na stałym poziomie; a w praktyce rozwiązania takie nas zazwyczaj nie interesują. ${ }^{2}$

Wzory (7.12-7.15) są sformułowane tak, aby można było łatwo uogólnić pojęcie optymalności Pareto do optymalności wektorowej.

2 Z wyjątkiem przypadków, kiedy preferencje mają wyraźnie hierarchiczny (leksykograficzny) charakter, jak w następującym przykładzie. Przypuśćmy, że dowiedzieliśmy się o ciekawej książce. Jeśli interesuje ona nas bez względu na cenę, to idziemy do najbliższej księgarni i ją kupujemy: to właśnie przykład rozwiązania słabo wektorowo optymalnego z dwoma kryteriami: jakość książki i jej cena. Rozwiązanie wektorowo optymalne w tym przykładzie polega na odwiedzeniu kilku księgarni i zakupie interesującej nas książki, ale po najniższej cenie. 
Definicja 7.4. Zbiory rezultatów i decyzji wektorowo optymalnych W sensie danego stożka dodatniego (wypukłego, domkniętego, różnego od całej przestrzeni) $\boldsymbol{D} \subseteq \boldsymbol{Y}=\boldsymbol{R}^{m}$ definiuje się tak jak we wzorach (7.12, 7.13), a słabo wektorowo optymalnych - jak we wzorach $(7.14,7.15)$.

W dalszym ciągu ograniczymy się jednak do stożków dodatnich nie o postaci dowolnej, ale stanowiących szczególne przypadki czy modyfikacje stożka (7.8) - czyli do optymalizacji Pareto uogólnionej o możliwości minimalizacji i stabilizacji poszczególnych wskaźników.

Rezultaty i decyzje wektorowo optymalne mają wiele nazw stosowanych $\mathrm{w}$ literaturze - wielokryterialnie optymalne, polioptymalne, skuteczne, sprawne (ang. efficient); możemy mówić też o brzegu sprawnym zbioru $\boldsymbol{Y}_{0}$. Nazwa rozwiązanie sprawne, choć wywodzi się $\mathrm{z}$ tradycji ekonomicznej, dobrze też koresponduje $\mathrm{z}$ intuicją konstruktora, który może definiować różne wskaźniki sprawności swojej konstrukcji i optymalizować je wektorowo; dlatego też będziemy się nią często posługiwać. Zauważmy, że rezultaty słabo sprawne są jeszcze mniej przydatne w zastosowaniach praktycznych, niż słabo Pareto-optymalne; np. jeśli Int $\boldsymbol{D}=\varnothing$, jak w przypadku stożka (7.8) dla $m_{2}<m$, to wszystkie rezultaty osiągalne są słabo sprawne.

Jednakże nawet rezultaty sprawne mogą mieć ograniczone znaczenie praktyczne, jeśli mają tę własność, że drogą nieznacznego pogorszenia jednego $\mathrm{z}$ atrybutów można uzyskać bardzo znaczną poprawę atrybutów innych. Związane jest to $\mathrm{z}$ pojęciem współczynników wymiany wśród rezultatów sprawnych. Można je definiować w rozmaity sposób. Definicja prostsza i bardziej intuicyjna zakłada, że brzeg sprawny zbioru $\boldsymbol{Y}_{0}$ ma pewne cechy gładkości (których nie będziemy tu dokładniej definiować) i w każdym punkcie $\boldsymbol{y}^{*} \in \boldsymbol{Y}^{*}{ }_{0}$ można określić granice:

$$
t_{i j}\left(y^{*}\right)=\lim _{y k \rightarrow y^{*}}\left(y_{i k}-y_{i}^{*}\right) /\left(y_{j}^{*}-y_{j k}\right), i \neq j, i, j=1, \ldots m
$$

gdzie ciąg $\left\{\boldsymbol{y}_{\mathrm{k}}\right\}, k=1, \ldots \infty$ jest dobrany tak, aby $y_{i k} \neq y_{i}{ }_{i}$ oraz $y_{j k} \neq y_{j}{ }_{j}$, ale $y_{l k}=y^{*}{ }_{l} \forall l \neq i, j, \forall k$. Granice (7.16) nazywamy lokalnymi wspótczynnikami wymiany pomiędzy atrybutami $i$ oraz $j$; mówią one, o ile można poprawić atrybut $i$, jeśli decydujemy się na pogorszenie o (odpowiednio małą) jednostkę atrybut $j$, nie zmieniając atrybutów pozostałych. Inna możliwa definicja (jest ich kilka) dotyczy globalnych współczynników wymiany, 
w których dopuszcza się zmiany większe i nie ograniczone poprzez utrzymanie wartości atrybutów pozostałych, a mianowicie:

$$
\begin{aligned}
& t_{i j}^{g}\left(\boldsymbol{y}^{*}\right)=\sup _{\boldsymbol{y \in Y}(i j)\left(y^{*}\right)}\left(y_{i}-y^{*}{ }_{i}\right) /\left(y^{*}{ }_{j}-y_{j}\right), \boldsymbol{y}^{*} \in \boldsymbol{Y}^{*}{ }_{0}, \text { gdzie } \\
& \boldsymbol{Y}_{0}^{(i j)}\left(\boldsymbol{y}^{*}\right)=\left\{\boldsymbol{y} \in \boldsymbol{Y}_{0}: y_{j}<y_{j}^{*}, y_{i}>y^{*}{ }_{i}, i \neq j\right\}
\end{aligned}
$$

Ponieważ we wzorze (7.17) określamy supremum tego samego ilorazu różnicowego co we wzorze (7.16), i to po większym zbiorze (definicja $\boldsymbol{Y}_{0}^{(i j)}\left(\boldsymbol{y}^{*}\right)$ nie narzuca żadnych warunków na $y_{l}$ dla $\left.l \neq i, j\right)$, przeto $t^{g}{ }_{i j}\left(y^{*}\right) \geq t_{i j}\left(y^{*}\right)$.

Pojęcie współczynników wymiany związane jest z dalszym ograniczeniem pojęcia rezultatów sprawnych:

\section{Definicja 7.5. Zbiory rezultatów i decyzji właściwie sprawnych} definiowane są ogólnie jako ta część zbiorów rezultatów i decyzji sprawnych, dla której ograniczone są odpowiednie współczynniki wymiany (Arthur Geoffrion, 1968).

Inną definicję rezultatów właściwie sprawnych, opartą o stożkową definicję sprawności, podał Henig (1982). Rozpatrzmy rodzinę $\boldsymbol{D}$ stożków $\boldsymbol{D}^{\prime}$ niejako nieco szerszych od $\boldsymbol{D}$, tj. $\boldsymbol{D}=\left\{\boldsymbol{D}^{\prime} \subset \boldsymbol{Y}\right.$ : $\left.\boldsymbol{D} \subset I n t \boldsymbol{D}^{\prime}\right\}$; dla każdego takiego stożka $\boldsymbol{D}^{\prime}$ można zdefiniować odpowiadający mu według (7.12) zbiór $\boldsymbol{Y}_{0}^{*}\left(\boldsymbol{D}^{\prime}\right)$. Zbiory rezultatów i decyzji właściwie sprawnych można wtedy zdefiniować następująco:

$$
\boldsymbol{Y}^{* p_{0}}=\cup_{D^{\prime}: \boldsymbol{D} \subset \operatorname{Int} \boldsymbol{D}^{\prime}} \boldsymbol{Y}^{*}{ }_{0}\left(\boldsymbol{D}^{\prime}\right)
$$

gdzie indeks górny $p$ odpowiada angielskiej nazwie proper. Przy odpowiednich założeniach dodatkowych można wykazać (zob. np. Yoshikazu Sawaragi et al. 1985), że są to definicje równoważne. Jednakże nawet definicja rezultatów sprawnych nie jest dostatecznie ograniczona dla potrzeb praktycznych, gdyż wyklucza tylko takie rezultaty sprawne, dla których współczynniki wymiany są nieskończone; natomiast w zastosowaniach oraz praktyce obliczeniowej bardziej istotne jest, aby współczynniki wymiany były mniejsze, niż konkretnie określone ich ograniczenie górne. Dlatego też wprowadzono jeszcze inną definicję:

Definicja 7.6. Zbiory rezultatów i decyzji właściwie sprawnych z ograniczonymi a priori współczynnikami wymiany definiowane są ogólnie jako ta część zbiorów rezultatów i decyzji właściwie sprawnych, dla której współczynniki wymiany są mniejsze od danej liczby $M$. 
Także powyższa definicja może być wyrażona w oparciu o stożkową definicję sprawności (zob. Wierzbicki, 1977, 1986). Należy w tym celu określić stożkowe $\varepsilon$-otoczenie stożka $D$ :

$$
\boldsymbol{D}_{\varepsilon}=\left\{\boldsymbol{y} \in \boldsymbol{R}^{m}: \operatorname{dist}(\boldsymbol{y}, \boldsymbol{D}) \leq \varepsilon\|\boldsymbol{y}\|\right\}
$$

gdzie $\varepsilon>0$ jest daną (małą) liczbą, $\operatorname{dist}(\boldsymbol{y}, \boldsymbol{D})$ oznacza odległość wektora $\boldsymbol{y}$ od stożka $\boldsymbol{D},\|$.$\| jest dowolną normą tego wektora w \boldsymbol{R}^{m}$ - niekoniecznie tą samą, która jest użyta w definicji odległości $\operatorname{dist}(\boldsymbol{y}, \boldsymbol{D})$ (mamy do tego prawo, gdyż wszystkie normy w $\boldsymbol{R}^{m}$ są topologicznie równoważne). Jeśli wybrać normę $l_{1}$ po prawej stronie nierówności w (7.19) oraz rozszerzoną normę Czebyszewa (mieszaną normę $l_{1}$ i $l_{\infty}$ ) dla określenia $\operatorname{dist}(\boldsymbol{y}, \boldsymbol{D})$, to okazuje się, że stożki $\boldsymbol{D}_{\varepsilon}$ są wypukłe przy odpowiednio małym $\varepsilon$. Dla przypadku $\boldsymbol{D}=\boldsymbol{R}^{m}{ }_{+}$, oznaczając przez $\boldsymbol{y}^{(-)}$wektor o współrzędnych $y_{i}^{(-)}=\min \left(0, y_{i}\right)-$ który to wektor określa odległość wektora $\boldsymbol{y}$ od stożka $\boldsymbol{D}=\boldsymbol{R}^{{ }^{m}}{ }_{+}-$można stożek $\boldsymbol{D}_{\varepsilon}$ wyrazić w następujących równoważnych postaciach:

$$
\begin{aligned}
\boldsymbol{D}_{\varepsilon}= & \left\{\boldsymbol{y} \in \boldsymbol{R}^{m}:\left\|\boldsymbol{y}^{(-)}\right\|_{11}+2 \varepsilon\left\|\boldsymbol{y}^{(-)}\right\|_{l_{\infty}} \leq \varepsilon\|\boldsymbol{y}\|_{11}\right\}=\left\{\boldsymbol{y} \in \boldsymbol{R}^{m}: \boldsymbol{y}=\sum_{j=1, \ldots m} \lambda_{j} \boldsymbol{y}^{(j)}, \lambda_{j} \geq 0\right\}, \\
& \text { gdzie: } \boldsymbol{y}^{(j)}=\left(-\varepsilon, \ldots-\varepsilon, \ldots(1+(m-1) \varepsilon)_{(j)},-\varepsilon, \ldots-\varepsilon\right)^{\mathrm{T}} \\
\boldsymbol{D}_{\varepsilon}= & \left\{\boldsymbol{y} \in \boldsymbol{R}^{m}: y_{j} \geq-\varepsilon \sum_{i=1, \ldots m} y_{i}, \forall j=1, \ldots m\right\}= \\
& \left\{\boldsymbol{y} \in \boldsymbol{R}^{m}:\left(\min _{i=1, \ldots m} y_{i}+\varepsilon \sum_{j=1, \ldots m} y_{j}\right) \geq 0\right\}
\end{aligned}
$$

Druga $\mathrm{z}$ tych postaci mówi, że stożek $\boldsymbol{D}_{\varepsilon}$ jest zbiorem wypukłym rozpiętym na wektorach $\boldsymbol{y}^{(\mathrm{j})}$. Ostatnia $\mathrm{z}$ tych postaci stożka $\boldsymbol{D}_{\varepsilon}$ jest szczególnie istotna: okazuje się, że stożek ten jest zbiorem poziomicowym funkcji $\min _{i=1, \ldots m} y_{i}+\varepsilon \sum_{j=1, \ldots m} y_{j}$. Stożek taki (także w przypadku, gdy stożek $D$ ma postać (7.8) i trzeba wtedy odpowiednio zmodyfikować stożek $\boldsymbol{D}_{\varepsilon}$ ) może być użyty dla jeszcze innej definicji rezultatów i decyzji właściwie optymalnych z ograniczonymi a priori współczynnikami wymiany. Dokładniej mówiąc, definiujemy najpierw:

Definicja 7.7. Rezultaty i decyzje właściwie $\varepsilon$-sprawne definiowane są jako rezultaty i decyzje słabo sprawne względem stożka $\boldsymbol{D}_{\varepsilon}$ :

$$
\begin{aligned}
& \boldsymbol{Y}^{* p \varepsilon}=\left\{\boldsymbol{y}^{*} \in \boldsymbol{Y}_{0}: \boldsymbol{Y}_{0} \cap\left(\boldsymbol{y}^{*}+\operatorname{Int} \boldsymbol{D}_{\varepsilon}\right)=\varnothing\right\} ; \\
& \boldsymbol{X}^{* p \varepsilon}=\left\{\boldsymbol{x}^{*} \in \boldsymbol{X}_{0}: \boldsymbol{f}\left(\boldsymbol{X}_{0}\right) \cap\left(\boldsymbol{f}\left(\boldsymbol{x}^{*}\right)+\operatorname{Int} \boldsymbol{D}_{\varepsilon}\right)=\varnothing\right\} ;
\end{aligned}
$$

Przy okazji tej definicji trzeba podkreślić, że stożek $\boldsymbol{D}_{\varepsilon}$ ma niepuste wnętrze dla każdego niepustego stożka $\boldsymbol{D}$ - nawet jeśli $\operatorname{Int} \boldsymbol{D}=\varnothing$. Łatwo też sprawdzić, że suma mnogościowa zbiorów $\boldsymbol{Y}^{*}{ }^{*}$ wszystkich $\varepsilon>0$ daje zbiór $\boldsymbol{Y}^{p}{ }_{0}$, 
podobnie jak we wzorze (7.18). Istotną jednak zaletą tej definicji jest fakt, że jest ona przy stożku $\boldsymbol{D}_{\varepsilon}$ o postaci $(7.20,7.21)$ równoważna Definicji 7.6: współczynniki wymiany dla rezultatów właściwie $\varepsilon$-sprawnych są ograniczone poprzez liczbę $M=1+1 / \varepsilon$. Użytkownik systemu wielokryterialnej analizy modeli matematycznych może więc określić, dla jakiego $M$ rezultaty właściwie sprawne są dla niego praktycznie nierozróżnialne od słabo sprawnych, i poprzez dobór odpowiedniego $\varepsilon=1 /(M-1)$ może ograniczyć analizę do rezultatów o współczynnikach wymiany mniejszych od $M$. Definicja Geoffriona odpowiada założeniu nieskończonego $M$, co nie sprawdza się w zastosowaniach praktycznych.

Podkreślimy na koniec tego punktu pewną ogólną własność zbiorów rezultatów sprawnych w rozmaitym sensie. Ponieważ rozszerzenie danego stożka dodatniego powoduje zawężenie odpowiadającego mu zbioru rezultatów sprawnych, przeto zawsze (przy dowolnych definicjach szczegółowych stożka dodatniego) obowiązuje zależność:

$$
\boldsymbol{Y}_{0}{ }^{*} p \varepsilon \subseteq \boldsymbol{Y}_{0}{ }^{*}{ }^{*} \subseteq \boldsymbol{Y}_{0}{ }^{*} \subseteq \boldsymbol{Y}_{0}{ }^{* w}
$$

Ćwiczenie 7.1: Udowodnić szczegółowo zależność (7.24).

Ćwiczenie 7.2: Podać takie przykłady, w których relacje zawierania w (7.24) są ścisłe, oraz takie, w których wszystkie te zbiory są równe sobie.

\subsection{Oszacowania zbioru rezultatów sprawnych}

W bardzo rzadkich przypadkach - nieistotnych dla zastosowań - zbiór rezultatów sprawnych $\boldsymbol{Y}_{0}{ }^{*}$ składa się z tylko jednego punktu, zwanego wtedy punktem jednoznacznie sprawnym. We wszystkich przypadkach istotnych dla zastosowań zbiór $\boldsymbol{Y}_{0}^{*}$ zawiera wiele punktów i zasadniczym problemem jest analiza tego zbioru. Zanim przejdziemy do metod obliczania punktów w tym zbiorze, istotne są następujące oszacowania „górne” i „dolne” tego zbioru.

Definicja 7.8. Zbiorem punktów ponad-utopijnych (lub ponad-idealnych w przestrzeni rezultatów $\boldsymbol{Y}$, przy danym stożku dodatnim $\boldsymbol{D}$ o $\operatorname{Int} \boldsymbol{D} \neq \varnothing$ i przy danym zwartym zbiorze $\boldsymbol{Y}_{0}$, nazywamy zbiór:

$$
\boldsymbol{Y}_{0 \text {,uto }}=\left\{\boldsymbol{y} \in \boldsymbol{Y}: \boldsymbol{Y}_{0} \subseteq \boldsymbol{y}-\mathrm{D}\right\}
$$

przy czym zachodzi zależność:

$$
\boldsymbol{Y}_{0 \text {,uto }}=\boldsymbol{y}_{\text {uto }}+\boldsymbol{D}
$$


gdzie $\boldsymbol{y}_{\text {uto }}$ zwany punktem utopijnym lub idealnym, jest „najniższym” punktem zbioru $\boldsymbol{Y}_{0 \text {,uto }}$ (w sensie porządku określonego przez stożek $\boldsymbol{D}$, czyli punktem sprawnym tego zbioru względem stożka $-\boldsymbol{D}$ ).

Zbiorem punktów poniżej nadiru nazywamy zbiór:

$$
\boldsymbol{Y}_{0, \text { nad }}=\left\{\boldsymbol{y} \in \boldsymbol{Y}: \boldsymbol{Y}_{0}^{*} \subseteq \boldsymbol{y}^{+\boldsymbol{D}}\right\}
$$

przy czym zachodzi zależność:

$$
\boldsymbol{Y}_{0, \text { nad }}=\boldsymbol{y}_{\text {nad }}-\boldsymbol{D}
$$

gdzie $\boldsymbol{y}_{\text {nad, }}$ zwany punktem nadiru, jest „najwyższym” punktem tego zbioru (sprawnym względem stożka $\boldsymbol{D}$ ).

Ćwiczenie 7.3: Na podstawie własności stożka dodatniego wykazać słuszność wzorów (7.26), (7.28) i zbadać warunki istnienia punktu utopijnego i nadiru.

Jeśli zbiór $Y_{0}{ }^{*}$ składa się $\mathrm{z}$ tylko jednego punktu, to punkt ten jest jednocześnie punktem utopijnym i nadiru, zob. Rys. 7.3 a). W przeciwnym przypadku, punkty utopijny i nadiru stanowią oszacowanie „od góry” i „od dołu” zbioru $\boldsymbol{Y}_{0}{ }^{*}$. Ze względu na własności tego zbioru, oszacowanie „od góry" dotyczy jednocześnie całego zbioru $\boldsymbol{Y}_{0}$, i dlatego też obliczanie punktu utopijnego jest $\mathrm{w}$ przypadku ogólnym znacznie łatwiejsze, niż obliczanie punktu nadiru. Ten ostatni bowiem oszacowuje „od dołu” tylko zbiór $Y_{0}{ }^{*}$, a nie cały zbiór $\boldsymbol{Y}_{0}$, zob. Rys. 7.3 b).

a)

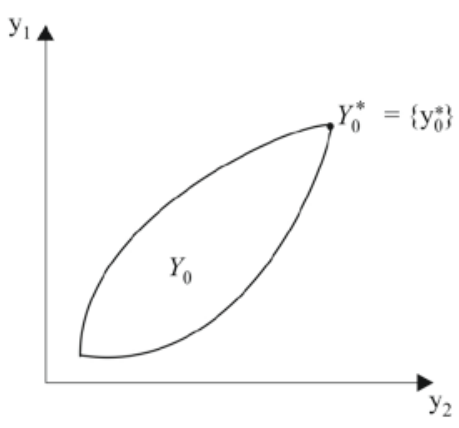

a) b)

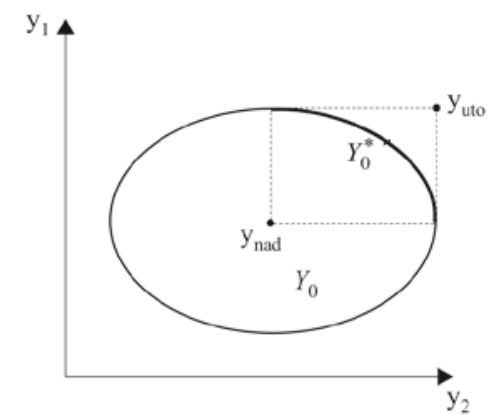

b)

Rys. 7.3. a) Przypadek szczególny punktu jednoznacznie sprawnego;

b) Przypadek ogólny oszacowania zbioru $\boldsymbol{Y}_{0}^{*}$ przez punkt utopijny $\boldsymbol{y}_{\text {uto }}$ oraz punkt nadiru $\boldsymbol{y}_{\text {nad. }}$. 
Jeśli $\boldsymbol{D}=\boldsymbol{R}^{\mathrm{m}}{ }_{+}$, to punkt utopijny można uzyskać drogą następujących obliczeń:

$$
\begin{aligned}
& y_{\text {uto }, i}=\max _{\mathbf{y e} \mathrm{Y} 0} y_{i}=\max _{\mathbf{x} \in \mathbf{X} 0} f_{i}(\boldsymbol{x}), \\
& \boldsymbol{y}_{\text {uto }}=\left(y_{\mathrm{uto}, 1}, \ldots y_{\mathrm{uto}, i}, \ldots y_{\mathrm{uto}, m}\right)^{\mathrm{T}}
\end{aligned}
$$

przy czym jeśli wyniki tych niezależnych optymalizacji dla każdego atrybutu są jednoznaczne względem $\boldsymbol{x}$, to uzyskujemy też następujące dane dodatkowe:

$$
\begin{aligned}
& \boldsymbol{x}_{\mathrm{uto}, i}^{*}=\operatorname{argmax}_{\boldsymbol{x \in X 0} 0} f_{i}(\boldsymbol{x}) ; \\
& y_{\mathrm{uto}, i j}=f_{j}\left(\boldsymbol{x}_{\mathrm{uto}, i}\right), j \neq i
\end{aligned}
$$

gdzie przez argmax oznaczamy punkt jednoznacznie maksymalizujący daną funkcję. Łatwo sprawdzić, że wyniki niezależnych optymalizacji (7.29) mogą być niejednoznaczne m.in. wtedy, gdy zbiór $\boldsymbol{Y}_{0}$ ma punkty ściśle słabo sprawne (nie będące sprawnymi); punkty $\boldsymbol{x}_{\text {uto,i }}^{*}$ mogą być wtedy decyzjami słabo sprawnymi. Jeśli natomiast wyniki tych niezależnych optymalizacji są jednoznaczne (co można sprawdzać stosując specjalne metody optymalizacji leksykograficznej), to zbiór $\boldsymbol{Y}_{0}$ nie ma punktów ściśle słabo sprawnych i punkty $\boldsymbol{x}_{\text {uto, } i}^{*}$ są decyzjami sprawnymi. Wartości $y_{\text {uto,ij }}$ to po prostu pozostałe współrzędne "skrajnych" rezultatów sprawnych $\boldsymbol{y}_{i}{ }_{i}=\boldsymbol{f}\left(\boldsymbol{x}_{\mathrm{uto}, i}\right)$, zob. Rys. 7.3 b).

Dwuwymiarowe ilustracje mogą sugerować, że punkt nadiru $\boldsymbol{y}_{\text {nad }}$ mógłby być wyznaczany drogą określania najmniejszych względem $i$ współrzędnych $y_{\text {uto,ij }}$ dla każdego $j$, a następnie połączenia tych wyników w jeden wektor, jak to sugeruje Rys. 7.3 a). Postępowanie takie jest jednak prawidłowe tylko dla $m=2$; można podać przykłady dla $m \geq 3$, w których taką drogą uzyskuje się nieprawidłowe (zbyt „wysokie”) oszacowania $\boldsymbol{y}_{\text {nad. }}$ Dokładne określenie $\boldsymbol{y}_{\text {nad }}$ jest wtedy problemem trudnym; można wykazać, że niezbędny nakład obliczeń rośnie wykładniczo z m. Z drugiej strony, dokładna znajomość punktu nadiru nie jest zwykle niezbędna; dla szczegółowych badań zbioru $\boldsymbol{Y}_{0}^{*}$ wystarcza zazwyczaj znajomość punktu utopijnego, wyznaczonego jak w (7.29), oraz pewne przybliżenie punktu nadiru. Można przy tym zaczynać od wzmiankowanego wyżej przybliżenia:

$$
\begin{aligned}
& \tilde{y}_{\text {nad }, j}=\min _{i=1, \ldots m} y_{\text {uto }, i j} ; \\
& \boldsymbol{y}_{\text {nad }}^{\sim_{\text {nad }}}=\left(\begin{array}{ll}
y_{\text {nad }, 1}, \ldots y_{\text {nad }, j}^{\sim}, \ldots & y_{\text {nad }, m}^{\sim}
\end{array}\right)^{\mathrm{T}}
\end{aligned}
$$

i ewentualnie poprawiać go dalej w trakcie analizy wielokryterialnej zbioru $Y_{0}$ (zob. dalsze rozdziały). 
Powyższy sposób określania $\boldsymbol{y}_{\text {uto }}$ i $\boldsymbol{y}_{\text {nad }}^{\sim}$ łatwo uogólnić na przypadek, w którym wprawdzie $\boldsymbol{D} \neq \boldsymbol{R}^{m}{ }_{+}$, ale występują tylko atrybuty minimalizowane lub maksymalizowane; w przypadku atrybutów minimalizowanych wystarczy zmienić maksymalizację na minimalizację (i odwrotnie przy oszacowaniu $\tilde{\boldsymbol{y}}_{\text {nad }}^{\sim}$ ). Natomiast założenie Int $\boldsymbol{D} \neq \varnothing$ w Definicji 5.8 wskazuje, że oszacowania $\boldsymbol{y}_{\text {uto }}$ i $\boldsymbol{y}_{\text {nad }}^{\sim}$ komplikują się w przypadku stożka dodatniego o postaci (7.8) przy $m_{2}<m$, czyli przy uwzględnieniu atrybutów stabilizowanych, gdy Int $\boldsymbol{D}=\varnothing$. Łatwo sprawdzić, że definicje (7.29), (7.31) są wtedy nieprzydatne. Poprzez analizę różnych przykładów $\boldsymbol{Y}_{0} \mathrm{w}$ takim przypadku dochodzimy do wniosku, że dla atrybutu stabilizowanego $y_{i}$ jako odpowiednią współrzędną $y_{\text {uto,i }}$ należy traktować podany przez użytkownika poziom stabilizacji $y_{i}^{-}$tego atrybutu, natomiast określać trzeba dwa niezależne oszacowania $y_{\text {nad, } i}$ : maksymalną wartość $y_{i} \mathrm{w}$ zbiorze $\boldsymbol{Y}_{0}$ (licząc współrzędną nadiru osobno dla $y_{i}>c$ oraz minimalną wartość tego atrybutu (licząc współrzędną nadiru osobno dla dla $y_{i}<y_{i}^{-}$).

\subsection{Funkcje skalaryzujące i podstawy charakteryzacji rezultatów sprawnych}

Podstawową metodą wyznaczania decyzji i rezultatów sprawnych jest optymalizacja (zwykle będziemy zakładać, że jest to maksymalizacja) specjalnie utworzonej funkcji skalaryzującej $s(\boldsymbol{y}, \boldsymbol{\alpha}), s: \boldsymbol{R}^{\mathrm{m}} \times \boldsymbol{A} \rightarrow \boldsymbol{R}^{1}$, gdzie $\boldsymbol{\alpha} \in \boldsymbol{A}$ jest dodatkowym parametrem, zwanym parametrem sterującym, którego zmiany powinny być pomocne w przeglądzie różnych $y \in \boldsymbol{Y}^{*}$; zwykle przy tym $\boldsymbol{A} \subseteq \boldsymbol{R}^{\mathrm{m}}$. Powinniśmy przy tym wybierać takie funkcje skalaryzujące, których punkty maksymalne względem $\boldsymbol{y} \in \boldsymbol{Y}_{0}$ są zawarte w zbiorze $\boldsymbol{Y}_{0}^{*}$, czyli posiadające następującą własność wystarczalności:

Definicja 7.9. Funkcja skalaryzująca $s(\boldsymbol{y}, \boldsymbol{\alpha})$ ma wlasność wystarczalności dla rezultatów sprawnych (słabo sprawnych, właściwie $\varepsilon$-sprawnych itp.) w pewnym zbiorze $\boldsymbol{A}_{s} \subset \boldsymbol{A}$, jeśli:

$$
\operatorname{Argmax} s(\boldsymbol{y}, \boldsymbol{\alpha}) \subseteq \boldsymbol{Y}_{0}^{*}\left(\boldsymbol{Y}^{*}{ }_{0}, \boldsymbol{Y}^{* p \varepsilon}{ }_{0,} \text { itp. }\right) \forall \boldsymbol{\alpha} \in \boldsymbol{A}_{s}
$$

gdzie przez Argmax oznaczamy zbiór wszystkich punktów maksymalizujących daną funkcję (Argmax = argmax, jeśli to tylko jeden punkt).

Okazuje się, że w optymalizacji wielokryterialnej stosunkowo łatwo jest zapewnić własność wystarczalności. 
Twierdzenie 7.1. Warunki dostateczne uzyskiwania rozwiązań sprawnych przez optymalizację funkcji skalaryzującej. Jeśli $r(\boldsymbol{y})=s(\boldsymbol{y}, \boldsymbol{\alpha})$ (dla danego $\boldsymbol{\alpha}$ ) jest funkcją ściśle monotoniczną względem stożka określającego dany typ sprawności, to maksima tej funkcji są rezultatami sprawnymi danego typu:

$$
\begin{aligned}
& \text { Jeśli } \boldsymbol{y}^{\prime} \in \boldsymbol{y}^{\prime \prime}+\boldsymbol{D}^{\neq} \rightarrow r\left(\boldsymbol{y}^{\prime}\right)>r\left(\boldsymbol{y}^{\prime \prime}\right) \text {, to } \operatorname{Argmax}_{\boldsymbol{y} \in \mathbf{Y} 0} r(\boldsymbol{y}) \subseteq \boldsymbol{Y}_{0}^{*} \\
& \text { Jeśli } \boldsymbol{y}^{\prime} \in \boldsymbol{y}^{\prime \prime}+\operatorname{Int} \boldsymbol{D} \rightarrow r\left(\boldsymbol{y}^{\prime}\right)>r\left(\boldsymbol{y}^{\prime \prime}\right), \text { to } \operatorname{Argmax}_{\boldsymbol{y} \in \mathbf{Y} 0} r(\boldsymbol{y}) \subseteq \boldsymbol{Y}^{*}{ }_{0} \\
& \text { Jeśli } \boldsymbol{y}^{\prime} \in \boldsymbol{y}^{\prime \prime}+\operatorname{Int} \boldsymbol{D}_{\varepsilon} \rightarrow r\left(\boldsymbol{y}^{\prime}\right)>r\left(\boldsymbol{y}^{\prime \prime}\right), \text { to } \operatorname{Argmax}_{\boldsymbol{y} \in \mathbf{Y} 0} r(\boldsymbol{y}) \subseteq \boldsymbol{Y}^{* p_{0}}{ }_{0}
\end{aligned}
$$

(gdzie $\left.\boldsymbol{D}^{\neq}=\boldsymbol{D} \backslash\{0\}\right)$.

Podamy tu szkic dowodu tego twierdzenia, przy czym przeprowadzimy go dla ostatniego z wymienionych tu przypadków - inne są analogiczne. Przypuśćmy, że istnieje takie $\boldsymbol{y}^{\prime} \in \operatorname{Argmax}_{y \in Y 0} r(\boldsymbol{y})$, że $\boldsymbol{y}^{\prime} \neg \in \boldsymbol{Y}^{*}{ }_{0}$ ( $\neg €$ oznacza „nie należy do”). Zgodnie z Definicją 7.7 mamy wtedy $\boldsymbol{Y}_{0} \cap\left\{\boldsymbol{y}^{\prime}+\right.$ Int $\left.\boldsymbol{D}_{\varepsilon}\right\} \neq \varnothing$; istnieje więc $\boldsymbol{y}^{\prime \prime} \in \boldsymbol{Y}_{0}, \boldsymbol{y}^{\prime \prime} \in \boldsymbol{y}^{\prime}+$ Int $\boldsymbol{D}_{\varepsilon}$. Z założenia o ścisłej monotoniczności wynika wtedy $r\left(y^{\prime \prime}\right)>r\left(y^{\prime}\right)$; ale ponieważ $\boldsymbol{y}^{\prime \prime} \in \boldsymbol{Y}_{0}$, przeczy to założeniu, że $\boldsymbol{y}^{\prime} \in \operatorname{Argmax}_{\mathbf{y} \in \mathbf{Y} 0} r(\boldsymbol{y})$.

Tak więc jako funkcje skalaryzujące wybierać będziemy takie funkcje, które są ściśle monotoniczne względem $\boldsymbol{y}$ w sensie odpowiedniego stożka, dla wszystkich wartości parametrów sterujących $\boldsymbol{\alpha}$ w pewnym zbiorze $\boldsymbol{A}$. Na przykład następująca, podstawowa liniowa (a nawet biliniowa względem obu argumentów) funkcja skalaryzująca:

$$
s(\boldsymbol{y}, \boldsymbol{\alpha})=\Sigma_{\mathrm{i}=1, \ldots m} \alpha_{i} y_{i}
$$

gdzie parametry $\alpha_{i}$ zwane są współczynnikami wagi, jest ściśle monotoniczna w sensie stożka $\boldsymbol{D}^{\neq}=\boldsymbol{R}^{m}{ }_{+} \backslash\{0\}$ jeśli $\boldsymbol{\alpha} \in$ Int $\boldsymbol{R}^{m}{ }_{+}$, czyli gdy $\alpha_{i}>0, \forall i=1, \ldots m$, i ściśle monotoniczna w sensie stożka Int $\mathrm{D}=\operatorname{Int} \boldsymbol{R}^{m}{ }$, jeśli $\boldsymbol{\alpha} \in \boldsymbol{D}^{\neq}=\boldsymbol{R}^{m}+\backslash\{0\}$, czyli gdy $\alpha_{i} \geq 0, \forall i=1, \ldots m$, ale istnieje $j=1, \ldots m: \alpha_{j}>0$. Zwykle zakłada się jeszcze dodatkowo, że współczynniki wagi są znormalizowane, czyli $\Sigma_{\mathrm{i}=1, \ldots m} \alpha_{i}=1$. Mamy więc wtedy $\boldsymbol{A}_{s}=\operatorname{Int} \boldsymbol{R}^{m}{ }_{+}$, $\boldsymbol{A}_{s}{ }^{w}=\boldsymbol{R}^{m}+\backslash\{0\} ;$ w jednym $\mathrm{z}$ następnych twierdzeń określimy też odpowiedni zbiór $\boldsymbol{A}_{s}^{p \varepsilon}$ gwarantujący uzyskanie rezultatów $\varepsilon$-sprawnych przez optymalizację liniowej funkcji skalaryzującej.

Jednakże nie zależy nam tylko na tym, aby każde maksimum funkcji skalaryzującej było sprawne (w odpowiednim sensie); zależy nam także na tym, aby za pomocą odpowiednich zmian parametru $\boldsymbol{\alpha}$ można było osiągnąć dowolny rezultat sprawny (w odpowiednim sensie) - i aby sterowanie za pomocą parametru $\boldsymbol{\alpha}$ miało własność ciągłości, czyli by małe zmiany 
parametru sterującego $\boldsymbol{\alpha}$ powodowały małe zmiany odpowiadających im rezultatów sprawnych. Prowadzi to do dalszych definicji:

Definicja 7.10. Funkcja skalaryzująca $s(y, \alpha)$ ma własność zupełności, czyli zupełnie (lub prawie zupełnie) charakteryzuje zbiór rezultatów sprawnych $\boldsymbol{Y}_{0}^{*}$ (lub $\boldsymbol{Y}^{*}{ }_{0}$, lub $\boldsymbol{Y}^{* p \varepsilon}{ }_{0}$ itp.), jeśli dla (prawie) każdego $\boldsymbol{y}^{*} \in \boldsymbol{Y}_{0}^{*}\left(\boldsymbol{Y}^{*}{ }_{0}, \boldsymbol{Y}^{* p \varepsilon}{ }_{0}\right.$ itp.) istnieje takie $\alpha \in A_{\mathbf{z}} \subseteq A$, że:

$$
y^{*} \in \operatorname{Argmax}_{y \in Y 0} s(y, \alpha)
$$

Definicja 7.11. Funkcja skalaryzująca ma własność ciąglej sterowalności, jeśli maksima we wzorze (7.35) są jednoznaczne dla każdego $\boldsymbol{\alpha} \epsilon \boldsymbol{A}_{\mathbf{z}}$, określają więc funkcję $\boldsymbol{y}^{*}(\boldsymbol{\alpha})$ i funkcja ta jest ciągła w sensie Lipschitza - czyli istnieje takie $\beta>0 \$$, że:

$$
\left\|\boldsymbol{y}^{*}\left(\boldsymbol{\alpha}^{\prime}\right)-\boldsymbol{y}^{*}\left(\boldsymbol{\alpha}^{\prime \prime}\right)\right\| \leq \beta\left\|\boldsymbol{\alpha}^{\prime}-\boldsymbol{\alpha}^{\prime \prime}\right\|
$$

O ile własność wystarczalności związana jest ze (stosunkowo prostymi, jak wynika z Twierdzenia 7.1) warunkami wystarczającymi dla sprawności rezultatów i decyzji, o tyle własność zupełności związana jest z warunkami koniecznymi. Warunki konieczne w teorii optymalizacji analizuje się zwykle za pomocą twierdzeń o rozdzielaniu zbiorów. Wykorzystuje się zwykle przy tym następujące twierdzenie Hahna-Banacha o rozdzielaniu zbiorów wypukłych za pomocą funkcji liniowej: w przestrzeni Banacha (a więc w szczególności w przestrzeni $\boldsymbol{R}^{m}$ ): jeśli dane są dwa zbiory wypukłe nie mające wspólnych punktów wewnętrznych, to istnieje funkcja liniowa (lub ogólniej funkcjonał) oraz liczba $\beta$, że wartości tej funkcji są większe lub równe $\beta$ dla wszystkich punktów jednego zbioru, natomiast mniejsze lub równe $\beta$ dla wszystkich punktów drugiego zbioru.

Ze względu na specyficzną postać definicji zbioru rezultatów sprawnych z warunkiem pustego przecięcia zbioru $\boldsymbol{Y}_{0}$ i pewnego przesuniętego stożka, np. $\boldsymbol{y}^{*}+\boldsymbol{D}^{\neq}-$w teorii optymalizacji wielokryterialnej można udowodnić i wykorzystać bardzo specyficzne twierdzenie o rozdzielaniu zbiorów, nie wymagające nawet wypukłości zbioru $\boldsymbol{Y}_{0}$, ale wykorzystujące stożkową postać zbioru $\boldsymbol{D}^{\ddagger}$. Przyjmiemy najpierw następującą definicję:

Definicja 7.12. Funkcja $r(\boldsymbol{y})$ (równa $s(\boldsymbol{y}, \boldsymbol{\alpha})$ dla danego $\boldsymbol{\alpha}$ ) ściśle rozdziela dwa rozłączne zbiory $\boldsymbol{Y}^{\prime}$ i $\boldsymbol{Y}^{\prime \prime}$ w punkcie $\boldsymbol{y}^{-} \in \boldsymbol{Y}$, jeśli $r(\boldsymbol{y}) \leq r\left(\boldsymbol{y}^{-}\right) \forall \boldsymbol{y} \in \boldsymbol{Y}^{\prime}$ oraz $r(\boldsymbol{y})>r\left(\boldsymbol{y}^{-}\right) \forall \boldsymbol{y} \in \boldsymbol{Y}^{\prime \prime}$. 
Twierdzenie 7.2. O rozdzielaniu zbioru od stożka dodatniego. Jeśli pewna funkcja $r: \boldsymbol{R}^{m} \rightarrow \boldsymbol{R}^{1}$ ściśle rozdziela w punkcie $\boldsymbol{y}^{-} \in \boldsymbol{Y}_{0}$ zbiory $\boldsymbol{Y}_{0}=\boldsymbol{Y}^{\prime}$ i $\boldsymbol{y}^{-}+\boldsymbol{D}^{\neq}=\boldsymbol{Y}^{\prime \prime}$ (lub $\boldsymbol{y}^{-}+\operatorname{Int} \boldsymbol{D}=\boldsymbol{Y}^{\prime \prime}$, lub $\boldsymbol{y}^{-}+\operatorname{Int} \boldsymbol{D}_{\varepsilon}=\boldsymbol{Y}^{\prime \prime}$ itp.), to własność ta jest równoważna następującym trzem własnościom łącznie:

(i) $\boldsymbol{y}^{-} \in \operatorname{Argmax}_{\boldsymbol{y} \in \mathrm{Y} 0} r(\boldsymbol{y})$;

(ii) $r(y)$ jest ściśle monotoniczna w punkcie $\boldsymbol{y}^{-} \mathrm{w}$ sensie stożka $\boldsymbol{D}^{\neq}$ (lub Int $\boldsymbol{D}$, lub Int $\boldsymbol{D}_{\varepsilon}$ itp.), czyli $r(\boldsymbol{y})>\mathrm{r}\left(\boldsymbol{y}^{-}\right) \forall \boldsymbol{y} \in \boldsymbol{y}^{-}+\boldsymbol{D}^{\neq}$ (lub $\forall \boldsymbol{y} \in \boldsymbol{y}^{-}+$Int $\boldsymbol{D}$, lub $\forall \boldsymbol{y} \in \boldsymbol{y}^{-}+$Int $\boldsymbol{D}_{\varepsilon}$ );

(iii) $\boldsymbol{y}^{-} \in \boldsymbol{Y}_{0}^{*}$ czyli jest rezultatem sprawnym (lub $\boldsymbol{y}^{-} \in \boldsymbol{Y}^{*}{ }_{0}$, lub $\boldsymbol{y}^{-} \in \boldsymbol{Y}^{* p \varepsilon}{ }_{0}$ itp.).

Dowód. Własność rozdzielania można zapisać jako:

$r(\boldsymbol{y}) \leq r\left(\boldsymbol{y}^{-}\right) \forall \boldsymbol{y} \in \boldsymbol{Y}_{0}$, co jest równoważne do (i), oraz $r\left(\boldsymbol{y}^{-}\right)<r(\boldsymbol{y}) \forall \boldsymbol{y} \in \boldsymbol{y}^{-}+\boldsymbol{D}^{\neq}$, co jest równoważne do (ii). Dlatego też, jeśli spełnione są własności (i), (ii), (iii), to oczywiście spełniona jest własność rozdzielania. Jeśli natomiast $r$ ma własność rozdzielania i $\boldsymbol{y}^{-}$nie byłoby sprawne, to istniałby punkt $\boldsymbol{y}^{\prime} \in \boldsymbol{Y}_{0}$ taki, że $\boldsymbol{y}^{\prime} \in \boldsymbol{y}^{-}+\boldsymbol{D}^{\neq}$, co prowadzi do sprzeczności, gdyż nie możemy mieć jednocześnie $r\left(y^{\prime}\right)>r\left(y^{-}\right)$i $r\left(y^{\prime}\right)<r\left(y^{-}\right)$. Zatem z własności rozdzielania wynika (iii), oraz oczywiście (i), (ii).

Twierdzenie 7.2 wydaje się bardzo proste, ale jest bardzo ważne. Podobnie jak inne twierdzenia o rozdzielaniu zbiorów, twierdzenie to niezmiernie upraszcza wiele dowodów o warunkach koniecznych sprawności. Wynika z niego, że funkcje skalaryzujące, aby mieć własność zupełności, powinny dla dowolnego punktu $\boldsymbol{y}^{-} \in \boldsymbol{Y}_{0}^{*}$ rozdzielać zbiór $\boldsymbol{Y}_{0}$ i przesunięty stożek $\boldsymbol{D}^{\neq}$.

Jeśli zbiór $\boldsymbol{Y}_{0}$ jest wypukły, to możemy wykorzystywać funkcję liniową względem $\boldsymbol{y}$ do rozdzielenia tego zbioru od wypukłego stożka $\boldsymbol{y}^{-}+\boldsymbol{D}^{\ddagger}-$ czyli funkcję skalaryzującą (7.34).

Twierdzenie 7.3. O wlasnościach liniowej funkcji skalaryzującej. Załóżmy, że $\boldsymbol{D}=\boldsymbol{R}^{m}{ }_{+}, s(\boldsymbol{y}, \boldsymbol{\alpha})=\sum_{\mathrm{i}=1, \ldots m} \alpha_{i} y_{i}$.

A. Jeśli $\boldsymbol{\alpha} \in \boldsymbol{A}^{w_{s}}=\boldsymbol{R}^{m}{ }_{+} \backslash\{0\}$, to $\operatorname{Argmax}_{y \in Y 0} s(\boldsymbol{y}, \boldsymbol{\alpha}) \subseteq \boldsymbol{Y}^{* w_{0}}$. Jeśli $\boldsymbol{\alpha} \in \boldsymbol{A}_{s}=$ Int $\boldsymbol{R}^{m}{ }$, to $\operatorname{Argmax}_{\boldsymbol{y} \in \mathbf{Y} 0} s(\boldsymbol{y}, \boldsymbol{\alpha}) \subseteq \boldsymbol{Y}^{*}{ }_{0}$. Odwrotnie, jeśli zbiór $\boldsymbol{Y}_{0}$ jest wypukły i $\boldsymbol{y}^{*} \in \boldsymbol{Y}^{*}{ }_{0}{ }_{0}$ (a więc w szczególności, jeśli $\boldsymbol{y}^{*} \in \boldsymbol{Y}_{0}^{*}$ ), to istnieje takie $\boldsymbol{\alpha} \in \boldsymbol{A}_{n}=\boldsymbol{A}^{w}{ }_{n}=\boldsymbol{A}^{w}{ }_{s}==\boldsymbol{R}^{m}{ }_{+} \backslash\{0\}$, że $\boldsymbol{y}^{*} \in \operatorname{Argmax}_{\boldsymbol{y} \in \mathbf{Y} 0} s(\boldsymbol{y}, \boldsymbol{\alpha})$. 
B. Jeśli: $\boldsymbol{\alpha} \in \boldsymbol{A}^{p \varepsilon}{ }_{s}=\left\{\boldsymbol{\alpha} \in \boldsymbol{R}^{m}{ }_{+}: \alpha_{j} / \sum_{\mathrm{i}=1, \ldots m} \alpha_{i} \geq \varepsilon /(1+m \varepsilon) \forall j=1, \ldots m\right\}$, to $\operatorname{Argmax}_{\boldsymbol{y} \in \mathbf{Y} 0} s(\boldsymbol{y}, \boldsymbol{\alpha}) \subseteq \boldsymbol{Y}^{*}{ }_{0} \varepsilon_{0}$ określonym jak we wzorze (7.22); ponadto, jeśli $\boldsymbol{y}^{*} \in \operatorname{Argmax}_{\boldsymbol{y} \in \mathbf{Y} 0} \quad s(\boldsymbol{y}, \boldsymbol{\alpha})$, to współczynniki wymiany $t_{i j}\left(\boldsymbol{y}^{*}\right) \leq M=1+1 / \varepsilon \forall i, j=1, \ldots m$. Odwrotnie, jeśli $\boldsymbol{Y}_{0}$ jest zbiorem wypukłym i $\boldsymbol{y}^{*} \in \boldsymbol{Y}^{* p \varepsilon}$, to istnieje takie $\boldsymbol{\alpha}^{*} \in \boldsymbol{A}_{n}^{p \varepsilon}=\boldsymbol{A}_{s}^{p \varepsilon}$, że $\boldsymbol{y}^{*} \in \operatorname{Argmax}_{\mathbf{y} \in \mathrm{Y} 0} s\left(\boldsymbol{y}, \boldsymbol{\alpha}^{*}\right)$.

Pełnego dowodu tego twierdzenia nie będziemy tu przytaczać. Dowód części A może być pozostawiony jako ćwiczenie - opiera się on w prosty sposób na wykorzystaniu Twierdzeń 7.1 i 7.2 oraz istnieniu funkcji liniowej rozdzielającej zbiory wypukłe. Dowód części B opiera się na wykazaniu, że stożek sprzężony do $\boldsymbol{D}_{\varepsilon}$ ma postać $\boldsymbol{D}_{\varepsilon_{-}}^{*_{\varepsilon_{-}}}=\boldsymbol{A}^{p \varepsilon}{ }_{s}$ oraz na wykorzystaniu Twierdzeń 7.1 i 7.2 .

Istotne są jednak pewne komentarze do Twierdzenia 7.3. Zauważmy, że zbiory $\boldsymbol{Y}^{* w_{0}}{ }_{0}$ oraz $\boldsymbol{Y}^{* p \varepsilon}{ }_{0}$ są zupełnie charakteryzowane (jeśli $\boldsymbol{Y}_{0}$ jest wypukły) przez funkcję liniową (7.34), gdyż $\boldsymbol{A}^{w}{ }_{s}=\boldsymbol{A}^{w}{ }_{n}$ oraz $\boldsymbol{A}^{p \varepsilon}{ }_{s}=. \boldsymbol{A}^{p \varepsilon}$. Natomiast zbiór $\boldsymbol{Y}_{0}^{*}$ jest tylko prawie zupełnie charakteryzowany przez tę funkcję, gdyż $\boldsymbol{A}_{s} \subset \boldsymbol{A}_{n}$ oraz $\boldsymbol{A}_{s}$ różni się od $\boldsymbol{A}_{n}$ punktami na swoim domknięciu (a więc na zbiorze miary zero).

Twierdzenie 7.3 jest na tyle silne, że wydawać by się mogło, jakoby funkcja liniowa (7.34) w pełni wystarczała dla obliczania decyzji i rezultatów sprawnych. Jednakże, po pierwsze, zupełna (czy prawie zupełna) charakteryzacja rozwiązań sprawnych przez tę funkcję nie dotyczy zbiorów niewypukłych, które często się zdarzają dla bardziej skomplikowanych modeli rzeczowych sytuacji decyzyjnych (w szczególności, w przypadku dyskretnych zbiorów $\boldsymbol{X}_{0}$ i $\boldsymbol{Y}_{0}$ mamy oczywiście do czynienia z niewypukłością).

Po drugie, Twierdzenie 7.3 nic nie mówi o ciągłej sterowalności punktów maksymalnych liniowej funkcji skalaryzującej (7.34) poprzez dobór $\boldsymbol{\alpha}$; co więcej, można wskazać dość podstawową klasę wypukłych modeli sytuacji decyzyjnych, dla których zależność $\boldsymbol{y}^{*}(\boldsymbol{\alpha})$ jest nieciągła. Są to modele wielokryterialnego programowania liniowego, o postaci standardowej:

$$
\boldsymbol{y}=\boldsymbol{C} \boldsymbol{x} \in \boldsymbol{R}^{m} ; \boldsymbol{X}_{0}=\left\{\boldsymbol{x} \in \boldsymbol{R}^{n}: \boldsymbol{A} \boldsymbol{x}=\boldsymbol{b} \in \boldsymbol{R}^{k}, \boldsymbol{B} \boldsymbol{x}+\boldsymbol{d} \geq 0 \in \boldsymbol{R}^{l}\right\}
$$


w której $\boldsymbol{A}, \boldsymbol{B}$ i $\boldsymbol{C}$ są macierzami o odpowiednich wymiarach. Wektor $\boldsymbol{x}$ nie musi w tej postaci, ściśle biorąc, być wektorem zmiennych decyzyjnych, gdyż postać standardową programowania liniowego (z założeniem tylko ograniczeń równościowych w definicji zbioru $\boldsymbol{X}_{0}$, bez ograniczeń nierównościowych $\boldsymbol{B} \boldsymbol{x}+\boldsymbol{d} \geq 0$ ) uzyskuje się z innych postaci (zawierających ograniczenia liniowe zarówno równościowe jak i nierównościowe) poprzez dodanie często bardzo dużej liczby zmiennych uzupełniających i sztucznych. Jednakże w kwestii ciągłej sterowalności istotne jest tu tylko, że zbiór $\boldsymbol{Y}_{0}$ dla zadań wielokryterialnego programowania liniowego ma charakter wielościanu wypukłego, ograniczonego nierównościami czy równościami liniowymi.

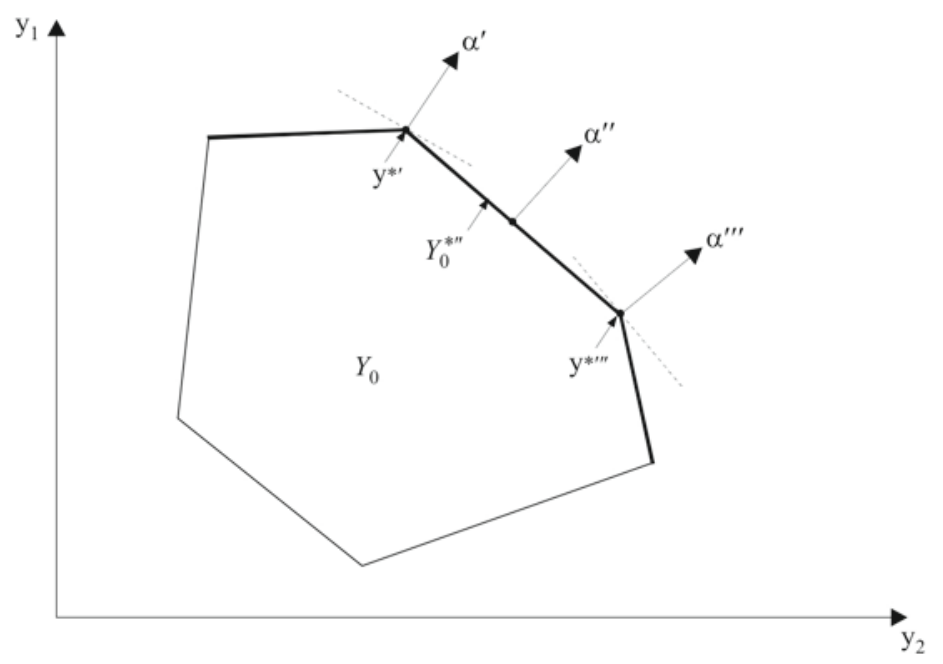

Rys. 7.4. Ilustracja nieciągłej (dla $\boldsymbol{\alpha}=\boldsymbol{\alpha}$ ") zależności punktów maksymalnych funkcji liniowej (7.34) od współczynników wagi.

Dla zbiorów $\boldsymbol{Y}_{0}$ o tym charakterze łatwo wykazać - patrz Rys. 7.4 - że punkty maksymalne funkcji liniowej zachowują się W sposób nieciągły przy zmianach współczynników wagi $\boldsymbol{\alpha}$. Stanowi to podstawową wadę liniowej funkcji skalaryzującej (7.34) i dlatego właśnie nie zaleca się jej stosowania. Różne inne funkcje skalaryzujące omawiane są w następnym rozdziale.

Sposoby uniknięcia takiej nieciągłej zależności omawiane są także w rozdziale następnym. 


\section{Literatura}

Geoffrion A.M. (1968) Proper efficiency and the theory of vector optimization. Journal of Mathematical Analysis and Applications 22: 618-630

Henig M.I. (1982) Proper efficiency with respect to cones. Journal of Optimization Theory and Applications 36: 387-407

Sawaragi Y., Nakayama H. ,Tanino T. (1985) Theory of Multiobjective Optimization. Academic Press, Orlando Fl.

Seo F., Sakawa M. (1988) Multiple Criteria Decision Analysis in Regional Planning: Concepts, Methods and Applications. D. Reidel Publishing Company, Dordrecht

Stachurski A. Wierzbicki A.P. (1999) Podstawy optymalizacji. Oficyna Wydawnicza Politechniki Warszawskiej, Warszawa

Steuer R.E. (1986) Multiple Criteria Optimization: Theory, Computation and Application. J.Wiley, New York

Wierzbicki A.P. (1977) Basic properties of scalarizing functionals for multiobjective optimization. Mathematische Operationsforschung und Statistik, s. Optimization 8: 55-60

Wierzbicki A.P. (1986) On the completeness and constructiveness of parametric characterizations to vector optimization problems. OR-Spektrum 8: 73-87

Wierzbicki A.P., Makowski M., Wessels J. (2000) Model-Based Decision Support Methodology with Environmental Applications. IIASA - Kluwer Academic Publishers, Dordrecht

Wierzbicki A.P. (2006) A reference point approach to coalition games. Journal of Multi-Criteria Decision Analysis 13:2-3:81-89

Yu P.L. (1985) Multiple-Criteria Decision Making - Concepts, Techniques and Extensions. Plenum Press, New York and London 


\section{Różne podejścia do optymalizacji wektorowej i klasy funkcji skalaryzujących}

Wady liniowej funkcji skalaryzującej powodowały poszukiwania rozmaitych innych podejść do optymalizacji wielokryterialnej, które możemy interpretować jako propozycje różnych klas funkcji skalaryzujących. Podejścia te można podzielić na dwie duże grupy: podejścia wykorzystujące współczynniki wagi jako parametry sterujące (do grupy tej można zaliczyć też podejścia oparte na liniowej funkcji $\left.s(\boldsymbol{y}, \boldsymbol{\alpha})=\sum_{\mathrm{i}=1, \ldots m} \alpha_{i} y_{i}\right)$ oraz podejścia oparte na innych parametrach sterujących, w szczególności poziomach odniesienia dla poszczególnych atrybutów (czy kryteriów). Omówimy je w tej kolejności. Zakładać będziemy przy tym, że wszystkie kryteria, wskaźniki jakości, atrybuty czy rezultaty decyzji $y_{i}$ są maksymalizowane, $\boldsymbol{D}=\boldsymbol{R}^{m}{ }_{+}$, chyba że wyraźnie podkreślimy odstępstwo od tego założenia.

\subsection{Metody przesuniętego ideału (utopii)}

Metody te były rozwinięte przez M.E. Salukvadze (1971, 1979), Milena Zeleny'ego (1973) i Po-Lung Yu (zob. 1985). Sprowadzają się one do wyboru punktu ponadutopijnego $\boldsymbol{y}^{\sim} \in \boldsymbol{Y}_{\text {,uto }}$ jako swojego rodzaju punktu odniesienia, a następnie do zastosowania normy odległości od tego punktu jako funkcji skalaryzującej, przy czym za parametry sterujące przyjmuje się współczynniki wagi w tej normie. Stosuje się przy tym normę $l_{p}, 1 \leq p<\infty$ (przypadek $p=\infty$, też wykorzystywany, rozpatrzymy osobno $\mathrm{z}$ uwagi na jego nieco odmienne własności):

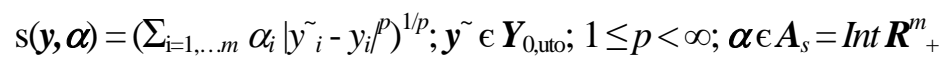

przy czym funkcję tę - jako normę odległości - minimalizuje się, nie maksymalizuje. Będziemy tu konsekwentnie stosować uproszczenie zapisu, minimalizując czy maksymalizując funkcję skalaryzującą względem $\boldsymbol{y} \in \boldsymbol{Y}_{0}$, 
choć w praktyce oczywiście trzeba najpierw podstawić $y=f(x)$, a następnie minimalizować czy maksymalizować względem $\boldsymbol{x} \in \boldsymbol{X}_{0}$. Odnośnie współczynników wagi często dodaje się dodatkowe wymaganie normalizacji:

$$
\sum_{\mathrm{i}=1, \ldots m} \alpha_{i}=1
$$

Jednakże wymaganie to ma raczej znaczenie teoretyczne; co więcej, jego zapis $\mathrm{w}$ powyższej postaci oznacza $\mathrm{w}$ istocie założenie, że wszystkie wskaźniki czy atrybuty $y_{i}$ mają ten sam wymiar fizyczny lub są bezwymiarowe (inaczej bowiem nie można sumować ich wartości $\mathrm{z}$ bezwymiarowymi współczynnikami wagi). Dlatego właśnie w zastosowaniach optymalizacji wielokryterialnej tak istotne są oszacowania zakresu zmienności poszczególnych atrybutów - i nie muszą one być przy tym bardzo dokładne, muszą tylko wystarczać do normalizacji zakresów zmienności tych atrybutów w skali bezwymiarowej. Pamiętać więc należy, że takie bezwymiarowe współczynniki wagi powinny być rozumiane jako współczynniki przy względnych wartościach przyrostów atrybutów, np. po ich podzieleniu przez oszacowania zakresów zmienności $y_{\mathrm{i}, \text { uto }}-y_{\mathrm{i} \text {,nad }}^{\sim}$ lub jakiegokolwiek innego oszacowania $y_{i, \max }-y_{i, \min }$. W stosunku do współczynników wagi we wzorze (8.1) oznacza to, że faktycznie mają one postać:

$$
\alpha_{i}=\alpha_{i} /\left(y_{i, \max }-y_{i, \min }\right), i=1, \ldots m
$$

gdzie $\alpha_{i}$ są już bezwymiarowymi współczynnikami wagi, do których można stosować wymaganie (8.2). Przy takim rozumieniu jasne jest też, że odwrotności współczynników wagi można interpretować też jako dany kierunek w przestrzeni rezultatów:

$$
d_{i}=1 / \alpha_{i}=\beta_{i}\left(y_{i, \text { max }}-y_{i, \text { min }}\right) ; \beta_{i}=1 / \alpha_{i} ; \boldsymbol{d}=\left(d_{1}, \ldots d_{i}, \ldots d_{m}\right)^{\mathrm{T}}
$$

Przy tych wszystkich zastrzeżeniach (które oczywiście stosują się też do liniowej funkcji $\left.s(y, \alpha)=\sum_{\mathrm{i}=1, \ldots m} \alpha_{i} y_{i}\right)$ będziemy nadal posługiwać się współczynnikami wagi tak, jak gdyby były one bezwymiarowe, pamiętając tylko o ich odpowiedniej interpretacji.

Twierdzenie 8.1. Jeśli $\boldsymbol{D}=\boldsymbol{R}^{m}, s(\boldsymbol{y}, \boldsymbol{\alpha})$ jest określone jak we wzorze (8.1), $\boldsymbol{y} \in \boldsymbol{Y}_{0, \text { uto }}, 1 \leq p<\infty, \alpha \in \boldsymbol{A}_{s}=$ Int $\boldsymbol{R}^{m}{ }^{\text {, }}$, to: 


$$
\operatorname{Argmin}_{y \in Y 0} s(\boldsymbol{y}, \boldsymbol{\alpha}) \subseteq \boldsymbol{Y}^{* p_{0}} \quad \forall \boldsymbol{\alpha} \in \boldsymbol{A}_{s}
$$

Odwrotnie, jeśli $\boldsymbol{y}^{*} \in \boldsymbol{Y}^{* p}{ }_{0}$, to dla dowolnego $\delta>0$ istnieje takie $\boldsymbol{y}^{-} \in \boldsymbol{Y}^{* p}{ }_{0}$, $\left\|\boldsymbol{y}^{-}-\boldsymbol{y}^{*}\right\|<\delta$, oraz takie $p \in[1 ; \infty)$ i takie $\boldsymbol{\alpha}^{-} \in \boldsymbol{A}_{s}$, że $\boldsymbol{y}^{-} \in \operatorname{Argmin}_{\boldsymbol{y} \in \mathrm{YO}} s\left(\boldsymbol{y}, \boldsymbol{\alpha}^{-}\right)$.

Nie podając tu pełnego dowodu tego twierdzenia (zob. np. Sawaragi 1979) zauważymy tylko, że jego pierwsza część może być uzyskana jako odpowiednio zmodyfikowany wniosek z twierdzenia 7.1, gdyż norma $l_{p}$ jest odpowiednio ściśle monotoniczna, jeśli jej argument jest ograniczony do $\boldsymbol{R}^{m}{ }_{+}$ - lub, jak w tym przypadku, do $-\boldsymbol{R}^{m}{ }$, ponieważ $\boldsymbol{y}^{\sim} \geq \boldsymbol{y} \forall \boldsymbol{y} \in \boldsymbol{Y}_{0}$, jeśli $\boldsymbol{y}^{\sim} \in \boldsymbol{Y}_{0, \text { uto. }}$. Natomiast dowód części drugiej, choć historycznie podany najpierw $\mathrm{w}$ innych terminach, jest ściśle związany $\mathrm{z}$ twierdzeniem 7.2 o rozdzielaniu stożka dodatniego od zbioru $\boldsymbol{Y}_{0}$. We wszystkich punktach regularnych $\boldsymbol{y}^{*} \in \boldsymbol{Y}^{* p_{0}}$, w których zbiór $\boldsymbol{Y}_{0}$ ma jednoznacznie określoną styczną, można dobrać taką funkcję $r(\boldsymbol{y})=s(\boldsymbol{y}, \boldsymbol{\alpha})$ (poprzez dobór odpowiednich $p$ i $\boldsymbol{\alpha}$ ), że jej zbiór poziomicowy rozdzieli $\boldsymbol{Y}_{0}$ i $\boldsymbol{y}^{*}+\operatorname{Int} \boldsymbol{D}_{\varepsilon}$ dla dowolnie małych $\varepsilon$, co ilustruje Rys. 8.1. Jednakże zbiór $\boldsymbol{Y}^{*}{ }_{0}$ może zawierać też izolowane punkty nieregularne $\boldsymbol{y}^{*}$, w których zbiór $\boldsymbol{Y}_{0}$ nie ma jednoznacznie określonej stycznej, i w których nie można rozdzielić $\boldsymbol{Y}_{0}$ i $\boldsymbol{y}^{*}+\operatorname{Int} \boldsymbol{D}_{\varepsilon}$ za pomocą różniczkowalnej funkcji $r(\boldsymbol{y})=s(\boldsymbol{y}, \boldsymbol{\alpha})$ dla jakiegokolwiek $\boldsymbol{\alpha}$ czy $p$; z drugiej strony, $\mathrm{w}$ dowolnie małym otoczeniu takiego nieregularnego $y^{*} \in \boldsymbol{Y}^{*}{ }_{0}$ znajdują się regularne punkty $\boldsymbol{y}^{-} \in \boldsymbol{Y}^{*}{ }_{0}$.

Twierdzenie 8.1 nie zakłada wypukłości zbioru $\boldsymbol{Y}_{0}$, a więc funkcja skalaryzująca (8.1) ma znacznie większy obszar zastosowań, niż liniowa funkcja skalaryzująca. Jednakże warunki konieczne sprawności w tym twierdzeniu nie są dostatecznie konstruktywne, nie jest też łatwe sterowanie wyborem $\boldsymbol{y}^{*} \in \boldsymbol{Y}_{0}{ }^{* p}$ za pomocą współczynników wagi. Użytkownikowi systemu wspomagania decyzji czy wielokryterialnej analizy modelu trudno bowiem ocenić, w jakim stopniu powinien on zmienić współczynniki wagi, aby uzyskać pożądaną zmianę rezultatu $y^{*}$. Można też próbować wykorzystać do sterowania dodatkowy parametr - punkt odniesienia $\boldsymbol{y}^{\sim}$ - ale sterowanie tym wyborem za jego pomocą też nie jest łatwe, gdyż z założenia jest on nader odległy od zbioru $Y_{0}$. Wady te można usunąć stosując normę $l_{\infty}$ lub jej modyfikacje. 


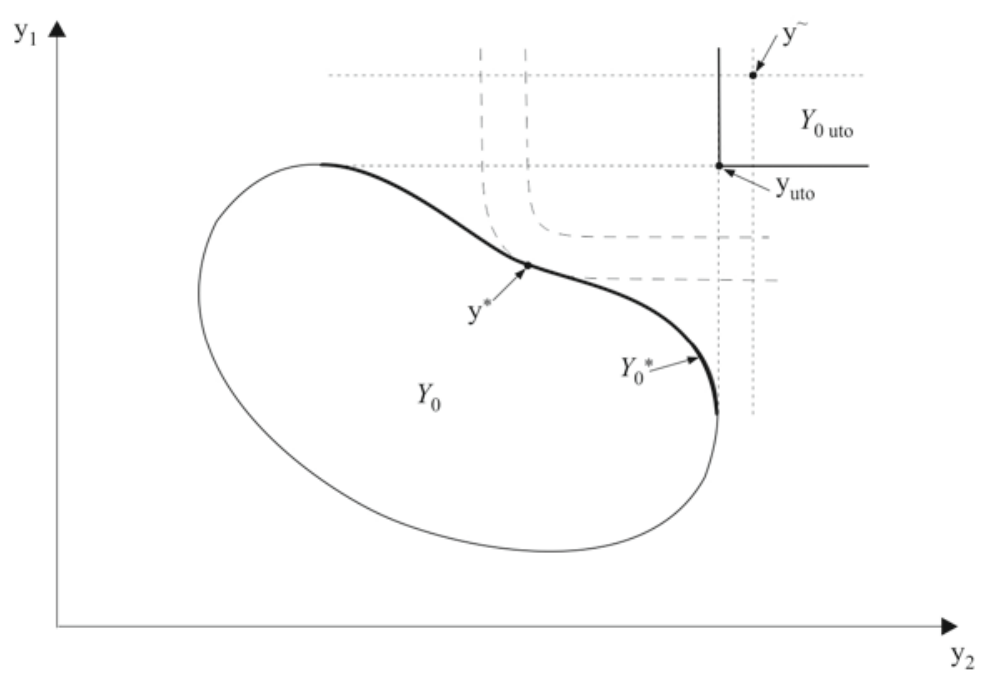

Rys. 8.1. Istnienie funkcji skalaryzującej skonstruowanej za pomocą normy $l_{p}$ rozdzielającej zbiór $\boldsymbol{Y}_{0}$ i stożek $\boldsymbol{y}^{-}+\boldsymbol{D}_{\boldsymbol{\varepsilon}}$.

\subsection{Norma Czebyszewa jako funkcji skalaryzująca}

Jeśli $p=\infty$, to w sposób analogiczny do (8.1) można zdefiniować następującą funkcję skalaryzującą:

$$
s(\boldsymbol{y}, \boldsymbol{\alpha})=\max _{1 \leq i \leq \mathrm{m}} \alpha_{i}\left|\tilde{y}_{i}-y_{i}\right| ; \boldsymbol{y}^{\sim} \in \operatorname{Int} \boldsymbol{Y}_{0, u t o}, \boldsymbol{\alpha} \in \boldsymbol{A}_{s}=\operatorname{Int} \boldsymbol{R}^{m}{ }_{+}
$$

Dodatkowe ograniczenie, że $\tilde{y}^{\sim} \in$ Int $\boldsymbol{Y}_{0, u t o}$, jest niezbędne ze względu na kształt zbiorów poziomicowych funkcji (8.6), które mogą mieć części równoległe do osi współrzędnych, zob. Rys.8.2.

Twierdzenie 8.2. Jeśli $s(\boldsymbol{y}, \boldsymbol{\alpha})$ jest określone jak we wzorze (8.6), $\boldsymbol{\alpha} \in \boldsymbol{A}_{s}=$ Int $\boldsymbol{R}^{m}+$ i $\tilde{\boldsymbol{y}} \tilde{\sim}$ Int $\boldsymbol{Y}_{0, \text { uto }}$, to:

$$
\operatorname{Argmin}_{\boldsymbol{y} \in \mathrm{Y} 0} s(\boldsymbol{y}, \boldsymbol{\alpha}) \subseteq \boldsymbol{Y}^{* w_{0}} \forall \boldsymbol{\alpha} \in \boldsymbol{A}_{s}
$$

Jeśli to minimum jest jednoznaczne, to:

$$
\operatorname{argmin}_{\mathbf{y \in} \mathbf{Y} 0} s(\boldsymbol{y}, \boldsymbol{\alpha}) \subseteq \boldsymbol{Y}_{0}^{*} \forall \boldsymbol{\alpha} \in \boldsymbol{A}_{s}
$$

Odwrotnie, jeśli $\boldsymbol{y}^{*} \in \boldsymbol{Y}^{*}{ }_{0}$, to istnieje takie $\boldsymbol{\alpha}^{*} \in \boldsymbol{A}_{s}$, że $\boldsymbol{y}^{*} \in \operatorname{Argmin}_{y \in Y 0} s\left(\boldsymbol{y}, \boldsymbol{a}^{*}\right)$; jeśli $\boldsymbol{y}^{*} \in \boldsymbol{Y}_{0}^{*}$, to istnieje takie $\boldsymbol{\alpha}^{*} \in \boldsymbol{A}_{s}$, że $\boldsymbol{y}^{*}=\operatorname{argmin}_{\boldsymbol{y} \in \mathrm{Y} 0} s\left(\boldsymbol{y}, \boldsymbol{\alpha}^{*}\right)$, gdzie odpowiednie minimum jest jednoznaczne. 
Ćwiczenie 8.1: udowodnić powyższe twierdzenie na podstawie twierdzeń 7.1 i 7.2 .

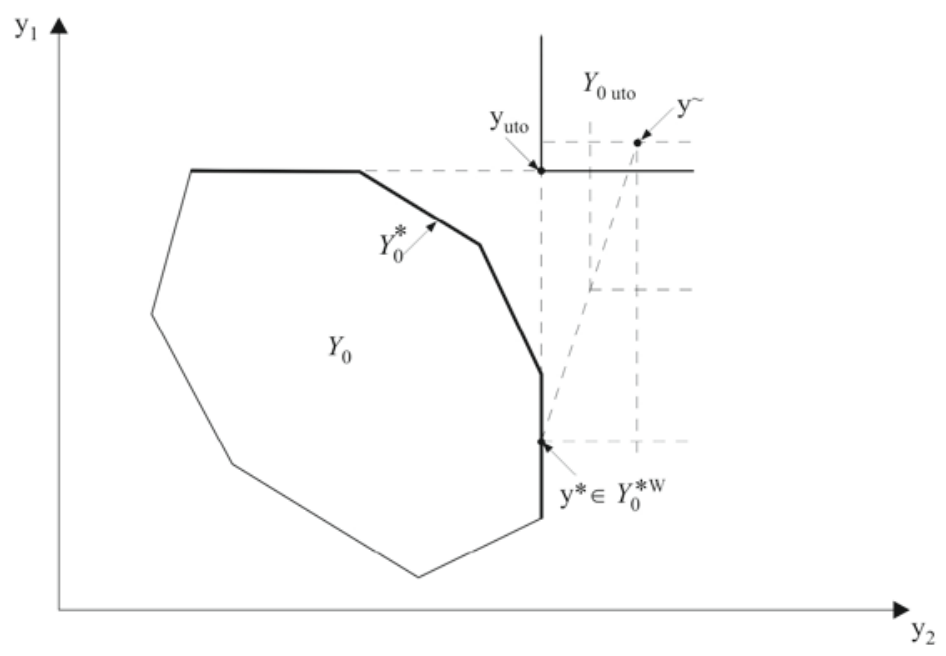

Rys. 8.2. Zbiory poziomicowe funkcji skalaryzującej (8.6) i uzyskiwanie rezultatów słabo sprawnych przy jej minimalizacji.

Twierdzenie powyższe może być stosowane dla charakteryzacji rozwiązań sprawnych, jeśli zapewnimy jednoznaczność minimum (8.6) np. za pomocą optymalizacji leksykograficznej - sprawdzającej nie tylko minimum największego z $\alpha_{i}\left|\tilde{y}_{i}-y_{i}\right|$, ale także dalszych $\alpha_{j}\left|y_{j}^{\tilde{j}_{j}}-y_{j}\right|$, jeśli minimum dla największego $\alpha_{i}\left|\tilde{y}_{i}-y_{i}\right|$ jest osiągnięte i może być niejednoznaczne. Jednym ze sposobów optymalizacji funkcji typu (8.6) jest jej zastąpienie zmienną sztuczną, np. $z \in \boldsymbol{R}^{1}$, oraz $m$ nierównościami o postaci $z \geq \alpha_{i}\left(\tilde{y}_{i}-y_{i}\right) \forall i=1, \ldots m$ (skoro z założenia $\tilde{y}_{i}>y_{i}$, to możemy pominąć znaki wartości bezwzględnej), a następnie minimalizacja zmiennej z; optymalizacja leksykograficzna jest nieco bardziej skomplikowanym sposobem podobnych obliczeń.

Istotne uogólnienie optymalizacji leksykograficznej zaproponował Ronald Yager (1988) jako metodę OWA (ordered weighted averaging), polegającą na przydzielaniu współczynników wagi $\alpha_{i}$ nie do określonych kryteriów $y_{i}$, lecz do kryteriów uporządkowanych według ich wielkości, a raczej do odchyleń $\left(y_{i}-y_{i}\right)$ tak uporządkowanych, z największym współczynnikiem wagi dla największego odchylenia i kolejno malejącymi współczynnikami wagi dla 
malejących odchyleń. Pozwala to na uogólnienie i ulepszenie zastosowania funkcji skalaryzującej (8.6) i stanowi jeden z najbardziej obiecujących kierunków rozwoju optymalizacji wielokryterialnej, zob. (Włodzimierz Ogryczak 1997, 2000), (Włodzimierz Ogryczak i Tomasz Śliwiński (2003).

Trudność w sterowaniu rezultatami sprawnymi za pomocą współczynników wagi $\alpha_{i}$ można zmniejszyć stosując metodę zaproponowaną przez Ralpha Steuera (zob. np. Steuer 1986), polegającą w swej istocie na wyrażeniu współczynników wagi jako funkcji dodatkowych poziomów aspiracji $\boldsymbol{y}^{-}<\boldsymbol{y}^{\sim}$ :

$$
\alpha_{i}=\left(\left(\tilde{y}_{i}-y_{i, m i n}\right) /\left(\tilde{y}_{i}^{\sim}-y_{i}^{-}\right)\right) /\left(\sum_{j=1, \ldots m}\left(\tilde{y}_{j}^{\sim}-y_{j, m i n}\right) /\left(\boldsymbol{y}_{j}^{\sim}-\boldsymbol{y}_{j}^{-}\right)\right)
$$

gdzie jako $y_{i, \min }$ może być np. stosowane oszacowanie $\tilde{y}_{i, \text { nad }}$, zobacz rozdział poprzedni. Taka zależność współczynników wagi od poziomów aspiracji $\boldsymbol{y}^{-}$ ma następującą interpretację: jeśli użytkownik przykłada większe znaczenie do danego atrybutu, to określa odpowiedni poziom aspiracji bliżej do punktu idealnego ( $\mathrm{w}$ sensie względnym, odnosząc to do całego oszacowania przedziału zmienności danego atrybutu). Okazuje się, że takie właśnie przekształcenie czyni funkcję skalaryzującą (8.6) znacznie bardziej dogodną dla użytkownika i znacznie ułatwia sterowanie rezultatami sprawnymi, zob. Rys. 8.3.

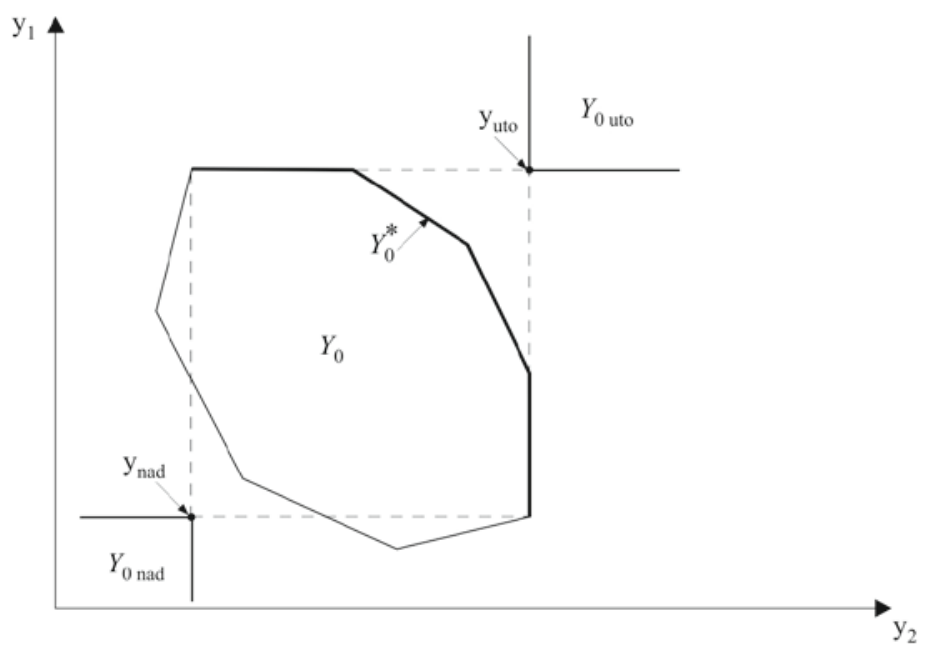

Rys. 8.3. Rozsądne ograniczenia poziomów aspiracji $y^{-}$przez $\boldsymbol{y}_{\text {uto }}$ oraz $\boldsymbol{y}_{\text {nad }}$. 
Oznacza to jednak w istocie sterowanie wyborem rezultatu sprawnego nie za pomocą współczynników $\alpha_{i}$, tylko za pomocą poziomów aspiracji $\boldsymbol{y}_{i}^{-}$, wpływających na $\alpha_{i}$ w dość złożony, nieliniowy sposób jak w (8.9). Jeśli natomiast potraktować funkcję skalaryzującą nie jako funkcję zależną od parametrów $\alpha_{\mathrm{i}}$, tylko - po podstawieniu (8.9) - jako funkcję zależną od parametrów $\boldsymbol{y}_{i}^{-}$, to staje się ona przykładem innego typu funkcji skalaryzujących, wzmiankowanych wcześniej funkcji osiągnięcia, które omawiamy szczegółowo w rozdziale następnym.

\subsection{Uzupelniona norma Czebyszewa jako funkcja skalaryzująca}

Pewną wadą normy Czebyszewa jako funkcji skalaryzującej jest fakt, że przedziałami liniowe granice jej zbiorów poziomicowych są równoległe do osi współrzędnych, nie są nachylone - a więc nie można za jej pomocą scharakteryzować rezultatów właściwie sprawnych z ograniczonymi a priori współczynnikami wymiany. Wadę tę można usunąć poprzez uzupełnienie tej normy, to jest dodanie do niej niewielkiego składnika o charakterze normy $l_{1}$; powstaje wtedy norma mieszana $l_{1, \infty}$, podobnie jak w definicji stożka $\boldsymbol{D}_{\varepsilon}$. Odpowiednia funkcja skalaryzująca ma wtedy postać:

$$
\begin{aligned}
& s(\boldsymbol{y}, \boldsymbol{\alpha})=\max _{i=1, \ldots m} \alpha_{i}\left|\tilde{y}_{i}-y_{i}\right|+\alpha_{m+1} \Sigma_{i=1, \ldots m} \alpha_{i}\left|\tilde{y}_{i}-y_{i}\right| \\
& \boldsymbol{y}^{\sim} \in \operatorname{Int} \boldsymbol{Y}_{0, u t o}, \boldsymbol{\alpha \in} \boldsymbol{A}_{s}=\operatorname{Int} \boldsymbol{R}^{m}{ }_{+}
\end{aligned}
$$

gdzie $\alpha_{m+1}>0$ jest małą liczbą ${ }^{1}$. Jeśli przyjąć $\alpha_{m+1}=\varepsilon, \alpha_{i}=1 / m \forall i=1, \ldots m$, to wtedy zbiory poziomicowe funkcji (8.10) w przypadku $\boldsymbol{y}<\boldsymbol{y}^{\sim}$ - co dla $\boldsymbol{y} \in \boldsymbol{Y}_{0}$ oraz $\boldsymbol{y}^{\sim} \in \operatorname{Int} \boldsymbol{Y}_{0, \text { uto }}$ wynika z definicji $\boldsymbol{Y}_{0, \text { uto }}$ - pokrywają się w istotnym zakresie, zobacz Rys. 8.4, ze zbiorami $\boldsymbol{y}^{-}+\boldsymbol{D}_{\varepsilon}$ dla odpowiednio dobranego $\boldsymbol{y}^{-}$. Później pokażemy, że odpowiedni wybór $\boldsymbol{y}^{-}$może być związany z przekształceniem

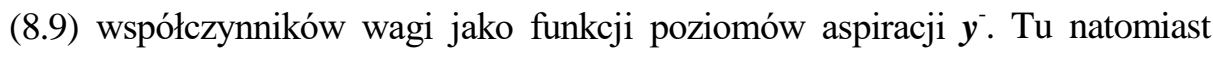
najbardziej istotna jest inna własność, wynikająca $\mathrm{z}$ interpretacji przedstawionej na Rys. 8.4: funkcję (8.10) można zastosować, przy $\alpha_{m+1}=\varepsilon$, $\alpha_{i}=1 / m \forall i=1, \ldots m$, do rozdzielania zbioru $\boldsymbol{Y}_{0}$ i stożka $\boldsymbol{y}^{-}+\boldsymbol{D}_{\varepsilon}$.

\footnotetext{
${ }^{1} \mathrm{~W}$ pewnym sensie, funkcja skalaryzująca (8.10) jest podobna do metody OWA (ordered weighted average), ale wymaga określenia odrębnego współczynnika wagi tylko dla największego odchylenia $\tilde{y}_{i}^{\sim}-y_{i}$ oraz dla sumy pozostałych odchyleń.
} 
Własności funkcji (8.10) badali pierwsi Werner Dinkelbach i Heinz Isermann (1976). Następujące twierdzenie wzmacnia nieco uzyskane przez nich wyniki, gdyż oparte jest na wykorzystaniu twierdzeń 7.1, 7.2 oraz oszacowaniu stożka sprzężonego do $\boldsymbol{D}_{\varepsilon}$ (podobnie jak w twierdzeniu 7.3):

Twierdzenie 8.3. Jeśli $\boldsymbol{D}=\boldsymbol{R}^{m}{ }_{+}, s(\boldsymbol{y}, \boldsymbol{\alpha})$ jest określone jak we wzorze (8.10), $\boldsymbol{\alpha} \in \boldsymbol{A}_{s}=\operatorname{Int} \boldsymbol{R}^{m}{ }_{+}, \boldsymbol{y}^{\sim} \in \operatorname{Int} \boldsymbol{Y}_{0, \text { uto }}$ oraz $\alpha_{m+1}=\varepsilon>0$, to:

$$
\operatorname{Argmin}_{y \in Y 0} s(\boldsymbol{y}, \boldsymbol{\alpha}) \subseteq \boldsymbol{Y}^{* p \varepsilon}{ }_{0} \forall \boldsymbol{\alpha} \in A_{s}
$$

gdzie $\boldsymbol{Y}_{0}^{* p \varepsilon}$ określone jest względem stożka $\boldsymbol{D}_{\varepsilon}$ jak w rozdziale poprzednim przy dodatkowym założeniu, że wszystkie rezultaty $\boldsymbol{y}_{i}$ są ważone ze współczynnikami $\alpha_{i}$. Odwrotnie, jeśli $\boldsymbol{y}^{*} \in \boldsymbol{Y}^{* p \varepsilon}{ }_{0}$ określonego w taki właśnie sposób, to istnieje takie $\alpha^{*} \in A_{s}$, że:

$$
\boldsymbol{y}^{*} \in \operatorname{Argmin}_{\mathbf{y} \in \mathbf{Y 0}} s\left(\boldsymbol{y}, \boldsymbol{\alpha}^{*}\right) \forall \alpha_{m+1} \leq \varepsilon
$$

przy czym współczynniki wymiany (względne wobec współczynników wagi $\left.\alpha_{i}, \alpha_{j}\right) t_{i j}\left(y^{*}\right) \leq M=1+1 / \varepsilon, \forall i, j=1, \ldots m$.

Twierdzenie powyższe jest niezwykle silne - charakteryzuje ono najbardziej istotne dla zastosowań rezultaty (a zatem i decyzje) właściwie $\varepsilon$-sprawne, i to niezależnie od wypukłości zbioru $\boldsymbol{Y}_{0}$, czy regularności punktu $\boldsymbol{y}^{*} \in \boldsymbol{Y}^{*}{ }_{0}$. Ten ostatni aspekt związany jest z faktem, że funkcja (8.10) jest wprawdzie nieróżniczkowalna, ale właśnie dlatego rozdziela zbiór $\boldsymbol{Y}_{0}$ i stożek $\boldsymbol{y}^{*}+$ Int $\boldsymbol{D}_{\varepsilon}$ także w nieregularnych punktach $\boldsymbol{y}^{*} \in \boldsymbol{Y}^{*}{ }_{0}$. Konstruktywne zastosowanie tego twierdzenia wymaga jednak wykorzystania przekształcenia (8.9) czyli uzależnienia współczynników wagi od poziomów aspiracji - i to zarówno w praktyce, przy sterowaniu wyborem $\boldsymbol{y}^{*} \in \boldsymbol{Y}^{* p \varepsilon}{ }_{0}$ za pomocą poziomów aspiracji $y^{-}$, jak i w teorii. Np. przy dowodzie drugiej, odwrotnej części twierdzenia 8.3 trzeba przyjąć dany $\boldsymbol{y}^{*} \in \boldsymbol{Y}^{*}{ }_{0}{ }_{0}$ jako punkt aspiracji, $\boldsymbol{y}^{-}=\boldsymbol{y}^{*}$, a następnie obliczyć odpowiadające mu współczynniki wagi według wzoru (8.9). Tak więc lepiej traktować funkcję typu (8.10) jako zależną od poziomów aspiracji, nie od współczynników wagi, co jednak omówimy bardziej szczegółowo w rozdziale następnym. 


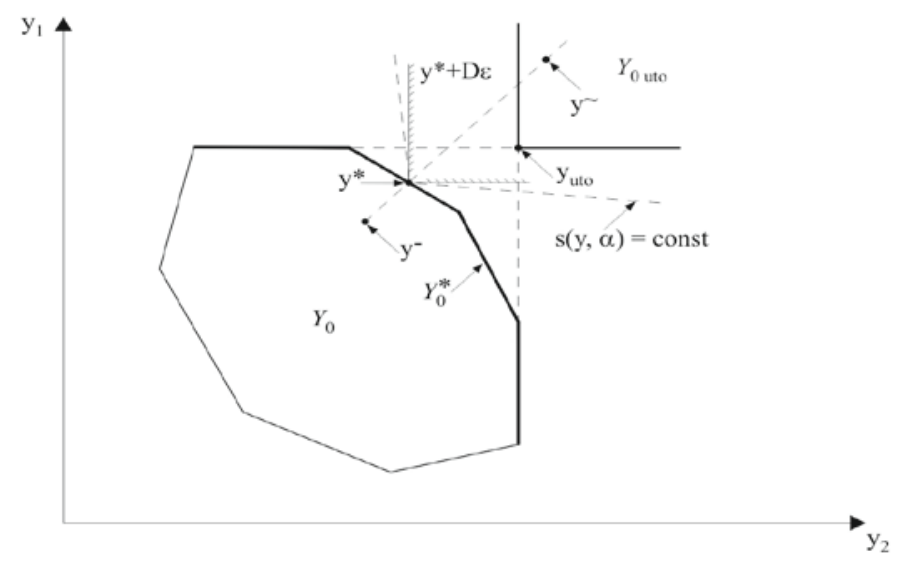

Rys. 8.4. Zbiory poziomicowe uzupełnionej normy Czebyszewa a stożki $\boldsymbol{y}^{-}+\boldsymbol{D}_{\varepsilon}$

Istnieje jeszcze kilka innych form funkcji skalaryzujących, w których głównym parametrem sterującym są współczynniki wagi, a nie poziomy odniesienia - chociaż, jak wykazaliśmy, poziomy odniesienia odgrywają też pewną rolę w przypadku funkcji wykorzystujących współczynniki wagi i trudno tu podać ostrą granicę. Poniższa klasa metod może być włączona do obu wspomnianych wyżej grup.

\subsection{Poszukiwania kierunkowe jako metoda optymalizacji wektorowej}

Zgodnie ze wzorem (8.4), odwrotności współczynników wagi mogą być interpretowane jako współrzędne pewnego kierunku $\boldsymbol{d} \in \boldsymbol{R}^{m}{ }_{+}$. W związku $\mathrm{z}$ tym naturalną jest idea, by potraktować dany ponadutopijny punkt $\boldsymbol{y}^{\sim} \in \boldsymbol{Y}_{0, \text { uto }}-\mathrm{a}$ W szczególności $\boldsymbol{y}^{\sim}=\boldsymbol{y}_{\text {uto }}-$ jako swojego rodzaju punkt obserwacji rezultatów sprawnych, a dany kierunek $\boldsymbol{d} \in \boldsymbol{R}^{{ }}{ }_{+}-$jako kierunek promienia światła prowadzącego od punktu sprawnego do oka obserwatora; odwrotnie, z punktu $\boldsymbol{y}^{\sim}$ będzie to oczywiście kierunek - $\boldsymbol{d}$. Interpretacja taka uzasadnia stosowaną niekiedy nazwę „metoda promienia świetlnego" (ang. light-beam search method). Trzeba jednak zdawać sobie sprawę, że metody takie - poszukiwania kierunkowego - były stosowane już bardzo dawno i wielokrotnie odkrywane na nowo, przy czym kryją one w sobie pewną pułapkę teoretyczną, którą można wprawdzie ominąć, ale trzeba ją dostrzegać. 
Pułapkę tę ilustruje pytanie: „W jakich warunkach obserwator, stojący np. w punkcie utopijnym, będzie dostrzegał wszystkie rezultaty sprawne i tylko rezultaty sprawne?" Jeśli obserwator stanie dalej, w punkcie ponadutopijnym, to oczywiście dostrzegał będzie także pewne rezultaty niesprawne; jeśli stanie bliżej, ,poniżej” punktu utopijnego, to oczywiście może nie dostrzec (ze względu na założony kierunek promieni światła) niektórych punktów sprawnych. Ale jeśli stoi dokładnie w punkcie utopijnym?

Otóż intuicja oparta na przypadku $m=2$ i wypukłym zbiorze $\boldsymbol{Y}_{0}$ podsuwa nam odpowiedź, że w takim przypadku obserwował będzie wszystkie rezultaty sprawne i tylko rezultaty sprawne. Pułapka polega zaś na tym, że odpowiedź taka jest prawdziwa tylko przy wypukłym zbiorze $\boldsymbol{Y}_{0}$ i $m=2$. Jeśli $\boldsymbol{Y}_{0}$ nie jest zbiorem wypukłym, to nawet dla $m=2$ zbiór $\boldsymbol{Y}_{0}^{*}$ może być niespójny, „mieć przerwy” - a obserwator będzie widział brzeg $\boldsymbol{Y}_{0} \mathrm{w}$ tych przerwach $\boldsymbol{Y}_{0}^{*}$. Jeśli zaś $\boldsymbol{Y}_{0}$ jest zbiorem wypukłym, ale $m>2$, to łatwo wskazać przypadki, gdy obserwator będzie widział poza punktami sprawnymi także punkty niesprawne. Na przykład, wyobraźmy sobie oko obserwatora ulokowane w górnym rogu pokoju i jako wypukły zbiór $\boldsymbol{Y}_{0}$ piłkę przytkniętą do ścian pokoju w tym rogu. Czy z rogu pokoju widoczne będą tylko punkty sprawne (względem $\boldsymbol{D}=\boldsymbol{R}^{m}{ }_{+}$) tej piłki? Łatwo sprawdzić, że jednak nie, widoczne będą (w obszarach „pomiędzy ścianami”) także punkty niesprawne.

Metoda poszukiwań kierunkowych polega na rozpatrywaniu promieni $\boldsymbol{y}^{\sim}-\tau \boldsymbol{d} i, \quad \tau \geq 0, \boldsymbol{d} \in \boldsymbol{R}^{m}{ }_{+}$oraz pierwszych ich punktów przecięcia (dla najmniejszego $\tau$ ) ze zbiorem $\boldsymbol{Y}_{0}$; jednakże, jak wynika z poprzedniej dyskusji, metoda ta może być co najwyżej rozpatrywana jako sposób nadmiarowego przeglądu rezultatów sprawnych. Jeśli punkt $\boldsymbol{y}^{\sim} \in \boldsymbol{Y}_{0, \text { uto, }}$, to łatwo wykazać, że widoczne $\mathrm{z}$ niego będą wszystkie rezultaty sprawne; ale każdy $\mathrm{z}$ takich rezultatów widocznych trzeba sprawdzać dodatkowo inną metodą, czy jest to rezultat sprawny.

\subsection{Metoda poziomów rezerwacji i dodatkowych ograniczeń}

Równie naturalnym i starym, jak metoda poszukiwań kierunkowych, podejściem do optymalizacji wektorowej jest metoda oparta na określaniu minimalnych poziomów akceptacji - zwanych poziomami rezerwacji $\boldsymbol{y}^{--}$ - dla wszystkich (być może, z wyjątkiem jednego) atrybutów czy rezultatów oraz zastąpieniu ich optymalizacji odpowiednimi ograniczeniami. W odróżnieniu od poszukiwań kierunkowych, które można interpretować jako 
sterowanie za pomocą wyboru kierunku czyli odwrotności współczynników wagi, metoda poziomów rezerwacji opiera się na sterowaniu za pomocą zmiany punktu odniesienia, którym w tym przypadku jest punkt rezerwacji $\boldsymbol{y}^{--}$. Metodę tę zbadali Yacov Haimes i Warren Hall (1974), choć to w istocie metoda jeszcze starsza. Istotnym aspektem tej metody jest uwypuklenie interakcji z użytkownikiem (opartej na zmianach poziomów rezerwacji przez użytkownika).Trzeba tu dodać, że do dzisiaj wiele przeglądowych podejść do optymalizacji wektorowej (np. Anas Alfaris 2015, Matlab 2015) niedostatecznie uwypukla znaczenie interakcji z użytkownikiem.

Za funkcję skalaryzującą $\mathrm{w}$ metodzie poziomów rezerwacji możemy uważać wybrany rezultat $y_{j}$; ograniczenia odnoszą się wtedy do pozostałych rezultatów:

$$
s_{j}\left(\boldsymbol{y}, \boldsymbol{y}^{--}\right)=y_{j} ; \boldsymbol{y} \in \boldsymbol{Y}_{0 j}\left(\boldsymbol{y}^{--}\right)=\left\{\boldsymbol{y} \in \boldsymbol{Y}_{0}: y_{i} \geq y^{--} \forall i \neq j\right\}
$$

przy czym zakładamy tu, jak poprzednio, że $\boldsymbol{D}=\boldsymbol{R}^{m}{ }$, czyli wszystkie atrybuty są maksymalizowane (w przypadku minimalizacji wystarczy zmienić znak ograniczeń, przypadek stabilizacji trzeba traktować jak ograniczenie równościowe twarde). Własności tej metody ujmuje następujące twierdzenie:

Twierdzenie 8.4. Załóżmy, że $\boldsymbol{D}=\boldsymbol{R}^{m}{ }_{+}, s_{j}\left(\boldsymbol{y}, \boldsymbol{y}^{--}\right)$oraz zbiory $\boldsymbol{Y}_{0 j}\left(\boldsymbol{y}^{--}\right)$ są określone jak w (8.13). Dla dowolnego $j=1, \ldots m$ oraz dowolnego $\boldsymbol{y}^{--} \in \boldsymbol{y}_{\text {uto }}-\boldsymbol{D}$, punkty maksymalne funkcji $s_{j}\left(\boldsymbol{y}, \boldsymbol{y}^{--}\right)$względem $\boldsymbol{y} \in \boldsymbol{Y}_{0}$ są słabo sprawne:

$$
\operatorname{Argmax}_{\boldsymbol{y} \in \mathbf{Y} 0 j\left(y_{--}\right)} s_{j}\left(\boldsymbol{y}, \boldsymbol{y}^{--}\right) \subseteq \mathbf{Y}_{0}^{* w}
$$

Jeśli powyższe minimum jest jednoznaczne $\mathrm{w}$ sensie minimalizacji wszystkich rezultatów \$y_\$, tj. jeśli:

$$
\boldsymbol{y}^{*} \in \operatorname{argmax}_{\boldsymbol{y} \in \mathbf{Y} 0 j\left(y_{--)}\right.} s_{j}\left(\boldsymbol{y}, \boldsymbol{y}^{--}\right) \forall j=1, \ldots m
$$

to wtedy $\boldsymbol{y}^{*} \in \boldsymbol{Y}_{0}{ }^{*}$, czyli jest to rezultat sprawny. Odwrotnie, jeśli $\boldsymbol{y}^{*} \in \boldsymbol{Y}_{0}{ }^{*}$, to istnieje takie $j=1, \ldots m$ oraz takie $\boldsymbol{y}^{--} \in \boldsymbol{y}_{\text {uto }}-\boldsymbol{D}$, że:

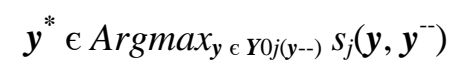

Jeśli natomiast $\boldsymbol{y}^{*} \in \boldsymbol{Y}_{0}{ }^{*}$, to istnieje takie $\boldsymbol{y}^{--} \in \boldsymbol{y}_{\text {uto }}-\boldsymbol{D}$ (dokładniej mówiąc, wystarczy wziąć $\left.\boldsymbol{y}^{--} \in \boldsymbol{y}^{*}\right)$, że zachodzi (8.15).

Dowód tego twierdzenia na podstawie twierdzeń 7.1 i 7.2 jest stosunkowo łatwy i pozostawiamy go jako ćwiczenie. 
Metoda ta jest w istocie podobna do metody opartej na normie Czebyszewa: daje ona pełną charakteryzację rozwiązań sprawnych, ale generuje rozwiązania słabo sprawne, jeśli nie przeprowadzi się dodatkowych optymalizacji (przy odpowiednich modyfikacjach, nie trzeba powtarzać optymalizacji $m$ razy, wystarczy specjalna wersja optymalizacji leksykograficznej). Nawet przy dodatkowych obliczeniach optymalizacyjnych, metoda ta w swej oryginalnej postaci nie pozwala - podobnie jak norma Czebyszewa - wprowadzić ograniczeń a priori na współczynniki wymiany. Natomiast jej nazwa angielska (Surrogate Worth Trade-off Method) związana jest z faktem, że stosunek współczynników Lagrange’a - obliczanych w niektórych metodach optymalizacji - dla ograniczeń na odpowiednie kryteria może posłużyć do estymacji współczynników wymiany dla tych kryteriów.

Inną wadą tej metody - nawet w porównaniu z normą Czebyszewa - jest fakt, że ograniczenia na kolejne atrybuty są traktowane jako ograniczenia twarde; jeśli więc przypadkiem użytkownik określi nieosiągalny punkt rezerwacji, to zbiór $\boldsymbol{Y}_{0 j}\left(\boldsymbol{y}^{--}\right)$może okazać się pusty i optymalizacja zawiedzie. Obydwu tym wadom można zapobiec, wprowadzając funkcje kary za przekroczenie ograniczeń $y_{i} \geq y^{--}$i czyniąc $z$ nich tym samym ograniczenia miękkie; ale podejście takie staje się wtedy równoważne podejściu ogólnemu opartemu na funkcji osiągnięcia, omawianemu szczegółowo w następnym rozdziale.

\subsection{Metody programowania celowego (goal programming)}

Jak już wspominaliśmy wcześniej, bardzo popularne w rozmaitych zastosowaniach - w badaniach operacyjnych i wspomaganiu decyzji - są stosunkowo proste metody oparte na poszukiwaniu minimum normy odległości nie od punktu ponadutopijnego, ale od dowolnego punktu aspiracji traktowanego jako punkt odniesienia. Metody te wprowadzone były przez Abrahama Charnes'a i Williama Cooper'a (1977) i rozwijane przez wielu innych badaczy. Stosuje się w nich niekoniecznie normę $l_{p}$, jak w równaniu (8.1), lecz zazwyczaj normę $l_{1}$ :

$$
s\left(\boldsymbol{y}, \boldsymbol{y}^{-}\right)=\sum_{\mathrm{i}=1, \ldots m} \alpha_{i}\left|y_{i}^{-}-y_{i}\right|, \boldsymbol{y}^{-} \in \boldsymbol{R}^{m}, \boldsymbol{\alpha} \in \boldsymbol{A}_{s}=\operatorname{Int} \boldsymbol{R}^{m}{ }_{+}
$$

przy czym zwykle - jeśli model wyrażony jest przez równania i nierówności liniowe, tak jak dla wielokryterialnego programowania liniowego - zadanie optymalizacji funkcji $s\left(\boldsymbol{y}, \boldsymbol{y}^{-}\right)$względem $\boldsymbol{y} \in \boldsymbol{Y}_{0}$ można zastąpić, przez wprowadzenie zmiennych sztucznych i dodatkowych ograniczeń, zadaniem programowania liniowego. Zauważmy, że funkcja (8.17) różni się od (8.1) 
nie tylko wyborem $p=1$ oraz dowolnego (niekoniecznie ponadutopijnego) punktu odniesienia, ale też traktowaniem tego właśnie punktu odniesienia jako podstawowy parametr sterujący; współczynniki wagi $\boldsymbol{\alpha}$ mogą być natomiast wykorzystywane jako dodatkowy parametr sterujący.

Metody programowania celowego są bardzo poglądowe i proste koncepcyjnie, stąd znajdują szerokie zastosowanie. Mają jednak one podstawową, wspomnianą już wcześniej wadę: nie gwarantują uzyskania rozwiązań sprawnych. Jeśli bowiem $\boldsymbol{y}^{-} \in \boldsymbol{Y}_{0}$ jest rezultatem osiągalnym, to minimum funkcji $s\left(\boldsymbol{y}, \boldsymbol{y}^{-}\right)$względem $\boldsymbol{y} \in \boldsymbol{Y}_{0}$ osiąga się dla $\boldsymbol{y}^{*}=\boldsymbol{y}^{-}$, przy czym ogólnie biorąc oczywiście $\boldsymbol{y}^{*}-\epsilon \boldsymbol{Y}_{0}^{*}$. Osiągnięcie rezultatów sprawnych można $\mathrm{w}$ tej metodzie zagwarantować tylko wtedy, jeśli $\boldsymbol{y}^{-}-\epsilon \boldsymbol{Y}_{0}, \boldsymbol{Y}_{0}$ jest zbiorem wypukłym i przy dodatkowych założeniach, sprowadzających się faktycznie do uprzedniej znajomości $\boldsymbol{Y}_{0}$ lub do przeprowadzenia szeregu prób optymalizacji, jak to wynika z następującego twierdzenia:

Twierdzenie 8.5. Załóżmy, że $\boldsymbol{D}=\boldsymbol{R}^{m}{ }_{+}, s\left(\boldsymbol{y}, \boldsymbol{y}^{-}\right)$jest określone jak we wzorze (8.17), $\boldsymbol{\alpha} \in \boldsymbol{A}_{s}=$ Int $\boldsymbol{R}^{m}{ }_{+}$, i albo $\boldsymbol{Y}_{0}$ jest zbiorem wypukłym, albo $\boldsymbol{y}^{-} \in \boldsymbol{Y}_{0}^{*}+\boldsymbol{D}=\cup_{\boldsymbol{y}^{*} \in \mathbf{Y}^{*} 0}\left\{\boldsymbol{y}^{*}+\boldsymbol{D}\right\}$. Jeśli:

$$
\boldsymbol{y}^{*} \in \operatorname{Argmin}_{\boldsymbol{y} \in \mathbf{Y} 0} s\left(\boldsymbol{y}, \boldsymbol{y}^{-}\right) \text {i } \boldsymbol{y}^{*} \in \boldsymbol{y}^{-}-\text {Int } \boldsymbol{D} \text {, }
$$

to $\boldsymbol{y}^{*} \in \boldsymbol{Y}_{0}{ }^{*}$. Odwrotnie, jeśli $\boldsymbol{y}^{*} \in \boldsymbol{Y}_{0}{ }^{*}{ }^{*}$, to istnieje takie $\boldsymbol{y}^{-}$, że zachodzi (8.18).

Pominiemy tu dowód tego twierdzenia (zob. np. Wierzbicki, 1986). $\mathrm{Z}$ twierdzenia tego wynika, że jeśli $\mathrm{w}$ wyniku programowania celowego osiągniemy $\boldsymbol{y}^{*}-\epsilon \boldsymbol{y}^{-}-$Int $\boldsymbol{D}$ (w szczególności np. $\boldsymbol{y}^{*}=\boldsymbol{y}^{-}$) i tym samym nie możemy wnioskować o sprawności $\boldsymbol{y}^{*}$, to - przy założeniu wypukłości $\boldsymbol{Y}_{0}-$ możemy przesuwać $\boldsymbol{y}^{-}$w kierunku $\boldsymbol{d} \in$ Int $\boldsymbol{D}$ i powtarzać optymalizację tak długo, aż osiągniemy $\boldsymbol{y}^{*} \in \boldsymbol{y}^{-}-$Int $\boldsymbol{D}$, co gwarantuje właściwą sprawność $\boldsymbol{y}^{*}$. W przypadku niewypukłego zbioru $\boldsymbol{Y}_{0}$, warunek $\boldsymbol{y}^{-} \in \boldsymbol{Y}^{*}{ }_{0}+\boldsymbol{D}$ jest trudniejszy do sprawdzenia i sprowadza się do faktycznej znajomości przynajmniej części zbioru $\boldsymbol{Y}_{0}^{*}$.

W sumie, metody programowania celowego mają zatem poważne braki dla praktycznych zastosowań. Istotna jest jednak ich podstawowa idea wykorzystanie nie ograniczonego, lecz dowolnego punktu odniesienia jako podstawowego parametru sterującego. Jak już wspomnieliśmy wcześniej, wykorzystując tę ideę ale stosując inne funkcje skalaryzujące - nie normy, ale funkcje osiągnięcia - można usunąć braki metod programowania 
celowego i uogólnić je poprzez klasę metod optymalizacji względem punktu odniesienia - które nawiązują do wielu metod wymienionych wyżej i je uogólniają oraz unikają ich wad. Dokładniejsza analiza tych metod jest przedmiotem następnego rozdziału.

\section{Literatura}

Alfaris A. (2015) Multidisciplinary System Design Optimization: Multiobjective Optimization. MIT Open Course Ware.

Charnes A., Cooper W.W. (1977) Goal programming and multiple objective optimization, Journal of Operations Research Society, 1:39-54

Dinkelbach W., Isermann H. (1976) Sensitivitätsanalysen bei Finanzplanungsmodellen. In: Handwörterbuch der Finanzwirtschaft, hrsg. von Hans E.Boschgen, Stuttgart

Haimes Y.Y., Hall W.A. (1974) Multiobjectives in Water Reources Systems Analysis: The Surrogate Worth Trade-off Method. Water Resources Research 10(4):615-624

Matlab Mathworks (2015) Multiobjective Optimization

http://www.mathworks.com/discovery/multiobjective-optimization.html

Ogryczak W. (1997) On the lexicographic minimax approach to location problems, European Journal of Operational Research 100:566-585.

Ogryczak W. (2000) Multiple criteria linear programming model for portfolio selection. Annals of Operations Research 97:143-162.

Ogryczak W., Śliwiński T. (2003) On solving linear programs with the ordered weighted averaging objective. European Journal of Operational Research 148: 80-91

Salukvadze M.E. (1971) Optimization of Vector Functionals. The Analytic Construction of Optimal Controls. Automation and Remote Control 32

Salukvadze M.E. (1979) Vector-Valued Optimization Problems in Control Theory. Academic Press, New York

Steuer R.E. (1986) Multiple Criteria Optimization: Theory, Computation and Application. J.Wiley, New York

Wierzbicki A.P. (1986) On the completeness and constructiveness of parametric characterizations to vector optimization problems. OR-Spektrum 8:73-87

Wierzbicki A.P., Makowski M., Wessels J. (2000) Model-Based Decision Support Methodology with Environmental Applications. IIASA - Kluwer Academic Publishers, Dordrecht

Yager R.R. (1988) On ordered weighted averaging aggregation operators in multicriteria decision making, IEEE Transactions on Systems Man and Cybernetics 18: 183-190.

Yu P.L. (1985) Multiple-Criteria Decision Making: Concepts, Techniques and Extensions. Plenum Press, New York 1985 


\section{Metody punktu odniesienia}

\subsection{Podstawowe przykłady funkcji osiągnięcia}

Metody programowania celowego można uogólnić i usunąć ich wady, zachowując ich podstawową zaletę: wykorzystanie dowolnego (lub prawie dowolnego, jeśli znane są już oszacowania zbioru rezultatów sprawnych) punktu odniesienia jako podstawowego parametru sterującego, zwykle interpretowanego jako punkt aspiracji $\boldsymbol{y}^{-} \in \boldsymbol{R}^{m}, \boldsymbol{y}^{-}=\left(y_{1}^{-}, \ldots y_{i}^{-}, \ldots \bar{y}_{m}^{-}\right)^{\mathrm{T}}$, gdzie $\overline{y_{i}^{-}}$ zwane są poziomami aspiracji. Trzeba jednak w tym celu skonstruować inne, niż norma, funkcje skalaryzujące (choć czasami można wykorzystywać pojęcie normy w tej konstrukcji, tylko odpowiednio zmodyfikowane), gdyż po prostu norma zachowuje własności monotoniczności tylko wtedy, gdy punkt odniesienia jest dostatecznie daleko położony względem zbioru rezultatów osiągalnych.

Pokazaliśmy już wcześniej możliwość konstruowania takich funkcji, teraz je przypomnimy i przeanalizujemy nieco bardziej szczegółowo. Zacznijmy od przypadku najprostszego, gdy $\boldsymbol{D}=\boldsymbol{R}^{m}{ }_{+}$i wszystkie atrybuty mają taki sam wymiar fizyczny. Przypuśćmy, że chcemy wykorzystać uzupełnioną normę Czebyszewa jak we wzorze (8.10), przyjmując co więcej $\alpha_{\mathrm{m}+1}=\varepsilon$, $\alpha_{i}=1 / m \forall i=1, \ldots m$, chcąc natomiast sterować wyborem rezultatów sprawnych wyłącznie poprzez zmianę punktu odniesienia. Zakładamy przy tym, że nie przeprowadziliśmy nawet wstępnego oszacowania zbioru rezultatów sprawnych i chcemy stosować dowolne punkty odniesienia $\boldsymbol{y}^{-} \in \boldsymbol{R}^{m}$, zamiast tylko punktów ponadutopijnych $\boldsymbol{y}^{\sim} \in \operatorname{Int} \boldsymbol{Y}_{0 \text {,uto, które }}$ zapewniały odpowiednie własności funkcji $s(y, \alpha)$ we wzorze (8.10), wyrażone przez Twierdzenie 8.3. Jak wtedy zmodyfikować funkcję $s(\boldsymbol{y}, \boldsymbol{\alpha})$, aby mimo wszystko zachować jej odpowiednie własności i siłę rezultatów Twierdzenia 8.3?

Okazuje się, że odpowiedź na to pytanie jest stosunkowo prosta koncepcyjnie, jeśli wykorzystamy Twierdzenia 7.1 i 7.2, a jeszcze prostsza rachunkowo. 
Potrzebna jest bowiem taka funkcja skalaryzująca, która ma własność ścisłej monotoniczności względem stożka $\boldsymbol{D}_{\varepsilon}$ dla dowolnych punktów odniesienia $\boldsymbol{y}^{-} \in \boldsymbol{R}^{m}$, a ponadto, jeśli dany punkt $\boldsymbol{y}^{-}=\boldsymbol{y}^{*} \in \boldsymbol{Y}^{* p \varepsilon}{ }_{0}$ jest sprawny, to funkcja ta powinna zawsze ściśle rozdzielać ten punkt oraz inne punkty $\boldsymbol{y} \in \boldsymbol{Y}_{0}$ od stożka $\boldsymbol{y}^{*}+$ Int $\boldsymbol{D}_{\varepsilon}$. Przypomnijmy tu wzór (7.15) określający kilka równoważnych postaci stożka $\boldsymbol{D}_{\varepsilon}$, definiowanego z użyciem normy mieszanej $l_{1, \infty}$. Ponieważ:

$$
\boldsymbol{D}_{\varepsilon}=\left\{\boldsymbol{y} \in \boldsymbol{R}^{m}: \min _{1 \leq i \leq m} y_{i}+\varepsilon \sum_{\mathrm{i}=1, \ldots m} y_{i} \geq 0\right\}
$$

przeto:

$$
\boldsymbol{y}^{-}+\boldsymbol{D}_{\varepsilon}=\left\{\boldsymbol{y} \in \boldsymbol{R}^{m}: \min _{1 \leq i \leq m}\left(y_{i}-y_{i}^{-}\right)+\varepsilon \sum_{\mathrm{i}=1, \ldots m}\left(y_{i}-y_{i}^{-}\right) \geq 0\right\}
$$

Wynika stąd, że wystarczy we wzorze (8.10) przyjąć $\alpha_{i}=1, \alpha_{m+1}=\varepsilon$, oraz pominać znaki modulu (których zastosowanie było niezbędne przy interpretacji funkcji $s(\boldsymbol{y}, \boldsymbol{\alpha})$ jako odpowiedniej normy), wreszcie zastąpić

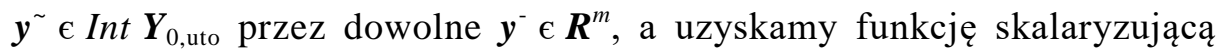
o odpowiednich własnościach ścisłej monotoniczności i rozdzielania:

$$
\sigma\left(\boldsymbol{y}, \boldsymbol{y}^{-}\right)=\min _{1 \leq i \leq m}\left(y_{i}-y_{i}^{-}\right)+\varepsilon \sum_{\mathrm{i}=1, \ldots m}\left(y_{i}-y_{i}^{-}\right)
$$

Powyższa funkcja $\sigma\left(\boldsymbol{y}, \boldsymbol{y}^{-}\right)$jest podstawowym przykładem osobnej klasy funkcji skalaryzujących o takich własnościach, które będziemy nazywać funkcjami osiagnięcia zgodnymi z porządkiem; dlatego też używamy dla nich odmiennego oznaczenia $\sigma$. Dla funkcji tej obowiązuje twierdzenie analogiczne do Twierdzenia 8.3:

Twierdzenie 9.1. Jeśli $\boldsymbol{D}=\boldsymbol{R}^{m}{ }_{+}, \sigma\left(\boldsymbol{y}, \boldsymbol{y}^{-}\right)$jest określone jak we wzorze (9.3), to dla dowolnego $\boldsymbol{y}^{-} \in \boldsymbol{R}^{m}$ i dowolnego $\varepsilon>0$ :

$$
\operatorname{Argmax}_{\mathbf{y \in} \mathbf{Y} 0} \sigma\left(\boldsymbol{y}, \boldsymbol{y}^{-}\right) \subseteq \boldsymbol{Y}_{0}{ }^{*}{ }^{*}
$$

gdzie $\boldsymbol{Y}_{0}{ }^{*}{ }^{p \varepsilon}$ określone jest względem stożka $\boldsymbol{D}_{\varepsilon}$ o postaci (9.1). Odwrotnie, jeśli $\boldsymbol{y}^{*} \in \boldsymbol{Y}_{0}^{* p \varepsilon}$ określonego $\mathrm{W}$ taki sposób, to istnieje takie $\boldsymbol{y}^{-} \in \boldsymbol{R}^{m}$ (w szczególności, $\boldsymbol{y}^{-}=\boldsymbol{y}^{*}$ ), że:

$$
\boldsymbol{y}^{*} \in \operatorname{Argmax}_{\boldsymbol{y} \in \mathbf{Y} 0} \sigma\left(\boldsymbol{y}, \boldsymbol{y}^{-}\right) \subseteq \boldsymbol{Y}_{0}{ }^{*}{ }^{p \varepsilon}
$$

przy czym odpowiadające punktowi $\boldsymbol{y}^{*}$ współczynniki wymiany $t_{i j}\left(y^{*}\right)$ są a priori ograniczone, $t_{i j}\left(y^{*}\right) \leq M=1+1 / \varepsilon, \forall i, j=1, \ldots m, i \neq j$.

Dowód Twierdzenia 9.1 opiera się na Twierdzeniach 7.1 i 7.2. Część pierwsza wynika bowiem z faktu, że funkcja $\sigma(y, y)$ jest ściśle monotoniczna, jako 
funkcja $\boldsymbol{y}$, względem stożka $\boldsymbol{D}_{\varepsilon}$, patrz także wzór (7.15). Część druga wynika natomiast z własności ścisłego rozdzielania zbioru $\boldsymbol{Y}_{0} \mathrm{w}$ punkcie $\boldsymbol{y}^{*}$ i zbioru $\boldsymbol{y}^{*}+$ Int $\boldsymbol{D}_{\varepsilon}$ przez funkcję $\sigma\left(\boldsymbol{y}, \boldsymbol{y}^{-}\right)$. Wreszcie ograniczenie na współczynniki wymiany wynika z postaci stożka sprzężonego $\boldsymbol{D}_{\varepsilon}^{*}$ do stożka $\boldsymbol{D}_{\varepsilon}$. Sposób dowodu tego twierdzenia uzasadnia nazwę funkcja osiagnięcia zgodna z porządkiem; nazwę tę stosujemy bowiem dla podkreślenia, że funkcja ta niejako idealnie charakteryzuje porządek związany ze stożkiem $\boldsymbol{D}_{\varepsilon}-$ jest ściśle monotoniczna względem tego stożka i rozdziela zbiory od tego stożka, zob. Definicja $9.1 \mathrm{w}$ punkcie następnym.

Zauważmy, że w funkcji $\sigma\left(\boldsymbol{y}, \boldsymbol{y}^{-}\right)$moglibyśmy założyć - jako pomocniczy parametr sterujący - współczynniki wagi $\alpha_{i} \neq 1$ przy każdym atrybucie, co wpłynęłoby tylko na przeskalowanie tych atrybutów - i spowodowałoby względność definicji zbioru $\boldsymbol{Y}_{0}{ }^{*}{ }^{p}$ i współczynników wymiany $t_{i j}\left(\boldsymbol{y}^{*}\right)$ w odniesieniu do tego przeskalowania, por. Twierdzenie 8.3. Twierdzenie 9.1 jest w pewnym sensie nawet silniejsze, niż Twierdzenie 8.3 (gdyż pozwala na stosowanie dowolnych punktów odniesienia); podobnie jak Twierdzenie 8.3, nie zakłada ono wypukłości zbioru $\boldsymbol{Y}_{0}$, a więc może być stosowane np. dla zadań o rozwiązaniach i rezultatach dyskretnych. Ilustruje to Rys. 9.1, gdzie użyto dokładnie takiego dyskretnego zbioru $\boldsymbol{Y}_{0}$, jak we wspomnianym wcześniej paradoksie Korhonena (a więc zastosowanie funkcji $\sigma\left(\boldsymbol{y}, \boldsymbol{y}^{\prime}\right.$ ) pozwala na uniknięcie niedogodności, sygnalizowanych przez ten paradoks).

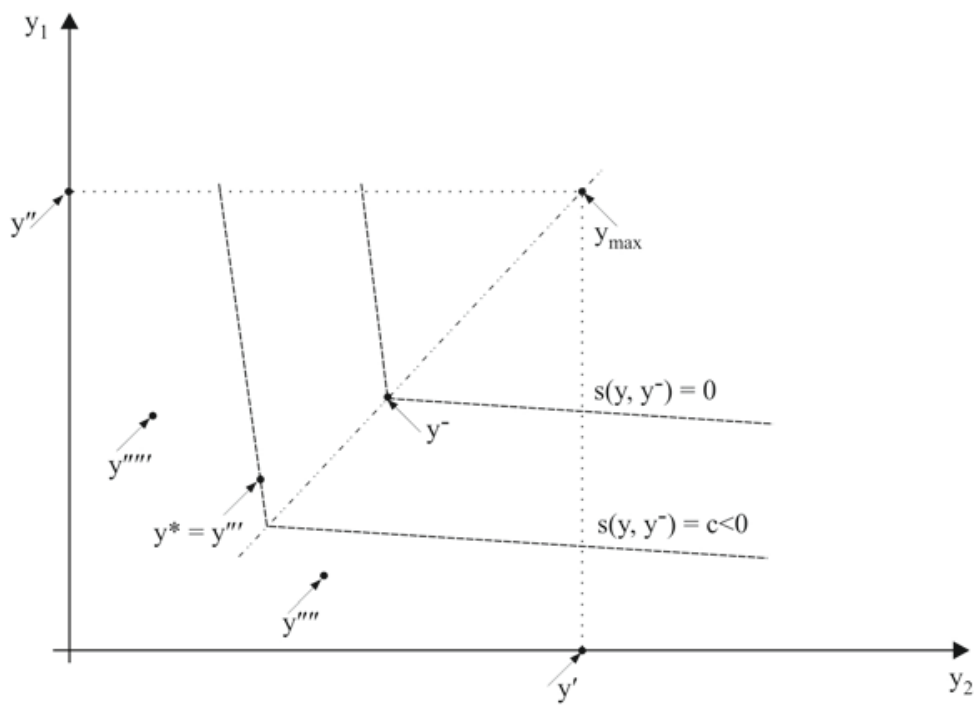

Rys. 9.1. Zastosowanie funkcji osiągnięcia dla dyskretnego zbioru rezultatów. 
Zauważmy ponadto, że twierdzenie powyższe można łatwo zmodyfikować dla przypadku $\varepsilon=0$; trzeba wtedy jednak zastąpić $\boldsymbol{Y}_{0}{ }^{*} \varepsilon \varepsilon$ przez $\boldsymbol{Y}_{0}{ }^{{ }^{*} w}$ i oczywiście zrezygnować $\mathrm{z}$ ograniczenia współczynników wymiany, ale do dowodu stosuje się te same argumenty o odpowiednim charakterze monotoniczności i rozdzielania. Uzyskuje się wtedy rezultat analogiczny do Twierdzenia 8.2, i można też w ten sposób charakteryzować zbiór rezultatów sprawnych $\boldsymbol{Y}_{0}{ }^{*}$, jeśli założyć jednoznaczność odpowiednich punktów minimalnych:

Twierdzenie 9.2. Jeśli $\sigma\left(y, y^{-}\right)$jest określone jak we wzorze (9.3), przy czym $\varepsilon=0$, to:

$$
\operatorname{Argmax}_{\mathbf{y} \in \mathbf{Y} 0} \sigma\left(\boldsymbol{y}, \boldsymbol{y}^{-}\right) \subseteq \boldsymbol{Y}_{0}{ }^{*} \forall \boldsymbol{y}^{-} \in \boldsymbol{R}^{m}
$$

Jeśli to minimum jest jednoznaczne, to:

$$
\operatorname{argmax}_{\boldsymbol{y} \in \mathbf{Y} 0} \sigma\left(\boldsymbol{y}, \boldsymbol{y}^{-}\right) \subseteq \boldsymbol{Y}_{0}^{*}, \forall \boldsymbol{y}^{-} \in \boldsymbol{R}^{m}
$$

Odwrotnie, jeśli $\boldsymbol{y}^{*} \in \boldsymbol{Y}^{*^{w}}{ }_{0}$, to istnieje takie $\boldsymbol{y}^{-} \in \boldsymbol{R}^{m}$, że $\boldsymbol{y}^{*} \in \operatorname{Argmax}_{\boldsymbol{y} \in \mathrm{Y} 0} \sigma\left(\boldsymbol{y}, \boldsymbol{y}^{-}\right)$; jeśli $\boldsymbol{y}^{*} \in \boldsymbol{Y}_{0}^{*}$, to istnieje takie $\boldsymbol{y}^{-} \in \boldsymbol{R}^{m}$ (w szczególności, $\boldsymbol{y}^{-}=\boldsymbol{y}^{*}$ ), że:

$$
y^{*}=\operatorname{argmax}_{\mathbf{y} \in \mathbf{Y} 0} \sigma\left(y, y^{-}\right)
$$

gdzie odpowiednie maximum jest jednoznaczne.

Twierdzenie powyższe charakteryzuje znane od dość dawna i stosowane dość powszechnie podejście maksmin do optymalizacji wielokryterialnej, zob. np. Elijah Polak (1976). ${ }^{1}$

Nazwa funkcja osiagnięcia stosowana w odniesieniu do $\sigma\left(y, y^{-}\right)$związana jest z wynikającym ze wzoru (9.3) faktem, że wartości tej funkcji są zerowe dla $\boldsymbol{y}=\boldsymbol{y}^{-}$, dodatnie dla $\boldsymbol{y} \in \boldsymbol{y}^{-}+$Int $\boldsymbol{D}_{\varepsilon}$, ujemne dla $\boldsymbol{y}\left\ulcorner\boldsymbol{\epsilon} \boldsymbol{y}^{-}+\operatorname{Int} \boldsymbol{D}_{\varepsilon}\right.$. Dlatego też wartości maksymalne tej funkcji mogą być wykorzystywane nie tylko do obliczania rezultatów właściwie $\varepsilon$-sprawnych, lecz także dla oceny osiągalności danego punktu aspiracji $y^{*}$

\footnotetext{
${ }^{1}$ Niestety, podejście to bywa stosowane nawet w dość popularnych systemach oprogramowania (zob. np. Optix w systemie Matlab) bez uprzedzenia użytkownika, że w przypadku niejednoznaczności rozwiązań - która może pojawić się dość łatwo przy stosowaniu ograniczeń typu kostka - gwarantowana jest tylko słaba sprawność rozwiązań.
} 
- Jeśli maksimum funkcji osiągnięcia $\sigma\left(\boldsymbol{y}, \boldsymbol{y}^{-}\right)$względem $\boldsymbol{y} \in \boldsymbol{Y}_{0}$ jest ujemne, to punkt aspiracji $\boldsymbol{y}^{-}$nie jest osiągalny $\left(\boldsymbol{y}^{-}-\epsilon \boldsymbol{Y}_{0}\right)$, natomiast maksymalny punkt $y^{*} \in \boldsymbol{Y}_{0}^{* p \varepsilon}$ tej funkcji jest rezultatem właściwie $\varepsilon$-sprawnym w pewnym sensie równomiernie najbliższym do punktu aspiracji $\boldsymbol{y}^{\circ}$;

- Jeśli maksimum funkcji osiągnięcia $\sigma\left(\boldsymbol{y}, \boldsymbol{y}^{-}\right)$względem $\boldsymbol{y} \in \boldsymbol{Y}_{0}$ jest zerowe, to punkt aspiracji $\boldsymbol{y}^{-}$jest osiągalny i właściwie $\varepsilon$-sprawny oraz jest (być może jednym z wielu) punktem maksymalnym tej funkcji;

- Jeśli maksimum funkcji osiągnięcia $\sigma\left(\boldsymbol{y}, \boldsymbol{y}^{-}\right)$względem $\boldsymbol{y} \in \boldsymbol{Y}_{0}$ jest dodatnie, to punkt aspiracji $\boldsymbol{y}^{-}$jest osiągalny ale nie jest właściwie $\varepsilon$-sprawny, natomiast maksymalny punkt $\boldsymbol{y}^{*} \in \boldsymbol{Y}^{* P \varepsilon}{ }_{0}$ tej funkcji jest rezultatem właściwie $\varepsilon$-sprawnym, w pewnym sensie równomiernie polepszonym w stosunku do punktu aspiracji $\boldsymbol{y}^{-}$.

Przypadki powyższe ilustruje Rys. 9.2. W celu lepszej interpretacji pojęć równomiernej bliskości i równomiernego polepszenia zauważmy, że zwykle jednak mamy do czynienia $\mathrm{z}$ atrybutami decyzji o różnych wymiarach fizycznych czy ekonomicznych. W takich przypadkach wstępne oszacowanie zbioru decyzji sprawnych staje się niezbędne, gdyż trzeba znać przynajmniej porównywalne zakresy zmienności poszczególnych atrybutów. Przypuśćmy, że obliczone zostały oszacowania „górne” zbioru rezultatów decyzji sprawnych $y_{i, \text { max }}$ (np. $y_{i, \max }=y_{i, u t o}$ ) oraz - chociażby przybliżone - oszacowania „dolne” tego zbioru $y_{i, \min }$ (np. $y_{i, \min }=\tilde{y}_{i, \text { nad }}^{\sim}$ ). Zakresy $y_{i, \max }-y_{i, \text { min }}$ wykorzystuje się wtedy w definicji względnych współczynników wagi jak we wzorze (8.3) czy kierunków w przestrzeni rezultatów jak w (8.4). Odpowiednią funkcję osiągnięcia zgodną z porządkiem dogodnie jest wtedy definiować poprzez cząstkowe funkcje osiągnięcia:

$$
\sigma_{i}\left(y_{i}, y_{i}^{-}\right)=\left(y_{i}-y_{i}^{-}\right) /\left(y_{i, \max }-y_{i, \min }\right)
$$

które po prostu charakteryzują stopień osiągnięcia punktu aspiracji dla poszczególnych atrybutów w odniesieniu do oszacowania zakresu zmienności tego atrybutu, przy czym $\sigma_{i}\left(y_{i}^{-}, y_{i}^{-}\right)=0$. Całościową funkcję osiągnięcia zgodną z porządkiem definiujemy analogicznie jak we wzorze (9.3):

$$
\sigma\left(y, y^{-}\right)=\min _{1 \leq i \leq m} \sigma_{i}\left(y_{i}, y_{i}^{-}\right)+\varepsilon \sum_{\mathrm{i}=1, \ldots m} \sigma_{i}\left(y_{i}, y_{i}^{-}\right)
$$

lub z uwzględnieniem dodatnich współczynników wagi $\alpha \in \operatorname{Int} \boldsymbol{R}^{m}+$ jako dodatkowych parametrów sterujących:

$$
\sigma\left(y, y^{-}\right)=\min _{1 \leq i \leq m} \alpha_{i} \sigma_{i}\left(y_{i}, y_{i}^{-}\right)+\varepsilon \sum_{\mathrm{i}=1, \ldots m} \alpha_{i} \sigma_{i}\left(y_{i}, y_{i}^{-}\right)
$$


W stosunku do takiej funkcji obowiązuje oczywiście Twierdzenie 9.1, z definicją zbioru $\boldsymbol{Y}^{* p \varepsilon}{ }_{0}$ oraz współczynników wymiany $t_{i j}\left(y^{*}\right)$ zmodyfikowaną poprzez zmianę skali atrybutów lub dodatkowo przez współczynniki wagi.

a)

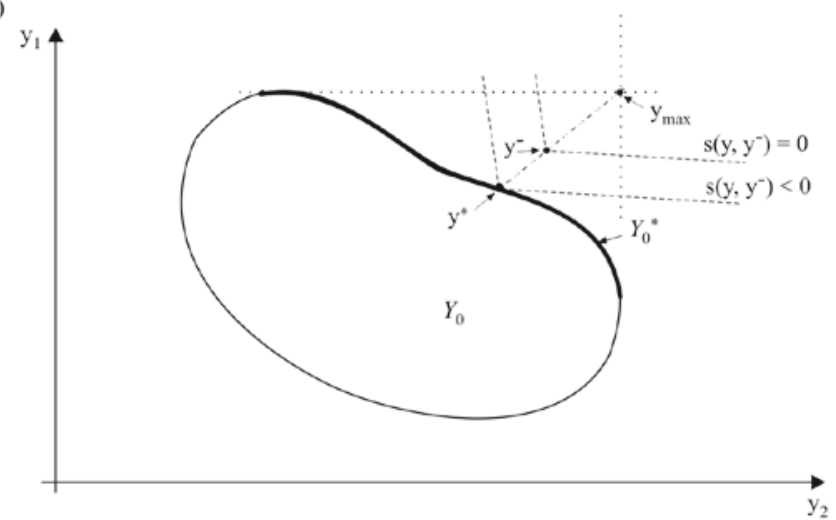

b)
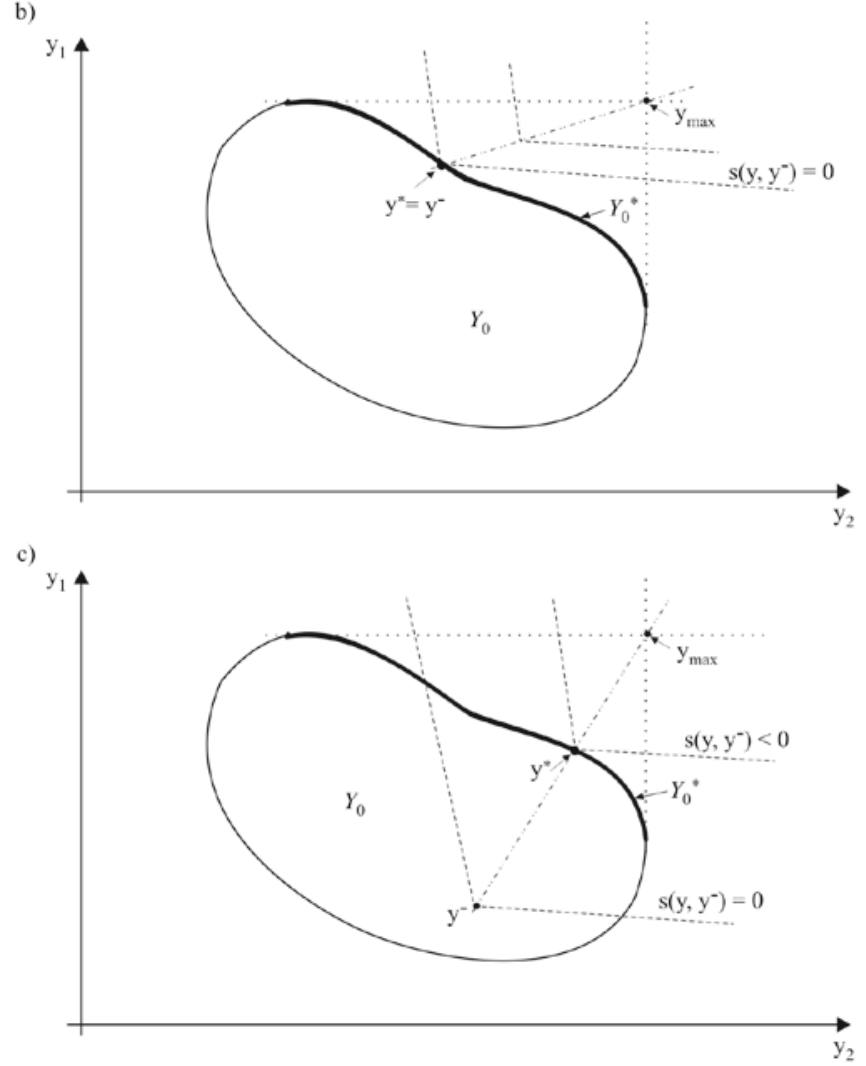

Rys. 9.2. Ocena osiągalności punktu odniesienia na podstawie maksymalnej wartości funkcji osiągnięcia a): $\boldsymbol{y}^{\top}$ nieosiągalne, b) $\boldsymbol{y}^{`}$ sprawne, c) $\boldsymbol{y}^{\boldsymbol{}}$ osiągalne. 
Pod warunkiem znajomości $y_{i, \max }=y_{i, u t o}$ i $y_{i, \min }=\tilde{y}_{i, \text { nad }}^{\sim}$ możemy zakładać, że użytkownik systemu wspomagania decyzji będzie dobierał „rozsądne” poziomy aspiracji $y_{i}^{-}-$niekoniecznie tylko nieosiągalne, ale takie, że $y_{i, \min }<y_{i}^{-}<\tilde{y}_{i}$, gdzie $\tilde{y}_{i}>y_{i, u t o}$ jest składową pewnego punktu ponadutopijnego - stosowanego po to, aby nie zabraniać użytkownikowi wyboru $y_{i}^{-}=y_{i, u t o}$. Można wtedy zdefiniować składowe funkcje osiągnięcia nieco inaczej, niż w (9.9) - a mianowicie przyjmować, że odwrotność odległości $\tilde{y}_{i}-y_{i}^{-}$określa niejawnie wagę danego atrybutu dla użytkownika (skoro decyduje się on na wybór poziomów aspiracji bliskich lub równych poziomom utopijnym dla niektórych atrybutów, to oznacza, że przykłada on dla tych atrybutów szczególną wagę - podobnie jak w definicji współczynników wagi Ralpha Steuera (8.3). Prowadzi to do definicji:

$$
\sigma_{i}\left(y_{i}, y_{i}^{-}\right)=\left(y_{i}-y_{i}^{-}\right) /\left(\tilde{y_{i}}-y_{i}^{-}\right)
$$

z taką samą, jak wyżej - np. (9.10) - definicją całościowej funkcji osiągnięcia $\sigma\left(y, y^{-}\right)$. Zmienia się wtedy tylko interpretacja równomiernej bliskości lub polepszenia dla punktów maksymalnych tej funkcji, zobacz Rys. 9.3.

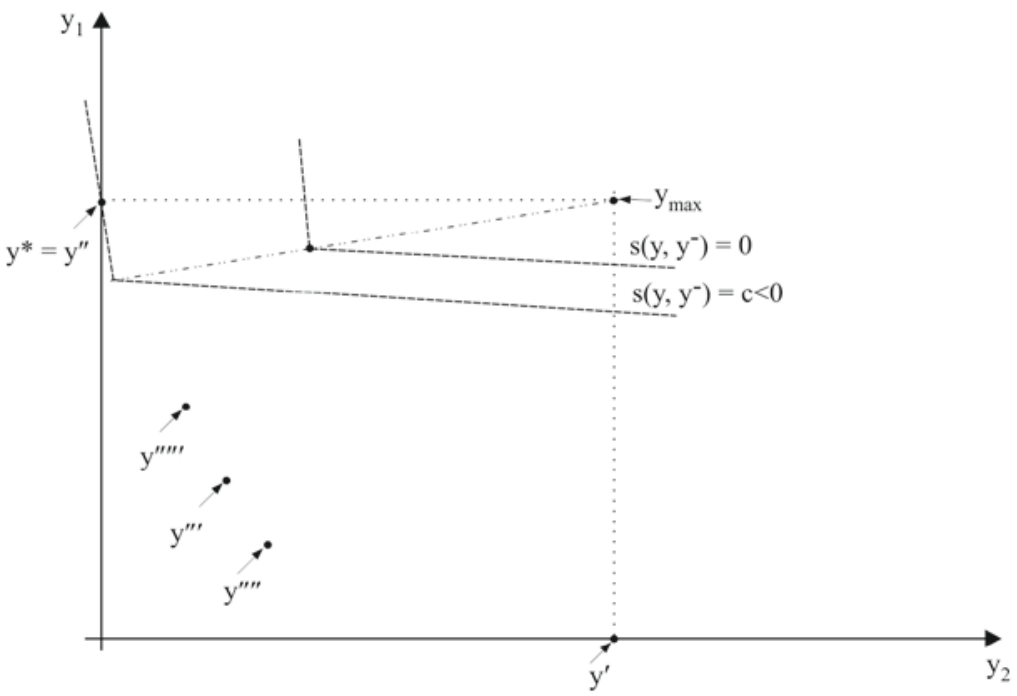

Rys. 9.3. Ilustracja wykorzystania niejawnego określenia wagi danego atrybutu przez położenie poziomu aspiracji względem poziomu maksymalnego. 
Na podstawie oczywistej zależności:

$$
\sigma_{i}\left(y_{i}, y_{i}^{-}\right)=\left(y_{i}-y_{i}^{-}\right) /\left(y_{i}^{\sim}-y_{i}^{-}\right)=1-\left(\tilde{y}_{i}^{\sim}-y_{i}\right) /\left(\tilde{y}_{i}^{\sim}-y_{i}^{-}\right)
$$

można dojść do wniosku, że w takim przypadku:

$$
\begin{aligned}
& \sigma\left(\boldsymbol{y}, \boldsymbol{y}^{-}\right)=\min _{1 \leq i \leq m} \sigma_{i}\left(y_{i}, y_{i}^{-}\right)+\varepsilon \sum_{\mathrm{i}=1, \ldots m} \sigma_{i}\left(y_{i}, y_{i}^{-}\right)= \\
& 1+m \varepsilon-\left(\max _{1 \leq i \leq m}\left(\tilde{y_{i}}-y_{i}\right) /\left(\tilde{y}_{i}-y_{i}^{-}\right)+\varepsilon \sum_{\mathrm{i}=1, \ldots m}\left(\tilde{y_{i}}-y_{i}\right) /\left(\tilde{y_{i}}-y_{i}^{-}\right)=\right. \\
& 1+m \varepsilon-s(\boldsymbol{y}, \boldsymbol{\alpha})
\end{aligned}
$$

gdzie $s(\boldsymbol{y}, \boldsymbol{\alpha})$ jest uzupełnioną normą Czebyszewa określoną jak w (8.10), ale ze współczynnikami wagi $\alpha_{m+1}=\varepsilon$ oraz $\alpha_{i}=1 /\left(\tilde{y}_{i}{ }_{i}-y_{i}^{-}\right)$, przy czym znaki wartości bezwzględnej możemy tu pominąć dlatego, że wobec założenia $\tilde{y}_{i}>y_{i}^{-}$oraz $\tilde{y}_{i}>y_{i}$ odpowiednie wartości są dodatnie. Ponieważ $1+m \varepsilon$ jest parametrem stałym przy maksymalizacji $\sigma\left(\boldsymbol{y}, \boldsymbol{y}^{-}\right)$względem $\boldsymbol{y} \in \boldsymbol{Y}_{0}$, przeto maksymalizacja ta jest równoważna minimalizacji uzupełnionej normy Czebyszewa $s(\boldsymbol{y}, \boldsymbol{\alpha})$. Trzeba jednak podkreślić, że całościowa funkcja osiągnięcia $\sigma\left(\boldsymbol{y}, \boldsymbol{y}^{-}\right)$oczywiście nie jest normą odległości $\boldsymbol{y}$ od $\boldsymbol{y}$, a jedynie jest równoważna przekształconej normie odległości $\boldsymbol{y}$ od $\boldsymbol{y}^{\sim}$ przy dodatkowych założeniach jak wyżej. Obowiązuje przy tym odpowiednio przekształcone Twierdzenie 9.1 ; zauważmy, że skoro stosujemy $\alpha_{i}=1 /\left(y_{i}^{\sim}-y_{i}^{-}\right)$oraz $\alpha_{j}=1 /\left(\tilde{y}_{j}-y_{j}^{-}\right)$, to odpowiednie ograniczenie dla $t_{i j}\left(y^{*}\right)$ będzie zmodyfikowane odpowiednio do ilorazu tych współczynników wagi.

W uzupełnieniu podstawowych własności funkcji osiągnięcia należy jeszcze dodać, że przy dodatkowych założeniach można udowodnić ciągłą sterowalność punktów maksymalnych funkcji osiągnięcia reprezentującej porządek, tj. ciągłość $\mathrm{W}$ sensie Lipschitza zależności tych punktów maksymalnych $y^{*}$ od punktu odniesienia czy aspiracji $y^{-}$. Obowiązuje mianowicie następujące twierdzenie (zob. Wierzbicki 1986):

Twierdzenie 9.3: Załóżmy, że funkcja osiągnięcia $\sigma\left(\boldsymbol{y}, \boldsymbol{y}^{-}\right)$określona jest jak we wzorze (9.3), przy czym $\varepsilon \geq 0$, że zbiór $\boldsymbol{Y}^{*}{ }_{0}$ jest spójny i dany jest zbiór wypukły $\boldsymbol{Y}$ taki, że $\boldsymbol{Y}^{*}{ }_{0} \subseteq \boldsymbol{Y}$. Jeśli dla wszystkich $\boldsymbol{y}^{-} \in \boldsymbol{Y}$ funkcja osiągnięcia $\sigma\left(\boldsymbol{y}, \boldsymbol{y}^{-}\right)$ma jednoznaczne maksima $\boldsymbol{y}^{*}\left(\boldsymbol{y}^{-}\right)=\operatorname{argmax}_{y \in \mathbf{Y} 0} \sigma\left(\boldsymbol{y}, \boldsymbol{y}^{-}\right)$, to maksima te są funkcją ciągłą w sensie Lipschitza ze stałą Lipschitza równą 4, $\left\|\boldsymbol{y}^{*}\left(\boldsymbol{y}^{-1}\right)-\boldsymbol{y}^{*}\left(\boldsymbol{y}^{-\prime}\right)\right\| \leq 4\left\|\boldsymbol{y}^{-\prime}-\boldsymbol{y}^{-\prime}\right\|$, gdzie $\|$.$\| oznacza normę Czebyszewa l_{\infty}$. 
Twierdzenie powyższe jest istotne dla zastosowań we wspomaganiu decyzji: mówi ono, że z wyjątkiem przypadków szczególnych (niejednoznaczności maksimum funkcji osiągnięcia, niespójności zbioru $\boldsymbol{Y}^{{ }^{*}{ }_{0}}$ ) możemy oczekiwać ciągłej sterowalności punktów maksymalnych funkcji osiągnięcia poprzez zmiany punktu odniesienia.

\subsection{Ogólne własności funkcji osiągnięcia}

Zastosowanie dowolnych (lub tylko rozsądnie ograniczonych) poziomów odniesienia czy aspiracji oraz funkcji skalaryzujących innych, niż norma, a mających charakter funkcji osiągnięcia, było zaproponowane najpierw w (Wierzbicki 1977, 1980), a następnie rozwijane przez wielu autorów (Hirotaka Nakayama i Yoshikazu Sawaragi, 1983; Ralph Steuer i Eng-Ung Choo, 1983; Pekka Korhonen i Jukka Laakso, 1986 - zob. literatura). Pełniejsza teoria funkcji osiągnięcia przedstawiona została w (Wierzbicki 1986); tu ograniczymy się tylko do wybranych pojęć i rezultatów.

Definicja 9.1. Funkcję $\sigma\left(\boldsymbol{y}, \boldsymbol{y}^{-}\right), \quad \sigma: \boldsymbol{R}^{m} \times \boldsymbol{R}^{m} \rightarrow \boldsymbol{R}^{1}$, nazywamy funkcja osiagnięcia reprezentująca porządek częściowy implikowany przez dany stożek dodatni $\boldsymbol{D}$ (lub odpowiednio rozszerzony stożek $\boldsymbol{D}_{\varepsilon}$, przy czym może to być rozszerzenie rozmaite, także określone względem pewnego przeskalowania rezultatów $\boldsymbol{y}_{i}$ odpowiednimi współczynnikami wagi), jeśli jest to funkcja ciągła i istnieje taki zbiór $\boldsymbol{Y} \subseteq \boldsymbol{R}^{m}$, że określony względem stożka D zbiór rezultatów słabo sprawnych zbioru $\boldsymbol{Y}_{0}$ jest podzbiorem tego zbioru, $\boldsymbol{Y}^{*}{ }_{0} \subseteq \boldsymbol{Y}^{-}$(lub, w przypadku porządku implikowanego przez $\boldsymbol{D}_{\varepsilon}, \boldsymbol{Y}^{*{ }^{p \varepsilon}}{ }_{0} \subseteq \boldsymbol{Y}$ ) i że dla wszystkich $\boldsymbol{y}^{-} \in \boldsymbol{Y}$ funkcja ta ma następujące własności:

a) $\boldsymbol{y}^{\prime}-\boldsymbol{y}^{\prime \prime} \in$ Int $\boldsymbol{D}$ (lub $\boldsymbol{y}^{\prime}-\boldsymbol{y}^{\prime \prime} \in$ Int $\left.\boldsymbol{D}_{\varepsilon}\right) \rightarrow \sigma\left(\boldsymbol{y}^{\prime}, \boldsymbol{y}^{-}\right)>\sigma\left(\boldsymbol{y}^{\prime \prime}, \boldsymbol{y}^{-}\right)$, czyli jest to funkcja ściśle monotoniczna względem Int $\boldsymbol{D}$ (lub, co jest silniejszym wymaganiem, względem Int $\left.\boldsymbol{D}_{\varepsilon}\right)$;

b) $\left\{\boldsymbol{y} \in \boldsymbol{R}^{m}: \sigma\left(\boldsymbol{y}, \boldsymbol{y}^{-}\right)>0\right\}=\boldsymbol{y}^{-}+$Int $\boldsymbol{D}\left(\right.$ lub $=\boldsymbol{y}^{-}+$Int $\left.\boldsymbol{D}_{\varepsilon}\right)$.

Wymagania a), b) łącznie oznaczają, że jeśli $y^{-}$jest rezultatem słabo sprawnym (lub właściwie $\varepsilon$-sprawnym), to funkcja $\sigma\left(\boldsymbol{y}, \boldsymbol{y}^{-}\right) \mathrm{w}$ punkcie $\boldsymbol{y}^{-}$ściśle rozdziela zbiór $\boldsymbol{Y}_{0}$ i $\boldsymbol{y}^{-}+\operatorname{Int} \boldsymbol{D}\left(\right.$ lub $\left.\boldsymbol{y}^{-}+\operatorname{Int} \boldsymbol{D}_{\varepsilon}\right)$.

Jeśli w wymaganiu b) zastąpimy zbiór $\boldsymbol{y}^{-}+\operatorname{Int} \boldsymbol{D}\left(\right.$ lub $\left.=\boldsymbol{y}^{-}+\operatorname{Int} \boldsymbol{D}_{\varepsilon}\right)$ przez inny zbiór $\boldsymbol{y}^{-}+$Int $\boldsymbol{D}^{\prime}$, gdzie $\boldsymbol{D}^{\prime}$ jest zbiorem w określonym sensie aproksymującym 
stożek $\boldsymbol{D}$ (lub $\boldsymbol{D}_{\varepsilon}$ ), to mówimy, że funkcja $\sigma\left(\boldsymbol{y}, \boldsymbol{y}^{-}\right)$aproksymuje porzadek. Ponieważ $\boldsymbol{D}_{\varepsilon}$ aproksymuje stożek $\boldsymbol{D}$, przeto funkcja reprezentująca porządek implikowany przez stożek $\boldsymbol{D}_{\varepsilon}$ jednocześnie aproksymuje porządek implikowany przez stożek $\boldsymbol{D}$; ale odpowiedni zbiór $\boldsymbol{D}^{\prime}$ aproksymujący $\boldsymbol{D}$ lub $\boldsymbol{D}_{\varepsilon}$ nie zawsze musi być stożkiem. Ogólniej, funkcje reprezentujące lub aproksymujące porządek (w sensie określonego stożka implikującego ten porządek) nazywamy funkcjami osiagnięcia zgodnymi z porządkiem.

Z Twierdzeń 7.1, 7.2 oraz Definicji 9.1 wynika bezpośrednio następujące twierdzenie:

Twierdzenie 9.4. Jeśli funkcja $\sigma\left(y, y^{-}\right)$reprezentuje porządek implikowany przez stożek $\boldsymbol{D}$ (lub $\boldsymbol{D}_{\varepsilon}$ ), to:

$$
\begin{aligned}
& \operatorname{Argmax}_{\boldsymbol{y e Y}_{0}} \sigma\left(\boldsymbol{y}, \boldsymbol{y}^{-}\right) \subseteq \boldsymbol{Y}^{*_{w}}{ }_{0} \forall \boldsymbol{y}^{-} \in \boldsymbol{Y}^{-} \\
& \left(\operatorname{lub} \operatorname{Argmax}_{\boldsymbol{y} \in \mathbf{Y} 0} \sigma\left(\boldsymbol{y}, \boldsymbol{y}^{-}\right) \subseteq \boldsymbol{Y}^{\boldsymbol{*}^{*} p \varepsilon}{ }_{0} \forall \boldsymbol{y}^{-} \in \boldsymbol{Y}^{-}\right)
\end{aligned}
$$

Odwrotnie, jeśli $\boldsymbol{y}^{*} \in \boldsymbol{Y}^{*}{ }_{0}$ (lub $\boldsymbol{y}^{*} \in \boldsymbol{Y}^{* p \varepsilon}$ ), to istnieje takie $\boldsymbol{y}^{-} \in \boldsymbol{Y}^{-}$ (w szczególności, $\boldsymbol{y}^{-=} \boldsymbol{y}^{*}$ ), że:

$$
\begin{aligned}
& \boldsymbol{y}^{*} \in \operatorname{Argmax}_{\mathbf{y \in Y} 0} \sigma\left(\boldsymbol{y}, \boldsymbol{y}^{-}\right) \subseteq \boldsymbol{Y}^{*}{ }_{0} \\
& \left(\operatorname{lub} \boldsymbol{y}^{*} \in \operatorname{Argmax}_{\boldsymbol{y \in Y} \mathbf{Y} 0} \sigma\left(\boldsymbol{y}, \boldsymbol{y}^{-}\right) \subseteq \boldsymbol{Y}^{*}{ }_{0}{ }_{0}\right)
\end{aligned}
$$

Dowód powyższego twierdzenia wynika bezpośrednio z Twierdzeń 7.1 i 7.2 o ścisłej monotoniczności i stożkowym rozdzielaniu zbiorów. Ważniejsze w zastosowaniach są części tego twierdzenia dotyczące właściwej $\varepsilon$-sprawności. Twierdzenie to podkreśla zatem, że jeśli chcemy skonstruować funkcję skalaryzującą dobrze charakteryzującą rezultaty właściwie $\varepsilon$-sprawne w sensie danego stożka, to funkcja ta powinna reprezentować lub co najmniej aproksymować porządek implikowany przez ten stożek. Zauważmy, że Definicja 9.1 oraz Twierdzenie 9.4 stosują się też do funkcji (9.3) oraz (9.10), które dla $\varepsilon>0$ reprezentują porządek implikowany przez stożek $\boldsymbol{D}_{\varepsilon}$ o postaci (9.1), natomiast dla $\varepsilon=0$ porządek implikowany przez stożek $\boldsymbol{D}=\boldsymbol{R}^{m}{ }_{+}$. Jednak Definicja 9.1 oraz Twierdzenie 9.4 są ogólniejsze w dwóch aspektach. Po pierwsze, nawet w przypadku $\boldsymbol{D}=\boldsymbol{R}^{m}{ }_{+}$można skonstruować inne funkcje mające własności a), b); po drugie, w przypadku innych stożków dodatnich niż $\boldsymbol{D}=\boldsymbol{R}^{m}{ }$, Definicja 9.1 i Twierdzenie 9.4 wskazują jak konstruować odpowiednie funkcje osiągnięcia. Przykłady takich funkcji podamy w punkcie następnym. 


\subsection{Szczególnie przydatne postaci funkcji osiągnięcia}

Funkcje osiągnięcia konstruuje się zazwyczaj w sposób podobny do zilustrowanego wyżej: najpierw określa się (ściśle monotoniczne) cząstkowe funkcje osiągnięcia $\sigma_{i}\left(y_{i}, y_{i}^{-}\right)$, a następnie agreguje je się tak, aby całościowa funkcja osiągnięcia reprezentowała lub aproksymowała porządek.

Jeśli $\boldsymbol{D}=\boldsymbol{R}^{m}{ }_{+}$, to oprócz funkcji osiągnięcia (9.3) oraz (9.10) przydatne jest jeszcze kilka innych postaci takich funkcji. Omówimy tu tylko jedną. Funkcje (9.3) oraz (9.10) są nieróżniczkowalne, przynajmniej dla $\boldsymbol{y}=\boldsymbol{y}^{-}$, a więc dla ich maksymalizacji trzeba wykorzystywać algorytmy optymalizacji nieróżniczkowalnej - z wyjątkiem szczególnego, ale ważnego przypadku, w którym model rzeczowy sytuacji decyzyjnej dany jest $\mathrm{w}$ formie wielokryterialnego programowania liniowego; wówczas maksymalizację przedziałami liniowych funkcji (9.3) oraz (9.10) można sprowadzić, za pomocą dodatkowych zmiennych sztucznych - zob. rozdział następny - do specyficznego zadania programowania liniowego ze zmiennym parametrem $\boldsymbol{y}^{\circ}$. Jeśli jednak model rzeczowy sytuacji decyzyjnej jest nieliniowy, to często dogodnie jest aproksymować funkcje osiągnięcia typu (9.3) oraz (9.10) poprzez odpowiednie funkcje różniczkowalne.

Taką funkcję osiągnięcia, aproksymującą porządek, można skonstruować poprzez wykorzystanie cząstkowych funkcji osiągnięcia (9.12), zależności (9.14) oraz normy $l_{p}$ jako aproksymacji normy $l_{\infty}$ czy $l_{1, \infty}$. Uzyskujemy wtedy następującą postać funkcji osiągnięcia:

$$
\begin{aligned}
& \sigma\left(\boldsymbol{y}, \boldsymbol{y}^{-}\right)=1-\left(1 / m \sum_{\mathrm{i}=1, \ldots \mathrm{m}}\left(1-\sigma_{i}\left(y_{i}, y_{i}^{-}\right)\right)^{p}\right)^{1 / p}= \\
& \left.1-\left(1 / m \sum_{\mathrm{i}=1, \ldots \mathrm{m}}\left(y_{{ }_{i}}^{{ }_{i}}-y_{i}\right) /\left(\tilde{y}_{i}-y_{i}^{-}\right)\right)^{p}\right)^{1 / p}
\end{aligned}
$$

przy czym $\boldsymbol{y}^{\sim}$ jest wybranym punktem ponadutopijnym, $\boldsymbol{y}^{\sim} \in \boldsymbol{y}_{\text {uto }}+$ Int $\boldsymbol{R}^{m}{ }_{+}$, i zakładamy - tak jak przy definicji cząstkowych funkcji osiągnięcia (9.12) że użytkownik definiuje punkty aspiracji w rozsądnym zakresie:

$$
\boldsymbol{y}^{-} \in \boldsymbol{Y}^{-}=\left\{\boldsymbol{y}^{-} \in \boldsymbol{R}^{m}: y_{i, \min }<y_{i}^{-}<\tilde{y}_{i} \forall i=1, \ldots m\right\}
$$

Zauważmy, że z definicji (9.12) wynika $\sigma_{i}\left(y_{i}^{-}, y_{i}^{-}\right)=0$, a więc także, według definicji (9.17), $\sigma\left(y^{-}, y^{-}\right)=0$, czyli $\boldsymbol{y}^{-}$należy do zbioru poziomicowego $\left\{\boldsymbol{y} \in \boldsymbol{R}^{m}: \sigma\left(\boldsymbol{y}, \boldsymbol{y}^{-}\right) \geq 0\right\}$. Zbiór ten wprawdzie nie jest równy $\boldsymbol{y}^{-}+\boldsymbol{R}^{m}{ }_{+}$, ale aproksymuje ten zbiór tym lepiej, im większe jest $p$. Łatwo sprawdzić, że jeśli $\boldsymbol{y}^{-} \in \boldsymbol{Y}$, to funkcja (9.17) jest ściśle monotoniczna względem $\boldsymbol{y}$ w sensie stożka Int $\boldsymbol{R}^{m}{ }_{+}$; nieco trudniej pokazać, że jest ona też lokalnie ściśle monotoniczna nawet w sensie stożka Int $\boldsymbol{D}_{\varepsilon}$ dla $\boldsymbol{D}_{\varepsilon}$ określonego jak w (9.1). Zatem każdy punkt maksymalny funkcji $\sigma\left(\boldsymbol{y}, \boldsymbol{y}^{-}\right)$określonej w (9.17) jest punktem nie tylko słabo sprawnym, lecz także właściwie $\varepsilon$-sprawnym. Natomiast odwrotnie, 
jeśli $\boldsymbol{y}^{*}$ jest punktem właściwie $\varepsilon$-sprawnym i przyjmiemy $\boldsymbol{y}^{-}=\boldsymbol{y}^{*}$, to nie mamy gwarancji, że uzyskamy maksimum funkcji $\sigma\left(\boldsymbol{y}, \boldsymbol{y}^{-}\right)$dokładnie w punkcie $\boldsymbol{y}^{*}-$ a tylko w punkcie dostatecznie bliskim $\boldsymbol{y}^{*}$, tym bliższym, im większe zastosujemy $p$ (por. Twierdzenie 8.1), co ilustruje Rys. 9.4. W praktyce jednak stosowanie zbyt dużych $p$ prowadzi do trudności numerycznych i zwykle stosuje się $p=6 \ldots 12$.

a)

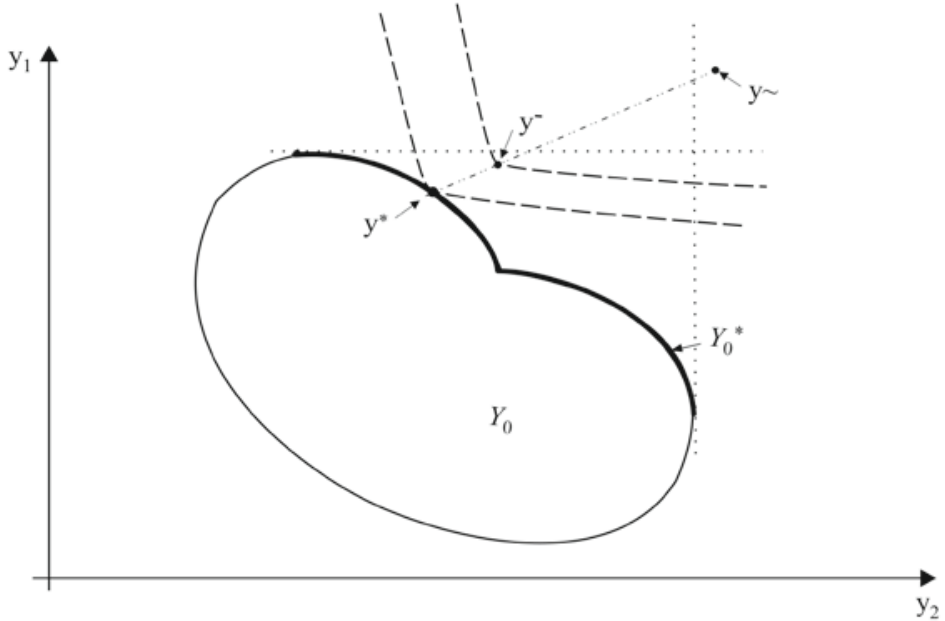

b)

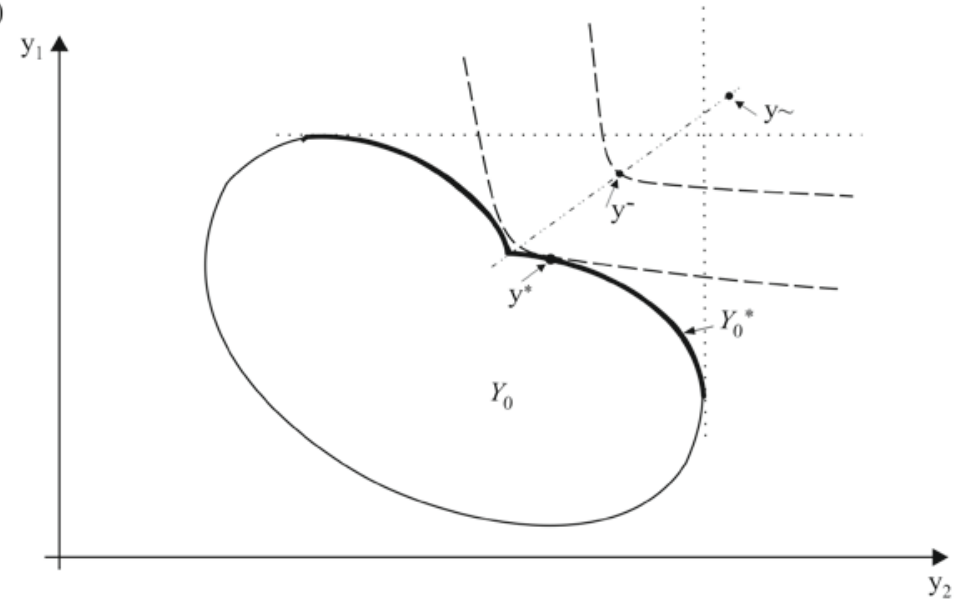

Rys. 9.4. Ilustracja zastosowania różniczkowalnej funkcji osiągnięcia aproksymującej porządek: a) dostateczność b) niepełna zupełność charakteryzacji rezultatów sprawnych przez maksima takiej funkcji. 
W odniesieniu do różniczkowalnych funkcji osiągnięcia trzeba też dodać, że pierwsza z postaci takich funkcji, zaproponowana w (Wierzbicki 1977), była funkcją kary za przekroczenie poziomów rezerwacji $\tilde{y}_{i}^{\sim}$ określanych podobnie jak $\mathrm{w}$ punkcie 8.5. Wspominaliśmy $\mathrm{w}$ tym punkcie, że wadą metody dodatkowych ograniczeń twardych związanych z poziomami rezerwacji jest możliwość złego sformułowania zadania optymalizacji (z pustym zbiorem rozwiązań), jeśli użytkownik pomyłkowo określi nieosiągalne poziomy rezerwacji. Otóż w celu uniknięcia tej wady można ograniczenia twarde zastąpić ograniczeniami miękkimi czyli np. kwadratowymi, zewnętrznymi funkcjami kary. Po wyborze $j$-tej składowej rezultatów jako podstawowej funkcji maksymalizowanej, uzyskuje się wtedy funkcję osiągnięcia:

$$
\sigma_{j}\left(y, y^{\sim}\right)=y_{j}-\tilde{y}_{j}-\rho \sum_{\mathbf{i} \neq \mathbf{j}}\left(\min \left(0, y_{i}-\tilde{y}_{i}\right)\right)^{2}
$$

gdzie $\rho>0$ jest współczynnikiem kary. Funkcja ta jest ściśle monotoniczna względem $\boldsymbol{D}^{\neq}=\boldsymbol{R}^{m}+\{\{0\}$, a więc każde jej maksimum jest rezultatem sprawnym; jest ona też funkcją osiągnięcia, gdyż $\sigma_{j}\left(\boldsymbol{y}^{\sim}, \boldsymbol{y}^{\sim}\right)=0$ i wartości dodatnie tej funkcji wskazują na osiągalność poziomów rezerwacji.

Różniczkowalną funkcję osiągnięcia można też modyfikować dla przypadku stożków $\boldsymbol{D}$ ogólniejszej postaci - gdy niektóre z atrybutów są minimalizowane czy stabilizowane, zob. Wierzbicki et al. (2000). Dla stożków takiej właśnie postaci omówimy tu inny przykład konstrukcji nieróżniczkowalnej funkcji osiągnięcia, powstałej jako uogólnienie omawianego wcześniej rozmytego zadania programowania wielokryterialnego, $\mathrm{z}$ funkcją zadowolenia użytkownika $\mathrm{z}$ uzyskanego rezultatu interpretowaną $\mathrm{w}$ terminach zbiorów rozmytych. Przypomnijmy, że odpowiednia funkcja przynależności miała postać:

$$
\mu(\boldsymbol{f}(\boldsymbol{x}))=\boldsymbol{\Pi}_{1 \leq i \leq m} \mu_{i}\left(f_{i}(\boldsymbol{x})\right)=\min _{1 \leq i \leq m} \mu_{i}\left(f_{i}(\boldsymbol{x})\right)
$$

gdzie $\boldsymbol{f}(\boldsymbol{x})=\boldsymbol{y}, f_{i}(\boldsymbol{x})=\boldsymbol{y}_{\boldsymbol{i}}$. Funkcja ta ma więc postać podobną do funkcji osiągnięcia (9.3) - tyle tylko, że maksima $\mu(\boldsymbol{y})$ względem $\boldsymbol{y} \in \boldsymbol{Y}_{0}$ byłyby słabo sprawne, $\mathrm{i}$ to pod warunkiem, że osiągane byłyby dla $0<\mu(y)<1$. Jeśli użytkownik byłby $\mathrm{w}$ pełni zadowolony $(\mu(y)=1)$ lub niezadowolony $(\mu(y)=0) \mathrm{z}$ osiąganych rezultatów, to maksima funkcji przynależności nie gwarantowałyby nawet słabej sprawności, gdyż funkcja ta nie jest ściśle monotoniczna w tym zakresie.

W celu uniknięcia tych wad trzeba, po pierwsze, dodać człon liniowy ze współczynnikiem $\varepsilon$ jak w funkcji osiągnięcia (9.3), co zapewni właściwą 
$\varepsilon$-sprawność odpowiednich punktów maksymalnych; po drugie zaś, zamiast cząstkowych funkcji przynależności $\mu_{i}\left(y_{i}\right)$ należy określić cząstkowe funkcje osiągnięcia $\sigma_{i}\left(y_{i}, y_{i}^{-}\right)$(lub $\sigma_{i}\left(y_{i}, y_{i}^{-}, y_{i}\right)$, zob. dalsze uwagi) takie, które można by interpretować jako funkcje przynależności w przedziale $(0 ; 1)$ ich wartości, ale które przyjmowałyby także wartości większe od jedności lub mniejsze od zera, zachowując przy tym ścisłą monotoniczność.

Załóżmy przy tym, że użytkownik będzie określał swe rozmyte preferencje poprzez podanie dwóch punktów odniesienia: punktu aspiracji $\boldsymbol{y}^{`}$ oraz punktu rezerwacji $\boldsymbol{y}^{\sim}$. Rozróżnimy też trzy przypadki optymalizacji rezultatów czyli atrybutów:

a) W przypadku atrybutów maksymalizowanych zakładamy: $y_{i, \min }<y_{i}<y_{i}^{-}<y_{i, \max }$, gdzie $y_{i, \max }$ jest współrzędną ponadutopijną;

b) W przypadku atrybutów minimalizowanych zakładamy: $y_{i, \min }<{y_{i}^{-}}_{i}<\tilde{y_{i}}<y_{i, \max }$, przy czym w tym przypadku $\boldsymbol{y}_{i, \min }$ jest współrzędną „ponadutopijną” (mniejszą w tym przypadku od współrzędnej utopijnej).

c) W przypadku atrybutów stabilizowanych zakładamy: $y_{i, \min }<\tilde{y}_{i, l o}<y_{i, l o}^{-}<y_{i, \text { mid }}^{-}<y_{i, u p}^{-}<\tilde{y}_{i, u p}<y_{i, \max }$, gdzie określone są dwie składowe $y_{i, l o}^{-}$i $y_{i, \text { up }}^{-}$poziomów aspiracji wraz z ich średnią $y_{i, m i d}^{-}$(np. $\left.y_{i, \text { mid }}^{-}=0,5\left(y_{i, l o}^{-}+y_{i, u p}^{-}\right)\right)$oraz odpowiednio dwie składowe $\tilde{y}_{i, l o}^{\tilde{i}_{0}} \tilde{y}_{i, \text { up }}^{\tilde{y}}$ poziomów rezerwacji; zarówno $y_{i, \min }$ jak i $y_{i, \max }$ są traktowane jako odpowiednie poziomy ,ponadutopijne”, określane raz przez minimalizację, a następnie maksymalizację współrzędnej $y_{i}$ po zbiorze $\boldsymbol{Y}_{0}$.

Możemy teraz przystąpić do określenia odpowiednich cząstkowych funkcji osiągnięcia. W przypadku a):

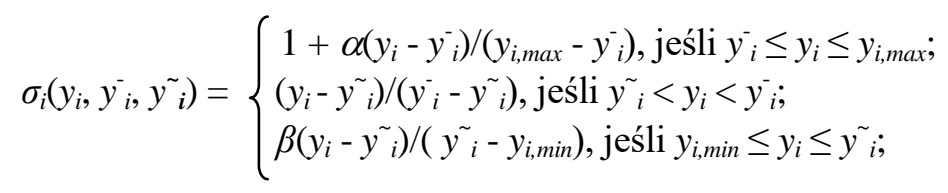

W przypadku b):

$$
\sigma_{i}\left(y_{i}, \overline{y_{i}}, \tilde{y_{i}}\right)=\left\{\begin{array}{l}
\beta\left(\tilde{y_{i}}-y_{i}\right) /\left(y_{i, \max }-y_{i}^{\sim}\right), \text { jeśli } \tilde{y}_{i} \leq y_{i} \leq y_{i, \max } ; \\
\left(\tilde{y_{i}}-y_{i}\right) /\left({\overline{y_{i}}}_{i}-y_{i}^{-}\right), \text {jeśli } y_{i}^{-}<y_{i}<y_{i}^{\sim} ; \\
1+\alpha\left(\overline{y_{i}}-y_{i}\right) /\left(\overline{y_{i}}-y_{i, \min }\right), \text { jeśli } y_{i, \min } \leq y_{i} \leq y_{i}^{-}
\end{array}\right.
$$


W przypadku c):

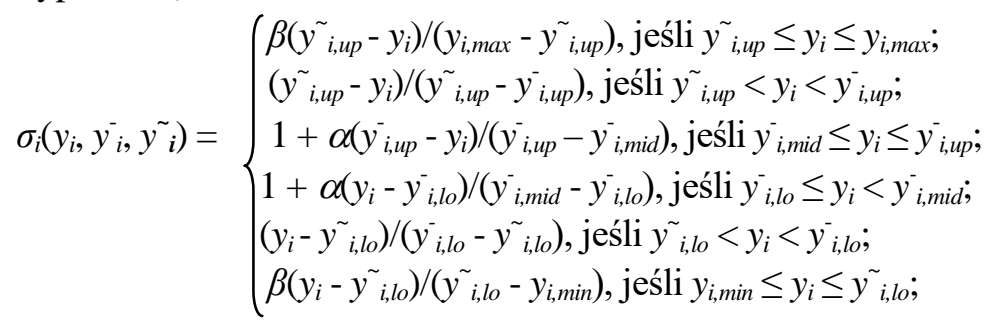

(a)

(b)

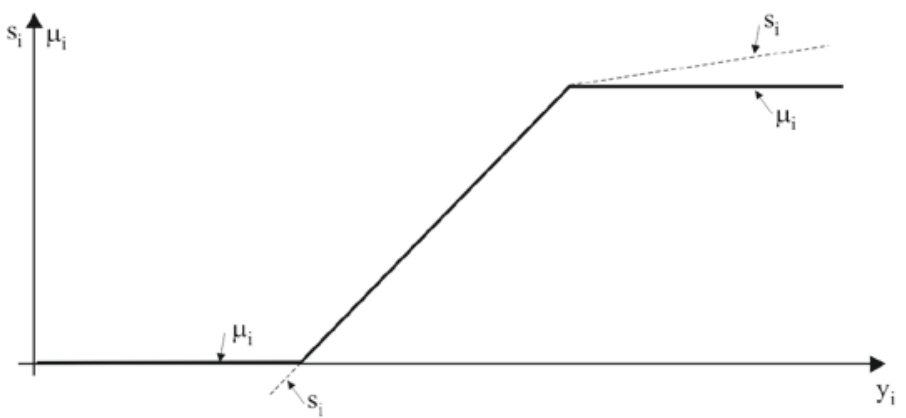

(c)
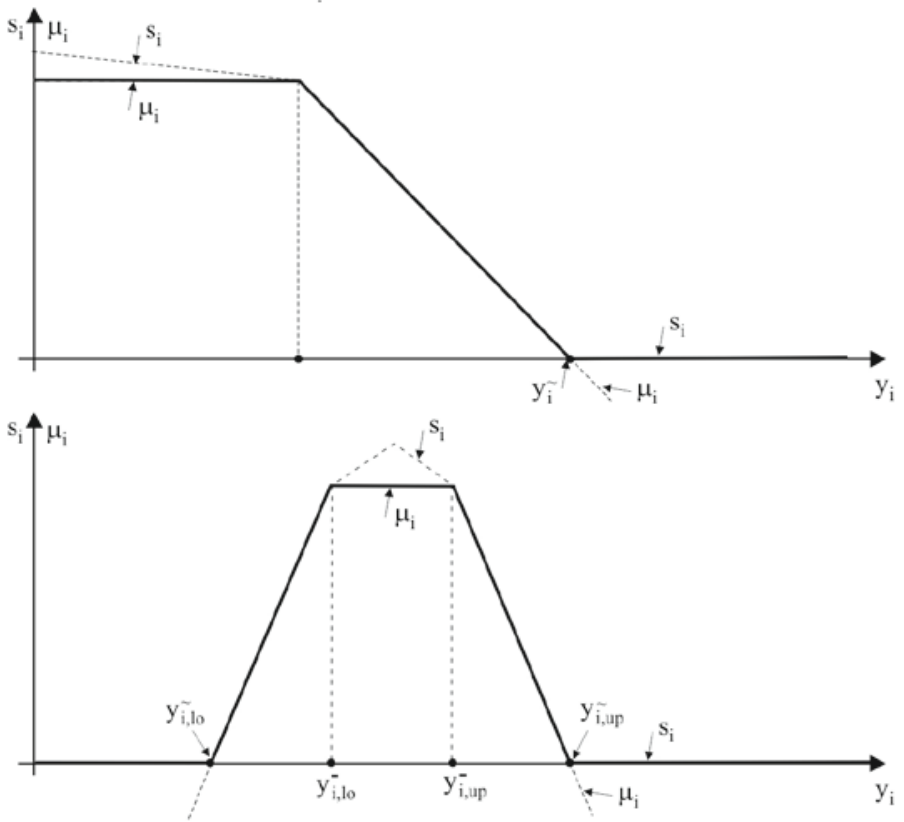

Rys. 9.5. Postaci cząstkowych funkcji osiągnięcia (dla przypadków a) maksymalizacji, b) minimalizacji i c) stabilizacji atrybutów) stosowanych wewnątrz systemu wspomagania decyzji oraz ich uproszczenia jako funkcje przynależności, przedstawiane podczas interakcji z użytkownikiem. 
Dodatnie współczynniki $\alpha, \beta$ można przy tym tak dobrać, aby wszystkie powyższe funkcje były wklęsłe, co ma istotne znaczenie dla przypadku modeli liniowych (gdyż tylko przy takim założeniu można sprowadzić maksymalizację całościowej funkcji osiągnięcia do zastępczego zadania programowania liniowego). Zauważmy, że rolę podstawowego parametru sterującego przejmuje teraz punkt rezerwacji $\boldsymbol{y}^{\sim}$, gdyż cząstkowe funkcje osiągnięcia przyjmują wartości zerowe dla $\boldsymbol{y}=\tilde{y}$, zob. Rys. 9.5. Można teraz zastosować standardową postać (9.10) całościowej funkcji osiągnięcia, którą tu powtórzymy dla przypomnienia:

$$
\sigma\left(\boldsymbol{y}, \boldsymbol{y}^{-}, \boldsymbol{y}^{\sim}\right)=\min _{1 \leq i \leq m} \sigma_{i}\left(y_{i},{\overline{y_{i}}}_{\overline{y_{i}}}^{\sim}\right)+\varepsilon \sum_{\mathrm{i}=1, \ldots m} \sigma_{i}\left(y_{i}, y_{i}^{-}, y_{i}^{\sim}\right)
$$

Punkty maksymalne tej funkcji są właściwie $\varepsilon$-sprawne, ale z następującą modyfikacją pojęcia $\varepsilon$-sprawności: odpowiednie współczynniki wymiany musimy odnosić nie do samych atrybutów $y_{i}$, lecz do stowarzyszonych $\mathrm{z}$ nimi cząstkowych funkcji osiągnięcia $\sigma_{i}\left(y_{i}, y_{i}^{-}, y_{i}^{\sim}\right)$. Ograniczenie na współczynniki wymiany $t_{i j}\left(y^{*}\right) \leq M=1+1 / \varepsilon$ dotyczy zatem współczynników wymiany nie pomiędzy wartościami atrybutów $y_{i}$ i $y_{j}$, lecz pomiędzy wartościami $\sigma_{i}\left(y_{i}, y_{i}^{-}, y_{i}^{\sim}\right)$ i $\sigma_{j}\left(y_{j}, y_{j}^{-}, y_{j}^{\sim}\right)$; chcąc z niego odczytać ograniczenie na współczynniki wymiany pomiędzy wartościami atrybutów $y_{i}$ i $y_{j}$, trzeba uwzględnić lokalne nachylenia częściowych funkcji osiągnięcia $\sigma_{i}\left(y_{i}, y_{i}{ }_{i}, y_{i}{ }_{i}\right)$ i $\sigma_{j}\left(y_{j}, y_{j}^{-}, y_{j}^{\sim}\right)$ w danym punkcie $\boldsymbol{y}=\boldsymbol{y}^{*}$, które oczywiście można określić na podstawie wzorów (9.21), (9.22), (9.23).

Wszystkie te szczegółowe wymagania odnośnie ścisłej monotoniczności, wklęsłości i innych własności funkcji osiągnięcia reprezentującej porządek częściowy określony przez użytkownika (poprzez wybór, które atrybuty powinny być maksymalizowane, które minimalizowane, a które stabilizowane) muszą być spełnione przez funkcje stosowane niejako wewnątrz systemu wspomagania decyzji, natomiast nie muszą komplikować interakcji systemu wspomagania decyzji z użytkownikiem. Dlatego też w interfejsie graficznym współpracy systemu wspomagania decyzji z użytkownikiem stosuje się - zob. np. Janusz Granat i Marek Makowski (1999) - nie skomplikowane cząstkowe funkcje osiągnięcia $\sigma_{i}\left(y_{i}, y_{i}^{-}, y_{i}^{\sim}\right)$, ale uproszczone funkcje przynależności $\mu_{i}\left(y_{i}\right)$, które ilustrują stopień zadowolenia użytkownika $\mathrm{z}$ osiągniętych wartości $y_{i}$ przy graficznie definiowanych poziomach aspiracji i rezerwacji, tak jak to pokazano na Rys. 9.5. 


\section{Literatura}

Andriole S.J. (1989) Handbook of Decision Support Systems, TAB Books, Inc., Blue Ridge Summit, PA

Gill Ph.E., Murray W., Wright M.H. (1981) Practical Optimization, Academic Press, London - New York

Granat J., Wierzbicki A.P. (1994) Interactive Specification of DSS User Preferences in Terms of Fuzzy Sets. Working Paper of the International Institute for Applied Systems Analysis, WP-94-29, Laxenburg, Austria

Granat J., Makowski M. (1999): Interactive specification and analysis of aspirationbased preferences. European Journal of Operational Research 122: 469-485

Jaszkiewicz A., Słowiński R. (1994) The LBS package - a microcomputer implementation of the Light Beam Search method for muliple-objective nonlinear programming. Working Paper of the International Institute for Applied Systems Analysis, WP-94-07, Laxenburg, Austria

Korhonen P., i Laakso J. (1986) Solving a generalized goal programming problem using visual interactive approaches. European Journal of Operational Research 26: $355-363$

Kręglewski T., Granat J., Wierzbicki A.P. (1991) IAC-DIDAS-N: A Dynamic Interactive Decision Analysis and Support System for Multicriteria Analysis of Nonlinear Models. Collaborative Paper of the International Institute for Applied Systems Analysis, CP-91-10, Laxenburg, Austria

Lewandowski A., Wierzbicki A.P., eds. (1989) Aspiration Based Decision Support Systems, Lecture Notes in Economic and Mathematical Systems 331, Springer Verlag, Berlin-Heidelberg

Makowski M., Sosnowski J. (1989) Mathematical programming package HYBRID. In: A. Lewandowski, A.P. Wierzbicki (op.cit)

Murtagh B.A., Saunders M.A. (1977) MINOS - a Large Scale Nonlinear Programming System for Problems with Linear Constraints. User Guide, Stanford Optimization Laboratory

Nakayama H., Sawaragi Y. (1983) Satisficing trade-off method for multiobjective programming. W: M. Grauer i A.P. Wierzbicki, eds.: Interactive Decision Analysis, Lecture Notes in Economics and Mathematical Systems 229, Springer-Verlag, Berlin-Heidelberg

Ogryczak W., Zorychta K. (1994) On solving multiobjective linear programs with implicit representation of minimax scalarizing function. Archives of Control Sciences 3 (XXXIV): 197-213

Polak E. (1976) On the Approximation of Solutions to Multiple Criteria Decision Making Problems. In: M. Zeleny, ed., Multiple Criteria Decision Making, Lecture Notes in Economics and Mathematical Systems 123:271-282, Springer Verlag, Heidelberg

Rogowski T., Sobczyk J., Wierzbicki A.P. (1989) IAC-DIDAS-L - A dynamic interactive decision analysis and support system for multicriteria analysis of linear and dynamic linear models on professional microcomputers. In: A. Lewandowski and A.P. Wierzbicki (op.cit.) 
Steuer R.E. (1986) Multiple Criteria Optimization: Theory, Computation, and Application, J.Wiley and Sons, New York

Wierzbicki A.P. (1977): Basic properties of scalarizing functionals for multiobjective optimization. Mathematische Operationsforschung und Statistik, s. Optimization 8: 55-60

Wierzbicki A.P. (1980) The use of reference objectives in multiobjective optimization. W: G. Fandel, T. Gal (eds.): Multiple Criteria Decision Making; Theory and Applications, Lecture Notes in Economic and Mathematical Systems 177: 468-486, Springer-Verlag, Berlin- Heidelberg

Wierzbicki A.P. (1986) On the completeness and constructiveness of parametric characterizations to vector optimization problems. OR-Spektrum 8: 73-87.

Wierzbicki A.P., Makowski M., Wessels J. (2000) Model-Based Decision Support Methodology with Environmental Applications. IIASA - Kluwer Academic Publishers, Dordrecht 


\section{Systemy wspomagania decyzji oparte na metodach punktu odniesienia}

W rozdziale tym przedstawiono różnorodne zadania analizy modeli rzeczowych, ogólne zasady budowy takich modeli, standardy zapisu modeli, uwagi na temat różnych metod symulacji i optymalizacji modeli, zasady wielokryterialnej analizy modeli, pojęcia symulacji odwrotnej i z miękkimi ograniczeniami przy wykorzystaniu optymalizacji wektorowej, pojęcia analizy wrażliwości oraz analizy postoptymalnej, wreszcie przykłady systemów wspomagania decyzji opartych na wykorzystaniu metod punktu odniesienia do analizy wielokryterialnej modeli rzeczowych i stosowanych do realnych problemów, zwłaszcza ekologiczno-ekonomicznych.

\subsection{Zadania analizy modelu rzeczowego}

Systemy wspomagania decyzji można dzielić według różnych kryteriów: paradygmatu teorii decyzji, typu i charakteru modelu preferencyjnego, sposobu reprezentacji niepewności, roli i rodzaju modelu rzeczowego, charakteru interakcji z użytkownikiem, zakresu zastosowań, stopnia uniwersalności lub specjalizacji dla danego zakresu zastosowań. Ten ostatni aspekt jest często najważniejszy; odpowiednie dostosowanie systemu wspomagania decyzji do potrzeb i przyzwyczajeń użytkownika oraz języka symboli charakterystycznego dla danej dziedziny zastosowań jest zazwyczaj najbardziej kosztowną częścią opracowania systemu wspomagania decyzji. $\mathrm{Z}$ tego też względu, wiele komercyjnie dostępnych systemów wspomagania decyzji specjalizuje się na danym zakresie zastosowań, $\mathrm{z}$ drugiej strony starając się wykorzystywać możliwie najprostsze modele sytuacji decyzyjnej, a zwłaszcza ich części rzeczowe. ${ }^{1}$

1 Przypominamy tu podział, wprowadzony w rozdziałach poprzednich: model rzeczowy określa obiektywną wiedzę o aspektach sytuacji decyzyjnej, niezależną od decydenta czy użytkownika systemu wspomagania decyzji, model preferencji określa wymagania lub preferencje decydenta czy użytkownika w stosunku do podejmowanych decyzji. 
W tym rozdziale skoncentrujemy się jednak na systemach wspomagania decyzji, w których możliwe jest wykorzystanie nawet stosunkowo skomplikowanych modeli rzeczowych sytuacji decyzyjnej. I znów mamy dużo klas systemów wspomagania decyzji, które wykorzystują stosunkowo złożone modele rzeczowe; na przykład, sytuacja taka jest typowa dla wszystkich systemów wspomagania projektowania inżynierskiego. Ze względu na tę dużą różnorodność zastosowań systemów wspomagania decyzji ograniczymy się tu do wybranej klasy systemów dość uniwersalnych, charakteryzujących się:

- Wykorzystaniem metod punktu odniesienia, a więc pojęć punktów aspiracji i maksymalizacji funkcji osiągnięcia w celu organizacji interakcji z użytkownikiem;

- Założeniem, że preferencje użytkownika nie są w pełni ukształtowane, zmieniają się $\mathrm{w}$ trakcie procesu decyzyjnego, natomiast zasadniczym zadaniem systemu wspomagania decyzji jest wspomaganie raczej uczenia się przez użytkownika niż końcowego aktu wyboru;

- W konsekwencji poprzedniego założenia, nieco większą wagą nadawaną analizie modeli rzeczowych sytuacji decyzyjnej, niż modeli preferencyjnych.

Zanim jednak przejdziemy do omówienia przykładów takich systemów, omówimy tu krótko najpierw ogólny problem analizy modelu rzeczowego sytuacji decyzyjnej.

W podręcznikach rozróżnia się zazwyczaj tylko symulację i optymalizację modelu; w zastosowaniach można wyróżnić cały szereg różnych zadań budowy i analizy modelu rzeczowego:

- formułowanie i budowa modelu;

- symulacja prosta (jednokrotna);

- symulacja parametryczna (powtarzanie symulacji prostych dla założonego scenariusza zmian parametrów modelu);

- symulacyjna analiza wrażliwości (na podstawie odpowiednio dobranej symulacji parametrycznej lub symulacji z obliczeniem pochodnych względem parametrów);

- optymalizacja skalarna (jednokrotna);

- optymalizacja skalarna parametryczna (powtarzalna); 
- ocena zakresu zmienności wskaźników (np. ocena przedziałów utopianadir przed optymalizacją wektorową czy wielokryterialną);

- optymalizacja wektorowa i analiza wielokryterialna;

- symulacja odwrotna lub z miękkimi ograniczeniami (w istocie, odpowiednie wykorzystanie technik optymalizacji wektorowej, zob. dalej);

- parametryczne eksperymenty postoptymalne (czy to dla optymalizacji skalarnej, czy wektorowej);

- eksperymenty hybrydowe (łączące kilka z podanych wyżej zadań analizy modelu);

- wybór wielokryterialny;

- analiza wrażliwości wdrożenia decyzji.

\subsection{Wskazówki przy budowie modeli}

Zaczynając od zadania pierwszego - formułowania i budowy modelu - trzeba podkreślić, że budowa modeli jest zawsze sztuką, choć wymagającą sporej wiedzy o różnych własnościach modeli i metodach analizy; zob. np. Wierzbicki (1977). Możemy jednak wymienić kilka zasad konstrukcji modeli, wynikających z długoletniego doświadczenia (zob. Wierzbicki et al. 2000):

- Przed budową modelu trzeba jasno określić cel jego konstrukcji. Konstruowanie „modeli uniwersalnych”, mających wyrazić całą naszą wiedzę o danej dziedzinie, kończy się zawsze niepowodzeniem. Nawet mały fragment rzeczywistości - np. woda w kubku - może mieć zbyt skomplikowane modele do praktycznego zastosowania, jeśli chcemy nimi wyrazić zbyt dużo aspektów - np. modele przemian fazowych cząsteczek przy zmianie stanu skupienia wody, wytrzymałość kubka na pęknięcia itp. Jeśli chodzi nam np. tylko o wyznaczanie temperatury wody, to wystarczy prosty model bilansu cieplnego, i nie trzeba go nadmiernie komplikować.

- Każdy model jest tylko przybliżeniem i trzeba dostosować jego dokładność, a także dokładność jego części, do celu jego budowy. Modele nadto dokładne mogą wymagać bardzo poważnego nakładu pracy przy ich skalowaniu, pozyskiwaniu danych niezbędnych do estymacji i weryfikacji parametrów modelu, itd. Jeśli chodzi nam np. o szczegóły dynamiki przepływu wody $\mathrm{w}$ rzece, to potrzebujemy modelu w postaci równania różniczkowego cząstkowego; jeśli jednak chodzi nam tylko o bilans zanieczyszczeń tej wody, to wystarczą modele znacznie prostsze, zdyskretyzowane w czasie i przestrzeni, wymagające znacznie mniejszego 
nakładu obliczeń, a za to pozwalające skoncentrować uwagę na głównych aspektach analizy takiego modelu.

- Opis modelu i zmienne wybrane do jego budowy powinny możliwie blisko odpowiadać interesującym nas zmiennym fizycznym, biologicznym, technicznym czy ekonomicznym oraz wiedzy o zależnościach między nimi. Nie należy naginać modelu do narzędzi jego analizy: np. budowa modelu programowania liniowego tylko po to, by łatwo go było optymalizować, nie jest uzasadniona gdy interesujące nas problemy mają wyraźnie charakter nieliniowy.

- Ufaj wiedzy ekspertów, nie ufaj założeniom, językowi oraz formatom modeli przez nich używanych. Najczęstszym błędem przy budowie modeli jest oparcie się na upraszczającym to zagadnienie podręczniku, który omawia np. programowanie liniowe, dynamiczne i algorytmy ewolucyjne dla optymalizacji skalarnej, wspominając wprawdzie o programowaniu nieliniowym i optymalizacji wektorowej, ale przedstawiając je jako zagadnienia zbyt skomplikowane. Czytelnik takiego podręcznika dochodzi wtedy do wniosku, że każdy praktyczny problem można rozwiązać za pomocą jednego $\mathrm{z}$ podejść tak prosto wyłożonych w podręczniku; tymczasem praktyczne problemy są z reguły jednak bardziej skomplikowane, zastosowanie standardowych metod może prowadzić po prostu do nasycenia mocy obliczeniowej komputera.

- Ostrożnie stosuj metody uniwersalne, bo co jest uniwersalne teoretycznie, okazuje się zwykle zbyt trudne obliczeniowo w praktyce. Wspomniane wyżej algorytmy ewolucyjne czy genetyczne przedstawia się dziś często jako antidotum na wszelkie trudności w rozwiązywaniu zadań optymalizacji. Opinia taka jest prawdziwa, ale dotyczy przykładów o bardzo ograniczonych wymiarach; przy większych, realistycznych wymiarach problemów, algorytmy ewolucyjne i genetyczne szybko nasycają dowolnie dużą moc obliczeniową komputera.

- Nie upraszczaj nadmiernie procesu analizy modelu, staraj się przeprowadzić możliwie wiele różnorodnych eksperymentów z modelem. Jako regułę należy przyjąć, że nie rozumiemy dostatecznie dobrze zachowania się danego modelu o realistycznym stopniu złożoności, jeśli nie przeprowadzimy z nim przynajmniej kilkudziesięciu eksperymentów analizy.

- Szukaj niespodzianek w zachowaniu się modelu. Jeśli model zachowuje się w pełni tak, jak przewidywaliśmy, to nie spełnia swojej podstawowej roli jako pola uczenia się nowych aspektów wiedzy o danej sytuacji decyzyjnej. 
- Buduj model wykorzystując możliwie proste standardy i opisuj go tak, aby móc go ponownie wykorzystać (samemu, czy udostępniając innym). Budowa i analiza modeli jest zbyt dużą inwestycją czasu i wysiłku badawczego, by nie wykorzystywać jej rezultatów ponownie.

\subsection{Standardy zapisu modeli analitycznych}

Trzeba jednak podkreślić, że brak jest jak dotąd uniwersalnych standardów zapisu modeli analitycznych, nie tylko pomiędzy różnymi dyscyplinami wiedzy i zastosowań, ale także wewnątrz poszczególnych dyscyplin - co oczywiście utrudnia ponowne wykorzystanie modeli przez innych użytkowników. Na przykład, metody badań operacyjnych - opierając się na ekonomicznym paradygmacie optymalizacji funkcji wartości - rozwinęły szereg tzw. języków modelowania, takich jak GAMS, AIMMS, AMPL. ${ }^{2}$ Jednakże języki te nie tylko różnią się standardami zapisu modeli, lecz także zdominowane są przez paradygmat optymalizacji skalarnej: model zapisuje się jako funkcję celu (optymalizowaną) i system ograniczeń; znacznie trudniej w takim podejściu określać wiele rezultatów decyzji czy przygotowywać model wielokryterialny.

Modele liniowe, związane z programowaniem liniowym (zob. Stachurski et al. 1999) mają powszechnie akceptowany, choć nie najlepszy standard zapisu, zwany MPS (zob. Bruce Murtagh et al. 1977). Dostosowany jest on do zapisu modeli programowania liniowego w postaci niemal standardowej:

$$
\text { maximize }_{\boldsymbol{X} \in \boldsymbol{X} 0} q=\boldsymbol{c}^{\mathrm{T}} \boldsymbol{x} ; \boldsymbol{X}_{0}=\left\{\boldsymbol{x} \in \boldsymbol{R}^{n}: \boldsymbol{A} \boldsymbol{x}=\boldsymbol{b} \in \boldsymbol{R}^{m}, \boldsymbol{I} \leq \boldsymbol{x} \leq \boldsymbol{u}\right\}
$$

$\mathrm{W}$ postaci tej możliwe jest też uwzględnienie ograniczeń nierównościowych, ale $\mathrm{w}$ zasadzie dąży się do ich przekształcenia w ograniczenia równościowe za pomocą wprowadzenia odpowiedniej liczby zmiennych sztucznych. W rezultacie, zmienna $\boldsymbol{x}$ w tym modelu nie reprezentuje tylko faktycznych zmiennych decyzyjnych, ale zawiera wiele zmiennych sztucznych (ogólna liczba zmiennych $n$ w takim modelu musi być nie mniejsza niż liczba ograniczeń $m$ ). Nie jest to standard dogodny dla analityka konstruującego model, który wymaga raczej jasnego rozróżnienia pomiędzy faktycznymi zmiennymi decyzyjnymi a zmiennymi pomocniczymi. Dogodny dla

\footnotetext{
${ }^{2}$ Zob. Wierzbicki et al. (2000), rozdział 6, w którym opisano bardziej szczegółowo zagadnienia języków modelowania.
} 
konstruktora modelu standard zapisu modeli programowania liniowego ma raczej postać:

$$
\boldsymbol{q}=\boldsymbol{C} \boldsymbol{x} \in \boldsymbol{R}^{k} ; \boldsymbol{X}_{0}=\left\{\boldsymbol{x} \in \boldsymbol{R}^{n}: \boldsymbol{b} \leq \boldsymbol{y}=\boldsymbol{A} \boldsymbol{x}+\boldsymbol{W} \boldsymbol{y} \leq \boldsymbol{b}+\boldsymbol{r} \in \boldsymbol{R}^{m}, \boldsymbol{I} \leq \boldsymbol{x} \leq \boldsymbol{u}\right\}
$$

gdzie macierz $\boldsymbol{C}$ określa cały wektor możliwych funkcji celu, czyli kryteriów optymalizacji wektorowej (z których użytkownik może potem wybierać jedno czy kilka optymalizowanych), natomiast wektor $\boldsymbol{x}$ reprezentuje tylko właściwe zmienne decyzyjne. Wszelkie zmienne pomocnicze, niezbędne w budowie bardziej złożonych modeli, reprezentowane są poprzez dodatkowy wektor $\boldsymbol{y}$ (rozbudowując ten wektor, można też do niego włączyć wszystkie składowe wektora $\boldsymbol{q}$ i dokonywać wyboru zmiennych optymalizowanych przez selekcję składowych wektora $\boldsymbol{y}$ ). W tym formacie zapisu modeli mamy więc zwykle $n<<m$ (w równaniach (10.1) i (10.2) oznaczamy za pomocą tych samych $\boldsymbol{x}, m, n$ zmienne i wskaźniki o oczywiście całkiem odmiennej interpretacji). Macierz $\boldsymbol{W}$ odzwierciedla fakt, że analityk może wprowadzić do swych modeli rozmaite zmienne zagregowane jako zmienne wyjściowe, a następnie używać te zmienne w definicjach dalszych zależności modelu.

Macierz $(\boldsymbol{I}-\boldsymbol{W})^{-1}$ zazwyczaj istnieje i teoretycznie można by próbować rozwikływać zależność $\boldsymbol{y}=\boldsymbol{A} \boldsymbol{x}+\boldsymbol{W} \boldsymbol{y}$ (oczywiście, nie ręcznie przez analityka, tylko automatycznie przez odpowiednie oprogramowanie); jednakże nie jest to zazwyczaj opłacalne. Modele liniowe, mimo bardzo prostej postaci, mają bowiem często bardzo duże wymiary i macierze $A, W$ są zwykle rzadkie (mają niewielkie liczby współczynników niezerowych - gdyby było inaczej, to dla modeli o dużych wymiarach, samo określenie ich współczynników byłoby zadaniem bardzo trudnym). Wykorzystuje się ten fakt dla zmniejszenia zajętości pamięci przy przechowywaniu tych macierzy i dla uproszczenia wykonywania operacji algebraicznych na tych macierzach - zob. np. Phillip Gill et al. (1981). Odpowiednie implementacje algorytmów rozwiązywania zadań optymalizacji liniowej, zwykle oparte na metodzie sympleksu, też wykorzystują cechy rzadkości macierzy zadania. Natomiast po rozwikłaniu modelu, macierz $(\boldsymbol{I}-\boldsymbol{W}\})^{-1} \boldsymbol{A}$ traci cechę rzadkości nawet dla rzadkich macierzy $\boldsymbol{A}, \boldsymbol{W}$. Ponadto, dla analityka modeli podział na zmienne $\boldsymbol{x}$, $\boldsymbol{y}$ oraz macierze $\boldsymbol{A}, \boldsymbol{W}$ jest istotny. W formacie MPS podział taki, choć możliwy, nie jest jednak jawny; z tych i innych przyczyn opracowywano inne formaty zapisu modeli liniowych, m.in. LP-DIT (zob. Marek Makowski, 1994); wciąż jeszcze brak formatu w pełni dogodnego dla użytkownika. 
Jednym z powodów tego braku jest fakt, że modele liniowe mają szereg ważnych postaci szczególnych. Jedną z nich jest postać liniowego zadania programowania dynamicznego, w którym zbiór decyzji dopuszczalnych definiowany jest $\mathrm{z}$ uwzględnieniem równań dynamiki modelu:

$$
\begin{aligned}
& \boldsymbol{X}_{0}=\left\{\boldsymbol{x} \in \boldsymbol{R}^{n}: \boldsymbol{w}_{t+1}=\boldsymbol{A}_{t} \boldsymbol{w}_{t}+\boldsymbol{B}_{t} \boldsymbol{x}_{t} ; \boldsymbol{b}_{t} \leq \boldsymbol{y}_{t}=\boldsymbol{C}_{t} \boldsymbol{w}_{t}+\boldsymbol{D}_{t} \boldsymbol{x}_{t} \leq \boldsymbol{b}_{t}+\boldsymbol{r}_{t} \in \boldsymbol{R}^{m} ; \boldsymbol{I}_{t} \leq \boldsymbol{x}_{t} \leq \boldsymbol{u}_{i} ;\right. \\
& t=1, \ldots T\}
\end{aligned}
$$

gdzie decyzje $\boldsymbol{x}=\left(\boldsymbol{x}_{1}, \ldots \boldsymbol{x}_{t}, \ldots \boldsymbol{x}_{T}\right)$ są też zwane sterowaniem modelu, $\boldsymbol{y}=\left(\boldsymbol{y}_{1}, \ldots \boldsymbol{y}_{t}, \ldots \boldsymbol{y}_{T}\right)-$ jego dynamiczną zmienną wyjściową, natomiast dodatkowa zmienna $\boldsymbol{w}=\left(\boldsymbol{w}_{1}, \ldots \boldsymbol{w}_{t}, \ldots \boldsymbol{w}_{T}\right)$ reprezentuje wektor dynamicznych zmiennych stanu modelu, wreszcie indeks $t=1, \ldots T$ interpretowany jest zwykle jako czas.

Jest to format liniowego modelu dynamicznego dyskretnego w czasie; odrębnym i znacznie szerszym zagadnieniem są różne ciągłe w czasie postaci modeli dynamicznych, zob. np. Wierzbicki (1977). Poprzez połączenie macierzy $\boldsymbol{A}_{t}, \boldsymbol{B}_{t}, \boldsymbol{C}_{t}$ i $\boldsymbol{D}_{t}$ w odpowiednio większe macierze można oczywiście sprowadzić format (10.3) modelu dynamicznego do postaci statycznej (10.2), z macierzami $\boldsymbol{A}, \boldsymbol{W}$ o odpowiednio dużej ilości zer.

Ćwiczenie 10.1: zapisać model (10.3) w postaci (10.2), z określeniem struktury macierzy $\boldsymbol{A}, \boldsymbol{W}$ oraz uwzględnieniem faktu, że wektor $\boldsymbol{y}$ w modelu (10.2) odpowiada faktycznie połączonym wektorom $(\boldsymbol{w}, \boldsymbol{y})$ w modelu (10.3).

Powyższe przykłady różnych standardów zapisu modeli liniowych nie wyczerpują pełnej różnorodności tych modeli. Jeszcze bardziej złożonym typem takich modeli jest np. struktura liniowej wieloetapowej optymalizacji stochastycznej, zbliżona do liniowego modelu dynamicznego, ale uwzględniająca na każdym etapie dodatkowe zakłócenia losowe, zob. Yuriy Ermolev et al. (1988).

O ile dla modeli rzeczowych typu programowania liniowego istnieją pewne standardy ich zapisu, to dla modeli typu programowania nieliniowego $\mathrm{w}$ zasadzie brak dobrych standardów. Chociaż istnieje kilka systemów wspomagania edycji modeli i skalarnej optymalizacji nieliniowej, jak GAMS, AIMMS, LANCELOT, AMPL itp., to jednak nie były one zazwyczaj konstruowane z myślą o wielokryterialnej analizie takich modeli, a zwłaszcza o włączeniu bardziej zaawansowanych funkcji takiej analizy - 
zob. Wierzbicki et al. (2000). Klasyczny format podręcznikowy optymalizacji wielokryterialnej takich modeli ma postać:

$$
\text { Mulmaximize }_{\mathbf{x} \in \mathbf{X} 0}\left(\boldsymbol{q}=\boldsymbol{f}(\boldsymbol{x}) \in \boldsymbol{R}^{k}\right) ; \boldsymbol{X}_{0}=\left\{\boldsymbol{x} \in \boldsymbol{R}^{n}: \boldsymbol{g}(\boldsymbol{x}) \leq 0 \in \boldsymbol{R}^{m}\right\}
$$

gdzie Mulmaximize ozanacza maksymalizacje wielokryterialną, $f_{i}(x)$ reprezentują kolejne funkcje celu czy kryteria, zaś $\boldsymbol{g}_{j}(\boldsymbol{x})$ reprezentują kolejne ograniczenia zbioru decyzji dopuszczalnych. Jednakże format taki też nie jest zazwyczaj dogodny dla budowy bardziej złożonych modeli, gdzie bardziej naturalne jest rozpatrywanie kolejnych zmiennych wyjściowych $\boldsymbol{y}_{i}$ oraz definiowanie zarówno kryteriów jak ograniczeń w terminach tych zmiennych wyjściowych.

Stosunkowo prosty a dogodny standard zapisu złożonych modeli nieliniowych przyjęto $\mathrm{W}$ starym i niezbyt popularnym systemie wielokryterialnego wspomagania decyzji i analizy modeli DIDAS-N. Pierwsza wersja tego systemu, napisana w już końcu lat 80 -tych, była systemem zamkniętym w języku PASCAL, $\mathrm{z}$ edycją modeli w odpowiednim formularzu elektronicznym, wyróżnia się jednak przemyślanym standardem zapisu i wspomagania analizy modeli nieliniowych. W standardzie tym wyróżnia się zmienne decyzyjne $\boldsymbol{x}$, parametry $\mathbf{z}$ (które różnią się od zmiennych decyzyjnych tym, że są ustalane przez użytkownika i nie mogą być zmiennymi optymalizacji) oraz zmienne wyjściowe $\boldsymbol{y}$. Użytkownik definiuje model poprzez określenie funkcji nieliniowych wyznaczających kolejne zmienne wyjściowe; funkcje te mogą zależeć od dawniej zdefiniowanych lub nowych zmiennych decyzyjnych i parametrów, a także od tylko wcześniej zdefiniowanych zmiennych wyjściowych:

$$
\begin{aligned}
& \boldsymbol{y}_{1}=\boldsymbol{f}_{1}(\boldsymbol{x}, \mathbf{z}) ; \ldots \\
& \boldsymbol{y}_{j+1}=\boldsymbol{f}_{j+1}\left(\boldsymbol{x}, \mathbf{z}, \boldsymbol{y}_{1}, \ldots y_{j}\right), j=1, \ldots m-1 ; \ldots \\
& \boldsymbol{y}_{m}=\boldsymbol{f}_{m}\left(\boldsymbol{x}, \mathbf{z}, \boldsymbol{y}_{1}, \ldots y_{m-1}\right)
\end{aligned}
$$

razem z ograniczeniami dla zmiennych decyzyjnych i wyjściowych:

$$
\boldsymbol{x}_{\text {ilo }} \leq \boldsymbol{x}_{i} \leq \boldsymbol{x}_{\text {iup }}, i=1, \ldots n ; \boldsymbol{y}_{j l o} \leq \boldsymbol{y}_{j} \leq \boldsymbol{y}_{j u p}, j=1, \ldots m
$$

W ten sposób użytkownik definiuje tylko modele w postaci jawnej (nieuwikłanej), które można symulować bez pomocy narzędzi optymalizacyjnych. Ponieważ jednak dla każdej zmiennej użytkownik określa też zakresy jej zmienności (nie jest to tak ważne, choć możliwe, 
w przypadku parametrów), to poprzez określenie $\boldsymbol{y}_{j l o}=\boldsymbol{y}_{\text {jup }}$ dla wybranych zmiennych można też definiować ograniczenia równościowe i tym samym modele w postaci niejawnej (uwikłanej), których rozwikływanie następuje w trakcie optymalizacji.

Ważnym problemem podczas analizy i optymalizacji modeli nieliniowych jest ich automatyczne różniczkowanie, to jest określenie (w drodze symbolicznej analizy algebraicznej) pochodnych cząstkowych i zupełnych odpowiednich zależności modelu, a także sposobu ich dalszego obliczania przy optymalizacji modelu. Wiadomo bowiem, że pochodne modelu zachowują w swej strukturze elementy struktury poszczególnych funkcji $\boldsymbol{f}_{i}$, a więc odpowiednie określenie struktury cząstkowych funkcji obliczanych może znacznie zmniejszyć nakład obliczeń, czy to przy symulacji modelu wraz z pochodnymi czy podczas optymalizacji. Nie wszystkie języki i systemy modelowania i optymalizacje zawierają te dwie funkcje automatycznego różniczkowania. System DIDAS-N zawiera implementacje obu tych funkcji: w formularzu elektronicznym modelu użytkownik może oglądać wyrażenia na odpowiednie pochodne cząstkowe lub zupełne generowane automatycznie, a wewnątrz systemu następuje optymalizacja nakładu obliczeń poprzez określenie dogodnych wyrażeń cząstkowych występujących zarówno w funkcjach $\boldsymbol{f}_{i}$ jak i ich pochodnych.

Doświadczenia $\mathrm{z}$ wykorzystaniem takich funkcji systemu wskazują na szczególną użyteczność rozbicia modelu na niezbyt skomplikowane wyrażenia dla kolejnych zmiennych wyjściowych $\boldsymbol{y}_{i}$. Jeśli bowiem zapiszemy daną skomplikowaną zależność nieliniową „w jednej linijce”, czyli bez użycia kilku pomocniczych zmiennych wyjściowych $\boldsymbol{y}_{\boldsymbol{i}}$, to automatyczne różniczkowanie takiej zależności może wymagać obliczeń trwających godzinami; jeśli tę samą zależność zapiszemy „w kilku linijkach”, czyli wyróżniając istotne części skomplikowanej struktury zależności nieliniowej i nadając im znaczenie pomocniczych zmiennych wyjściowych, to automatyczne różniczkowanie tegoż złożonego modelu może się skrócić do sekund. Oznacza to, że człowiek znacznie szybciej od komputera potrafi całościowo ocenić strukturę skomplikowanych zależności w modelu i wybrać odpowiednią jej reprezentację. 


\subsection{Symulacja a optymalizacja modeli}

Każdy nowoskonstruowany model powinien być poddany przynajmniej kilkakrotnej symulacji, przy różnych wartościach parametrów i zmiennych decyzyjnych, w celu weryfikacji modelu - to jest sprawdzenia, czy przy rozsądnych założeniach daje on rozsądne wyniki. Symulacja prosta jest to ustalenie wartości parametrów oraz zmiennych decyzyjnych, a następnie obliczenie zmiennych wyjściowych modelu; symulacja parametryczna to powtarzanie symulacji prostych dla ustalonego scenariusza kolejnych zmian parametrów czy zmiennych decyzyjnych; wreszcie symulacja wrażliwościowa obejmuje też obliczenie wybranych pochodnych zmiennych wyjściowych (względem wybranych parametrów czy zmiennych decyzyjnych). Wielu użytkowników bardziej skomplikowanych modeli, zwłaszcza opracowanych przez inne osoby, ogranicza się do symulacji prostych czy parametrycznych, nie zdając sobie sprawy ze współczesnych możliwości automatycznego różniczkowania. ${ }^{3}$ Te właśnie możliwości powodują, że możemy dziś mówić nie tylko o symulacji, lecz także o optymalizacji skalarnej i wektorowej bardziej złożonych modeli.

Jednakże symulacja pewnych klas modeli jest trudna. Dotyczy to, po pierwsze, modeli uwikłanych (niejawnych), gdzie warunkiem wyznaczenia zmiennych wyjściowych modelu jest rozwikłanie zależności o charakterze ograniczeń równościowych; może być to wykonane za pomocą specjalnego oprogramowania, ${ }^{4}$ może też być włączone do zadania optymalizacji modelu. Po drugie, w modelach o dużej liczbie ograniczeń, na przykład modelach liniowych, wyznaczenie decyzji dopuszczalnej, czyli spełniającej wszystkie ograniczenia, może być zadaniem bardzo trudnym - co niejako uniemożliwia rozsądną symulację tych modeli. Dlatego też użytkownicy modeli liniowych bardzo często stosowanych - zazwyczaj zaczynają ich analizę od razu od optymalizacji, co jest poważnym błędem metodologicznym (gdyż omija etap

3 Każdy program komputerowy, jeśli wyraża zależność różniczkowalną, może być poddany automatycznemu różniczkowaniu przy użyciu odpowiednio nowoczesnego oprogramowania analizy symbolicznej, zob. Andreas Griewank (1994).

${ }^{4} \mathrm{~Np}$. modele wyrażone za pomocą równań różniczkowych czy całkowych też mogą być uważane za modele uwikłane, a specjalne oprogramowanie rozwiązujące te równania służy do rozwikłania takich modeli, zob. np. Wierzbicki (1977). 
weryfikacji modelu). Tymczasem istnieją techniki specjalne symulacji modeli liniowych, uwzględniające ograniczenia, są one jednak w istocie oparte na optymalizacji wielokryterialnej, zob. dalszy punkt o symulacji odwrotnej i z ograniczeniami miękkimi.

Optymalizacja skalarna modelu wymaga określenia funkcji celu (optymalizowanej; w przypadku modelu o wielu zmiennych wyjściowych, co jest podejściem bardziej uzasadnionym metodologicznie, może to być wybór jednej z tych zmiennych do optymalizacji). Następnie optymalizuje się tę funkcję przy ograniczeniach (na zmienne decyzyjne i wyjściowe). Stosowana przy tym metoda optymalizacji oraz oprogramowanie optymalizacyjne, niekiedy zwane solwerem, zależą w znacznym stopniu od typu modelu: inaczej optymalizujemy modele liniowe, inaczej dyskretne czy mieszane, inaczej nieliniowe, jeszcze inaczej dynamiczne czy stochastyczne. Nie będziemy tu opisywać bardziej dokładnie różnorodnych podejść oraz dostępnych dziś solwerów, czy to komercyjnych czy ogólnie dostępnych; zob. np. Andrzej Stachurski et al. (1999). Podkreślić tylko trzeba, że większość solwerów dostosowana jest do optymalizacji skalarnej, nie wektorowej; wiele z nich można dostosować też do zadań optymalizacji wektorowej, wymaga to jednak dodatkowego zachodu.

\subsection{Formułowanie zadań analizy wielokryterialnej i optymalizacja wektorowa}

Przez analizę wielokryterialną modelu rozumiemy wielokrotne rozwiązywanie zadań optymalizacji wektorowej, $\mathrm{z}$ ewentualnie zmienianymi ich sformułowaniami. Jeśli model jest określony $\mathrm{w}$ formacie $\mathrm{z}$ wieloma zmiennymi wyjściowymi $y_{i}$, to sformułowanie zadania optymalizacji wektorowej polega na wyborze wśród $y_{i}$ zmiennych optymalizowanych, które tu oznaczamy $q_{i}$, oraz określeniu rodzaju optymalizacji (maksymalizacji, minimalizacji, stabilizacji) dla każdej z tych zmiennych. ${ }^{5}$

${ }^{5} \mathrm{O}$ ile w poprzednich rozdziałach nie podkreślaliśmy rozróżnienia pomiędzy zmiennymi wyjściowymi $\boldsymbol{y} \in \boldsymbol{R}^{m}$ a zmiennymi optymalizowanymi, kryteriami $\boldsymbol{q} \in \boldsymbol{R}^{k}$, to przy analizie wielokryterialnej modeli trzeba dokonać już tego rozróżnienia, gdyż dla danego modelu możemy wybierać różne $\boldsymbol{q}$ i różne $k \leq m$. 
Po określeniu zadania optymalizacji wektorowej trzeba oszacować zakres zmienności interesujących nas zmiennych wyjściowych, czyli oszacować zbiór rezultatów sprawnych dla tego zadania. Oszacowanie to można zacząć od generowania ekstremalnych rezultatów sprawnych, czyli optymalizacji skalarnej poszczególnych kryteriów; połączone rezultaty takich $k$ optymalizacji skalarnych (gdyż $k$ to liczba kryteriów; liczba takich optymalizacji może być odmienna, jeśli niektóre kryteria są stabilizowane, gdyż dla kryterium stabilizowanego za składową punktu utopijnego trzeba uważać wymagany poziom jego stabilizacji) określają punkt utopijny, patrz rozdziały poprzednie. Jednakże w rozdziałach tych podkreśliliśmy, że rezultaty takich optymalizacji skalarnych dają tylko bardzo przybliżone oszacowanie punktu nadiru, jeśli liczba kryteriów jest większa od dwóch. Lepsze oszacowanie punktu nadiru można jednak uzyskać drogą dodatkowych optymalizacji skalarnych, jeśli wykorzystać metody punktu odniesienia i własności funkcji osiągnięcia.

Dla uproszczenia rozważań załóżmy, że wszystkie kryteria są maksymalizowane i stosujemy najprostszą postać funkcji osiągnięcia: ${ }^{6}$

$$
\sigma\left(\boldsymbol{q}, \boldsymbol{q}^{-}\right)=\min _{1 \leq i \leq k}\left(q_{i}-q_{i}^{-}\right)+\varepsilon \sum_{i=1, \ldots k}\left(q_{i}-q_{i}^{-}\right)
$$

i przypomnijmy, że optymalizacja takiej funkcji osiągnięcia daje rezultaty sprawne $\boldsymbol{q}^{*}$ możliwie bliskie do punktu odniesienia $\boldsymbol{q}^{-}$. Chcąc uzyskać oszacowania punktu utopijnego i nadiru, powinniśmy najpierw wykonać k optymalizacji skalarnych poszczególnych kryteriów; najlepsze (tu największe) rezultaty dla poszczególnych kryteriów dają punkt utopijny, najgorsze (tu - najmniejsze) rezultaty osiągnięte podczas tych optymalizacji dla innych kryteriów dają oszacowanie punktu nadiru (tu - od góry; faktyczny punkt nadiru może mieć składowe gorsze, czyli tu mniejsze). W celu poprawy tego oszacowania, trzeba przeprowadzić dodatkowo $k$ optymalizacji funkcji osiągnięcia (10.7), z odpowiednio dobranymi poziomami odniesienia. Otóż istotnym powodem tego, że przy optymalizacji

${ }^{6} \mathrm{~W}$ funkcji tej dla uproszczenia zakładamy też, że wszystkie zmienne $q_{i}$ są bezwymiarowe, np. już podzielone przez wstępnie oszacowane zakresy swej zmienności. 
jednego kryterium możemy otrzymać jeszcze nie najgorszy rezultat dla innego kryterium, jest fakt, że przy łącznej optymalizacji kilku kryteriów wyniki dla kryteriów pozostałych mogą się jeszcze pogorszyć. A więc w celu poprawy oszacowania nadiru trzeba dobrać poziomy odniesienia dla wszystkich kryteriów, z wyjątkiem jednego, na poziomie ich składowych punktu utopijnego (czyli żądać wspólnej optymalizacji ich wszystkich); natomiast dla tego jednego kryterium, którego oszacowanie składowej nadiru chcemy poprawić, trzeba dobrać składową punktu odniesienia poniżej dotychczasowego oszacowania składowej nadiru. Optymalizacja funkcji osiągnięcia da wtedy rezultat sprawny o możliwie najmniejszej składowej dla tego jednego kryterium, a więc poprawi oszacowanie nadiru. Obliczenia takie trzeba powtórzyć, odpowiednio zmieniając punkty odniesienia, dla kolejnych $k$ kryteriów. W sumie, dobre oszacowanie punktów utopii i nadiru wymaga $2 k$ optymalizacji skalarnych. Taka metoda korekty oszacowań punktu nadiru okazuje się bardzo skuteczna i wystarczająca dla celów praktycznych.

Metodę tę z łatwością można uogólnić na przypadek, gdy część rezultatów jest minimalizowana (trzeba tylko pamiętać, że wtedy rezultat najlepszy jest najmniejszy, a najgorszy - największy). Nieco trudniejszy jest przypadek, gdy część rezultatów jest stabilizowana: trzeba wtedy pamiętać, że składowa punktu utopijnego jest dana przez wymagany poziom stabilizacji, natomiast mamy niejako dwie osobne składowe punktu nadiru: wartość największą i wartość najmniejszą kryterium stabilizowanego (wśród rezultatów sprawnych). A więc obliczeń składowych punktu utopii dla kryteriów stabilizowanych nie trzeba przeprowadzać, natomiast trzeba dwa razy prowadzić oszacowania składowych punktu nadiru - raz traktując to kryterium tak jak maksymalizowane, a następnym razem tak jak minimalizowane (w sumie, też potrzeba $2 k$ optymalizacji skalarnych).

Podstawową trudność sprawia natomiast oszacowanie punktów utopii i nadiru dla modeli dynamicznych, w których liczba kryteriów może być bardzo duża. $\mathrm{Z}$ modelami dynamicznymi wiąże się bowiem ważne pojęcie wielokryterialnej optymalizacji trajektorii. Jest znanym faktem 
psychologicznym, że umysł ludzki nie radzi sobie z jednoczesną analizą zbyt dużej liczby zmiennych - przekraczających liczbę 5-9, przeciętnie 7 . Jednocześnie jednak, umysł ludzki radzi sobie dobrze z odpowiednimi agregatami zmiennych, zawierającymi znacznie większe liczby zmiennych cząstkowych - jak np. wykresy funkcji - pod warunkiem dobrego opanowania pojęciowego takich agregatów.

Dla modelu dynamicznego o dużej liczbie etapów czasowych $\mathrm{T}$, optymalizacja wielokryterialna zmiennych każdego etapu traktowanych niezależnie jest więc zadaniem pojęciowo zbyt trudnym; przestaje natomiast być zadaniem trudnym pojęciowo (choć nadal jest trudna obliczeniowo), jeśli połączymy odpowiednie zmienne w ich trajektorie, czyli będziemy interpretować je wykreślnie jako funkcje np. czasu - np. jedną zmienną wyjściową maksymalizowaną w każdej chwili czasu, inną minimalizowaną w każdej chwili czasu. ${ }^{7}$ Połączenie odpowiedniej liczby podobnych zmiennych wyjściowych modelu w optymalizowaną trajektorię użyteczne jest także przy innych postaciach czy interpretacjach modeli - np. w przypadku optymalizacji różnych charakterystyk urządzeń elektronicznych. Przy optymalizacji wielokryterialnej trajektorii czy charakterystyk szczególnie korzystne dla użytkownika jest wykorzystanie pojęcia trajektorii czy charakterystyki aspiracji czyli odniesienia, traktowanej jako jeden obiekt, zob. Rys. 10.1. Konstruuje się wtedy odpowiednie funkcje osiągnięcia, o charakterze podobnym do (10.7). Pierwsze zastosowanie metod poziomów odniesienia i skalaryzującej funkcji osiągnięcia - zob. np. Andrzej Lewandowski et al. (1989) - związane było właśnie z optymalizacją trajektorii w modelu rozwoju przemysłu drzewnego i wzrostu lasów w Finlandii.

\footnotetext{
${ }^{7}$ Można do tego oczywiście dołączyć stabilizację, czy np. maksymalizację wybranej zmiennej wyjściowej $\mathrm{w}$ danej chwili czasu, np. T. W przypadku charakterystyk urządzeń technicznych - np. charakterystyk częstotliwościowych filtrów - można też maksymalizować jedną część charakterystyki, a minimalizować części inne.
} 
a)

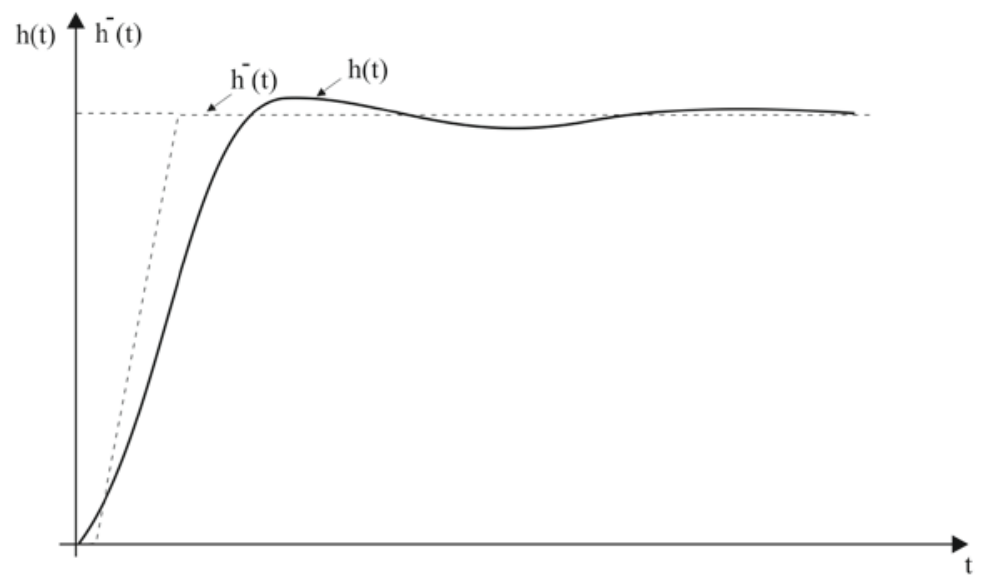

b)

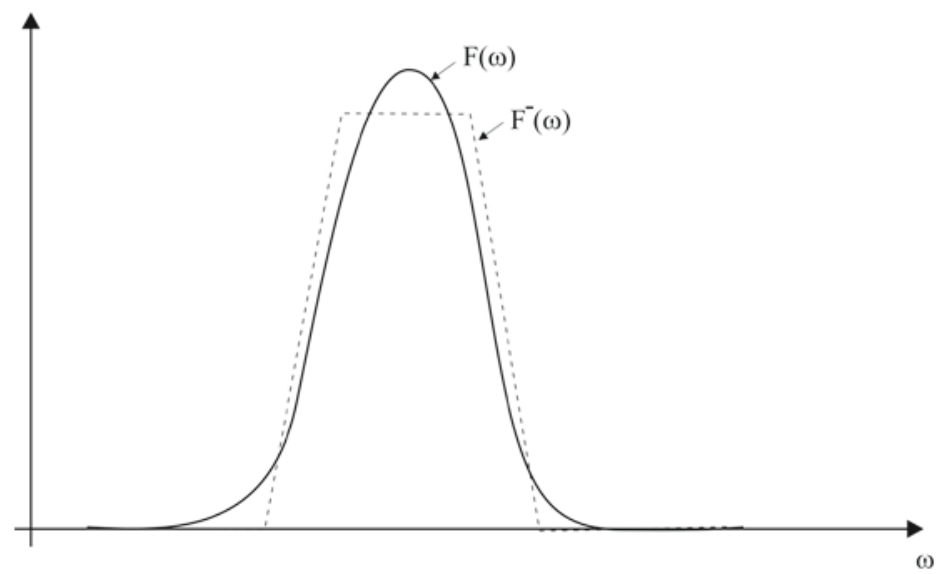

Rys. 10.1. Przykład optymalizacji wielokryterialnej trajektorii dynamicznej (a) oraz charakterystyki częstotliwościowej (b).

Przy analizie wielokryterialnej modeli liniowych ważnym aspektem jest, aby zadanie optymalizacji nieliniowej funkcji osiągnięcia typu (10.7) dało się przekształcić w skalarne zadanie programowania liniowego. Transformacja taka jest możliwa i stosunkowo prosta, choć nie powinna oczywiście obciążać użytkownika, tylko projektanta systemu wspomagania decyzji czy analizy wielokryterialnej modeli. W przypadku maksymalizacji funkcji osiągnięcia postaci (10.7), przy maksymalizacji wszystkich kryteriów zależnych liniowo od $\boldsymbol{x}, \boldsymbol{q}=\boldsymbol{C} \boldsymbol{x}$, odpowiednią transformację tego zadania do jednokryterialnego zadania programowania liniowego uzyskuje się poprzez wprowadzenie zmiennej sztucznej z oraz dodatkowych ograniczeń: 


$$
\max _{x \in X 0, a, z \in R 1}\left(Z^{+}+\varepsilon \sum_{i=1, \ldots k}\left(q_{i}-q_{i}^{-}\right)\right)
$$

gdzie $\boldsymbol{q}=\boldsymbol{C} \boldsymbol{x}$, zaś przez $\boldsymbol{X}_{0, a}$ oznaczono zbiór $\boldsymbol{X}_{0}$ obcięty poprzez uwzględnienie ograniczeń dodatkowych:

$$
z \leq q_{i}-q_{i}^{-} \forall i=1, \ldots k
$$

Podobnie dają się przekształcić bardziej złożone postaci funkcji osiągnięcia pod warunkiem, że składowe funkcje osiągnięcia $\sigma_{i}$ są przedziałami liniowymi funkcjami wypukłymi, zob. np. Wierzbicki et al. (2000). Przy wykorzystaniu algorytmów sympleksowych dla rozwiązywania tego zastępczego zadania programowania liniowego trzeba jednak pamiętać, że sformułowanie powyższe wprowadza dodatkowe wiersze o specyficznej strukturze do macierzy A; strukturę tę można też odpowiednio wykorzystać w obliczeniach. Co więcej, sympleks dla powyższego zadania ma więcej wierzchołków (wierzchołki w każdym punkcie właściwie sprawnym zbioru $\boldsymbol{Q}_{0}=\boldsymbol{C} \boldsymbol{X}_{0}$, osiągane przez odpowiednie zmiany parametru $\left.\boldsymbol{q}^{-}\right)$niż sympleks dla zadania ze skalaryzacją liniową $s(\boldsymbol{q}, \boldsymbol{\alpha})=\boldsymbol{\alpha}^{\mathrm{T}} \boldsymbol{C} \boldsymbol{x}$ (wierzchołki tylko $\mathrm{w}$ punktach wierzchołkowych zbioru $\boldsymbol{Q}_{0}$, osiągane przez zmiany parametru $\alpha$ ).

Ćwiczenie 10.2: a) Zapisać odpowiednie transformacje zadania maksymalizacji funkcji osiągnięcia w różnych postaciach przedziałami liniowych, podanych $\mathrm{w}$ rozdziałach poprzednich, do zadania skalarnego programowania liniowego. b) Jakie znaczenie ma przy tym założenie o takim doborze cząstkowych funkcji osiągnięcia, aby były one wklęsłe?

Ćwiczenie 10.3: Zapisać odpowiednie warianty funkcji osiągnięcia oraz transformacje zadania ich maksymalizacji do postaci skalarnego programowania liniowego dla:

a) zadania, w którym część zmiennych jest minimalizowana, a część stabilizowana;

b) zadania z dynamicznym modelem liniowym, w którym trajektoria dla jednej zmiennej ma być maksymalizowana, a dla drugiej - minimalizowana w każdym punkcie czasu.

W przypadku modeli dyskretnych czy mieszanych (liniowych z częścią zmiennych całkowitoliczbowych) stosuje się analogiczne transformacje zadania maksymalizacji przedziałami liniowej funkcji osiągnięcia. Natomiast w przypadku modeli nieliniowych sytuacja zmienia się. Przedziałami liniowa 
funkcja osiągnięcia jest nieróżniczkowalna i można wprawdzie zastosować taką samą transformację zadania, jak dla modeli liniowych czy mieszanych, ale nie ma wtedy gwarancji, że solwer nieliniowy przeznaczony dla problemów różniczkowalnych będzie poprawnie działał. Jednym ze sposobów rozwiązania tego problemu jest zastąpienie przedziałami liniowej funkcji osiągnięcia (10.7) następującą funkcją różniczkowalną:

$$
\sigma\left(\boldsymbol{q}, \boldsymbol{q}^{-}\right)=1-\left(\left((1 / k) \sum_{i=1, \ldots k}\left(\tilde{q}_{i}^{\sim}-q_{i}\right) /\left(\tilde{q}_{i}-q_{i}^{-}\right)\right)^{p}\right)^{1 / p}
$$

gdzie $p \geq 2$ jest parametrem, zaś $\boldsymbol{q}^{\sim}$ jest wybranym punktem ponadutopijnym. ${ }^{8}$ Sposób ten stosowany jest np. w systemie DIDAS-N. Dobiera się przy tym wartość parametru $p=6 \ldots 8$; przy większych wartościach tego parametru, funkcja (10.10) lepiej aproksymuje funkcję (10.7), ale jej optymalizacja stwarza większe trudności numeryczne.

\subsection{Symulacja odwrotna i z miękkimi ograniczeniami}

Funkcję osiągnięcia w optymalizacji wektorowej można też wykorzystać do rozwiązania problemu symulacji przy konieczności znajdowania dopuszczalnych decyzji spełniających wiele ograniczeń. Ogólna idea takiej symulacji jest następująca: przypuśćmy, że określimy pewną decyzję $\boldsymbol{x}$,' przy której chcemy symulować rozwiązania modelu, ale nie wiemy, czy jest to decyzja dopuszczalna. Możemy ją jednak wykorzystać jako punkt odniesienia dla zadania wielokryterialnej stabilizacji wszystkich decyzji, formułując odpowiednią funkcję osiągnięcia. Po maksymalizacji tej funkcji, jeśli decyzja $\boldsymbol{x}^{-} \in \boldsymbol{X}_{0}$, uzyskamy $\boldsymbol{x}^{-}=\boldsymbol{x}^{*}$; jeśli natomiast $\boldsymbol{x}^{-} \neg \epsilon \boldsymbol{X}_{0}$, uzyskamy $\boldsymbol{x}^{*} \in \boldsymbol{X}_{0}$, możliwie bliskie do $\boldsymbol{x}^{-}$. Tę samą ideę wykorzystywano początkowo do sprawdzania, czy osiągalne są pożądane przez użytkownika rezultaty $\boldsymbol{y}^{\circ}$; stąd nazwa symulacja odwrotna, związana z założeniem zmiennych wyjściowych i poszukiwaniem odpowiednich zmiennych wejściowych.

Ideę symulacji odwrotnej można uogólnić, łącząc wymaganie osiągnięcia pożądanych zmiennych wyjściowych $\mathrm{z}$ bliskością do danych decyzji. Odpowiednia funkcja osiągnięcia ma wtedy postać:

\footnotetext{
${ }^{8}$ Przy tej postaci nie musimy już zakładać, że wszystkie kryteria są bezwymiarowe, gdyż niezbędne było i tak podzielenie ich przez odpowiednie zakresy zmienności w celu sprowadzenia do wartości bezwzględnej wyrażeń sumowanych.
} 


$$
\begin{aligned}
& \sigma\left(\boldsymbol{y}, \boldsymbol{y}^{-}, \boldsymbol{x}, \boldsymbol{x}^{-}\right)=(1-\rho)\left(\min _{1 \leq i \leq n} \sigma_{i}\left(x_{i}, x_{i}^{-}\right)+\varepsilon \Sigma_{i=1, \ldots n} \sigma_{i}\left(x_{i}, x_{i}^{-}\right)\right)+ \\
& \rho\left(\min _{1 \leq i \leq m} \sigma_{j}\left(y_{j}, y_{j}^{-}\right)+\varepsilon \sum_{i=1, \ldots m} \sigma_{j}\left(y_{j}, y_{j}^{-}\right)\right)
\end{aligned}
$$

gdzie $\rho \in[0 ; 1]$ jest parametrem określającym, czy ważniejsza jest bliskość do założonych decyzji $\boldsymbol{x}^{-}$, czy do założonych rezultatów $\boldsymbol{y}^{-}$(dla $\rho=1$ mamy do czynienia z czystą symulacją odwrotną). Cząstkowe funkcje osiągnięcia $\sigma_{i}, \sigma_{j}$ mogą mieć różne postaci (niekoniecznie odpowiadając tylko za zbliżanie się do $\left(x^{-}, y^{-}\right)$), ale w przypadku uogólnionej symulacji odwrotnej możemy stosować $\sigma_{i}\left(x_{i}, x_{i}^{-}\right)=-\left|x_{i}-\bar{x}_{i}^{-}\right|, \sigma_{j}\left(y_{j}, y_{j}^{-}\right)=-\left|y_{j}-y_{j}^{-}\right|$, gdzie znak ,-” związany jest z konwencją, że funkcję osiągnięcia maksymalizujemy, a nie minimalizujemy jak normę.

Analogicznym sposobem można rozwiązać odmienny problem miękkich ograniczeń. Nierówność w modelowaniu może bowiem oznaczać trzy różne sytuacje:

1) ograniczenie o charakterze fizycznym, którego po prostu nie można przekroczyć (wyobraźmy sobie kulę toczącą się po stole z bandami);

2) ograniczenie zakresu ważności określonej formy modelu (wyobraźmy sobie kulę toczącą się po stole bez band; może ona przekroczyć granice stołu, ale zmieniają się jej prawa ruchu);

3) ograniczenie wyrażające nasze intencje (wyobraźmy sobie bilans wspólnego rachunku bankowego małżeństwa; może on być ujemny, ale to wysoce niepożądane).

Pierwsze dwie sytuacje nazywamy ograniczeniami twardymi; choć są one odmienne, możemy je wspólnie modelować przez nierówności. Trzecią sytuację nazywamy ograniczeniem miękkim; choć często też jest modelowana przez nierówność, nie jest to podejście poprawne metodologicznie. Intencje nasze odpowiadają bowiem w istocie dodatkowym kryteriom oraz poziomom aspiracji czy rezerwacji w stosunku do tych kryteriów (maksymalizujemy bilans konta - co może być w sprzeczności z innymi kryteriami, na przykład zadowolenia z zakupów - ale stan zerowy konta to poziom rezerwacji). Dlatego też należy przyjąć, że wszelkie ograniczenia miękkie powinny być poprawnie modelowane nie jako nierówności, ale jako dodatkowe kryteria wraz z odpowiednimi poziomami aspiracji czy rezerwacji. Zauważmy, że jeśli ograniczenia miękkie mogą dotyczyć bądź to decyzji, bądź też zmiennych wyjściowych modelu, to możemy je uwzględnić przy maksymalizacji funkcji osiągnięcia (10.11) - tyle 
tylko, że wtedy odpowiednia cząstkowa funkcja osiągnięcia $\sigma_{i}$ lub $\sigma_{j}$ nie powinna odpowiadać stabilizacji (jak przy uogólnionej symulacji odwrotnej), tylko maksymalizacji lub minimalizacji danej składowej (zależnie od znaku nierówności ograniczenia miękkiego na tę składową) i przyjmować jedną $\mathrm{z}$ odpowiednich postaci omawianych w rozdziale poprzednim.

\subsection{Wybór wielokryterialny i wrażliwość wdrożenia decyzji}

Wielokryterialne wspomaganie decyzji w oparciu o modele rzeczowe zakłada specyficzną strukturę procesu decyzyjnego. Etapy rozpoznania problemu i zbierania danych są już zazwyczaj dalece zaawansowane poprzez użytkownika systemu, zwykle - analityka określonej dziedziny, np. zależności ekonomiczno-ekologicznych. Dlatego też proces decyzyjny koncentruje się na następujących etapach:

1) Edycja i wstępna analiza modelu rzeczowego sytuacji decyzyjnej w którym to etapie dla analityka ważne są standardy zapisu modeli, możliwość wykorzystania i modyfikacji modeli opracowanych wcześniej lub przez innych specjalistów, narzędzia wspomagania wstępnej analizy modelu. Do narzędzi tych należy symulacja, w razie potrzeby - symulacja odwrotna i z miękkimi ograniczeniami. Dlatego też narzędzia optymalizacji wektorowej i metodyka punktu odniesienia mogą być pomocne nawet przed określeniem specyficznego problemu analizy wielokryterialnej, interesującego użytkownika.

2) Określenie specyficznego problemu analizy wielokryterialnej, oszacowania zbioru rezultatów sprawnych - w którym to etapie dla użytkownika ważna jest kompletność modelu, to jest reprezentacja w nim wszelkich istotnych wielkości i kryteriów, następnie zaś definicja, które z wielkości wyjściowych modelu mają być traktowane jako kryteria i optymalizowane wielokryterialnie (maksymalizowane, minimalizowane, stabilizowane), wreszcie automatyczne wspomaganie oszacowań zbioru rezultatów sprawnych, czyli obliczeń punktu utopijnego i oszacowań punktu nadiru.

3) Interakcyjna analiza zbioru rezultatów sprawnych - w którym to etapie istotna dla użytkownika jest łatwość sterowania wstępnym wyborem rezultatów sprawnych za pomocą parametrów sterujących systemu, i szczególnie przydatne okazały się metody punktu odniesienia wraz z maksymalizacją funkcji osiągnięcia. 
4) Wnioski, wybór rezultatów szczególnie interesujących (zwykle w formie kilku scenariuszy) - w którym to etapie dla użytkownika może być istotne wspomaganie zbieżności przeglądu rezultatów sprawnych do opcji najbardziej preferowanej; w praktyce jednak okazuje się, że większe znaczenie ma generacja kilku opcji alternatywnych według zaleceń użytkownika oraz ich pełniejsza analiza, wraz z postoptymalną analizą wrażliwości. Charakterystyczne bowiem dla takiego procesu decyzyjnego jest, że - ponieważ służy on analitykom - nie prowadzi on zazwyczaj do jednoznacznej decyzji, a tylko do generacji kilku interesujących opcji decyzyjnych. Ma więc on służyć raczej wzbogaceniu intuicji użytkownika poprzez analizę danego modelu rzeczowego, niż określeniu opcji najbardziej preferowanej.

Tym niemniej, mogą się zdarzać takie sytuacje, w których użytkownik zapyta o wspomaganie wyboru opcji najbardziej przez siebie preferowanej. Trzeba zatem doprowadzić do zbieżności opcji decyzyjnych generowanych w systemie do opcji najbardziej preferowanej. Istnieje wiele metod wspomagania takiej zbieżności, w tym trzy związane z metodyką punktu odniesienia - Pareto Race, zob. Pekka Korhonen et al. (1986), Satisficing Trade-off, zob. Hirotaka Nakayama et al. (1994), Outranking Trials, zob. Wierzbicki (1998). Potrzeba takiej zbieżności rzadko jednak występuje w praktyce, więc nie omawiamy tych metod szczegółowo.

Po wyborze opcji decyzyjnej trzeba jeszcze przygotować jej wdrożenie. Ważnym elementem przygotowania wdrożenia (a nawet samego wyboru opcji) jest postoptymalna analiza wrażliwości. Może ona mieć różnorodny charakter. Klasycznie, ograniczana jest ona często do pytania, jak zmieni się rozwiązanie optymalne, jeśli zmienimy niektóre parametry modelu (w przypadku modeli programowania liniowego możemy też rozpatrywać najpierw pytanie prostsze: $\mathrm{w}$ jakim zakresie możemy zmieniać parametry modelu, nie powodując zmiany rozwiązania). Naprawdę jednak przy zastosowaniu decyzji, która została wybrana na podstawie pewnego modelu reprezentującego rzeczywistość w sposób tylko przybliżony, interesuje nas odpowiedź na nieco inne pytanie: jakie będą rezultaty tej decyzji, jeśli zastosujemy ją do rzeczywistości - a ponieważ nie znamy dokładnego modelu rzeczywistości, to jakie będą rezultaty tej decyzji, jeśli ją zastosujemy do modelu odbiegającego nieco od modelu podstawowego, który stosowaliśmy przy wyborze tej decyzji. To bardziej złożone pytanie wymaga nieco bardziej złożonych metod analizy - zob. np. Wierzbicki (1977). 


\subsection{Systemy analizy modeli wielokryterialnych: struktura, interfejsy użytkownika}

Systemy takie zaczęto rozwijać od roku 1980 w związku z pracami Międzynarodowego Instytutu Stosowanej Analizy Systemowej (IIASA) w Laxenburgu k. Wiednia. Charakteryzowały się one wykorzystaniem pojęć punktu odniesienia czy aspiracji oraz optymalizacji funkcji osiągnięcia dla analizy złożonych modeli zależności ekonomicznych i ekologicznych zwykle dynamicznych, początkowo tylko liniowych, później także nieliniowych, zazwyczaj dotyczących ciągłych zmian opcji decyzyjnych, później włączających też elementy dyskretności.

W trakcie wieloletnich prac nad konstrukcją takich systemów zmieniały się też podejścia do ich implementacji komputerowej. Pierwsze $\mathrm{z}$ nich miały charakter specyficznych narzędzi oprogramowania, dostosowanych tylko do konkretnego modelu i problemu. Później konstruowano systemy bardziej uniwersalne, ułatwiające analizę wielu modeli z wybranej klasy; były to jednak zwykle systemy zamknięte, o niemodularnej budowie, trudne do modyfikacji i dostosowania do nowych wymagań. Obecnie konstruuje się takie systemy jako modularne zestawy narzędzi oprogramowania dla wielokryterialnej analizy modeli i wspomagania decyzji, w których moduły mogą być wymienne i są łatwe do modyfikacji dzięki wykorzystaniu możliwości programowania obiektowego.

Jednymi z pierwszych takich systemów były systemy wielokryterialnej analizy modeli liniowych dla wspomagania decyzji DIDAS-L i HYBRID. System DIDAS-L (zob. Tomasz Kręglewski et al., 1989) obejmuje definicję $\mathrm{i}$ edycję liniowych modeli wielokryterialnych $\mathrm{w}$ formacie zbliżonym do (10.2, 10.3) i w postaci formularza elektronicznego, w który wpisuje się dane dotyczące macierzy $\mathrm{A}, \mathrm{W}$ (bez rozróżnienia tych macierzy, ale z możliwością dowolnego wyboru zmiennych $q_{i}$ pomiędzy $y_{j}$ i określenia ich sposobu optymalizacji). Zarówno dla modeli pierwotnych, jak i tzw. problemów - czyli modeli wraz z wyborem zmiennych optymalizowanych i sposobu ich optymalizacji - utworzona jest odpowiednia baza modeli i problemów; dla każdego problemu utworzona jest dodatkowa baza rezultatów, związanych z oszacowaniami zbioru rozwiązań sprawnych oraz $\mathrm{z}$ generowanymi $\mathrm{w}$ interakcji $\mathrm{z}$ użytkownikiem przykładami rozwiązań sprawnych. Oszacowania zbioru rezultatów sprawnych oraz uzyskane przykłady rezultatów sprawnych są ilustrowane graficznie $\mathrm{w}$ formie 
wykresów słupkowych, także $\mathrm{w}$ porównaniu z rezultatami uzyskiwanymi uprzednio. Użytkownik może podawać poziomy aspiracji zarówno alfanumerycznie, jak i wprowadzać je podczas interakcji graficznej za pomocą myszy. Dla optymalizacji funkcji osiągnięcia w systemie DIDAS-L wykorzystany jest specjalny solwer liniowy - algorytm sympleksowy z wykorzystaniem specyfiki zadań wielokryterialnych - przystosowany jednak tylko do rozwiązywania zadań niewielkich rozmiarów. System DIDAS-L był niemodularnym systemem zamkniętym, napisanym w języku PASCAL. Możliwe jest w nim wykorzystanie modeli dynamicznych, ale drogą powtarzania ich definicji dla kolejnych etapów czasu $t \mathrm{w}$ formularzu elektronicznym edycji modelu. System DIDAS-L był stosowany jako dobre narzędzie badawcze i szkoleniowe, dla przykładów o niewielkich modelach rzeczowych.

System HYBRID (zob. Marek Makowski et al., 1989) był już systemem znacznie bardziej zaawansowanym, choć wykorzystywał bardzo podobne pojęcia i metody. Był to system modułowy, w wersji napisanej w języku $\mathrm{C}++$. Był to system specjalnie przystosowany dla edycji $\mathrm{i}$ analizy wielokryterialnej modeli dynamicznych, $\mathrm{z}$ wielokryterialną optymalizacją trajektorii. Dla optymalizacji funkcji osiągnięcia w systemie HYBRID stosowany jest specjalny solwer niesympleksowy (dualnej metody uzupełnionej funkcji Lagrange'a) dla zadań programowania liniowego i kwadratowego. System HYBRID znalazł wiele zastosowań w analizie dynamicznych modeli ekonomiczno-ekologicznych w IIASA.

Pewną modyfikacją systemu DIDAS-L był system MENTAT, który powstał $\mathrm{W}$ związku $\mathrm{z}$ doświadczeniami $\mathrm{w}$ praktycznej analizie wielokryterialnej złożonych modeli liniowych. Okazało się bowiem, że przed przystąpieniem do ostatecznej analizy wielokryterialnej, dla analityka niezmiernie ważny jest etap analizy wstępnej modelu. Podstawową metodą takiej analizy wstępnej jest symulacja modelu; jednak $\mathrm{w}$ przypadku złożonych modeli programowania liniowego użytkownik zazwyczaj nie wie, czy założona przez niego decyzja $\boldsymbol{x}$ jest dopuszczalna w sensie przyjętego zbioru $\boldsymbol{X}_{0}$ i - co ważniejsze - czy przyjęty przez niego wstępnie opis zbioru $\boldsymbol{X}_{0}$ odpowiada jego wyobrażeniom o dopuszczalności. Zdarza się to w szczególności w przypadkach, gdy podczas konstrukcji modelu przyjmuje się intuicyjnie, że pewne wskaźniki optymalizowane zastąpione będą ograniczeniami. Oznacza to, że pewne ograniczenia miękkie - takie, które w rzeczywistości mogą być przekroczone 
kosztem pewnej kary za ich przekroczenie - zastępowane są dla uproszczenia przez ograniczenia twarde, nierówności lub równania, które w danym modelu powinny być spełnione bezwzględnie.

Ze względu na te doświadczenia, system MENTAT (zob. Roman Zakrzewski, 1989) wprowadził takie narzędzia wielokryterialnej analizy modelu, jak omawiane wcześniej symulacja odwrotna czy z ograniczeniami miękkimi, które mogą być przekroczone, natomiast wartości zmiennych tak ograniczonych są interpretowane jako dodatkowe kryteria optymalizacji $q_{i}$, zaś określone przez użytkownika wartości takich ograniczeń miękkich - jako poziomy aspiracji $q_{i}^{-}$dla tych kryteriów; przez $\boldsymbol{X}_{0}$ oznaczamy wtedy zbiór decyzji dopuszczalnych z uwzględnieniem tylko ograniczeń twardych. Ponieważ użytkownik nadal może nie być pewny, czy założona przez niego decyzja jest dopuszczalna w sensie ograniczeń twardych, powinien on określać tę decyzję też jako punkt aspiracji $\boldsymbol{x}^{-}$- traktując wszystkie zmienne decyzyjne jako dodatkowe kryteria stabilizowane. Aby ułatwić użytkownikowi takie przekształcenia, w systemie MENTAT zaproponowano specjalną funkcję systemu - symulację z elastycznymi ograniczeniami - w której użytkownik zapytywany jest o określenie decyzji odniesienia $\boldsymbol{x}$, wybór zmiennych ograniczonych elastycznie $q_{i}$ oraz specyfikację ich poziomów aspiracji $\boldsymbol{q}_{i}^{-}$.

Inne modyfikacje systemów wielokryterialnej analizy modeli i wspomagania decyzji wiążą się ze zmianą charakteru analizowanego modelu, np. poprzez wprowadzenie zmiennych binarnych czy całkowito-liczbowych. W wielu modelach opcje decyzyjne reprezentowane są wyłącznie jako opcje dyskretne jako problem wyboru pomiędzy skończoną liczbą rozwiązań. Oznacza to jednak niewypukły zbiór rozwiązań dopuszczalnych - i niewypukły zbiór rezultatów osiągalnych. Metody punktu odniesienia, wykorzystujące maksymalizację funkcji osiągnięcia nadają się dobrze dla takich modeli, gdyż maksima funkcji osiągnięcia są rozwiązaniami sprawnymi niezależnie od charakteru zbioru rezultatów osiągalnych. Niewiele jednak systemów wspomagania wyboru pomiędzy opcjami dyskretnymi wykorzystuje tę własność (zapewne dlatego, że systemy takie często koncentrują się na modelowaniu preferencji użytkownika). Jednym $\mathrm{z}$ wyjątków jest system DISCRET (zob. Janusz Majchrzak, 1989), w którym pojęcie punktu rezerwacji i odpowiedniej funkcji osiągnięcia wykorzystuje się dla rozwiązania problemu przeszukiwania dużej liczby opcji dyskretnych. W fazie wstępnej rozważa się tylko te opcje, które dominują punkt rezerwacji (wyróżniają się dodatnią wartością odpowiedniej 
funkcji osiągnięcia), a następnie wśród nich przeszukuje się opcje sprawne poprzez odpowiednie przesunięcie punktu aspiracji względem punktu rezerwacji i maksymalizację funkcji osiągnięcia, zob. Rys. 10.2. Optymalizacja funkcji osiągnięcia przy przeglądzie opcji dyskretnych jest zwykle zadaniem łatwym, które sprowadza się do obliczenia i porównania kilkuset liczb.

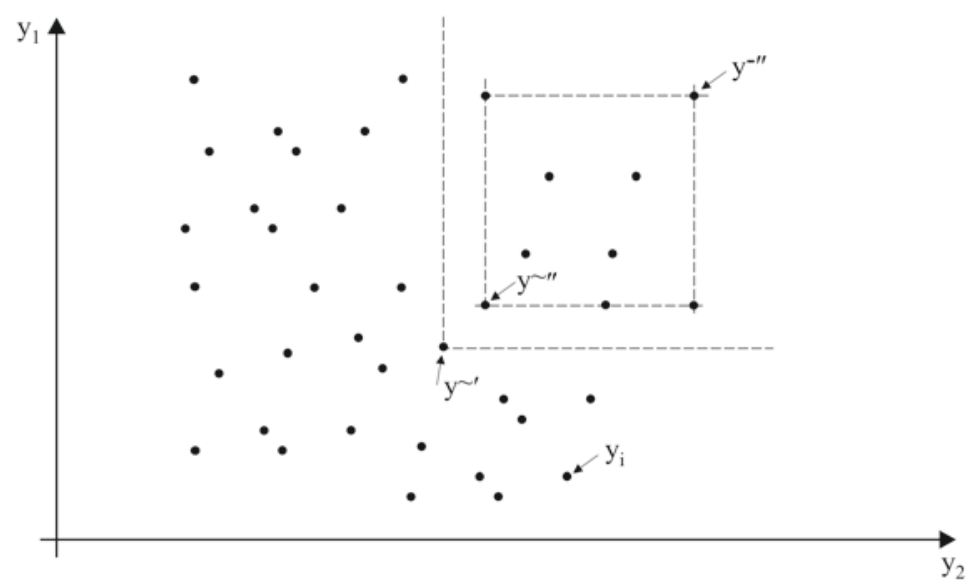

Rys. 10.2. Ograniczenia przeglądu wielu opcji dyskretnych poprzez określenie wstępne punktu rezerwacji $\boldsymbol{y}^{\sim^{\prime}}$, a następnie modyfikację punktu rezerwacji do $\boldsymbol{y}^{\sim \prime}$ i określenie odpowiedniego punktu aspiracji $y^{-"}$.

Nieco inny i trudniejszy problem pojawia się przy analizie modeli dyskretnociągłych, w których też można stosować optymalizację funkcji osiągnięcia, ale jest ona zwykle zadaniem trudnym, wymagającym stosowania specjalnych algorytmów. Duża klasa zagadnień analizy wielokryterialnej modeli dyskretnociągłych ma jednak tę własność, że optymalizacja funkcji osiągnięcia daje się sprowadzić (przez przekształcenia podobne, jak dla modeli liniowych) do parametrycznego zadania programowania liniowego z ograniczeniami części zmiennych decyzyjnych do wartości całkowito-liczbowych. Zadania takie rozwiązuje się zwykle poprzez powtarzanie rozwiązań zadań programowania liniowego metodą podziału i ograniczeń. Dla wybranych problemów tej klasy - sieciowych zadań lokalizacji - skonstruowano najpierw specjalny system DINAS (zob. Włodzimierz Ogryczak et al., 1989), o eleganckim interfejsie graficznym definicji modeli sieciowych; system ten stosowano m.in. dla rozwiązywania zadań lokalizacji w sieciach masowej obsługi. Później, już dla modularnych systemów analizy wielokryterialnej, opracowano 
specjalny solwer MOMIP dla modeli mieszanych, oparty na metodzie podziału i ograniczeń ze specjalnymi heurystykami wyboru drogi w drzewie logicznym tej metody, zob. Włodzimierz Ogryczak et al. (1993).

Podobnie jak dla modeli dyskretnych i mieszanych, także dla modeli nieliniowych - z uwagi na ich specyfikę - początkowo konstruowano oddzielne systemy dla ich wielokryterialnej analizy i wspomagania decyzji o nie opartych. Przykładami takich systemów są DIDAS-N i DIDAS-N++. W przypadku modeli nieliniowych szczególnie istotny jest wybór odpowiedniego solwera, czyli implementacji wybranego algorytmu optymalizacji nieliniowej z ograniczeniami. Wybór tego algorytmu zależy m.in. od stosowanej formy funkcji osiągnięcia. Dla postaci (10.7) czy (10.11) takiej funkcji niezbędne byłoby zastosowanie algorytmów optymalizacji nieróżniczkowalnej. Jednocześnie, istotnym wymaganiem od solwera systemu wielokryterialnej analizy modeli nieliniowych jest jego odporność, czyli możliwość rozwiązywania złożonych zadań optymalizacji nieliniowej nawet niezbyt dokładnie, ale stosunkowo niezawodnie - bez konieczności strojenia parametrów algorytmu optymalizacji przez użytkownika, który może nie być specjalistą w tym zakresie. Ze względu na brak odpornych wersji algorytmów optymalizacji nieróżniczkowalnej, w czasie implementacji systemu DIDAS-N zdecydowano się na wykorzystanie różniczkowalnego przybliżenia funkcji osiągnięcia typu (10.10), z dodatkowymi modyfikacjami użytych tam cząstkowych funkcji osiągnięcia tak, by uwzględniały one możliwości minimalizacji i stabilizacji poszczególnych kryteriów oraz możliwości specyfikacji przez użytkownika dwóch poziomów odniesienia: aspiracji i rezerwacji. Taka różniczkowalna funkcja osiągnięcia jest w systemie DIDAS-N różniczkowana automatycznie w celu ułatwienia obliczeń optymalizacyjnych. Jako stosunkowo odporny solwer nieliniowy wykorzystano w systemie DIDAS-N algorytm przesuwanej funkcji kary (uzupełnionej funkcji Lagrange'a) dla ograniczeń nieliniowych, połączony z algorytmem kierunków sprzężonych dla optymalizacji bez ograniczeń i z ograniczeniami kostkowymi.

System DIDAS-N był wykorzystywany m.in. dla zadań wielokryterialnej analizy modeli transportu i akumulacji osadów kwaśnych deszczy, modeli optymalizacji portfela akcji itp. Nową wersją systemu DIDAS-N był system 
DIDAS-N++. Jest to system napisany w języku C++ i umożliwia definicję modeli $\mathrm{w}$ trybie tekstowym, a nie $\mathrm{w}$ formularzu elektronicznym, choć zachowuje główne standardy definicji modeli systemu DIDAS-N. Obok funkcji systemu DIDAS-N, system DIDAS-N++ realizuje także podstawowe funkcje systemu MENTAT dla modeli nieliniowych. Jednak najważniejszą zmianą w stosunku do systemu DIDAS-N jest modularność i otwartość systemu DIDAS-N++: system ten składa się z wymiennych modułów, a więc może też być przystosowany - pod warunkiem wymiany solwera - do analizy modeli liniowych, dyskretnych, mieszanych (tj. z niektórymi zmiennymi całkowito-liczbowymi - np. przy wykorzystaniu solwera MOMIP) itp.

Tę ideę modularności systemu wykorzystano konsekwentnie w kilku dalszych wariantach systemów wielokryterialnej analizy modeli i wspomagania decyzji; warianty te były jednak zorganizowane wokół specjalnego interfejsu użytkownika zwanego ISAAP, zob. Janusz Granat et al. (1994). Ten graficzny interfejs służy do określania preferencji użytkownika w terminach punktów aspiracji, rezerwacji oraz cząstkowych funkcji osiągnięcia $\sigma_{i}\left(q_{i}, q_{i}^{-}, q_{i}^{\sim}\right)$, tak jak to było ilustrowane na Rys. 9.5.

Graficzny tryb interakcji wykorzystuje między innymi mechanizm „przeciągania myszą” dla modyfikacji punktów aspiracji i rezerwacji na wykreślnym przedstawieniu cząstkowej funkcji osiągnięcia, wyświetlanie rezultatów poprzednich oraz nowych rezultatów sprawnych na tle wykresu tej funkcji itp. Jednakże zasadniczą cechą interfejsu ISAAP jest jego wykorzystanie nie tylko dla określania preferencji użytkownika w terminach punktów odniesienia i ich aproksymacja za pomocą funkcji osiągnięcia, lecz także wykorzystanie tych danych do organizacji systemu wielokryterialnej analizy modeli oraz dla wspomagania organizacji procesu decyzyjnego. ISAAP bowiem określa postać funkcji osiągnięcia, która będzie optymalizowana z wykorzystaniem analizowanego modelu i odpowiedniego solwera optymalizującego, organizuje procesy wymiany danych pomiędzy tymi i innymi modułami systemu itp. Strukturę modularnego systemu analizy wielokryterialnej modeli i wspomagania decyzji, zorganizowanego wokół interfejsu ISAAP, przedstawia Rys. 10.3. 


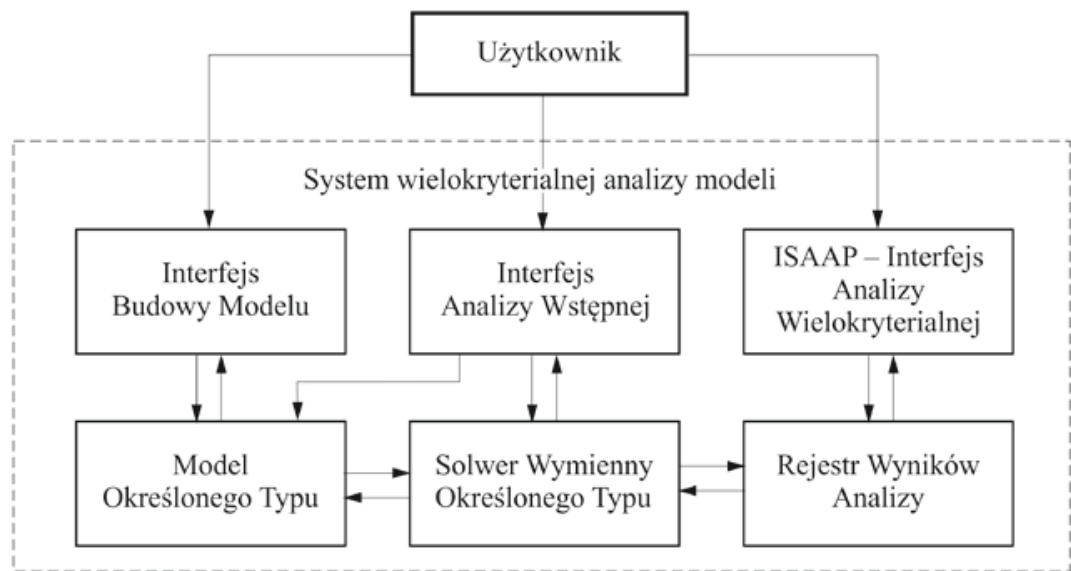

Rys. 10.3. Struktura modularnego systemu wspomagania decyzji zorganizowanego wokół interfejsu ISAAP.

Tak zorganizowany system może mieć wymienne solwery, dostosowywane do charakteru analizowanego modelu - liniowe, nieliniowe, dyskretne, mieszane, dynamiczne itp. Tę modularną strukturę wykorzystano dla praktycznej analizy wielu problemów środowiskowych i ekonomicznych w IIASA i współpracujących organizacjach - problemów takich jak zagospodarowanie terenów rolnych (na zlecenie FAO), analiza transgranicznego transportu zanieczyszczeń środowiska (kwaśnych deszczy, ozonu troposferycznego) itp., zob. Wierzbicki et al. (2000).

\subsection{Problemy implementacji systemów wspomagania decyzji}

Wraz z rozwojem systemów wspomagania decyzji różnorodnych rodzajów zmieniało się podejście do ich implementacji komputerowej. Zmiany te częściowo sygnalizowaliśmy już wcześniej, tu ograniczymy się do krótkiego zarysu wymagań co do implementacji systemów wspomagania decyzji.

W ogólnej technologii oprogramowania, prototypowanie (czyli najpierw opracowanie prototypu oprogramowania, potem jego testowanie i modyfikacje) uważane było dawniej za metodykę błędną: uważano, że najpierw należy bardzo dokładnie sformułować wymagania co do produktu programistycznego, potem trzymać się wiernie tych wymagań i wykonać gotowy produkt. Przekonanie o znaczeniu dokładnego określenia wymagań wstępnych jest prawdziwe i dzisiaj, ale okazało się, że opracowanie złożonych systemów 
oprogramowania wymaga tak istotnej współpracy z przyszłym użytkownikiem, że opracowanie ich bez przygotowania prototypu i jego przetestowania przez przyszłego użytkownika jest po prostu niemożliwe. Jednocześnie, modularne oprogramowanie obiektowe umożliwia dziś znacznie łatwiejsze modyfikacje częściowo opracowanego oprogramowania niż dawniej.

Doświadczenia tego typu odnoszą się w szczególności do oprogramowania systemów wspomagania decyzji, w których podkreśla się szczególną rolę użytkownika. Dlatego też, prototypowanie jest uważane dziś za jedynie poprawną drogę implementacji systemów wspomagania decyzji. Oznacza to, że proces przygotowania systemu wspomagania decyzji, który niżej podzielimy na specyficzne etapy, powinien przejść przez te etapy przynajmniej dwa razy: raz w trakcie przygotowania prototypu, potem dla końcowego produktu.

Stephen Andriole (1989) sugeruje następujące etapy projektowania i implementacji systemu wspomagania decyzji:

1. Analiza i ustalenie wymagań;

2. Ustalenie modelu funkcjonalnego systemu;

3. Wybór oprogramowania gotowego, uzupełnienia i implementacja oprogramowania dodatkowego;

4. Wybór sprzętu niezbędnego dla działania systemu;

5. Kompletacja systemu, czyli opracowanie dokumentacji, zestawienie sprzętu i oprogramowania u użytkownika;

6. Transfer systemu, czyli jego testowanie wraz z użytkownikiem i szkolenie użytkownika w jego funkcjach;

7. Ocena systemu, czyli analiza wszelkich niezbędnych modyfikacji;

8. Sprzężenie zwrotne czy rekursja, czyli powrót do wcześniejszych faz procesu.

Ta klasyfikacja głównych etapów implementacji pozostaje aktualna do dziś. Nie będziemy tu prowadzić głębszej dyskusji tych etapów, które oczywiście mogą same też podlegać modyfikacji. Podkreślić tylko trzeba, że samo opracowanie oprogramowania kosztuje zwykle niewiele wobec kosztów innych faz. Z drugiej strony, o sukcesie systemu wspomagania decyzji decyduje zwykle opracowanie inteligentnego graficznego interfejsu, który powinien być dostosowany nie tylko do jawnych wymagań użytkownika, ale także do pewnych wymagań niejawnych, których często nie potrafi on sformułować 
(gdyż „nie każdy wie, że mówi prozą”). Najlepiej bowiem, jeśli system przemawia do użytkownika $\mathrm{w}$ terminach takich symboli graficznych, do których jest on intuicyjnie przyzwyczajony, które stanowią język symboli właściwy dla jego zawodu. Dlatego też np. błędem jest, jeśli informatyk twórca oprogramowania - narzuca (jak to się często zdarza nawet największym firmom) użytkownikowi ,ikony” czy symbole graficzne $\mathrm{w}$ przekonaniu, że to wszystko jedno, że ma on prawo narzucić takie symbole, jakie mu się podobają. Opracowanie takich inteligentnych i prawdziwie przyjaznych użytkownikowi interfejsów jest więc sztuką, wymaga zarówno ścisłej współpracy z użytkownikiem jak i sporego nakładu pracy programistycznej.

\section{Literatura}

Andriole S.J. (1989) Handbook of Decision Support Systems. TAB Books, Inc., Blue Ridge Summit, PA

Ermolev Yu., Wets R.J-B. (1988) Numerical Techniques for Stochastic Optimization. Springer-Verlag, Berlin-Heidelberg.

Gill Ph.E., Murray W., Wright M.H. (1981) Practical Optimization. Academic Press, London-New York

Granat J., Wierzbicki A.P. (1994) Interactive Specification of DSS User Preferences in Terms of Fuzzy Sets. Working Paper of the International Institute for Applied Systems Analysis, WP-94-29, Laxenburg, Austria

Griewank A. Computational differentiation and optimization, in: J.R. Birge and K.G. Murty, eds., Mathematical Programming: State of the Art 1994

Jaszkiewicz A., and Słowiński R. (1994) The LBS package - a microcomputer implementation of the Light Beam Search method for muliple-objective nonlinear programming. Working Paper of the International Institute for Applied Systems Analysis, WP-94-07, Laxenburg, Austria

Korhonen P., Laakso J. (1986) Solving a generalized goal programming problem using visual interactive approaches. European Journal of Operational Research Vol. 26, pp. 355-363

Kręglewski T., Granat J., Wierzbicki A.P. (1991) IAC-DIDAS-N: A Dynamic Interactive Decision Analysis and Support System for Multicriteria Analysis of Nonlinear Models. Collaborative Paper of the International Institute for Applied Systems Analysis, CP-91-10, Laxenburg, Austria

Lewandowski A., Wierzbicki A.P., eds. (1989) Aspiration Based Decision Support Systems. Lecture Notes in Economic and Mathematical Systems Vol. 331, Springer-Verlag, Berlin-Heidelberg 
Majchrzak J. (1989) DISCRET - Package for Multicriteria Problems with Discrete Alternatives. In: A. Lewandowski, I. Stanchev, eds: Methodology and Software for Interactive Decision Support, Springer, Heidelberg

Makowski M., Sosnowski J. (1989) Mathematical programming package HYBRID. In: A.Lewandowski and A.P. Wierzbicki (1989, op.cit.)

Makowski M. (1994) LP-DIT, Data Interchange Tool for Linear Programming Problems. WP-94-36, Working paper of the International Institute for Applied Systems Analysis, Laxenburg, Austria

Murtagh B.A. Saunders M.A. (1977) MINOS - a Large Scale Nonlinear Programming System for Problems with Linear Constraints. User Guide, Stanford Optimization Laboratory

Nakayama H., Sawaragi Y. (1983) Satisficing trade-off method for multiobjective programming. In: M. Grauer and A.P. Wierzbicki, eds.: Interactive Decision Analysis, Lecture Notes in Economics and Mathematical Systems, Vol. 229, Springer-Verlag, Berlin-Heidelberg

Ogryczak W., Zorychta K. (1994) On solving multiobjective linear programs with implicit representation of minimax scalarizing function. Archives of Control Sciences 3 (XXXIV): 197-213.

Steuer R.E. (1986) Multiple Criteria Optimization:Theory, Computation, and Application. Wiley \& Sons, New York

Rogowski T., Sobczyk J., Wierzbicki A.P. (1989) IAC-DIDAS-L - A dynamic interactive decision analysis and support system for multicriteria analysis of linear and dynamic linear models on professional microcomputers. In: A. Lewandowski and A.P. Wierzbicki (1989, op.cit.)

Wierzbicki A.P. (1977) Modele i wrażliwość układów sterowania. WNT, Warszawa.

Wierzbicki A.P. (1980) The use of reference objectives in multiobjective optimization. In: G. Fandel, T. Gal (eds.): Multiple Criteria Decision Making; Theory and Applications, Lecture Notes in Economic and Mathematical Systems Vol. 177, pp. 468-486, Springer-Verlag, Berlin-Heidelberg.

Wierzbicki A.P. (1986) On the completeness and constructiveness of parametric characterizations to vector optimization problems. OR-Spektrum 8: 73-87.

Wierzbicki A.P., Makowski M., Wessels J. (2000) Model-based decision support methodology with environmental applications. IIASA - Kluwer Academic Publishers, Dordrecht - Boston - London.

Zakrzewski R. (1989) Analiza liniowych modeli matematycznych za pomocą systemu MENTAT-L. Praca magisterska, Instytut Automatyki Politechniki Warszawskiej. 
IV. Teoria gier a wspomaganie decyzji 



\section{Podstawy teorii gier}

\subsection{Przedmiot i historia teorii gier}

Przedmiot teorii gier definiowany bywa jako analiza modeli matematycznych konfliktu i kooperacji pomiędzy inteligentnymi i racjonalnymi decydentami, zwanymi graczami. Dlatego też teorię gier można traktować jako część teorii decyzji, choć uzyskała ona rangę niezależnej dyscypliny. Tym niemniej teoria gier motywuje wiele rezultatów teorii decyzji. W szczególności, jest ona podstawą analizy grupowych sytuacji decyzyjnych. Sytuacje te możemy podzielić na następujące trzy typy:

1. Sytuacje decyzji growych (ang. game decision making), gdy każdy $\mathrm{z}$ decydentów może mieć odmienne preferencje i podejmować niezależne decyzje, ale skutki tych decyzji wpływają także na rezultaty ważne dla innych graczy-decydentów; sytuacje takie opisuje teoria gier niekooperatywnych.

2. Sytuacje decyzji grupowych (ang. group decision making), gdy każdy z decydentów może mieć odmienne preferencje, ale muszą razem podjąć wspólną decyzję, z dwóch możliwych powodów: albo doszli do wniosku, że powinni kooperować - dostrzegając np. przy braku kooperacji możliwość eskalacji konfliktu, zob. rozdział następny - albo też jest to sytuacja decyzji ściśle grupowej, w której decyzje indywidualne są z natury rzeczy niemożliwe. Przykładem takiej sytuacji jest np. podział wspólnego budżetu; innym jest opracowanie zbiorowej opinii ekspertów. Sytuacje decyzji grupowych opisuje - do pewnego stopnia - teoria gier kooperatywnych.

3. Sytuacje decyzji zespołowych (ang. team decision making), gdy decydenci mają w zasadzie wspólne preferencje i podejmują wspólną decyzję; teoria gier nie obejmuje tego przypadku, ale pozwala lepiej zrozumieć jego uwarunkowania. 
Początki teorii gier można datować od ponad stu lat (pojedyncze artykuły na ten temat publikowali np. Ernst Zermelo w r. 1913, Emile Borel w r. 1921, John von Neumann w r. 1928). Natomiast jako odrębna dyscyplina zaczęła się ona kształtować od roku 1944, kiedy to była opracowana podstawowa monografia Johna von Neumanna i Oscara Morgensterna pt. Teoria gier i zachowań ekonomicznych.

Przez wiele lat badań wykształcił się przy tym specyficzny paradygmat teorii gier. Jej celem ma być przewidywanie wyników sytuacji growych (konfliktowych bądź kooperacyjnych) pomiędzy racjonalnymi graczami, kierującymi się maksymalizacją swej wygranej, czyli funkcji użyteczności oraz umiejącymi w pełni ocenić ( $w$ razie potrzeby, także $w$ sensie probabilistycznym) skutki decyzji swoich i innych graczy, przy czym zakłada się znajomość nie tylko własnej, ale także innych funkcji użyteczności. Co więcej, w teorii gier wygrana traktowana jest jako wartość oczekiwana funkcji użyteczności z rozkładami prawdopodobieństw określonymi w razie potrzeby subiektywnie. Zakłada się też, że każdy z graczy potrafi w pełni operować prawdopodobieństwami warunkowymi i regułami Bayesa przekształcania tych prawdopodobieństw. Założenia te są bardzo silne, w praktyce bowiem:

- nie znamy funkcji użyteczności (co najwyżej - potrafimy określić wielokryterialne cele) innych graczy, a i własną nie zawsze znamy dokładnie;

- nie potrafimy w pełni oceniać wyników wszystkich możliwych decyzji własnych i innych graczy nawet w sytuacjach, gdy niepewność co do tych wyników daje się modelować probabilistycznie;

- nie potrafimy intuicyjnie dokonywać złożonych przekształceń prawdopodobieństw warunkowych - a zresztą oprócz niepewności o charakterze probabilistycznym, występują też różne inne rodzaje niepewności.

Dlatego też o graczu zachowującym się w pełni zgodnie z paradygmatem teorii gier mówi się niekiedy jako o graczu superracjonalnym - potrafiącym $\mathrm{w}$ pełni oceniać rezultaty sytuacji $\mathrm{z}$ niepewnością probabilistyczną oraz motywacje innych graczy.

Przypominamy tu jednak, że źródeł niepewności jest wiele, i nie wszystkie odpowiadają niepewności probabilistycznej; mogą one wynikać też z uproszczonego opisu językowego, ze złożoności systemowej otaczającego nas świata, w którym często pojawiają się zachowania chaotyczne - w sensie deterministycznej teorii chaosu, nie niepewności 
probablilistycznej. Stąd też pojęcie superracjonalności można traktować jako część mechanistycznego rozumienia świata, w którym albo wszystko jest prosto zdeterminowane, albo co najwyżej przypadkowe. Jak pokażemy w następnym rozdziale, teoria gier stała się też podstawą klasycznej teorii rynku - która, niestety, w tym sensie też jest częścią mechanistycznego widzenia świata.

Powyższe uwagi nie oznaczają bynajmniej, że teoria gier jest nieprzydatna dla zrozumienia świata; wręcz przeciwnie. Trzeba ją tylko ostrożniej interpretować, niż to czyni większość jej twórców. Nie nadaje się ona do przewidywania zachowań ludzkich $\mathrm{w}$ sytuacjach konfliktowych; ludzkie zachowania są znacznie bardziej złożone, niż to zakłada teoria gier. Natomiast nadaje się ona do przygotowania zrozumienia pewnych typów zachowań w sytuacjach konfliktowych - i już taki rezultat jest bardzo wartościowy.

Tak więc, przy dobrym zrozumieniu ograniczeń paradygmatu teorii gier, jest ona ważnym narzędziem wyjaśniania świata. Matematyczne podstawy teorii decyzji - aksjomaty racjonalności - rozwinęły się właśnie w związku z teorią gier. Jak wiemy, wydają się one często naturalne, mogą jednak wzbudzać wątpliwości po bliższej analizie (tak jak aksjomat niezależności od opcji ubocznej w związku z paradoksem Maurice Alais). W dyskusjach nad tymi aksjomatami, w obronie paradygmatu teorii decyzji i gier powstała wspomniana już wcześniej w tej książce interpretacja tej teorii jako narzędzia normatywnego lub preskryptywnego, według której gracz superracjonalny powinien się tak zachowywać, jak to przewiduje ta teoria; jeśli nie, to gorzej dla niego. Trudno jednak się zgodzić $\mathrm{z}$ tak dalece idącą interpretacją; lepiej traktować teorię gier jako narzędzie poznawcze, silne choć uproszczone.

Rola teorii gier w tworzeniu podstaw współczesnej ekonomii matematycznej została doceniona w połowie i pod koniec XX wieku, kiedy to John Nash, Reinhart Selten i John Harsanyi zostali laureatami nagrody Nobla w dziedzinie ekonomii za wyniki w teorii gier. ${ }^{1}$

John Nash w roku 1951 wprowadził pojęcie punktu równowagi gry niekooperatywnej $\mathrm{w}$ postaci normalnej i badał warunki jego istnienia. W roku 1953 wprowadził pierwsze z rozwiązań kooperatywnych w teorii gier.

${ }^{1}$ Choć teorię gier można uważać za część matematyki, to jednak w dziedzinie matematyki nie przyznaje się nagród Nobla. 
Reinhart Selten i John Harsanyi wprowadzili w 1968 roku nową postać bayesowskiego modelu gry dla informacji a posteriori; badali różne wzmocnione definicje punktu równowagi w dążeniu do jego jednoznaczności; wreszcie, w odpowiedzi na pojęcie ewolucji kooperacji Roberta Axelroda (który opisał je w roku 1984) wprowadzili w roku 1988 procedurę wyboru najbardziej odpornego punktu równowagi, jednoznacznego dla gier w postaci strategicznej. Stosowane w tym krótkim zarysie historycznym pojęcia będą stopniowo wyjaśniane w dalszych rozdziałach.

\subsection{Podstawowe typy modeli czyli postaci gier}

Stosuje się wiele typowych modeli gier. Wymienimy tu tylko najważniejsze:

1. Postać ekstensywna gry jest to drzewo logiczne możliwych działań, kolejnych ruchów graczy, probabilistycznych stanów natury, pozyskiwania przez graczy informacji na temat tych stanów, itd. Jest to niewątpliwie najbardziej ogólna postać modelu gry; można za jej pomocą opisać np. gry dynamiczne i inne złożone sytuacje growe. Jednak stosowanie tej postaci ma też wady: wraz ze wzrostem złożoności drzewa logicznego jeszcze szybciej rośnie złożoność nakładu obliczeń niezbędnego do analizy tego drzewa, co powoduje m.in. trudność sensownego uzasadnienia założenia o superracjonalności graczy.

2. Postać normalna gry jest to jej model określony przez dane funkcje wygranej czy wartości każdego gracza zależne od decyzji wszystkich n graczy (jeśli wygrane są losowe, to funkcje te określają wartości oczekiwane funkcji użyteczności). Decyzje dopuszczalne modeluje się przy tym poprzez określenie zbioru decyzji dopuszczalnych, który jest iloczynem kartezjańskim zbiorów decyzji dopuszczalnych dla każdego gracza:

$$
\boldsymbol{x}=\left(\boldsymbol{x}_{1}, \ldots \boldsymbol{x}_{i}, \ldots \boldsymbol{x}_{n}\right) ; \boldsymbol{x} \in \boldsymbol{X}_{0}=\bigcap_{\mathrm{i}=1, \ldots, n} \boldsymbol{X}_{0, i}
$$

przy czym każda decyzja może być nie tylko skalarna, ale nawet wektorowa, natomiast założenie $\boldsymbol{x}_{i} \in \boldsymbol{X}_{0, i}$ oznacza, że decyzje graczy mogą być podejmowane w pełni niezależnie. Gdybyśmy bowiem dopuścili wspólne ograniczenia na decyzje graczy - np. ograniczenie sumy zmiennych decyzyjnych dwóch graczy, jak np. sumy wypłat użytkowników wspólnego konta - to oznaczałoby, że decyzje ich nie są faktycznie niezależne. Zresztą przypadki takich wspólnych ograniczeń, nawet jeśli występują w praktyce, 
są zazwyczaj zamieniane na ograniczenie miękkie poprzez wprowadzenie odpowiednich kar za przekroczenie ograniczeń - tak jak zwiększenie stopy oprocentowania długu w przypadku debetu na wspólnym koncie. Dlatego też możemy zakładać, że decyzje graczy są faktycznie niezależne, chociaż oczywiście funkcje wygranej nie zależą od decyzji pojedynczego gracza, a od wszystkich graczy:

$$
y_{i}=f_{i}\left(\boldsymbol{x}_{1}, \ldots \boldsymbol{x}_{i}, \ldots \boldsymbol{x}_{n}\right), i=1, \ldots n
$$

gdzie wygrane $y_{i}$ oraz funkcje wygranej $f_{i}$ traktowane są jako skalarne (uogólnienie gier na przypadek wielokryterialny komplikuje znacznie ich opis, zob. dalsze rozdziały). Choć wydawałoby się, że w zapisie powyższym obowiązuje pełna symetria względem decyzji każdego gracza, to jednak takiej symetrii nie ma, skoro każdy gracz stara się działać na swoją korzyść: będzie on zatem maksymalizował $f_{i}$ względem zmiennej $\boldsymbol{x}_{i}$, traktując inne decyzje jako parametry czy dane zewnętrzne. Dla podkreślenia tej asymetrii, równania (11.2) zapisuje się niekiedy w innej równoważnej formie, podkreślając tylko rozróżnienie pomiędzy decyzjami, na które nie mamy wpływu (z tym samym oznaczeniem $\left.\boldsymbol{x}=\left(\boldsymbol{x}_{1}, \ldots \boldsymbol{x}_{i}, \ldots \boldsymbol{x}_{n}\right)\right)$ oraz na decyzje, o których decydujemy (wprowadzając nowe oznaczenie $\boldsymbol{u}_{i}$ W miejsce $\boldsymbol{x}_{i}$ ). Równania (11.2) przybierają wtedy postać:

$$
y_{i}=f_{i}\left(\boldsymbol{x}_{1}, \ldots \boldsymbol{u}_{i}, \ldots \boldsymbol{x}_{n}\right), i=1, \ldots n
$$

gdzie oczywiście $\boldsymbol{u}_{i} \in \boldsymbol{X}_{i, 0}$ oznacza zmienną, względem której funkcje wygranej są maksymalizowane.

Zaletą postaci normalnej gry jest jej zwartość; syntetyzuje ona znacznie informacje, które w postaci ekstensywnej mogły być bardzo rozbudowane. Wadą tej postaci jest ukrycie w jej zwartej postaci niektórych informacji o dużym znaczeniu - np. wartości działań mających na celu pozyskanie informacji. Przejście od postaci ekstensywnej do postaci normalnej może być przy tym niełatwe i wymagać założeń upraszczających.

3. Postać strategiczna gry nie jest terminem używanym jednoznacznie. Niekiedy nazywana jest tak postać normalna, lub postać normalna dla dyskretnych decyzji graczy (postać macierzowa lub wielomacierzowa gry, zob. dalsze punkty). Tu będziemy stosować określenie postać strategiczna gry w stosunku do jej formy koalicyjnej: postać strategiczna w formie koalicyjnej to wartości najlepszych możliwych wygranych dla każdego gracza i każdej koalicji kilku (aż do $n$ ) graczy w grze przeciwko innym graczom czy 
koalicjom. Jest to jeszcze silniejsza agregacja informacji o grze, gdyż nawet przejście od postaci normalnej do strategicznej koalicyjnej upraszcza informacje - i nie musi być określone jednoznacznie. Zaletą strategicznej postaci koalicyjnej jest fakt, że syntetyzuje ona informacje o punktach równowagi i jest praktycznie jedyną formą adekwatną do analizy złożonych gier koalicyjnych; wadą dla jakichkolwiek innych zastosowań jest nadmierna agregacja informacji.

Istnieje jeszcze wiele innych szczegółowych postaci gier. Wspomnianą już wyżej użyteczną formą zapisu gier prostszych jest postać (jedno- lub wielo-) macierzowa gry - przy założeniu skończonej liczby decyzji każdego gracza, postać ta wyraża przedstawienie wszystkich możliwych decyzji i odpowiadających im wygranych w postaci odpowiednich macierzy.

\subsection{Punkt równowagi Nasha}

Punkt równowagi (Johna) Nasha definiowany jest dla gry w postaci normalnej jako taka (łączna) decyzja graczy $\boldsymbol{x}^{*} \in \boldsymbol{X}_{0}$, że:

$$
f_{i}\left(\boldsymbol{x}_{1}^{*}, \ldots \boldsymbol{x}_{i}^{*}, \ldots \boldsymbol{x}_{n}^{*}\right) \leq f_{i}\left(\boldsymbol{x}_{1}^{*}, \ldots \boldsymbol{x}_{i}, \ldots \boldsymbol{x}_{n}^{*}\right) \forall \boldsymbol{x}_{i} \in \boldsymbol{X}_{0, i} \forall i=1, \ldots n
$$

Decyzja taka dla danej postaci gry nie musi istnieć; problemy istnienia punktu równowagi są jednym z centralnych zagadnień matematycznej teorii gier, zob. np. Jean-Pierre Aubin (1979) lub Roger Myerson (1991). Przy rozsądnych założeniach można jednak wykazać istnienie punktu równowagi dla gier w postaci normalnej; znacznie trudniej natomiast wykazać jego jednoznaczność - wymaga to zazwyczaj znacznie silniejszych założeń.

Celem ilustracji trudności związanych z wyznaczaniem punktu równowagi, przyjmijmy założenia o skalarnym charakterze $x_{i}$, różniczkowalności funkcji $f_{i}$ i poszukiwaniu równowagi Nasha we wnętrzu zbioru $\mathrm{X}_{0}$. Wynika stąd odpowiedni układ (lokalnych) warunków koniecznych:

$$
\partial f_{i}\left(\boldsymbol{x}^{*}\right) / \partial x_{i}=0, \forall i=1, \ldots n,
$$

przy czym jeśli decyzje graczy nie są skalarne i wymiar decyzji każdego gracza wynosi $n_{i}$, to równanie (11.5) trzeba uzupełnić do układu $n^{\sim}=\sum_{i=1, \ldots n} n_{i}>n$ równań nieliniowych, z których rozwiązania powinno wynikać $\boldsymbol{x}^{*}=\left(\boldsymbol{x}_{1}{ }_{1}, \ldots \boldsymbol{x}_{i}{ }_{i}, \ldots \boldsymbol{x}_{n}{ }_{n}\right)$. Rozwiązanie takiego układu równań 
nieliniowych wcale nie musi istnieć, a jeśli istnieje - to wcale nie musi należeć do wnętrza $\boldsymbol{X}_{0}$, ani być jednoznacznie określone. Numeryczne rozwiązywanie takiego układu równań, a tym bardziej wyznaczanie równowag Nasha przy ogólniejszych założeniach (np. z uwzględnieniem ograniczeń) jest bardzo trudnym zadaniem obliczeniowym. Dość powszechnie stosowana $\mathrm{w}$ rozważaniach ekonomicznych jest metoda iteracji optymalizacyjnej typu Gaussa-Seidela: każdy z graczy kolejno optymalizuje swe decyzje, znając poprzednie decyzje pozostałych graczy. Ale metoda ta wcale nie musi być zbieżna, a jeśli jest zbieżna, to może być bardzo powolna, choć jest oczywiście prosta koncepcyjnie. Inne metody iteracyjne - np. dla równania (11.5) można stosować iteracje analogiczne do optymalizacyjnych metod gradientowych lub Newtona-Raphsona - też nie zawsze muszą być zbieżne, a ponadto nie można ich ustabilizować przez optymalizację kierunkową tak jak przy optymalizacji jednej funkcji, bo przecież maksymalizujemy jednocześnie $n$ funkcji.

Jedno z najbardziej ogólnych podejść do wyznaczania punktu równowagi, zaproponowane przez Jean-Pierre Aubina (zob. np. 1979) polega na wykorzystaniu postaci (11.3) gry wraz z wprowadzeniem funkcji pomocniczych z wyraźnie wyróżnionymi decyzjami własnymi:

$$
\begin{aligned}
& y_{i}=f^{\sim}{ }_{i}\left(\boldsymbol{u}_{i}, \boldsymbol{x}\right)=f_{i}\left(\boldsymbol{x}_{1}, \ldots \boldsymbol{u}_{i}, \ldots \boldsymbol{x}_{n}\right), \forall i=1, \ldots n ; \\
& \boldsymbol{f}^{\sim}(\boldsymbol{u}, \boldsymbol{x})=\left(f^{\sim}{ }_{1}\left(\boldsymbol{u}_{1}, \boldsymbol{x}\right), \ldots f^{\sim}{ }_{i}\left(\boldsymbol{u}_{i}, \boldsymbol{x}\right), \ldots f^{\sim}{ }_{n}\left(\boldsymbol{u}_{n}, \boldsymbol{x}\right)\right) ; \\
& \varphi(\boldsymbol{u}, \boldsymbol{x})=\sum_{\mathrm{i}=1, \ldots n}\left(f^{\sim}{ }_{i}\left(\boldsymbol{u}_{i}, \boldsymbol{x}\right)-f_{i}(\boldsymbol{x})\right)
\end{aligned}
$$

Twierdzenie 11.1. (o charakteryzacji punktów równowagi Nasha jako zadania optymalizacji, zob. Jean-Pierre Aubin 1979). Jeśli zbiory $\boldsymbol{X}_{0, i}$ są zwarte, natomiast funkcje $f_{i}$ są ciągłe, to $\boldsymbol{x}^{*}$ jest punktem równowagi Nasha wtedy i tylko wtedy, gdy:

$$
\min _{\boldsymbol{x} \in \mathbf{X} 0} \max _{\boldsymbol{u} \in \mathbf{X} 0} \varphi(\boldsymbol{u}, \boldsymbol{x})=\max _{\boldsymbol{u} \in \mathbf{X} 0} \varphi\left(\boldsymbol{u}, \boldsymbol{x}^{*}\right)=0
$$

Powyższe twierdzenie Aubina sprowadza zadanie wyznaczania równowagi Nasha do wyznaczania punktu siodłowego czyli do minimaksowej optymalizacji jednej funkcji. Jak wszelkie zadania minimaksowe, jest to jednak zadanie optymalizacji nieróżniczkowalnej. 


\subsection{Gry w postaci macierzowej}

\subsubsection{Gry o sumie zerowej}

Jeden z prostszych modeli gry dotyczy przypadku, gdy każdy z dwóch graczy ma do wyboru skończoną liczbę (niekoniecznie taką samą) decyzji dyskretnych, oraz wygrana jednego gracza jest przegraną drugiego. Jest to gra macierzowa o sumie zerowej (ogólniej - stałej). Celem prostego jej zapisu, zmieniamy tu oznaczenia w porównaniu z ogólną postacią normalną gry:

- $i=1, \ldots n$ - decyzje pierwszego gracza (uwaga: tu $n$ oznacza nie liczbę graczy, tylko liczbę różnych decyzji jednego gracza);

$\bullet j=1, \ldots m$ - decyzje drugiego gracza (uwaga j.w.);

- $a_{i j}$ - wypłaty (np. dla pierwszego gracza od drugiego) przy decyzjach $i, j$;

- $\boldsymbol{A}=\left[a_{i j}\right]$ - macierz wypłat.

Jeśli dodatkowo wprowadzimy wektory decyzji:

- $\boldsymbol{w}=\left(0, \ldots, 0,1_{i}, 0, \ldots 0\right) \in \boldsymbol{R}^{n}$

- $\mathbf{z}=\left(0, \ldots, 0,1_{j}, 0, \ldots 0\right) \in \boldsymbol{R}^{m}$

odpowiednio dla pierwszego i drugiego gracza (są to wektory o jednej składowej równej 1 - np. na pozycjach $i, j$, jeśli takie były decyzje obu graczy - oraz pozostałych składowych zerowych), to dopuszczalne decyzje opiszemy przez ograniczenia całkowito-liczbowe:

$$
\begin{aligned}
& \boldsymbol{w} \in \boldsymbol{W}_{0}=\left\{\boldsymbol{w} \in \boldsymbol{R}^{n}: w_{i}=0 \text { lub } 1, \forall i=1, \ldots n ; \sum_{i=1, \ldots n} w_{i}=1\right\} \\
& \mathbf{z} \in \mathbf{Z}_{0}=\left\{\mathbf{z} \in \boldsymbol{R}^{m}: z_{j}=0 \text { lub } 1, \forall j=1, \ldots m ; \sum_{j=1, \ldots m} z_{j}=1\right\}
\end{aligned}
$$

natomiast całą grę sprowadzimy wtedy do zadania minimaksowego lub poszukiwania punktu siodłowego:

$$
\min _{\boldsymbol{z} \in \mathbf{Z} 0} \max _{\boldsymbol{w} \in \boldsymbol{W}_{0} 0}\left(\mathrm{a}_{i j}=\mathbf{z}^{\mathrm{T}} \boldsymbol{A} \boldsymbol{w}\right)
$$

Okazuje się jednak, że dla dowolnej macierzy $\boldsymbol{A}$ punkt siodłowy powyższego zadania wcale nie musi istnieć. $\mathrm{W}$ związku $\mathrm{z}$ tym wprowadzono następujące uogólnienie tego zadania. Decyzje $\boldsymbol{w} \in \boldsymbol{W}_{0}$ i $\mathbf{z} \in \boldsymbol{Z}_{0}$ określone jak wyżej nazwiemy strategiami czystymi, a uogólnimy powyższe zadanie traktując je jako szczególne przypadki strategii mieszanych:

$$
\begin{aligned}
& \boldsymbol{w} \in \boldsymbol{W}_{0}=\left\{\boldsymbol{w} \in \boldsymbol{R}^{n}: w_{i} \in[0 ; 1] \forall i=1, \ldots n ; \sum_{i=1, \ldots n} w_{i}=1\right\} \\
& \mathbf{z} \in \boldsymbol{Z}_{0}=\left\{\mathbf{z} \in \boldsymbol{R}^{m}: z_{j} \in[0 ; 1] \forall j=1, \ldots m ; \sum_{i=1, \ldots m} z_{j}=1\right\}
\end{aligned}
$$


gdzie $\boldsymbol{w}$ i $\mathbf{z}$ mają interpretację rozkładów prawdopodobieństw wyboru decyzji $i$ oraz $j$ - tak, jakby obaj gracze jednocześnie stosowali niezależne generatory liczb losowych dla wyboru swoich decyzji, a ich właściwa decyzja sprowadzała się do określenia rozkładu prawdopodobieństwa.

Łatwo sprawdzić, że funkcja $\mathbf{z}^{\mathrm{T}} \boldsymbol{A} \boldsymbol{w}$ jest wtedy wartością oczekiwaną wygranej pierwszego gracza (przegranej drugiego). Jej wartość siodłową - jeśli punkt siodłowy istnieje - oznaczamy przez $v(\boldsymbol{A})$ i nazywamy wartością gry. Warunkowe wartości gry przy danych decyzjach jednego lub drugiego gracza oznaczamy przez $v_{1}(w)$ (jest to gwarantowana wygrana pierwszego gracza przy danych jego decyzjach) i $v_{2}(\mathbf{z})$ (gwarantowana przegrana drugiego gracza przy jego decyzjach); wyrażone są one przez zależności:

$$
v_{1}(\boldsymbol{w})=\min _{\mathbf{z} \in \mathbf{Z} 0} \mathbf{z}^{\mathrm{T}} \boldsymbol{A} \boldsymbol{w} \leq v(\boldsymbol{A}) \leq \max _{\boldsymbol{w} \in \boldsymbol{W}_{0}} \mathbf{z}^{\mathrm{T}} \boldsymbol{A} \boldsymbol{w}
$$

Twierdzenie 11.2. (o istnieniu punktu równowagi gier macierzowych o sumie zerowej). Dla gry macierzowej o sumie zerowej ze strategiami mieszanymi zawsze istnieje punkt siodłowy o jednoznacznie określonej wartości gry.

Innymi słowy, w grze macierzowej ze strategiami mieszanymi można wyznaczyć w pewnym sensie jednoznaczny punkt równowagi Nasha, który $\mathrm{W}$ istocie jest uogólnieniem punktu siodłowego (decyzje równowagowe nie muszą być przy tym jednoznaczne, ale nie ma to większego znaczenia, skoro wartość gry jest określona jednoznacznie).

Dowód twierdzenia 11.2. opiera się na następującej metodzie sprowadzenia zadania wyznaczania punktu siodłowego do zadania programowania liniowego. Ponieważ warunek $\sum_{i=1, \ldots n} w_{i}=1$ można zapisać jako $\mathbf{1}_{n}{ }^{\mathrm{T}} \boldsymbol{w}=1$ (gdzie $\boldsymbol{1}_{n} \in \boldsymbol{R}^{n}$ jest wektorem złożonym z samych jedynek), przeto obowiązuje $\mathbf{1}_{n}{ }^{\mathrm{T}} \boldsymbol{w} / v(\boldsymbol{w})=1 / v_{1}(\boldsymbol{w})$, którą to wielkość gracz pierwszy będzie minimalizował $\mathrm{w}$ dążeniu do maksymalizacji $1 / v_{1}(w)$; wprowadźmy zmienną pomocniczą $\boldsymbol{w}^{-}=\boldsymbol{w} / v_{1}(\boldsymbol{w})$ i minimalizujmy $\boldsymbol{1}_{n}{ }^{\mathrm{T}} \boldsymbol{w}^{-}=1 / v_{1}(\boldsymbol{w})$ przy warunku $\boldsymbol{w} \geq 0$. Dodatkowy warunek dla tej minimalizacji wynika $\mathrm{z}$ nierówności $v_{1}(\boldsymbol{w})=\min _{\boldsymbol{z} \in \mathbf{z}_{0}} \mathbf{z}^{\mathrm{T}} \boldsymbol{A} \boldsymbol{w} \leq \mathbf{z}^{\mathrm{T}} \boldsymbol{A} \boldsymbol{w} \forall \mathbf{z} \in \boldsymbol{Z}_{0}$, czyli $1 \leq \mathbf{z}^{\mathrm{T}} \boldsymbol{A} \boldsymbol{w}^{-} \forall \mathbf{z} \in \boldsymbol{Z}_{0}$; wybierając kolejno $z_{j}=e_{j}=\left(0, \ldots, 0,1_{j}, 0, \ldots 0\right)$ możemy zapisać ten warunek w postaci układu nierówności lub równoważnej nierówności wektorowej $A \boldsymbol{w}^{-} \geq \boldsymbol{1}_{m}$ (gdzie $\boldsymbol{1}_{m} \in \boldsymbol{R}^{m}$ jest też wektorem złożonym z samych jedynek). Możemy w ten sposób udowodnić, że punkt siodłowy dla gry macierzowej o sumie zerowej wyznaczony jest poprzez rozwiązanie dwóch dualnych względem siebie zadań programowania liniowego:

mininimize $\mathbf{1}_{n}^{\mathrm{T}} \boldsymbol{w}^{-}, \boldsymbol{A} \boldsymbol{w}^{-} \geq \mathbf{1}_{m}, \boldsymbol{w}^{-} \geq 0$;

maximize $\mathbf{1}_{m}{ }^{\mathrm{T}} \mathbf{z}^{-}, \boldsymbol{A}^{\mathrm{T}} \mathbf{z}^{-} \leq \mathbf{1}_{n}, \mathbf{z}^{-} \geq 0$ 
przy czym po obliczeniu rozwiązań $w^{-*}, z^{-*}$ tych zadań określamy wartość gry i strategie równowagowe według wzoru:

$$
v(\boldsymbol{A})=1 /\left(\mathbf{1}_{n}^{\mathrm{T}} \boldsymbol{w}^{-*}\right)=1 /\left(\mathbf{1}_{m}{ }^{\mathrm{T}} \mathbf{z}^{-*}\right), \boldsymbol{w}^{*}=v(\boldsymbol{A}) \boldsymbol{w}^{-*}, \mathbf{z}^{*}=v(\boldsymbol{A}) \mathbf{z}^{-*}
$$

Wykorzystując powyższe rezultaty można też sprawdzić, że gry różniące się macierzą o jednakowych elementach - np. z macierzą wypłat $\boldsymbol{A}^{\prime}=\boldsymbol{A}+c \mathbf{1}_{m} \mathbf{1}_{n}^{\mathrm{T}}$, gdzie $c$ jest stałą dowolną - są strategicznie równoważne, tj. mają takie same strategie optymalne dla obu graczy.

\section{Ćwiczenie 11.1:}

a) Posługując się powyższym sposobem rozumowania, sprawdzić szczegółowo równoważność zadania poszukiwania punktu siodłowego gry macierzowej w strategiach mieszanych do zadań programowania liniowego (11.12). Wskazówka: wykorzystać podstawowe twierdzenia o dualności zadań programowania liniowego.

b) Dla macierzy $\boldsymbol{A}$ o wymiarach $6 \times 6$ oraz $a_{i j}=1 /(i+j)$ sprawdzić, że istnieje punkt siodłowy w strategiach czystych i określić odpowiednią wartość gry; ponadto sprawdzić, że obliczenie optymalnych strategii mieszanych daje strategię mieszaną zdegenerowaną, czyli czystą.

c) Jak zmodyfikować określoną wyżej (i powtórzoną w tabeli poniżej) macierz $\boldsymbol{A}$, aby gra nie miała punktów siodłowych w strategiach czystych?

\begin{tabular}{|c|c|c|c|c|c|c|}
\hline & $j=1$ & $j=2$ & $j=3$ & $j=4$ & $j=5$ & $j=6$ \\
\hline$i=1$ & $1 / 2$ & $1 / 3$ & $1 / 4$ & $1 / 5$ & $1 / 6$ & $1 / 7$ \\
\hline$i=2$ & $1 / 3$ & $1 / 4$ & $1 / 5$ & $1 / 6$ & $1 / 7$ & $1 / 8$ \\
\hline$i=3$ & $1 / 4$ & $1 / 5$ & $1 / 6$ & $1 / 7$ & $1 / 8$ & $1 / 9$ \\
\hline$i=4$ & $1 / 5$ & $1 / 6$ & $1 / 7$ & $1 / 8$ & $1 / 9$ & $1 / 10$ \\
\hline$i=5$ & $1 / 6$ & $1 / 7$ & $1 / 8$ & $1 / 9$ & $1 / 10$ & $1 / 11$ \\
\hline$i=6$ & $1 / 7$ & $1 / 8$ & $1 / 9$ & $1 / 10$ & $1 / 11$ & $1 / 12$ \\
\hline
\end{tabular}

Tabela 11.1. Przykład symetrycznej gry macierzowej o sumie zerowej, mającej punkt siodłowy w strategiach czystych.

Można przy tym albo rozwiązać numerycznie odpowiednie zadania (11.12), jeśli się dysponuje solwerem numerycznym zadań programowania liniowego, albo też udowodnić metodami analizy zadań programowania liniowego, że odpowiednie strategie czyste odpowiadają istotnie rozwiązaniom odpowiednich zadań (11.12). 


\subsubsection{Gry o sumie niezerowej}

Większość praktycznych sytuacji growych jest jednak bardziej skomplikowana - suma wygranych obu graczy nie jest stała (jak w starym przysłowiu ,gdzie dwóch się kłóci..." - nawet, jeśli jest tylko dwóch graczy, to mogą oni wnosić pewne wpłaty na korzyść strony trzeciej, np. dwóch przedsiębiorców płacących podatki).

Gry o sumie niezerowej lub niestałej dla dwóch graczy opisywane są dwoma macierzami, np. macierzą $\boldsymbol{A}$ określającą wygrane pierwszego gracza i macierzą $\boldsymbol{B}$ wygranych drugiego gracza (w przypadku gier o sumie zerowej mamy po prostu $\boldsymbol{B}=-\boldsymbol{A}$ ). Gry o sumie stałej mają zawsze dobrze określoną wartość gry (przynajmniej w strategiach mieszanych); natomiast gry o sumie niestałej mogą mieć wiele rozwiązań równowagowych Nasha, którym odpowiadają zupełnie odmienne wartości wypłat dla poszczególnych graczy.

\begin{tabular}{|c|c|c|c|c|c|c|}
\hline$i \backslash j$ & 1 & 2 & 3 & 4 & 5 & 6 \\
\hline 1 & $a_{1,1} b_{1,1}$ & $\ldots$ & $\ldots$ & $\ldots$ & $\ldots$ & $a_{1,6} b_{1,6}$ \\
\hline 2 & $\ldots$ & $\ldots$ & $\ldots$ & $\ldots$ & $\ldots$ & $\ldots$ \\
\hline 3 & $\ldots$ & $\ldots$ & $a_{i, j} b_{i, j}$ & $\ldots$ & $\ldots$ & $\ldots$ \\
\hline 4 & $\ldots$ & $\ldots$ & $\ldots$ & $\ldots$ & $\ldots$ & $\ldots$ \\
\hline 5 & $\ldots$ & $\ldots$ & $\ldots$ & $\ldots$ & $\ldots$ & $\ldots$ \\
\hline 6 & $a_{1,6} b_{1.6}$ & $\ldots$ & $\ldots$ & $\ldots$ & $\ldots$ & $a_{6,6} b_{6,6}$ \\
\hline
\end{tabular}

Tabela 11.2. Ilustracja opisu gry dwumacierzowej.

Ponadto, w grach o sumie niestałej pojawia się możliwość kooperacji graczy w celu maksymalizacji wspólnego wyniku; rozwiązanie równowagowe niekooperatywne Nasha wcale nie musi być rozwiązaniem sprawnym w sensie wygranych obu graczy. Ilustruje to następujący przykład.

Przykład 11.1: "Dylemat więźnia" (ang. Prisoners Dillemma) jest to gra dwumacierzowa o dwóch decyzjach dla obu graczy $(n=m=2)$ i o następującej strukturze:

\begin{tabular}{|c|c|c|}
\hline$i \backslash j$ & $C$ & $D$ \\
\hline$C$ & $c c$ & $d a$ \\
\hline$D$ & $a d$ & $b b$ \\
\hline
\end{tabular}

Tabela 11.3. Gra dwumacierzowa zwana dylematem więźnia, przy założeniu $a<b<c<d$, przy czym każdy z graczy ma dwa ruchy:

$C$ - dochowaj umowy (ang. cooperate) i $D$ - odstąp od umowy (ang. defect). 
Przytoczymy tu klasyczną interpretację tej gry, o zabarwieniu negatywnym (jest też wiele innych interpretacji, o odmiennych zabarwieniach, ale ta akurat jest podstawowa). Złapano dwóch przestępców. Policja proponuje każdemu z nich z osobna umowę: za przyznanie się i zdradzenie kolegi po fachu (obciążenie go zeznaniami) - obniżenie wyroku. Możliwe są następujące przypadki:

- obaj nie przyznają się, a wiec obaj dostają po c (np. po 3 lata więzienia, $c=-3$, gdzie znak "-" odpowiada założeniu, że funkcje wypłat są maksymalizowane);

- gdy jeden się przyzna, a drugi będzie odmawiał zeznań, to pierwszy dostanie $d$ (np. 1 rok więzienia, $d=-1$ ), natomiast drugi, obciążony zeznaniami pierwszego, dostanie większą karę $a$ (np. 8 lat, $a=-8$ );

- gdy obaj się przyznają, to obaj dostaną po $b$ (np. po 5 lat, $b=-5$ ), co jest gorszym rezultatem, niż w przypadku nieprzyznawania się przez obu.

Mimo to łatwo pokazać, że równowaga niekooperatywna Nasha odpowiada tu przyznaniu się obu: jeśli jeden nie przyznaje się, to drugiemu opłaca się przyznać, jeśli jeden przyznaje się, to drugiemu też opłaca się przyznać. Paradoks ten wyraża swoistą krótkowzroczność pojęcia równowagi Nasha. Ilustruje to Rys. 11.1.

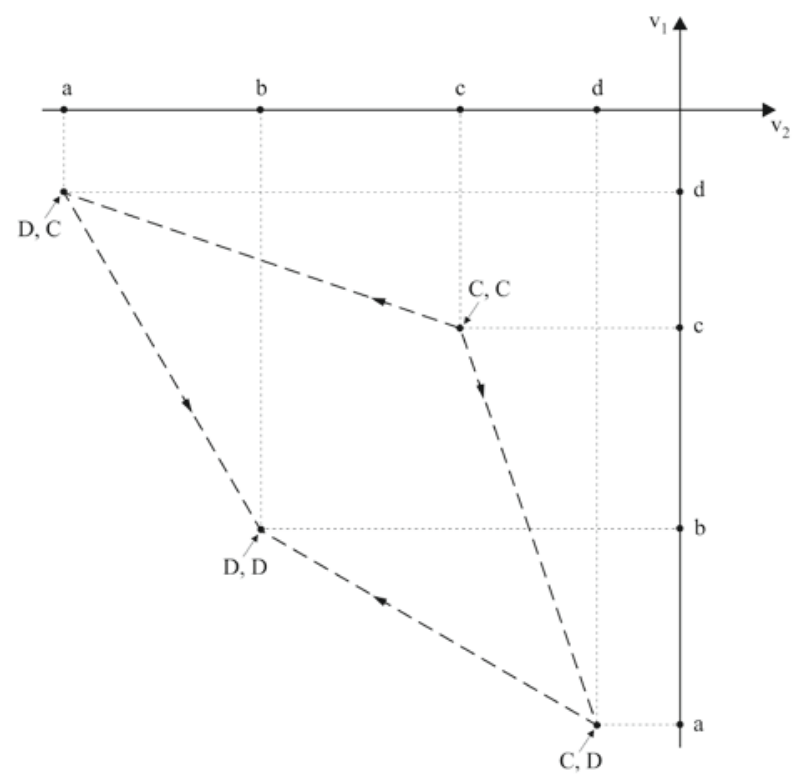

Rys. 11.1. Ilustracja dylematu więźnia w przestrzeni wygranych. 
Dylemat więźnia jest tylko jednym z przykładów całej klasy gier o sumie niezerowej, zwanych "pułapkami racjonalności", a ilustrujących zwodniczość czy trudności interpretacyjne niektórych założeń teorii gier. Drugim przykładem, ilustrującym możliwość występowania wielu równowag w grze o niestałej sumie (przy czym niejednoznaczność tych równowag jest istotna, nie da się wyeliminować żadnym rozsądnym sposobem) jest tak zwana "gra $w$ tchórza" (ang. game of chicken). ${ }^{2}$ Jest to gra o tej samej strukturze, co "dylemat więźnia" - patrz Tabela 11.3, tylko z nieco odmiennymi parametrami: zakładamy tu mianowicie, że $b<a<c<d$ zamiast, jak uprzednio, $a<b<c<d$. Ta drobna zmiana założeń prowadzi do zasadniczej zmiany charakteru gry. Zmienia się też podstawowa interpretacja, dlatego też powtórzymy tu Tabelę $11.3 \mathrm{z}$ odpowiednimi zmianami.

\begin{tabular}{|c|c|c|}
\hline$i \backslash j$ & $S$ & $P$ \\
\hline$S$ & $c c$ & $d a$ \\
\hline$P$ & $a d$ & $b b$ \\
\hline
\end{tabular}

Tabela 11.4. Gra dwumacierzowa zwana ,grą w tchórza” przy założeniu $b<a<c<d$, przy czym każdy z graczy ma dwa ruchy: $P$ - nie ustępuj (ang. persist) i $S$ - ustąp, skręć (ang. swerve).

Interpretacja tej gry to jazda na zderzenie czołowe dwóch samochodów; kto skręci i ustąpi z drogi, przegrywa i nazywany jest „tchórzem”. Decyzja $S$ odpowiada takiemu ustępstwu, natomiast decyzja $P$ odpowiada nieustępliwości, jeździe na wprost.

Okazuje się, ze stosunkowo drobna zmiana parametrów powoduje zasadniczą zmianę struktury punktów równowagi: w przykładzie tym, zamiast jednego, choć niesprawnego, punktu równowagi pojawiają się dwa, w pełni symetryczne - są to pary decyzji $(P, S)$ i $(S, P)$. Jeśli bowiem wiemy, że przeciwnik na pewno nie ustąpi, to jednak opłaca się ustąpić; jeśli podejrzewamy, że przeciwnik ustąpi, to opłaca się nie ustępować. ${ }^{3}$ A więc

\footnotetext{
${ }^{2}$ To klasyczny przykład, ze nie wolno pospiesznie i dosłownie thumaczyć terminów angielskich na polski. Amerykańskie idiomatyczne znaczenie chicken to odpowiednik polskiego przenośnego znaczenia tchórza.

${ }^{3}$ Dlatego też jako "niezawodną strategię" dla gry w tchórza zaleca się wyrwanie kierownicy i pokazywanie jej kierowcy jadącemu na przeciw.
} 
pojęcie równowagi gry nie pozwala na przewidywanie jej rezultatu, gdyż dwie odmienne równowagi są $\mathrm{w}$ pełni symetrycznymi, równo uprawnionymi rozwiązaniami. Jeśli jest się pewnym, ze przeciwnik nie ustąpi, to racjonalne jest ustąpić; ale tak mogą rozumować obie strony, co jest podstawowym przykładem pojęcia eskalacji konfliktu: jeśli obaj gracze jadą prosto, starając się wymusić ustępstwo na przeciwniku, to rozwiązaniem takiej gry staje się punkt nierównowagowy $(P, P)$ - czyli zderzenie czołowe. Przykład ten ilustruje Rys. 11.2.

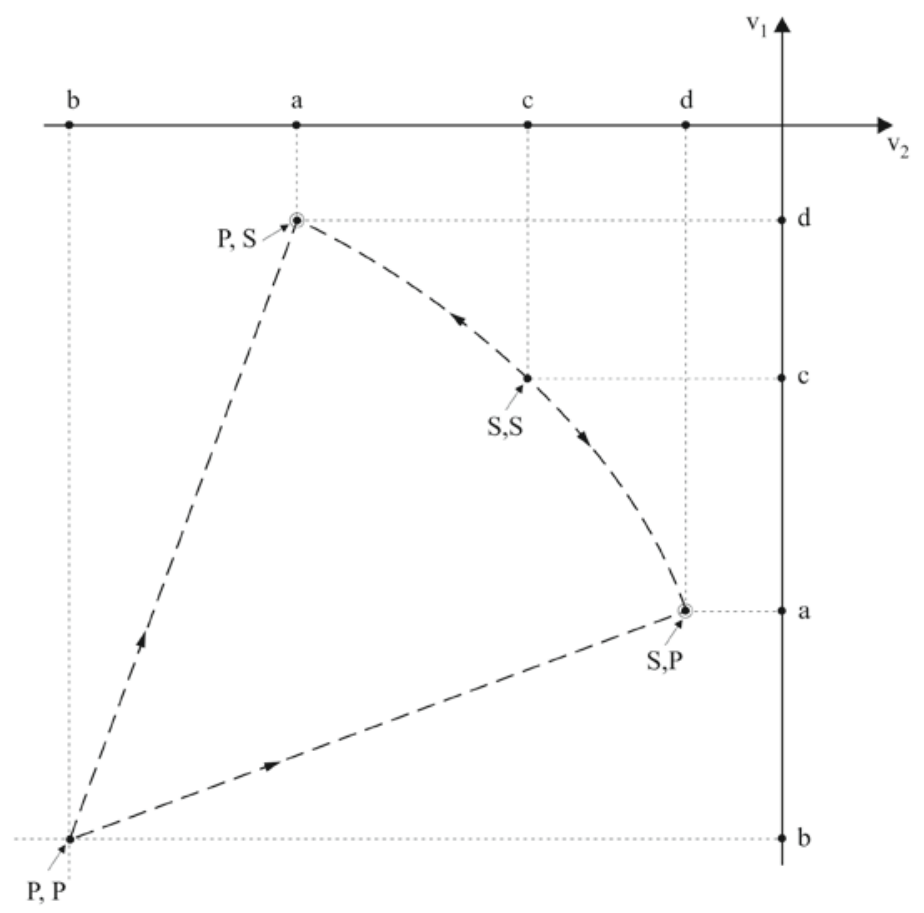

Rys. 11.2. Ilustracja "gry w tchórza” w przestrzeni wygranych.

Przykład "gry w tchórza" jest bardzo ważny pojęciowo: dowodzi on, że ilekroć mamy do czynienia z niejednoznacznymi równowagami Nasha, obstawanie graczy przy strategiach, które by prowadziły do najlepszego dla nich wyniku wśród wielu równowagowych (gdyby gracz przeciwny zachował się "racjonalnie" i ustąpił) daje w rezultacie rozwiązania nierównowagowe i to gorsze dla obu graczy. To właśnie nazywamy eskalacja konfliktu (gdyż w rzeczywistości, przy wielu kryteriach postępowania, proces taki może następować stopniowo, zob. rozdział następny). 
Jeszcze inna z pułapek racjonalności, zwana - niezbyt trafnie - walka płci (ang. battle of sexes) posłuży nam też do ilustracji sposobów obliczania równowag dla gier dwumacierzowych oraz pojęć stabilności równowagi gry. Gra ta interpretowana jest następująco: gracz pierwszy lubi chodzić do filharmonii $(\mathrm{Ph})$, gracz drugi - na mecze piłkarskie (Ft), ale przede wszystkim chcieliby być razem (lub po prostu spotykać się). Jeśli nie weźmiemy pod uwagę możliwości bezpośredniej koordynacji decyzji w drodze umowy którą to możliwość się niejawnie wyklucza w grach niekooperatywnych - to grę tę opiszemy w następującej postaci dwumacierzowej:

\begin{tabular}{|c|c|c|}
\hline$i \backslash j$ & $P h$ & $F t$ \\
\hline$P h$ & $a_{1,1}=11 b_{1,1}=10$ & $a_{1,2}=0 b_{1,2}=0$ \\
\hline$F t$ & $a_{2,1}=1 b_{2,1}=1$ & $a_{2,2}=10 b_{2,2}=11$ \\
\hline
\end{tabular}

Tabela 11.5. Gra dwumacierzowa zwana walką płci z konkretnymi założeniami o wartościach wygranych, przy czym każdy z graczy ma dwa ruchy: $\mathrm{Ph}$ - pójść na koncert dofilharmonii (ang. Philharmony) i Ft - pójść na mecz piłkarski (ang. Football). ${ }^{4}$

W przykładzie z Tabeli 11.5 przyjęto konkretne wartości użyteczności: 10 punktów za spotkanie, 1 punkt za ulubioną formę rozrywki. Równowagami Nasha są tu pary decyzji $(P h, P h)$ i $(F t, F t)$ - bo jeśli wiadomo, że ona (on) pójdzie do filharmonii (na mecz piłkarski), to lepiej odpowiednio dostosować swoją decyzję. Obstawanie przy ulubionej formie rozrywki nie daje wprawdzie rezultatu najgorszego (jak $\mathrm{w}$ grze $\mathrm{w}$ tchórza), ale niezbyt zadowalający. Przypuśćmy, że jest to gra powtarzalna i ma sens rozpatrywanie strategii mieszanych $x_{1}=\left(p_{1, p}, p_{1, f}\right)$ oraz $x_{2}=\left(p_{2, p}, p_{2, f}\right){ }^{5}$ Jak obliczyć możliwe równowagi tej gry $\mathrm{w}$ strategiach mieszanych? Uwzględniając zależności $p_{1, f}=1-p_{1, p}$ oraz $p_{2, p}=1-p_{2, f} \quad$ (jako podstawowe zmienne decyzyjne wybieramy $\mathrm{w}$ ten sposób prawdopodobieństwa pójścia na rozrywkę preferowaną przez danego gracza), wartości oczekiwane wygranych można wyrazić następująco:

\footnotetext{
${ }^{4} \mathrm{~W}$ oryginalnej interpretacji chodzi tu o football amerykański, czyli odmianę rugby; football europejski zwany jest w amerykańskim języku angielskim soccer.

${ }^{5}$ Oznacza to jednak, ze młodzi ludzie chcący się spotkać, zamiast zgodnie ze zdrowym rozsądkiem zatelefonować, będą zakładać prawdopodobieństwa pójścia do filharmonii czy na mecz i obliczać najkorzystniejsze strategie - tylko po to, aby być w zgodzie z definicją racjonalności teorii decyzji i gier.
} 


$$
\begin{aligned}
& E\left(y_{1}\right)=a_{1,1} p_{1, p}\left(1-p_{2, f}\right)+a_{1,2}\left(1-p_{1, p}\right)\left(1-p_{2, f}\right)+a_{2,1} p_{1, p} p_{2, f}+a_{2,2}\left(1-p_{1, p}\right) p_{2, f}= \\
& \left(-a_{1,1}+a_{1,2}+a_{2,1}-a_{2,2}\right) p_{1, p} p_{2, f}+\left(a_{1,1}-a_{1,2}\right) p_{1, p}+\left(a_{2,2}-a_{1,2}\right) p_{2, f}+a_{1,2}= \\
& -20 p_{1, p} p_{2, f}+11 p_{1, p}+9 p_{2, f} ; \\
& E\left(y_{2}\right)=b_{1,1} p_{1, p}\left(1-p_{2, f}\right)+b_{1,2}\left(1-p_{1, p}\right)\left(1-p_{2, f}\right)+b_{2,1} p_{1, p} p_{2, f}+b_{2,2}\left(1-p_{1, p}\right) p_{2, f}= \\
& \left(-b_{1,1}+b_{1,2}+b_{2,1}-b_{2,2}\right) p_{1, p} p_{2, f}+\left(b_{1,1}-b_{1,2}\right) p_{1, p}+\left(b_{2,2}-b_{1,2}\right) p_{2, f}+b_{1,2}= \\
& -20 p_{1, p} p_{2, f}+9 p_{1, p}+11 p_{2, f}
\end{aligned}
$$

a więc są $\mathrm{w}$ pełni symetryczne względem $p_{1, p}$ oraz $p_{2, f}$. Ich pochodne względem tych własnych zmiennych decyzyjnych wynoszą:

$$
\partial E\left(y_{1}\right) / \partial p_{1, p}=-20 p_{2, f}+11 ; \partial E\left(y_{2}\right) / \partial p_{2, f}=-20 p_{1, p}+11
$$

Zauważmy, że gracz pierwszy przy wyborze swojej decyzji (prawdopodobieństwa) musi zakładać znajomość decyzji (prawdopodobieństwa) drugiego gracza, i vice versa. Jesli $p_{1, p}=p_{2, f}=11 / 20$, to gracz pierwszy nie musi zmieniać swej decyzji; ale żeby obliczyć, jakiej to decyzji nie ma zmieniać, musi się postawić w sytuacji gracza drugiego i obliczyć, że ten nie zmieni swej decyzji przy założeniu, że decyzja gracza pierwszego wyniesie też $p_{2, p}=p_{1, f}=11 / 20$. Taka „superracjonalna” dedukcja graczy prowadzi do jednej z równowagowych par decyzji $\left(p_{1, p}, p_{2, f}\right)=(11 / 22,11 / 22)$, z wartościami gry $E\left(y_{1}\right)=E\left(y_{2}\right)=4,95$; nie jest to wynik zbyt pomyślny.

$\mathrm{Na}$ szczęście dla obu graczy, ta równowaga jest niestabilna. Załóżmy bowiem, że gracz pierwszy będzie miał uzasadnione przesłanki, aby założyć $p_{2, f}<11 / 22$; wówczas opłaci mu się zwiększać swoje $p_{1, p}$ wobec dodatniej wartości pochodnej $\partial E(y 1) / \partial p 1, p$. Załóżmy, że zauważy to gracz drugi; wówczas opłaci mu się zmniejszać $p_{2, f}$, wobec ujemnej wartości pochodnej $\partial E\left(y_{2}\right) / \partial p_{2, f}$. W rezultacie, obaj gracze przesuną swe decyzje do innej, stabilnej pary decyzji równowagowych $\left(p_{1, p}, p_{2, f}\right)=(1,0)$; gdyby na początku gracz pierwszy założył $p_{2, f}>11 / 22$, to przesunięcie nastąpiłoby do $\left(p_{1, p}, p_{2, f}\right)=(0,1)$. Ilustruje to Rys.11.3. 


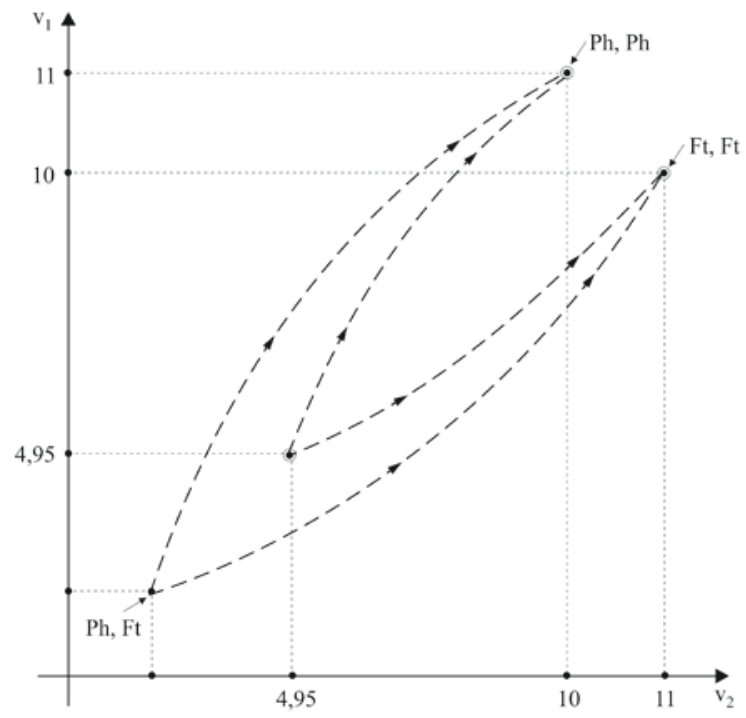

Rys. 11.3. Ilustracja równowag stabilnych i niestabilnych

Przykład ten i Rys. 11.3 są bardzo ważne pojęciowo: bardziej złożona postać gry może faktycznie mieć wiele równowag, stabilnych $i$ niestabilnych, zaś problemem staje się wtedy sposób wyboru jednej z tych równowag. Na przykład, w powyższym przykładzie rezultaty uzyskiwane przez obu graczy $\mathrm{w}$ równowagach stabilnych $-\left(y_{1}, y_{2}\right)=(11,10)$ lub $(10,11)$ - są wprawdzie „niesprawiedliwe” (jeden z graczy jest zawsze uprzywilejowany), ale znacznie lepsze niż rezultat równowagi niestabilnej $\left(E\left(y_{1}\right), E\left(y_{2}\right)\right)=(4,95,4,95)$. Przypuśćmy, ze gracze dążyliby do uzyskania rezultatu „sprawiedliwego” wobec oczywistej symetrii gry; jak go osiągnąć? Jednym ze sposobów jest zastosowanie skoordynowanych strategii przypadkowych: nadal zakładamy, że gracze nie porozumiewają się miedzy sobą, ale rozumują identycznie $\mathrm{W}$ dążeniu do rozwiązania kooperatywnego. Zakładają zatem $p=p_{1, p}=p_{2, f}$ czyli jednakowe prawdopodobieństwa pójścia na preferowaną rozrywkę. Wartości oczekiwane użyteczności decyzji wyrażają się wtedy wzorem:

$$
E\left(y_{1}\right)=E\left(y_{2}\right)=-20 p^{2}+20 p
$$


i są oczywiście jednakowe. Możemy znaleźć ich maksimum względem $p$, co osiągane jest przy $p=1 / 2$ i daje niewiele lepszy rezultat $\left(E\left(y_{1}\right), E\left(y_{2}\right)\right)=$ $(5,0,5,0)$; czy zatem wynik "sprawiedliwy" w tej grze musi zawsze być znacznie gorszy od „niesprawiedliwego”?

Oczywiście - nie, gdyż gracze mogliby jednak porozumieć się ze sobą i umówić się na uzgodnioną strategię skoordynowaną: po prostu chodzić na przemian razem do filharmonii i na mecze, uzyskując średni rezultat $(10,5,10,5)$. Przykład ten ilustruje istotne ograniczenie, jakie wnosi do niekooperatywnej teorii gier założenie o braku komunikacji pomiędzy graczami (założenie takie jest wprawdzie usprawiedliwione dla gier silnie konfliktowych, gdy przekazanie przeciwnikowi informacji nawet o własnych preferencjach może być zgubne, ale nie jest korzystne przy grach o bardziej kooperatywnym charakterze).

\section{Literatura}

Aubin J.P. (1979) Mathematical Methods of Game and Economic Theory. North Holland, Amsterdam.

Axelrod R. (1984) The Evolution of Cooperation. Basic Books, New York.

Basar T., Olsder G.J. (1982) Dynamic Noncooperative Game Theory. Academic Press, New York.

Julmi Ch. (2012) Introduction to Game Theory. BookBooN, Copenhagen

Myerson R.B. (1991) Game Theory - Analysis of Conflict. Harvard University Press, Cambridge, Massachusetts.

Rapoport A. (1989) Decision Theory and Decision Behavior. Kluwer Academic Publishers, Dordrecht. 


\section{Zastosowania i modyfikacje teorii gier}

\subsection{Zastosowania teorii gier $\mathrm{w}$ teorii rynku}

Możliwe są różne ujęcia teorii rynku. Przedstawimy tu ujęcie bardziej realistyczne (nie tylko w warunkach polskich), które wywodzi własności rynku idealnego jako granice rynków: monopolistycznego, duopolistycznego, oligopolistycznego przy liczbie producentów $n \rightarrow \infty$. Rozpatrzymy tu też tylko przypadek najprostszy: jeden produkt i rynek, $n$ producentów, producent $i$-ty produkuje i sprzedaje ilość $x_{i}$ tegoż produktu.

Każdy producent ma określoną krzywą kosztów produkcji $c_{i}\left(x_{i}\right)$. Istotna też jest jej pochodna, czyli koszty krańcowe produkcji (marginal production cost):

$$
\partial c_{i}\left(x_{i}\right) / \partial x_{i}=c_{m i}\left(x_{i}\right)
$$

Zakładamy przy tym, że w wyniku konkurencji krzywe kosztów produkcji sa już zminimalizowane przez producenta względem różnych technologii czy czynników oraz zasobów produkcyjnych. Przy analizie rynku idealnego zakłada się, że w wyniku konkurencji krzywe te są nie tylko zminimalizowane krótkoterminowo, ale także długoterminowo, przez odpowiednie inwestycje, bowiem zmiana inwestycji w oprzyrządowanie produkcji może oczywiście powodować, ze będziemy mieli do czynienia z odmienną krzywą $c_{i}\left(x_{i}\right){ }^{1}$ Taka długoterminowa optymalizacja powinna teoretycznie doprowadzić do jednakowych krzywych kosztów produkcji u każdego producenta. Jest to jednak założenie teoretyczne, nieprawdziwe nawet w praktyce rozwiniętych

\footnotetext{
${ }^{1}$ Przy czym w wyniku rewolucji informacyjnej minimalizacja kosztów produkcji zazwyczaj prowadzi do rugowania pracy trwałej, zastępowania jej przez techniki informacyjne i pracę nietrwałą. Zob. (Wierzbicki 2015).
} 
krajów gospodarki rynkowej, tym bardziej w Polsce. Ceny rynkowe, jak pokażemy niżej, powinny być teoretycznie ściśle związane z krańcowymi kosztami produkcji $c_{m i}\left(x_{i}\right)$, natomiast porównywalne z nimi koszty produkcji odpowiadają średnim kosztom jednostkowym:

$$
c_{a i}\left(x_{i}\right)=c_{i}\left(x_{i}\right) / x_{i}
$$

Opłacalny rozmiar produkcji - co wykażemy niżej - odpowiada teoretycznie takim $x_{i}$, dla których koszty krańcowe $c_{m i}\left(x_{i}\right)$ są większe od kosztów jednostkowych $c_{a i}\left(x_{i}\right)$. Rozmaite typy krzywych kosztów produkcji ilustruje Rys. 12.1. Na Rys. 12.1.a mamy do czynienia z krzywą kosztów typową dla małego przedsiębiorstwa: koszty stałe (dla $x_{i}=0$ ) są małe lub wręcz zerowe, koszty krańcowe szybko rosną, a wiec opłacalne rozmiary produkcji mogą być bardzo małe. Na rys. 12.1.b mamy jednak do czynienia również z dość częstą sytuacją poważnego zmniejszania się kosztów krańcowych wraz ze wzrostem produkcji, co jest typowe po zastosowaniu nowoczesnych technologii z dużym stopniem automatyzacji produkcji. ${ }^{2}$ Jeśli popyt na danym rynku lokalnym jest niewielki, może to doprowadzić do monopolizacji pozycji rynkowej przez producenta, który pierwszy wprowadzi tak nowoczesną technologię; globalizacja rynków może chronić przed pojawianiem się nowych monopoli, ale tylko teoretycznie (w praktyce znane są przykłady monopolizacji pozycji rynkowej nawet na rynku globalnym). Wreszcie na Rys. 12.1.c mamy do czynienia z krzywą kosztów produkcji o dużym udziale kosztów stałych, co nawet przy stopniowym wzroście kosztów krańcowych powoduje, że opłacalne rozmiary produkcji są bardzo duże. Jest to klasyczny przykład sytuacji tzw. monopolu naturalnego, w którym tylko jedna firma ma szanse zyskownych operacji na rynku. Sytuacja taka była typowa dla starszych technologii w telekomunikacji, zwłaszcza dla sieci dalekiego zasięgu; jednak postęp technologiczny powoduje, ze sieci dalekiego zasięgu staja się coraz tańsze (w sensie kosztu jednostkowego), co podważa argumenty o sytuacji monopolu (praktycznie zastępuje go oligopol, zob. dalej) jako naturalnej w telekomunikacji.

\footnotetext{
${ }^{2}$ Co z drugiej strony wywołuje właśnie wspomniane wyżej zagrożenia trwałości pracy.
} 


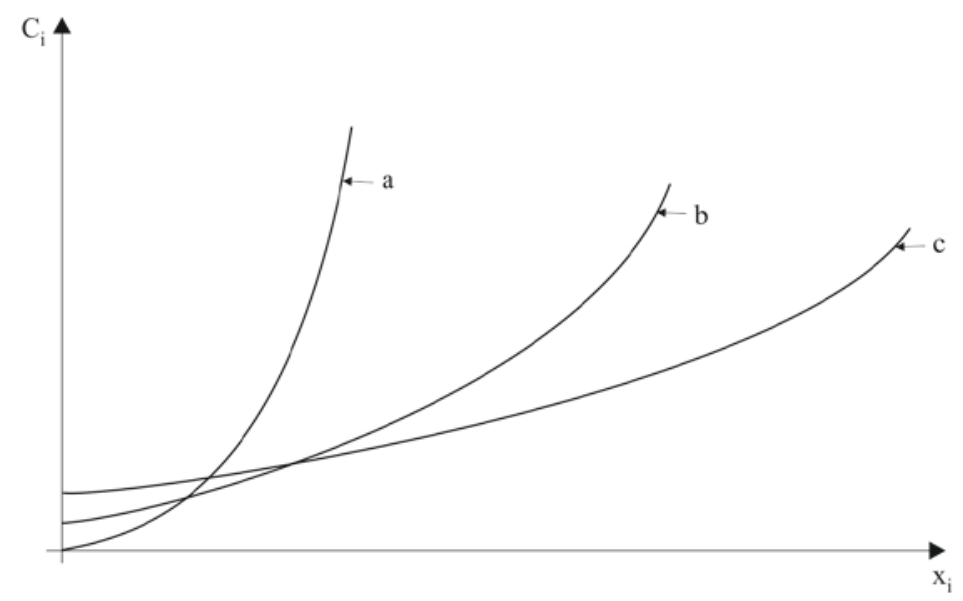

Rys. 12.1. Trzy typy krzywych kosztów produkcji: a) w małych przedsiębiorstwach;

b) przy dużej skali automatyzacji produkcji; c) przy dużych kosztach stałych, przypadek monopolu naturalnego.

Niezależnie od kosztów produkcji, suma sprzedanych ilości produktów odpowiada popytowi $x(p)$, zależnemu od ceny $p$, którą “ustala rynek" tak, aby podaż $\Sigma_{1 \leq i \leq n} X_{i}$ była równa popytowi:

$$
\Sigma_{1 \leq i \leq n} x i=x(p)
$$

W rzeczywistości cenę ustala producent - zakładając, że jego produkt jest jednak inny od produktów konkurenta i że jego stali klienci preferują specyficzne cechy jego produktu; jednak nie może ustalać cen zbyt wysokich, bo stopniowo straci klientów - a także, w sytuacji oligopolu, nie chce zachęcać innych do wejścia na ten rynek. W klasycznej teorii rynku upraszcza się opis tej sytuacji tak, jakby liczba producentów $n$ była już dostatecznie duża oraz jakby klienci natychmiast odwracali się od producenta oferującego towar po zbyt wysokiej cenie; w tym sensie cenę $p$ „ustala rynek”.

Zakładamy przy tym, że $x(p)$ charakteryzuje wyłącznie popyt konsumentów - a nie podaż producentów, choć zgodnie z równaniem (12.3) ma być tej podaży równy - a więc popyt jest ściśle malejącą funkcją ceny. Istotna jest przy tym funkcja odwrotna $p(x)$, czyli zależność ceny od popytu, też ściśle malejąca: nie chodzi tu jeszcze o to, że producent przy wyższym popycie może brać wyższą cenę - to wyniknie dopiero $\mathrm{z}$ równań równowagi - a o to, że konsumenci mają ograniczone budżety i mogą zapłacić tylko niższą cenę, jeśli mają kupić więcej produktu. Funkcje $x(p)$ 
czy $p(x)$ można wyprowadzić $\mathrm{z}$ ograniczeń budżetowych konsumenta. Np., jeśli konsumenci przeznaczają stały budżet $b$ na zakup danego produktu, to $x(p)=b / p, p(x)=b / x$; realistycznie trzeba jednak zakładać, że konsument przeznacza swój budżet na różne cele czy produkty, w związku z czym może pojawić się możliwość zastąpienia jednego produktu drugim.

Charakter rozpatrywanego produktu można uwzględnić opisując go za pomocą parametru, zwanego współczynnikiem elastyczności. Może to być elastyczność ceny względem podaży $\varepsilon_{p x}$ lub jej odwrotność, elastyczność popytu względem ceny $\varepsilon_{x p}$ (która ma bardziej naturalną interpretację):

$$
\varepsilon_{x p}=1 / \varepsilon_{p x}=-(d x(p) / d p) p / x(p)
$$

Elastyczność popytu $\varepsilon_{x p}$ mówi, o ile procent zmniejszy się popyt przy wzroście ceny o 1 procent. Jeśli np. $x(p)=b / p$, to $\varepsilon_{x p}=\varepsilon_{p x}=1$. Elastyczność popytu $\varepsilon_{x p}$ jest mniejsza od jedności dla produktów o charakterze podstawowym (niezbędnych dla życia) oraz większa od jedności dla produktów o charakterze luksusowym, zob. przykład na Rys. 12.2. Ogólnie biorąc, $\varepsilon_{x p}$ nie jest stałe, lecz zmienia się wraz z $x$.
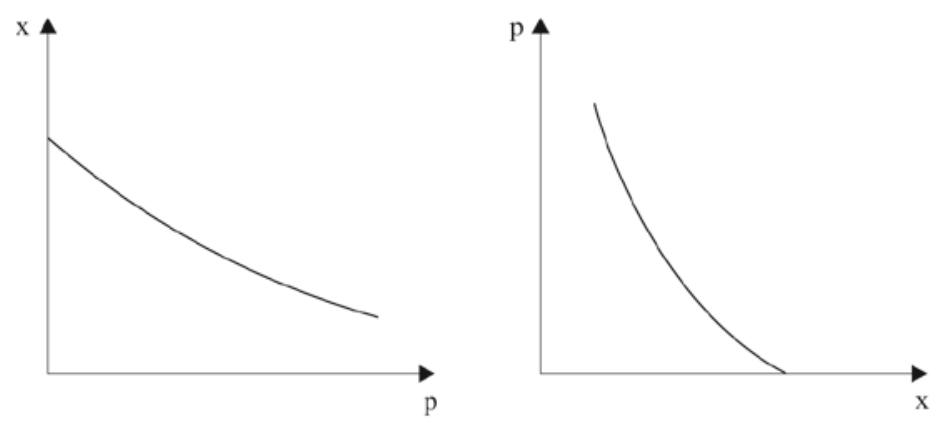

Rys. 12.2. Typowe postaci zależności popytu od ceny $x(p)$ oraz ich zależności odwrotnej ( $w$ przypadku produktu o charakterze luksusowym).

W teorii rynku zwykle zakładamy, że każdy z producentów dobiera swój rozmiar produkcji $x_{i}$ tak, aby zmaksymalizować swój zysk (są też możliwe inne założenia). Przy więcej niż jednym producencie odpowiada to klasycznej sytuacji growej; wygrana gracza czyli zysk producenta $i$ wyraża się wzorem:

$$
y_{i}=p(x) x_{i}-c_{i}\left(x_{i}\right)
$$


Jeśli określona byłaby - ustalona w jakikolwiek sposób, nie przez rynek cena $p(x)=p$, a przedmiotem decyzji producenta byłby tylko dobór rozmiaru produkcji przy danej cenie, to przyrównując do zera odpowiednią pochodną $d y_{i} / d x_{i}$ uzyskalibyśmy zależność $p=c_{m i}\left(x_{i}\right)$. Ponieważ jest to zależność taka sama, jak wyprowadzona niżej dla rynku idealnego, dawało to centralnemu planiście złudzenie, że może on zastąpić rynek. Jednakże w rozumowaniu takim nie uwzględnia się warunku równowagi popytu i podaży (12.3); planista musiałby mierzyć podaż i popyt, szybko zmieniać cenę $p$ dla ich zrównoważenia - co jest praktycznie niewykonalne i kończyło się nierównowagą rynkową (na ogół - przewagą popytu nad podażą, tzw. gospodarka niedoboru).

Natomiast równowaga rynku następuje w punkcie równowagi Nasha, gdy każdy producent osiąga maksymalny możliwy dla niego zysk - a ,rynek ustala" cenę stosownie do popytu. Spełnione musi być więc równanie (12.3), a ponadto $n$ równań wynikających $\mathrm{z}$ przyrównania pochodnych zysków $y_{i}$ względem $x_{i}$ do zera:

$$
p(x)+x_{i} d p(x) / d x=p(x)\left(1+\left(x_{i} / x\right)(x / p(x)) d p(x) / d x\right)=c_{m i}\left(x_{i}\right), i=1, \ldots n
$$

lub równoważnie:

$$
p(x)\left(1-\kappa_{i} \varepsilon_{p x}\right)=\mathrm{c}_{m i}\left(x_{i}\right), i=1, \ldots n
$$

gdzie $\kappa_{i}=x_{i} / x$ nazywane jest udziałem w rynku $i$-tego producenta. Równania powyższe można rozwiązać względem udziałów w rynku, uzyskując równoważnie:

$$
\kappa_{i}=x_{i} / x=\varepsilon_{x p}\left(1-\mathrm{C}_{m i}\left(x_{i}\right) / p(x)\right), i=1, \ldots n
$$

gdzie użyliśmy już elastyczności popytu względem ceny, jako łatwiejszej do interpretacji. Ze zsumowania udziałów w rynku i przyrównania ich sumy do jedności (co odpowiada równości podaży i popytu (12.3)) można wyznaczyć cenę rynkową:

$$
p(x)=p=1 / n \sum_{1 \leq i \leq n} c_{m i}\left(x_{i}\right) /\left(1-1 /\left(\mathrm{n} \varepsilon_{x p}\right)\right)
$$

w oparciu o średnie koszty krańcowe i średni udział w rynku (równy 1/n), przy czym równania (12.7) można też przepisać w analogicznej indywidualnej postaci:

$$
p(x)=p_{i}\left(x_{i}\right)=c_{m i}\left(x_{i}\right) /\left(1-\kappa_{i} / \varepsilon_{x p}\right)
$$


To ostatnie równanie można interpretować tak, że cena $p=p_{i}\left(x_{i}\right)$ zapewnia maksymalny zysk $i$-tego producenta przy założeniu, że produkuje on sam na zastępczy „własny” rynek o zmniejszonym popycie $x_{i}=\kappa_{i} x$, ale o zwiększonej elastyczności $\varepsilon_{x p} / \kappa_{i}$ (to zwiększenie elastyczności popytu to właśnie skutek konkurencji rynkowej). Interpretacja taka dotyczy producentów, którzy trafnie przewidzieli popyt rynkowy i zainwestowali odpowiednio w oprzyrządowanie produkcji. Jeśli któryś z nich zainwestował za mało, to okaże się, że zbyt szybko rosnące koszty krańcowe $\boldsymbol{c}_{m i}\left(x_{i}\right)$ spowodują u niego zmniejszenie jego udziału w rynku według wzoru (12.8) - inaczej mówiąc, przy założonym przez niego, pożądanym udziale w rynku okaże się, że $p_{i}\left(x_{i}\right)$ jest większe od $p=p(x)$, a zatem będzie on musiał zmniejszyć $\kappa_{i}, x_{i}$ oraz $p_{i}\left(x_{i}\right)$ do poziomu $p=p(x)$.

Jeśli natomiast któryś z producentów zainwestował zbyt dużo, ma nadmierne zdolności produkcyjne, to może być zmuszony do produkcji przy cenie poniżej kosztów jednostkowych produkcji - czyli bez zysku netto, ze stratą, gdyż łatwo sprawdzić, że zysk wyraża się też wzorem:

$$
y_{i}=x_{i}\left(p(x)-c_{a i}\left(x_{i}\right)\right)
$$

Można też sprawdzić, że równowaga rynkowa wyznaczona przez wzory (12.9), (12.10) istnieje pod warunkiem, że:

$$
\varepsilon_{x p}>\kappa_{i} \forall i=1, \ldots n \rightarrow \varepsilon_{x p}>1 / n ; \kappa_{i} \in[0 ; 1] \forall i=1, \ldots n
$$

Ostatnie z tych warunków są dosyć oczywiste - jeśli udział w rynku któregoś z producentów miałby się zmniejszyć poniżej zera, oznaczałoby to, że bankrutuje on i trzeba albo zmniejszyć $n$, albo przypisać mu $\kappa_{i}=0$. Natomiast pierwsze $\mathrm{z}$ tych warunków są oczywiście spełnione na rynku $\mathrm{z}$ dużą ilością producentów, z których żaden nie dominuje rynku - jeśli $n \rightarrow \infty$ oraz $\kappa_{i} \rightarrow 0, \forall i=1, \ldots n$. Rynek taki nazywamy idealnym. Na rynku takim obowiązuje zależność:

$$
p(x)=c_{m}=c_{m i}\left(x_{i}\right) \forall i=1, \ldots n
$$

czyli cena jest równa kosztom krańcowym produkcji (dla każdego producenta, bo musieli oni wszyscy zminimalizować koszty produkcji; ci, którzy tego nie uczynili, a zwłaszcza dopuścili do produkcji przy kosztach jednostkowych wyższych od krańcowych, zbankrutowali). 
Jeśli dobrali oni właściwą skalę inwestycji, to ich koszty krańcowe są wyższe niż koszty jednostkowe, a więc zysk:

$$
y_{i}=x_{i}\left(c_{m i}\left(x_{i}\right)-c_{a i}\left(x_{i}\right)\right)
$$

jest dodatni. Dopiero z uwzględnieniem rynku kapitałowego, inwestującego w tych przedsiębiorców którzy uzyskują największy zysk, uzyskuje się ogólną równowagę rynkową - taką, w której stopa zysku dla każdego produktu jest równa oprocentowaniu kapitału (a więc zysk netto producenta staje się zerowy). Rozważając tego typu modele ogólnej równowagi dla wielu rodzajów produkcji można też wykazać, że idealna równowaga rynkowa zapewnia Pareto-optymalną, sprawną alokację środków produkcji.

Wiele rynków w Polsce i na świecie ma jednak dziś charakter oligopolistyczny lub wręcz monopolistyczny. Wyprowadzone wyżej wzory dla $n=1$ są warunkami maksymalizacji zysku monopolistycznego. Jeśli monopolista nie obawia się inwazji rynku przez innych konkurentów, to ustala cenę maksymalizującą zysk (na rynku towarów luksusowych, gdzie $\varepsilon_{x p}>1$ ):

$$
p(x)=p=c_{m}(x) \varepsilon_{x p} /\left(\varepsilon_{x p}-1\right)
$$

przy czym cena ta $\mathrm{i}$ tym samym zysk monopolisty są $\varepsilon_{x p} /\left(\varepsilon_{x p}-1\right)$ razy wyższe (a rozmiar produkcji odpowiednio mniejszy) niż cena na rynku idealnym; jest to współczynnik zysku nadzwyczajnego (lub inaczej renta monopolu). Już dla $\varepsilon_{x p}=1,2$ współczynnik ten wynosi 6 , czyli monopolista mógłby wtedy brać ceny sześciokrotnie wyższe, niż na rynku idealnym. Jeśli $\varepsilon_{x p} \rightarrow 1$, to $\varepsilon_{x p} /\left(\varepsilon_{x p}-1\right) \rightarrow \infty$; jeśli $\varepsilon_{x p}<1$, czyli monopolista działa na rynku towarów podstawowych, to wzór (12.13) przestaje obowiązywać i monopolista mógłby zwiększać zyski teoretycznie do nieskończoności dyktując dowolnie duże ceny. W praktyce nie może się to zdarzyć, gdyż $\varepsilon_{x p}$ zależy jednak od $p$ i zawsze wzrośnie powyżej jedności, jeśli ceny dostatecznie wzrosną; ponadto, monopolista $\mathrm{w}$ takiej sytuacji przestaje maksymalizować zysk, a stara się ustalić cenę i poziom zysku tak, aby nie zachęcać innych konkurentów do inwazji rynku. W obawie przed konkurencją, monopolista często ukrywa zysk - to jest mnoży koszty produkcji, przyznaje specjalne premie pracownikom i zarządowi itp. W rezultacie, monopol prowadzi prawie zawsze do niesprawnego wykorzystania zasobów. Tym niemniej, zdarzają się przypadki monopolu naturalnego - przy specjalnym charakterze krzywej kosztów produkcji - gdzie produkcja monopolistyczna 
może być tańsza, niż rezultat konkurencji rynkowej. Teoretycy idealnego, wolnego rynku twierdzą, że przypadki takie nie mogą się zdarzyć na rynkach wysokiej techniki, że jakoby wysoka technika wyklucza monopol; twierdzenia takie nie odpowiadają jednak rzeczywistości, gdyż właśnie na rynkach wysokiej techniki powstają nowe monopole, chociaż częściej dominują oligopole.

W sytuacji oligopolu (dla $n=2$ zwanego duopolem) - prawo większości państw usiłuje nie dopuścić do monopolistycznego ustalenia ceny poprzez jawne porozumienie cenowe (kartel) producentów. Gdyby rzeczywiście nie było porozumień cenowych (bo mogą też być ukryte, zob. dalej), to obowiązywałoby następujące oszacowanie wspólczynnika zysku nadzwyczajnego lub inaczej renty oligopolu, wynikające $\mathrm{z}$ prostej interpretacji równania (12.9):

$$
p=c_{m i, \dot{s} r} /\left(1-1 /\left(n \varepsilon_{x p}\right)\right)
$$

Zatem współczynnik zysku nadzwyczajnego oligopolu teoretycznie wynosi:

$$
\delta_{n}=1 /\left(1-1 /\left(n \varepsilon_{x p}\right)\right)
$$

i liczba producentów $n$ wpływa na niego bardzo silnie. Na przykład, jeśli $\varepsilon_{x p}=1,2$ (co zdarza się często np. na rynkach usług telekomunikacyjnych), to w przypadku $n=4$ mamy $\delta_{4}=1,263$. Oznacza to, że nawet przy czterech konkurentach na rynku, każdy z nich może osiągnąć dodatkowe 26,3\% zysku od kapitału za sam fakt ograniczenia liczby producentów. Przy pięciu konkurentach mielibyśmy wtedy $\delta_{5}=1,20$, czyli $20 \%$ zysku nadzwyczajnego; przy trzech konkurentach mamy wtedy $\delta_{5}=1,385 \$$, a więc $38,5 \%$ zysku nadzwyczajnego. W sytuacji duopolu $\delta_{2}=1,714$, a więc już $71,4 \%$ zysku nadzwyczajnego; wreszcie $\mathrm{w}$ sytuacji monopolu $\delta_{1}=6,00$, a więc już 500\% zysku nadzwyczajnego! Może się jednak też zdarzyć, że na rynku towarów podstawowych (np. lekarstw) o $\varepsilon_{x p}$ bliskim $1 / n$ zyski nadzwyczajne oligopolu są też bardzo duże, albo też - jeśli $\varepsilon_{x p}<1 / n$ - równowaga rynkowa nie istnieje i ceny mogą być dyktowane dowolnie.

Rozważania powyższe nie mają jednak zastosowania, jeśli na rynku oligopolistycznym występuje ukryta zmowa cenowa. Mechanizm takiej zmowy jest bardzo prosty: lider rynku, czyli ważny producent, ustala jakąś cenę, a pozostali producenci stosują się do niej lub tylko nieznacznie 
ją modyfikują - dbając tylko o to, aby nie zachęcić zbytnio nowych graczy do inwazji rynku. Takie działanie rynków oligopolistycznych opisał już w 1962 roku Labini Sylos, który stwierdzil, że ceny na rynkach oligopolistycznych nie mają żadnego związku z kosztami krańcowymi produkcji, a są praktycznie ustalane przez lidera rynku. Obserwacje Sylosa potwierdzają ceny np. na rynkach farmaceutycznych, gdzie koszt produkcji dodatkowej pigułki lekarstwa jest znikomy, a faktyczne ceny przekraczają go często ponad stukrotnie. Podobne relacje cenowe występują także faktycznie na rynkach usług telekomunikacyjnych, gdzie producenci starannie ukrywają swoje koszty krańcowe, a swoje wysokie ceny motywują zwykle konicznością pokrycia trudnych do sprawdzenia kosztów nowych technik. W sumie więc, oligopolistyczne rynki wysokiej techniki nie zachowują się tak, jak by to przewidywała teoria gier i związana $\mathrm{z}$ nią teoria wolnego rynku. Tym niemniej, rozważania powyższe przytoczono tu po to, aby zilustrować, jak wątpliwe są założenia teoretyczne doktryny wolnego rynku.

Na szczęście dla konsumentów, na rynkach oligopolistycznych zdarzają się niekiedy wojny cenowe - czyli próby przyciągnięcia klientów i uzyskania większego udziału w rynku poprzez stosowanie ceny niższej od cen powszechnie stosowanych (oczywiście, po bankructwie strony przegrywającej taką wojnę, liczba producentów maleje i ceny rosną ponad ich poziom początkowy, ale w czasie wojny cenowej konsumenci mogą jeszcze skorzystać). Dlatego też nowoczesna teoria rynku zakłada raczej rozróżnialność produktów każdego producenta, samodzielne ustalanie przez niego ceny, oraz przypływ lub odpływ konsumentów kupujących produkty danego producenta $\mathrm{w}$ zależności od ich jakości i ceny - co też można opisywać za pomocą teorii gier, tyle że dynamicznych i wielokryterialnych.

Trzeba tu dodać, że już uwzględnienie realistycznych modeli handlu międzynarodowego wymaga znacznie bardziej złożonych modeli gry ekonomicznej, które mogą mieć kilka równowag - stabilnych i niestabilnych, jak w opisanym poprzednio przykładzie walki płci. Praktycznie, wybór równowagi często dyktuje gracz silniejszy - np. równowaga „wolnego handlu” pomiędzy krajem rozwijającym się i rozwiniętym oznacza faktycznie neoliberalną eksploatację finansową kraju rozwijającego się. 


\subsection{Gry wielokryterialne}

W praktycznych negocjacjach najczęściej zdarza się, że każdy z ich uczestników ma wiele celów lub kieruje się wieloma kryteriami. Można ten problem sprowadzić do gry o jednym kryterium dla każdego gracza, jeśli zakładać znajomość ich funkcji użyteczności agregujących poszczególne kryteria; ale uczestnicy praktycznych negocjacji pilnie ukrywają swe faktyczne funkcje użyteczności (nawet jeśli są one określone i nie zmieniają się w trakcie negocjacji). Trudno zatem zakładać, że gracze mogą poprawnie przewidywać rozwiązania równowagowe i na ich podstawie wyciągać dalsze wnioski - np. wyznaczać funkcję charakterystyczną gry koalicyjnej, zob. rozdział następny. Nie można też zakładać, że gracze zwierzą się ze swej faktycznej funkcji użyteczności bezstronnemu mediatorowi, ani też że zgodzą się na identyfikację swych funkcji użyteczności przez takiego mediatora (próby takich identyfikacji zawodziły we wszystkich poważniejszych negocjacjach). Jako pewne uproszczenie takiej konfliktowej sytuacji wielokryterialnej można też np. zakładać, że każde z kryteriów każdego z graczy reprezentowane jest przez gracza zastępczego; w większości przypadków jest to jednak uproszczenie nadmierne. Dlatego też niezbędne jest niekiedy rozpatrywanie gier wielokryterialnych w ich pełnej postaci nie w celu przewidywania ich rozwiązań, co jest niemożliwe, ale w celu zrozumienia możliwych rozwiązań, możliwych przyczyn eskalacji konfliktu, sposobów jej zapobiegania. W celu osiągnięcia takiego zrozumienia, trzeba jednak zaczynać - podobnie jak w grach jednokryterialnych - od analizy możliwych równowag niekooperatywnych.

\subsubsection{Niekooperatywne rozwiązania gier wielokryterialnych.}

Określimy najpierw wielokryterialny model gry $\mathrm{w}$ postaci normalnej. Przypuśćmy, że $i$-ty gracz, $i=1, \ldots n$, z decyzjami $\boldsymbol{x}_{i} \in \boldsymbol{X}_{0 i}$, ma określoną nie jedną, ale cały wektor funkcji wygranych:

$$
\boldsymbol{y}_{i}=\boldsymbol{f}_{i}\left(\boldsymbol{x}_{1}, \ldots \boldsymbol{x}_{i}, \ldots \boldsymbol{x}_{n}\right) \in \boldsymbol{R}^{m i}
$$

Określimy też zindywidualizowane funkcje wygranych (podobnie jak dla gier jednokryterialnych, ale dla gier wielokryterialnych są one szczególnie 
potrzebne) poprzez uwypuklenie w oznaczeniach tych składowych decyzji, które zależą od danego gracza:

$$
\boldsymbol{y}_{i}=\boldsymbol{f}_{i}\left(\boldsymbol{x}_{1}, \ldots \boldsymbol{x}_{i-1}, \boldsymbol{u}_{i}, \boldsymbol{x}_{i+1}, \ldots \boldsymbol{x}_{n}\right) \in \boldsymbol{R}^{m i} ; \boldsymbol{y}_{i}=\boldsymbol{f}_{i}^{\sim}\left(\boldsymbol{u}_{i}, \boldsymbol{x}\right) \in \boldsymbol{R}^{m i}
$$

gdzie oznaczyliśmy krótko $\boldsymbol{x}=\left(\boldsymbol{x}_{1}, \ldots \boldsymbol{x}_{i}, \ldots \boldsymbol{x}_{n}\right) \in \boldsymbol{X}_{0}=\prod_{i=1, \ldots n} \boldsymbol{X}_{0 i}$. Podobnie, można też oznaczyć krótko $\boldsymbol{u}=\left(\boldsymbol{u}_{1}, \ldots \boldsymbol{u}_{i}, \ldots \boldsymbol{u}_{n}\right) \in \boldsymbol{X}_{0}$ oraz $\boldsymbol{y}=\left(\boldsymbol{y}_{1}, \ldots \boldsymbol{y}_{i}, \ldots \boldsymbol{y}_{n}\right)=$ $f(x)=f^{\sim}(u, x)$.

Przy danym $\boldsymbol{x} \in \boldsymbol{X}_{0}$, zbiór osiągalnych rezultatów $\boldsymbol{Y}_{i}(\boldsymbol{x})$ dla gracza $i$ jest określony przez wszystkie możliwe jego odpowiedzi $\boldsymbol{u}_{i} \in \boldsymbol{X}_{0 i}$ (a nie tylko przez $\left.\boldsymbol{u}_{i}=\boldsymbol{x}_{i}\right)$ :

$$
\boldsymbol{Y}_{i}(\boldsymbol{x})=\boldsymbol{f}_{i}^{\sim}\left(\boldsymbol{X}_{0 i}, \boldsymbol{x}\right)=\left\{\boldsymbol{y}_{i} \in \boldsymbol{R}^{m i}: \boldsymbol{y}_{i}=\boldsymbol{f}_{i}^{\sim}\left(\boldsymbol{u}_{i}, \boldsymbol{x}\right), \boldsymbol{u}_{i} \in \boldsymbol{X}_{0 i}\right\}
$$

podczas gdy zbiór osiągalnych rezultatów wszystkich graczy wyraża się prościej przez $\boldsymbol{Y}=\boldsymbol{f}\left(\boldsymbol{X}_{0}\right)$.

Przypuśćmy, że każdy z graczy maksymalizuje wszystkie swe kryteria, co wyrazimy poprzez stożek dodatni w przestrzeni jego kryteriów $\boldsymbol{D}_{i}=\boldsymbol{R}^{m i}{ }_{+}$ (możliwe są oczywiście inne założenia przy innej formie stożków dodatnich). Możemy więc zdefiniować różne rodzaje rezultatów sprawnych w zbiorach $\boldsymbol{Y}_{i}(\boldsymbol{x})$; podstawowe $\mathrm{z}$ nich to po prostu rezultaty sprawne (zwane też Pareto-optymalnymi) dla których, jak przypominamy, nie można polepszyć - za pomocą zmiany $\boldsymbol{u}_{i} \in \boldsymbol{X}_{0 i}$ - jednej z ich składowych bez pogarszania innych składowych, zob. Rys. 12.3. Zbiór takich rezultatów sprawnych oznaczamy przez $\boldsymbol{Y}_{i}^{*}(\boldsymbol{x})$, a odpowiadający mu zbiór decyzji sprawnych lub też Pareto-optymalnych przez $\boldsymbol{X}_{0 i}^{*}(\boldsymbol{x})$. Rezultaty te i decyzje są definiowane wzorami:

$$
\begin{aligned}
& \boldsymbol{Y}_{i}^{*}(\boldsymbol{x})=\left\{\boldsymbol{y}_{i}^{*} \in \boldsymbol{Y}_{i}(\boldsymbol{x}): \boldsymbol{Y}_{i}(\boldsymbol{x}) \cap\left(\boldsymbol{y}_{i}^{*}+\boldsymbol{D}^{\neq}\right)=\varnothing\right\}, \boldsymbol{D}^{\neq}=\boldsymbol{D} \backslash\{0\} \\
& \boldsymbol{X}_{0 i}^{*}(\boldsymbol{x})=\left\{\boldsymbol{u}_{i}^{*} \in \boldsymbol{X}_{0 i}: \boldsymbol{y}_{i}^{*}=\boldsymbol{f}^{\sim}\left(\boldsymbol{u}_{i}^{*}, \boldsymbol{x}\right) \in \boldsymbol{Y}_{i}^{*}(\boldsymbol{x})\right\}
\end{aligned}
$$




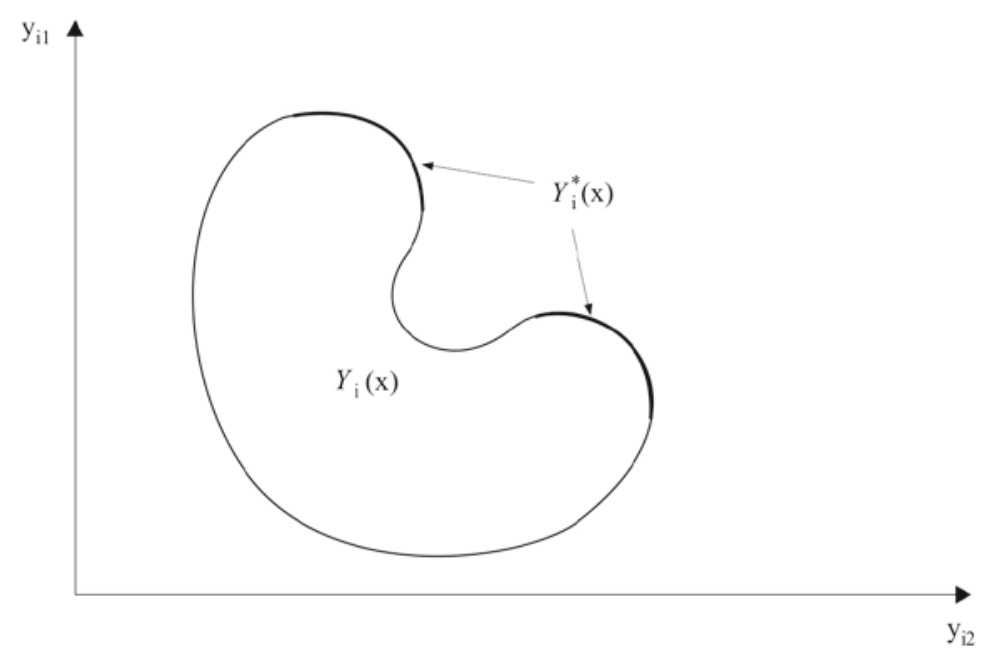

Rys. 12.3. Zbiory rezultatów sprawnych dla danego gracza przy założonej decyzji gracza przeciwnego.

Podobnie możemy w zbiorze $\boldsymbol{Y}_{i}(\boldsymbol{x})$ definiować inne rodzaje rezultatów sprawnych. Jeśli np. są to rezultaty właściwie $\varepsilon$-sprawne odniesione do stożków $\boldsymbol{D}_{i, \varepsilon}$ określonych jako stożkowe $\varepsilon$-otoczenia $\boldsymbol{D}_{i}$, zob. Rozdz. 7-9, to rezultaty te i odpowiadające im decyzje właściwie $\varepsilon$-sprawne określone są wzorami:

$$
\begin{aligned}
& \boldsymbol{Y}^{* p \varepsilon}(\boldsymbol{x})=\left\{\boldsymbol{y}_{i}^{*} \in \boldsymbol{Y}_{i}(\boldsymbol{x}): \boldsymbol{Y}_{i}(\boldsymbol{x}) \cap\left(\boldsymbol{y}_{i}^{*}+\operatorname{Int} \boldsymbol{D}_{i, \varepsilon}\right)=\varnothing\right\} \\
& \boldsymbol{X}^{* p \varepsilon}{ }_{0 i}(\boldsymbol{x})=\left\{\boldsymbol{u}_{i}^{*} \in \boldsymbol{X}_{0 i}: \boldsymbol{y}_{i}^{*}=\boldsymbol{f}^{\sim}\left(\boldsymbol{u}^{*}{ }_{i}, \boldsymbol{x}\right) \in \boldsymbol{Y}^{* p \varepsilon}{ }_{i}(\boldsymbol{x})\right\}
\end{aligned}
$$

Podobnie możemy określić zbiór rezultatów słabo sprawnych $\boldsymbol{Y}^{*}{ }_{i}(\boldsymbol{x})$, np. kładąc $\varepsilon=0$ w powyższych wzorach. Wszystkie te zbiory zależą jednak od założonych przez gracza $i$ decyzji innych graczy $\boldsymbol{x}$. Ponadto, zbiory te mają zazwyczaj wiele punktów, zwykle nie ma jednoznacznie określonych rozwiązań sprawnych. Fakt ten określa istotę optymalizacji wielokryterialnej; jak już wspominaliśmy wcześniej, początkowo uważano ten fakt za podstawową trudność i usiłowano określić w jakimś sensie najlepsze sprawne rozwiązania kompromisowe. Później uznano, że kompromisów pomiędzy kryteriami może być wiele, a niejednoznaczność rozwiąań sprawnych jest zaleta, nie wada: można ją wykorzystać do organizacji systemów wspomagania decyzji wielokryterialnych, jak to opisane jest w poprzednich rozdziałach. 
W każdym bądź razie, ze względu na niejednoznaczność rozwiązań sprawnych, nie możemy dla gier wielokryterialnych określać równowagi gry jako jednego punktu charakteryzującego najbardziej racjonalny, przewidywany rezultat gry. Dlatego też lepiej mówić może o niekooperatywnym rozwiąaniu gry wielokryterialnej w sensie Pareto-Nasha - czyli takim, w którym każdy z graczy wybiera decyzje sprawne dla niego, zakładając znajomość decyzji innych graczy. Odpowiedni zbiór rozwiązań Pareto-Nasha określony jest zależnością:

$$
\boldsymbol{X}_{0}^{*}=\left\{\boldsymbol{x}^{*} \in \boldsymbol{X}_{0}: \boldsymbol{y}_{i}^{*}=\boldsymbol{f}^{\sim}\left(\boldsymbol{u}_{i}^{*}, \boldsymbol{x}\right) \in \boldsymbol{Y}_{i}^{*}(\boldsymbol{x}) \forall i=1, \ldots n\right\} ; \boldsymbol{Y}^{*}=\boldsymbol{f}\left(\boldsymbol{X}_{0}^{*}\right)
$$

Podobnie możemy określić niekooperatywne rozwiąania e-sprawne gry wielokryterialnej:

$$
\boldsymbol{X}^{* p \varepsilon}{ }_{0}=\left\{\boldsymbol{x}^{*} \in \boldsymbol{X}_{0}: \boldsymbol{y}_{i}^{*}=\boldsymbol{f}^{\sim}\left(\boldsymbol{u}^{*}, \boldsymbol{x}\right) \in \boldsymbol{Y}^{* p \varepsilon}{ }_{i}(\boldsymbol{x}) \forall i=1, \ldots n\right\} ; \boldsymbol{Y}^{* p \varepsilon}=\boldsymbol{f}\left(\boldsymbol{X}^{* p \varepsilon}{ }_{0}\right)
$$

dla $\varepsilon>0$. Dla $\varepsilon=0$ powyższy wzór określa też niekooperatywne rozwiązania słabo Pareto-Nasha $\boldsymbol{X}^{{ }^{*}{ }_{0}}{ }_{0}, \boldsymbol{Y}^{{ }^{w}}$. Ponieważ $\boldsymbol{Y}^{*{ }_{p} \varepsilon}{ }_{i}(\boldsymbol{x}) \subseteq \boldsymbol{Y}_{i}^{*}(\boldsymbol{x}) \subseteq \boldsymbol{Y}^{{ }^{*}{ }_{i}}{ }_{i}(\boldsymbol{x})$ dla wszystkich $\boldsymbol{x} \in \boldsymbol{X}_{0}$ oraz wszystkich $i$, mamy też $\boldsymbol{X}^{{ }_{p} p \varepsilon}{ }_{0} \subseteq \boldsymbol{X}^{*}{ }_{0} \subseteq \boldsymbol{X}^{{ }^{*}{ }_{0}}{ }_{0}$, $\boldsymbol{Y}^{*} p \varepsilon \subseteq \boldsymbol{Y}^{*} \subseteq \boldsymbol{Y}^{*}$. Gdyby liczba kryteriów wynosiła $m_{i}=1$ dla każdego gracza, to wszystkie trzy typy rozwiązań sprowadziłyby się do niekooperatywnej równowagi Nasha.

Zasadniczą różnicą pomiędzy równowagami Nasha a rozwiązaniami niekooperatywnymi gier wielokryterialnych jest fakt, że rozwiązania wielokryterialne nie muszą składać się z dyskretnych punktów - którą to własność posiadają, z wyjątkiem przypadków zdegenerowanych, równowagi gier jednokryterialnych. Ilustruje to przykład wielokryterialnej gry dotyczącej praw połowu ryb w punkcie następnym, patrz Rys. 12.4.

Dlatego też rozwiązania gier wielokryterialnych mogą być analizowane raczej interaktywnie, w formie przeglądu ich przykładowych punktów. Dla takiej selekcji przykładowych punktów w zbiorze rozwiązań gier wielokryterialnych można wykorzystać pojęcie funkcji skalaryzujących lub funkcji osiągnięcia. Możliwość tę scharakteryzujemy dwoma następującymi twierdzeniami:

Twierdzenie 12.1. Załóżmy, że zbiory $\boldsymbol{Y}_{i}(\boldsymbol{x})$ są wypukłe i domknięte dla wszystkich $\boldsymbol{x} \in \boldsymbol{X}_{0 i}$. Wtedy liniowe funkcje skalaryzujące $s_{i}\left(\boldsymbol{y}_{i}, \boldsymbol{\alpha}_{i}\right)=\sum_{j=1, \ldots m i} \alpha_{i j} y_{i j} \quad \mathrm{z}$ wektorami dodatnich współczynników wagi 
$\boldsymbol{\alpha}_{i} \in \operatorname{Int} \boldsymbol{R}^{m i}{ }_{+}$prawie zupełnie charakteryzują zbiór $\boldsymbol{Y}^{*}$ niekooperatywnych rezultatów Pareto-Nasha: dla każdego $\boldsymbol{y}^{*} \in \boldsymbol{Y}^{*}$ istnieją wektory $\boldsymbol{\alpha}_{i} \in \boldsymbol{R}^{m i}+\backslash\{0\}$ takie, że $\boldsymbol{y}^{*}$ odpowiada niekooperatywnej równowadze Nasha zastępczej gry jednokryterialnej z wygranymi $\sum_{j=1, \ldots m i} \alpha_{i j} y_{i j}$, zaś każda niekooperatywna równowaga Nasha takiej zastępczej gry przy $\boldsymbol{\alpha}_{i} \in \operatorname{Int} \boldsymbol{R}^{m i}{ }_{+}$daje rezultaty $\boldsymbol{y}^{*} \in \boldsymbol{Y}^{*}$. Przy $\boldsymbol{\alpha}_{i} \in \boldsymbol{R}^{m i}+\backslash\{0\}$, funkcje te zupełnie charakteryzują (w analogiczny sposób) zbiór $\boldsymbol{Y}^{* w}$ rezultatów słabo Pareto-Nasha. Przy $\boldsymbol{\alpha}_{i} \in \operatorname{Int} \boldsymbol{R}^{m i}{ }_{+}$oraz $\alpha_{i j} / \sum_{j=1, \ldots m i} \alpha_{i j} \geq \delta_{i}=\varepsilon /\left(1+m_{i} \varepsilon\right)$, liniowe funkcje skalaryzujące zupełnie charakteryzują zbiór niekooperatywnych rezultatów właściwie $\varepsilon$-sprawnych $\boldsymbol{Y}^{* p \varepsilon} \mathrm{z}$ ograniczeniem $1+1 / \varepsilon$ na współczynniki wymiany.

W wielu zastosowaniach nie możemy gwarantować wypukłości $\boldsymbol{Y}_{i}(\boldsymbol{x})$ (a wypukłość ta potrzebna jest dla wszystkich $\boldsymbol{x} \in \boldsymbol{X}_{0}$ ). Dlatego też celowe jest raczej zastosowanie funkcji osiągnięcia $\sigma_{i}\left(\boldsymbol{y}_{i}, \boldsymbol{y}_{i}^{-}\right)$, por. Rozdz. 7-9. Daje ono wynik nie tylko silniejszy teoretycznie, gdyż obowiązujący też dla problemów niewypukłych, lecz także pozwala na ciągłą sterowalność wyboru rezultatów $\boldsymbol{y}^{*} \in \boldsymbol{Y}$, podobnie jak $\mathrm{w}$ optymalizacji wielokryterialnej. Odpowiednie twierdzenie brzmi:

Twierdzenie 12.2. Załóżmy, że dla każdego gracza $i=1, . . n$ określony jest pewien punkt aspiracji $\boldsymbol{y}_{i}^{-} \in \boldsymbol{R}^{m i}$ oraz odpowiednia funkcja osiągnięcia, np. postaci:

$$
\sigma_{i}\left(\boldsymbol{y}_{i}, \boldsymbol{y}_{i}^{-}\right)=\min _{1 \leq j \leq m i}\left(y_{i j}-y_{i j}^{-}\right) / \Delta y_{i j}+\varepsilon \sum_{j=1, \ldots m i}\left(y_{i j}-y_{i j}^{-}\right) / \Delta y_{i j}
$$

gdzie $\Delta y_{i j}$ są wybranymi zakresami zmienności $y_{i j}$. Wtedy:

(a) Jeśli $x^{*}, y^{*}=f\left(x^{*}\right)$ odpowiadają niekooperatywnej równowadze Nasha zastępczej gry jednokryterialnej z wygranymi $\sigma_{i}\left(\boldsymbol{y}_{i}, \boldsymbol{y}_{i}^{-}\right)$dla dowolnych $\boldsymbol{y}_{i}^{-} \in \boldsymbol{R}^{m i}$, to są one też niekooperatywnym rozwiązaniem właściwie $\varepsilon$-sprawnym gry wielokryterialnej (z ograniczeniem $1+1 / \varepsilon$ na współczynniki wymiany liczone dla względnych wartości rezultatów $y_{i j} / \Delta y_{i j}$ ).

(b) Jeśli $\boldsymbol{x}^{*}, \boldsymbol{y}^{*}=\boldsymbol{f}\left(\boldsymbol{x}^{*}\right)$ są niekooperatywnym rozwiązaniem właściwie e-sprawnym (z ograniczeniem współczynników wymiany określonym jak wyżej) gry wielokryterialnej, wtedy istnieje takie $\boldsymbol{y}^{-}=\left(\boldsymbol{y}_{1}^{-}, \ldots \boldsymbol{y}_{i}^{-}, \ldots \boldsymbol{y}_{n}^{-}\right)-$ przy czym wystarczy wziąć $y^{-}=y^{*}-$ że $x^{*}$ i $y^{*}=f\left(x^{*}\right)$ odpowiadają 
niekooperatywnej równowadze Nasha zastępczej gry jednokryterialnej z wygranymi $\sigma_{i}\left(\boldsymbol{y}_{i}, \boldsymbol{y}_{i}^{-}\right)$.

Takie samo twierdzenie obowiązuje - przy $\varepsilon=0$ - dla niekooperatywnych rozwiązań słabo Pareto-Nash'a. Dowody powyższych twierdzeń opierają się na twierdzeniach o monotoniczności i o stożkowym rozdzielaniu zbiorów, jak w optymalizacji wielokryterialnej, por. Rozdz. 7-9.

\subsubsection{Zastosowania gier wielokryterialnych}

Zilustrujemy tu możliwość eskalacji konfliktu na przykładzie gry wielokryterialnej opisującej konflikt o prawa połowu ryb. Pełen model takiego konfliktu wymagałby jej zapisu jako gry dynamicznej, nieliniowej, stochastycznej i wielokryterialnej. Podamy tu tylko model uproszczony, obejmujący tylko aspekty wielokryterialne i nieliniowe oraz niektóre aspekty dynamiczne, przy zastąpieniu gry dynamicznej przez grę powtarzalną.

Rozpatrujemy tylko dwa państwa 1 i 2 z flotami rybackimi o rozmiarach $\tilde{X_{1}}{ }_{1} \mathrm{i} \tilde{X}_{2}$. Ograniczymy model do takich gatunków ryb, które rozmnażają się w rzekach krajów 1 lub 2; można wtedy mówić o zasobach (rozmiarach populacji) ryb $z_{1}$ i $z_{2}$, które pochodzą $z$ kraju 1 lub 2 i powracają celem rozmnażania się do wód przybrzeżnych lub rzek tych krajów. Na morzu otwartym oba kraje mogą łowić ryby obu gatunków; połowy na wodach przybrzeżnych możemy uznać (dla uproszczenia) za zabronione. ${ }^{3}$

Niezmiernie uproszczony model połowu ryb zakłada, że część wspólnych zasobów $z_{1}+z_{2}$ może być odłowiona na morzu otwartym proporcjonalnie do względnych wielkości flot rybackich, z intensywnością połowów na jednostkę floty zmniejszającą się eksponencjalnie, jeśli łączna liczba tych jednostek wzrasta. Zakładamy, że oba kraje mogą wpływać (np. przez politykę podatkową) na liczbę jednostek floty $x_{1}$ i $x_{2}$ biorących udział w połowach.

\footnotetext{
${ }^{3}$ Przynajmniej dla floty rybackiej kraju obcego. W sytuacji poważnego zagrożenia populacji ryb, połowy na wodach przybrzeżnych ryb powracających dla rozmnażania się są szczególnie niekorzystne dla wzrostu tej populacji.
} 
Połowy np. kraju 1 na morzu otwartym wyrażą się wzorem:

$$
c_{1}=\left(z_{1}+z_{2}\right)\left(1-\exp \left(-a\left(x_{1}+x_{2}\right)\right) x_{1} /\left(x_{1}+x_{2}\right)\right.
$$

gdzie:

$$
0 \leq x_{1} \leq \tilde{x_{1}} ; 0 \leq x_{2} \leq \tilde{X_{2}}
$$

natomiast $a$ jest dodatnim współczynnikiem.

Po połowach - np. w danym roku - pozostaje tylko $z_{1} \exp \left(-a\left(x_{1}+x_{2}\right)\right)$ ryb $\mathrm{z}$ początkowego zasobu $z_{1}$ i powraca do wód przybrzeżnych oraz rzek kraju 1; analogicznie dla kraju 2. Można by też analogicznie wyrazić połów w wodach przybrzeżnych, ale okaże się, że jest on długoterminowo nieopłacalny dla kraju 1 (nawet, gdyby zabraniał łowić w swoich wodach przybrzeżnych krajowi 2); dlatego też zakładamy, że połów w wodach przybrzeżnych jest zabroniony dla flot obu krajów.

Współczynnik rozmnażania się ryb oznaczymy przez $r$. W zasadzie, jest on funkcją liczby pozostałych ryb danego gatunku, $r=r\left(z_{1} \exp \left(-a\left(x_{1}+x_{2}\right)\right)\right)$, ale dla prostoty założymy, że jest on stałą $r$. Zasób ryb kraju $1 \mathrm{w}$ następnym sezonie wynosi więc:

$$
z^{+}{ }_{1}=r z_{1} \exp \left(-a\left(x_{1}+x_{2}\right)\right)
$$

Równanie powyższe, wraz $\mathrm{z}$ analogicznym dla zasobów $\mathrm{z}_{2}^{+}$, może być uważane za podstawowe równanie dynamiki w długoterminowej grze dynamicznej. Z drugiej strony, możemy też uważać zasoby ryb w następnym sezonie jako jedno z kryteriów krajów 1 i 2 w statycznej grze powtarzalnej. Można sformułować różne kryteria dla takiej gry wielokryterialnej; dla ilustracji problematyki eskalacji konfliktu, wystarczy analizować po dwa kryteria dla każdego kraju.

Pierwsze kryterium kraju 1 (podobnie dla kraju 2) może reprezentować interesy rybaków, którzy są przede wszystkim zainteresowani w poziomie połowów:

$$
y_{1,1}=c_{1}
$$


Drugie kryterium reprezentuje bardziej ogólne interesy kraju 1 (lub 2), włącznie z poziomem połowów, ale biorąc także pod uwagę koszty utrzymania floty i wartość (nie tylko rynkową, także ekologiczną) zasobów ryb w następnym sezonie:

$$
y_{1,2}=c_{1}-p x_{1}+b z_{1}^{+}
$$

gdzie $p, b$ są odpowiednimi współczynnikami. Podobnie definiujemy kryteria dla kraju 2.

Zbiór niekooperatywnych rozwiązań Pareto-Nasha dla tego modelu może być obliczony w rozmaity sposób. Ilustruje go Rys. 12.4, gdzie dla celów obliczeniowych zastosowano odpowiednie techniki funkcji kary za przekraczanie zastępczych ograniczeń dla funkcji osiągnięcia określonej jak w Twierdzeniu 12.2. W całym zbiorze możliwych rezultatów gry są dwa podzbiory niekooperatywnych rozwiązań Pareto-Nasha: jeden (A) odpowiadający rozsądnym poziomom połowów, drugi (B) - silnemu spadkowi zasobów ryb i perspektywie katastrofy ekologicznej.

W grze powtarzalnej, eskalacja konfliktu może powstać następująco. Przypuśćmy, że oba kraje łowią początkowo ryby na rozsądnym poziomie, odpowiadającym punktowi $P_{1} € A$. Przypuśćmy, że rybacy kraju 2 chcieli mieć większe połowy i zwiększyli ich poziom do punktu $P_{2} \neg € A$. Jeśli $\mathrm{w}$ tym momencie kraj 1 spróbuje porozumieć się z krajem 2, przyjmie arbitraż organizacji międzynarodowej itp., to może uniknąć eskalacji konfliktu. Jeśli natomiast rybacy kraju 1 będą obstawać przy połowach takich samych, jak kraj 2, i wyślą po prostu więcej jednostek na połowy, rozwiązanie może się przesunąc do punktu nierównowagowego $P_{3} \neg \in A$; po dalszych pociągnięciach retaliacyjnych tego rodzaju (powodowanych tym, że połowy na jednostkę rybacką będą systematycznie spadać i rybacy obu krajów będą obwiniać się wzajemnie), proces eskalacji konfliktu może skończyć się znów w rozwiązaniu Pareto-Nasha $P_{5} \in B$ - przy znacznie jednak niższym poziomie kryteriów ogólnych $y_{1,2}, y_{2,2}$ oraz znacznie mniejszych zasobach ryb na następne sezony. 


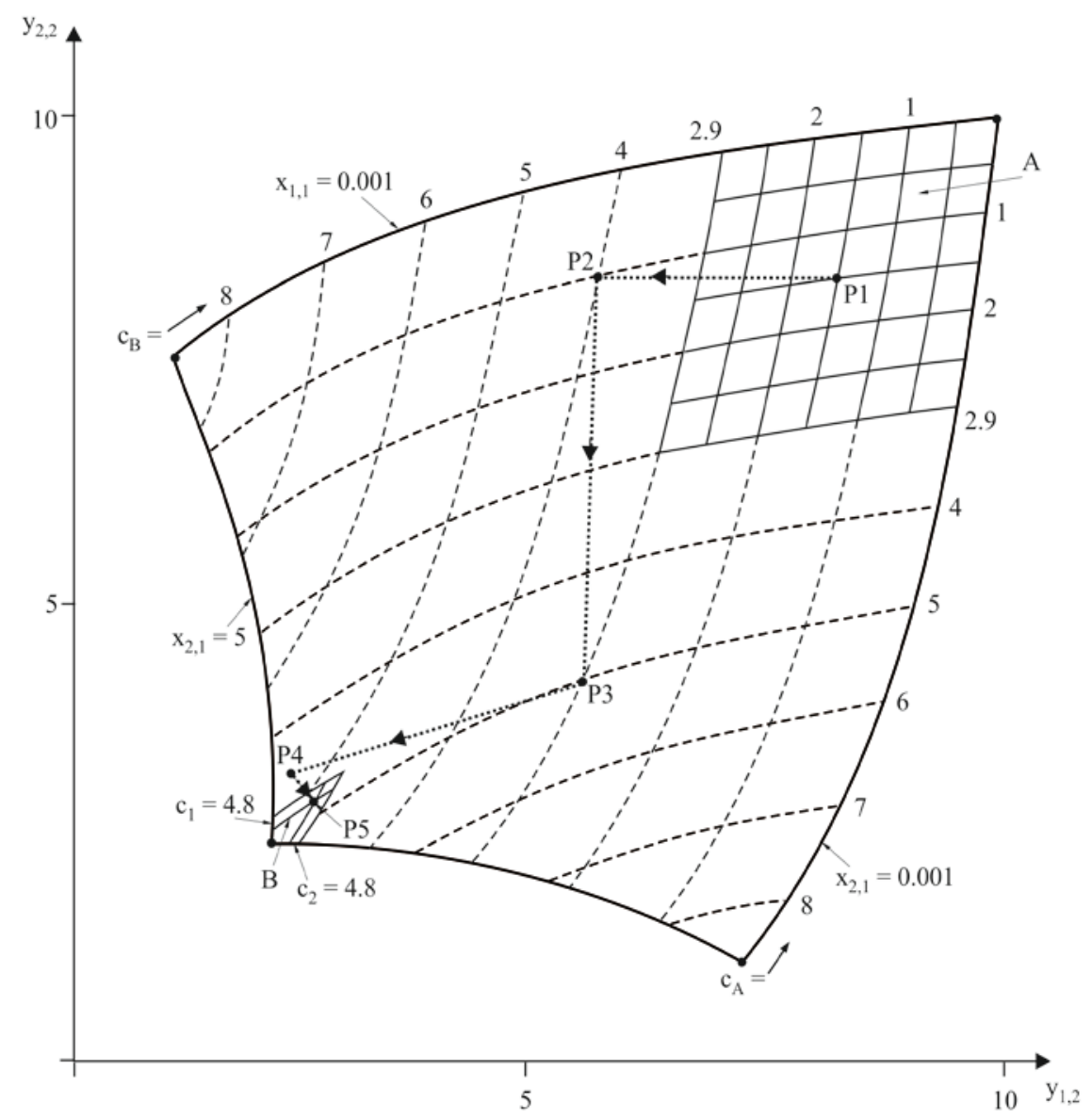

Rys. 12.4. Rozwiązania Pareto-Nasha oraz ilustracja możliwości eskalacji konfliktu dla przykładu gry wielokryterialnej połowu ryb.

Przykład ten wskazuje, że eskalacja konfliktu może być immanentną cechą gier o wielu rozwiązaniach równowagowych czy Pareto-Nasha gdyż, tak jak w grze w tchórza, każda ze stron może uważać, że korzystniejsza dla nich równowaga jest racjonalna i to druga strona zachowuje się nieracjonalnie. Tymczasem nie należy winić drugiej strony: winny za to zjawisko jest po prostu charakter gry i brak komunikacji ze stroną przeciwną. 


\subsubsection{Przykład eksperymentalnej gry wielokryterialnej}

Innym przykładem jest eksperymentalna gra wielokryterialna „Humble Shall be Rewarded", skonstruowana jako przedmiot adaptacji i uczenia się w trakcie działania. Gra jest rozgrywana parami, ale może w niej uczestniczyć wiele par; jest ona też skomputeryzowana, ale dla ilustracji podamy tu jej krótki opis tak, jak gdybyśmy nie używali komputera.

Zbiory dopuszczalnych decyzji graczy są bardzo proste: jednocześnie, kładą oni na stół od 0 do 5 żetonów każdy (lub pokazują od 0 do 5 palców). Każdy z graczy ma jednakowy kapitał początkowy, 100 żetonów (groszy, czy jenów - gra była rozgrywana początkowo w Japonii). Każdy z graczy ma dwa cele: pomnożyć swój kapitał początkowy i zdobyć jak najwięcej punktów wygrywających (honorowych - jest to więc gra „honor a pieniądze").

Gra trwa 50 rund lub jest zatrzymywana wcześniej, jeśli którykolwiek z graczy zużyje swój kapitał początkowy. W danej rundzie, gracz kładący więcej żetonów wygrywa punkty honorowe: 1 jeśli wygrał przewaga 1 żetonu, 2 jeśli wygrał większą przewagą (niezależnie, czy to 2 czy 5 żetonów). Przy jednakowej liczbie żetonów, lub w przypadku przegranej, gracz uzyskuje 0 punktów honorowych.

Celem gry jest zgromadzenie jak największej liczby punktów honorowych zarówno większej od przeciwnika, jak i wśród innych par rozgrywających tę grę. Pieniądze są celem dodatkowym, niejako podrzędnym, ale wpływają istotnie na możliwość prowadzenia gry. Obaj gracze zaczynają ze 100 żetonami kapitału $a$ vista, ale:

- Jeśli gracz przegrywa rundę, musi zapłacić drugiemu 10 żetonów (jenów);

- Jeśli runda jest nierozstrzygnięta, musi zapłacić 5 żetonów i dodatkowo po 2 żetony za każdy żeton zagrany (wyłożony na stół) do osobnego „funduszu organizacji następnych gier”.

Po grze, pozostały kapitał a vista gracza uzupełniany jest o nagrody płacone przez organizatora gry z tegoż „funduszu”: 
- Za każdy „żeton oszczędzony” (nie zagrany w danej rundzie w porównaniu z maksymalną ich liczbą 5), liczy się do nagród 1 żeton; jeśli na przykład gracz 1 zagrał 4 żetony (,,pokazał 4 palce”), a gracz 2 tylko 1 żeton, to graczowi 1 zapisuje się tylko 1, natomiast graczowi 2 aż 4 żetony nagrody, przy czym po grze sumuje się takie nagrody z każdej zagranej rundy.

- Zwycięzca tak zwanej rundy „szczęśliwego trafu” - zdefiniowanej jako taka, w której różnica pomiędzy liczbą zagranych żetonów była 1 oraz zwycięzca miał liczbę nieparzystą - dostaje nagrodę 10 żetonów, a przegrywający nawet 20 żetonów (jako pocieszenie), co także sumuje się po grze.

- Jeśli gra kończy się z powodu wyczerpania kapitału a vista, wymagane opłaty z ostatniej rundy są odejmowane od końcowych nagród.

Ponadto, są ważne reguły ograniczające. Gracze nie mogą się ze sobą komunikować i uzgadniać strategii przed i podczas gry; mogą myśleć o strategiach kooperatywnych, ale sugerować je przeciwnikowi mogą tylko poprzez odpowiednie decyzje growe (liczby zagranych żetonów). Ponadto, istnieje też wariant gry, w której nie wolno być „zbyt szczęśliwym”. Jeśli liczba rund „szczęśliwego trafu” przekroczy 12, lub jeśli zdarzy się więcej niż przez 4 kolejne rundy „szczęśliwego trafu” - nieistotne, który z graczy to spowoduje i czy naumyślnie, czy nie - to gra jest uznawana za nieważną, przerywana, i gracze tracą wszelkie nagrody.

Dla podsumowania dość złożonych reguł tej gry, rezultaty netto (z uwzględnieniem nagród płaconych na koniec gry) pojedynczej rundy są przedstawione $\mathrm{w}$ następujących tabelach, gdzie $(i, j)$ oznacza liczbę żetonów zagranych przez gracza 1 i gracza $2,(x, y)$ oznaczają punkty honorowe, $(w, z)$ oznaczają wygrane finansowe netto.

Gracze powinni być jednak uprzedzeni, że - ze względu na dynamikę gry - są w niej faktycznie ukryte także inne kryteria, niż przedstawione w powyższych tabelach. Gra ma wiele ,pułapek racjonalności” i początkujący gracze mogą łatwo spowodować proces eskalacji konfliktu. Aby zagrać tę grę dobrze, gracze muszą przemyśleć - i w miarę doświadczeń zmieniać perspektywę strategiczną dotyczącą percepcji, co w tej grze jest istotnie 
najważniejsze, jak w sposób dozwolony (przez ciąg swoich decyzji) komunikować się z przeciwnikiem itp.

\begin{tabular}{|c|c|c|c|c|c|c|}
\hline \multicolumn{7}{|c|}{ Tablica 1: punkty honorowe za pojedynczą rundę } \\
\hline$j$ & 0 & 1 & 2 & 3 & 4 & 5 \\
\hline$i$ & \multicolumn{7}{|c|}{ Punkty honorowe $x, y$ przy decyzjach $i, j$} \\
\hline 0 & 0,0 & 0,1 & 0,2 & 0,2 & 0,2 & 0,2 \\
\hline 1 & 1,0 & 0,0 & 0,1 & 0,2 & 0,2 & 0,2 \\
\hline 2 & 2,0 & 1,0 & 0,0 & 0,1 & 0,2 & 0,2 \\
\hline 3 & 2.0 & 2,0 & 1,0 & 0,0 & 0,1 & 0,2 \\
\hline 4 & 2,0 & 2,0 & 2,0 & 1,0 & 0,0 & 0,1 \\
\hline 5 & 2,0 & 2,0 & 2,0 & 2,0 & 1,0 & 0,0 \\
\hline
\end{tabular}

Tablica 2: zyski finansowe za pojedynczą rundę z uwzględnieniem nagród końcowych

\begin{tabular}{|c|c|c|c|c|c|c|}
\hline$j$ & 0 & 1 & 2 & 3 & 4 & 5 \\
\hline$i$ & \multicolumn{7}{|c|}{ Zyski finansowe netto $w, z$ za decyzje $i, j$} \\
\hline 0 & 0,0 & 15,24 & $-5,13$ & $-5,12$ & $-5,11$ & $-5,10$ \\
\hline 1 & 24,15 & $-3,-3$ & $-6,13$ & $-6,12$ & $-6,11$ & $-6,10$ \\
\hline 2 & $13,-5$ & $13,-6$ & $-6,-6$ & 13,22 & $-7,11$ & $-7,10$ \\
\hline 3 & $12,-5$ & $12,-6$ & 22,13 & $-9,-9$ & $-8,11$ & $-8,10$ \\
\hline 4 & $11,-5$ & $11,-6$ & $11,-7$ & $11,-8$ & $-12,-12$ & 11,20 \\
\hline 5 & $10,-5$ & $10,-6$ & $10,-7$ & $10,-8$ & 20,11 & $-15,-15$ \\
\hline
\end{tabular}

Doświadczenia z wielu gier wskazują, że jest kilka wyraźnie odmiennych perspektyw strategicznych spojrzenia na tę grę, i rezultaty gry zależą bardzo silnie od przyjętej perspektywy. Dlatego też gra może być stosowana jako sprawdzian umiejętności adaptacji i uczenia się w trakcie działania, zmiany hierarchii celów; przy większych takich umiejętnościach, osiąga się w niej szybciej dobre wyniki.

\subsection{Pojęcie ewolucji kooperacji i strategia „tit for tat”}

Różne paradoksy teorii gier motywowały wielu badaczy do rozszerzenia jej interpretacji. W badaniach teoretycznych prowadziło to zazwyczaj do obrony paradygmatu np. poprzez różnorodne sposoby wzmocnienia założeń 
i modyfikacje definicji rozwiązań równowagowych tak, aby były one jednoznaczne (patrz np. wcześniejsze uwagi o pracach Reinharta Seltena i Johna Harsanyi). Badania skierowane bardziej na zastosowania teorii gier wskazują jednak, że „ograniczona racjonalność” postępowań ludzkich w przeciwieństwie do „superracjonalności” - jest raczej regułą niż wyjątkiem. Znamienne jest bowiem, że stosowane dość powszechnie w wielu dziedzinach (ekonomia, wojskowość itp.) gry symulacyjne (oznaczane po angielsku gaming) rozwinęły się jako dziedzina niezależna od teorii gier (ang. game theory), niewiele wykorzystując z jej rezultatów.

Anatol Rapoport i Robert Axelrod w swych badaniach rozpatrywali pytanie: a jak ludzie faktycznie rozwiązują dylematy, ilustrowane przez „pułapki racjonalności” w teorii gier? Anatol Rapoport zajmował się przy tym analizą opisową i eksperymentalną, jak ludzie faktycznie postępują w sytuacjach konfliktowych (zob. spis literatury). Robert Axelrod prowadził najpierw badania historyczne sposobów unikania pułapek racjonalności, potem zajął się symulacją komputerową porównań różnych strategii postępowania - które można podzielić na klasy „egoistycznie zachłannych” i ,racjonalnego altruizmu". Strategie te porównywał w ujęciu ewolucyjnym, to jest przy założeniu gry powtarzalnej, z możliwością zwielokrotnienia (,rozmnażania”) strategii uzyskujących największe liczby punktów. Zorganizował kilka otwartych dla wszystkich specjalistów w zakresie teorii gier - takich konkursów strategii rozwiązywania powtarzalnego „dylematu więźnia”. Zaskoczeniem dla wielu specjalistów był fakt, że w kolejnych konkursach konsekwentnie najlepszą okazywała się strategia „racjonalnego altruizmu” zwana tit for tat Anatola Rapoporta.

Strategia ta jest następująca. Załóżmy, że dany gracz spotyka się wielokrotnie z różnymi innymi graczami, a przy każdym spotkaniu rozgrywa z jednym z nich jednokrotną grę typu „dylemat więźnia”. Gracz ten może zapamiętać, jakie decyzje stosowali poszczególni inni gracze przy poprzednich z nim spotkaniach. Strategia tit for tat polega na zastosowaniu decyzji $C$ (cooperate) kiedykolwiek spotkamy nowego partnera, natomiast przy ponownym spotkaniu - na zastosowaniu takiej decyzji (C, cooperate, lub $D$, 
defect), którą gracz przeciwny stosował przy poprzednim spotkaniu, powracając do decyzji $C \mathrm{w}$ kolejnym spotkaniu, jeśli gracz przeciwny zastosował ostatnio taką decyzję. Można ją więc ująć w następujące zasady: nigdy nie inicjuj sam decyzji niekooperatywnych; jeśli partner zachowa się niekooperatywnie, odpłać mu za to przy następnym spotkaniu, ale bądź gotów do przebaczenia i powrotu do decyzji kooperatywnych. Odpłać przynajmniej raz - jest też bowiem łagodniejszy wariant strategii tit for tat, z przyspieszonym wybaczaniem, zakładający tylko jednokrotne zastosowanie strategii $D$, jeśli gracz przeciwny ją ostatnio zastosował, a potem powrót do strategii $C$ bez względu na ostatnie decyzje gracza przeciwnego. Dlatego też stosowane niekiedy tłumaczenie nazwy tej strategii na polskie „wet za wet" nie jest całkiem trafne: istotą tej strategii jest szybki odwet, ale i szybkie wybaczenie.

Chociaż wielu autorów próbowało skonstruować warianty strategii zachłannych (np. stosujących z małym prawdopodobieństwem decyzję $D$, mimo że partner stosuje konsekwentnie C) mające na celu pokonać strategię tit for tat w konkursie ewolucyjnym, ta ostatnia wygrywała kolejne konkursy. Doprowadziło to do powstania nowego działu teorii gier, mającego związek m.in. z badaniami ekologicznymi i biologicznymi, tzw. gier ewolucyjnych, wraz ze specjalnym pojęciem równowagi ewolucyjnej. Natomiast Axelrod, komentując wyniki swojego konkursu, wprowadził pojęcie ewolucji kooperacji i koncentrował się raczej na analogiach społecznych i historycznych, ilustrując ewolucyjny rozwój pojęć etycznych. Społeczeństwo w procesie ewolucyjnym uczy się rozwiązywać wciąż nowe pułapki racjonalności i wynajduje często niepisane normy postępowania (przykładami mogą tu być reguły milczenia w mafii, czy specyficznych zachowań żołnierzy w okopach na froncie I wojny światowej). Co pewien czas zdarza się Mojżesz lub Hammurabi, który kodyfikuje doświadczenia etyczne w akceptowane ogólnie prawa. Zmieniający się świat wywołuje jednak wciąż nowe dylematy etyczne - np. kwestie własności intelektualnej czy kwestie zasad dostępu i sposobów wykorzystania informacji w sieci komputerowej. 


\section{Literatura}

Aubin J. P. (1979) Mathematical Methods of Game and Economic Theory. North Holland, Amsterdam.

Axelrod R. (1984) The Evolution of Cooperation. Basic Books, New York.

Basar, T. and G.J. Olsder (1982) Dynamic Noncooperative Game Theory. Academic Press, New York.

Bronisz P., Kruś L., Wierzbicki A.P. (1989) Towards interactive solutions in a bargaining problem. In: A. Lewandowski et al., eds: Aspiration Based Decision Support Systems, Springer Verlag, Berlin.

Myerson R.B. (1991) Game Theory - Analysis of Conflict. Harvard University Press, Cambridge, Massachusetts.

Raiffa H. (1982) The Art and Science of Negotiations. Harward University Press, Cambridge, Massachusetts.

Rapoport A. (1989) Decision Theory and Decision Behavior. Kluwer Academic Publishers, Dordrecht.

Sylos-Labini P. (1962) Oligopoly and technical progress. Harvard University Press, Cambridge, Massachusetts.

Wierzbicki A.P. (1992) Multiple Citeria Games: Theory and Applications. International Institute for Applied Systems Analysis, WP-79-92, Laxenburg, Austria.

Wierzbicki A.P. (1992) An Experimental Multi-Objective Game "Humble Shall be Rewarded”. International Institute for Applied Systems Analysis, WP-081-92, Laxenburg, Austria. 


\section{Rozwiązania kooperatywne w teorii gier}

\subsection{Wprowadzenie}

Jak wynika $\mathrm{z}$ rozdziału poprzedniego, potrzeba kooperacji pomiędzy niezależnymi graczami może wynikać bądź to ze stwierdzonej niesprawności niekooperatywnych równowag gry, bądź też z dostrzeżenia groźby eskalacji konfliktu, bądź wreszcie z historycznego doświadczenia i potrzeby uniknięcia pułapek krótkoterminowej racjonalności. W sytuacjach decyzji grupowych, nie growych, potrzeba kooperacji jest narzucona przez charakter sytuacji decyzyjnej, w której gracze nie mają możliwości w pełni niezależnych decyzji. Stąd też zagadnienie decyzji kooperatywnych od dawna było analizowane przez teorię gier.

Podstawowym jest przy tym pytanie: jeśli już stwierdzona lub narzucona jest potrzeba kooperacji, to czy można racjonalnie przewidzieć, jakie porozumienie pomiędzy graczami zostanie zawarte? Odpowiedź na to pytanie jest tylko częściowo pozytywna: można bowiem postulować racjonalne porozumienia, ale nie są one jednoznacznie określone, zależą od przyjętych założeń, a więc pozostawiają pole do dyskusji i negocjacji. Tym niemniej, znajomość różnych podejść do porozumień racjonalnych pozwala na lepsze zrozumienie kooperacyjnych sytuacji growych i daje argumenty w negocjacjach.

Kooperatywna teoria gier jest sama w sobie działem dość bogatym, tu możemy przedstawić tylko w wielkim skrócie jej podstawowe rezultaty. Ograniczymy się przy tym do dwóch przypadków: pojęć aksjomatycznie umotywowanych rozwiązań kooperatywnych w grach o postaci normalnej oraz pojęć rozwiązań koalicyjnych w grach o koalicyjnej postaci strategicznej. 


\subsection{Rozwiązania kooperatywne dla gier w postaci normalnej}

Rozpatrzymy tu przypadek podstawowy: dwóch graczy, o niezależnych decyzjach $\boldsymbol{x}=\left(\boldsymbol{x}_{1}, \boldsymbol{x}_{2}\right) \in \boldsymbol{X}_{0}=\boldsymbol{X}_{01} \times \boldsymbol{X}_{02}$, rezultaty skalarne (wygrane) $y_{1}=f_{1}\left(\boldsymbol{x}_{1}, \boldsymbol{x}_{2}\right), y_{2}=f_{2}\left(\boldsymbol{x}_{1}, \boldsymbol{x}_{2}\right), \boldsymbol{y}=\boldsymbol{f}(\boldsymbol{x})=\left(f_{1}\left(\boldsymbol{x}_{1}, \boldsymbol{x}_{2}\right), f_{2}\left(\boldsymbol{x}_{1}, \boldsymbol{x}_{2}\right)\right)$. Załóżmy, że jest to gra o niestałej sumie i gracze mogą zyskać przez kooperację (jak np. w dylemacie więźnia). Jakie wspólne decyzje są dla nich racjonalne?

Pytanie to nie ma jednoznacznej odpowiedzi, nawet w przypadku gier o stałej sumie (gdyby miało, nie potrzeba by było tak ważnej ludzkiej umiejętności, jaką jest sztuka negocjacji). Przykładem prototypowym jest tu inna pułapka racjonalności, zwana grą podziału: przypuśćmy, że dwóch graczy ma do podziału określoną sumę, np. 100 zł. Jeśli uzgodnią między sobą sposób podziału w określonym czasie, to otrzymają uzgodnione sumy; jeśli jednak nie uzgodnią podziału, cała suma przepada (np. musi być wypłacona osobie trzeciej). Jak powinni podzielić tę sumę? Oczywiście, pół na pół, jeśli nie ma żadnych czynników dodatkowych w grze. Ale czynniki dodatkowe zawsze się pojawią. Jeśli jeden z graczy jest uboższy, a drugi bogatszy, to bogatszy może argumentować, że powinni podzielić tę sumę według proporcjonalnych przyrostów użyteczności dla każdego z graczy (a więc więcej dla bogatszego, który ma mniejszą użyteczność $\mathrm{z}$ danej sumy), natomiast uboższy, że sprawiedliwy podział powinien maksymalizować sumę ich użyteczności (a więc wszystko, a co najmniej większość, dla uboższego). Gdyby dać tę grę jako praktyczne ćwiczenie studentom i uzależnić ich oceny od osiągalnych rezultatów, to ich zachowanie zależało by też od stosowanej reguły ocen.

Jak wynika z tego przykładu, dla odpowiedzi na pytanie o racjonalną decyzję kooperatywną niezbędne jest określenie co najmniej dwóch elementów dodatkowych: punktu status quo $\boldsymbol{y}^{-}=\left(\bar{y}_{1}^{-}, y_{2}^{-}\right)$, po angielsku disagreement point, określający jakie będą rezultaty graczy, jeśli nie dojdą do porozumienia - oraz założeń co do porównywalności skal użyteczności. John Nash (1953) zaproponował odpowiedź na to pytanie niezależne od skal użyteczności i opierające się na pewnych aksjomatach racjonalnego podziału. 
Nazwał on ten problem problemem targu (bargaining problem) ${ }^{1}$ i określił następująco.

Problem jest w swej istocie niezależny od postaci funkcji $\boldsymbol{f}_{1}, \boldsymbol{f}_{2}$, wystarczy go rozpatrywać w przestrzeni rezultatów gry. Dla określenia problemu przetargu wystarczy więc podać punkt status quo $\boldsymbol{y}^{-}$oraz zbiór $\boldsymbol{Y}$ rezultatów niegorszych od status quo, który następująco wynika z przyjętego normalnego modelu gry:

$$
\boldsymbol{Y}=\left\{\boldsymbol{y} \in \boldsymbol{R}^{2}: y_{1}=f_{1}\left(\boldsymbol{x}_{1}, \boldsymbol{x}_{2}\right) \geq \overline{y_{1}}, y_{2}=f_{2}\left(\boldsymbol{x}_{1}, \boldsymbol{x}_{2}\right) \geq \overline{y_{2}}, \boldsymbol{x}_{1} \in \boldsymbol{X}_{01}, \boldsymbol{x}_{2} \in \boldsymbol{X}_{02}\right\}
$$

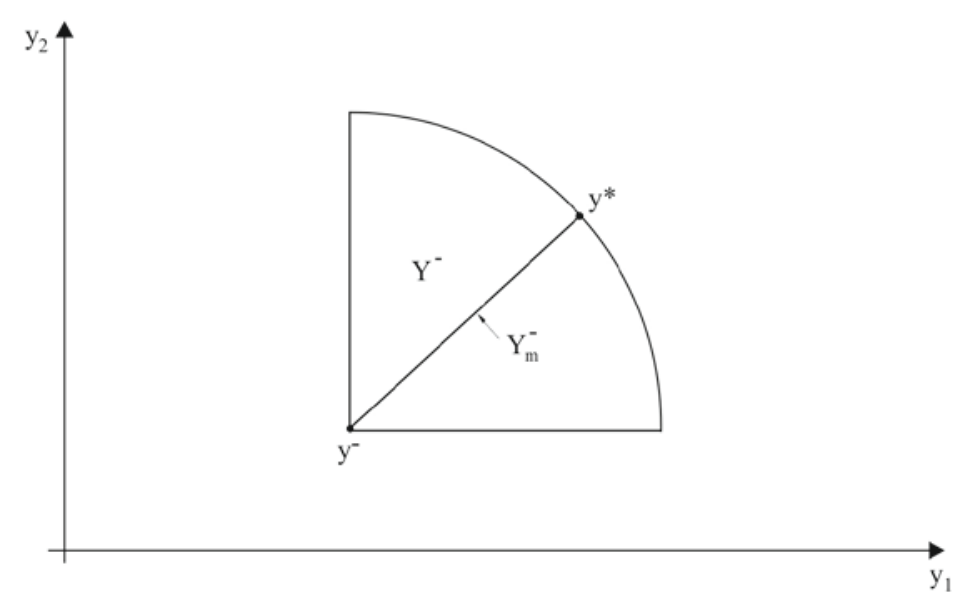

Rys. 13.1. Przykład zbioru $\boldsymbol{Y}$ rezultatów niegorszych od danego punktu status quo $\boldsymbol{y}^{-}$ oraz ilustracja aksjomatu niezależności od opcji nieistotnych ( $\boldsymbol{Y}_{m}$ - skrajna modyfikacja zbioru $\boldsymbol{Y}$ zgodna z tym aksjomatem).

Para $\boldsymbol{y}^{\complement}, \boldsymbol{Y}$ określa więc problem przetargu i w tych terminach można go analizować, poszukując wektora $\boldsymbol{y}^{*}$ rezultatów racjonalnego przetargu jako pewnego odwzorowania $\boldsymbol{\Phi}$ tej pary:

$$
y^{*}=\Phi\left(y^{-}, \boldsymbol{Y}\right)=\left(\Phi_{1}\left(\boldsymbol{y}^{-}, \boldsymbol{Y}\right), \Phi_{2}\left(\boldsymbol{y}^{-}, \boldsymbol{Y}\right) \in \boldsymbol{Y}\right.
$$

\footnotetext{
${ }^{1}$ John Nash starał się w tym problemie rozwiązać analitycznie problem przewidywania wyników negocjacji.
} 
spełniającego dodatkowe aksjomaty racjonalności. Oczywiście, w zastosowaniach praktycznych trzeba określić także odpowiednie decyzje $\boldsymbol{x}^{*}$ takie, że $\boldsymbol{y}^{*}=\boldsymbol{f}\left(\boldsymbol{x}^{*}\right)$.

Nash rozpatrywał ten problem przy założeniu, że zbiór $\boldsymbol{Y}$ jest domknięty i wypukły, oraz przyjął następujące aksjomaty racjonalności targu:

A1. Sprawność: $\boldsymbol{y}^{*}=\boldsymbol{\Phi}\left(\boldsymbol{y}^{-}, \boldsymbol{Y}\right)$ jest punktem sprawnym (Paretooptymalnym) zbioru $\boldsymbol{Y}$.

A2. Indywidualna racjonalność: $y^{*}=\Phi\left(y^{-}, Y^{-}\right) \geq y^{-}$.

A3. Niezależność od skali użyteczności: liniowe przekształcenia skali użyteczności i tym samym danych zadania:

$\boldsymbol{W}=\left\{w_{1}=\lambda_{1} y_{1}+\gamma_{1}, w_{2}=\lambda_{2} y_{2}+\gamma_{2}, \boldsymbol{y \in} \boldsymbol{Y}^{-} ; \boldsymbol{w}^{-}=\left(\lambda_{1} y_{1}^{-}+\gamma_{1}, \lambda_{2} y_{2}^{-}+\gamma_{2}\right)\right.$ dla dowolnych $\lambda_{1}>0, \lambda_{2}>0$ i dowolnych $\gamma_{1}, \gamma_{2}$ nie wpływają istotnie na wynik, to jest powodują tylko jego analogiczne przekształcenie:

$\boldsymbol{\Phi}\left(\boldsymbol{w}^{-}, \boldsymbol{W}^{-}\right)=\left(\lambda_{1} \Phi_{1}\left(\boldsymbol{y}^{-}, \boldsymbol{Y}^{-}\right)+\gamma_{1}, \lambda_{2} \Phi_{2}\left(\boldsymbol{y}^{-}, \boldsymbol{Y}\right)+\gamma_{2}\right)$

A4. Niezależność od opcji nieistotnych: dla dowolnego (domkniętego i wypukłego) zbioru $\boldsymbol{Y}^{\prime} \subseteq \boldsymbol{Y}$, jeśli $\boldsymbol{y}^{-} \in \boldsymbol{Y}^{\prime}, \Phi\left(\boldsymbol{y}^{-}, \boldsymbol{Y}\right) \in \boldsymbol{Y}^{\prime}$, to $\Phi\left(\boldsymbol{y}^{-}, \boldsymbol{Y}^{\prime}\right)=\Phi\left(\boldsymbol{y}^{-}, \boldsymbol{Y}^{\prime}\right)$.

A5. Symetria: jeśli problem jest symetryczny, czyli jeśli $y_{1}^{-}=y_{2}^{-}$oraz $\left\{\left(y_{2}, y_{1}\right) \in \boldsymbol{R}^{2}:\left(y_{1}, y_{2}\right) \in \boldsymbol{Y}^{\top}\right\}=\boldsymbol{Y}$, to $\Phi_{1}\left(\boldsymbol{y}^{-}, \boldsymbol{Y}^{\top}\right)=\Phi_{2}\left(\boldsymbol{y}^{-}, \boldsymbol{Y}\right) \$$.

Aksjomaty: sprawności, indywidualnej racjonalności, niezależności od skali użyteczności oraz symetrii są bardzo naturalne. Naturalnym też wydaje się na pierwszy rzut oka aksjomat niezależności od opcji nieistotnych, ale w istocie nie jest on naturalny - gdyż naprawdę mówi on, że cały kształt zbioru $\boldsymbol{Y}$ poza odcinkiem $\left(\boldsymbol{y}^{-}, \Phi\left(\boldsymbol{y}^{-}, \boldsymbol{Y}\right)\right)$ - do którego redukuje się najmniejszy zbiór $\boldsymbol{Y}^{\prime}$ - nie ma wpływu na rozwiązanie problemu, por. Rys. 13.1.

Przy założeniu tych aksjomatów (oraz wypukłości, domkniętości i niepustości $\boldsymbol{Y})$ Nash udowodnił, że rozwiązanie problemu przetargu jest jednoznacznie określone jak następuje:

$$
\boldsymbol{\Phi}\left(\boldsymbol{y}^{-}, \boldsymbol{Y}\right)=\boldsymbol{y}^{*}=\operatorname{argmax}_{\boldsymbol{y} \in \mathbf{Y}-}\left(y_{1}-y_{1}^{-}\right)\left(y_{2}-y_{2}^{-}\right)
$$

Jest to oczywiście poszukiwanie maksymalnego poziomu podstawowej hiperboli stycznej do zbioru $\boldsymbol{Y}$ (i skoro jest to zbiór wypukły, to rozwiązanie jest oczywiście jednoznaczne); zob. Rys. 13.2. 


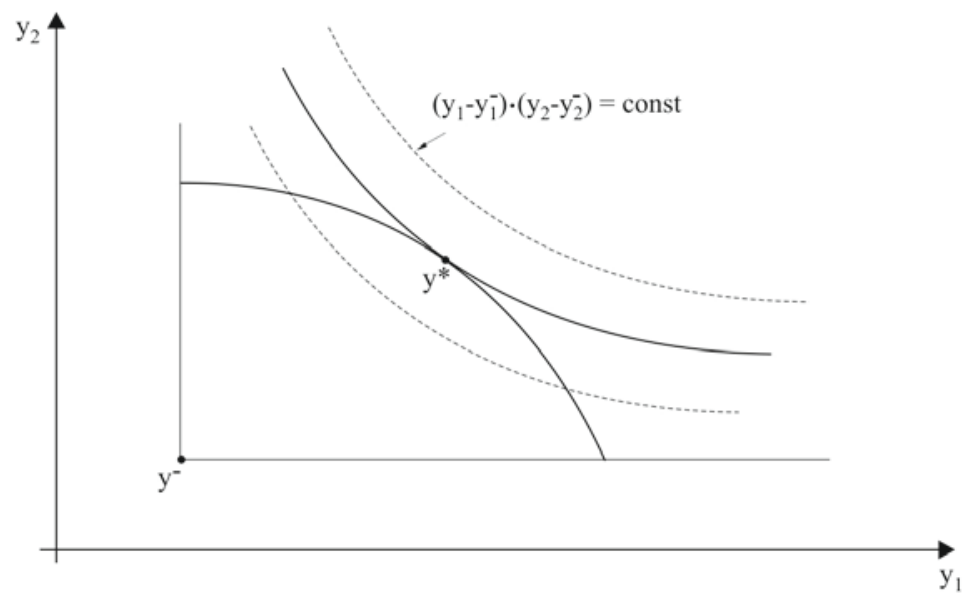

Rys. 13.2. Ilustracja kooperatywnego rozwiązania Nash'a.

Wobec kontrowersyjności aksjomatu A4, rezultat Nasha ma raczej znaczenie teoretyczne. Bardziej praktyczne rozwiązanie problemu targu zaproponował Howard Raiffa; Ehud Kalai i Meir Smorodinsky udowodnili, że rozwiązanie to jest jednoznacznym rozwiązaniem spełniającym aksjomaty A1-A5 $\mathrm{z}$ aksjomatem A4 zastąpionym poprzez aksjomat następujący:

A4' (KS). Indywidualna monotoniczność. Jeśli powiększyć zbiór $\boldsymbol{Y}$ tak, że zwiększeniu ulegnie maksymalny rezultat tylko dla jednego z graczy, na przykład:

$$
\boldsymbol{Y} \subset \boldsymbol{Y}^{\prime} ; \max _{y \in \mathbf{Y}^{-}} y_{1}<\max _{y \in \mathrm{Y}^{-}} y_{1}, \max _{y \in \mathbf{Y}-} y_{2}=\max _{y \in \mathbf{Y}^{-}} y_{2}
$$

to zwiększeniu ulegnie też rezultat kooperatywny przypisany temu graczowi:

$$
\Phi_{1}\left(\boldsymbol{y}^{-}, \boldsymbol{Y}^{\prime}\right)>\Phi_{1}\left(\boldsymbol{y}^{-}, \boldsymbol{Y}^{\prime}\right)
$$

i analogicznie dla drugiego gracza. Zob. ilustrację graficzną tego aksjomatu na Rys. 13.3.

Jeśli oznaczymy:

$$
\boldsymbol{y}_{\text {uto }}=\left(\max _{\boldsymbol{y e Y} \mathbf{Y}} y_{1}, \max _{\boldsymbol{y} \in \mathbf{Y}-} y_{2}\right)
$$

czyli posłużymy się punktem utopijnym dla zbioru $\boldsymbol{Y}$ (por. Rozdz. 6), to rozwiązanie Raiffy-Kalaia-Smorodinsky'ego jest (przy założeniach wypukłości, domkniętości i niepustości zbioru $\boldsymbol{Y}^{\top}$ ) takim rezultatem sprawnym $\boldsymbol{y}^{*} \in \boldsymbol{Y}$, że:

$$
\left(y_{1}^{*}-y_{1}^{-}\right) /\left(y_{2}^{*}-y_{2}^{-}\right)=\left(y_{1, \text { uto }}-y_{1}^{-}\right) /\left(y_{2, \text { uto }}-y_{2}^{-}\right)
$$




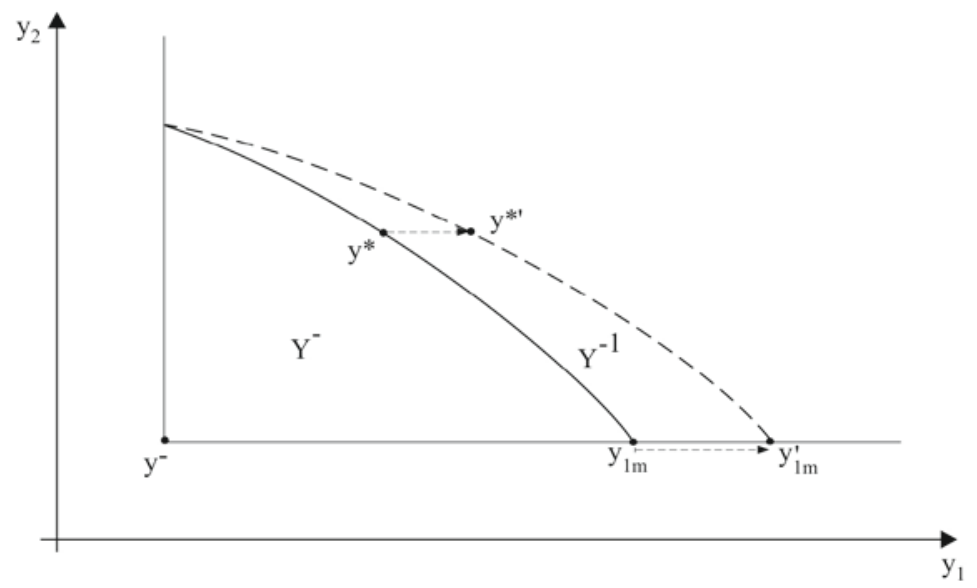

Rys. 13.3. Ilustracja graficzna aksjomatu indywidualnej monotoniczności.

Rozwiązanie to można interpretować jako wynik poszukiwania punktu sprawnego w zbiorze $\boldsymbol{Y}$ na kierunku wyznaczonym przez punkty $\boldsymbol{y}^{-}$oraz $\boldsymbol{y}_{\text {uto }}$ zob. Rys. 13.4.a. Można je jednak także traktować jako rozwiązanie pewnego problemu optymalizacji. Mianowicie, wykorzystamy tu - podobnie jak w Rozdziale 9 - następującą funkcję osiągnięcia:

$$
\sigma\left(\boldsymbol{y}, \boldsymbol{y}^{-}\right)=\min _{i=1,2}\left(y_{i}-y_{i}^{-}\right) /\left(y_{i, u t o}-y_{i}^{-}\right)+\varepsilon \sum_{\mathrm{i}=1,2}\left(y_{i}-y_{i}^{-}\right) /\left(y_{i, u t o}-y_{i}^{-}\right)
$$

gdzie $\varepsilon \geq 0 \$$ jest parametrem o odpowiednio małej wartości. Przypominamy, że w wielokryterialnej optymalizacji punkt odniesienia wcale nie musi być punktem status quo, lecz może być dowolnie wybierany (jako $\boldsymbol{y}^{-} € \boldsymbol{R}^{2}$ ) przez decydenta czy użytkownika systemu wspomagania decyzji. Natomiast w zastosowaniu do rozwiązania kooperatywnego Raiffy-Kalaia-Smorodinsky'ego przyjmujemy punkt status quo jako punkt odniesienia, i okazuje się, że powyższa funkcja osiągnięcia określa to rozwiązanie poprzez swoje maksimum względem $\boldsymbol{y \in} \boldsymbol{Y}$ (jeśli ten zbiór jest wypukły; jeśli nie jest on wypukły, to otrzymujemy uogólnienie tego rozwiązania):

$$
\Phi\left(y^{-}, Y\right)=y^{*}=\operatorname{argmax}_{y \in Y_{-}} \sigma\left(y, y^{-}\right)
$$

przy dostatecznie małych $\varepsilon \geq 0$ (w tym zastosowaniu, przy wypukłym zbiorze $\boldsymbol{Y}$, można faktycznie przyjąć $\varepsilon=0$, zaś stosowanie $\varepsilon>0 \$$ zaleca się przy uogólnieniach, tak jak w ogólniejszych zastosowaniach do optymalizacji 
wielokryterialnej). Zob. Rys. 13.4.b. Uogólnienie (13.7) rozwiązania RaiffyKalaia-Smorodinsky'ego jest przy tym istotne, gdyż w zastosowaniach często zdarzają się niewypukłe zbiory $\boldsymbol{Y}$.

a)

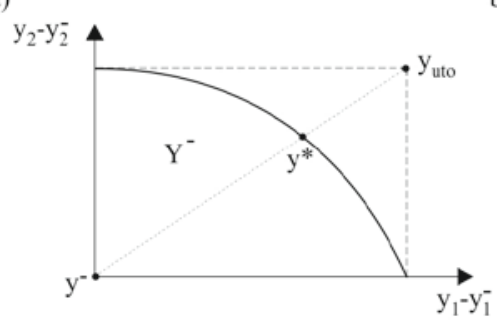

b)

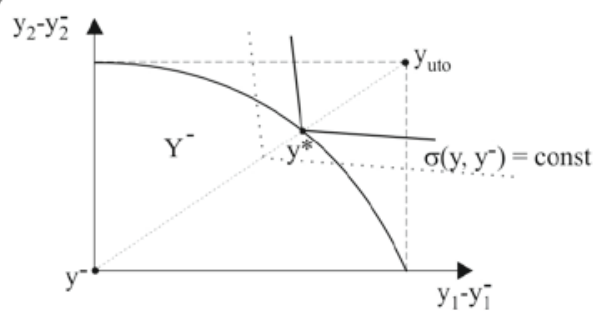

Rys. 13.4. a) Ilustracja rozwiązania Raiffy-Kalaia-Smorodinsky'ego

b) Obliczanie i uogólnienie tego rozwiązania poprzez maksymalizację funkcji osiągnięcia.

Powyższy sposób określania rozwiązania kooperatywnego można z łatwością uogólnić na więcej niż $n=2$ graczy. Nieco trudniejsze jest jego uogólnienie na rozwiązania kooperatywne gier wielokryterialnych, zob. Piotr Bronisz et al. w cytowanej już książce Andrzej Lewandowski et al. (1989).

\subsection{Rozwiązania kooperatywne dla gier w postaci koalicyjnej}

Jeśli jest więcej graczy niż dwóch, to można wprawdzie próbować uogólniać rozwiązania kooperatywne omawiane wyżej, ale zasadniczym problemem staje się określenie takiego rozwiązania, które nie byłoby zagrożone przez koalicję kilku graczy wykluczającą innych. Zagadnienie to można badać przy założeniu, że znane są wartości gwarantowanych wygranych dla każdej możliwej koalicji kilku graczy grających przeciwko innym (np. sumy wygranych dla graczy biorących udział w koalicji, przy założeniu gry przeciwko wszystkim graczom nie biorącym udziału $w$ tej koalicji). Abstrahując od innych cech gry i określając tylko takie wartości wygranych, definiujemy tzw. funkcję charakterystyczną gry w postaci koalicyjnej. 
Niech $\mathscr{P}=\{1, \ldots n\}$ oznacza koalicję wszystkich graczy (czyli rozwiązanie w pełni kooperatywne), natomiast $\mathscr{G} \subset \mathscr{N}^{\mathscr{D}}$ jest jakąkolwiek koalicją mniejszą, w szczególności $\quad G=\{i\}$ oznacza koalicję jednoosobową, czyli samego gracza $i$.

Gra w koalicyjnej postaci strategicznej dana jest przez jej funkcję charakterystyczną $v(\mathcal{G})$ dla wszystkich $\mathcal{G}-$ od $\mathcal{G}=\{i\}, i=1, \ldots n$, poprzez wszystkie koalicje kilkuosobowe $\mathscr{G} \subset \mathscr{P}$ aż do $\mathscr{G}=\mathscr{P}$; koalicji takich może być $2^{n}-1$. Funkcję tę interpretujemy jako gwarantowaną wygraną łączną danej koalicji, maksymalną względem jej własnych decyzji, ale przy założeniu gry przeciwko jakiejkolwiek wersji innych koalicji. Inni gracze mogą np. stworzyć przeciwkoalicję $\mathscr{N} \backslash \mathcal{G}$, grać każdy oddzielnie itp. - a więc $v(\mathcal{G})$ trzeba interpretować jako minimalną wartość wygranej koalicji $\bar{G}$ względem różnych równowag niekooperatywnych wynikających $\mathrm{z}$ tych wersji. Nie jest przy tym gwarantowane, że dla danej gry w postaci normalnej potrafimy dobrze określić funkcję charakterystyczną (bo równowagi mogą być istotnie niejednoznaczne, tak jak w grze w tchórza). Tym niemniej, założenie określonej funkcji charakterystycznej - nawet kosztem pewnych uproszczeń - jest niezbędne dla analizy rozwiązań koalicyjnych gier (inaczej analiza ta, wobec dużej liczby możliwych koalicji, stawała by się niemal niemożliwa).

Funkcję charakterystyczną gry w strategicznej formie koalicyjnej zapisujemy zatem jako:

$$
v(\mathcal{G})=v_{\tau}, \forall \mathcal{G} \subset 2^{\mathscr{R}}
$$

gdzie $2^{\mathscr{P}}$ jest zbiorem wszystkich podzbiorów $\mathscr{N}=\{1, \ldots i, \ldots n\}$. O funkcji tej zwykle zakładamy, że jest superaddytywna, czyli że:

$$
v\left(\mathcal{G} \cup \mathcal{G}^{\prime}\right) \geq v(\mathcal{G})+v\left(\mathcal{G}^{\prime}\right) \text {, jeśli } \mathcal{G}^{\prime} \cap \mathcal{G}^{\prime \prime}=\varnothing
$$

czyli że koalicje nie mogą stracić na możliwości łączenia się. Można wykazać, że jeśli określamy funkcję charakterystyczną gry za pomocą operacji minmax (minimum po innych koalicjach i ich decyzjach, zaś maksimum po własnych decyzjach koalicji) z np. postaci wielomacierzowej gry, to funkcja ta jest superaddytywna; inne sposoby określania tej funkcji nie muszą gwarantować jej superaddytywności. 
Przez dopuszczalny podzial wygranych koalicji (ang. feasible allocation) rozumiemy takie przydziały wygranych $y_{i}, i \in \mathcal{G}$, że:

$$
\Sigma_{i \in \epsilon} y_{i} \leq v(\mathcal{G})
$$

Oczywiście, gracze będą zainteresowani tylko takimi podziałami dopuszczalnymi, które nie mogą być ulepszone, czyli w których we wzorze powyższym zachodzi równość. Podstawowym warunkiem zgody na pełną koalicję graczy $\widetilde{G}=\mathscr{P}$ jest warunek, aby żadna z możliwych podkoalicji nie mogła ulepszyć swego podziału opuszczając koalicję główną, czyli:

$$
\Sigma_{i \in \mathscr{X}} y_{i}=v(\mathscr{D}) \text { oraz } \Sigma_{i \in \tau} y_{i} \geq v(\mathcal{G}) \forall \mathscr{G} \subset \mathscr{D}
$$

przy czym tu może występować nierówność silna w warunku $\Sigma_{i \in \tau} y_{i} \geq v(\mathcal{G})$, gdyż w grze super-addytywnej gracze podkoalicji mogą zyskać wchodząc do koalicji większej. Zbiór wektorów $\boldsymbol{y} \in \boldsymbol{R}^{n}$, których składowe spełniają warunek (3.11), nazywamy rdzeniem gry koalicyjnej (ang. core). Podziały wygranych należące do rdzenia są bardzo atrakcyjnymi kandydatami na rozwiązanie koalicyjne, gdyż:

- wygrane wszystkich graczy są traktowane symetrycznie, a siła przetargowa graczy związana jest tylko z wygranymi podkoalicji, w których mogą wziąć udział;

- wszystkie rezultaty w rdzeniu są osiągalne i sprawne w sensie Pareto w przestrzeni wypłat wszystkich graczy;

- żadnej z podkoalicji nie opłaca się opuszczać koalicji pełnej, jeśli proponowany podział wypłat jest $\mathrm{w}$ rdzeniu gry.

Przykład (patrz Howard Raiffa 1982). Rozważmy trzy firmy, które negocjują połączenie i dyskutują możliwe podziały akcji po połączeniu. Przeprowadziły one staranne badania rynkowe i określiły wartość każdej z firm, każdej z koalicji dwóch firm oraz koalicji pełnej (np. mierzoną przewidywaną wartością sprzedaży produktów każdej z koalicji, w M\$). Przypuśćmy, że wartości te są następujące:

\begin{tabular}{|c|c|c|c|c|c|c|c|c|c|}
\hline$v_{1}$ & $v_{2}$ & $v_{3}$ & $v_{12}$ & $v_{3} \mid v_{12}$ & $v_{13}$ & $v_{2} \mid v_{13}$ & $v_{23}$ & $v_{1} \mid v_{23}$ & $v_{123}$ \\
\hline 32 & 23 & 6 & 59 & 5 & 45 & 22 & 39 & 30 & 77 \\
\hline
\end{tabular}


gdzie, dla dodania realizmu, zacytowaliśmy też wartości $v_{i} \mid v_{j k}$ takie, które firma $i$ uzyskałaby konkurując $\mathrm{z}$ koalicją firm $j$ oraz $k$; przy minimaksowym określaniu wartości gry, te właśnie wartości $v_{i} \mid v_{j k}$ powinniśmy stosować zamiast $v_{i}$. Rdzeń gry określony jest więc przez następujące nierówności:

$$
y_{1} \geq 30, y_{2} \geq 22, y_{3} \geq 5, y_{1}+y_{2} \geq 59, y_{1}+y_{3} \geq 45, y_{2}+y_{3} \geq 39, y_{1}+y_{2}+y_{3}=77
$$

Eliminując zmienną $y_{3}$ na podstawie ostatniej równości, możemy te nierówności wyrazić następująco:

$$
30 \leq y_{1} \leq 38,22 \leq y_{2} \leq 32,59 \leq y_{1}+y_{2} \leq 72
$$

i łatwo sprawdzić, że nierówności te mają rozwiązania - rdzeń gry jest niepusty. Zbiór warunków (13.13) jest wprawdzie łatwiejszy do analizy graficznej (zob. Rys. 13.5), ale może wprowadzać w błąd perspektywy zorientowanej wyłącznie na firmy 1 i 2 . Na przykład, możemy stwierdzić - to przecież jest zadanie wielokryterialnej analizy problemu programowania liniowego, a więc najlepszy, sprawny podział to $y=(38,32,7) \$$. To prawda, ale wyłącznie $\mathrm{z}$ perspektywy firm $1 \mathrm{i} 2$; jeśli włączymy $\mathrm{w}$ to także perspektywę firmy 3, to jest więcej podziałów sprawnych, a podział kompromisowy znajduje się gdzieś w środku rdzenia. Jaki zaś wybrać podział kompromisowy - to właśnie może być przedmiotem negocjacji.

Rdzeń gry może być pusty. Zmodyfikujmy tabelę w powyższym przykładzie następująco:

\begin{tabular}{|c|c|c|c|c|c|c|c|c|c|}
\hline$v_{1}$ & $v_{2}$ & $v_{3}$ & $v_{12}$ & $v_{3} \mid v_{12}$ & $v_{13}$ & $v_{2} \mid v_{13}$ & $v_{23}$ & $v_{1} \mid v_{23}$ & $v_{123}$ \\
\hline 0 & 0 & 0 & 60 & 0 & 56 & 0 & 50 & 0 & 80 \\
\hline
\end{tabular}

Nierówności $y_{1}+y_{2} \geq 60, y_{1}+y_{3} \geq 56, y_{2}+y_{3} \geq 50$ sumują się do $2\left(y_{1}+y_{2}+y_{3}\right) \geq 166$, czyli $y_{1}+y_{2}+y_{3} \geq 83$, podczas gdy pełna koalicja może zapewnić tylko $y_{1}+y_{2}+y_{3}=80$. Ale ta ocena wartości połączonych trzech firm może im wydawać się zbyt ostrożna - firmy mogą mieć nadzieję, że po połączeniu wywalczą sobie jednak większy udział w rynku (wszystko to może np. zależeć od założonych w analizie rynku współczynników elastyczności, patrz wykłady poprzednie). 


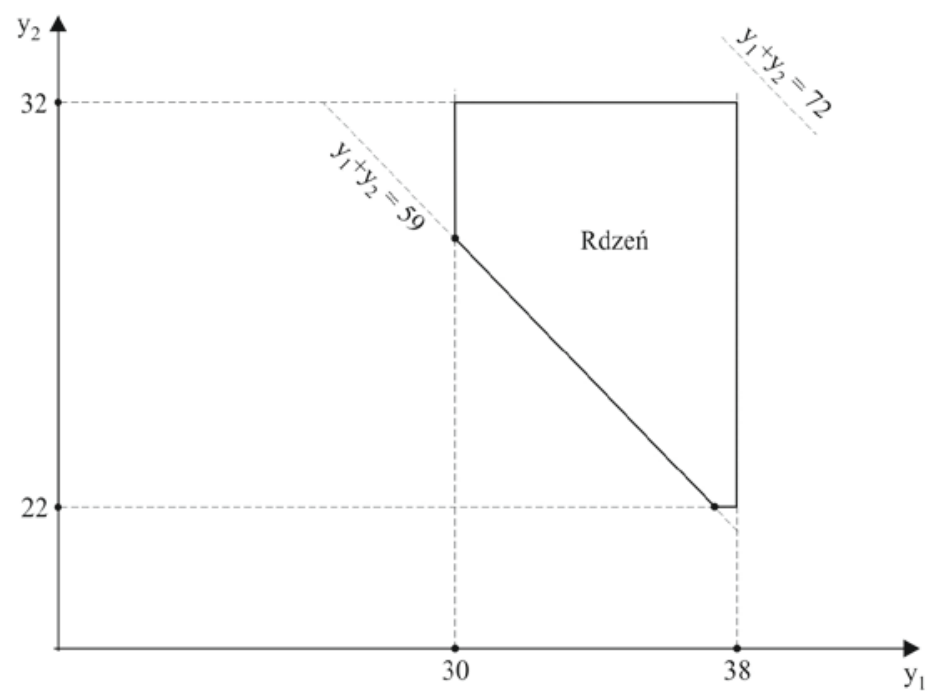

Rys. 13.5. Analiza graficzna trójwymiarowego rdzenia gry na płaszczyźnie.

Jeśli takie czynniki dodatkowe przemawiają za pełną koalicją, to pomimo pustego rdzenia można znaleźć podział wygranych dopuszczalny do akceptacji przez graczy. Rozszerzony $\delta$-rdzeń definiowany jest wtedy tak, jakby pełna koalicja miała dodatkową wartość $\delta$ :

$$
\Sigma_{i \in \mathscr{X}} y_{i}=v(\mathscr{D})+\delta \text { oraz } \Sigma_{i \in \tau} y_{i} \geq v(\mathcal{G}) \forall \mathscr{G} \subset \mathscr{N}
$$

gdzie wartość zmiennej pomocniczej $\delta$ może być dobrana jako taka jej najmniejsza wartość, która zapewni niepusty rdzeń (który staje się wtedy często jednym tylko punktem). Ponieważ tak obliczony podział wygranych jest zazwyczaj niedopuszczalny dla gry $\mathrm{w}$ pierwotnym sformułowaniu, można go potraktować jako swoisty punkt aspiracji i znaleźć bliski mu punkt w zbiorze określonym przez $\Sigma_{i \in \mathfrak{X}} y_{i}=v(\mathscr{D})$.

W teorii gier koalicyjnych zwraca się też uwagę na fakt, że rozwiązania w rdzeniu - nawet jeśli jest niepusty - mogą faworyzować graczy w pewnym sensie silniejszych. Dlatego też wprowadza się pojęcie $\varepsilon$-rdzenia, w pewnym sensie dualne do $\delta$-rdzenia:

$$
\Sigma_{i \in \mathscr{X}} y_{i}=v(\mathscr{N}) \text { oraz } \Sigma_{i \in \tau} y_{i} \geq v(\mathcal{G})-\varepsilon|\mathcal{G}|, \forall \widetilde{G} \subset \mathscr{N}
$$


gdzie $|\mathcal{G}|$ jest liczebnością koalicji C. Oznacza to, że żadna z podkoalicji nie może zaoferować graczom podziału wypłat lepszego o $\varepsilon$ dla każdego gracza, niż uzyskiwany $\mathrm{w} \varepsilon$-rdzeniu. Jeśli rdzeń jest pusty, to znów możemy obliczać najmniejsze $\varepsilon$ zapewniające niepusty $\varepsilon$-rdzeń. Zaletą $\varepsilon$-rdzenia jest obliczanie za jego pomocą podziału wypłat, który jest dopuszczalny dla gry pierwotnej bez żadnych modyfikacji. Odmianą $\varepsilon$-rdzenia jest względny $\varepsilon$-rdzeń, gdzie zakładamy, że żadna z koalicji nie może zaoferować graczom wypłat o $\varepsilon \%$ większych, niż uzyskiwane we względnym $\varepsilon$-rdzeniu, który definiowany jest wobec tego jako zbiór takich wektorów $\boldsymbol{y} \in \boldsymbol{R}^{n}$, których składowe spełniają warunki:

$$
\Sigma_{i \in \mathscr{X}} y_{i}=v(\mathscr{N}) \text { oraz } \Sigma_{i \in \tau} y_{i} \geq v(\mathcal{G})(1-\varepsilon / 100), \forall \tau \subset \mathscr{P}
$$

W negocjacjach koalicyjnych istotne jest często pojęcie synergii wnoszonej przez poszczególnych graczy do różnych koalicji: dołączenie danego gracza do jakiejś koalicji ma tym większe znaczenie, im większy on wnosi przyrost funkcji charakterystycznej. Synergię danego gracza $i$ względem koalicji $\mathcal{G}, i \neg \epsilon \mathcal{G}$, określamy zatem jako

$$
S_{i}(v, \mathcal{G})=v(\mathcal{G} \cup\{i\})-v(\mathcal{G})
$$

Wartość synergii może być wykorzystana do obliczenia jeszcze innego dopuszczalnego podziału rezultatów pomiędzy graczy. Załóżmy, że rozpatrzymy wszystkie możliwe synergie przy przypadkowych kolejnościach tworzenia koalicji, a ich współczynniki wagi określimy kombinatorycznie - jako prawdopodobieństwo tego, że przy przypadkowym uporządkowaniu graczy dany gracz $i$ znajduje się zaraz za koalicją $\mathcal{G}$, wynoszące: $|\mathcal{G}| !(n-|\mathcal{G}|-1) ! / n !$, gdzie $n=|\mathscr{P}|$. Tak obliczony przydział wygranej dla każdego gracza $i$ (zależny od całej funkcji charakterystycznej v) nazywamy wartością (Lloyda) Shapleya:

$$
\Phi(\boldsymbol{v})=\boldsymbol{y}^{S}=\left(y_{1}^{S}, \ldots y_{n}^{S}\right) ; \Phi_{i}(\boldsymbol{v})=y_{i}^{S}=\sum_{\boldsymbol{\tau} \subseteq \boldsymbol{\tau}(i)} S_{i}(\boldsymbol{v}, \boldsymbol{\tau})|\boldsymbol{T}| !(n-|\boldsymbol{G}|-1) ! / n !
$$

gdzie $\boldsymbol{G}(i)=\mathscr{P}\{i\}, n=|\mathscr{P}|$, oraz $\mathrm{w}$ obliczeniu należy uwzględniać też koalicje puste $\left(\mathrm{z} S_{i}(v, \varnothing)=v(\{i\})\right.$ oraz $\left.|\varnothing|=0,|\varnothing| !=1\right)$. 
Wartość Shapleya była przez jej autora (Lloyd Shapley 1953) uzasadniona w sposób aksjomatyczny, ale jej znaczenie praktyczne jest mniejsze, niż rdzenia czy $\varepsilon$-rdzenia. Łatwo wprawdzie sprawdzić, że dla superaddytywnej funkcji charakterystycznej wartość Shapleya jest indywidualnie racjonalna, $\Phi_{i}(v) \geq v(\{i\})$, ale może ona nie być elementem rdzenia nawet w przypadku, gdy jest on niepusty ${ }^{2}$; zatem rozmaitym podkoalicjom może się opłacać opuszczać koalicję pełną, jeśli ta umówi się o podziale wypłat według wartości Shapleya. Wartość Shapleya może być jednak użyta jako argument $\mathrm{w}$ negocjacjach, gdyż charakteryzuje ona $\mathrm{w}$ pewnym sensie średniq wartość danego gracza przy tworzeniu koalicji. Można więc, w przypadku niepustego rdzenia, obliczać wartość Shapleya, a następnie starać się znaleźć dopuszczalny podział wygranych zawarty w rdzeniu oraz najbliższy wartości Shapleya.

Proponowano też różne modyfikacje wartości Shapley'a, np. wartość (Johna) Banzhafa (średnią wartość synergii przy równomiernym rozkładzie, zob. np. Wierzbicki 2006):

$$
\boldsymbol{y}^{B}=\left(y^{B}{ }_{1}, \ldots y^{B}{ }_{n}\right) ; y^{B}{ }_{i}=\left(1 / 2^{n-1}\right) \sum_{\boldsymbol{\tau} \subseteq \boldsymbol{\tau}(i)} S_{i}(\boldsymbol{v}, \boldsymbol{\tau})
$$

Ponieważ w zastosowaniach nie możemy być pewni, że wartość Shapleya czy Banzhafa należy do rdzenia, przeto wartości te należy raczej traktować jako punkty odniesienia dla analizy gry koalicyjnej. Należy zatem najpierw sprawdzić, czy rdzeń jest niepusty, a jeśli jest pusty, to zastosować wybrane rozszerzenie pojęcia rdzenia. Jeśli rdzeń jest niepusty, to można przeprowadzić jego wielokryterialną analizę: obliczyć najpierw jego punkt utopijny $y^{u}$ i punkt nadiru $y^{l}$ :

$$
\boldsymbol{y}^{u}=\left(y_{1}^{u}, \ldots y_{n}^{u}\right), y_{i}^{u}=v(\mathscr{\mathfrak { X }})-v\left(\mathcal{G}_{i}\right) \cdot \boldsymbol{y}^{l}=\left(y_{1}^{l}, \ldots y_{n}^{l}\right), y_{i}^{l}=v(\{i\})
$$

które łącznie określają neutralny punkt odniesienia:

$$
y^{n}=\left(y^{l}+y^{u}\right) / 2
$$

${ }^{2}$ Wartość Shapleya jest elementem rdzenia przy dodatkowym założeniu, że gra koalicyjna jest wypukła, co w praktyce często nie jest spełnione, zob. np. (Wierzbicki 2006). 
Dla wybranego punktu odniesienia $\boldsymbol{y}^{-}$można następnie szukać rozwiązań sprawnych $\mathrm{w}$ rdzeniu poprzez maksymalizację funkcji osiągnięcia $\sigma\left(\boldsymbol{y}, \boldsymbol{y}^{-}\right)$, stosując jako $\boldsymbol{y}^{-}$bądź to $\boldsymbol{y}^{S}$, bądź $\boldsymbol{y}^{B}$, czy też $\boldsymbol{y}^{n}$.

Ćwiczenie 13.1: Dla podanego wyżej przykładu z niepustym rdzeniem obliczyć wartości Shapleya, Banzhafa, sprawdzić, czy wartości te należą do rdzenia, a jeśli nie należą, to znaleźć punkty w rdzeniu najbliższe do tych wartości. Dla porównania obliczyć punkty utopijny, nadiru, oraz neutralny punkt odniesienia i wykonać podobne sprawdzenie.

Ćwiczenie 13.2: Dla podanego wyżej przykładu z pustym rdzeniem obliczyć $\delta$-rdzeń, $\varepsilon$-rdzeń oraz względny $\varepsilon$-rdzeń.

\section{Literatura}

Banzhaf J.F. (1965) Weighted voting doesn't work: A mathematical analysis. Rutgers Law Review, 19 (2): 317-343

Bronisz P., Kruś L., Wierzbicki A.P. (1989) Towards interactive solutions in a bargaining problem. In: A. Lewandowski, A.P. Wierzbicki (eds.) AspirationBased Decision Support Systems. Lecture Notes in Economics and Mathematical Systems Vol. 331. Springer-Verlag, Berlin-Heidelberg

Lewandowski A., Wierzbicki A.P., eds. (1989) Aspiration Based Decision Support Systems, Lecture Notes in Economic and Mathematical Systems 331, Springer Verlag, Berlin-Heidelberg

Kalai E., Smorodinsky M. Other solutions to Nash's bargaining problem. Econometrica. 43, 1975, pp. 513-518.

Myerson R.B. (1991) Game Theory - Analysis of Conflict. Harvard University Press, Cambridge Mass.

Raiffa H. (1982) The Art and Science of Negotiations. Harvard University Press, Cambridge Mass.

Shapley L.S. (1953) "A value of n-person games” Annals of Mathematical Studies 28 pp. 307-318

Wierzbicki A.P. (2006) A reference point approach to coalition games. Journal of Multi-Criteria Decision Analysis 13 (2-3): 81-89

Zimmermann H.J., Gutsche L. (1991) Multi-Criteria Analyse. Springer-Verlag, Berlin-Heidelberg 
V. Wspomaganie Decyzji Grupowych 



\section{Techniki podziału zasobów oraz kosztów}

Rozdział ten oraz następny przedstawiają problem wspomagania decyzji grupowych - w wielkim skrócie, gdyż jest to przedmiot wielu monografii ujmujących zagadnienia decyzji grupowych z różnorodnych punktów widzenia. Po krótkim wprowadzeniu, omówione są przeglądowo najpierw zagadnienia podziału zasobów, następnie zagadnienia podziału kosztów.

\subsection{Wprowadzenie}

Potrzeba wspomagania decyzji grupowych pojawia się bardzo często $\mathrm{w}$ praktyce - czy to w związku $\mathrm{z}$ dążeniem do kompromisu w sytuacji konfliktowej, czy też w związku z istotnie grupowym charakterem sytuacji decyzyjnej, nie pozwalającej praktycznie na decyzje indywidualne każdego uczestnika grupy (tak, jak to zachodzi przy podziale wspólnej dotacji budżetowej). W sytuacjach takich można niekiedy zastosować techniki wynikające $\mathrm{z}$ kooperatywnej teorii gier, omówione w rozdziale poprzednim. Jest jednak bardzo wiele zagadnień szczególnych, wymagających specjalnych technik we wspomaganiu decyzji grupowych, a także problemów wykraczających poza format kooperatywnej teorii gier - choćby dlatego, że wiele praktycznych sytuacji decyzyjnych wymaga ocen wielokryterialnych, nie da się sprowadzić do maksymalizacji wygranej czy funkcji użyteczności.

Do zagadnień szczególnych, pojawiających się często w praktyce decyzji grupowych, należą zagadnienia podziału zasobów (czyli np. podziału majątku w spadku) oraz podziału kosztów (lub dokładniej, przypisania kosztów poszczególnym uczestnikom grupy, ang. cost allocation). Teoretycznie, zarówno przy podziale zasobów jak i kosztów moglibyśmy odwołać się do kooperatywnej teorii gier, ale zagadnienia podziału mają swoją specyfikę i warto ją wykorzystać. Problemy wykraczające poza format 
kooperatywnej teorii gier to, przede wszystkim, problemy wyboru grupowego lub inaczej techniki głosowania w grupie, a następnie cała obszerna problematyka wielokryterialnych ocen grupowych oraz rankingu; omawiane są one w następnym rozdziale. Każda $\mathrm{z}$ wymienionych tu pięciu grup problemów była przedmiotem długoletnich studiów (najdłużej chyba techniki głosowania, których teoria datuje się od ok. 1770 roku) oraz licznych monografii. W tym rozdziale zarysujemy w wielkim skrócie podstawowe wyniki związane z pierwszymi dwiema grupami problemów.

Decyzje grupowe są bardzo często też przedmiotem negocjacji, i wszystkie omawiane tu techniki są też pomocne jako techniki wspomagania negocjacji choć często wspomaganie takie sprowadza się po prostu do wiedzy, jakie to techniki mogą być przydatne w danej sytuacji negocjacyjnej czy decyzyjnej.

\subsection{Zagadnienia podziału zasobów}

Zagadnienia podziału zasobów są bardzo często przedmiotem decyzji grupowych lub negocjacji. Opierają się one zazwyczaj na wybranych zasadach sprawiedliwego podziału - które mogą być różnorodne, jak to wynika z dyskusji aksjomatów racjonalności określenia rozwiązania kooperatywnego gry przedstawionej w rozdziale poprzednim.

Do typowo akceptowanych zasad sprawiedliwego podziału zalicza się poszanowanie status quo i indywidualną racjonalność - to jest rozważanie przyrostów ponad pewien punkt odniesienia, który uważa się za dany. Zasadą sprawiedliwego podziału jest też symetria, choć zasada ta może być odpowiednio modyfikowana. Na przykład, przy zagadnieniu podziału spadku, zgodnie z prawem większości państw jest on dzielony na odpowiednie części zależne od stopnia pokrewieństwa. Często też wymaga się sprawności, czyli podziału całości zasobów czy kosztów. Natomiast niezależność od skali użyteczności ma już swoje odmiany. Chociaż większość zagadnień podziału dotyczy zasobów o wymiernych wartościach pieniężnych, to jednak mogą one być inaczej szacowane przez uczestników podziału - co jest zazwyczaj główną przyczyną negocjacji zagadnień podziału i różnorodnych stosowanych w niej technik, zwanych procedurami podziału. 
Oczywiście, mogą też być różne warianty bardziej dyskusyjnych aksjomatów racjonalności, typu niezależności od opcji nieistotnych czy indywidualnej monotoniczności. Najczęściej przyjmowanymi wymaganiami dodatkowymi są niezależność od zniekształceń strategicznych, czyli od prób manipulacji wyników przez podawanie nieprawdziwych danych np. dotyczących oceny przedmiotów do podziału (która to niezależność może mieć różne stopnie, co omówimy dalej) oraz dostateczna prostota i wynikająca z niej przejrzystość procedury. Jeśli bowiem uczestnicy nie mogą ogarnąc mentalnie zasad procedury, to mogą obawiać się rożnych manipulacji - których znaną formą jest tzw. manipulacja agendowa, czyli taki wybór procedury i jej szczegółów, aby faworyzować jedną ze stron.

Zagadnienia podziału zasobów, występujące np. przy podziale spadków, są zazwyczaj nieco łatwiejsze niż zagadnienia podziału kosztów. Oba typy podziału mają wiele problemów szczegółowych i technik, którym poświęcono często całe książki - patrz np. Peyton Young (1984), Howard Raiffa (1982).

Rozważania oprzemy na prostym przykładzie, cytowanym według Raiffy (1982). W postępowaniu spadkowym uczestniczą trzy osoby (numerowane $1,2,3)$ o jednakowych prawach ${ }^{1}$. Do podziału są 4 przedmioty, oznaczone A, B, C, D. Który przedmiot powinien przypaść któremu ze spadkobierców, i jakie należy wyznaczyć opłaty wyrównawcze? Oczywiście, powinno to zależeć od wyceny poszczególnych przedmiotów - ale każdy ze spadkobierców może podać własną wycenę. Przypuśćmy, że wyceny te są następujące:

\begin{tabular}{|c|c|c|c|}
\hline \multicolumn{4}{|c|}{ Wycena poszczególnych spadkobierców (w zł) } \\
\hline Przedmiot & Spadkobierca 1 & Spadkobierca 2 & Spadkobierca 3 \\
\hline A & 250000 & 100000 & 175000 \\
\hline B & 50000 & 25000 & 100000 \\
\hline C & 12500 & 37500 & 50000 \\
\hline D & 20000 & 50000 & 25000 \\
\hline
\end{tabular}

1 Co jest oczywistym uproszczeniem, zakładającym że wszyscy spadkobiercy pozostawali w jednakowym stopniu spokrewnieni ze spadkodawcą. Ogólniej, każdy spadkobierca może mieć prawa do określonej części spadku: np. w Polsce (a także np. w Massachussetts) wdowa ma prawo do $50 \%$ spadku po mężu, dzieci dzielą pozostałe $50 \%$ na równe części, jeśli jedno z dzieci nie żyje, to jego część dzieli się na jego spadkobierców, itd. Techniki podziału dyskutowane w tym punkcie można jednak łatwo uogólnić na przypadek określonych a nierównych części podziału spadku. 
Określenie, komu przydzielić który z przedmiotów, jest dość proste: temu, kto go najwyżej wycenił, a jeśli jest kilku takich, to albo pierwszemu z nich na liście, albo przypadkowo jednemu $\mathrm{z}$ nich. Można też przydzielać przedmioty przypadkowo wszystkim spadkobiercom z prawem wystawienia tych przedmiotów na przetarg wśród pozostałych spadkobierców (i własnego uczestnictwa w tym przetargu). Procedura taka nie wymaga wyceny przedmiotów a priori przez wszystkich spadkobierców.

Trudniej określić opłaty wyrównawcze. Howard Raiffa wymienia cztery procedury określania takich wypłat:

1) Procedura naiwna: każdy spadkobierca wpłaca do wspólnej puli tyle, na ile wycenił przedmiot mu przyznany, następnie dzieli się tę pulę na równe części i odejmuje wartości przedmiotów przyznanych. Wyniki takiej procedury $\mathrm{w}$ omawianym wyżej przykładzie są przedstawione Iw następnej tabeli. Wadą procedury naiwnej jest oczywiście fakt, że zachęca ona do zniekształceń strategicznych - a więc można w jej wyniku znaleźć się w posiadaniu przedmiotów, których się nie chciało.

\begin{tabular}{|c|c|c|c|c|}
\hline \multicolumn{5}{|c|}{ Wyniki procedury naiwnej (w zł) } \\
\hline Przedmiot & Spadkobierca 1 & Spadkobierca 2 & Spadkobierca 3 & Razem \\
\hline Wycena A & 250000 & 100000 & 175000 & \\
\hline Wycena B & 50000 & 25000 & 100000 & \\
\hline Wycena C & 12500 & 37500 & 50000 & \\
\hline Wycena D & 20000 & 50000 & 25000 & \\
\hline $\begin{array}{c}\text { Przedmioty } \\
\text { otrzymane }\end{array}$ & $\mathrm{A}$ & $\mathrm{D}$ & $\mathrm{B}, \mathrm{C}$ & \\
\hline $\begin{array}{c}\text { Wartość } \\
\text { uzyskana }\end{array}$ & 250000 & 50000 & 150000 & 450000 \\
\hline $\begin{array}{c}\text { Udział } \\
\text { uzasadniony }\end{array}$ & 150000 & 150000 & 150000 & 450000 \\
\hline $\begin{array}{c}\text { Wypłata } \\
\text { uzupełniająca }\end{array}$ & -100000 & +100000 & 0 & 0 \\
\hline $\begin{array}{c}\text { Wynik } \\
\text { końcowy }\end{array}$ & $\mathrm{A}-100000$ & $\mathrm{D}+100000$ & $\mathrm{~B}, \mathrm{C}$ & \\
\hline
\end{tabular}

2) Procedura przetargowa: zamiast a priori dokonywać wyceny przedmiotów, dokonuje się przetargu na zakup tych przedmiotów przez spadkobierców, zaś sumy uzyskane podczas przetargu dzieli się pomiędzy 
spadkobierców. W takiej procedurze, o wartości danego przedmiotu decyduje nie jego wycena największa, lecz druga $\mathrm{z}$ kolei (gdyż tyle w przybliżeniu musi zapłacić spadkobierca oceniający ten przedmiot najwyżej, aby go kupić). Rezultaty takiej procedury ilustruje poniższa tabela. Widzimy w niej, że wartość uzyskana netto nie jest przy tym równa dla wszystkich spadkobierców - ale o tym nie wiadomo $w$ tej procedurze, gdyż spadkobiercy nie podają $\mathrm{w}$ niej wycen a priori, tylko biorą udział w przetargu. W sensie proceduralnym, metoda przetargowa jest bardziej sprawiedliwa, niż procedura naiwna: wszyscy mają jednakowe szanse, a procedura nie zachęca do zniekształceń strategicznych.

\begin{tabular}{|c|c|c|c|c|}
\hline \multicolumn{5}{|c|}{ Wyniki procedury przetargowej (w zł) } \\
\hline Przedmiot & Spadkobierca 1 & Spadkobierca 2 & Spadkobierca 3 & Razem \\
\hline Wycena A & 250000 & 100000 & 175000 & \\
\hline Wycena B & 50000 & 25000 & 100000 & \\
\hline Wycena C & 12500 & 37500 & 50000 & \\
\hline Wycena D & 20000 & 50000 & 25000 & \\
\hline $\begin{array}{l}\text { Przedmioty } \\
\text { otrzymane }\end{array}$ & A & $\mathrm{D}$ & $\mathrm{B}, \mathrm{C}$ & \\
\hline $\begin{array}{l}\text { Wartość } \\
\text { uzyskana }\end{array}$ & 250000 & 50000 & 150000 & 450000 \\
\hline $\begin{array}{c}\text { Cena } \\
\text { zapłacona }\end{array}$ & 175000 & 25000 & 87500 & 287500 \\
\hline $\begin{array}{c}\text { Udział w puli } \\
\text { wypłat }\end{array}$ & 95833 & 95833 & 95833 & 287500 \\
\hline $\begin{array}{c}\text { Cena } \\
\text { zapłacona netto }\end{array}$ & 79167 & - 70833 & -8333 & 0 \\
\hline $\begin{array}{c}\text { Wartość } \\
\text { uzyskana netto }\end{array}$ & 170833 & 120833 & 158333 & 450000 \\
\hline $\begin{array}{l}\text { Wynik } \\
\text { końcowy }\end{array}$ & A - 79167 & $\mathrm{D}+70833$ & $\mathrm{~B}, \mathrm{C}+8333$ & A, B, C \\
\hline
\end{tabular}

\section{3) Procedura przydziału losowego $\mathrm{z}$ przetargiem uzupełniającym:}

po losowym przydziale początkowej własności, spadkobiercy mogą urządzić przetarg uzupełniający (zakładamy przy tym, że prawidłowo oceniają oni możliwości uzyskania lepszej ceny w takim przetargu). Wyniki mogą być 
następujące: jeśli przypadkiem przedmiot trafił do spadkobiercy, którego wycena tego przedmiotu jest najwyższa, to zachowuje on ten przedmiot. Jeśli nie, to sprzedaje go na przetargu - zatem nie za cenę najwyższą, a drugą z kolei, zachowując dla siebie tę zapłatę. Kupuje też od innych spadkobierców przedmioty, za które gotów jest zapłacić cenę najwyższą, płacąc oczywiście też cenę drugą z kolei. Wyniki w sensie wartości oczekiwanych uzyskanych przedmiotów i wypłat są podane $\mathrm{w}$ poniższej tabeli. Wynika $\mathrm{z}$ niej, że procedura losowa $\mathrm{z}$ przetargiem daje taki sam rezultat $\mathrm{w}$ sensie wartości oczekiwanych, jak procedura przetargowa bez początkowego losowego przydziału własności. Przewagą procedury przetargowej nad losową z przetargiem uzupełniającym jest fakt, że nie mogą $\mathrm{w}$ niej wystąpić losowe korzyści którejś ze stron (gdyż jednakowy wynik w sensie wartości oczekiwanych bynajmniej nie oznacza jednakowych wyników konkretnych realizacji procesu losowego).

\begin{tabular}{|c|c|c|c|c|}
\hline \multicolumn{5}{|c|}{ Wyniki procedury przetargowej (w zł) } \\
\hline Przedmiot & Spadkobierca 1 & Spadkobierca 2 & Spadkobierca 3 & Razem \\
\hline Wycena A & 250000 & 100000 & 175000 & \\
\hline Wycena B & 50000 & 25000 & 100000 & \\
\hline Wycena C & 12500 & 37500 & 50000 & \\
\hline Wycena D & 20000 & 50000 & 25000 & \\
\hline $\begin{array}{c}\text { Przedmioty } \\
\text { uzyskane }\end{array}$ & A & D & B, C & \\
\hline $\begin{array}{c}\text { Wartość tych } \\
\text { przedmiotów }\end{array}$ & 250000 & 50000 & 150000 & 450000 \\
\hline $\begin{array}{c}\text { Wartość } \\
\text { uzyskana } \\
\text { z przetargów }\end{array}$ & $112500 / 3$ & $262500 / 3$ & $200000 / 3$ & 575000 \\
\hline $\begin{array}{c}\text { Cena } \\
\text { zapłacona } \\
\text { na przetargach }\end{array}$ & $2 * 175000 / 3$ & $2 * 25000 / 3$ & $2 * 87500 / 3$ & $575000 / 3$ \\
\hline $\begin{array}{c}\text { Wartość } \\
\text { uzyskana netto }\end{array}$ & 170833 & 120833 & 158333 & 450000 \\
\hline $\begin{array}{c}\text { Wynik } \\
\text { końcowy }\end{array}$ & A - 79 167 & D + 70 833 & B, C + 8 333 & A, B, C \\
\hline
\end{tabular}


4) Procedura Steinhausa. Polski matematyk Hugo Steinhaus zaproponował szereg procedur sprawiedliwego podziału. $^{2}$ Procedura Steinhausa tu omawiana dotyczy przypadku, gdy każdy ze spadkobierców dokona wyceny a priori przedmiotów spadku, i trzeba jak najlepiej wykorzystać tę informację. Przedmioty spadku przydziela się, jak w innych procedurach, spadkobiercom oceniającym je najwyżej; ale bierze się pod uwagę fakt, że każdy spadkobierca inaczej mógł ocenić łączną wartość spadku, a więc wyznaczył właściwy sobie początkowy udział zasadny - czyli swoją ocenę wartości spadku podzieloną przez liczbę spadkobierców. Od wartości przydzielonych mu przedmiotów odejmuje się jego początkowy udział zasadny, określając właściwy mu nadmiar; wynik może być ujemny lub dodatni, ale można udowodnić, że przy różnorodnych ocenach suma takich nadmiarów jest zawsze dodatnia (zerowa przy jednakowych ocenach). Suma nadmiarów dzielona przez liczbę spadkobierców określa nieujemną korektę początkowych udziałów zasadnych; tak obliczone końcowe udziały zasadne są podstawą określenia wypłat uzupełniających. W rozważanym tu przykładzie uzyskujemy rezultaty przedstawione w poniższej tabeli.

Oczywiście, trudno przy tym wybierać procedurę podziału tylko na tej podstawie, że każda z nich daje większe korzyści konkretnemu spadkobiercy. $\mathrm{Z}$ przedstawionych wyżej metod podziału procedura przetargowa wymaga najmniej informacji wstępnej, ale wymaga za to zorganizowania przetargu; dominuje natomiast nad procedurą przetargową ze wstępnym przydziałem losowym (bo nie wymaga uśrednienia statystycznego wyników). Przy większej informacji wstępnej - pełnej wycenie a priori - i braku czasu na organizację przetargu lepszą jest procedura Steinhausa, która wprawdzie nie

\footnotetext{
${ }^{2}$ M.in. uogólnienie prostej procedury podziału ciastka - jeden dzieli, drugi wybiera na przypadek podziału tortu przez wielu osób. Jeden z uczestników podziału wycina sobie kawałek tortu i przedstawia do inspekcji innym. Każdy ma prawo zmniejszyć ten kawałek tortu, ale tak zmniejszony kawałek przypada temu, kto go ostatni dotknął nożem (jeśli nikt nie dokona dalszych poprawek). W ten sposób kolejne osoby dostają po kawałku tortu, aż zostają tylko dwie; wówczas jedna dzieli, a druga wybiera. Hugo Steinhaus był też autorem słynnej odpowiedzi na prośbę, aby usprawiedliwił swoje nieobecności na zebraniach PAN, na które z zasady nie uczęszczał: „usprawiedliwię moją nieobecność, jeśli inni usprawiedliwią swoją obecność”.
} 
zabezpiecza całkiem przed zniekształceniami strategicznymi danych, ale też do nich nie zachęca. ${ }^{3}$

\begin{tabular}{|c|c|c|c|c|}
\hline \multicolumn{5}{|c|}{ Wyniki procedury Steinhausa (w zł) } \\
\hline Przedmiot & Spadkobierca 1 & Spadkobierca 2 & Spadkobierca 3 & Razem \\
\hline Wycena A & 250000 & 100000 & 175000 & \\
\hline Wycena B & 50000 & 25000 & 100000 & \\
\hline Wycena C & 12500 & 37500 & 50000 & \\
\hline Wycena D & 20000 & 50000 & 25000 & \\
\hline $\begin{array}{c}\text { Łączna wycena } \\
\text { wartości }\end{array}$ & 332500 & 212500 & 350000 & \\
\hline $\begin{array}{c}\text { Początkowy } \\
\text { udział zasadny }\end{array}$ & 110833 & 70833 & 116667 & \\
\hline $\begin{array}{c}\text { Przedmioty } \\
\text { uzyskane }\end{array}$ & A & D & B, C & 450000 \\
\hline $\begin{array}{c}\text { Wartość tych } \\
\text { przedmiotów }\end{array}$ & 250000 & 50000 & 150000 & 151667 \\
\hline $\begin{array}{c}\text { Nadmiar } \\
\text { uzyskany }\end{array}$ & 139167 & -20833 & 33333 & 450000 \\
\hline $\begin{array}{c}\text { Końcowy } \\
\text { udział zasadny }\end{array}$ & 161389 & 121389 & 167222 & A, B, C \\
\hline $\begin{array}{c}\text { Wynik } \\
\text { końcowy }\end{array}$ & A - 88 611 & D + 71 389 & B, C + 17 222 & \\
\hline
\end{tabular}

Jako podejście praktyczne można zalecić procedurę Steinhausa w przypadkach o niezbyt uwypuklonych konfliktach interesów oraz procedurę przetargową przy wyraźnie zarysowanych konfliktach interesów (gdyż jest ona przejrzysta i nie może budzić wątpliwości co do jej sprawiedliwych założeń).

\subsection{Techniki podziału kosztów}

Problem podziału kosztów jest psychologicznie trudniejszy od problemu podziału zasobów, bardziej skłaniający uczestników do zniekształceń strategicznych - co jest zresztą zgodne $\mathrm{z}$ badaniami nad psychologią

\footnotetext{
${ }^{3}$ Można udowodnić, że w procedurze Steinhausa wyceny zgodne z prawdziwymi odczuciami są najlepszym postępowaniem w przypadku ostrożnego, minimaksowego podejścia graczy.
} 
wspomagania decyzji, zob. np. Amos Tversky et al. (1974). Częścią tego problemu jest bowiem określenie gotowości do opłaty za dobro publiczne, co jest zawsze problemem bardzo trudnym.

Chociaż zagadnieniami technik głosowania zajmiemy się bardziej szczegółowo w następnym rozdziale, to jednak rozpatrzmy tutaj, jako przykład trudności problemu opłaty za dobro publiczne, głosowanie - w ramach zespołu czy komitetu, mającego pełnomocnictwo do dysponowania pieniędzmi - nad sumą, którą należy przyznać na dane przedsięwzięcie czy projekt o charakterze dobra publicznego. Przypuśćmy, że celem orientacji wstępnej każdy z członków komitetu ma podać sumę finansowania projektu, którą uważa za zasadną. Jaki przyjąć sposób agregacji tych wyników głosowania - czy zwykłe uśrednianie?

Agregacja przez zwykłe uśrednianie skłania do zniekształceń strategicznych. Członek tego komitetu, przekonany o słuszności finansowania projektu, wie że ma w komitecie przeciwników, więc będzie zawyżał podaną sumę; przeciwnicy finansowania projektu będą zaniżać podaną sumę. Zatem im kto bardziej zniekształci swój głos, tym większy ma wpływ na wynik. ${ }^{4}$

Trzeba jednak wiedzieć, że $\mathrm{w}$ tym prostym problemie istnieje procedura agregacji, sktaniajaca do prawdomówności, a mianowicie - obliczanie rezultatu głosowania jako mediany jego rozkładu. Oznacza to, że jeśli jest nieparzysta liczba głosujących, to rezultatem głosowania jest "środkowy" głos (po uporządkowaniu głosów według podanych w nich sum uważanych za uzasadnione); przy parzystej liczbie głosujących rezultatem jest średnia arytmetyczna dwóch głosów "środkowych". Zauważmy, że głosy krańcowe nie mają wpływu na wynik przy takiej procedurze agregacji - a kto chce mieć wpływ na wynik, powinien wyrażać jak najbardziej wyważone opinie. Mediana obliczana jako rezultat głosowania też może być podatna na manipulację, ale dopiero wtedy, gdy manipulację taką stosuje duża liczebnie koalicja głosujących.

4 Uczestnicząc w komisjach konkursowych przekonałem się, że im bardziej członkowie komisji chcieli manipulować wynikiem, tym bardziej przeciwstawiali się zasadzie skreślania głosów krańcowych. 
Powstaje przy tym ogólny problem procedur skłaniajacych do wyrażania opinii prawdziwych. Problem ten może wydawać się dziwny w europejskim kręgu kulturowym, gdzie opinie w sprawach fachowych traktuje się bardziej jako kwestię honoru, niż pieniędzy; jest on jednak dość często spotykany w anglo-amerykańskim kręgu kulturowym i analizowany w literaturze fachowej, zob. np. Peyton Young (1984). Jako przykład rozważmy problem opłat a posteriori za wyrażanie opinii fachowych. Przypuśćmy, że specjalista - meteorolog ma otrzymać zapłatę zależną od przewidywanego przez niego prawdopodobieństwa deszczu $p$ oraz od faktu, czy prognoza jego była trafna. Oznaczmy przez $p^{\sim}$ prawdziwe prawdopodobieństwo deszczu i rozpatrzmy dwa schematy obliczania takiej zapłaty.

W jednym ze schematów, przyjmijmy wynagrodzenie prognosty jako 10000p, jeśli pada, oraz $10000 *(1-p)$, jeśli nie pada, co wyraża zależność na wartość oczekiwaną wypłaty:

$$
y=10000\left(p p^{\sim}+(1-p)\left(1-p^{\sim}\right)\right)
$$

gdzie współczynnik 10000 odpowiada arbitralnie wybranej skali wynagrodzenia; istotna oczywiście jest tylko jego zależność od $p$ i $p^{\sim}$. Po zróżniczkowaniu względem $p$ zauważamy, że prognoście opłaca się wyrażać opinię $p=0$, jeśli $p^{\sim}<0,5$ oraz opinię $p=1$, jeśli $p^{\sim}>0,5$; nie jest to więc schemat skłaniający do prawdomówności.

Do prawdomówności skłania natomiast schemat zwany Brier Score, gdzie wypłata wynosi $10000\left(1-(1-p)^{2}\right)$, jeśli pada, oraz 10000(1- $\left.p^{2}\right)$, jeśli nie pada. Daje to wartość oczekiwaną wypłaty:

$$
y=10000\left(\left(1-(1-p)^{2}\right) p^{\sim}+\left(1-p^{2}\right)\left(1-p^{\sim}\right)\right)
$$

gdzie po zróżniczkowaniu względem $p$ z łatwością przekonujemy się, że wynagrodzenie to ma maksimum dla $p=p^{\sim}$.

Przykład powyższy ilustruje tylko istnienie procedur skłaniajacych do prawdomówności, w których zawsze opłaca się podawać prawdziwe dane. Dla agregacji opinii grupowych nieco mniejszym wymaganiem jest zachowanie zgodnych motywacji poprzez procedury, w których opłaca się mówić prawdę, jeśli inni uczestnicy mówią prawdę. 
Wracając do zagadnienia podziału kosztów zauważmy, że ogólny przypadek tego zagadnienia jest bardzo złożony - można w nim albo dyskutować ogólne zasady podziału kosztów, albo też pytać każdego z uczestników o gotowość zapłaty części kosztów, z różnymi schematami faktycznej zapłaty, zależnie od zgłoszonej gotowości. Najprostsza procedura negocjacji wieloosobowych, w których każdy uczestnik wyraża gotowość zapłaty części kosztów, nie skłania do mówienia prawdy ani nie daje zgodnych motywacji, co łatwo sprawdzić na przykładach.

Istnieją przy tym procedury podziału wspólnych kosztów, skłaniające do prawdomówności, są one jednak dość złożone i wymagają wstępnej umowy proceduralnej. Stosunkowo najprostszym przykładem jest procedura (Peytona) Younga, neutralna względem interesów własnych i psychologicznie zachęcająca do prawdomówności. Polega ona na głosowaniu przez każdego uczestnika, ile to procent kosztów całości ma wpłacić każdy z uczestników; tyle tylko, że przy agregacji $\mathrm{w}$ stosunku do danego uczestnika uśrednia się głosy wszystkich innych uczestników, z wyjątkiem jego własnego. Wynik takiego głosowania wynika więc ze wzoru:

$$
y_{i}=\Sigma_{j \neq i} y_{i j} * 100 \% /\left(\Sigma_{i=1, . . n} \Sigma_{j \neq i} y_{i j}\right)
$$

gdzie $y_{i}$ jest procentowym udziałem strony $i$, reprezentowanej przez głosującego $i$, w opłacie za dobro wspólne, zaś $y_{i j}$ - postulowanym przez głosującego $j$ udziałem strony $i \mathrm{w}$ tej opłacie.

Ten dość abstrakcyjny zapis procedury Younga można zilustrować następującym przykładem. Przypuśćmy, że $n=6$ posiadaczy domów przy odległej ulicy $\mathrm{w}$ nowym osiedlu postanowiło się wspólnie podłączyć do kolektora kanalizacji. Dysponują oni pełnymi danymi kosztorysu przedsięwzięcia, ale nie mogą uzgodnić zasad podziału: posiadacze domów (np. $i=1,2,3)$ bliższych kolektora argumentują, że powinni zapłacić znacznie mniej, posiadacze domów dalszych (np. i=4, 5, 6) twierdzą, że zasadnicza część kosztów inwestycji jest niezależna od odległości, a więc wszyscy powinni płacić równo. Jeśli zgodziliby się na zastosowanie procedury Younga, to ich przykładowe głosy oraz wynikające stąd udziały ilustruje przytoczona poniżej tabela. W tabeli tej podano wyniki głosowania nad udziałami procentowymi w zapłacie za dobro wspólne; nawet, gdyby głosujący nie podawał oceny udziału własnego, ocena taka wynika z odjęcia 
sumy jego pozostałych głosów od $100 \%$, dlatego też jest podana (w nawiasie) w poniższej tabeli.

\begin{tabular}{|c|c|c|c|c|c|c|}
\hline \multicolumn{7}{|c|}{ Ilustracja procedury Younga (w \% opłaty za dobro wspólne) } \\
\hline & Udział 1 & Udział 2 & Udział 3 & Udział 4 & Udział 5 & Udział 6 \\
\hline Głosujący 1 & $(8 \%)$ & $10 \%$ & $12 \%$ & $22 \%$ & $22 \%$ & $26 \%$ \\
\hline Głosujący 2 & $10 \%$ & $(9 \%)$ & $11 \%$ & $20 \%$ & $23 \%$ & $27 \%$ \\
\hline Głosujący 3 & $11 \%$ & $11 \%$ & $(8 \%)$ & $21 \%$ & $24 \%$ & $25 \%$ \\
\hline Głosujący 4 & $16 \%$ & $16 \%$ & $16 \%$ & $(16 \%)$ & $17 \%$ & $19 \%$ \\
\hline Głosujący 5 & $15 \%$ & $16 \%$ & $17 \%$ & $17 \%$ & $(16 \%)$ & $19 \%$ \\
\hline Głosujący 6 & $16 \%$ & $17 \%$ & $17 \%$ & $17 \%$ & $17 \%$ & $(16 \%)$ \\
\hline $\begin{array}{c}\text { Wynik } \\
\text { Younga }\end{array}$ & $12,8 \%$ & $13,1 \%$ & $13,5 \%$ & $18,7 \%$ & $19,8 \%$ & $22,1 \%$ \\
\hline $\begin{array}{c}\text { Wynik } \\
\text { mediany }\end{array}$ & $13,2 \%$ & $14,1 \%$ & $14,1 \%$ & $17,6 \%$ & $19,1 \%$ & $21,9 \%$ \\
\hline
\end{tabular}

Dane użyte w tej tabeli ilustrują pewnego rodzaju scenariusz głosowania oraz wrażliwość procedury Younga na manipulację koalicyjną. Wrażliwość ta oczywiście wynika z założenia, że wyklucza się tylko głosy samych zainteresowanych - a więc można umówić się $\mathrm{z}$ innym głosującym, że będziemy go popierać, a on poprze nas. W powyższej tabeli zilustrowany jest inny scenariusz: głosujący 1, 2, 3 umówili się, że każdy z nich znacznie wyżej oceni niezbędne udziały 4, 5, 6 (łącznie na ok. 70\%) niż własne; natomiast głosujący 4, 5, 6 umówili się, że będą głosować za mniej więcej równymi udziałami, z drobnymi tylko modyfikacjami szczegółowymi.

Nieco mniejszą wrażliwość na takie manipulacje koalicyjne wykazuje modyfikacja procedury Younga, ${ }^{5}$ polegająca na zastąpieniu obliczania średniej Younga (14.3) obliczaniem mediany:

$$
y_{i}=\operatorname{med}_{j \neq i}\left(y_{i j}\right) * 100 \% / \Sigma_{i=1, \ldots n} \operatorname{med}_{j \neq i}\left(y_{i j}\right)
$$

gdzie $\operatorname{med}_{j \neq i}\left(y_{i j}\right)$ oznacza medianę ocen $y_{i j}$ kolejnych głosujących $j$ odnośnie udziału $i, \mathrm{z}$ wyłączeniem oceny własnej $i=j$. Wyniki takich obliczeń ilustruje

${ }^{5}$ Proponowana przez autora niniejszej książki procedura mediany. Procedurę mediany - nawet w uproszczeniu do obliczania zwykłej mediany głosów - zaleca się do zastosowania przy głosowaniu komisyjnym nad rezultatami konkursów czy przetargów; sposoby rozstrzygania przetargów zalecane przez prawo polskie są naiwne i ułomne. 
ostatni wiersz powyższej tabeli: modyfikacja procedury Younga z wykorzystaniem mediany daje więc procedurę bardziej odporną na manipulacje.

Dodajmy jeszcze, że można wyobrazić sobie procedury, w których opłacałoby się podawać wyższą gotowość do zapłaty, niż faktyczna. Jako przykład podamy tu procedurę wykorzystującą zewnętrznego sponsora - nazwiemy ją procedurą złośliwego sponsora - który może oznajmić: „Gotów jestem zapłacić za sporą część waszego wspólnego projektu - i to tym wyższą, im bardziej go uważacie za potrzebny. Dlatego też umówmy się, że każdy z was zapłaci za koszt projektu minus suma kwot zgłoszonych przez innych uczestników; jeśli suma takich wpłat będzie za mała, to resztę kosztów pokryję ja jako sponsor".

Ćwiczenie 14.1: Przeprowadzić szczegółową analizę zarysowanej wyżej procedury złośliwego sponsora, wraz $\mathrm{z}$ analizą przykładu zbliżonego do ilustracji procedury Younga.

Podkreślimy na koniec, że - ze względu na szczególną trudność zagadnienia podziału kosztów - lepiej w nim koncentrować się na dyskusji zasad podziału (których może być oczywiście wiele, zależnie od konkretnej sytuacji), niż na bezpośredniej negocjacji wyników podziału.

\section{Literatura}

Arrow K.J. (1983) Social Choice and Individual Values, Wiley, New York

Bronisz P., Kruś L., i Wierzbicki A.P. (1989) Towards interactive solutions in a bargaining problem. In A. Lewandowski, A.P. Wierzbicki (eds.) AspirationBased Decision Support Systems. Lecture Notes in Economics and Mathematical Systems Vol. 331. Springer-Verlag, Berlin-Heidelberg

Myerson R.B. (1991) Game Theory - Analysis of Conflict. Harvard University Press, Cambridge Mass.

Raiffa H. (1982) The Art and Science of Negotiations. Harvard University Press, Cambridge Mass.

Roy B. (1990) Wielokryterialne wspomaganie decyzji. WNT, Warszawa

Steinhaus, H. (1954) Kalejdoskop matematyczny, PZWS, Warszawa

Tversky A., Kahneman D. (1974) Judgement under Uncertainty: Heuristics and Biases. Science 185, 1124-31

Young H.P. (1984) Cost Allocation: Methods, Principles, Applications. NorthHolland, Amsterdam 



\section{Techniki glosowania oraz techniki rankingu}

Rozdział ten omawia nieco dokładniej zagadnienia technik głosowania, metod wspomagania wielokryterialnych decyzji grupowych, wreszcie metod rankingu wraz z pojęciem rankingu obiektywizowanego (,obiektywnego”).

\subsection{Techniki głosowania}

Zarówno w zagadnieniach sprawiedliwego podziału, jak i w innych przypadkach decyzji grupowych, można stosować dodatkowo bądź to techniki głosowania, bądź ocen wielokryterialnych, które omówimy kolejno i bardzo skrótowo $\mathrm{w}$ tym $\mathrm{i}$ w następnym punkcie. Znów trzeba ostrzec, że zagadnieniom tym poświęcono już liczne książki; w tym punkcie przedstawimy wprawdzie krótko, ale dość szczegółowo problematykę technik głosowania, ze względu na jej podstawowe znaczenie dla wielu zagadnień decyzji grupowych.

Głosowanie można uznać za sposób wyboru grupowego, przy następujących założeniach: mamy do czynienia z decyzją grupową (która to decyzja ze swej natury jest jedna dla całej grupy, trzeba ją tylko uzgodnić), a oceny sytuacji są w gruncie rzeczy jednokryterialne, jednoprzedmiotowe, przy czym każdy z uczestników głosowania (głosujący, będziemy go też nazywać decydentem) może uporządkować opcje decyzyjne w skali od najlepszej do najgorszej.

Takie uporządkowanie nazywamy profilem preferencji $i$-tego decydenta. $\mathrm{Na}$ przykład, przy opcjach - wariantach - oznaczonych przez $A, B, \ldots L, M$, decydent $i$-ty może mieć profil preferencji (jeśli uważa wariant $D$ za najlepszy, zaś $C$ za najgorszy):

$$
\{P\}_{i}=\{D>K>A>B>F>E>G>H>I>J>L>M>C\}
$$


Taki zapis profilu preferencji $P$ (przechodniej i zupełnej) nazywamy profilem Condorceta. ${ }^{1}$ Profile Condorceta wszystkich głosujących niosą w sobie wiele informacji, a każda próba ich agregacji poprzez zastosowanie określonej techniki głosowania może doprowadzić do rozmaitych paradoksów. Rozpatrzmy najpierw następujący przykład. Załóżmy, że dla trzech wariantów $A, B, C$ oraz 21 głosujących mamy następujące profile preferencji:

- 7 głosujących: $A>C>B$;

- 7 głosujących: $B>C>A$;

- 6 głosujących: $C>B>A$;

$\checkmark 1$ głosujący: $A>B>C$.

Zastosujmy najprostszą (i powszechnie stosowaną) technikę jednokrotnego głosowania prostego: każdy z głosujących ma jeden głos, który powinien oddać na jeden $\mathrm{z}$ wariantów uważany przez niego za najlepszy, a wygrywa wariant mający największą liczbę głosów. W przykładzie powyższym wygra wtedy wariant $A$, który uzyskuje 8 głosów. Jeśli jednak przyjrzymy się dokładniej powyższym profilom preferencji, to zauważymy, że wariant $A$ wygrał by też $\mathrm{w}$ głosowaniu na wariant najgorszy, i to uzyskując absolutną większość 13 głosów. Zatem głosowanie jednokrotne proste może dać w efekcie wybór wariantu uważanego za najgorszy przez większość glosujacych; wynik ten zwany jest paradoksem (Jean'a) Bordy. ${ }^{2}$

\footnotetext{
${ }^{1}$ Od Marie Jean Antoine Nicolas de Caritat, markiza de Condorcet, który w trakcie rewolucji francuskiej intensywnie analizował techniki głosowania jako podstawę działania systemu demokratycznego. Każdy przełom demokratyczny - także w Polsce w roku 1989 - wywołuje zwiększenie zainteresowania technikami i paradoksami głosowania, przy czym rozmaite zgromadzenia poświęcają wiele godzin debat proceduralnych na dyskusje tych technik (nie zawsze zdając sobie sprawę, jak wiele już analizy teoretycznej i literatury fachowej poświęcono tym zagadnieniom).

2 Od artylerzysty i inżyniera Jean’a Borda z czasów jeszcze sprzed rewolucji francuskiej, który zagadnienia technik głosowania badał wcześniej (w roku 1770), niż Condorcet, ale stosował podejście pragmatyczne. Condorcet natomiast stosował (od roku 1785, zob. Vansnick, 1986) podejście aksjomatyczne i stał się prekursorem teorii głosowania i wyboru grupowego. Tym niemniej, do dziś obserwuje się w tej teorii główne kontrowersje według linii podziału, zarysowanej już przez Bordę i Condorceta: czystość aksjomatyczna nadal prowadzi do paradoksów, natomiast podejścia pragmatyczne, choć bardziej skuteczne, uważane są za mniej eleganckie.
} 
Zauważmy, że w powyższym przykładzie nie jest prosty wybór rozsądnego wariantu. Jeśli bowiem zastosujemy wielokrotne glosowanie proste - czyli powtarzać będziemy głosowania, eliminując za każdym powtórzeniem wariant, który uzyskał najmniej głosów - to po pierwszym głosowaniu, z wynikami $A-8$ głosów, $B-7$ głosów, $C-6$ głosów, wyeliminujemy wariant $C$. Ale w drugim głosowaniu wariant $B$ otrzyma 13 głosów, zaś $A$ nadal tylko 8 głosów, a więc $B$ będzie wybrany. Nie oznacza to, że jest to wariant najlepszy: jeśli zastosujemy wielokrotne glosowanie akceptacyjne czyli powtarzać będziemy głosowania, ale głosując nad tym, który wariant należy usunąć jako najgorszy - to po pierwszym głosowaniu usuniemy wariant $A$, który ma wtedy 13 głosów „ujemnych”, natomiast w drugim głosowaniu to właśnie wariant $B$ uzyska 13 głosów „ujemnych” i zwycięży wariant $C$ - tylko 8 głosów „ujemnych” w drugim głosowaniu.

Dla rozwiązania paradoksu sygnalizowanego przez powyższy przykład, Jean Borda zaproponował stosunkowo prostą technikę zliczania punktów w głosowaniu jednokrotnym, ale z pełnym uszeregowaniem wariantów. Przy $m$ wariantach podlegających głosowaniu, wariant pierwszy $w$ profilu preferencji danego głosującego uzyskuje $m-1$ punktów, wariant drugi $-m-2$ punktów itd., wariant przedostatni -1 punkt, wariant ostatni -0 punktów. Zastosowanie tej techniki Bordy daje w omawianym wyżej przykładowym paradoksie wynik 16 punktów dla $A$, 21 punktów dla $B$ oraz 26 punktów dla $C-$ czyli wariantem zwycięskim jest $C$, podobnie jak w wielokrotnym głosowaniu akceptacyjnym. W celu formalizacji techniki Bordy $\mathrm{w}$ terminach współczesnych i wykorzystania obliczeń komputerowych, trzeba w niej sumować tzw. wektory preferencji Bordy, które na pozycji odpowiadającej danemu wariantowi podają przypadające mu punkty Bordy. Np. dla przytoczonego wcześniej w równaniu (15.1) przykładu profilu Condorceta, odpowiadający mu wektor Bordy ma postać (przy $m=13$ ):

$$
\boldsymbol{b}_{i}=(10,9,0,12,7,8,6,5,4,3,11,2,1) .
$$

Rozpatrzmy jeszcze jeden przykład dotyczący także 3 wariantów do wyboru i 21 głosujących, ale z następującymi profilami preferencji:

- 12 głosujących: $A>B>C$;

- 4 głosujących: $C>B>A$;

- 5 głosujących: $B>C>A$. 
Przy zastosowaniu techniki Bordy największą liczbę punktów - 26 - uzyskuje wariant $B$; wariant $C$ zbiera tylko 13 punktów, natomiast wariant $A$, który za najlepszy uważa większość czyli 12 głosujących, uzyskuje tylko 24 punkty Bordy, gdyż 9 głosujących uważa go za wariant najgorszy. Wariant $B$ wygrywa w technice Bordy dlatego, że jest to wariant średnio najlepszy: wszyscy ci głosujący, którzy uważali wariant $A$ lub wariant $C$ za najlepszy, uznali wariant $B$ za drugi z kolei. W technice Bordy wygrywa więc wariant „najmniejszego zła”. Ale czy mamy prawo dopuścić, aby w demokratycznym głosowaniu wygrywał wariant „najmniejszego zła” $B$, gdy istnieje inny wariant $A$ uznany za najlepszy przez większość głosujących?

Takie właśnie pytanie postawił Condorcet, który po Bordzie sformułował następujące aksjomaty wyboru grupowego, charakteryzujące (jego zdaniem) rozsądne procedury wyboru grupowego czy głosowania:

(C1) Wariant, który $\mathrm{w}$ porównaniach parami $\mathrm{z}$ innymi wariantami uzyskuje zawsze większość głosów, czyli tak zwany wariant zwycięski w sensie Condorceta, powinien zostać uznany za najlepszy, czyli wybrany;

(C2) Wariant, który w porównaniach parami z innymi wariantami uzyskuje zawsze mniejszość głosów, czyli tzw. wariant przegrywający w sensie Condorceta, nie powinien zostać wybrany.

Technika prostego głosowania jednokrotnego spełnia aksjomat $\mathrm{C} 1$, ale - jak wynika z pierwszego z powyższych przykładów - nie spełnia aksjomatu C2. Technika Bordy spełnia aksjomat C2, ale - jak wynika z drugiego z tych przykładów - nie spełnia aksjomatu C1. Jaką więc trzeba zaproponować technikę głosowania, aby spełniała oba ona aksjomaty Condorceta?

W odpowiedzi na to pytanie, Condorcet zaproponował zliczanie wszystkich przypadków, w których z profilu preferencji poszczególnych głosujących wynika preferencja jednego wariantu nad innym. Tak więc dla pierwszego przykładu 21 profili preferencji głosujących mamy:

- 8 przypadków, gdy $A>B$ oraz 13 przypadków, gdy $B>A$;

- też 8 przypadków, gdy $A>C$ oraz 13 przypadków, gdy $C>A$;

- wreszcie 8 przypadków, gdy $B>C$ oraz 13 przypadków, gdy $C>B$. 
czyli wariant $C$ jest zwycięskim, natomiast wariant $A$ - przegrywającym w sensie Condorceta.

W technice Condorceta zlicza się te wszystkie porównania parami, a następnie zaczyna się eliminację, niejako jak w wielokrotnym głosowaniu akceptacyjnym (tyle, że nie jest tu konieczne powtarzanie głosowań, gdyż zakłada się, że głosujący podali pełne profile preferencji). Najpierw usuwa się ten wariant, który miał najmniejszą liczbę zwycięstw w porównaniach parami - w tym przykładzie wariant $A$, który miał łącznie tylko 16 zwycięstw. Przy większej, niż trzy, liczbie wariantów usuwa się dalej kolejno najgorsze warianty. $Z$ pozostałych wariantów $B$ i $C$ lepszy jest $C$, gdyż ma większą liczbę zwycięstw $\mathrm{w}$ porównaniach parami. W pierwszym $\mathrm{z}$ rozpatrywanych przykładów technika Condorceta daje więc taki sam rezultat, jak technika Bordy.

Jednak $\mathrm{w}$ drugim $\mathrm{z}$ rozpatrywanych przykładów wynik jest odmienny. Zliczanie porównań parami daje $\mathrm{w}$ tym przypadku następujące wyniki:

- 12 przypadków, gdy $A>B$ oraz 9 przypadków, gdy $B>A$;

- też 12 przypadków, gdy $A>C$ oraz 9 przypadków, gdy $C>A$;

- wreszcie 17 przypadków, gdy $B>C$ oraz 4 przypadki, gdy $C>B$.

a więc wariant $A$ jest zwycięskim (łatwo wykazać, że wariant mający większość w głosowaniu prostym musi być zwycięskim w sensie Condorceta), natomiast wariant $C$ - przegrywającym w sensie Condorceta. Stosując technikę Condorceta eliminujemy najpierw wariant $C$, który ma najmniejszą liczbę - tylko 13 - zwycięskich porównań parami. Z pozostałych dwóch wariantów $A$ i $B$ lepszy jest wariant $A$, gdyż ma większą liczbę zwycięskich porównań parami. Można udowodnić, że technika Condorceta zawsze da w wyniku wariant zwycięski w sensie Condorceta, jeśli taki wariant istnieje; z jej konstrukcji opartej na eliminacji wariantów najgorszych łatwo wywnioskować, że technika ta nigdy nie da w wyniku wariantu przegrywającego w sensie Condorceta.

Technika Condorceta jest jednak dość złożona - zarówno w sensie mechanizmu głosowania (trzeba określić całe profile preferencji, ale to samo niezbędne jest $\mathrm{w}$ technice Bordy), jak i w sensie niezbędnych obliczeń wyników. Można w niej zastosować obliczenia komputerowe, ale trzeba ją 
sformalizować w terminach współczesnych, np. w formie macierzowej. Jeśli zamiast liter przyporządkujemy poszczególnym wariantom liczby naturalne $j=1, \ldots . m$, to możemy profil preferencji $i$-tego decydenta wyrazić w postaci macierzy $m \times m$, którą oznaczymy $\boldsymbol{P}_{i}$, z elementami $p_{i, j k}=(0 v 1)$, przy czym $p_{i, j k}=1$ oznacza, że decydent $i$ ściśle preferuje wariant $j \mathrm{w}$ porównaniu $\mathrm{z}$ wariantem $k$, natomiast $p_{i, j k}=0$ oznacza przypadek przeciwny. Wynika stąd np., że $p_{i, j j}=0$ oraz $p_{i, k j}=1-p_{i, j k}$ dla $k \neq j$; ale nawet przy spełnieniu tych wymagań, macierz zero-jedynkowa może nie reprezentować przechodniego profilu (gdyż może zawierać cykle preferencji) i konieczne jest tego sprawdzanie, np. za pomocą określenia grafu preferencji odpowiadającego danej macierzy. Macierz preferencji odpowiadającą przechodniemu profilowi Condorceta nazywamy spójną.

Dla zastosowania techniki Condorceta trzeba zsumować macierze $\boldsymbol{P}_{i}$ dla wszystkich $i$, gdyż wtedy uzyskamy potrzebne w tej technice dane, ile razy dany wariant $j$ był preferowany w stosunku do wariantu $k$ - lub odwrotnie, po przeciwległej stronie przekątnej macierzy. Dla pierwszego z rozpatrywanych przykładów odpowiednia suma macierzy $\boldsymbol{P}_{i}$ ma postać:

\begin{tabular}{|c|c|c|c|}
\hline & $A$ & $B$ & $C$ \\
\hline$A$ & - & 8 & 8 \\
\hline$B$ & 13 & - & 8 \\
\hline$C$ & 13 & 13 & - \\
\hline
\end{tabular}

natomiast dla przykładu drugiego:

\begin{tabular}{|c|c|c|c|}
\hline & $A$ & $B$ & $C$ \\
\hline$A$ & - & 12 & 12 \\
\hline$B$ & 9 & - & 17 \\
\hline$C$ & 9 & 4 & - \\
\hline
\end{tabular}

Dla zastosowania techniki Condorceta wystarcza więc sumować liczby w wierszach sum macierzy $\boldsymbol{P}_{i}$ oraz eliminować kolejno wiersze o najmniejszej sumie (i odpowiednie kolumny): w pierwszym z tych przykładów najpierw eliminujemy wariant $A$, w drugim - wariant $C$. Zauważmy, że w drugim $\mathrm{z}$ omawianych przykładów wariant $B$ (który był wariantem zwycięskim $\mathrm{w}$ sensie Bordy, ale nie $\mathrm{w}$ sensie Condorceta) ma na początku procedury największą sumę wygranych porównań parami, ale po usunięciu wiersza 
(i kolumny) $C$ staje się jednak gorszy od wariantu $A$. Na tym właśnie polega sens eliminacji wierszy i kolumn; bez takiej eliminacji, sumowanie wierszy sum macierzy $\boldsymbol{P}_{i}$ odpowiadałoby dokładnie technice Bordy.

Ćwiczenie 15.1: Zaproponować i przeanalizować wykorzystanie sumowania wierszy sum macierzy $\boldsymbol{P}_{i}$ dla obliczeń niezbędnych w technice Bordy.

Technika głosowania Condorceta może nie dać w wyniku wariantu zwycięskiego w sensie Condorceta, gdyż taki wariant może nie istnieć. Związane jest to $\mathrm{z}$ podstawowym paradoksem: agregacja przechodnich profili preferencji polegająa na sumowaniu głosów z porównań parami może nie prowadzić do przechodniej preferencji zagregowanej. Przypomnijmy tu znany przykład: mamy trzy warianty $A, B, C$ i trzech decydentów o profilach A $>B>C ; C>A>B ; B>C>A$. Przykład ten podany był faktycznie przez Condorceta i zwany jest paradoksem Condorceta: po agregacji takich profili preferencji, wariant zwycięski w sensie Condorceta nie istnieje, a technika Condorceta (zresztą także żadna inna technika głosowania bez manipulacji) nie daje jednoznacznego rezultatu.

Zarówno technika Bordy, jak jeszcze bardziej technika Condorceta, są skomplikowane $\mathrm{w}$ realizacji praktycznej, zwłaszcza bez wspomagania komputerowego. Wyobraźmy sobie komisję wyborczą przy głosowaniu na kandydatów do zarządu dużej organizacji, liczącej np. ponad 1000 członków, przy 10 miejscach w zarządzie i 25 kandydatach, która to komisja zobowiązana byłaby do przeprowadzenia wyborów techniką Bordy lub, co gorzej, Condorceta, zaczynając od analizy ważności głosów czyli ustalenia poprawności profilu podanego przez każdego z członków. Nawet przy wspomaganiu komputerowym, technika Condorceta może być krytykowana za zbyt optymistyczne założenia o psychologicznej odpowiedzialności decydentów, którzy z natury ludzkiej będą się koncentrować na prawidłowym ustaleniu kolejności wariantów dla nich najważniejszych, mniej jednak uwagi poświęcą kolejności wariantów mniej ważnych. Założenie o możliwości pełnego porównania parami dużego zbioru wariantów, często przyjmowane $\mathrm{w}$ teorii decyzji, nie jest w tym sensie realistyczne.

Wady tej unika pewne uogólnienie techniki Condorceta polegające na zastosowaniu w głosowania akceptującego wielokrotnego, gdy za każdym głosowaniem głosujemy nad wariantem najgorszym i usuwamy go z listy. 
Jest to uogólnienie, gdyż głosujący mogą w tym przypadku zmieniać profile preferencji w zależności od kontekstu, czyli pozostałych kandydatów; unikamy zaś wady, gdyż w pierwszych głosowaniach uczestnicy mogą się skoncentrować na eliminacji najgorszych, potem zaś - na wyborze najlepszych. Jednakże, w podanym wyżej przykładzie (10 miejsc i 25 kandydatów) trzeba mimo wszystko przeprowadzić 15 głosowań.

Technika głosowania Bordy może być też w różny sposób uogólniana np. technika jury polega na przyznawaniu wszystkim wariantom ocen z odpowiedniego przedziału (w odróżnieniu od techniki Bordy, mogą to być oceny jednakowe dla kilku wariantów). ${ }^{3}$ Technika (Edwarda) Nansona polega na stosowaniu techniki Bordy wielokrotnie, z odrzucaniem wariantów uzyskujących nie więcej, niż średnia ocena Bordy $n *(m-1) / 2$, gdzie $m$ - liczba wariantów, $n$ - liczba głosujących), a następnie obliczaniu nowych ocen Bordy; technika ta gwarantuje wybór wariantu zwycięskiego w sensie Condorceta, jeśli taki istnieje.

Jednakże większość autorów prac w zakresie teorii głosowania zajmowało się modyfikacjami techniki Condorceta, ze względu na jej elegancję teoretyczną. Charles Dodgson (m.in. autor Alicji w krainie czarów pod pseudonimem Lewis Carroll) zajmował się też matematyczną teorią głosowania. Rozpatrywał pojęcie najmniejszej liczby $t(\boldsymbol{P}, \boldsymbol{M})$ koniecznych zmian porównań parami profili preferencji $\boldsymbol{P}$ (łącznie dla wszystkich decydentów) dla danego zbioru wariantów $\boldsymbol{M}$ takiej, aby dany wariant stał się wariantem zwycięskim w sensie Condorceta. Zbiór takich wariantów, które są zwycięskie bez modyfikacji (przy $t(\boldsymbol{P}, \boldsymbol{M})=0$ ) nazwał jądrem. Jeśli jądro jest niepuste, to wybiera się jego element; jeśli jest puste, to wybiera się wariant o najmniejszym $t(\boldsymbol{P}, \boldsymbol{M})$. Choć też bardzo elegancka, technika Dodgsona ma znaczenie raczej teoretyczne. Technika (Bernarda) Blacka

\footnotetext{
3 Technika jury jest powszechnie stosowana przy ocenach różnych konkursów, jednakże jest bardzo podatna na manipulacje indywidualne lub grupowe. Dlatego też często stosuje się w niej odrzucanie ocen skrajnych, ale wtedy nadal pozostaje podatna na manipulacje grupowe. $Z$ doświadczenia autora tej książki wynika, że technikę jury najlepiej uzupełniać proponowaną w rozdziale poprzednim techniką mediany (która odpowiada wielokrotnemu odrzucaniu ocen skrajnych, aż pozostaje tylko jedna lub dwie oceny).
} 
polega na innej modyfikacji - wyborze wariantu zwycięskiego w sensie Condorceta, jeśli istnieje, a w jego braku - zastosowaniu techniki Bordy.

Istnieje w sumie chyba kilkadziesiąt różnych technik głosowania. Wyliczymy tu jeszcze kilka istotnych ich przykładów. Procedura poprawek (jej nazwa pochodzi od sposobu głosowania poprawek ustaw w Kongresie Stanów Zjednoczonych) polega na określeniu porządku porównania wariantów, a następnie głosowaniu parami nad ich porównaniem, $\mathrm{z}$ usuwaniem wariantów przegrywających w tych porównaniach. Technika (Arthura) Copelanda polega na przypisywaniu każdemu wariantowi po jednym punkcie za każdą wygraną porównania parami z innym wariantem; wygrywa wariant o największej sumie takich punktów. Technika maksminu polega na obliczeniu dla każdego wariantu jego najmniejszej ilości głosów w porównaniach parami z innymi wariantami, a następnie wybór wariantu o największej z tych najmniejszych ilości głosów. Technika akceptacji polega na pozwoleniu głosowania na dowolną ilość wariantów; każdemu z nich można przypisać 0 lub 1 punkt. Najczęściej stosowana praktycznie jest wspomniana na wstępie technika glosowania prostego jednokrotnego; jeśli nie da ona w wyniku wariantu wybranego większością absolutną głosów, można stosować technikę głosowania prostego dwukrotnego, z pozostawieniem do drugiej tury głosowania tylko dwóch wariantów o największej liczbie głosów, lub technikę głosowania prostego wielokrotnego, ze stopniowym usuwaniem wariantów uzyskujących najmniejszą liczbę głosów. Podobna do głosowania prostego wielokrotnego jest technika (Thomasa) Hare, wymagająca jednak podania pełnych profili preferencji przez głosujących. Jeśli któryś z wariantów ma większość absolutną, to jest wybierany; jeśli nie, eliminuje się wariant uważany za najlepszy przez najmniejszą liczbę głosujących, i analizuje się ponownie profile preferencji dla pozostałych wariantów (w pierwszym $\mathrm{z}$ rozważanych tu przykładów o 21 głosujących eliminacji ulega akurat wariant $C$-zwycięski zarówno w sensie Condorceta jak i Bordy).

Przy tak dużej liczbie technik głosowania powstaje oczywiste pytanie, które $\mathrm{z}$ tych technik są dobre bądź zalecane do zastosowania w praktyce. Przed próbą odpowiedzi trzeba jednak określić kryteria oceny technik głosowania. Hannu Nurmi (1999, 2000) wylicza kilkanaście takich kryteriów, z których najważniejsze to: 
a. Wybór wariantu zwycięskiego Condorceta (aksjomat C1);

b. Eliminacja wariantu przegrywającego Condorceta (aksjomat C2);

c. Wybór wariantu uzyskującego absolutną większość głosów w głosowaniu prostym;

d. Monotoniczność: jeśli dany wariant wygrywa przy danym zbiorze profili preferencji głosujących, to modyfikacja tych profili powodująca wzrost poparcia dla tego wariantu nie powinna spowodować jego przegranej;

e. Pareto optymalność: jeśli jakiś wariant zostaje wybrany, to nie ma wariantu go dominującego, czyli takiego, który by preferowali w porównaniu parami z wariantem wybranym wszyscy głosujący;

f. Spójność: dla dowolnego podziału zbioru głosujących na podzbiory, jeśli dany wariant jest wybrany przy głosowaniu w każdym podzbiorze, to powinien być też wybrany przy głosowaniu w całym zbiorze.

Nurmi (2000) podaje następującą tabelę ${ }^{4}$ wskazującą, czy poszczególne techniki głosowania spełniają (1) lub nie spełniają (0) powyższe kryteria oceny:

\begin{tabular}{|l|c|c|c|c|c|c|}
\hline Technika\Kryterium & a. & b. & c. & d. & e. & f. \\
\hline Poprawki & 1 & 1 & 1 & 1 & 0 & 0 \\
\hline Copeland & 1 & 1 & 1 & 1 & 1 & 0 \\
\hline Dodgson & 1 & 0 & 1 & 0 & 1 & 0 \\
\hline Maksmin & 1 & 0 & 1 & 1 & 1 & 0 \\
\hline Zwykłe jednokrotne & 0 & 0 & 1 & 1 & 1 & 1 \\
\hline Borda & 0 & 1 & 0 & 1 & 1 & 1 \\
\hline Akceptacja & 0 & 0 & 0 & 1 & 0 & 1 \\
\hline Black & 1 & 1 & 1 & 1 & 1 & 0 \\
\hline Zwykłe dwukrotne & 0 & 1 & 1 & 0 & 1 & 0 \\
\hline Nanson & 1 & 1 & 1 & 0 & 1 & 0 \\
\hline Hare & 0 & 1 & 1 & 0 & 1 & 0 \\
\hline
\end{tabular}

${ }^{4}$ Tabelę tę przytaczamy z nieznacznym uproszczeniem, pomijając jeszcze jedno kryterium o bardziej teoretycznym charakterze. 
Nurmi wnioskuje, że gdyby za podstawę wyboru przyjąć liczbę spełnionych kryteriów, to najlepszą byłaby technika Blacka; gdyby zaś żądać spełnienia kryterium eliminacji wariantu przegrywającego Condorceta, monotoniczności i spójności (jako wymogów naturalnych), to najlepsza byłaby technika Bordy. Widzimy jednak, że nie ma techniki najlepszej, spełniającej wszystkie kryteria a są to dopiero kryteria teoretyczne. Można bowiem do nich dodać różnorodne kryteria pragmatyczne względnej prostoty i przejrzystości, łatwości zastosowania, odporności na zniekształcenia strategiczne, zwane też manipulacją indywidualną (czyli pozorną zmianę preferencji przez jednego decydenta w celu uzyskania pożądanego wyniku), manipulację grupową czy na manipulację agendową (czyli na wybór techniki i ustalenie szczegółów głosowania przez jego organizatora, w tym samym celu).

Trzeba wreszcie podkreślić, że znaczenie poszczególnych kryteriów teoretycznych wiąże się z różnorodnymi paradoksami głosowania, z których jak dotąd wymieniliśmy tylko paradoksy Bordy i Condorceta. Zacytujemy, znów według Nurmiego (2000) kilka paradoksów dalszych.

Paradoks dodatkowego wsparcia polega na tym, że dodatkowe głosy za danym wariantem $\mathrm{w}$ mogą zmienić go $\mathrm{z}$ wariantu wygrywającego na przegrywający w niektórych technikach głosowania, np. w często stosowanej technice dwukrotnego głosowania prostego. Ilustruje to następujący przykład o $n=63$ głosujących:

- 22 głosujących: $A>B>C$;

- 21 głosujących: $B>C>A$;

- 20 głosujących: $C>A>B$.

W pierwszej rundzie głosowania zwykłego wariant $A$ uzyskuje 22 głosy, wariant $B-21$ głosów, wariant $C-20$ głosów. Ponieważ żaden nie uzyskał większości absolutnej 32 głosów, niezbędna jest druga runda $\mathrm{z}$ usunięciem wariantu $C$, którą wygrywa $A$ stosunkiem głosów 42 do 21, gdyż 20 głosujących w pierwszej rundzie na $C$ będzie w drugiej rundzie głosować na $A$. Przypuśćmy jednak, że wariant $A$ uzyskał dodatkowe poparcie: 2 głosujących o profilu $B>C>A$ zdecydowało się zmienić ten profil na $A>B>C$. Mamy zatem: 
- 24 głosujących: $A>B>C$;

- 19 głosujących: $B>C>A$;

- 20 głosujących: $C>A>B$.

i znów potrzeba drugiej rundy głosowania, tym razem $z$ usunięciem wariantu $B$. Jednakże wyborcy głosujący w pierwszej rundzie na wariant $B$ będą teraz w drugiej rundzie głosować na wariant $C$, a zatem wariant $A$ przegra w drugiej rundzie stosunkiem głosów 24 do 39; dodatkowe poparcie zmieniło pozycję wygrywającą $A$ na przegrywającą.

Paradoks spójności polega na tym, że przy podziale głosujących np. na dwie połowy, proste głosowanie dwukrotne może dać zupełnie inny wynik, niż przy liczeniu wszystkich głosów razem. Ilustruje to następujący przykład o $n=100$ głosujących:

- W pierwszej połowie (50 głosujących):

- 20 głosujących: $A>B>C$;

- 20 głosujących: $B>C>A$;

- 10 głosujących: $C>A>B$.

- W drugiej połowie (50 głosujących):

- 26 głosujących: $A>B>C$;

- 4 głosujących: $B>C>A$;

- 20 głosujących: $C>A>B$.

Przy podziale głosowań, wariant $A$ wygrywa w pierwszej połowie (w drugiej rundzie, stosunkiem głosów 30 do 20 do wariantu $B$ ) oraz w drugiej połowie (w pierwszej rundzie, mając absolutną większość 26 głosów). Jednakże po połączeniu wszystkich głosujących, wariant $A$ spotyka się w drugiej rundzie z wariantem $C$, z którym przegrywa stosunkiem głosów 46 do 54 . Zatem dwukrotne głosowanie proste nie spełnia kryterium spójności.

Paradoksy spójności związane są z podstawami wyborów demokratycznych, a więc zasługują na szczególną uwagę. Nurmi przytacza jeszcze jeden paradoks związany ze spójnością, a raczej kwestią odmienności wyników wyborów do parlamentu od wyników referendum:

Paradoks (Moiseya) Ostrogorskiego. Przypuśćmy, że dwie partie $X$ i $Y$ różnią się opiniami co do trzech przedmiotów walki wyborczej, które oznaczymy 
numerami 1, 2, 3. Elektorat składa się z czterech grup $A, B, C$ i $D$ o różnych udziałach procentowych, które charakteryzują się odpowiednimi profilami poparcia dla partii $X$ lub $Y$ co do różnych przedmiotów walki wyborczej. Ilustruje to następująca tabela:

\begin{tabular}{|c|c|c|c|c|}
\hline Grupa & $\begin{array}{c}\text { Przedmiot } \\
1\end{array}$ & $\begin{array}{c}\text { Przedmiot } \\
2\end{array}$ & $\begin{array}{c}\text { Przedmiot } \\
3\end{array}$ & $\begin{array}{c}\text { Partia } \\
\text { popierana }\end{array}$ \\
\hline$A(20 \%)$ & $X$ & $X$ & $Y$ & $X$ \\
\hline$B(20 \%)$ & $X$ & $Y$ & $X$ & $X$ \\
\hline$C(20 \%)$ & $Y$ & $X$ & $X$ & $X$ \\
\hline$D(40 \%)$ & $Y$ & $Y$ & $Y$ & $Y$ \\
\hline
\end{tabular}

Wnioskujemy przy tym, że jeśli dana grupa popiera jakąś partię co do większej liczby przedmiotów walki wyborczej, to będzie głosować na tę partię w wyborach do parlamentu. Ilustruje to ostatnia kolumna tabeli, w której zaznaczono partię $\mathrm{w}$ sumie popieraną $\mathrm{w}$ wyborach. Jeśli takie rozumowanie jest prawidłowe, to partia $X$ zwycięży w wyborach stosunkiem głosów $60 \%$ do $40 \%$. Jeśli jednak najpierw przeprowadzimy referendum $\mathrm{z}$ trzema pytaniami - czy popieracie stanowisko partii $X$, czy $Y \mathrm{w}$ trzech kolejnych przedmiotach walki wyborczej, to w każdym z tych przedmiotów stanowisko partii $Y$ zwycięży stosunkiem głosów $60 \%$ do $40 \%$ - a więc wynik wyborów nie odzwierciedla opinii wyborców w stosunku do poszczególnych przedmiotów walki wyborczej. ${ }^{5}$

Paradoks (Kennetha) Arrowa jest jednym z najbardziej znanych i podstawowych paradoksów wyboru grupowego; dotyczy on nie tyle paradoksalnych wyników głosowania w konkretnej sytuacji, co niespójności kilku, jak by się zdawało, całkowicie racjonalnych wymagań co do agregacji grupowej preferencji indywidualnych. Kenneth J. Arrow (1951) przyjął trzy aksjomaty racjonalności takiej agregacji grupowej - które przedstawiamy tu tak, jakby dotyczyły przypadku szczególnego, czyli techniki głosowania:

${ }^{5}$ Znajomość takiego paradoksu mogłaby motywować partię $Y$ do przeforsowania referendum przed wyborami parlamentarnymi; wyniki takiego referendum mogłyby wpłynąć na poparcie wyborców dla tej partii. 
A1. Równość czyli brak dyktatora: nie ma takiego uczestnika głosowania, którego profil indywidualny decydowałby o wyniku głosowania niezależnie od profili innych uczestników;

A2. Pareto optymalność (identycznie $\mathrm{z}$ kryterium f. cytowanym powyżej): w przypadku jednomyślnej oceny najlepszego wariantu, należy go wybrać;

A3. Niezależność od wariantów nieistotnych: o wyborze danego wariantu decydują wyłącznie jego porównania z innymi wariantami, nie porównania innych wariantów między sobą. ${ }^{6}$

Z aksjomatów A3 i A2 wynika też aksjomat C1 Condorceta; technika Condorceta spełnia aksjomaty Arrowa, natomiast technika Bordy ich nie spełnia.

Znane twierdzenie Arrowa mówi, że nie można skonstruować techniki głosowania, która spetniała by te trzy aksjomaty oraz dawała przechodnia i zupetna preferencje zbiorowa (czyli acykliczne uszeregowanie wariantów) dla dowolnych przechodnich i zupełnych profili preferencji indywidualnych, obejmujących porównanie więcej niż dwóch wariantów.

Inni badacze udowodnili nawet, że racjonalne w sensie Arrowa techniki głosowania zawsze będą podatne na manipulacje indywidualne (oprócz tego, że czasem mogą nie dać acyklicznych wyników). Różne mogą być interpretacje paradoksu Arrowa - wydaje się jednak, że jego istotą jest zbytnie znaczenie, jakie przywiązuje się do logiki porównań parami, a w konsekwencji do aksjomatu niezależności od wariantów nieistotnych lub do wymagania Condorceta C1. Nie ma bowiem paradoksu w stwierdzeniu zgodnie z logiką Bordy - że za najlepszy należy wybrać wariant oceniony

6 Jest to inny aksjomat niezależności, niż podobnie nazwany aksjomat Nasha. Dokładniej, aksjomat A3 formułuje się w terminach preferencji indywidualnych i zbiorowych: jeśli mamy dwa różne zestawy preferencji indywidualnych, które jednak jednakowo dla każdego głosującego oceniają porównanie parami wybranych dwóch wariantów, to takie porównanie parami musi być zachowane po agregacji preferencji, czyli preferencja grupowa w stosunku do tych dwóch wariantów musi być taka sama zarówno dla pierwszego jak i drugiego zestawu preferencji indywidualnych. 
przez wszystkich w średniej ocen lepiej, niż wariant zwycięski w sensie Concordeta (który jest wprawdzie uważany za najlepszy przez większość, ale w średniej ocen może być gorszy). Trudne jest tylko przyzwyczajenie do takiego rozumowania wyborców, którzy przywykli utożsamiać demokrację z techniką głosowania prostego.

Rozumując w ten sposób, Hanno Nurmi - zob. np. (1999) - podał modyfikację techniki Bordy na przypadek głosowania probabilistycznego lub procentowego, która unika większości pułapek wyrażonych przez rozmaite paradoksy głosowania. Ponieważ interpretacja probabilistyczna technik głosowania może nie być akceptowana przez typowego głosującego, podamy tu tylko interpretację procentową techniki Nurmiego. ${ }^{7}$ Każdemu z głosujących przyznaje się 100 punktów, które można interpretować jako procenty poparcia dla poszczególnych wariantów, nad którymi głosuje. Głosujący ma prawo przydzielić te punkty dowolnie dla poszczególnych wariantów - przyznać je wszystkie jednemu, podzielić je równo lub nierówno itp. Głos jest nieważny, jeśli głosujący przyzna w sumie więcej niż 100 punktów (można też wymagać, aby przyznał dokładnie 100 punktów, ale to wymaganie może być uważane za zbyt szczegółowe). Wariantem zwycięskim w technice Nurmiego jest wariant, który uzyska największą sumę punktów Nurmiego (czyli tak, jak w technice Bordy, tyle że punkty Bordy dokładnie odpowiadają miejscu danego wariantu w profilu preferencji, natomiast punkty Nurmiego określają też to miejsce, ale w przybliżeniu).

Technika Nurmiego jest godna zalecenia do zastosowań praktycznych (chociaż jest podatna na manipulacje indywidualne i zbiorowe, ale aby ją uodpornić, można ją wzbogacić o technikę mediany) - wszędzie tam, gdzie można ją zastosować bez obawy o brak jej zrozumienia. Dla większych zbiorów wyborców jeszcze przez wiele lat bardziej przejrzyste będzie głosowanie proste. Bowiem tak jak już wspominaliśmy, jest wiele technik głosowania, ale nie ma techniki uniwersalnie najlepszej - trzeba dobierać technikę głosowania do konkretnego typu zastosowania.

${ }^{7}$ Technika ta jest podobna do omówionej wcześniej procedury Younga, ale technika Nurmiego jest pierwotna: to Young dostosował opublikowaną wcześniej technikę Nurmiego do szczególnego przypadku głosowania nad podziałem kosztów. 
Poszczególne techniki głosowań mogą też, np. przy jednowymiarowym rozkładzie opinii politycznych typu lewica-prawica, preferować bądź to kandydatów skrajnych, bądź z centrum spektrum. Innym problemem technik głosowania jest zagadnienie reprezentacji wyborców w parlamencie. Przy założeniu proporcjonalnej reprezentacji, istnieje wiele sposobów dokonania koniecznych zaokrągleń wynikających z faktu, że nie można mieć ułamkowego reprezentanta. Dlatego też, przy opracowywaniu zasad konkretnych głosowań, Kongres USA posługuje się opiniami badaczy specjalistów w tym zakresie.

Znane jest też doświadczenie, że niektóre zgromadzenia - nawet uczonych, jak np. rady wydziałów - mogą wiele godzin spędzać nad dyskusją konkretnej procedury głosowania, odkrywając kolejne paradoksy w nieświadomości, że je już dawno i dość dogłębnie zbadano teoretycznie - lub krytykując konkretne propozycje systemu ocen czy wyboru z powodu, że nie spełniają najprostszych intuicyjnie wymogów racjonalności (przy czym to prawda - ale systemy spełniające jednocześnie kilka takich wymogów zazwyczaj po prostu nie istnieją, i trzeba wybierać, które wymogi uznamy za ważniejsze).

\subsection{Wspomaganie wielokryterialnych decyzji grupowych}

Uogólnieniem problematyki technik głosowania jest kwestia grupowej oceny wielokryterialnej dyskretnego zbioru wariantów czy opcji decyzyjnych; wartości poszczególnych kryteriów charakteryzujące poszczególne warianty nazywa się wtedy też atrybutami tych wariantów. Jest to dziedzina o bardzo złożonej problematyce. Jeśli już grupowy wybór jednokryterialny jest problemem o wielu paradoksach racjonalności, to oczywiście przenosi się to na wybór wielokryterialny. Tym niemniej, istnieje wiele technik wyboru wielokryterialnego; często rezygnuje się przy tym ze ściśle aksjomatycznych definicji racjonalności, stosując podejścia bardziej pragmatyczne.

Trzeba jednak na wstępie przestrzec, że grupowe podejścia do problemów wyboru wielokryterialnego mają powodzenie praktyczne tylko wtedy, 
gdy decydenci $\mathrm{w}$ grupie są ekspertami fachowo przygotowanymi do przeprowadzenia takiego procesu decyzyjnego. Trudność psychologiczna polega tu na nieufności do skomplikowanych procedur agregacji ocen, jeśli się ich dobrze nie rozumie. Na przykład, sędziowie jazdy figurowej na łyżwach czy skoków narciarskich dokonują w praktyce ocen wielokryterialnych - ale mają ustalone tradycją sposoby agregacji tych ocen i wielokrotnie dyskutowane w grupach fachowców kryteria pomocnicze, służące do określania ocen zbiorczych. Grupa fachowców w danej dziedzinie konstrukcji inżynierskich też może się zgodzić na dokonanie ocen wielokryterialnych kilku konstrukcji, jeśli przedtem starannie przedyskutuje problematyke modelowania sytuacji decyzyjnej (zob. rozdział 6), czyli uzgodni sposoby opisu i kryteria oceny wariantów, sposoby ich agregacji, sposoby agregacji ocen wewnątrz grupy. Gorzej jednak jest w innych przypadkach - grup osób o różnorodnych specjalnościach, nie czujących się w pełni ekspertami w ocenianej dziedzinie itp.; takie grupy będą nalegały na oceny bardzo ogólne, wyrażone w formie pojedynczego wskaźnika oceny, tak jak stopnie na egzaminach.

Wybór kryteriów dla ocen grupowych jest kwestią niezmiernie istotną. Oczywiście, muszą być to wskaźniki istotne dla danej sytuacji decyzyjnej, a sposób i skala ich pomiaru czy subiektywnej oceny muszą być dobrze zrozumiałe dla danej grupy. Warto też dla każdego z kryteriów określać nie tylko skalę czy zakres ocen, ale dyskutować i uzgadniać poziomy aspiracji i rezerwacji - odgrywające ogromną rolę zarówno w praktyce, jak i w teorii ocen czy optymalizacji wielokryterialnej. Wstępne dyskusje problematyki opisu prowadzone są często metodą burzy mózgów - czyli specjalnej techniki pracy grupowej, w której nie krytykuje się wstępnych pomysłów, tylko je starannie rejestruje, żeby dopiero później przejść do ich selekcji. Metoda ta często bywa bardzo płodna, ale równie często grozi nadmiarem pomysłów trywialnych. Dlatego też należy się wystrzegać:

- Pułapki narzędziowej, polegającej na koncentracji uwagi na wskaźnikach czy kryteriach łatwych do pomiaru, ale o drugorzędnym znaczeniu, z pominięciem wskaźników o znaczeniu zasadniczym tylko dlatego, że są 
trudne do pomiaru bądź wymagają ocen intuicyjnych. Jest wiele przykładów takich pułapek. ${ }^{8}$

- Nadmiernej liczby kryteriów komplementarnych - to jest takich, których oceny łatwo ze sobą sumować (zwiększona ocena jednego z kryteriów komplementarnych kompensuje zmniejszoną ocenę innego kryterium). Kryteria takie zaciemniają istotę wyboru wielokryterialnego, polegającą na decyzji o kompromisie pomiędzy kryteriami zasadniczymi - czyli niekomplementarnymi.

- Zbyt uproszczonych sposobów agregacji (np. poprzez sumę ważoną) kryteriów zasadniczych, niekomplementarnych, dla oceny których potrzeba raczej stosować agregację przez nieliniową funkcję osiągnięcia z określeniem poziomów rezerwacji i aspiracji.

Prawidłowy wynik modelowania sytuacji decyzyjnej to niewielka liczba kryteriów zasadniczych, niekomplementarnych, o dobrze określonej interpretacji i sposobie pomiaru lub oceny, z określonymi poziomami rezerwacji i aspiracji. Za maksymalną liczbę kryteriów przyjmuje się powszechnie siedem, niekiedy - dziewięć. W stosunku do kryteriów komplementarnych należy na wstępie określić sposoby ich agregacji do mniejszej liczby kryteriów zasadniczych, które to sposoby mogą opierać się na sumie prostej lub ważonej.

\footnotetext{
${ }^{8}$ Jednym $\mathrm{z}$ nich jest kwestia wyboru komputera dużej mocy, równoległego czy wektorowego. Komputer taki można oceniać według najbardziej różnorodnych wskaźników; ale najprostszym jest stosunek mocy szczytowej (sumy teoretycznej mocy obliczeniowej licznych procesorów komputera), mierzonej np. w Mflops/sek (milionach operacji zmiennoprzecinkowych na sekundę) do ceny komputera. Ponieważ jest to wskaźnik prosty i łatwy do interpretacji, można wpaść w pułapkę narzędziową przez ocenę wybieranych komputerów wyłącznie według tego wskaźnika - bowiem inne wskaźniki, znacznie ważniejsze przy wykorzystaniu takich komputerów, są dużo trudniejsze do oceny. Inny przykład to ocena poziomu badań w danej instytucji naukowej. W dążeniu do obiektywizacji tej oceny, KBN (Komitet Badań Naukowych) określił kilka wskaźników, z których za jeden z najważniejszych uznał liczbę publikacji w czasopismach naukowych rejestrowanych na tzw. liście filadelfijskiej. Tyle tylko, że lista filadelfijska klasyfikuje czasopisma z zakresu nauk ścisłych, mniej z nauk technicznych, prawie wcale z informatyki, i na pewno nie $\mathrm{z}$ historii czy literatury polskiej. Zatem KBN nie tylko wpadł w pułapkę narzędziową, wybierając za najważniejsze kryterium takie, które akurat daje się stosunkowo łatwo obliczyć, ale uległ także manipulacji agendowej (bo kryterium to wprowadzono akurat na wniosek przedstawicieli nauk ścisłych).
} 
Istotny jest też dalszy sposób agregacji wielokryterialnej i grupowej. Wiąże on się też z zasadniczym pytaniem: czy najpierw agregować wielokryterialnie wiele atrybutów oceny danego wariantu przez każdego $z$ decydentów osobno $w$ jego indywidualna ocenę taczna tego wariantu, a następnie postępować tak, jak przy grupowym wyborze jednokryterialnym, czy też odwrotnie - najpierw uśredniać w ramach grupy decydentów oceny dla każdego atrybutu i wariantu z osobna, a potem przyjąć uzgodniony sposób agregacji wielokryterialnej niejako uśrednionych ocen poszczególnych atrybutów?

Pierwszy z tych sposobów ma większą tradycję w teorii decyzji; ale powinien być stosowany tylko wtedy, gdy w grupowym problemie wyboru chcemy podkreślić różnice preferencji czy interesów poszczególnych decydentów. Jeśli natomiast sytuacja wyboru grupowego jest w istocie zbliżona do wyboru zespołowego - to jest, jeśli oczekujemy od grupy podobnych lub wspólnych preferencji, natomiast wykorzystujemy ją dla porównania różnych spojrzeń fachowych na ocenę wskaźników o bardziej intuicyjnym czy subiektywnym charakterze - to uzasadniony jest sposób drugi. Trzeba wtedy najpierw uśrednić oceny poszczególnych atrybutów i wariantów w ramach grupy z ich dyskusją i modyfikacją, gdyż opinia członka grupy uznanego przez nią za eksperta może (i powinna w sytuacji wyboru zespołowego, wbrew niektórym opiniom przestrzegającym przed narzucaniem opinii grupie) wpłynąć na ocenę innych członków grupy. Potem dopiero trzeba dokonać agregacji wielokryterialnej ocen uśrednionych.

Możliwe jest przy tym kilka sposobów uśredniania ocen wewnątrz grupy stosowanych też np. w technice głosowania jury w przypadku ocen jednokryterialnych. Jednym z nich, godnym polecenia w przypadku grup o dostatecznej liczności ( $n \geq 5)$, jest odrzucanie ocen skrajnych. Motywuje to oceniających do większego obiektywizmu (nikt nie lubi, by jego ocena nie wpływała na wynik) i może być stosowane, jeśli nawet jest kilka ocen skrajnych o takich samych wartościach (odrzuca się wtedy jedną z ocen największych i jedną z ocen najmniejszych; nie jest przy tym istotne, które $\mathrm{z}$ nich się odrzuca). Wielokrotne odrzucanie ocen skrajnych prowadzi w końcu do obliczania mediany zamiast średniej; technika mediany jest najbardziej godnym polecenia sposobem uśredniania ocen wewnątrz grupy. 
Przy analizie ocen grupy można stosować rozmaite wskaźniki niezgodności ocen; często istotne jest, aby wskaźnik taki mierzyć w naturalnej i prostej do interpretacji skali, najlepiej - od 0 do 1. Jeśli np. dla konstrukcji takiego wskaźnika użyjemy statystycznego pojęcia wariancji - średniej kwadratów odchyleń od średniej ocen - to trzeba najpierw obliczyć, jaka może być wariancja maksymalna przy danej skali ocen i liczności grupy oceniającej, a następnie wykorzystać tę informację do obliczania wskaźnika względnego. Wariancja jednak nie daje dobrych informacji o polaryzacji opinii w grupie - często bowiem bardzo istotne jest pytanie, czy rozkład opinii jest mniej więcej równomierny, czy też istnieje faktyczny podział na dwie części grupy o wyraźnie odmiennych opiniach.

We wstępnej dyskusji kryteriów, ich sposobów pomiaru, agregacji i oceny, pojawia się niekiedy problem kompletności zbioru opcji lub wariantów. Nie dotyczy to wprawdzie sytuacji wyboru czy porządkowania kandydatów w konkursie, ale w wielu innych sytuacjach - konstrukcji, zakupów, złożonych negocjacji - problematyka generacji wariantów jest szczególnie istotna. Czy jesteśmy pewni, że uwzględniliśmy wszystkie warianty istotne? Jak wzbogacać zbiór wariantów? Jak generować warianty szczególnie atrakcyjne jako kompromis pomiędzy negocjującymi stronami?

Dopiero po zakończeniu analizy problematyki modelowania sytuacji decyzyjnej i generacji wariantów można przejść do problematyki wyboru wielokryterialnego. Istnieje przy tym wiele metod wspomagania takiego wyboru, jak np. metody ELECTRE oraz PROMETHEE, zob. np. (Bernard Roy 1990). Większość $\mathrm{z}$ tych metod nie jest jednak bezpośrednio przystosowana do wyboru grupowego, zakłada (na ogół niejawnie) pojedynczego decydenta użytkującego te metody.

Omówimy tu przykład metody bezpośrednio dostosowanej do pracy grupowej, zrealizowanej początkowo jako tzw. system SCDAS oparty na pojęciach poziomów aspiracji i rezerwacji - zob. Andrzej Lewandowski et al. (1986), A. Lewandowski i A.P. Wierzbicki (1988); poniższy opis uogólnia nieco wybrane aspekty tej metody.

Rozpatrujemy w tej metodzie wspomaganie pracy komitetu ekspertów, o którym zakłada się, że dokonał już wstępnego modelowania sytuacji 
decyzyjnej i generacji wariantów czy opcji decyzyjnych. Tym niemniej, w metodzie tej zakłada się następujący proces decyzyjny:

1) Dyskusja wstępnej definicji problemu i procedur postępowania. W punkcie tym dyskutuje się najpierw, jakie jest ogólne zadanie pracy komitetu (ranking, czy wybór części wariantów itp.). Następnie dyskutuje się, czy definicja kryteriów oceny (atrybutów opcji) i ich skal oceny jest zrozumiała dla wszystkich ekspertów, czy lista kryteriów jest kompletna i czy nie jest nadmiarowa; czy dysponujemy dostateczną liczbą wariantów czy opcji decyzyjnych. Dalej dyskutuje się kwestie proceduralne: jakie opcje proceduralne pracy komitetu (wśród opcji wymienionych niżej przy bardziej szczegółowym opisie metody) są preferowane, jakie przyjąć reguły głosowania i postępowania przy wnioskach o reasumpcję (powrót do poprzednich punktów procedury) itp.

2) Dyskusja poziomów aspiracji i rezerwacji dla poszczególnych kryteriów. Znając skale ocen poszczególnych kryteriów, komitet powinien ustalić wspólne (zbiorowe) poziomy aspiracji i rezerwacji dla poszczególnych kryteriów. Może to być zadanie niekontrowersyjne, z rezultatami uzyskiwanymi niejako w drodze konsensusu, lub też może być kontrowersyjne, z ustaleniem indywidualnych poglądów (ocen) tych poziomów, a następnie ich zbiorową agregacją $\mathrm{w}$ grupie - wspomaganą przez system SCDAS, a nawet $\mathrm{z}$ dyskusją stopnia i powodów zróżnicowania opinii, na podstawie odpowiednich wskaźników też obliczanych przez SCDAS.

3) Szczegółowa dyskusja wariantów decyzyjnych. Po ustaleniu poziomów aspiracji i rezerwacji celowe jest podjęcie szczegółowej dyskusji opcji decyzyjnych wraz z analizą, które z nich mogą nie spełniać poziomów rezerwacji czy aspiracji dla niektórych kryteriów (atrybutów), czy niektórych nie należałoby usunąć z listy wariantów rozpatrywanych, czy ich liczba jest dostateczna, czy nie nadmierna.

4) Indywidualne oceny wariantów decyzyjnych, indywidualna agregacja ocen wielokryterialnych, ustalenie indywidualnych list rankingowych. Jest to główny etap pracy ekspertów: szczegółowa ocena wszystkich rozpatrywanych wariantów z uwzględnieniem wszystkich ich atrybutów (ocen wartości kryteriów). Przewiduje się, że system wspomaga indywidualną agregację ocen wielokryterialnych za pomocą obliczania 
wartości funkcji osiągnięcia, i na tej podstawie proponuje ustalenie indywidualnych list rankingowych.

5) Dyskusja różnic w indywidualnych ocenach wariantów decyzyjnych, $z$ ewentualną zbiorową agregacją tych ocen. Po dokonaniu ocen indywidualnych celowa jest ich zbiorowa dyskusja, gdyż żaden ekspert nie jest specjalistą we wszystkich dziedzinach i często chętnie wysłucha opinii innych, a nawet może zdecydować się na modyfikację swych opinii szczegółowych. W tym punkcie szczególnie przydatne jest obliczenie przez system wskaźników zróżnicowania opinii - gdyż dyskusja zbiorowa sensowna jest tylko w wypadku takich wariantów i ich atrybutów, co do których występuje największe zróżnicowanie opinii. Po tej dyskusji można zdecydować, czy w celu uzyskania zbiorowego rankingu najpierw przyjąć za oceny poszczególnych wariantów indywidualne agregacje ich ocen wielokryterialnych, uzyskane za pomocą obliczania wartości funkcji osiągnięcia, a następnie agregować (uśredniać) w grupie te wartości funkcji osiągnięcia, czy też agregować (uśredniać) oceny poszczególnych atrybutów i wariantów w grupie, a następnie dokonać ich wielokryterialnej agregacji za pomocą funkcji osiągnięcia. System powinien wspomagać obie opcje proceduralne, gdyż odpowiadają one różnym założeniom o charakterze pracy komitetu (pierwsza podkreśla uśrednianie wartości indywidualnych, druga - działanie zespołowe), a zresztą dwa warianty listy rankingowej i analiza ich różnic mogą być przydatne w pracy komitetu.

6) Dyskusja różnic $w$ indywidualnych rankingach wariantów, porównanie z możliwymi rankingami zbiorowymi. Eksperci - członkowie komitetu mogą zechcieć porównać swoje indywidualne rankingi - czy to między sobą, czy to ze wspomnianymi wyżej wariantami rankingów zbiorowych, oraz przeprowadzić odpowiednią dyskusję.

7) Reasumpcja postępowania (powrót do punktów poprzednich) lub przyjęcie rankingu zbiorowego. Zależnie od przyjętych reguł postępowania, powrót do punktów poprzednich może być wnioskowany (i głosowany) po zakończeniu każdego punktu procedury, bądź też tylko na początku punktu ostatniego. Jeśli nie został przyjęty wniosek o reasumpcję, następuje ostateczne głosowanie listy rankingowej - np. wybór pomiędzy dwiema opcjami list rankingowych określonymi w punkcie 5). 
W metodzie SCDAS zakładamy wspomaganie pracy komitetu złożonego z $N$ ekspertów oznaczanych przez $n=1, \ldots N$, przy czym każdy z nich może mieć prawo do jednego lub kilku głosów; współczynnik siły głosów $n$-tego eksperta oznaczamy przez $v_{n}$. Zakładamy też $M$ opcji czy wariantów decyzyjnych oznaczanych przez $m=1, \ldots M$, oraz $K$ kryteriów numerowanych przez $k=1, \ldots K$. Wartości tych kryteriów będziemy oznaczać przez $q_{k}$, przy czym zakładamy, że wszystkie te kryteria mają charakter rosnący (im ich wartości są większe, tym są one lepsze). Możliwe jednak są dwie sytuacje:

a) Wartości kryteriów dla poszczególnych wariantów są dane obiektywnie - oznaczamy je wtedy przez $q_{k m}$ (wartość $k$-tego kryterium dla $m$-tego wariantu, czyli $k$-ty atrybut $m$-tego wariantu);

b) Wartości kryteriów dla poszczególnych wariantów są przedmiotem ocen ekspertów - członków komitetu, o których oczywiście zakładamy, że zapoznali już się ze wszelkimi obiektywnymi danymi dotyczącymi tych wariantów i mogą dokonać subiektywnej oceny odpowiednich kryteriów na podstawie tych danych obiektywnych oraz swej wiedzy i intuicji. Oceny ekspertów oznaczamy wtedy przez $q_{k m n}$ (ocena wartości $k$-tego kryterium dla $m$-tego wariantu czy opcji decyzyjnej dokonana przez $n$-tego eksperta, czyli ocena $k$-tego atrybutu $m$-tego wariantu przez $n$-tego eksperta).

W opisie metody SCDAS skoncentrujemy się na przypadku b), choć metodę te można stosować także wtedy, gdy niektóre kryteria mają oceny czy wartości obiektywne. Metoda ocen SCDAS opiera się na uprzedniej grupowej dyskusji poziomów aspiracji i rezerwacji dla każdego kryterium; mogą tu znów zajść dwa przypadki. W pierwszym z nich, komitet może być zgodny co do przyjmowanych poziomów aspiracji, oznaczanych przez $p_{k}$, oraz rezerwacji, oznaczanych przez $r_{k}$, dla poszczególnych kryteriów - chodzi tu przecież tylko o ustalenie pewnej skali ocen i minimalnych poziomów akceptowalności czy zadowolenia na tej skali ocen. W drugim z nich komitet może różnić się poglądami co do poziomów aspiracji oraz rezerwacji i życzyć sobie formalnego głosowania. Zakłada się wtedy, że komitet może wybrać jedną $\mathrm{z}$ dwóch metod agregacji opinii co do poziomów aspiracji oraz rezerwacji: metodę średniej ważonej i metodę uogólnionej (ważonej) mediany. W metodzie średniej ważonej grupowe poziomy aspiracji i rezerwacji ustala się według wzorów: 


$$
p_{k}=\Sigma_{n=1, . . N} v_{n} p_{k n} / \Sigma_{n=1, . . N} v_{n} ; r_{k}=\Sigma_{n=1, . . N} v_{n} r_{k n} / \Sigma_{n=1, . . N} v_{n}
$$

gdzie $p_{k n}$ oraz $r_{k n}$ są odpowiednio poziomem aspiracji i rezerwacji dla $k$-tego kryterium proponowanym przez $n$-tego eksperta. $\mathrm{W}$ metodzie tej współczynniki siły głosów $v_{n}$ mogą być dowolnymi dodatnimi liczbami rzeczywistymi. W metodzie uogólnionej mediany ważonej zakładamy, że współczynniki siły głosów są dodatnimi liczbami naturalnymi. W celu obliczenia mediany ważonej porządkujemy proponowane według ekspertów poziomy aspiracji (analogicznie rezerwacji) w ich skali rosnącej z tym, że przy $v_{n}>1$ odpowiednie $p_{k n}$ powtarzamy $v_{n}$ razy; łączna długość tak uporządkowanej listy wynosi wtedy $N^{\sim}=\Sigma_{n=1, \ldots N} v_{n}$. Z listy tej następnie usuwamy po dwa elementy skrajne, powtarzając to usuwanie tak długo, aż na liście zostaje jeden lub dwa elementy. Jeśli jeden, to on jest wynikiem mediany ważonej; jeśli dwa, to ich średnia arytmetyczna traktowana jest jako mediana ważona. Wynik takiej procedury oznaczymy przez $\operatorname{med}_{n=1, \ldots N ; v n} p_{k n}$ (odpowiednio dla $r_{k n}$ ), a przyjęte grupowe poziomy aspiracji i rezerwacji mają wtedy postać:

$$
p_{k}=\operatorname{med}_{n=1, \ldots N ; v n} p_{k n} ; \quad r_{k}=\operatorname{med}_{n=1, \ldots N ; v n} r_{k n}
$$

Następnie komitet może zdecydować, czy przy ustalaniu indywidualnych ocen i rankingów $\mathrm{w}$ dalszych punktach procedury należy stosować zagregowane grupowo, czy też indywidualne poziomy aspiracji i rezerwacji dla poszczególnych kryteriów. Poziomy te powinny spełniać zależności:

$$
\begin{aligned}
& q_{k, l_{o}}<r_{k}<p_{k}<q_{k, u p} ; q_{k, l o}<r_{k n}<p_{k n}<q_{k, u p} ; \\
& \boldsymbol{r}=\left(r_{1}, \ldots, r_{k}, \ldots, r_{K}\right) ; \boldsymbol{p}=\left(p_{1}, \ldots, p_{k}, \ldots, p_{K}\right) ; \\
& \left.\boldsymbol{r}_{n}=\left(r_{1 n}\right\}, \ldots, r_{k n}, \ldots, r_{K n}\right) ; \boldsymbol{p}_{n}=\left(p_{1 n}, \ldots, p_{k n}, \ldots, p_{K n}\right)
\end{aligned}
$$

gdzie $q_{k, l o}, q_{k, u p}$ są odpowiednio dolnym i górnym kresem wartości $k$-tego kryterium czy atrybutu. Przy subiektywnej ocenie wszystkich atrybutów, można przyjąć jednolitą skalę oceny, np. $0 \leq q_{k} \leq 10$, dla każdego z nich, ale nie jest to wymagane w systemie SCDAS.

Choć jest mało prawdopodobne, aby tak niekontrowersyjna kwestia, jak ustalanie poziomów aspiracji i rezerwacji, powodowała dłuższe dyskusje, to jednak wykorzystamy ten przykład dla ilustracji obliczania tzw. wskaźnika niezgody, użytecznego podczas dyskusji kwestii bardziej kontrowersyjnych. 
Można proponować rozmaite wskaźniki charakteryzujące stopień różnorodności opinii grupy, np. oparte na statystycznym pojęciu wariancji rozkładu itp. Chcemy jednak uzyskać współczynnik, który byłby równy jedności w wypadku maksymalnej polaryzacji opinii w komitecie (połowa ekspertów ma jedną, druga połowa - inną opinię), i równy zeru w przypadku jednomyślnej opinii. Korzystna jest zatem następująca formuła wskaźnika niezgody. Porządkujemy proponowane przez ekspertów oceny (np. poziomów aspiracji $p_{k n}$ ) w ich skali rosnącej. Jeśli chcemy przy tym uwzględnić różnorodne siły głosów (które muszą być wtedy dodatnimi liczbami naturalnymi, tak jak przy liczeniu mediany ważonej), to powtarzamy odpowiednie oceny $v_{n}$ razy. Określamy bezwzględną różnicę opinii między największą a najmniejszą oceną (np. $\Delta P_{k N}=p_{k N}-p_{k 1}$, gdyż po takim uporządkowaniu $p_{k 1}$ jest oceną najmniejszą, zaś $p_{k N}$ - największą). Określamy kolejne przyrosty oceny (np. $\Delta p_{k n}=p_{k n}-p_{k, n-1}$, dla $\mathrm{n}=2, \ldots, N^{\sim}$, gdzie $N^{\sim}=\Sigma_{n=1, \ldots N} v_{n}$, licząc powtórzenia z uwagi na siłę głosów jako zwiększenie liczby ekspertów. Następnie dobieramy takie współczynniki wagi $c_{n}$, aby średnia ważona przyrostów ocen była równa ich sumie $\Delta P_{k N}$ tylko w przypadku maksymalnej polaryzacji ocen. Możliwe są różne sposoby doboru takich współczynników wagi. Jednym z nich jest sposób następujący:

$$
\begin{aligned}
& c_{2}=0 ; c_{n}=16(n-1)^{2}\left(N^{\sim}-1-n\right)^{2} /\left(N^{\sim}-2\right)^{4}, \\
& \mathrm{n}=3, \ldots, N^{\sim}-1=\Sigma_{n=1, \ldots N} V_{n}-1 ; c\left(N^{\sim}\right)=0
\end{aligned}
$$

gdzie przyjęto, że opinie skrajne nie liczą się nawet przy ustalaniu współczynnika niezgody. ${ }^{9}$ Względny współczynnik niezgody ma wtedy postać:

$$
d p_{k}=\Sigma_{n=2, \ldots N \sim} C_{n} \Delta p_{k n} /\left(p_{k N \sim}-p_{-k 1}\right)
$$

i zawiera się między zerem a jednością (zero przy jednomyślności z wyjątkiem opinii skrajnych, jedność przy całkowitej polaryzacji). Jest to oczywiście współczynnik względny: nawet przy całkowitej polaryzacji opinii, gdy współczynnik ten wynosi jedność, może to nie mieć znaczenia, jeśli bezwzględna różnica opinii $\Delta P_{k N \sim}=p_{k N \sim}-p_{k 1}$ jest odpowiednio mała.

\footnotetext{
${ }^{9}$ Przy założeniu, że w każdym, nawet najbardziej zgodnym gronie ekspertów znajdzie się przynajmniej dwóch oryginałów, którzy wyrażą dla zasady opinie skrajne.
} 
Po określeniu poziomów aspiracji i rezerwacji, metoda SCDAS przewiduje zbiorową dyskusję poszczególnych wariantów decyzyjnych, a następnie indywidualną ocenę wszystkich atrybutów (wartości kryteriów) dla tych wariantów. Ocenę wartości kryterium $k$ dla wariantu $m$ przez eksperta $n$ oznaczymy przez $q_{k m n}$; określenie $k^{*} m$ ocen może być oczywiście ciężkim zadaniem dla eksperta. System może jednak wspomagać eksperta poprzez obliczenie wartości funkcji osiągnięcia dla każdego wariantu. Oznaczmy przez $\boldsymbol{q}_{m n}=\left(q_{1 m n}, \ldots, q_{k m n}, \ldots, q_{K m n}\right)$ wektorową ocenę wariantu $m$ przez eksperta $n$. Znając poziomy odniesienia spełniające odpowiednie nierówności jak w (5.13) i zakładając stosowanie indywidualnych poziomów aspiracji i rezerwacji, możemy zastosować następującą funkcję osiągnięcia:

$$
\sigma\left(\boldsymbol{q}_{m n}, \boldsymbol{p}_{r \boldsymbol{r}} \boldsymbol{r}_{n}\right)=\min _{1 \leq k \leq K} \sigma_{k}\left(\boldsymbol{q}_{k m n}, \boldsymbol{p}_{k \boldsymbol{r}} r_{k n}\right)+\varepsilon \sum_{\mathrm{i}=1, \ldots m} \sigma_{k}\left(\boldsymbol{q}_{k m n}, \boldsymbol{p}_{k \boldsymbol{r}} r_{k n}\right) /(1+\varepsilon)
$$

gdzie $\varepsilon>0$ jest małym współczynnikiem, a cząstkowe funkcje osiągnięcia $\sigma_{k}$ mają postać:

$$
\sigma_{k}\left(\boldsymbol{q}_{k m n}, \boldsymbol{p}_{k n \boldsymbol{v}} r_{k n}\right)= \begin{cases}1+\alpha\left(q_{k m n}-p_{k n}\right) /\left(q_{k, u p}-p_{k n}\right), & p_{k n}<q_{k m n} \leq q_{k, u p} \\ \left(q_{k m n}-r_{k n}\right) /\left(p_{k n}-r_{k n}\right), & r_{k n}<q_{k m n} \leq p_{k n} \\ \beta\left(q_{k m n}-r_{k n}\right) /\left(r_{k n}-q_{k, l o}\right), & q_{k, l o} \leq q_{k m n} \leq r_{k n}\end{cases}
$$

Jeśli wybrać $\alpha=\beta=1$, to pozostałe współczynniki w funkcji (15.17) zostały tak dobrane, aby jej wartość wynosiła -1 , jeśli wszystkie oceny atrybutów są na poziomach dolnych $q_{k, l o}$, wynosiła 0 jeśli wszystkie oceny atrybutów są na poziomach rezerwacji $r_{k n}$, wynosiła 1 jeśli wszystkie oceny atrybutów są na poziomach aspiracji $p_{k n}$, wreszcie wynosiła 2 jeśli wszystkie oceny atrybutów są na poziomach górnych $q_{k, u p}$. Daje to możliwość uporządkowania wszystkich wariantów w indywidualnej liście rankingowej według malejących wartości $\sigma\left(\boldsymbol{q}_{m n}, \boldsymbol{p}_{n}, \boldsymbol{r}_{n}\right)$ - tak, jakby wartości te aproksymowały funkcję wartości $n$-tego eksperta. Oczywiście, jest to tylko propozycja listy rankingowej, którą ekspert może zaakceptować lub zmodyfikować.

Jeśli została przyjęta jednolita skala $0 \leq q_{k} \leq 10$ dla wszystkich atrybutów, to sensowne jest też przyjęcie $\alpha=\beta=10 \mathrm{w}$ powyższym wzorze. Wtedy wszystkie warianty niezadowalające - o ocenach poniżej poziomów 
rezerwacji - mają oceny skalarne $\mathrm{w}$ granicach $-10, \ldots 0$; wszystkie warianty zadowalające, o ocenach pomiędzy poziomami rezerwacji a aspiracji - mają oceny skalarne $\mathrm{w}$ granicach $0, \ldots 10$; wreszcie wszystkie warianty wybitne, o ocenach przekraczających aspiracje - mają oceny skalarne w granicach $10, \ldots 20$.

Po dokonaniu wszystkich indywidualnych ocen ekspertów w stosunku do każdego atrybutu każdego wariantu, system SCDAS może obliczyć absolutne różnice $\Delta Q_{k m N}$ (analogiczne do $\Delta P_{k N}$ ) oraz wskaźniki niezgody $d q_{k m}$ (analogiczne do $d p_{k}$ ) dla ocen każdego atrybutu i wariantu. Pozwala to wybrać takie oceny atrybutu i wariantu, w stosunku do których są największe różnice opinii w komitecie, i na tych właśnie ocenach skoncentrować dyskusję porównania ocen. Analogicznie można też zaproponować odpowiednie wskaźniki niezgody co do pozycji danego wariantu na indywidualnych listach rankingowych.

Ćwiczenie 15.2: Zaproponować definicję wskaźnika niezgody co do położenia danego wariantu na indywidualnych listach rankingowych tak, aby wskaźnik ten był równy jedności, gdy połowa komitetu uważa ten wariant za najlepszy, druga połowa zaś za najgorszy, natomiast równy zeru, jeśli wszyscy członkowie komitetu (być może, z wyjątkiem dwóch członków o opiniach skrajnych) dają temu wariantowi takie samo miejsce na listach rankingowych.

Po dyskusji ocen może nastąpić reasumpcja ocen indywidualnych, jeśli eksperci przegłosują taki wniosek. Jeśli nie, to możliwe jest przystąpienie do ustalania rankingów grupowych. Jak już wspomniano, możliwe są dwa sposoby takiego rankingu. Jeśli przykładamy większą wagę do pracy zespołowej, to możemy dokonać najpierw agregacji ocen szczegółowych stosując metodę średniej ważonej czy mediany ważonej do ocen $q_{\mathrm{km} n}$ i uzyskując odpowiednie grupowe oceny $q_{k m}$ :

$$
\begin{aligned}
& q_{k m, a v}=\Sigma_{n=1, \ldots N} v_{n} q_{k m n} / \Sigma_{n=1, \ldots N} v_{n} \\
& q_{k m, \text { med }}=\operatorname{med}_{n=1, \ldots N ; v n} q_{k m n}
\end{aligned}
$$

Obliczane są następnie - analogicznie jak we wzorach $(15.16,15.17)$

- funkcje osiągnięcia $\sigma\left(\boldsymbol{q}_{m, a v}, \boldsymbol{p}, \boldsymbol{r}\right)$ oparte o wektory ocen grupowych 
$\boldsymbol{q}_{m, a v}=\left(q_{1 m, a v}, \ldots, q_{\mathrm{km}, \mathrm{av}}, \ldots, q_{K m, a v}\right)$ (analogicznie w przypadku stosowania mediany) oraz o wektory grupowych poziomów aspiracji i rezerwacji $\boldsymbol{p}, \boldsymbol{r}$ :

$$
\sigma\left(\boldsymbol{q}_{m, a v}, \boldsymbol{p}, \boldsymbol{r}\right)=\min _{1 \leq k \leq K} \sigma_{k}\left(\boldsymbol{q}_{k m, a v}, \boldsymbol{p}_{\boldsymbol{b}} r_{k}\right)+\varepsilon \sum_{\mathrm{i}=1, \ldots m} \sigma_{k}\left(\boldsymbol{q}_{k m, a v}, \boldsymbol{p}_{\boldsymbol{b}} r_{k}\right) /(1+\varepsilon)
$$

gdzie cząstkowe funkcje osiągnięcia $\sigma_{k}$ mają postać:

$$
\sigma_{k}\left(\boldsymbol{q}_{k m, a v}, \boldsymbol{p}_{\boldsymbol{b}} r_{k}\right)= \begin{cases}1+\alpha\left(q_{k m, a v}-p_{k}\right) /\left(q_{k, u p}-p_{k}\right), & p_{k}<q_{k m, a v} \leq q_{k, u p} \\ \left(q_{k m, a v}-r_{k}\right) /\left(p_{k}-r_{k}\right), & r_{k}<q_{k m, a v} \leq p_{k} \\ \beta\left(q_{k m, a v}-r_{k}\right) /\left(r_{k}-q_{k, l o}\right), & q_{k, l o} \leq q_{k m, a v} \leq r_{k}\end{cases}
$$

Można teraz uporządkować warianty według malejących wartości $\sigma\left(\boldsymbol{q}_{m, a v}, \boldsymbol{p}, \boldsymbol{r}\right)$ tej funkcji osiągnięcia, uzyskując pierwszą wersję rankingu grupowego (wykorzystując medianę ważoną do agregacji ocen grupowych, uzyskamy jeszcze podwariant tego pierwszego wariantu).

Jeśli natomiast przykładamy większą wagę do indywidualnych wartościowań wariantów decyzyjnych - aproksymowanych przez wartości indywidualnych funkcji osiągnięcia $\sigma_{m n}=\sigma\left(\boldsymbol{q}_{m n}, \boldsymbol{p}_{n}, \boldsymbol{r}_{n}\right)$ wykorzystane wcześniej dla utworzenia indywidualnych list rankingowych - to możemy określić drugi wariant grupowej listy rankingowej, stosując metodę średniej lub mediany ważonej nie do ocen szczegółowych, tylko do wartości indywidualnych funkcji osiągnięcia dla poszczególnych wariantów:

$$
\begin{aligned}
& \sigma_{m, a v}=\Sigma_{n=1, \ldots N} v_{n} \sigma_{m n} / \Sigma_{n=1, \ldots N} v_{n} \\
& \sigma_{m, \text { med }}=\operatorname{med}_{n=1, \ldots N} \text {; vn } \sigma_{m n}
\end{aligned}
$$

Następnie porządkujemy warianty według malejących wartości $\sigma_{m, a v}$, tworząc drugi wariant listy rankingowej (lub jeszcze jeden podwariant tego wariantu, jeśli wykorzystujemy medianę ważoną). Różnice pomiędzy tymi dwoma (lub czterema) wersjami listy rankingowej mogą pomóc ekspertom skoncentrować dyskusję na tych wariantach, które są istotnie kontrowersyjne - inaczej oceniane przez różnych ekspertów, czy mające inne miejsce na alternatywnych listach rankingowych. Te wersje list rankingowych mogą też być przedmiotem głosowania nad wyborem wersji ostatecznej. 
System SCDAS, jak i wiele innych systemów oceny wielokryterialnej, zakłada dyskretny charakter opcji decyzyjnych. Jeśli odejść od założenia o danym z góry, dyskretnym zbiorze wariantów czy opcji decyzyjnych, to problemy decyzji grupowych stają się znacznie bogatsze, ale też komplikują się znacznie. Można wtedy wykorzystać metody optymalizacji wektorowej i wielokryterialnej analizy decyzji, omawiane we wcześniejszych rozdziałach. Tu podkreślimy tylko, że także w tym przypadku zalecane jest wykorzystanie metod punktu odniesienia oraz odpowiednich funkcji osiągnięcia, zob. Piotr Bronisz et al. (1989).

\subsection{Problem obiektywizacji rankingu (rankingu “obiektywnego”)}

Ranking opcji czy wariantów dyskretnych jest klasycznym problemem wielokryterialnej analizy decyzji. Jednakże wszystkie podejścia klasyczne np. (Ralph Keeney i Howard Raiffa 1976), czy (Thomas Saaty 1982), czy też (Ralph Keeney 1992) - koncentrują się na rankingu subiektywnym. Przez pojęcie to rozumiemy tu nie intuicyjny ranking subiektywny, dokonywany przez jakiegokolwiek doświadczonego decydenta w oparciu o jego intuicję, lecz racjonalny ranking subiektywny, oparty na danych charakteryzujących sytuację decyzyjną, ale wykorzystujący aproksymację preferencji osobistych przy agregacji wielu kryteriów.

I to właśnie jest problemem, gdyż $w$ wielu sytuacjach praktycznych, jeśli decydent chce nawet uzyć wspomagania komputerowego $i$ racjonalnego rankingu, to wcale nie chce określać preferencji osobistych, woli uzyskać ranking możliwie obiektywny. Sytuacja taka występuje np. przy projektowaniu sieci teleinformatycznych; występuje też często w zagadnieniach zarządzania, kiedy decyzja nie jest czysto osobista, ale dotyka wielu ludzi przy czym zazwyczaj byłoby bardzo trudno osiągnąć racjonalny ranking intersubiektywny, uwzględniający osobiste preferencje wszystkich ludzi, których to dotyczy. Ten oczywisty fakt ilustruje najlepiej następujący przykład.

Przyklad korporacji międzynarodowej. Rozpatrujemy korporację międzynarodową, która ma sześć oddziałów A,...F. Oddziały te charakteryzują rozmaite dane, takie jak nazwa, położenie, liczba pracowników itp. 
Jednakże, przypuśćmy że szef tej korporacji chce mieć ranking tych oddziałów na podstawie następujących atrybutów czy kryteriów: 1) zysk (w \% dochodu), 2) udział w rynku (m.share, w \% zaspokajania popytu na określonym rynku), 3) współpraca wewnętrzna (i.trade, w \% dochodu uzyskiwanego z zaspokajania potrzeb innych oddziałów korporacji), wreszcie 4) lokalny odbiór społeczny (local social image, 1.s.i.), oznaczający punktową ocenę pozycji publicznej oddziału w kraju, gdzie jest ten oddział zlokalizowany, w skali $0 \ldots 100$ punktów). Wszystkie te kryteria są maksymalizowane (im większe wartości, tym lepiej). Przykład takich danych ilustruje poniższa tabela: ${ }^{10}$

\begin{tabular}{|c|c|c|c|c|c|c|c|}
\hline Oddział & Nazwa & Lokalizacja & $\begin{array}{c}\text { Zatrudnie- } \\
\text { nie }\end{array}$ & $\begin{array}{c}q_{1}: \\
\text { zysk }\end{array}$ & $\begin{array}{c}q_{2}: \\
\text { m.share }\end{array}$ & $\begin{array}{c}q_{3}: \\
\text { i.trade }\end{array}$ & $\begin{array}{c}q_{4}: \\
\text { l.s.i. }\end{array}$ \\
\hline A & Alpha & USA & 250 & $11 \%$ & $8 \%$ & $10 \%$ & 40 \\
\hline B $^{*}$ & Beta & Brasilia & 750 & $23 \%$ & $40 \%$ & $34 \%$ & 60 \\
\hline C $^{*}$ & Gamma & China & 450 & $16 \%$ & $50 \%$ & $45 \%$ & 70 \\
\hline D $^{*}$ & Delta & Dubai & 150 & $35 \%$ & $20 \%$ & $20 \%$ & 44 \\
\hline E* $^{*}$ & Epsilon & C. Europe & 350 & $18 \%$ & $30 \%$ & $20 \%$ & 80 \\
\hline F & Fi & France & 220 & $12 \%$ & $8 \%$ & $9 \%$ & 30 \\
\hline
\end{tabular}

Dane dla przykładu międzynarodowego zarządzania w biznesie

(* oznacza opcje Pareto-optymalne)

Załóżmy, że szef tej korporacji wynajął firmę konsultingową i zażyczył sobie rankingu możliwie obiektywnego, nie chcąc wyrażać osobistych preferencji co do agregacji poszczególnych kryteriów. Metodą, którą najłatwiej zastosować dla uzyskania racjonalnego rankingu zobiektywizowanego, ${ }^{11}$ jest metoda punktów odniesienia - ponieważ poziomy aspiracji i rezerwacji dla tej metody nie muszą być określane subiektywnie przez decydenta, moga być określone względnie obiektywnie statystycznie na podstawie danego zbioru danych. Metodę tę można zastosować nie tylko dla zobiektywizowanego rankingu, także dla zobiektywizowanej klasyfikacji (podziału na określone klasy opcji).

\footnotetext{
${ }^{10}$ Dane w tej tabeli są symulowane, nie odpowiadają żadnej realnej korporacji.

11 W skrócie - rankingu obiektywnego, chociaż żaden ranking nie jest w pełni obiektywny (sam wybór metody jest przecież subiektywny).
} 
Oznaczmy przez $q_{k m}$ wartość $k$-tego kryterium dla $m$-tej opcji (oddziału), zaś wartości funkcji osiągnięcia dla tej opcji przez $\sigma_{m}=\sigma\left(\boldsymbol{q}_{m}, \boldsymbol{p}, \boldsymbol{r}\right)$, gdzie $\boldsymbol{q}_{m}$ jest odpowiednim wektorem wartości kryteriów; wartości $\sigma_{m}$, zaczynając od najwyższej, są podstawą utworzenia listy rankingowej. Jak przy tym określić poziom aspiracji $\boldsymbol{p}$ oraz rezerwacji $\boldsymbol{r}$, aby uzyskać racjonalny ranking zobiektywizowany? W (Janusz Granat et al. 2007) zaproponowano kilka metod: neutralna, glosowania, statystyczna; tu koncentrujemy się na metodzie statystycznej.

Metoda statystyczna wykorzystuje wartości średnie $s_{k}$ poszczególnych kryteriów jako podstawowe poziomy odniesienia, z ich modyfikacją w stronę wartości minimalnych kryteriów $q_{k, l o}$ dla określenia poziomów rezerwacji oraz w stronę wartości maksymalnych kryteriów $q_{k, u p}$ dla określenia poziomów aspiracji:

$$
s_{k}=\sum_{m \epsilon \boldsymbol{M}} \boldsymbol{q}_{k m} / M ; \quad r_{k}=0.5\left(q_{k, l o}+s_{k}\right) ; \quad p_{k}=0.5\left(q_{k, u p}+s_{k}\right), \quad \forall k \epsilon \boldsymbol{K}
$$

gdzie $M$ oznacza liczbę rozpatrywanych opcji, a więc $s_{k}$ jest wartością średnią $k$-tego kryterium wśród alternatywnych opcji, zaś poziomy aspiracji i rezerwacji - średnimi tych wartości średnich i odpowiednich poziomów maksymalnych i minimalnych wartości kryteriów.

Nie ma przy tym powodów, dla których powinniśmy stosować uśrednianie wśród wszystkich opcji alternatywnych; jeśli mamy dodatkowe dane (np. historyczne), to możemy uśredniać po większym zbiorze, natomiast jeśli chcemy być bardziej wymagający, to możemy uśredniać po mniejszym zbiorze opcji Pareto-optymalnych.

$\mathrm{Na}$ przykład, dane $\mathrm{z}$ powyższej tabeli pozwalają na rozpatrzenie dwóch rodzajów rankingu:

a) z poziomami odniesienia wynikającymi ze średnich danych z tej tabeli;

b) z poziomami odniesienia wynikającymi ze średnich z opcji Paretooptymalnych; zob. następne dwie tabele.

Bardziej wymagający ranking b) wykazuje zmiane porzadku ${ }^{12}$ : oddziały $C$ i $E$, zajmujące pozycje 2 i $3 \mathrm{w}$ rankingu a), zamieniają swe pozycje

\footnotetext{
${ }^{12}$ Angielskie rank reversal.
} 
w rankingu b). Jest to jednak zjawisko naturalne: średnie aspiracje gwarantują standardowo dobre rozwiązania, szczególnie dobre rozwiązania wynikają $\mathrm{z}$ aspiracji wymagających.

\begin{tabular}{|c|c|c|c|c|c|c|c|}
\hline $\begin{array}{c}\text { Ranking a) } \\
\text { Oddziały }\end{array}$ & $\sigma_{1}$ & $\sigma_{2}$ & $\sigma_{3}$ & $\sigma_{4}$ & $\sigma$ & $\begin{array}{c}\text { Pozycja } \\
\text { w rankingu }\end{array}$ & Klasa \\
\hline A & 0.00 & 0.00 & 0.37 & 2.50 & 0.29 & 5 & III \\
B & 5.63 & 7.50 & 7.00 & 5.88 & 8.23 & 1 & I \\
C & 3.30 & 10.0 & 10.0 & 7.62 & 6.39 & 2 & II \\
D & 10.0 & 3.57 & 3.89 & 3.32 & 5.40 & 4 & II \\
E & 3.97 & 5.48 & 3.89 & 10.0 & 6.30 & 3 & II \\
F & 0.73 & 0.00 & 0.00 & 0.00 & 0.07 & 6 & III \\
\hline
\end{tabular}

Przykład rankingu ze średnimi aspiracjami

\begin{tabular}{|c|c|c|c|c|c|c|c|}
\hline $\begin{array}{c}\text { Ranking b) } \\
\text { Oddziały }\end{array}$ & $\sigma_{1}$ & $\sigma_{2}$ & $\sigma_{3}$ & $\sigma_{4}$ & $\sigma$ & $\begin{array}{c}\text { Pozycja } \\
\text { w rankingu }\end{array}$ & Klasa \\
\hline A & 0.00 & 0.00 & 0.29 & 1.80 & 0.21 & 5 & III \\
B & 5.00 & 6.61 & 6.24 & 5.13 & 7.30 & 1 & I \\
C & 2.50 & 10.0 & 10.0 & 6.73 & 5.28 & 3 & II \\
D & 10.0 & 3.47 & 3.13 & 2.51 & 4.42 & 4 & II \\
E & 3.33 & 5.04 & 3.13 & 10.0 & 5.43 & 2 & II \\
F & 0.50 & 0.00 & 0.00 & 0.00 & 0.05 & 6 & III \\
\hline
\end{tabular}

Przykład rankingu z wymagającymi aspiracjami

Mimo zmiany porządku, ranking zobiektywizowany jest odporny; zmiana porządku jest niewielka, i znika, jeśli zamiast rankingu rozpatrujemy klasyfikację z podziałem na trzy klasy:

I: Bardzo dobra,

II: Dobra,

III: Słaba.

Oddziały $C$ i $E$ pozostają w klasie II, zarówno dla średnich jak i dla wymagających aspiracji.

W niektórych zastosowaniach w zarządzaniu, opcje najsłabsze $w$ rankingu sa najbardziej interesujące, gdyż wskazują one na potrzebę działań korekcyjnych. Pierwotna motywacja dla zastosowania rankingu zobiektywizowanego powstała w związku z rzeczywistym zastosowaniem do 
oceny warunków kreatywności w japońskim uniwersytecie badawczym, Japan Advanced Institute of Science and Technology (JAIST), zob. (Jing Tian et al. 2006). W istocie, słowo zastosowanie wprowadza tu w błąd: rzeczywisty problem zostat rozwiąany $w$ sposób innowacyjny, co umotywowato dalszy rozwój teorii. To się zdarza często w rozwoju techniki: technika nie jest wyłacznie zastosowaniem podstawowych nauk ścistych, często wyprzedza rozwój teorii - tak jak wynalazek koła wyprzedził pojęcie okręgu, zaś wynalazek teleskopu wyprzedził rozwój optyki.

Problem w tym przypadku polegał na ocenie warunków kreatywności w oparciu o rezultaty ankiety. Ankieta obejmowała 48 pytań z rozmaitymi możliwościami odpowiedzi; wypełniło ją 140 respondentów o różnych cechach: przypisaniu do określonego wydziału, narodowości (JAIST ma sporo studentów spoza Japonii), pozycji badawczej (studenci magisterscy, doktoranci, współpracownicy badawczy itp.). Wynikła stąd baza danych nie była bardzo duża, ale wymagała wspomagania obliczeniowego.

Pytania były trzech typów:

- Pytania o ocenę, oceniające sytuację studentów na uniwersytecie; najbardziej krytyczne kwestie tego typu dotyczyły ocen najgorszych.

- Pytania o znaczenie (ważność), oceniające znaczenie danej kwestii; najbardziej ważne kwestie tego typu wynikały z ocen najlepszych.

- Pytania kontrolne, testujące w sposób pośredni odpowiedzi na pytania pierwszych dwóch typów albo wymagające bardziej szczegółowego wyjaśnienia.

W pytaniach dwóch pierwszych typów, respondenci byli proszeni o zaznaczenie odpowiedzi na skali vg (bardzo dobry), $\boldsymbol{g}$ (dobry), a (przeciętny), b (zły), $\boldsymbol{v b}$ (bardzo zły) - czasami w odwróconej skali jeśli pytania były sformułowane negatywnie. Odpowiedzi do pytań pierwszych dwóch typów były wyceniane we wspólnej skali jako dystrybucje procentowe (histogramy) odpowiedzi $\boldsymbol{v g}-\boldsymbol{g}-\boldsymbol{a}-\boldsymbol{b}-\boldsymbol{v b}$. Odpowiedź przeciętny była interpretowana jako niemal zły. Histogramy odpowiedzi były interpretowane $\mathrm{w}$ sensie optymalizacji wielokryterialnej, z podziałem zbioru kryteriów $\boldsymbol{K}=\boldsymbol{G} \cup \boldsymbol{B}$, $\boldsymbol{G}=\{\boldsymbol{v g}, \boldsymbol{g}\}, \boldsymbol{B}=\{\boldsymbol{a}, \boldsymbol{b}, \boldsymbol{v b}\}, \mathrm{z} k \in \boldsymbol{G}=\{\boldsymbol{v} \boldsymbol{g}, \boldsymbol{g}\}$ traktowanymi jako kryteria 
maksymalizowane, zaś $k \epsilon \boldsymbol{B}=\{\boldsymbol{a}, \boldsymbol{b}, \boldsymbol{v} \boldsymbol{b}\}$ jako kryteria minimalizowane (dla pytań o ocenę ważności).

Metoda punktu odniesienia była zastosowana w tym szczególnym przypadku rankingu histogramów; inne metody byłyby znacznie bardziej skomplikowane (zob. np. Włodzimierz Ogryczak i Andrzej Ruszczyński 2001). Jednakże, kiedy zapytaliśmy dziekana School of Knowledge Science w JAIST (zresztą specjalistę $\mathrm{w}$ zakresie optymalizacji wielokryterialnej, Yoshiteru Nakamori) o określenie jego preferencji w formie poziomów aspiracji, rzeczywistość tej sytuacji zarządczej pokonała jego teoretyczne przygotowanie - odpowiedział on: w tym przypadku, potrzebuje rankingu jak najbardziej obiektywnego; muszę dyskutować rezultaty tych badań z dziekanami innych szkót oraz innymi profesorami. To stało się początkiem badań nad zobiektywizowanymi metodami rankingu.

Zatem statystyczna średnia procentów odpowiedzi w całym zbiorze danych została przyjęta jako profil odniesienia. W celu testowania odporności metody, skonstruowano również bardziej wymagające profile odniesienia $\mathrm{z}$ przesunięciem ich $\mathrm{w}$ odpowiednią stronę (nie obliczano opcji Paretooptymalnych z uwagi na rozmiar zbioru danych).

Szczegółowe rezultaty tych badań okazały się bardzo użyteczne dla zarządzania uniwersytetem, zob. (Jing Tian et al. 2006). Siedem kwestii pierwszego typu (oceny), które uzyskały ranking bardzo zły, nie ulegało zmianie przy modyfikacji profili odniesienia, zatem ranking zobiektywizowany dat rezultaty odporne przy typowaniu problemów wymagajacych najpilniejszej interwencji władz uniwersytetu. Najlepiej oceniane kwestie drugiego typu (ważności) były bardziej zmienne zależnie od modyfikacji profili odniesienia, tylko trzy z nich pozostawały najlepsze $\mathrm{w}$ rankingu niezależnie od tej modyfikacji. Ponadto, jeśli stosowano przeciętne profile odniesienia, najlepiej oceniane kwestie byty dość oczywiste, rzeczywiście interesujace rezultaty osiagano przy bardziej wymagajacych profilach odniesienia. 
Innym zastosowaniem metod rankingu zobiektywizowanego jest problem wykrywania ważnego zdarzenia $\mathrm{w}$ sieci telekomunikacyjnej (np. awarii połączenia w sieci komputerowej). Możemy obserwować wybrane zmienne charakterystyczne w sieci i ich histogramy - empiryczne rozkłady prawdopodobieństwa. W przypadku awarii, te rozkłady ulegną zmianie w porównaniu z przypadkiem normalnego działania sieci; problemem jest wykorzystanie tej zmiany dla wykrycia typu awarii. Zatem opcje decyzyjne $m \in M \mathrm{w}$ tym problemie to możliwe typy zdarzeń; dla każdego zdarzenia możemy mieć histogram odniesienia, uzyskany np. poprzez symulację zdarzenia awarii $\mathrm{w}$ sieci. W tym przypadku, wykrycie typu zdarzenia jest związane $\mathrm{z}$ określeniem, który $\mathrm{z}$ histogramów odniesienia jest najbliższy do aktualnie obserwowanego histogramu, co odpowiada optymalizacji wielokryterialnej $\mathrm{z}$ kryteriami stabilizowanymi (zob. Rozdział 9). Specyfika różnych typów awarii może jednak powodować, że korzystne jest określenie innych porządków częściowych w przestrzeni histogramów i zastosowanie rankingu zobiektywizowanego dla określenia listy rankingowej możliwych zdarzeń wynikającej z obserwacji empirycznego histogramu, zob. (Granat et al. 2007).

\section{Literatura}

Arrow, K. (1951) Social choice and individual values. J. Wiley / Chapman \& Hall, New Haven, New York / London

Bronisz, P., Kruś L., Wierzbicki A.P. (1989) Towards interactive solutions in a bargaining problem. In A. Lewandowski, A.P. Wierzbicki (eds.) AspirationBased Decision Support Systems. Lecture Notes in Economics and Mathematical Systems Vol. 331. Springer-Verlag, Berlin-Heidelberg.

Granat J., Makowski M., Wierzbicki A.P. (2006) Hierarchical Reference Approach to Multicriteria Analysis of Discrete Alternatives. CSM'06: 20th Workshop on Methodologies and Tools for Complex System Modeling and Integrated Policy Assessment. IIASA, Laxenburg, Austria

Granat J., Wierzbicki A.P. (2007) Objective Classification of Empirical Probability Distributions and the Issue of Event Detection 23rd IFIP TC 7 Conference on System Modelling and Optimization, Cracow, Poland, July 2007 
Greco S., Matarazzo B., Slowinski R. (2001) Rough sets theory for multicriteria decision analysis. European J. of Operational Research, 129: 1: 1-47.

Hołubiec, J.W. i Mercik J.W. (1992) Techniki i tajniki głosowania Omnitech Press, Warszawa.

Keeney R. (1992) Value Focused Thinking, a Path to Creative Decision Making. Harvard University Press, Cambridge, Mass.

Keeney R., Raiffa H. (1976) Decisions with Multiple Objectives: Preferences and Value Tradeoffs. J. Wiley and Sons, New York

Lewandowski, A., Johnson S., Wierzbicki A.P. (1986) A Prototype Selection Committee Decision Analysis and Support Systems, SCDAS. IIASA WP-86-27, Laxenburg, Austria.

Lewandowski, A., Wierzbicki A.P., eds. (1989) Aspiration-Based Decision Support Systems. Lecture Notes in Economics and Mathematical Systems Vol. 331. Springer-Verlag, Berlin-Heidelberg.

Miettinen K. (1999) Nonlinear Multiobjective Optimization. Kluwer Academic Publishers, Boston

Nurmi, H. (1998) Voting Paradoxes and Referenda, Social Choice and Welfare 15(3): 333-350

Nurmi, H. (1999) Voting Paradoxes and How to Deal with Them, Springer-Verlag, Berlin-Heidelberg-New York.

Ogryczak W., Ruszczyński A. (2001) On consistence of stochastic dominance and mean-semideviation models. Mathematical Programming 89:217-232

Ogryczak W. (2006) On Multicriteria Optimization with Fair Aggregation of Individual Achievements. CSM'06: 20th Workshop on Methodologies and Tools for Complex System Modelling and Integrated Policy Assessment, International Institute for Applied Systems Analysis (IIASA), Laxemburg, Austria

Roy B. (1990) Wielokryterialne wspomaganie decyzji. WNT, Warszawa.

Saaty T. (1982) Decision Making for Leaders: the Analytical Hierarchy Process for Decisions in a Complex World. Lifetime Learning Publications, Belmont, Ca

Tian J., Wierzbicki A.P., Ren H., Nakamori, Y. (2006) A Study on Knowledge Creation Support in a Japanese Research Institute. Proceeding of First International Conference on Knowledge Science, Engineering and Management (KSEM06, pp. 405-417, Springer Verlag, Berlin Heidelberg

Vansnick J.C. (1986) De Borda et Condorcet ál ágrégation multicritériere. Cahier du Lamsade 70, Université Paris-Dauphine.

Vincke, Ph. (1992) Multicriteria Decision-Aid. J, Wiley and Sons, Chichester.

Wierzbicki A.P. (2008) The problem of objective ranking: foundations, approaches and applications. Journal of Telecommunications and Information Technology, 3/2008: $15-23$

Young, H.P. (1988) Condorcet's Theory of Voting, American Political Review 82, 1231-1244.

Zimmermann H.J., Gutsche L. (1991) Multi-Criteria Analyse. Springer-Verlag, Berlin-Heidelberg. 


\section{Indeks}

A

Alfaris Anas 191, 194

Allais Maurice 54, 80, 137, 138, 154

Andriole Stephen J. 36, 47, 211, 240, 241

Archimedes 58

Arrow Kenneth 54, 80, 315, 329, 330, 351

Aubin Jean-Pierre 250, 251, 262, 286

Axelrod Robert 55, 80, 248, 262, 284, 285, 286

B

Bangemann Martin 11, 29

Banzhaf John 299, 300

Baran Paul 22, 29

Bard Alexander 21, 29

Barzilay Jonathan 50, 52, 53, 80, 88, 103, 113, 128, 134

Basar Tamer 262, 286

Bellman Richard 59

Belton Valerie 47

Bergson Henri 58, 80

Berners-Lee Timothy 12

Bernoulli Daniel 116, 128

Bernoulli Mikołaj 116, 125

Bertalanffy von Ludwig 58, 80

Birge John 241

Black Bernard 324, 326, 327

Borda Jean 318, 319, 320, 321, 322, 323, 324, 325, 326, 327, 330, 331, 352

Borel Emile 246 
Braudel Fernand 10, 14, 15, 16, 29

Bronisz Piotr 286, 293, 300, 315, 345, 351

Brundtland Gro Harlem 29, 63, 80

Bush Vannevar 12

C

Čapek Karel 12

Carey George 12

Carroll Lewis - patrz Dodgson Charles

Charnes Abraham 53, 80, 141, 154, 192, 194

Chomsky Noam 61, 80

Choo Eng-Ung 203

Cobb Charles 104, 130

Condorcet Marie Jean Antoine Nicolas de Caritat 94, 318, 319, 320, 321, 322, 323, 324, 325, 326, 327, 330, 352

Cooper William 53, 80, 141, 154, 192, 194

Copeland Arthur H. 325, 326

D

Debreu Gerard 29, 47, 52, 102, 103, 113

dematerializacja pracy 14, 18, 19, 23

Derrida Jacques 61, 80

Deutsch Georg 64, 82

Devol Georg 12

Dinkelbach Werner 188, 194

Dodgson Charles (Lewis Carroll) 324, 326

Douglas Paul 104, 130

Draper Norman 112, 113, 132, 134

Dreyfus Hubert 59, 60, 73, 80, 77

Dreyfus Stuart 59, 60, 73, 80

Drucker Peter F. 11, 29

$\mathbf{E}$

Ehrgott Matthias 47, 80, 113, 134

Einstein Albert 25

Ermolev Yuriy 219, 241 


\section{$\mathbf{F}$}

fale rewolucji informacyjnej 12, 13, 16, 18, 22

Fermat Pierre 116

Figueira Josė Rui 47, 80, 113, 134

Fishburn Peter C. 47, 128, 134, 138, 154

Fisher Roger 47

Fodor Jerry 61, 80

Freeman Richard B. 16, 29

Frege Gottlob 61, 80

Freud Zygmunt 73

\section{G}

Galbraith John Kenneth 29

Gardner Howard 61, 80

Geoffrion Arthur 169, 171, 180

Gill Phillip 211, 218, 241

Gleick James 25, 29

Głuszkov Viktor 53, 80

Gödel Kurt 59, 61, 80

Goodwin Paul 154

Granat Janusz 80, 210, 211, 238, 241, 347, 351

Grauer Manfred 57, 80, 81, 211, 242

Greco Salvatore 47, 80, 113, 134, 352

Griewank Andreas 222, 241

Gutsche Lothar 48, 134, 300, 352

\section{H}

Hacking Ian 55, 80, 81

Haimes Yacov Y. 191, 194

Hall Warren 191, 194

Hamm Bernd 21, 29

Hansson Sven Ove 154

Hare Thomas 325, 326

Harsanyi John 247, 248, 284

Harvey David 29

Henig Mordechai 169, 180

Hołubiec Jerzy 47, 94, 113, 352 


\section{I}

Ihde Don 67, 80

Internet rzeczy 12

inżynieria biomedyczna 13

inżynieria wiedzy $9,12,13,45,52,59$

Irikov V.I. 53, 81

Isermann Heinz 188, 194

\section{$\mathbf{J}$}

Jaszkiewicz Andrzej 211, 241

Jobs Steve 12

Johnson Sarah 352

Julmi Christian 262

Jung Carl Gustav 73

$\mathbf{K}$

Kacprzyk Janusz 149, 154

Kahneman Daniel 54, 80, 110, 113, 138, 141, 154, 315

Kalai Ehud 291, 292, 293, 300

Kant Immanuel 65, 66

Keeney Ralph L. 47, 131, 133, 134, 154, 345, 352

Korhonen Pekka 110, 111, 197, 203, 211, 232, 241

Kosslyn Stephen 80

Kręglewski Tomasz 211, 233, 241

Kruś Lech 286, 300, 315, 351

Kuhn Thomas 49, 55, 56, 57, 68, 80, 81, 136

Kurcjusz Stanisław 98, 113

$\mathbf{L}$

Laakso Jukka 203, 211, 241

Lewandowski Andrzej 32, 47, 75, 81, 211, 226, 241, 242, 286, 293, 300, 315, 336, 351, 352

Lloyd Barbara 70, 81

Locke John 65, 66, 81

Lorentz Konrad 55, 68, 81

Lubacz Józef 29 
$\mathbf{L}$

Łukasiewicz Jan 42, 149, 154

\section{M}

Machina Mark 54, 81, 138, 154

Majchrzak Janusz 235, 242

Makowski Marek 48, 82, 180, 194, 210, 211, 212, 218, 234, 242, 351

Markowitz Harry 121, 134

Masuda Yoneji 11, 29

Matarazzo Benedetto 352

McCarthy John 60

megatrendy cywilizacji informacyjnej 22-28

Mercik Jacek 47, 113, 352

Miettinen Kaisa 47, 352

Minsky Marvin 60

model decyzyjny 34, 36-44

Moor Rafi 29

Morawski Roman 62, 81

Morgenstern Oscar 52, 81, 128, 134, 246

Motycka Alina 66, 81

Mousseau Vincent 134

Murray Walter 211, 241

Murtagh Bruce 211, 217, 242

Murty Katta 241

Myerson Roger B. 47, 250, 262, 286, 300, 315

$\mathbf{N}$

Naisbitt John 22,29

Nakamori Yoshiteru 77, 82, 350, 352

Nakayama Hirotaka 47, 81, 113, 180, 203, 211, 232, 242

Nanson Edward 324, 326

Nash John 247, 250, 251, 253, 255, 256, 258, 259, 267, 275, 276, 277, 279, 280, 288, 289, 290, 291, 300, 330

neoliberalizm 19, 26, 271

Neumann von, John 52, 81, 128, 134, 246

Nurmi Hannu 325, 326, 327, 328, 331, 352 
$\mathbf{O}$

Ochorowicz Julian 12

Ogryczak Włodzimierz 41, 47, 186, 194, 211, 236, 237, 242, 350, 352

Olsder Geert Jan 262, 286

Ostrogorski Moisiey 328

\section{$\mathbf{P}$}

Pacut Andrzej 132, 134

Pareto Vilfredo 39, 94, 95, 96, 121, 122, 125, 143, 158, 163, 164, 165, 166, 167, 168, 232, 269, 273, 275, 276, 277, 279, 280, 290, 295, 326, 330, 346, 347, 350

Pascal Blaise 116

Pawlak Zdzisław 42, 47, 54, 141, 154

Platon 55, 62, 64, 65

Polak Elijah 198, 211

Popper Karl 55, 56, 57, 58, 64, 68, 70, 72, 79, 81, 136

Pospelov G.S. 53, 81

\section{Q}

Quine Willard Van Orman 64, 81

$\mathbf{R}$

Raiffa Howard 47, 131, 133, 134, 154, 286, 291, 292, 293, 295, 300, 305, 306, 315, 345, 352

Rapoport Anatol 47, 55, 81, 113, 262, 284, 286

Rawls John 21, 29, 62, 63, 81

Rios Sixto 47, 76, 81, 88, 113, 129, 134, 154

roboty, robotyka 12, 13, 60

Rockafellar Tyrrell 98, 113

Rogowski Tadeusz 81, 211, 242

Röntgen Wilhelm 13

Rosh Eleanor 70, 81

Roy Bernard 36, 47, 54, 81, 89, 112, 113, 315, 336, 352

Russel Bertrand 61, 81

Ruszczyński Andrzej 350, 352 


\section{S}

Saaty Thomas L. 47, 107, 113, 345, 352

Sakawa Masatoshi 47, 113, 180

Salukvadze M.E. 181, 194

Saunders Michael 211, 242

Sawaragi Yoshikazu 47, 78, 81, 82, 105, 113, 169, 180, 183, 203, 211, 242

Selten Reinhart 247, 248, 284

Seo Fumiko 47, 113, 180

Shannon Claude 66, 67, 82

Shapley Lloyd 298, 299, 300

Simon Herbert A. 32, 34, 48, 53, 74, 82, 107, 109, 110, 113, 136, 139, $140,141,144,145,147,154$

Słowiński Roman 134, 211, 241, 352

Smith Harry 112, 113, 132, 134

Smorodinsky Meir 291, 292, 293, 300

Sobczyk Jerzy 81, 211, 242

Sőderqvist Jan 21, 29

Sokrates 65

Sosnowski Janusz 211, 242

Springer Sally 64, 82

sprzężenie zwrotne 13, 15, 16, 17, 19, 24, 25, 32, 71, 240

Stachurski Andrzej 41, 48, 112, 113, 157, 180, 217, 223

Stallman Richard 21, 29

Stanchev Ivan 242

Steinhaus Hugo 309, 310, 315

Steuer Ralph E. 48, 82, 113, 180, 186, 194, 201, 203, 212, 242

Stewart Theodor 47

Sylos Labini 271, 286

sztuczna inteligencja 9, 12, 32, 39, 49, 50, 59, 60, 61, 62

Śliwiński Tomasz 186, 194

\section{$\mathbf{T}$}

Tanino Tetsuzo 47, 113, 180

Tarski Alfred 61, 62, 82

Thurow Lester C. 11, 29 
Tian Jing 349, 350, 352

Tihanyi Kalman 12

Toffler Alvin 11,14, 15, 29

trwały rozwój (sustainable development) 63

Turing Alan 62, 82

Tversky Amos 54, 80, 110, 113, 138, 141, 154, 311, 315

$\mathbf{U}$

Urbański Jarosław 29

Ury William L. 47

$\mathbf{V}$

Vansnick Jean-Claude 318, 352

Vincke Philippe 485, 113, 352

Vollmer Gerhard 82

\author{
W \\ Wall Kent 54, 82 \\ Wallerstein Immanuel 29 \\ wartość demokracji 21 \\ Watt James 14, 17 \\ Weizenbaum Joseph 62, 82 \\ Wessels Jaap 48, 82, 180, 194, 212, 242 \\ Wets Roger 241 \\ Whitehead Alfred N. 61, 81 \\ Wittgenstein Ludwig 61, 68, 82 \\ własność intelektualna 20, 285 \\ Wozniak Steve 12 \\ Wright George 154 \\ Wright Margaret 211, 241 \\ Wuketits Franz 55, 68, 82

\section{$\mathbf{Y}$} \\ Yager Ronald R. 185, 194 \\ yaoyorozu 12 \\ Young Laurence F. 72, 82 \\ Young Peyton 305, 312, 313, 314, 315, 331, 352 \\ Yu Po-Lung 48, 57, 83, 113, 180, 181, 194
}


$\mathbf{Z}$

Zadeh Lofti A. 42, 48, 54, 83, 149, 154

Zakrzewski Roman 235, 242

założenie metaetyczne 62

zastępowanie pracy przez kapitał 19, 23, 24

Zeleny Milan 83, 181, 211

Zermelo Ernst 246

Zimmermann Hans-Jürgen 48, 117, 134, 300, 352

Zorychta Krystian 211, 242

Zuse Konrad 12

Zvorikin Vladimir 12 
Michał Krych

\section{Analiza}

matematyczna dla ekonomistów
Beata Glinka, Jacek Pasieczny

TWORZENIE PRZEDSIĘBIORSTWA

Szanse, realizacja, rozwój

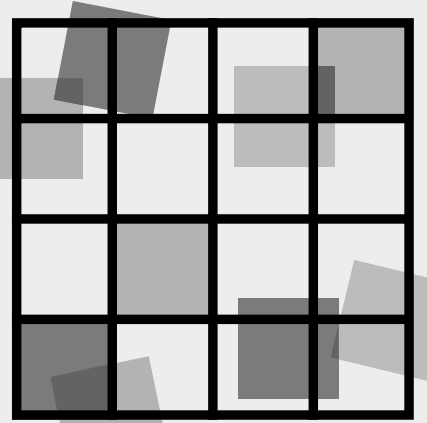

Mirosława Lasek, Marek Peczkowski

\section{Enterprise Miner}

Wykorzystywanie narzędzi

Data Mining w systemie $S A S$

\section{z zatrudnienia}

\section{Dekompozycja i wycena}

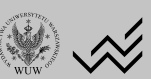

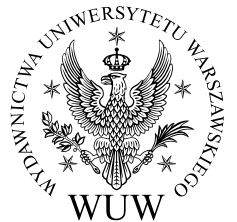

Wydawnictwa Uniwersytetu Warszawskiego

ul. Nowy Świat 4, 00-497 Warszawa

tel. 225531333

www.wuw.pl 
Podstawowe pojęcia teorii decyzji, teorii wartości i użyteczności, optymalizacji wielokryterialnej, teorii gier, metod wspomagania negocjacji itp. mają zasadnicze znaczenie zarówno dla dobrego pojmowania współczesnego świata, początku epoki cywilizacji informacyjnej, jak i dla umiejętnego konstruowania systemów wspomagania decyzji. Komputerowe wspomaganie decyzji jest dziś dziedziną bardzo szeroką ze względu na stosowane podejścia teoretyczne i metodyczne oraz dziedziny i metodykę zastosowań. Ponieważ wspomaganie decyzji zawsze obejmuje automatyzację pewnych etapów czy czynności w procesie decyzyjnym, nieuchronny jest spór o zakres i prawomocność takiej automatyzacji. Autor książki reprezentuje w tym sporze bardziej praktyczny i psychologiczny punkt widzenia (oparty na ponad 40-letnim doświadczeniu w tej dziedzinie), podkreślając rolę decydenta lub użytkownika systemu wspomagania decyzji oraz znaczenie jego intuicji i zakładając, że może on być wprawdzie wspomagany przez automatyzację niektórych etapów procesu decyzyjnego, ale powinien suwerennie i w pełni świadomie dokonywać ostatecznego wyboru decyzji. Zwraca też uwagę na możliwości wykorzystania teorii i modeli matematycznych oraz metod optymalizacji w celu wspomagania, a nie zastępowania decydenta. Do grupy takich metod należą m.in. interaktywne systemy wspomagania decyzji, oparte na optymalizacji wielokryterialnej, szeroko omówione w książce. 